\title{
Prawo
}

\section{Urlop wypoczynkowy jako instrument realizacji prawa pracownika do odpoczynku}

Monika Nowak

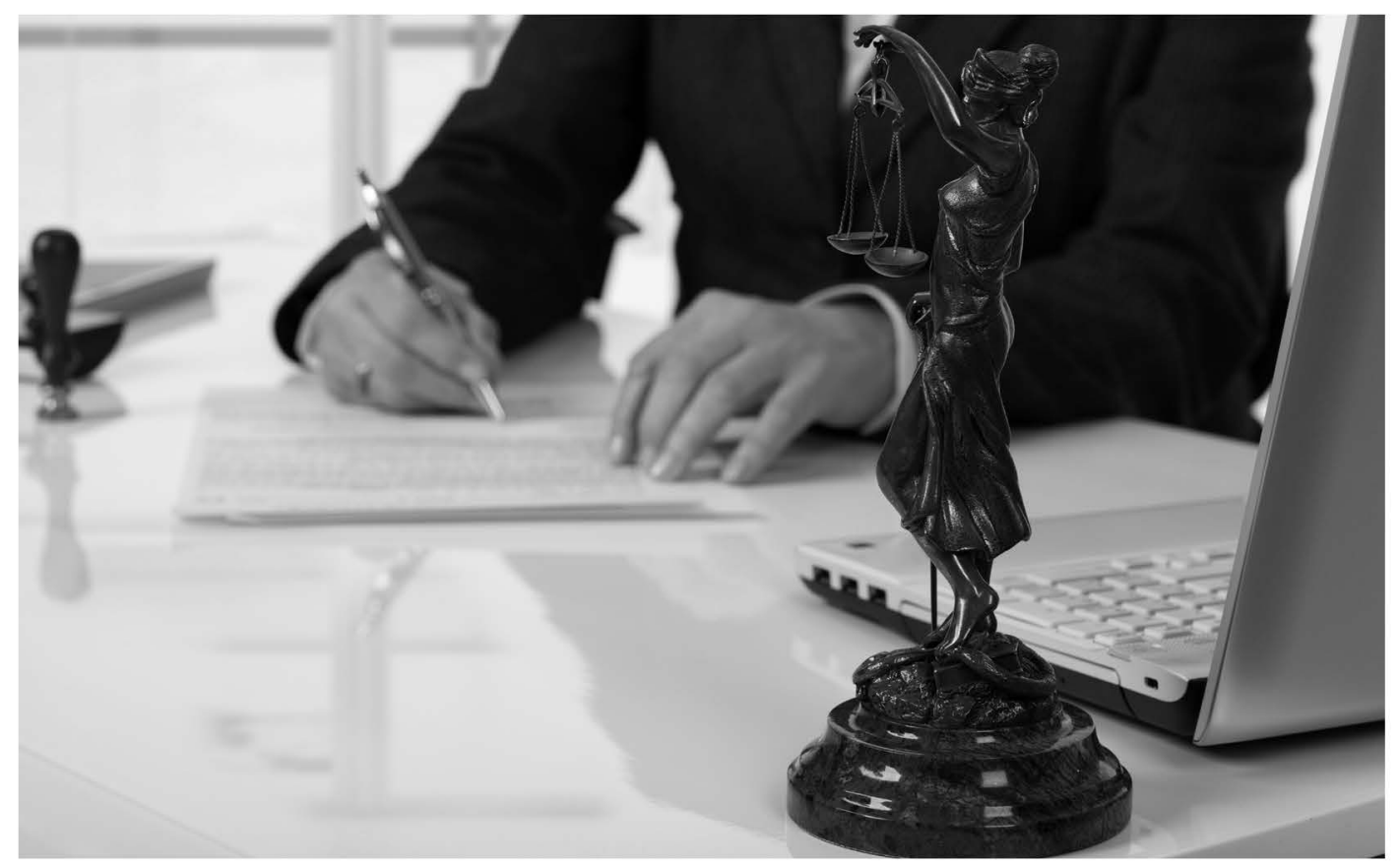




\section{Urlop wypoczynkowy}

jako instrument realizacji prawa pracownika do odpoczynku 
皆 


\section{Prawo}

\section{Urlop wypoczynkowy \\ jako instrument realizacji prawa pracownika do odpoczynku}

Monika Nowak 
Monika Nowak - Uniwersytet Łódzki, Wydział Prawa i Administracji

Katedra Prawa Pracy, 90-232 Łódź, ul. Kopcińskiego 8/12

\author{
RECENZENT \\ Krzysztof Walczak \\ REDAKTOR INICJUJĄCY \\ Monika Borowczyk \\ Joanna Balcerak \\ SKŁAD I ŁAMANIE \\ AGENT PR \\ PROJEKT OKŁADKI \\ Katarzyna Turkowska
}

REDAKTOR WYDAWNICTWA UŁ

Zdjęcie wykorzystane na okładce: @ Depositphotos.com/IuriiSokolov

(c) Copyright by Monika Nowak, Łódź 2018

(c) Copyright for this edition by Uniwersytet Łódzki, Łódź 2018

Stan prawny na dzień 30.09.2017 r.

Wydane przez Wydawnictwo Uniwersytetu Łódzkiego

Wydanie I. W.08216.17.0.M

Ark. wyd. 28,5; ark. druk. 24,125

ISBN 978-83-8088-932-3

e-ISBN 978-83-8088-933-0

https://doi.org/10.18778/8088-932-3

Wydawnictwo Uniwersytetu Łódzkiego

90-131 Łódź, ul. Lindleya 8

www.wydawnictwo.uni.lodz.pl

e-mail: ksiegarnia@uni.lodz.pl

tel. (42) 6655863 


\section{Spis treści}

Wykaz ważniejszych skrótów $\quad 7$

Wstęp 9

Część l

Prawo do odpoczynku - ogólna charakterystyka

1. Pojęcie czasu wolnego i pojęcie odpoczynku 15

2. Przesłanki prawnej regulacji prawa do odpoczynku i jego aksjologiczne uzasadnienie 27

3. Prawo do odpoczynku jako jedno z podstawowych praw człowieka 41

3.1. Prawo do odpoczynku w prawie międzynarodowym 41

3.1.1. Akty o charakterze uniwersalnym 41

3.1.2. Europejska Karta Społeczna Rady Europy 54

3.2. Prawo do odpoczynku w prawie Unii Europejskiej 59

3.3. Regulacja odpoczynku w konstytucyjnym porządku prawnym państw
europejskich

4. Instrumenty realizacji prawa do odpoczynku w polskim prawie pracy 96

4.1. Uwagi wstępne 96

4.2. Okresy odpoczynku dobowego i tygodniowego 99

4.2.1. Prawne limitowanie dobowego i tygodniowego czasu pracy - rys historyczny 99

4.2.2. Prawo do odpoczynku dobowego i tygodniowego w obowiązujących $\begin{array}{ll}\text { przepisach polskiego prawa pracy } & 108\end{array}$

$\begin{array}{ll}\text { 4.3. Przerwy w pracy } & 119\end{array}$

4.4. Dni wolne od pracy 123

4.5. Prawo do odpoczynku a urlopy pracownicze 141

5. Urlop wypoczynkowy jako podstawowy instrument realizacji prawa do odpoczynku w ujęciu ewolucyjnym 
Część II

Elementy konstrukcyjne prawa do urlopu wypoczynkowego sprzyjające realizacji prawa do odpoczynku

165

1. Pojęcie urlopu wypoczynkowego i jego charakter prawny 165

2. Nabycie prawa do urlopu wypoczynkowego 177

2.1. Nabycie prawa do urlopu wypoczynkowego w świetle powszechnego prawa pracy 177

2.2. Nabycie prawa do urlopu wypoczynkowego w świetle wybranych ustaw szczególnych

3. Wymiar urlopu wypoczynkowego 209

4. Zasady prawa urlopowego 243

4.1. Niezbywalność prawa do urlopu wypoczynkowego 243

4.2. Nieprzerwany charakter urlopu wypoczynkowego 246

4.3. Spokój urlopowy 260

4.4. Coroczność prawa do urlopu wypoczynkowego 264

4.5. Udzielanie urlopu w naturze 273

$\begin{array}{ll}\text { 4.6. Odpłatność urlopu } & 278\end{array}$

\section{Część III}

Dysfunkcjonalne elementy regulacji prawa urlopowego z punktu widzenia realizacji prawa do odpoczynku

1. Uwagi wprowadzające

2. Pracodawca jako podmiot decydujący o planowanym terminie urlopu wypoczynkowego

3. Przesuwanie terminu urlopu ze względu na szczególne potrzeby pracodawcy

298

4. Skierowanie pracownika na urlop wypoczynkowy w okresie wypowiedzenia

305

5. Odwołanie z urlopu

318

6. Urlop na żądanie

329

7. Ekwiwalent za urlop

Zakończenie

Bibliografia

Wykaz ważniejszych aktów prawnych

Wykaz orzeczeń

379

Summary

383

Od Redakcji 


\section{Wykaz ważniejszych skrótów}

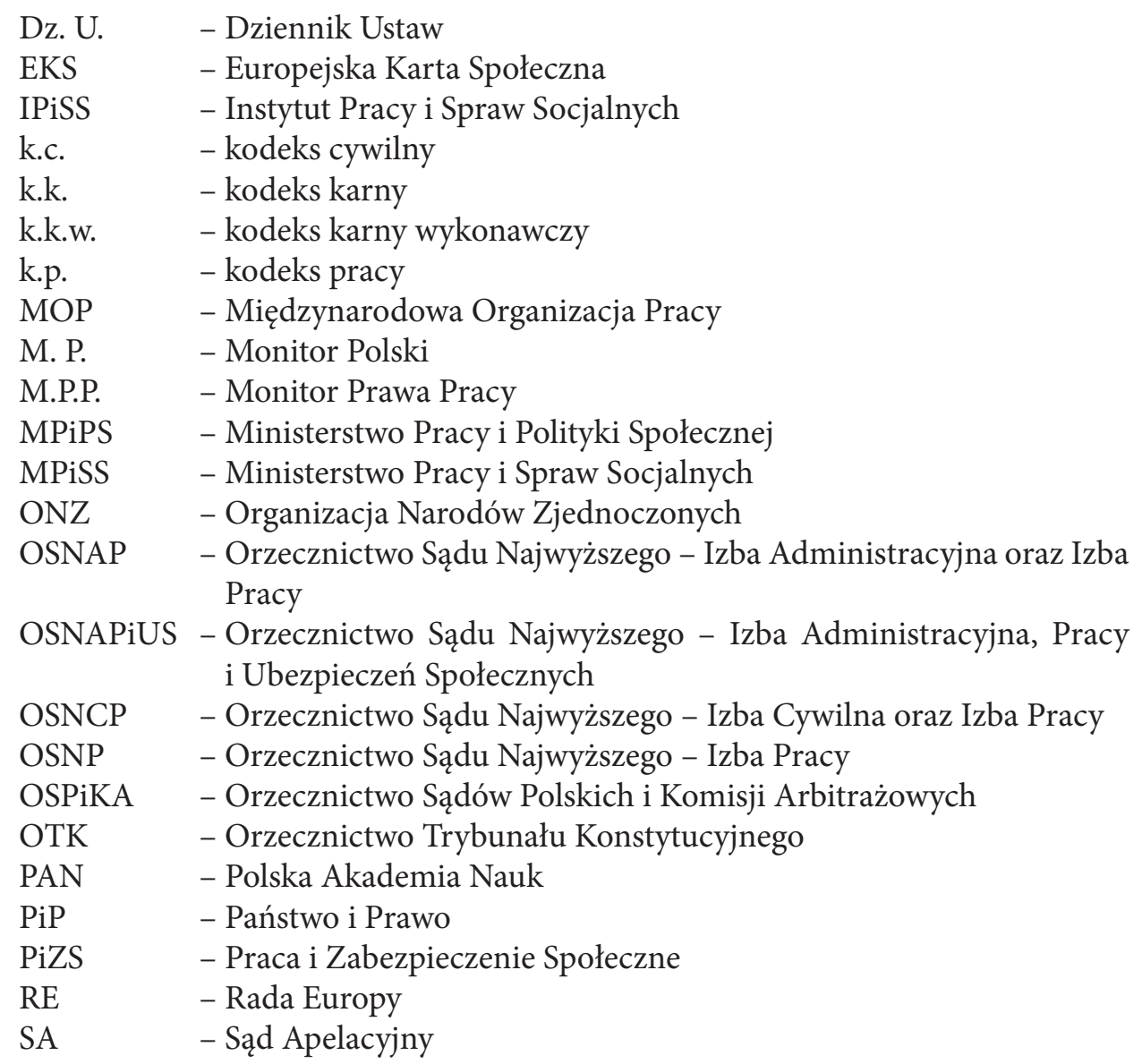


8

Wykaz ważniejszych skrótów

SN - - Sąd Najwyższy

TK - - Trybunał Konstytucyjny

TSUE - Trybunał Sprawiedliwości UE

UE - Unia Europejska 


\section{Wstęp}

Praca i odpoczynek stanowią dwa nierozłączne elementy ludzkiego życia. W zasadzie każdej aktywności podejmowanej przez człowieka towarzyszy potrzeba przynajmniej regeneracji sił po jej zakończeniu. Kwestia odpoczynku wpisuje się zatem w naturalny cykl życia ludzkiego. Przez bardzo długi okres nie rozgraniczano jednak wyraźnie tych dwóch sfer ludzkiej egzystencji oraz nie wyodrębniano pojęcia odpoczynku na gruncie prawnym. Przyjmuje się, że w świadomości społecznej i prawnej pojawiło się ono wraz ze zjawiskiem rewolucji przemysłowej, kiedy to czas wolny (w tym odpoczynek stanowiący jego główny cel) zaczął być postrzegany jako odrębna kategoria będąca przeciwieństwem pojęcia czasu pracy ${ }^{1}$. Początkowo utożsamiano go jednak zasadniczo z okresem niezbędnym do fizycznego odnowienia sił zużytych $\mathrm{w}$ procesie produkcji. Współcześnie jest już chyba oczywiste, że odpoczynek ów ma znaczenie z punktu widzenia odzyskania energii wydatkowanej w pracy, przede wszystkim jednak warunkuje pełny rozwój człowieka jako osoby. Prawo do niego, skutecznie gwarantowane, umożliwia bowiem urzeczywistnienie innych podstawowych praw jednostki, takich jak m.in. prawo do życia, wolności, bezpieczeństwa, ochrony zdrowia, rodziny, czy samorealizacji. Dlatego też podkreśla się często, że czas wolny w holistycznym ujęciu człowieka i jego potrzeb powinien być spędzany w sposób, który będzie mu dawać satysfakcję i przyjemność, a nade wszystko pozwoli odpocząć zarówno fizycznie, jak i psychicznie ${ }^{2}$, zwłaszcza od pracy zawodowej.

Podejście do problematyki prawnej regulacji czasu pracy i czasu od niej wolnego jest jednak zmienne, uzależnione od aktualnej sytuacji społeczno-gospodarczej,

1 Por. R. Dyoniziak, Społeczeństwo w procesie zmian, Kraków, Szczecin, Zielona Góra 1997, s. 239; A. Chobot, Czas pracy w znowelizowanym kodeksie pracy, Poznań 2003, s. 12 i n.

2 B. Kolny, Czas wolny w świetle zrównoważonego rozwoju, „Konsumpcja i Rozwój” 2014, nr 2, s. 28. 
nowych tendencji, zjawisk i związanych z tym zagrożeń w życiu społeczeństw. $\mathrm{O}$ ile w połowie XX w. bardzo silne były postulaty ograniczania czasu pracy, o tyle obecnie zwraca się większą uwagę na swobodę w jego elastycznym kształtowaniu. Wśród czynników wymuszających poszukiwanie nowych form gospodarowania czasem pracy wymienia się m.in. globalizację życia i związaną z nią silną konkurencję, a także postępującą wraz z końcem XX w. arytmię w zakresie warunków życia, prowadzenia działalności gospodarczej i funkcjonowania zakładów pracy ${ }^{3}$. Sprzyja to również większej akceptacji pewnej nieregularności w zakresie czasu pracy i wypoczynku. Jak słusznie zauważono $\mathrm{w}$ literaturze przedmiotu, zasadniczym motywem, podstawą zmian w regulacji szeroko pojętego czasu pracy stają się względy efektywności gospodarczej przedsiębiorstw, kryteria stricte ekonomiczne, przy jednoczesnym marginalizowaniu pierwotnych podstaw o charakterze humanitarnym i antropologicznym, co w konsekwencji prowadzi do stopniowego pogarszania sytuacji osób zatrudnionych w omawianym obszarze ${ }^{4}$.

Niezależnie od zmieniających się warunków gospodarczych i tendencji rozwojowych oraz związanych z tym nowych wyzwań nie można zapominać, że cele o charakterze ekonomicznym, produkcyjnym nie mogą spychać na dalszy plan kwestii socjalnych, dotyczących m.in. regulacji czasu pracy. Trzeba mieć bowiem na uwadze, że ilość czasu poświęconego na pracę nie jest w pełni adekwatnym miernikiem ilości wykonywanej pracy, a tym samym osiąganych rezultatów gospodarczych. Istotna jest przede wszystkim wydajność pracy, która może być doskonalona m.in. poprzez rozwój techniki i technologii oraz należyte zagospodarowanie czasu pracy. Sami ekonomiści dostrzegli, o czym będzie dalej mowa, bezpośredni związek wydajności pracy ze stopniem zmęczenia pracownika. Również w socjologii zaobserwowano, że ilość czasu wolnego i sposób jego wykorzystywania bezpośrednio przekłada się na liczbę i sposób wykonywania obowiązków zawodowych i odwrotnie. Stąd musi zostać zawsze zachowana odpowiednia równowaga między poziomem ochrony interesów pracodawców oraz pracowników, m.in. w aspekcie omawianego prawa. Tymczasem współczesne konstrukcje czasu pracy zbyt często są budowane na potrzebie dostosowania długości tego czasu i jego rozkładu do zmieniających się potrzeb gospodarczych kosztem prawa pracownika do czasu wolnego od pracy, w tym odpoczynkus. Kwintesencją takiego podejścia jest dokonana w Polsce w 2013 r. zmiana polegająca na dopuszczeniu 12-miesięcznych okresów rozliczeniowych, niezależnie od systemu czasu pracy ${ }^{6}$, co, jak wynika z badań przeprowadzonych na zlecenie Komisji Europejskiej, ma szczególnie negatywny wpływ na życie i zdrowie pracownika oraz zdolność harmonijnego łączenia życia zawodowego z rodzinnym.

3 Por. A. Chobot, Czas pracy..., s. 13 i n.

4 Por. M. Skąpski, Funkcje regulacji czasu pracy wobec idei równości i sprawiedliwości, „Annales Universitatis Mariae Curie-Skłodowska", sectio G, 2015, vol. LXII, 2, s. 204.

5 Tamże, s. 207.

6 Ustawa z dnia 12 lipca 2013 r. o zmianie ustawy - Kodeks pracy oraz ustawy o związkach zawodowych, Dz. U. 2013, poz. 896. 
Jednocześnie stale wzrasta świadomość, że prawo do odpoczynku, niezwykle ważne w okresie rozwoju stosunków najmu pracy, obecnie nie traci na znaczeniu, a wręcz jego rola jeszcze wzrasta. Globalizacja, względy konkurencyjności, wzrost tempa życia i pracy, powodują, że ciągle rosną oczekiwania wobec pracowników nie tylko w zakresie ich kwalifikacji, lecz także dyspozycyjności. Generuje to coraz większe zmęczenie oraz stres, a co za tym idzie - wiele chorób i psychosomatycznych zaburzeń, ponadto jest przyczyną obserwowanego procesu słabnącej roli rodziny oraz społecznych więzi. Zarówno dla dobra jednostki, jak i całego społeczeństwa konieczne jest zatem ustanowienie czy zachowanie tego prawa oraz wprowadzenie takich instrumentów prawnych, które pozwolą na jego skuteczną realizację, a w jakiejś mierze będą też stanowić przeciwwagę dla wspomnianych wyżej tendencji. Jednym z takich instrumentów, o zasadniczym znaczeniu, jest niewątpliwie prawo do urlopu wypoczynkowego, który w swej istocie jest corocznym, dłuższym zwolnieniem pracownika z obowiązku wykonywania pracy w celu regeneracji psychofizycznej organizmu, a przez to ochrony życia i zdrowia zatrudnionego.

Problematyka urlopów wypoczynkowych jest stale obecna w literaturze prawa pracy. Trzeba jednak zauważyć, że dotychczasowe opracowania poświęcone tej tematyce albo stanowią łączne omówienie treści poszczególnych przepisów wchodzących w zakres prawa urlopowego, albo dotyczą jedynie wybranych jego aspektów. Celem niniejszej pracy nie jest natomiast szczegółowa prezentacja i analiza wszystkich przyjętych przez ustawodawcę rozwiązań dotyczących urlopu wypoczynkowego, ale ocena konstrukcji tego urlopu i reguł jego udzielania w kontekście realizacji funkcji, które urlop ten ma spełniać, oraz stopnia, w jakim instytucja ta urzeczywistnia prawo pracownika do wypoczynku - prawo podniesione przez ustawodawcę do rangi podstawowej zasady prawa pracy (mającej również swoje konstytucyjne umocowanie). Dlatego też uwaga zostanie skoncentrowana na tych elementach prawa urlopowego, które dla realizacji wskazanego celu mają istotne znaczenie. Z pewnością takie ujęcie tej materii nie było dotychczas prezentowane, a waga omawianych z tej perspektywy kwestii wydaje się znaczna ze względów, o których była wyżej mowa.

Postrzeganie tytułowego urlopu jako istotnego instrumentu realizacji prawa pracownika do wypoczynku wymaga niewątpliwie, w pierwszej kolejności, usystematyzowanej prezentacji materiału normatywnego oraz dorobku doktryny i orzecznictwa, które dotyczą omawianego prawa, co pozwoli nie tylko wyjaśnić samo pojęcie odpoczynku, jego znaczenie i charakter, lecz także wskazać środki prawne, które, w przeszłości i obecnie, mają umożliwiać jego realizację. Wynikają one $\mathrm{z}$ podstawowej zasady prawa do odpoczynku przyjętej na gruncie polskiego prawa pracy, znalazły również swoje odzwierciedlenie w prawie międzynarodowym oraz prawie Unii Europejskiej, które w tym zakresie wyraźnie ewoluowały w kierunku wzmocnienia ochrony pracownika. Zaliczyć do nich należy instytucję odpoczynku dobowego i tygodniowego, przerwy w pracy czy dni wolne od pracy, ale także urlopy wypoczynkowe stanowiące główny przedmiot podjętych 
rozważań. W konsekwencji trzeba założyć, że regulacja prawna urlopów wypoczynkowych powinna być taka, aby w maksymalnym stopniu spełniała swoją rolę gwaranta wskazanego prawa. Nie zawsze jednak tak się dzieje. Niekiedy bowiem sam ustawodawca ją osłabia, w sposób bardziej lub mniej zasadny i właściwy, stąd zadaniem autorki w kolejnych, wyodrębnionych częściach pracy będzie wykazanie, $w$ jakim zakresie przyjęte unormowania funkcję tę spełniają, a w jakim $z$ tego punktu widzenia są dysfunkcjonalne, tj. nie służą osiągnięciu i zabezpieczeniu optymalnego wypoczynku. Nie oznacza to oczywiście, że nie są one w jakiejś mierze usprawiedliwione innymi względami, często znajdują bowiem swoje oparcie w konieczności ochrony słusznego interesu pracodawcy, zabezpieczenia odpowiedniej organizacji pracy zakładu.

Pełna analiza tego zagadnienia nie byłaby możliwa bez uprzedniego odwołania się do regulacji międzynarodowych oraz prawa UE, w których, w sposób bardziej lub mniej bezpośredni, nie tylko wskazuje się na samo prawo do odpoczynku i poszczególne instytucje prawne, które powinny służyć jego realizacji, do jakich powszechnie zaliczono również urlop wypoczynkowy, ale określa się w nich także pewne minimalne standardy, jakie powinny zostać w omawianym zakresie przyjęte, aby prawo do odpoczynku mogło być faktycznie urzeczywistniane. Ważną rolę odgrywa przy tym orzecznictwo Trybunału Sprawiedliwości UE, w którym dokonuje się wykładni poszczególnych, często dość ogólnych uregulowań wchodzących w zakres omawianego prawa, formułuje określone zasady, czuwając m.in. w odniesieniu do urlopu wypoczynkowego, aby rozwiązania prawne poszczególnych państw nie naruszały podstawowej funkcji urlopu i jego celów określonych $\mathrm{w}$ dyrektywie. Urlop ten jest postrzegany zarówno przez Trybunał, jak i inne organy kontrolujące prawidłowe wykonanie zobowiązań zawartych w ratyfikowanych przez dane państwo aktach, jako podstawowy gwarant prawa do odpoczynku, bezpieczeństwa i ochrony zdrowia ludzkiego. Jego regulacja w prawie krajowym i związana z nią interpretacja musi ten cel uwzględniać.

Należy ponadto podkreślić, że ocena przyjętych w prawie urlopowym rozwiązań musi być dokonywana również z uwzględnieniem zachodzących we współczesnym świecie przeobrażeń i pojawiających się nowych zagrożeń, związanych choćby z rozwojem form komunikowania się na odległość. Na świecie coraz częściej dostrzega się płynące stąd niebezpieczeństwa dla skuteczności zagwarantowania wypoczynku pracownika, m.in. w czasie urlopu, i podejmuje określone próby, także legislacyjne, przeciwdziałania im. W Polsce problem ten również zaczyna być zauważany, choć jeszcze w stosunkowo ograniczonym zakresie. Wstępna analiza obowiązującego w Polsce prawa dotyczącego urlopów wypoczynkowych pozwala stwierdzić, że większość problemów powstających na tym tle daje się rozwiązać bez uszczerbku dla wypoczynkowej funkcji urlopu poprzez odpowiednią wykładnię istniejących przepisów, co nie wyklucza jednak w określonych aspektach podjęcia stosownej interwencji przez ustawodawcę (co mogłoby mieć też pewne znaczenie psychologiczne i uświadamiające). 
Analiza uregulowań urlopowych z perspektywy ich wpływu na efektywność wypoczynku pracownika będzie dokonywana przede wszystkim na podstawie przepisów powszechnego prawa pracy, a więc odpowiednich unormowań zawartych w Kodeksie pracy, które dotyczą przeważającej liczby osób wykonujących pracę w ramach stosunku pracy. Niemniej uwaga zostanie również zwrócona na niektóre ustawy szczególne, określające uprawnienia urlopowe dość licznych grup pracowniczych, których regulacje budzą wątpliwości z punktu widzenia zachowania gwarancji optymalnego wypoczynku. Chodzi o nauczycieli, także akademickich, oraz pracowników tymczasowych. Szczególnie w odniesieniu do tych ostatnich prawna regulacja urlopów wypoczynkowych cechuje się wysokim stopniem autonomii w stosunku do rozwiązań kodeksowych, a przy tym wywołuje obawy co do poziomu ochrony wypoczynku tej kategorii pracowników.

Realizacji sformułowanych głównych zadań badawczych, a także zachowaniu klarowności wywodu w opracowaniu służy przede wszystkim tradycyjna metoda formalno-dogmatyczna z pewnymi odniesieniami do metody historycznej. Celem opracowania nie jest przy tym dokonanie pełnej analizy przyjętych w Polsce regulacji urlopowych, ale skupienie uwagi na tych aspektach obowiązującego prawa, które mają decydujące znaczenie z punktu widzenia realizacji podstawowej zasady prawa pracy - prawa pracownika do odpoczynku. Szersze odwołanie się w pierwszej części, z natury swej ogólniejszej, do przepisów o charakterze historycznym pozwala na zaprezentowanie genezy obowiązujących rozwiązań oraz pewnej ewolucji, jaka dokonała się nie tylko pod względem wzmocnienia wypoczynkowej funkcji samego urlopu, ale też innych instrumentów składających się na pracownicze prawo do odpoczynku, związanej również w jakimś stopniu ze zmianą warunków ustrojowych oraz wstąpieniem Polski do UE. Świadomie zrezygnowano natomiast z metody komparatystycznej, która, jak się wydaje, nie ma istotniejszego znaczenia przy tak zarysowanym celu niniejszej pracy. Przedmiotem analizy są bowiem instytucje polskiego prawa urlopowego z punktu widzenia zasadniczej funkcji, jaką urlop ten ma spełniać. Wprowadzenie wątków prawnoporównawczych powodowałoby nadmierne rozbudowanie pracy oraz odwrócenie uwagi od głównego nurtu rozważań, a tym samym utrudniało osiągnięcie opisanych wcześniej zamierzeń badawczych. W rezultacie w opracowaniu będą występować jedynie przykładowe odwołania do unormowań przyjętych w prawie urlopowym wybranych państw, które ewentualnie mogłyby posłużyć do udoskonalenia prawa polskiego. 



\section{Część I}

\section{Prawo do odpoczynku \\ - ogólna charakterystyka}

\section{Pojęcie czasu wolnego i pojęcie odpoczynku}

Zarówno pojęcie odpoczynku, jak i pojęcie czasu wolnego nie są łatwe do zdefiniowania, podobnie jak ustalenie relacji między nimi. W teorii wyróżnia się bardzo wiele odmiennych sposobów podejścia do problematyki czasu wolnego, w tym zwłaszcza do jego istoty. Różne kryteria, jakie mogą być stosowane przy próbie porządkowania tej materii, pozwalają wyróżniać szereg koncepcji czasu wolnego ${ }^{1}$. Ponadto sposób rozumienia wymienionych pojęć ulegał na przestrzeni wieków ciągłym zmianom. Z historycznie zróżnicowanymi formami i charakterem pracy w poszczególnych etapach rozwoju społeczno-gospodarczego wiąże się odmienność form oraz istoty wypoczynku.

Przez bardzo długi okres kwestia szeroko ujmowanego czasu wolnego była rozpatrywane wyłącznie w kontekście tzw. warstw uprzywilejowanych. W ustroju przedkapitalistycznym (w okresie niewolnictwa i poddaństwa) życie „w czasie wolnym” było „z natury” przypisane osobom należącym do określonych elit². $\mathrm{W}$ czasach antycznych niewolnik był $\mathrm{z}$ prawnego punktu widzenia rzeczą, swego rodzaju narzędziem $\mathrm{w}$ procesie wytwarzania dóbr pozbawionym jakichkolwiek praw w związku z wykonywaną pracą ${ }^{3}$. Sama praca podejmowana w celach

1 Na przykład M. Bombol na podstawie różnych opisywanych teoretycznych ujęć czasu wolnego wyróżnia trzy sposoby podejścia do jego definiowania: a) rozumienie czasu wolnego w czystej postaci, b) rozumienie czasu wolnego jako specyficznych zachowań w nim podejmowanych i c) czas wolny jako stan umystu. Por. M. Bombol, Czas wolny jako kategoria diagnostyczna procesów rozwoju społeczno-gospodarczego, Warszawa 2008, s. 19 i n.

2 Por. A. Chobot, Czas pracy w znowelizowanym kodeksie pracy, Poznań 2003, s. 12 i n.

3 Por. T. Zieliński, Zarys wykładu prawa pracy, cz. I, Katowice 1979, s. 74 i n. Jak słusznie zauważono w literaturze, w okresie niewolnictwa w zasadzie nie dostrzegano potrzeby praw- 
zarobkowych, szczególnie fizyczna, była generalnie dla starożytnych przedmiotem pogardy, aktywnością nielicującą z godnością wolnego obywatela ${ }^{4}$, stąd nie zajmowano się w zasadzie problemem jej czasowego ograniczania. W stosunkach feudalnych, choć odstąpiono od przedmiotowego traktowania osób pracujących na rzecz konstrukcji „osobowego” podporządkowania ich właścicielom środków produkcji, nadal ci ostatni dysponowali często nieograniczonym prawem korzystania $\mathrm{z}$ poddanej ich władzy siły roboczej ${ }^{5}$. Dotyczyło to w szczególności pracy chłopów pańszczyźnianych, bo w warsztatach rzemieślniczych, przy braku regulacji pochodzącej od państwa, wzajemne relacje między majstrami i czeladnikami oraz uczniami ustalano w tzw. prawie cechowym, które miało charakter wewnętrz$n y^{6}$. Bywało, że prawo to $\mathrm{w}$ jakiś sposób ograniczało czas pracy zarówno majstrów, jak i czeladników przez wzgląd na kwestie dotyczące konkurencji ${ }^{7}$. Niemniej przez bardzo długi okres, w zasadzie aż do tzw. ery przemysłowej, nie odróżniano wyraźnie czasu wolnego od czasu pracy. W okresie niewolnictwa i poddaństwa czas wolny traktowano raczej jako samoistne dobro niepowiązane z pracą̧.

Samo pojęcie czasu wolnego występowało już w starożytności ${ }^{9}$. Niemniej rozpatrywano je nie w aspekcie okresu „wolnego od”, pracy czy obowiązków, ale „czasu wolnego do", np. do zabawy, szczęścia, radości ${ }^{10}$.

W starożytnej Grecji po zajęciach następował odpoczynek, który obejmował trzy elementy:

- kontemplację,

- rozrywkę oraz

- rekreację (odtworzenie sił) ${ }^{11}$.

Grecki termin schole, używany na oznaczenie czasu wolnego, był utożsamiany z najwyższą formą jego spędzania, obejmującą dyskurs lub kontemplację, to swego rodzaju stan umysłu dający poczucie wolności ${ }^{12}$.

nego zabezpieczenia jakichkolwiek interesów osób utrzymujących się z pracy własnych rąk. Por. L. Mitrus, Powstanie i ewolucja prawa pracy, [w:] System prawa pracy, t. 1: Część ogólna, red. K.W. Baran, Warszawa 2017, s. 343.

4 Por. szerzej: Z. Góral, Prawo do pracy. Studium prawa polskiego w świetle porównawczym, Łódź 1994, s. 5 i n.

5 Tamże, s. 77 i n.

6 Tamże, s. 79.

7 Por. M. Święcicki, Prawo pracy, Warszawa 1968, s. 470.

8 Por. A. Chobot, Pracowniczy obowiq̨zek dbałości o dobro zakładu a ograniczenia zasady wolności pracy, Poznań 1983, s. 27.

9 Chociaż w ówczesnej literaturze bardziej eksponowano kwestię określonych zachowań człowieka, wynikających z przynależności do poszczególnych grup społecznych. Por. B. Lorens, Czas wolny i formy jego spędzania w miastach polskich doby nowożytnej (XVI-XVIII wiek), [w:] Czas wolny: przeszłość - teraźniejszość - przyszłość, red. J. Daszykowska, R. Pelczar, Stalowa Wola 2009, s. 23.

10 Por. M. Truszkowska-Wojtkowiak, Fenomen czasu wolnego, Gdańsk 2012, s. 21.

11 Por. M. Jaroszewska, Urlopy wypoczynkowe, Warszawa 2009, s. 5.

12 Tłumaczony jako: czas wolny, korzystanie ze spokoju, bezczynność. Por. szerzej M. Truszkowska-Wojtkowiak, Fenomen..., s. 9 i n. 
Dla mieszkańców Aten czas ten był „nadrzędną wartością życiową”, gwarantem prawdziwej wolności, duchowego i intelektualnego rozwoju. W klasycznym ujęciu czasu wolnego, opartym w dużej mierze na poglądach Arystotelesa, staje się on immanentną częścią godziwego życia, „czasem pokoju i umiarkowania”. Jego głównym przeznaczeniem jest sztuka, udział w życiu społecznym, aktywność fizyczna oraz kontemplacja ${ }^{13}$. Ta ostatnia, zdaniem Arystotelesa, jest synonimem szczęścia ${ }^{14}$. Czas ten był jednak udziałem obywateli, a więc ludzi najlepszych, a nie mas pracujących (robotników, kupców, rolników), które, według Arystotelesa, nie wiodły szlachetnego życia i nie miały czasu wolnego. W filozofii greckiej uznaje się, że człowiek wolny powinien podjąć wszelkie możliwe środki, aby dysponować czasem wolnym według własnego uznania, ponieważ to w istocie odróżnia go od niewolnika ${ }^{15}$.

Biorąc powyższe pod uwagę, w literaturze przedmiotu ocenia się, że w ramach kultury greckiej można mówić o etosie czasu wolnego, gdyż w zasadzie wyższe formy ludzkiego bytowania były łączone $\mathrm{z}$ podejmowaniem pewnych zachowań właśnie w czasie wolnym ${ }^{16}$, niemniej czas ten był przywilejem wyłącznie wolnych obywateli.

Obok pojęcia czasu wolnego (schole), przeznaczonego na kształtowanie intelektualnej i fizycznej sprawności wolnych obywateli, pojawiało się również pojęcie zabawy (odpoczynku), której nie przypisywano jednak w ówczesnych czasach większego znaczenia, a nawet traktowano ją z pewną pogardą ${ }^{17}$. Dał temu wyraz Arystoteles, uznając, że zabawa będąca w istocie wypoczynkiem stanowi konsekwencję zmęczenia, jakie niesie za sobą praca. „Gdzie jest praca, tam musi być zabawa, bo zmęczenie wymaga wypoczynku, a ponieważ praca jest wykonywana $\mathrm{z}$ trudem i wysiłkiem, zatem zabawa istniejąca dla wypoczynku może być stosowana tylko we właściwym czasie, gdy się jej potrzebuje jako lekarstwa. Taka bowiem czynność duszy jest wytchnieniem i z powodu łączącej się z nią przyjemności - wypoczynkiem"18.

Zatem tak rozumiany odpoczynek nie był uważany przez starożytnych za szczególnie pożyteczny (ani też szkodliwy), wiązał się bowiem bezpośrednio z odtworzeniem sił zużytych w procesie pracy, która, jak wcześniej wskazano, była udziałem przede wszystkim niewolników, zajęciem nielicującym z godnością wolnego obywatela. Nie przyczyniał się zatem do doskonalenia człowieka, jego wewnętrznego rozwoju ${ }^{19}$.

Kontynuatorzy tej myśli negują zasadniczo pracę, a także potrzebę psychofizycznej regeneracji organizmu jako źródło czasu wolnego, staje się on dla nich

13 Por. M. Bombol, Czas wolny..., s. 12.

14 M. Truszkowska-Wojtkowiak, Fenomen..., s. 31.

15 Por. Arystoteles, Dzieła wszystkie, t. 6, Warszawa 2003, s. 208.

16 Por. M. Truszkowska-Wojtkowiak, Fenomen..., s. 33.

17 Por. R. Kantor, Zabawa w dobie społeczeństwa konsumpcyjnego: Szkice o ludyzmie, ludyczności i powadze, a w istocie o jej braku, Kraków 2013, s. 15.

18 Tamże.

19 Tamże. 
raczej swego rodzaju „wyższym stanem ludzkiego bytu”, niezbędnym warunkiem samorealizacji oraz zdolności pokonywania trudów życia wynikających z konieczności podejmowania pracy. Czas ten nie powinien być zatem przywilejem, jak sądzono wcześniej, jedynie wybranych grup społecznych ${ }^{20}$.

Pojęcie czasu wolnego (otium) pojawiło się również w starożytnym Rzymie. Ów czas wolny był rozumiany także w charakterystyczny sposób. Terminem tym posługiwano się bowiem do określania wszelkiej aktywności, która nie miała charakteru publicznego czy politycznego, obejmującej różne formy działalności intelektualnej, pracę literacką oraz jej wytwory ${ }^{21}$. Otia post negotia (odpoczynek po „pracy”, od zajęć stałych, obowiązków) nie był zatem utożsamiany z bezczynnością. Bardzo często ludzie wykształceni, oddający się pracy naukowej czy literackiej, czynili to właśnie w czasie wolnym, gdyż nie postrzegali tego rodzaju zajęć jako obowiązkowych ${ }^{22}$.

Ideę takiego właśnie wypoczynku czynnego propagował szczególnie Cyceron, który uznawał, że człowiek ze swej natury jest przeznaczony do rzeczy poważniejszych niż rozrywki i zabawy, a co za tym idzie powinien szukać odpoczynku duchowego w pracy naukowej ${ }^{23}$.

W praktyce występowały jednak istotne różnice między sposobem spędzania czasu wolnego przez prostego Rzymianina a człowieka dobrze urodzonego i wykształconego ${ }^{24}$.

Ponadto czas wolny łączono $\mathrm{z}$ wykonywaniem obowiązków godnych wolnego człowieka. Trzeba bowiem przypomnieć, że praca zarobkowa, podobnie jak w starożytnej Grecji, była uważana za poniżającą godność obywatela ${ }^{25}$. Między innymi powoływany już wcześniej Cyceron pisał, że kto sprzedaje swą pracę w zamian za pieniądze, $\mathrm{w}$ zasadzie stawia siebie na równi z niewolnikami ${ }^{26}$.

Tym samym owo otium wolnego Rzymianina opierało się w dużej mierze na pracy ludności zniewolonej.

Określone formy spędzania czasu wolnego obowiązywały również w późniejszych latach tzw. wyższe stany.

Naukowe podwaliny dla takiego postrzegania czasu wolnego można odnaleźć w pracach T. Veblena. Według jego słynnej koncepcji ${ }^{27}$, czas wolny jest ściśle powiązany z przynależnością do określonej klasy lub grupy społecznej. Czas wolny,

20 J. Pieper, Czas wolny jako kategoria diagnostyczna procesów rozwoju społeczno-gospodarczego, Warszawa 2008. Zob. szerzej M. Bombol, Czas wolny..., s. 12.

21 A. Wojciechowska, Otium i negotium w starożytnym Rzymie, www.wilanów-pałac.pl [dostęp 6.02.2017].

22 Por. L. Winniczuk, Ludzie i obyczaje starożytnej Grecji i Rzymu, Warszawa 2006, s. 359.

23 Czas wolny w starożytnym Rzymie, www.imperiumromanum.edu.pl [dostęp 6.02.2017].

24 Ci pierwsi spędzali często czas na rynku miejskim, w publicznych łaźniach i restauracjach, amfiteatrach, cyrku itp. Por. szerzej Czas wolny w starożytnym Rzymie...

25 Por. szerzej Z. Góral, Prawo do pracy..., s. 5 i n.

26 Cicero, O powinnościach, [w:] tenże, Pisma filozoficzne, t. 2, Warszawa 1960, s. 408.

27 Por. T. Veblen, Teoria klasy próżniaczej, Warszawa 1998. 
samo jego posiadanie i wykorzystywanie w określony sposób stały się wyznacznikiem uprzywilejowania, bogactwa, władzy, swego rodzaju papierkiem lakmusowym przynależności do danego stanu w strukturze społecznej ${ }^{28}$.

Ponadto przez bardzo długi okres, jak wskazuje się w literaturze, czas wolny był zjawiskiem bliższym środowiskom miejskim. W „tradycyjnej kulturze chłopskiej” życie wypełniała działalność produkcyjna, gospodarcza oraz obrzędowo-religijna ${ }^{29}$. Rytm pracy był zdeterminowany w dużej mierze czynnikami naturalnymi, a zwiększenie czasu przeznaczonego na pracę było jedyną możliwością zdobycia dodatkowych środków na zaspokajanie potrzeb. Czas wolny był zatem postrzegany w środowisku wiejskim jako czas stracony. Często jednak sama pracy była urozmaicana jakąś formą rozrywki (taniec, śpiew itp.). Granica między czasem wolnym a czasem pracy była w związku z tym dość płynna ${ }^{30}$. Dopiero stopniowy wzrost ludności wiejskiej podejmującej pracę zawodową poza rolnictwem spowodował częściową zmianę tej sytuacji.

Początkowo (zwłaszcza w średniowieczu) również życie mieszczan sprowadzało się przede wszystkim do pracy, której rozpoczęcie i zakończenie wyznaczały odpowiednio wschody i zachody słońca oraz godziny otwierania i zamykania bram miasta. W późniejszych latach czas pracy nadal stanowił przeważający udział w ogólnym budżecie czasu, jakim dysponowali mieszkańcy miast i w zasadzie w dni powszednie nie było okresu przeznaczonego na odpoczynek. Ten ostatni był jednak wpisany w niedziele i dni świąteczne, których liczba od drugiej połowy XV w. znacznie wzrosła. Sam sposób pojmowania czasu wolnego był jednak wówczas zgoła odmienny od współczesnego, dostosowany do panujących warunków społeczno-gospodarczych i kulturowych ${ }^{31}$. Postępująca w XIV i XV w. urbanizacja w dużej mierze przyczyniła się do wprowadzenia podziału na czas pracy i czas przeznaczony na rozrywkę. Niemniej, jak przekonuje B. Lorens, nie doszło wówczas jeszcze do wyodrębnienia czasu wolnego ${ }^{32}$.

Wypoczynek, w jego dzisiejszym, prawnym ujęciu, jest ściśle powiązany z ograniczaniem czasu pracy. Każda praca wymusza bowiem również czas niezbędny do regeneracji organizmu człowieka, zachowania i rozwoju jego zdolności do pra$\mathrm{cy}^{33}$. Słusznie przy tym zwrócono uwagę w literaturze przedmiotu, że w zasadzie współczesne pojmowanie czasu pracy (a tym samym i odpoczynku z nim związanego) zaczęło się kształtować wraz z rozwojem najmu pracy, jest zatem ściśle

28 Szerzej na temat tej koncepcji por. M. Bombol, Czas wolny..., s. 12 i n.

29 E. Wnuk-Lipiński, Budżet czasu - struktura społeczna - polityka społeczna, Wrocław 1981, s. 47 in.

30 Por. B. Lorens, Czas wolny..., s. 24.

31 Jak wskazuje B. Lorens, oceniając ówczesny stan z dzisiejszej perspektywy można odnieść wrażenie, że w okresie od XVI do XVIII w. ludność była w zasadzie pozbawiona czasu wolnego. Por. taż, Czas wolny..., s. 24 i n.

32 Tamże.

33 Por. Prawo do wypoczynku, [w:] Zagadnienia prawne Konstytucji Polskiej Rzeczypospolitej Ludowej, t. 3, red. S. Grzybowski, Warszawa 1954, s. 475. 
powiązane ze zjawiskiem rewolucji przemysłowej ${ }^{34}$. Czas wolny uznaje się więc za kategorię historyczną, która na pewnym etapie rozwoju cywilizacyjnego stała się przeciwstawieństwem dla pojęcia czasu pracy ${ }^{35}$. W pierwszym etapie owego rozróżnienia utożsamiano go jednak wyłącznie z okresem niezbędnym dla fizycznego odnowienia sił zużytych w procesie produkcji. Dopiero w kolejnych latach XX w. następuje pewna zmiana sposobu postrzegania czasu wolnego i odpoczynku jako czasu pozostawionego do dyspozycji pracownika, służącego jego psychofizycznej odnowie, ale też rozwojowi osobowości.

W literaturze brak jest jednolitej definicji czasu wolnego, różni autorzy, w ramach określonych dyscyplin naukowych, zwracają bowiem uwagę na różne jego aspekty.

Z perspektywy biologa czas wolny jest to przede wszystkim czas regeneracji organizmu.

Inaczej jest on postrzegany $\mathrm{w}$ psychologii i pedagogice, gdzie odpowiednio główny nacisk kładzie się na kwestie walki ze stresem i zmęczeniem, relaks czy podtrzymywanie więzi i nawiązywanie relacji międzyludzkich ${ }^{36}$.

Według W. Gaworeckiego, czas wolny to „czas poza pracą zawodową, pozostający do swobodnego wykorzystania na wypoczynek, uczestniczenie w zdobyczach współczesnej cywilizacji, rozwijanie zainteresowań własnych i rozrywkę" ${ }^{37}$.

Pojęcie to bywa także charakteryzowane węziej - jako „czas, który pozostaje człowiekowi do jego swobodnej dyspozycji po wykonaniu czynności związanych z zaspokojeniem potrzeb biologicznych i higienicznych (sen, jedzenie, toaleta) oraz czynności obowiązkowych (praca, nauka, obowiązki rodzinne, dojazd do pracy lub szkoły)" 38 .

W socjologicznym ujęciu czas wolny jest najczęściej definiowany jako „czas, który pozostaje człowiekowi po wypełnieniu przez niego obowiązków zawodowych, domowych i szkolnych i który jest przeznaczony na wypoczynek, rozrywkę i rozwój osobowości”’39.

Na gruncie tej definicji eksponuje się kwestię obligatoryjności określonych czynności i zachowań ${ }^{40}$.

34 Por. A. Chobot, Czas pracy..., s. 12 i n.

35 Por. R. Dyoniziak, Społeczeństwo w procesie zmian, Kraków, Szczecin, Zielona Góra 1997, s. 239.

36 M. Bombol, Czas wolny..., s. 11.

37 Za: K. Kwilecki, Rozważania o czasie wolnym. Wybrane zagadnienia, Katowice 2011, s. 9.

38 K. Przecławski, Czas wolny dzieci i młodzieży, [w:] Encyklopedia pedagogiczna, red. W. Pomykało, Warszawa 1993, za: K. Kwilecki, Rozważania o czasie..., s. 9.

39 Jest to definicja rozpowszechniona w latach 60. XX w. przez francuskiego socjologa J. Dumazediera. Za: E. Wnuk-Lipiński, Czas wolny. Współczesność i perspektywy, Warszawa 1975, s. 8.

40 Podobne poglądy prezentują J. Robinson i G. Godbey, uznając, że czas wolny to czas pozostały po wyeliminowaniu pracy zarobkowej, obowiązków domowych, czynności osobistych (np. higiena) oraz czasu przeznaczonego na dojazdy. Por. M. Bombol, Czas wolny..., s. 14. 
Wyróżnia się przy tym trzy rodzaje czasu wolnego ${ }^{41}$ :

- krótki czas wolny - odnoszony do dnia roboczego,

- średni czas wolny - realizowany w ramach weekendów,

- długi czas wolny - związany z instytucją urlopów wypoczynkowych.

Inny znany francuski socjolog G. Friedmann wprowadził z kolei podział na czas wolny i czas swobodny, dostrzegając, że człowiek wolny od pracy ma jednak określone obowiązki rodzinne, społeczne, czas po pracy nie jest zatem czasem wolnym w dosłownym tego słowa rozumieniu ${ }^{42}$. Wprowadzona przez niego odrębna kategoria tzw. czasu swobodnego miała obejmować czynności, które nie mieszczą się ani w pojęciu czasu wolnego, ani w zakresie czasu pracy.

Angielski socjolog E. Dunning dokonał z kolei wprost rozróżnienia na czas wolny i czas odpoczynku, mając na uwadze, że czas wolny obejmuje również pewien rodzaj pracy, choć niezarobkowej, natomiast odpoczynek ma być przeznaczony wyłącznie na relaks ${ }^{43}$.

Pojęcie czasu wolnego w opozycji do czasu pracy tłumaczy ogólnie L. Milian, uznając, że chodzi o czas, który człowiek wykonujący pracę zarobkową może sobie świadomie wygospodarować i w którym nie będąc poddanym obowiązkowi pracy, może „robić to, na co ma ochotę" 44 .

Zbliżoną do ostatniej koncepcję czasu wolnego przedstawił w przeszłości również W. Muszalski. Autor wyróżnił czas związany z pracą (czas pracy oraz czas dotyczący pracy, np. przeznaczony na dojazd do miejsca zatrudnienia) oraz czas poza pracą, którego jednym z elementów jest czas wolny ${ }^{45}$. Stanowi on „nadwyżkę czasu, jaka pozostaje poza czasem związanym z pracą oraz czasem potrzeb fizjologicznych i czasem obowiązku, którą każdy rozporządza stosownie do swych upodobań i zainteresowania”. Zwykle jest to czas spożytkowany na rozrywkę, rekreację, sport, kulturę itp., ale też na kształcenie czy „zajęcia typu rozwijającego” 46 .

Niewątpliwie z punktu widzenia większości przytoczonych wyżej definicji, odpoczynek jest tylko elementem czasu wolnego, który może być przeznaczany też na inne cele, np. dokształcanie. Jednocześnie ów wypoczynek, sprowadzony początkowo przede wszystkim do czasu niezbędnego do biologicznej regeneracji organizmu w celu dalszego wykonywania pracy, stał się podstawową funkcją czasu wolnego ${ }^{47}$.

41 E. Wnuk-Lipiński, Czas wolny..., s. 8.

42 Por. G. Friedmann, Maszyna i człowiek, Warszawa 1961.

43 Por. E. Dunning, O emocjach w sporcie i wypoczynku, [w:] Socjologia codzienności, red. P. Sztompka, M. Bogunia-Borowska, Kraków 2008, s. 662.

44 Za: P. Czarnek, Rodzaje rozrywki w polskiej radiofonii komercyjnej, Łódź 2014, s. 27.

45 Na czas „poza pracą” składa się, w ocenie wspomnianego autora, również czas potrzeb fizjologicznych oraz „czas obowiązku”. Por. W. Muszalski, Czas pracy i czas poza praca, [w:] Polityka społeczna, red. A. Rajkiewicz, Warszawa 1979, s. 421.

46 Tamże, s. 422.

47 Funkcje te są bardzo różnie określane i klasyfikowane. Wymienia się m.in. takie funkcje czasu wolnego jak: kulturalna, integracyjna, wychowawcza, oświatowa, kompensacyjna czy też, w innym ujęciu, np. rekreacyjna i rozwojowa. Por. szerzej K. Kwilecki, Rozważania o czasie..., s. 11 i n. Por. ponadto E. Wnuk-Lipiński, Czas wolny..., s. 44. 
W rezultacie eksploracji przeprowadzanych przez socjologów nad relacjami między pracą a wypoczynkiem ukształtowały się ostatecznie trzy zasadnicze teorie ${ }^{48}$.

Pierwsza za punkt wyjścia przyjmuje pracę. W efekcie czas wolny, w pewnym uproszczeniu, uzupełnia czas pracy. Wypoczynek pełni więc podrzędną rolę w stosunku do samej pracy, pozwala na psychofizyczną regenerację umożliwiającą ponowne podjęcie pracy.

Według drugiej koncepcji punktem centralnym staje się czas wolny. Praca pozwala jedynie na pozyskanie środków (wynagrodzenia) warunkujących możliwość godziwego odpoczynku.

Trzecia teoria zakłada, że oba te czynniki, tj. praca i czas wolny są sobie równoważne i wzajemnie się uzupełniają. Stąd poprawa warunków życia poza pracą oznacza również poprawę warunków pracy.

Reasumując, należy podkreślić, że pojęcie czasu wolnego jest bardzo niejednolite. Na potrzeby konkretnych rozważań nadaje się temu pojęciu określoną treść, akcentując te aspekty, które mają dla danej dyscypliny największe znaczenie.

Ponadto sposób postrzegania owego czasu, kształtowania pojęć z nim związanych jest mocno uzależniony od panujących w danym okresie stosunków produkcji oraz towarzyszącej im ideologii społecznej przesądzającej o obowiązującej w tym czasie hierarchii wartości społeczno-moralnych, a także propagowanym wzorcu życia ${ }^{49}$.

W prawie pracy ani pojęcie czasu wolnego, ani pojęcie wypoczynku nie zostało bezpośrednio zdefiniowane. Niemniej przeciwstawia się je pojęciu czasu pracy. Stąd w pewnym uproszczeniu można przyjąć, że wszystko co nie jest czasem pracy wchodzi do sfery czasu wolnego ${ }^{50}$. Czas pracy staje się zatem podstawowym wyznacznikiem ilości czasu wolnego. Ustawodawca przy tym zdaje się nie rozróżniać bezpośrednio pojęcia czasu wolnego od pojęcia odpoczynku, można jednak przyjąć, że odpoczynek jest podstawowym celem czasu wolnego. Ustalając maksymalne normy czasu pracy pracownika, tworzy się określoną pulę czasu wolnego (w sensie wolnego od pracy zarobkowej), w ramach którego wskazuje się dodatkowo na optymalny okres, w skali doby, tygodnia i roku, jaki powinien (w znaczeniu pewnej szansy, a nie obowiązku pracownika) zostać przeznaczony na wypoczynek. Prawnymi gwarantami tego ostatniego staje się przede wszystkim instytucja urlopów wypoczynkowych oraz okresy odpoczynku dobowego i tygodniowego.

Niemniej w doktrynie prawa pracy ów okres odpoczynku definiuje się często jako czas, który pozostaje w całkowitej dyspozycji pracownika, tj. pracownik ma pełną swobodę w zakresie decyzji dotyczącej sposobu jego wykorzystania (choć już niekoniecznie miejsca ${ }^{51}$. Podobnie, choć nieco szerzej, bywa określany jed-

48 Por. E. Wnuk-Lipiński, Czas wolny..., s. 43 in.

49 Por. J. Penc, Dialektyka podzielonego czasu, „Ruch Prawniczy, Ekonomiczny i Socjologiczny” 1985, z. 2, s. 268.

50 Pomijam instytucje szczególne, takie jak czas podróży służbowej czy okres dyżuru pracowniczego.

51 Tak por. A. Sobczyk, Zasady prawnej regulacji czasu pracy, Warszawa 2005, s. 228. 
nak współcześnie w literaturze prawniczej czas wolny - jako „okres, który pozostaje po wypełnieniu przez pracownika obowiązków zawodowych i którym może on dowolnie dysponować (wykorzystywać go) zgodnie z własnymi potrzebami i zainteresowaniami. Czas wolny jest przeznaczony na potrzeby fizjologiczne organizmu, takie jak sen, odpoczynek, spożywanie posiłków i regeneracja sił, a także na rozwój osobisty, kształtowanie osobowości, udział w życiu publicznym, rodzinnym oraz rozrywkę" 52 .

Mimo że w ostatniej definicji wymienia się wypoczynek jako część czasu wolnego, to jednak w literaturze dominuje tendencja do traktowania tych pojęć łącznie, nienadawania wymienionym terminom odmiennego znaczenia prawnego ${ }^{53}$. Pojawiała się nawet łącząca w pewnym sensie oba pojęcia koncepcja „prawa do odpoczynku od pracy” czy „prawa do wolności człowieka od pracy” ${ }^{4}$, która neguje wypoczynek jako jedyny cel prawa do odpoczynku i w ramach której akcentuje się duży zakres swobody pracownika w aspekcie sposobów i form realizacji tego prawa. Wynika to, jak się wydaje, $\mathrm{z}$ istotnych trudności nie tylko z wykazaniem dających się wyraźnie wyodrębnić różnic teoretycznych w zakresie czasu wolnego i odpoczynku (zwłaszcza wobec wskazywanego wyżej braku jednolitości w sposobie ich pojmowania), ale też praktycznych trudności z oddzieleniem sfery odpoczynku od sfery czasu wolnego, szczególnie, że różne osoby preferują różne formy wypoczynku, oraz ograniczonych możliwości kontrolowania sposobu wykorzystywania tego czasu przez pracodawcę. Łącznemu traktowaniu wskazanych pojęć sprzyjają niewątpliwie również przepisy prawa wspólnotowego, w ramach których przyjmuje się, że w zasadzie każdy okres, który nie jest czasem pracy, jest okresem odpoczynku ${ }^{55}$.

Jednocześnie warto zwrócić uwagę, że przyjęcie określonego sposobu rozumienia tego prawa może mieć w konkretnych sytuacjach znaczący wpływ na sposób interpretacji poszczególnych przepisów prawo to urzeczywistniających. Jeśli uznamy bowiem, że pracownik ma prawo do odpoczynku, w sensie „czasu wolnego od pracy”, to w ramach odpowiednich instytucji, które prawo to realizują, ustawodawca powinien stworzyć pracownikowi warunki do odpoczynku, ale kwestia skorzystania z nich lub nie staje się wyłączną sprawą zatrudnionego, co może mieć istotne znaczenie, zwłaszcza w kontekście urlopów wypoczynkowych. Jeśli natomiast prawo do odpoczynku będzie postrzegane dosłownie, wąsko, jako czas stricte przeznaczony na odpoczynek, wówczas sposób korzystania przez pracownika ze szczegółowych uprawnień składających się na to prawo musi być konsekwentnie oceniany z punktu widzenia tego celu.

52 Por. M. Jaroszewska, Urlopy wypoczynkowe..., s. 6.

53 Odpoczynek jest zwykle utożsamiany z wszelkim okresem wolnym od pracy zarobkowej, którym pracownik może swobodnie dysponować. Por. m.in. M. Nałęcz, [w:] Kodeks pracy. Komentarz, red. W. Muszalski, Warszawa 2011, s. 441. Wydaje się, że nieco inaczej postrzega tę kwestię A. Chobot, który wskazywał na „prawo do czasu wolnego i odpoczynku”. Por. tenże, Pracowniczy obowiq̨zek..., s. 107 i n.

54 Por. A. Sobczyk, Prawo pracy w świetle Konstytucji RP, t. 1: Teoria publicznego i prywatnego indywidualnego prawa pracy, Warszawa 2013, s. 197.

55 Por. szerzej m.in. M.B. Rycak, Planowanie i rozliczanie czasu pracy, Warszawa 2009, s. 31. 
Biorąc pod uwagę konstrukcję przepisów o czasie pracy i urlopach wypoczynkowych można, w mojej ocenie, wyróżnić:

- czas pracy - zgodnie z art. 128 k.p. jest to czas, w którym pracownik pozostaje $\mathrm{w}$ dyspozycji pracodawcy $\mathrm{w}$ zakładzie pracy lub $\mathrm{w}$ innym miejscu wyznaczonym do wykonywania pracy;

- czas wolny od pracy - każdy okres, który nie jest czasem pracy, w tym: okres odpoczynku dobowego, tygodniowego i rocznego.

W związku z powyższym wydaje się, że możliwa do przyjęcia jest również taka interpretacja, według której prawo do odpoczynku jest elementem czasu wolnego od pracy, jego podstawową (ale nie jedyną) formą. Nie każda instytucja prawa pracy gwarantująca czas wolny od pracy ma bowiem w założeniu cel wypoczynkowy ${ }^{56}$, np. tzw. urlopy okolicznościowe. Można chyba zatem uznać, że pojęcie odpoczynku jest pojęciem węższym w stosunku do pojęcia czasu wolnego od pracy także na gruncie prawnym. Nie oznacza to jednak, że należy je utożsamiać z pojęciem bezczynności czy celem, jak to było pierwotnie, jedynie biologicznej regeneracji organizmu. Pojęcie odpoczynku na przestrzeni lat niewątpliwie ewoluowało i współcześnie musi być postrzegane nieco szerzej - jako czas pozostawiony do dyspozycji pracownika, służący jego psychofizycznej odnowie, rozwojowi osobowości, obejmujący zarówno elementy bierne (np. sen, czas poświęcony na kontemplację itp.), jak i czynne (umiarkowany wysiłek fizyczny, np. sport, turystykę, obcowanie z przyrodą, kontakty interpersonalne).

Odróżnienie pojęcia czasu wolnego od pracy od pojęcia odpoczynku od pracy nie powoduje też, według mnie, że można mówić o prawnym obowiązku wypoczywania po stronie pracownika ${ }^{57}$. Warto zauważyć, że sam ustawodawca nie wprowadza szczególnych instrumentów, choćby w zakresie urlopów wypoczyn-

56 Jak wskazywał J. Loga, urlop wypoczynkowy różni od innych zwolnień od pracy przede wszystkim jego cel, którym jest „regeneracja sił fizycznych i duchowych pracownika zużytych w procesie pracy”, a zatem wypoczynek. Por tenże, Poglady nauki burżuazyjnej na charakter prawny urlopu wypoczynkowego, „Zeszyty Naukowe Uniwersytetu Łódzkiego” 1958, seria I, zeszyt 14, s. 53. Bardzo podobnie też W. Szubert, Zarys prawa pracy, Warszawa 1976, s. 225.

57 Tak też zob. m.in.: J. Wratny, Kodeks pracy. Komentarz, Warszawa 2013, s. 299 oraz M. Nałęcz, [w:] Kodeks pracy..., 2011, s. 441. Podobnie komentarz do art. 14 k.p., [w:] Kodeks pracy. Komentarz, red. L. Florek, Warszawa 2011. Odmienne stanowisko w tej kwestii, w kontekście prawa do odpoczynku dobowego, przedstawił K. Kulig, który przyjmuje, że zapewnienie odpoczynku dobowego ma charakter publicznoprawny, a w związku z tym sankcje za jego naruszenie powinny dotyczyć obu stron stosunku pracy. Autorowi nie chodzi jednak o samą niedopuszczalność zrzeczenia się tego prawa, ale również o obowiązek celowego jego wykorzystania. Konkluzja jest taka, że pracownik ma „obowiązek odpocząć, a nie tylko nie pracować zarobkowo". Por. tenże, Prawo pracownika do odpoczynku dobowego, PizS 2015, nr 2 , s. 16. Ten sam autor sformułowat jednak inną koncepcję w odniesieniu do pracy w niedziele i święta, uznając, że mamy w tym zakresie do czynienia z „wolnością od pracy”, którą pracownik może ograniczyć lub nawet z niej zrezygnować, tj. wręcz zrzec się prawa do wolnej niedzieli czy święta, a więc tym bardziej wykorzystać w sposób sprzeczny z ich podstawowymi funkcjami. Por. tenże, Aksjologia ,zakazu pracy” w niedziele i święta w kontekście nowelizacji Kodeksu pracy, M.P.P. 2014, nr 6, s. 298. 
kowych, które dają pracodawcy możliwość kontrolowania sposobu realizacji tego urlopu przez pracownika ani też specjalnych sankcji z tym związanych, co byłoby niewątpliwie argumentem za przyjęciem tezy o obligatoryjności wypoczynku w rozumieniu wyżej wskazanym. Wydaje się więc, że trzeba raczej rozważać prawo pracownika do wypoczynku w kontekście pewnej szansy, jaką przepisy prawa, a co za tym idzie i pracodawcy, muszą w tym zakresie stwarzać, a nie powinności, której niedopełnienie przez pracownika (w sensie realizacji ich funkcji) będzie prawnie sankcjonowane. Ideą tego prawa, jak trafnie zauważono w literaturze przedmiotu, jest bowiem raczej stworzenie dla pracownika określonej sfery „możności postępowania”, ukierunkowanej na regenerację sił fizycznych i psychicznych w związku z ich uszczupleniem wskutek wykonywanej pracy ${ }^{58}$. Jego konsekwencją jest zatem przede wszystkim powstanie roszczenia o zwolnienie z obowiązku świadczenia pracy, a nie powinność jego wykorzystania w sposób zgodny z oczekiwaniami podmiotu zatrudniającego, a zarazem udzielającego takiego zwolnienia. Tym samym pozostawiono pracownikowi szeroki margines swobody w przedmiocie decyzji odnośnie do rzeczywistego sposobu zagospodarowania czasu udzielonego na wypoczynek. Być może należałoby jednak zastrzec, że przyjęcie powyższej ogólnej konstatacji nie może też oznaczać całkowitej dowolności w sposobie korzystania przez pracownika ze swych uprawnień, zwłaszcza wykorzystywania pewnych instytucji w sposób oczywiście sprzeczny z ich przeznaczeniem (por. rozważania dotyczące urlopów wypoczynkowych), szczególnie jeśli prowadziłoby to do zagrożenia nie tylko życia i zdrowia zatrudnionego, ale też bezpieczeństwa jego współpracowników.

Swoboda dysponowania prawem do odpoczynku, o czym należy pamiętać, jest również, co do zasady, ograniczana zakazem zrzeczenia się tego prawa przez pracownika, niekiedy wprost formułowanym w przepisach regulujących poszczególne instytucje składające się na to prawo (jak np. w odniesieniu do urlopu wypoczynkowego), a czasami wywodzonym z charakteru danej instytucji oraz całokształtu regulujących ją przepisów (tak m.in. w odniesieniu do odpoczynku dobowego i tygodniowego oraz niedziel i świąt jako dni ustawowo wolnych od pracy ${ }^{59}$ ).

Z drugiej strony, trzeba, moim zdaniem, przyjąć, mimo braku definicji ustawowej, ale przy uwzględnieniu norm prawa unijnego i celu dyrektywy o czasie pracy, dalej szerzej analizowanej, że okres odpoczynku to czas, w którym pracownik pozostaje poza zakresem dyspozycji wobec pracodawcy, tj. ma pełną swobodę osobistą, swobodę decydowania o sobie i sposobie wykorzystania swojego czasu, a także, co do zasady, miejscu, w jakim to prawo będzie realizowane ${ }^{60}$. Stąd, wydaje się,

58 Por. A. Bigaj, Wybrane aspekty prawa do wypoczynku, [w:] Aktualne zagadnienia prawa pracy i polityki socjalnej (zbiór studiów), t. 2, red. B.M. Ćwiertniak, Sosnowiec 2013, s. 86 i n.

59 T. Liszcz, Kiedy pracownik nie powinien pracować, [w:] Prawo pracy. Między gospodarkq a ochrona pracy. Księga Jubileuszowa Profesora L. Florka, red. M. Latos-Mitkowska, Ł. Pisarczyk, Warszawa 2016, s. 240 i n.

60 Por. ciekawie na ten temat W. Uziak, Czas pracy - kilka uwag do dyskusji, [w:] Człowiek, obywatel, pracownik. Studia z zakresu prawa pracy, „Gdańskie Studia Prawnicze” 2007, t. XVII, s. 290 in. 
że w okresach, które są bezpośrednio przeznaczone na odpoczynek, pracodawca w żaden sposób nie może, wbrew woli pracownika, zobowiązywać go do pozostawania w stałym kontakcie z zakładem pracy, np. telefonicznym, stanowiącym swego rodzaju oczekiwanie na wezwanie (kwestia ta będzie jeszcze analizowana przy okazji omawiania problematyki odwołania pracownika $\mathrm{z}$ urlopu). Teza ta znalazła pośrednio swój wyraz w przepisach Kodeksu pracy o dyżurach. Nawet dyżur pracowniczy, o którym stanowi art. $151^{5}$ k.p., w tym tzw. dyżur pod telefonem, nie może bowiem naruszać prawa pracownika do odpoczynku dobowego i tygodniowego. Zgadzam się jednak w pełni z poglądem wyrażonym przez W. Uziaka, że podstawowa zasada prawa do odpoczynku wyrażona w art. 14 k.p. stanowi główny cel, a zarazem wytyczną, według której muszą być interpretowane przepisy o czasie pracy. A zatem, nawet jeśli jakaś kwestia nie została bezpośrednio rozstrzygnięta w tych przepisach, to nie można dokonywać ich wykładni w sposób rozszerzający sferę dyspozycyjności pracownika. W sytuacjach wątpliwych należy przyjmować interpretację najpełniej chroniącą czas wolny pracownika ${ }^{61}$.

W kontekście powyższego problematyczne, z punktu widzenia ich kwalifikacji prawnej, stają się niektóre okresy wyróżnione w polskim prawie, niezaliczane zasadniczo do czasu pracy, takie jak czas dyżuru, podróży służbowej czy okres szkoleń pracowniczych. W literaturze były formułowane różne propozycje rozstrzygnięcia pojawiających się w związku z tym wątpliwości ${ }^{62}$, szczególnie w kontekście norm unijnych oraz orzecznictwa Trybunału Sprawiedliwości UE, dalej omawianego. $Z$ punktu widzenia wyżej przyjętego rozumienia pojęcia odpoczynku, okresy te nie mogą być $\mathrm{z}$ nim zrównywane. W każdym ze wskazanych przypadków dochodzi bowiem do, mniejszego lub większego, ograniczenia swobody pracownika w zakresie dysponowania swym czasem, a niekiedy też, w przypadku dyżuru, napięcia związanego $z$ oczekiwaniem na ewentualne wezwanie. W szczególności w kontekście podróży służbowej, należy zgodzić się w pełni z poglądem, że samo przemieszczanie się pracownika na polecenie podmiotu zatrudniającego jest równoznaczne z pozbawieniem go możliwości decydowania o sposobie wykorzystania swojego $\mathrm{Czasu}^{63}$, wymusza zachowania, które potencjalnie mogą nawet potęgować zmęczenie, w zależności od warunków odbywania tej podróży. Stąd czas przeznaczony na jej odbywanie nie może być utożsamiany z okresem odpoczynku. Przy zastosowaniu powyższego kryterium, również czas szkolenia oraz dyżuru (choćby „pod telefonem”) nie może być rozważany w omawianych kategoriach.

61 Tamże, s. 290.

62 W odniesieniu do dyżuru por. np.: Z. Kubot, Pojęcie dyżuru medycznego, PiZS 2000, nr 4, s. 14 i n.; A. Chobot, Czas pracy..., s. 322. Zob. też: S. Driczinski, Elastyczność pojęcia czasu pracy, Szczecin 2002, s. 128 i n. Szerzej na temat tych okresów por. też: A. Sobczyk, Zasady..., s. 28 i n. oraz K. Stefański, Czas pracy, Warszawa 2013, s. 31 i n.

Por. W. Uziak, Czas pracy..., s. 292. 


\section{Przestanki prawnej regulacji prawa do odpoczynku i jego aksjologiczne uzasadnienie}

W literaturze przedmiotu zwrócono uwagę, że ilość i sposób korzystania z czasu wolnego stanowi jeden $\mathrm{z}$ podstawowych elementów determinujących jakość życia człowieka ${ }^{64}$. Już w zasadzie od średniowiecza w świadomości społecznej ugruntowywało się przekonanie, że to właśnie czas wolny daje możliwość podejmowania działań sprzyjających samorealizacji człowieka, rozwojowi jego osobowości, a w konsekwencji także tożsamości kulturowej poszczególnych narodów. Poszukując jednak uzasadnienia dla wprowadzenia prawa do odpoczynku, należy wskazać na kilka aspektów tego zagadnienia.

Początek XX w. przyniósł wyraźne ograniczenie długości czasu pracy, poszerzając tym samym potencjalnie zakres czasu wolnego. U podstaw tego procesu legły czynniki natury zarówno politycznej, ekonomicznej, jak i społecznej. Bardziej szczegółową ich klasyfikację zaprezentował w przeszłości M. Święcicki, według którego kwestia limitowania czasu przeznaczonego na pracę była podyktowana względami zdrowotnymi, politycznymi, techniczno-organizacyjnymi, ekonomicznymi i socjologiczno-kulturalnymi ${ }^{65}$. W jeszcze innych opracowaniach zwraca się uwage na polityczne, gospodarcze, społeczne, konstytucyjne, międzynarodowe i techniczne uwarunkowania czasu pracy ${ }^{66}$. Niezależnie od różnych kryteriów podziału przyczyn, które legły u podstaw zmniejszania dopuszczalnej liczby godzin pracy oraz dokonywanych na ich podstawie rozróżnień, wymienione czynniki są ze sobą ściśle powiązane i wzajemnie się przenikają (trudno zatem analizować np. aspekty polityczne czy społeczne omawianego zagadnienia bez uwzględnienia kwestii zdrowotnych). One też ostatecznie przyczyniły się, pośrednio lub bezpośrednio, do wyodrębnienia jednego z podstawowych dziś praw pracowniczych - prawa do odpoczynku.

Nie ulega wątpliwości, że podstawowym motywem zagwarantowania osobom pracującym prawa do odpoczynku były kwestie związane z ochroną życia i zdrowia ludzkiego, a w konsekwencji z szeroko pojętym bezpieczeństwem i higieną pracy. Chodzi przy tym o czynniki zarówno biologiczne, ochronę przed nadmierną eksploatacją organizmu, ale też łączące się z tym bezpośrednio względy bezpieczeństwa pracy - minimalizowanie ryzyka wypadku przy pracy wskutek przemęczenia pracownika. Praca ponad siły w początkowym okresie tzw. rewolucji przemysłowej, bez zagwarantowanej faktycznie i prawnie możliwości psychofizycznej regeneracji organizmu, doprowadziła do znacznego wyniszczenia całej

64 E. Wnuk-Lipiński, Czas wolny..., s. 6.

65 Por. M. Święcicki, Prawo pracy, s. 470.

66 Por. W. Sanetra, Uwarunkowania instytucji czasu pracy, [w:] Czas pracy, red. L. Florek, Warszawa 2011, s. 15 i n. 
rzeszy robotników ${ }^{67}$. Z punktu widzenia fizjologii pracy współcześnie pozostaje bezdyskusyjne, że w celu zapobieżenia pogarszaniu stanu zdrowia człowieka oraz jego sprawności w pracy konieczne jest osiągnięcie stanu równowagi pomiędzy wydatkowaniem sił $\mathrm{w}$ związku z pracą a ich regeneracją $\mathrm{w}$ okresie od tej pracy wolnym $^{68}$. Dostrzeżono to wyraźnie $\mathrm{w}$ początkach XX w., kiedy to $\mathrm{w}$ literaturze już wyraźnie wskazywano, że ograniczanie ilości pracy „to kwestia siły i zdrowia fizycznego, intelektualnego oraz moralnego społeczeństwa"69.

Samo zwrócenie uwagi ustawodawców krajowych i międzynarodowych na konieczność ograniczania czasu pracy, a tym samym poszerzania okresów potencjalnego wypoczynku była jednak, zwłaszcza na początku, podyktowana w dużej mierze czynnikami natury politycznej. Zapoczątkowana jeszcze w XIX w. krytyka doktryny liberalnej oraz roli państwa jako tzw. „nocnego stróża”"70, wzrost siły i znaczenia związków zawodowych, a co za tym idzie i wywieranej przez nie na władzach presji $^{71}$, a także propagowana idea pokoju społecznego, będąca reakcją na wzmagające się nastroje rewolucyjne, spowodowały stopniową zmianę w podejściu do problemów świata pracy, przede wszystkim w obszarze czasu pracy. Jednym z głównych postulatów robotniczych w tamtym okresie była bowiem konieczność ograniczenia dnia pracy poprzez wprowadzenie dobowych (z czasem i tygodniowych) limitów czasu pracy, co przekładało się ostatecznie również na rozszerzenie okresu wolnego od pracy. Słynne stało się hasło tzw. trzech ósemek - ośmiu godzin pracy, ośmiu godzin snu i ośmiu godzin odpoczynku ${ }^{72}$, które legło u podstaw skracania czasu pracy w okresie międzywojennym. Pod wpływem rozwijającego się ruchu związkowego stopniowo zaczęła się też kształtować zasada szeroko rozumianej wolności pracy, której ważnym elementem staje się kwestia „czynienia pracowników panami

67 Por. na ten temat W. Szubert, Zarys..., s. 21. Również M. Święcicki oceniał, że w zasadzie do końca pierwszej wojny światowej wyłącznym motywem podejmowania określonych działań w przedmiocie ograniczania czasu pracy był właśnie wzgląd na kwestię zdrowia ludności poszczególnych krajów. Por. tenże, Prawo pracy, s. 471.

68 Por. G. Lehmann, Praktyczna fizjologia pracy, Warszawa 1960, s. 42 i n. Zob. też M. Lewy, Prawo przemystowe i robotnicze, Warszawa 1918, s. 11 oraz 89 i n.

69 Por. M. Lewy, Prawo przemysłowe..., s. 156.

70 Państwo miało stać na straży bezpieczeństwa zewnętrznego i wewnętrznego, ale nie socjalnego. Por. szerzej S. Zawadzki, „Państwo dobrobytu”. Doktryna i praktyka, Warszawa 1964.

71 Właśnie skrócenia czasu pracy dotyczyły pierwsze strajki. Por. A. Chobot, Czas pracy..., s. 13. O silnym wpływie związków zawodowych na skracanie czasu pracy w XIX w. por. też J. Kuczynski, Położenie robotników w Stanach Zjednoczonych. Od roku 1789 do czasów dzisiejszych, Warszawa 1950, s. 108 i n. O ruchu tzw. czartystów w Anglii (pierwszego masowego ruchu robotników angielskich z pierwszej połowy XIX w.), głoszących m.in. hasło ośmiogodzinnego dnia pracy (ostatecznie wywalczyli oni w 1847 r. dziesięciogodzinny dzień pracy), por.: A. Szczypiorski, Czartyzm (z dziejów walk robotników angielskich o prawa polityczne), Warszawa 1925; B. Jędrzejowski, Ruch czartystów w Anglji, Warszawa 1907 oraz O. Salimowa, Walka czartystów o oświatę ludowa , „Rozprawy z Dziejów Oświaty” 1960, nr 3, s. 5.

72 Por. W. Szubert, Zarys..., s. 21. Por. też W. Landau, Ośmiogodzinny dzień pracy, Warszawa 1927, s. 4 i n. 
swojego czasu"73. Ponadto władze poszczególnych krajów, przyjmując odpowiednie regulacje prawne w zakresie czasu pracy, starały się jednak przeciwdziałać fizycznemu wyniszczeniu znacznej części społeczeństwa w związku z pracą przekraczającą granice ludzkiej wytrzymałości, co mogło ostatecznie (i tak też się działo) zagrozić szeroko pojętemu bezpieczeństwu państwa, zwłaszcza w aspekcie jego obronności. W wielu regionach Europy okazywało się bowiem, że stopień wyniszczenia nawet młodych organizmów pracą był tak duży, że nie można było przeprowadzić skutecznej rekrutacji do służby wojskowej ${ }^{74}$.

Przekonanie o niezbędności zagwarantowania osobom świadczącym pracę minimalnych okresów odpoczynku znalazło również swoje uzasadnienie ekonomiczne. Ekonomiści zwrócili uwagę, że w normalnych, prawidłowych warunkach gospodarczych musi zostać zachowana odpowiednia równowaga między czasem pracy, czasem wolnym od pracy, rozwojem gospodarczym oraz poziomem dochodów poszczególnych gospodarstw domowych. Wzrost tych ostatnich powoduje m.in. konieczność wygospodarowania określonej ilości czasu wolnego przeznaczonego na konsumpcję nabytych dóbr i usług, a zarazem na regenerację sił wydatkowanych w pracy $^{75}$.

$\mathrm{Z}$ niemal powszechną aprobatą spotkała się też teza, według której brak dostatecznej ilości czasu wolnego i odpoczynku są jedną z istotniejszych przyczyn spadku wydajności pracy człowieka ${ }^{76}$. Już w XIX w. R. Owen dowodził, że istnieje pewne optimum czasu pracy (tzw. optimum produkcyjne), które gwarantuje największą wydajność, a stanowi je ośmiogodzinny dzień pracy. W konsekwencji dłuższe zatrudnianie pracownika staje się dla pracodawcy nieopłacalne, może on bowiem liczyć na pełną wydajność pracownika tylko przez ograniczony czas (każda kolejna godzina pracy daje stosunkowo mniejszy przyrost produkcji), a nadmierne zmęczenie zatrudnionego może narazić go na poważne szkody, zwłaszcza jeśli w pracy są wykorzystywane cenne narzędzia, surowce itp. ${ }^{77}$. Wynika to ze względów fizjologicznych. Podkreśla się bowiem, że każda praca łączy się z określonym wysiłkiem, który może być podejmowany tylko przez określony czas. Po jego upływie, w związku z wyczerpywaniem się zapasu energii w organizmie ludzkim oraz gromadzeniem groźnych substancji, nasila się jego zmęczenie, obniża odporność, czego efektem jest spadek zdolności do pracy. Maleje jej intensywność i jakość, a rośnie podatność pracownika na wypadki ${ }^{78}$.

73 Por. A. Chobot, Czas pracy..., s. 13. Zob. też M. Święcicki, Prawo pracy, s. 468 i n.

74 Por. A. Chobot, Czas pracy..., s. 13.

75 E. Wnuk-Lipiński, Czas wolny..., s. 9 i n.

76 Por. m.in. M. Bombol, Czas wolny jako..., s. 7. Na ten temat też J. Kuczynski, Położenie robotników..., s. 109 oraz W. Landau, Ośmiogodzinny dzień pracy, s. 63.

77 Por. M. Święcicki, Prawo pracy, s. 469. Na temat optimum produkcyjnego czasu pracy oraz optimum społecznego por. też: W. Muszalski, Czas pracy..., s. 412. Na temat relacji między rosnącą wydajnością pracy a kwestią skracania czasu pracy por. też J. Kuczynski, Die theorie der Lager der Arbeiter, Berlin 1952, s. 293.

78 Por. J. Penc, Fizjologiczne przesłanki optymalizacji czasu pracy, „Ekonomia i Organizacja Pracy" 1977, nr 12, s. 4 i n. 
Również D. Ricardo, twórca klasycznej ekonomii politycznej, rozważał kwestię ograniczania czasu pracy i poszukiwał maksymalnego, efektywnego ekonomicznie jego wymiaru ${ }^{79}$.

Ostatecznie w literaturze poświęconej funkcjom i znaczeniu odpoczynku, rozwijanej szczególnie w połowie ubiegłego stulecia, bezspornie wykazano jego efektywność ekonomiczną. Wpływa on na wzrost wydajności pracy pojedynczego pracownika, a w konsekwencji podniesienie wydajności społecznej, zmniejsza absencję chorobową, zabezpieczając tym samym ciągłość pracy oraz obniżając jej koszty, obniża ryzyko wypadku przy pracy i związanych z tym strat, pozwala na zmniejszenie wydatków na leczenie profilaktyczne, a także podwyższanie okresu wydatkowania wysiłku w związku z przedłużeniem sprawności psychofizycznej organizmu $^{80}$.

Ponadto czas ten spożytkowany częściowo na kontakt z kulturą, nie tylko kształtuje odczucia estetyczne człowieka, ale skłaniając do „przeżywania piękna”, pociąga za sobą "produkowanie na zasadach piękna" ${ }^{21}$. Jest on również istotny z punktu widzenia zachowania prawidłowej dyscypliny pracy oraz bardziej kreatywnego jej wykonywania. Jak bowiem wskazują ekonomiści, niski poziom społecznej kultury przekłada się bezpośrednio na nie najlepszą kulturę pracy, a w rezultacie na m.in. niską jakość produkcji, brak inicjatywy, słabą dbałość o dobro pracodawcy i należyte wykonywanie swych obowiązków, wysoki wskaźnik wypadków przy pracy ${ }^{82}$.

Do ograniczania czasu pracy przyczyniło się także pośrednio zjawisko bezrobocia, szczególnie odczuwalne w okresie słynnego kryzysu gospodarczego w latach 1929-1933. Samo w sobie nie stanowi ono, co oczywiste, uzasadnienia dla zagwarantowania pracownikowi prawa do odpoczynku, niemniej im większe gwarancje prawne w zakresie tego ostatniego, tym krótszy czas pracy, a tym samym potencjalnie więcej osób potrzebnych do wykonania określonej puli zadań danego zakładu. I choć w literaturze wskazuje się, że wpływ zmniejszania rozmiarów czasu pracy na redukcję bezrobocia jest ograniczony, to jednak, zdaniem W. Sanetry, jest on na tyle duży, że nie można go lekceważyćc ${ }^{83}$. Na przykład warto przypomnieć, że kwestia walki z bezrobociem była jednym $\mathrm{z}$ istotniejszych celów przyjęcia przez MOP konwencji nr $47 \mathrm{z} 1935 \mathrm{r}^{84}$ dotyczącej skracania czasu pracy do 40 godzin tygodniowo ${ }^{85}$ czy bezpośrednią przyczyną ustanowienia we Francji w 1936 r. owego 40 -godzinnego tygodnia pracy ${ }^{86}$.

79 Por. J. Sieg, Problem cywilizacji czasu wolnego, „Śląskie Studia Historyczno-Teologiczne” 1970, nr 3, s. 97.

80 J. Penc, Dialektyka..., s. 277.

81 Tamże, s. 279 i n.

82 Tamże.

83 W. Sanetra, Uwarunkowania..., s. 22.

84 Por. konwencja nr 47 MOP z 22 czerwca 1935 r. dotycząca skracania czasu pracy do 40 godzin tygodniowo, www.mop.pl.

85 Por. Z. Góral, O kodeksowym katalogu zasad indywidualnego prawa pracy, Warszawa 2011, S. 180.

86 Por. M. Święcicki, Prawo pracy, s. 470. 
Wśród czynników o charakterze gospodarczym, które miały wpływ na prawne regulacje czasu pracy, w tym kwestie wypoczynku, należy wymienić również dążenie do wyeliminowania zjawiska nieuczciwej konkurencji. Niższe standardy w zakresie czasu pracy wpływają ostatecznie na obniżenie kosztów pracy, a w rezultacie kosztów całej produkcji, co następnie przekłada się na niższe ceny oferowanych towarów i usług. Podjęto zatem wysiłki na rzecz ujednolicenia obowiązujących w tym zakresie standardów, szczególnie w obrębie państw należących do UE.

Bardzo wiele argumentów uzasadniających konieczność zagwarantowania odpoczynku osobom świadczącym pracę dostarczają względy o charakterze społecznym. Nie ulega bowiem wątpliwości, że zapewnienie człowiekowi czasu wolnego od pracy jest podstawą nie tylko prawidłowego rozwoju jednostki, ale całego społeczeństwa. Pozwala na prawidłowe kształtowanie więzi rodzinnych, nawiązywanie relacji międzyludzkich, dbałość o zdrowie, daje możliwość samorealizacji i udziału w życiu społeczno-kulturalnym ${ }^{87}$. Nie bez znaczenia są też kwestie religijne i kulturowe - dni wolne od pracy umożliwiają odpowiednie celebrowanie świąt państwowych i kościelnych, sprzyjając m.in. większej integracji rodzinnej i społecznej.

Względy, o których wyżej mowa, bywają określane w literaturze jako tzw. optimum społeczne, które łącznie ze wskazanym wcześniej optimum produkcyjnym powinny wpływać i od około połowy XX w. wpływają na przyjęty w poszczególnych państwach powszechny wymiar czasu pracy, wyznaczając tym samym określoną sferę czasu wolnego ${ }^{88}$.

Do wzrostu roli i znaczenia prawa do odpoczynku przyczynił się niewątpliwie również gwałtowany wzrost tempa życia, a zwłaszcza samej pracy. Z badań przeprowadzonych w drugiej połowie XX w. przez Radę Europy wynika, że zmęczenie oraz stres wytwarzane przez współczesne warunki pracy oddziałują na jednostką znacznie silniej niż w przeszłości, stąd zwiększanie czasu wolnego od pracy staje się niezbędnym warunkiem dalszego prawidłowego funkcjonowania współczesnej cywilizacji ${ }^{89}$. Brak czasu niezbędnego na wypoczynek ma zatem bardzo negatywne skutki nie tylko zdrowotne, ale również ujemnie wpływa na osiągnięcia osobiste czy sposób postrzegania ludzi i świata. Jest to czas, który może być przeznaczony nie tylko na relaks, aktywność fizyczną ${ }^{90}$, ale też pogłębianie własnych zainteresowań, samorealizację, nabywanie dodatkowych umiejętności, wzmacnianie więzi rodzinnych i społecznych. Tym samym zagwarantowanie jednostce odpowiedniej ilości czasu wolnego przyczynia się w sposób istotny do podnoszenia kultury całego społeczeństwa ${ }^{91}$.

87 Au-delà de l'emploi, ed. A. Supiot, Paris 1999, s. 130 i n.

88 Por. W. Muszalski, Czas pracy..., s. 412.

89 Council of Europe, 1966, s. 5, za: E. Wnuk-Lipiński, Czas wolny..., s. 44.

90 Jak dowiedziono, właśnie ona jest najważniejszym czynnikiem determinującym stan zdrowia, jakość i długość życia ludzkiego. Aktywność ruchowa przyczynia się do zmniejszenia poziomu lęku, depresji i gniewu. Por. K. Kwilecki, Rozważania o czasie..., s. 16 i n.

91 Tamże, s. 10. 
Kwestia ta jest wyraźnie dostrzegana w literaturze, jak przekonują bowiem niektórzy autorzy, dzisiejsza organizacja pracy i życia społecznego niesie za sobą potrzebę intensywnego wydatkowania energii i sił psychicznych człowieka. Mimo wspomagającego człowieka rozwoju techniki, nowych technologii, zużywanie się ludzkich sił nie jest wcale mniejsze, przesunął się jedynie punkt ciężkości - z fizycznej wytrzymałości człowieka na jego układ nerwowy ${ }^{92}$.

Ponadto, jak słusznie zauważono, pracownik w środowisku pracy nadal nie został uwolniony od wielu występujących w nim zagrożeń, takich jak hałas, temperatura, pyły itp., czy negatywnych następstw pracy monotonnej, co istotnie nasila zmęczenie i znużenie organizmu ludzkiego. Czynniki te występowały w znacznie większym natężeniu również wcześniej, niemniej rozwój przemysłu, urbanizacja spowodowały, że coraz trudniej przebiega proces adaptacji człowieka do nowych warunków „zubożonego środowiska ekologicznego i społecznego”, a to wzmaga z kolei potrzebę odpowiedniej regeneracji sił. Stąd należycie ukształtowany okres odpoczynku uznaje się za swego rodzaju „akumulator sił witalnych człowieka”, a w konsekwencji podstawowy czynnik neutralizujący negatywny wpływ warunków życia i pracy na jego zdrowie oraz gwarant zachowania równowagi psychofizycznej ${ }^{93}$. W pracy powstają różnego rodzaju napięcia emocjonalne, które współczesny człowieka musi rozładować w czasie wolnym, m.in. poprzez kontakty ze sztuką, kulturą, przyrodą. Podnosi to, jak słusznie zauważono, na wyższy poziom jego życie duchowe, „ułatwia dostrzeganie piękna, wpływa korzystnie na kształtowanie stosunków międzyludzkich (kultura współżycia społecznego), a także twórczego stosunku do pracy i swego życia"94.

W literaturze przedmiotu już w połowie XX w. pojawiły się rozważania na temat pewnego minimum czasu wolnego, przy ustalaniu którego należy brać pod uwagę z jednej strony potrzeby pojedynczego człowieka, a z drugiej strony potrzeby szerszej zbiorowości ludzkiej ${ }^{95}$. Za jeden z głównych instrumentów jego realizacji uznano przy tym odpowiednie ograniczanie wymiaru czasu pracy.

Poszukując aksjologicznego uzasadnienia prawa do odpoczynku należy wskazać niewątpliwie na godność ludzką, która, jak się powszechnie przyjmuje, jest przyrodzona i niezbywalna i jako taka stanowi źródło praw człowieka, w tym wolności i praw pracowniczych. Potwierdza to wprost m.in. art. 30 Konstytucji RP, ale też wiele aktów prawa międzynarodowego ${ }^{96}$.

Pojęcie godności bywa jednak bardzo różnie ujmowane. W literaturze wyróżnia się godność osobową (jako wartość wrodzoną każdego człowieka), do któ-

92 Por. J. Penc, Dialektyka..., s. 276 i n.

93 Tamże.

94 Tamże, s. 280.

95 E. Wnuk-Lipiński, Czas wolny..., s. 126.

96 Konstytucja Rzeczypospolitej Polskiej z 2 kwietnia 1997 r., Dz. U., Nr 78, poz. 483, ze zm. Przepis ten stanowi, że przyrodzona i niezbywalna godność człowieka stanowi źródło wolności i praw człowieka i obywatela. Jest ona nienaruszalna, a jej poszanowanie i ochrona jest obowiązkiem władz publicznych. 
rej odnosi się właśnie wymieniony wyżej art. 30 Konstytucji RP, osobowościową (kształtowaną przez rozwój cech i właściwości osobniczych każdego człowieka), ale też godność osobistą (konkretyzującą się w poczuciu własnej wartości) ${ }^{97}$. W przeszłości podejmowano nawet próby, na ogół krytycznie oceniane ${ }^{98}$, wyodrębnienia w ramach tej ostatniej tzw. godności pracowniczej definiowanej jako „poczucie własnej wartości oparte na opinii dobrego fachowca i sumiennego pracownika"99.

Wyjaśnienie samej istoty godności jest niezwykle trudne i złożone. W różnych nurtach filozoficznych powstało bowiem bardzo wiele definicji godności ${ }^{100}$. Nie podejmując się próby precyzyjnego określenia znaczenia tego pojęcia, w dużym uproszczeniu można uznać, że stanowi ona taką właściwość wewnętrzną przypisaną każdej jednostce ludzkiej, dzięki której człowiek musi być postrzegany jako cel działania, a nie jako jego środek. Z Powszechnej Deklaracji Praw Człowieka wynika, że jest ona wewnętrzną właściwością człowieka o charakterze powszechnym, niezbywalnym i nienabywalnym ${ }^{101}$.

Rozważając godność jako źródło praw socjalnych, w doktrynie prawa pracy zaproponowano jednak powiązanie jej z pojęciem potrzeb podstawowych, rozumianym jako konieczność zapewnienia każdej jednostce ludzkiej autonomii pozwalającej człowiekowi na „dokonywanie wyborów i stawienie celów”102. Do potrzeb tych zaliczyć należy również „okresowy odpoczynek i relaks”103.

Realne poszanowanie owej godności, według A. Sobczyka, oznacza m.in. konieczność zagwarantowania każdemu człowiekowi odpowiednich warunków do samorealizacji, szans na pełny rozwój jego osobowości w danych warunkach kulturowych i cywilizacyjnych, możliwość jak najszerszego uczestnictwa w życiu społecznym. Do osiągnięcia opisanego stanu niezbędne są nie tylko środki materialne, ale także czas wolny od pracy ${ }^{104}$.

97 Por. Z. Góral, O kodeksowym katalogu..., s. 136 i n.

98 Negatywna ocena potrzeby wyodrębniania „godności pracowniczej” opiera się na słusznym, moim zdaniem, przekonaniu, że człowiek ma jedną tylko godność osobistą, która obejmuje różne elementy powiązane z pełnionymi przez niego rolami społecznymi - por. Z. Duniewska, Polisemia godności w terminologii prawnej, „Studia Prawno-Ekonomiczne” 2005, t. LXXI, s. 23.

99 Tak: J. Jończyk, Zagadnienie ochrony dóbr osobistych w prawie pracy, PiP 1963, nr 7-8, s. 818 i n.

100 Por. ciekawie o pojęciu godności m.in.: J. Mazurek, Pojęcie godności człowieka. Historia i miejsce w projektach Konstytucji III Rzeczypospolitej, „Roczniki Nauk Prawnych” 1996, t. VII, s. 5 in.

101 Przysługuje bowiem każdemu człowiekowi, niezależnie od podejmowanych działań czy okoliczności i nikt nie może się jej wyzbyć ani też zostać jej pozbawiony - tak por. M. Piechowiak, Filozofia praw człowieka. Prawa człowieka w świetle ich międzynarodowej ochrony, Lublin 1999, s. 80.

102 Tak por.: A. Sobczyk, Prawo pracy..., s. 113.

103 Tamże.

104 Por. A. Sobczyk, Prawo i człowiek pracujacy - między ochrona godności a równości, [w:] Aksjologiczne podstawy prawa pracy i ubezpieczeń społecznych, red. M. Skąpski, K. Ślebzak, Poznań 2014, s. 39 in. 
Pogląd ten wpisuje się bardzo mocno w pewną ogólną filozofię ochrony praw człowieka wynikającą z wielu aktów międzynarodowych, w ramach których godność traktuje się w sposób dynamiczny, jako cel do którego należy zmierzać poprzez jej poszanowanie i ciągły rozwój. Chodzi więc z jednej strony o ochronę owej godności, ale też stwarzanie odpowiednich warunków do jej rozwoju - do osiągnięcia pełni rozwoju osobowego ${ }^{105}$.

Problematyka odpoczynku związanego z wykonywaną pracą była również szeroko uzasadniana w niektórych doktrynach społeczno-ekonomicznych.

Kwestia godności ludzkiej jako źródła wolności i praw pracowniczych była szczególnie eksponowana w społecznej nauce Kościoła katolickiego. Jan Paweł II w liście apostolskim Dies Domini wprost wskazywał, że zagwarantowanie odpoczynku i możliwości „odprężenia” jest konieczne ze względu na ludzką godność oraz związane z nią potrzeby, zarówno religijne, jak i rodzinne, kulturowe oraz społeczne. Czas ten, wpisany, zdaniem papieża, w ludzką naturę, ma fundamentalne znaczenie z punktu widzenia osobistego rozwoju każdej jednostki ludzkiej, wszechstronnego kształtowania jej osobowości. Pozbawienie pracownika prawa do odpoczynku nie tylko godzi w niego samego, ale również w jego bliskich i stanowi istotną przeszkodę na drodze do osiągnięcia przez człowieka właściwej mu „osobowej pełni” ${ }^{106}$. Jan Paweł II w encyklice Laborem exercens wprost uznaje prawo pracownika do realizacji co najmniej odpoczynku tygodniowego oraz rocznego, związanego z urlopem wypoczynkowym, a także przypomina bardzo wyraźnie, że chociaż człowiek jest „powołany i przeznaczony do pracy”, to jednak praca jest dla człowieka, a nie człowiek dla pracy ${ }^{107}$.

Na godność człowieka jako uzasadnienie dla jego praw, m.in. w zakresie odpoczynku, wskazywali też wcześniejsi papieże, zwłaszcza Pius XII oraz Jan XXIII ${ }^{108}$. Ten ostatni w encyklice Pacem in terris ${ }^{109}$, określanej jako karta praw człowieka, do powszechnych, nienaruszalnych i niemożliwych do utracenia praw, których podstawą jest godność osoby ludzkiej, zaliczył m.in. szeroko pojęte prawo do życia, egzystencji godnej człowieka. Jego niezwykle ważną częścią, jak wynika z powołanej encykliki, jest również odpoczynek rozumiany już nie tylko jako czas fizycznie niezbędny, ale jako czas wolny od pracy, który powinien umożliwiać człowiekowi wzbogacenie swej osobowości, rozwój duchowy i intelektualny ${ }^{110}$.

105 Por. szerzej: M. Piechowiak, Filozofia praw człowieka..., s. 81.

106 Por. A. Szostek Mic, „Communio personarum” przez pracę, [w:] Jan Paweł II, Laborem exercens. Tekst i komentarze, red. J. Gałkowski, Lublin 1986, s. 159 i n.

107 Por. Z. Gładzicki, Humanizacja pracy ludzkiej w encyklice, [w:] „Powołany do pracy”. Komentarz, red. J. Krucina, Wrocław 1983, s. 278.

108 Por. W. Piwowarski, Społeczne nauczanie ojca świętego Jana Pawła II, [w:] Jan Paweł II, Laborem exercens..., s. 146.

109 Tekst encykliki zob. http://www.nonpossumus.pl/ [dostęp 30.01.2017]. Prawo do odpoczynku zostało wymienione w rozdziale I, w ramach „prawa do życia oraz godnego człowieka poziomu życia".

110 Por. F.J. Mazurek, Ochrona praw człowieka w świetle encyklik Jana XXIII, „Kościół i Prawo” 1991, t. IX, s. 10 i n. 
Kwestia godności ludzkiej jako podstawy społeczno-ekonomicznych praw człowieka znalazła również swój bezpośredni wyraz w dokumentach Soboru Watykańskiego II $^{111}$. W konstytucji duszpasterskiej o Kościele w świecie współczesnym, Gaudium et spes, konieczność zagwarantowania wypoczynku osobom pracującym staje się jednym z ważniejszych zagadnień w obszarze pracy i warunków jej wykonywania. Zwrócono przede wszystkim uwagę, że należycie zorganizowany proces pracy musi być dostosowany do potrzeb osoby ludzkiej i trybu jej życia, szczególnie domowego. Każdy pracownik powinien dysponować wystarczającym odpoczynkiem i czasem wolnym, który umożliwi mu odpowiedni udział w życiu rodzinnym, kulturalnym, społecznym i religijnym, a przede wszystkim da sposobność do swobodnego rozwijania swych sił i uzdolnień, szczególnie tych, których nie może doskonalić w pracy zawodowej ${ }^{112}$.

Warto przypomnieć, że prawo do odpoczynku, wówczas jeszcze fizycznie niezbędnego, zostało sformułowane także w pierwszej encyklice papieskiej poświęconej problemom robotniczym Rerum novarum z 15 maja 1891 r., napisanej przez Leona XIII ${ }^{113}$, a także w najbardziej znanej encyklice Piusa XI z 1931 r. Quadragesimo anno, niemniej, jak wskazują niektórzy autorzy, jego uzasadnienia upatrywano raczej w prawie naturalnym ujmowanym tomistycznie. Prawo do odpoczynku wynikało zatem z norm prawa naturalnego ${ }^{114}$. Tę koncepcję praw naturalnych eksponowała szczególnie średniowieczna myśl chrześcijańska, rozwijając w tym zakresie poglądy greckich sofistów i stoików. Jej przedstawicielem był m.in. św. Tomasz z Akwinu, który uznawał, że pewne prawa są nieodłącznym elementem natury człowieka, stąd prawo stanowione musi być zawsze wywodzone $z$ prawa pierwotnego i z nim zgodne.

Pewne wzmianki na temat ograniczania czasu pracy można odnaleźć zresztą bezpośrednio w Piśmie Świętym. Wskazuje się szczególnie w tym kontekście

111 Por. F.J. Mazurek, Jacquesa Maritaina koncepcja praw człowieka, „Kościół i Prawo” 1993, t. XI, s. 18.

112 Por. Gaudium et spes, pkt 67 - por. www.cyf-kr.edu.pl [dostęp 2.08.2016].

113 Jak wskazywał papież, „Jeśli zaś chodzi o dobra cielesne i zewnętrzne, to naprzód winno państwo wyzwolić pracowników z niewoli ludzi chciwych, którzy dla celów zysku bez miary nadużywają osób, jak rzeczy martwych. Ani sprawiedliwość, ani uczucie ludzkości nie pozwalają wymagać takiej pracy, by umysł tępiał od zbytniego trudu, a ciało upadało od zmęczenia. Sprawność ludzka, jak i cała natura ma swoje określone granice, których przekraczać nie wolno. Wzmaga się niewątpliwie przez ćwiczenie i działanie, ale pod tym warunkiem tylko, że się jej da wypoczynek i przerwę w pracy. Dlatego praca dzienna nie powinna wykraczać poza liczbę godzin dozwoloną przez siły ludzkie. W ogóle więc spoczynek winien być tak długi, jak długiego czasu trzeba na odzyskanie sił zniszczonych przez pracę; ten jest bowiem cel spoczynku, żeby odnawiał siły starte pracą. Podwójne to prawo do spoczynku jest wyraźnym lub domyślnym warunkiem, który się w każdej umowie o pracę między pracodawcą a pracownikiem mieści". Por. encyklika Leona XIII, Rerum novarum, www.nonpossumus.pl [dostęp 17.02.2016].

114 W. Piwowarski, Społeczne nauczanie..., s. 146. Chociaż część autorów wskazuje, że także np. Pius XI odwoływał się expressis verbis do godności osoby ludzkiej jako źródła praw człowieka. Por. F.J. Mazurek, Katalog praw człowieka w dokumentach społecznego nauczaniu Kościoła, „Kościół i Prawo” 1998, t. XIII, s. 83. 
na Stary Testament - Księgę Wyjścia, z której wynika zakaz żądania od ludzi pracy po zachodzie słońca, a także kładzie się wyraźny nacisk na zagwarantowanie dnia wolnego od pracy („odpoczynku sobotniego”) ${ }^{115}$.

Wyraźne odrodzenie koncepcji praw naturalnych, jako źródła praw człowieka, miało miejsce również w epoce renesansu. Przedstawiciele nowej szkoły prawa naturalnego, tacy jak Thomas Hobbes, czy John Locke, opierali swą koncepcję na idei wolności należnej każdemu człowiekowi z racji tego, że jest człowiekiem, a nie z powodu jego pochodzenia, przynależności do określonego stanu, abstrahując przy tym od właściwego średniowiecznej filozofii tzw. prawa odwiecznego, prawa pochodzącego od Stwórcy ${ }^{116}$. Dość ważne dla późniejszego rozwoju praw społecznych, takich jak m.in. prawo do odpoczynku, było przeświadczenie reprezentantów wspomnianej szkoły, że stanem naturalnym jest stan, w którym każdy ma możliwość korzystania z przynależnych jego człowieczeństwu praw, takich jak prawo do życia, wolności i równości ${ }^{117}$. Zdaniem J. Locke’a, „[...] skoro wszyscy są równi i niezależni, nikt nie powinien wyrządzać drugiemu szkód na życiu, zdrowiu, wolności [...] każdy, tak jak jest zobowiązany do zachowania siebie samego, powinien także, według swych możliwości, zachować resztę rodzaju ludzkiego"118. I chociaż faktem jest, że wówczas jeszcze eksponowano przede wszystkim wolność jednostki od tyranii czy ingerencji władzy, ograniczania swobody działania, a nie „Wolność od konieczności”, to postulaty reprezentantów szkoły prawa naturalnego wywarły bardzo duży wpływ na publiczną dyskusję w kwestii ochrony praw człowieka, a z czasem także na ustawodawstwo wielu państw. Stopniowo następuje zmiana sposobu postrzegania praw człowieka i godność zaczyna być odnoszona nie tylko do „etosu samodzielnej jednostki”, ale również podstawowych potrzeb życiowych człowieka ${ }^{119}$, w tym prawa osób pracujących do odpoczynku.

W oświeceniowej koncepcji praw człowieka istotnym argumentem, odwołującym się do postulatów równościowych, jest też kwestia sprawiedliwości społecznej, widoczna szczególnie w poglądach J.J. Rousseau, który odnosił ją nie tylko do sfery politycznej, ale również społeczno-ekonomicznej ${ }^{120}$. Pośrednio dla ideowych źródeł prawa do odpoczynku nie bez znaczenia jest sformułowana przez niego teza, według której „umowa społeczna ustanawia między obywatelami taką równość, że wszyscy zobowiązują się pod tymi samymi warunkami i wszyscy powinni korzystać z tych samych praw” oraz że „każdy człowiek ma prawo do wszystkiego, co jest mu niezbędne"121.

Pod silnym wpływem filozofii Rousseau pozostawało wielu twórców XVIII-wiecznych utopii społecznych, wyrosłych na gruncie krytyki przedkapitalistycz-

115 Por. J. Majka, Katolicka nauka społeczna, Warszawa 1988, s. 42.

116 S. Ruchała, Współczesne filozoficzne spory o ugruntowanie praw człowieka, Katowice 2006, S. 18.

117 Tamże, s. 19.

118 J. Locke, Dwa traktaty o rzqdzie, tłum. Z. Rau, Warszawa 1992, s. 165.

119 S. Ruchała, Wspótczesne filozoficzne spory..., s. 131.

120 Por. A. Peretiakowicz, Filozofia społeczna J.J. Rousseau, Poznań 1921, s. 41 i n.

121 Por. J.J. Rousseau, Umowa społeczna, Warszawa 1966, s. 28 i n. 
nych stosunków produkcji, w których kwestia ograniczenia czasu poświęcanego na pracę była już dość wyraźnie zarysowywana. Dotyczy to m.in. G. Babeufa, którego teorie z kolei, jak się ocenia, wywarły wpływ na wszystkie ruchy socjalistyczne XIX i XX w. ${ }^{122}$. Uznawał on, że trzeba zbudować nowe społeczeństwo - społeczeństwo równych, w którym praca jest obowiązkiem każdego według posiadanych zdolności, ale w którym „wszyscy będą jednocześnie producentami i konsumentami w takim stosunku ażeby wszystkie potrzeby były zaspokajane, ażeby nikt nie cierpiał nędzy ani nie znał przepracowania”, w którym wszystko opiera się na równowadze i kompensacie ${ }^{123}$. W sprawiedliwym społeczeństwie, którego wizję kreował Babeuf, należy położyć kres sytuacji, w której, jak to sam określał, większość jest „stadem, które się strzyże do skóry, które się zarzyna. [...] pracuję szczerze i spokojnie i robię tylko tyle, ile człowiek może robić bez szkody dla własnego organizmu"124.

Prawo pracownika do odpoczynku należy niewątpliwie do praw o dynamicznym charakterze, tj. takich, które zmieniają się i rozwijają wraz z ewolucją stosunków społecznych, pojawianiem się nowych wyzwań cywilizacyjnych. Nie może zatem dziwić, że odpoczynek w związku z wykonywaną pracę zarobkową został wysunięty na pierwszy plan w komunistycznej doktrynie praw człowieka, która generalnie prawa społeczno-ekonomiczne traktowała jako materialny gwarant praw i wolności politycznych i której kolektywistyczne podejście sprzyjało rozwojowi tychże praw lepiej niż ideologia indywidualistyczno-liberalna oparta na kulcie wolności jednostki. Doktryna ta negowała jednak ideę praw natury oraz przyrodzonej godności ludzkiej, opierając prawa pracownicze na szczególnej pozycji państwa komunistycznego, jako wyłącznego suwerena ${ }^{125}$. Marksiści, doceniając zasadniczo wartość samej pracy jako czynnika rozwoju człowieka i podstawę rozwoju cywilizacyjnego, próbowali wyeksponować też znaczenie odpoczynku, który w przeszłości bardzo często utożsamiano z lenistwem czy stratą czasu. Rozważali go jednak zwykle w kategoriach czynnika niezbędnego do regeneracji sił koniecznych w procesie produkcji. Podobnie zresztą jak pozostający w opozycji do ideologii socjalistycznej liberałowie, którzy również mieli świadomość braku niezbędnego minimum w zakresie czasu wolnego ${ }^{126}$.

Takie podejście do problematyki czasu wolnego bywało zresztą już w XIX w. mocno krytykowane, zwłaszcza na gruncie filozofii. Między innymi F. Nietzsche podkreślał, że utrata rzymskiego spojrzenia na czas wolny stanowi jedną z największych bolączek tamtego stulecia. Czas ten zatracił bowiem swe pierwotne znaczenie, został zdominowany poprzez pracę i przestał być „czasem dla mnie”, a stał się „momentem reprodukcji mojej siły roboczej, odpoczynkiem włączonym organicznie w rytm pracy"127.

122 Por. G. Babeuf, Pisma wybrane, przedmowa i komentarz G. i C. Willard, Warszawa 1951, s. 23 i n.

123 Tamże, s. 91.

124 Tamże, s. 94.

125 Por. A. Soltys, Prawa człowieka, http://bip.ms.gov.pl [dostęp 2.02.2017].

126 Por. M. Truszkowska-Wojtkowiak, Fenomen czasu..., s. 7.

127 Za: J. Majmurek, Prawo do pracy, prawo do lenistwa, www.krytykapolityczna.pl [dostęp 6.02.2017]. 
Sam K. Marks wskazywał na wyraźną antynomię pracy i wolności. Ta ostatnia zaczyna się, według niego, tam, gdzie kończy się praca, którą „dyktuje nędza i konieczność zewnętrzna"128. Receptą jest wysoko rozwinięte społeczeństwo komunistyczne, w którym każdy człowiek będzie miał pełną możliwość samorealizacji, swobodę w decydowaniu nie tylko o rodzaju i miejscu pracy, ale też o czasie jej wykonywania, w którym zostaną stworzone właściwe warunki dla zharmonizowania pracy zawodowej z życiem prywatnym ${ }^{129}$.

W ekonomii marksistowskiej, rozwijanej w państwach socjalistycznych, za wyznacznik optymalnej długości czasu pracy przyjmowano kryterium społecznej efektywności produkcji. Optimum czasu pracy było zatem zasadniczo charakteryzowane jako „wielkość dziennej lub tygodniowej normy trwania pracy, przy której występuje najwyższa społeczna efektywność produkcji"130. Chodziło więc o wypracowanie takich norm czasu pracy, które będą możliwie najkorzystniejsze nie tylko z punktu widzenia aktualnych potrzeb społeczeństwa, ale też zapotrzebowania przyszłego, m.in. w zakresie oświaty, kultury czy rozszerzania sfery wypoczynku (w praktyce najczęściej niejako „z automatu” uznawano, że takie optimum realizują przyjęte przez państwo przepisy w zakresie czasu pracy, które urzeczywistniają konstytucyjne prawo do odpoczynku) ${ }^{131}$. Nie zawsze jednak, jak przekonuje J. Penc, było to założenie w pełni słuszne.

W myśli socjalistycznej nie brakowało jednak i skrajnych postaw, które negowały obowiązek pracy na rzecz dowartościowania czasu wolnego od pracy. Czołowym przedstawicielem tego kierunku był P. Lafargue. Uznawał on, że źródłem wszelkich nieszczęść w społeczeństwie kapitalistycznym jest wiara w etos pracy. Jak pisał Lafargue w 1883 r., „wszystkie indywidualne i społeczne niedole zrodziły się z pasji człowieka do pracy"132. Propagował potrzebę przekonania proletariatu, że praca $\mathrm{w}$ obecnej postaci jest zaprzeczeniem praw natury i że powinna stać się jedynie „przyjemnym dodatkiem do lenistwa, dobrym ćwiczeniem dla organizmu ludzkiego i pasją użyteczną dla organizmu społecznego", a żeby to osiągnąć, należy docelowo ograniczyć ją do trzech godzin dziennie ${ }^{133}$. Do momentu osiągnięcia owego poziomu, co, jak sam autor dostrzegał, będzie sprawą bardzo trudną, należy czas pracy możliwie skracać. W ograniczaniu godzin pracy na rzecz poszerzania sfery czasu wolnego widział P. Lafargue skuteczny instrument walki $\mathrm{z}$ wieloma bolączkami kapitalistycznego systemu produkcji, w tym m.in. brakiem zbytu na towary, ale przede wszystkim z pojawiającym się systematycznie bezro-

128 Por. K. Marks, Kapitat, t. 3, cz. 2, Warszawa 1959, s. 400 i n.

129 Zdaniem Marksa i Engelsa, należy stworzyć taki system społeczny, który umożliwi ludziom robienie tego, na co mają akurat ochotę. Zob. K. Marks, F. Engels, Dzieła, t. 3, Warszawa 1967, s. 35.

130 Por. J. Penc, Dialektyka..., s. 284.

131 Tamże.

132 Por. P. Lafargue, Prawo do lenistwa, Warszawa 2006, s. 4 i n.

133 Tamże, s. 9. 
bociem ${ }^{134}$. Wspomniany autor przekonywał ponadto, powołując się na przykłady i wypowiedzi konkretnych właścicieli fabryk, że zmniejszenie godzin pracy nie musi oznaczać spadku produkcji. Przeciwnie, zdaniem Lafargue’a, dla zwiększenia wydajności pracy ludzkiej należy bezwzględnie zredukować liczbę godzin pracy i zwiększyć liczbę wolnych dni płatnych oraz świąt ${ }^{135}$. Pisał on: „[...] Czyż robotnicy nie mogą zrozumieć, że przemęczając się nadmierną pracą, wyczerpują siły swoje i swego potomstwa i przed czasem stają się niezdolni do jakiejkolwiek pracy, że otumanieni jedną namiętnością przestają być ludźmi i stają się cieniami; że zabijają w sobie wszystkie wspaniałe zdolności, by zachować w stanie kwitnącym tylko szaloną namiętność do pracy?"136.

Cytowany wyżej P. Lafargue nie był w swym podejściu do kwestii pracy i czasu od niej wolnego odosobniony. Również inny socjalista, G. Deborad już w XX w. doszedł do jeszcze bardziej radykalnego przekonania, że prawdziwe wyzwolenie człowieka może nastąpić wyłącznie poprzez uwolnienie go od pracy ${ }^{137}$, szczególnie w postaci, jaką przybrała ona w kapitalizmie, prowadząc do gwałtownego wyobcowania człowieka i wynaturzenia stosunków społecznych. Wyodrębnił on w swych rozważaniach tzw. czas pseudocykliczny - „czas konsumpcji nowoczesnego przetrwania ekonomicznego, przetrwania rozszerzonego, w którym ludzie w swej codziennej egzystencji nie mają mocy podejmowania decyzji i podlegają już nie porządkowi naturalnemu, lecz pseudonaturze będącej wytworem wyobcowanej pracy"138. Naśladuje on jedynie, zdaniem wspomnianego autora, naturalny rytm życia, tworząc charakterystyczne dla siebie nowe warianty, w postaci m.in. pracy i weekendowego odpoczynku, okresowych wakacji ${ }^{139}$.

Nurt ten, choć nie należał do głównych, stał się, jak można przypuszczać, w pewnej mierze zalążkiem nowego spojrzenia na charakter pracy w życiu człowieka oraz wartość czasu przeznaczonego na wypoczynek, co znalazło swój wyraz

134 Jak pisał P. Lafargue, „[...] Rokrocznie we wszystkich gałęziach przemysłu bezrobocie zjawia się z regularnością pór roku. Po morderczej, szkodliwej dla organizmu, nadmiernej pracy następuje absolutny odpoczynek, trwający od trzech do sześciu miesięcy - a bez pracy nie ma chleba. Ponieważ żądza pracy jest głęboko zakorzeniona w sercu robotnika, ponieważ zagłusza ona wszystkie inne jego instynkty, ponieważ ilość pracy, której domaga się społeczeństwo, ograniczona jest konsumpcją i ilością surowców, dlaczegóż więc pracę całego roku ma się pochłaniać w ciągu sześciu tylko miesięcy? Dlaczego nie rozdzielić jej równomiernie na dwanaście miesięcy i nie zmusić robotnika, by zadowalał się pięcioma lub sześcioma godzinami pracy dziennie przez cały rok? W ten sposób uniknęłoby się niestrawnych, dwunastogodzinnych porcji dziennie w ciągu tych sześciu miesięcy. Mając zapewnioną codzienną pracę, robotnicy nie będą sobie nawzajem zazdrościć, nie będzie więcej waśni między nimi o pracę i chleb. A wtedy - rześcy na ciele i umyśle - poczną praktykować cnoty lenistwa". Zob. P. Lafargue, Prawo..., s. 14 i n.

135 Tamże, s. 15.

136 Tamże.

137 Por. J. Majmurek, Prawo do pracy...

138 Por. G. Deborad, Społeczeństwo spektaklu, „Panoptikum” 2008, nr 7, s. 91.

139 Tamże. 
zarówno w koncepcjach teoretycznych kształtowanych w połowie XX w., jak i w dokumentach prawnych. Wraz z rozwojem cywilizacyjnym i technologicznym, a także zmianami w świadomości społecznej w XX w. następowało bowiem systematyczne upowszechnianie się czasu wolnego ${ }^{140}$. Towarzyszyła temu, jak wskazują niektórzy autorzy, zmiana w podejściu do relacji czas pracy - czas odpoczynku. Obserwuje się bowiem, w ocenie D. Riesmana, wraz z rozwojem społeczeństwa konsumpcyjnego, odchodzenie od dominującego do drugiej połowy ubiegłego stulecia „modelu człowieka pracy”, tj. postrzegania pracy jako podstawy, istoty życia ludzkiego, na rzecz „modelu człowieka zabawy”, dla którego niezmiernie ważna staje się „konsumpcja dóbr rozrywkowych” ${ }^{141}$. W rezultacie już w latach 80 . ubiegłego stulecia zaobserwowano nasilenie się dążeń do rozszerzania sfery czasu wolnego od pracy zarobkowej jako obszaru zaspokajania różnorodnych potrzeb bytowych i podnoszenia jakości życia, i traktowania ustawowego ograniczania wymiaru czasu pracy jako potrzeby społecznej ${ }^{142}$.

W wyniku zachodzących zmian, z biegiem lat, zwłaszcza w literaturze socjologicznej czy z zakresu fizjologii pracy, prawo do odpoczynku zaczyna się jawić jako jedno z praw podstawowych. Szczególne jego znaczenie podkreślał m.in. w połowie XX w. G. Friedmann, który wprost wskazywał, że na tę kwestię powinno się kłaść największy nacisk, czas ten sprzyja bowiem samorealizacji i osiąganiu równowagi psychicznej ${ }^{143}$.

Niezależnie od wyżej prezentowanych różnych sposobów ujęcia i uzasadnienia prawa do odpoczynku i czasu wolnego od pracy, nie ma wątpliwości, że współczesna koncepcja praw człowieka opiera się na przekonaniu, że skuteczna realizacja praw politycznych i wolności obywatelskich, w tym tak podstawowych jak prawo do życia, szeroko pojętej wolności ${ }^{144}$, ochrony zdrowia, wymaga zagwarantowania również praw o społeczno-ekonomicznym charakterze. Jednym $\mathrm{z}$ takich praw jest niewątpliwie prawo do odpoczynku, które w sposób wyraźny wpisuje się w wymienione wyżej fundamentalne wartości. Nie ulega bowiem wątpliwości, że każda praca wymaga czasu niezbędnego do co najmniej psychofizycznej regeneracji organizmu, odtworzenia sił w niej zużytych, co bezpośrednio przekłada się na kondycję całego organizmu. Jak pokazały doświadczenia XIX w., a także całkiem współczesne przypadki „śmierci z przepracowania” występujące szczególnie w krajach azjatyckich, brak odpoczynku stanowi bardzo poważne zagrożenie dla życia i zdrowia zarówno samego zatrudnionego, jak i współpracujących z nim osób. Każdy człowieka ma jednak także prawo do wolności, w tym wolności

140 Por. P. Czarnek, Rodzaje rozrywki..., s. 28.

141 Tamże. Por. też R. Kantor, Zabawa..., s. 11.

142 Por. J. Penc, Dialektyka..., s. 271.

143 Por. G. Friedmann, Maszyna i człowiek, Warszawa 1961.

144 Jak wskazuje się w literaturze przedmiotu, maksymalizacja wolności jest obok godności zasadniczym celem ochrony praw człowieka. Por. M. Piechowiak, Filozofia praw człowieka..., s. 93. 
od pracy, życia prywatnego, kultywowania dni świątecznych, czasu niezbędnego na samorealizację, którym może swobodnie dysponować itd. Tym samym prawo do odpoczynku staje się z jednej strony pochodną prawa do ochrony życia i zdrowia, wolności czy prawa do ochrony życia prywatnego sensu largo, czerpie z nich swoje uzasadnienie, ale $\mathrm{z}$ drugiej stanowi bardzo ważnych gwarant ich faktycznej realizacji.

\section{Prawo do odpoczynku jako jedno z podstawowych praw człowieka}

\subsection{Prawo do odpoczynku w prawie międzynarodowym}

\subsubsection{Akty o charakterze uniwersalnym}

Współcześnie prawo do odpoczynku, realizowane przede wszystkim poprzez uregulowanie czasu pracy i prawo do urlopów wypoczynkowych, stanowi niekwestionowany standard ochrony praw pracowniczych. Niemniej na przestrzeni wieków przeszło ono bardzo wyraźną ewolucję. Początkowo podejmowano przede wszystkim wysiłki na rzecz ograniczenia dobowej i tygodniowej normy czasu pracy osób wykonujących pracę zarobkową ze względu na ich zdrowie i bezpieczeństwo. Chodziło więc o odpoczynek fizycznie niezbędny. Okazało się bowiem, że liberalizm ekonomiczny, silnie oddziałujący w pierwszym okresie kształtowania się pracy najemnej na życie społeczno-gospodarcze, stał się, jak wcześniej wskazano, źródłem wielu negatywnych zjawisk i zagrożeń. Wobec ujawniających się stopniowo zgubnych skutków niczym nieograniczonej wolności gospodarczej, żywiołowego działania praw rynkowych, nędzy, narastających konfliktów społecznych, a także rozwoju ideologii socjalistycznej i wynikających stąd niebezpieczeństw już w połowie XIX w. sami zwolennicy liberalizmu podjęli pierwsze próby modyfikacji jego dotychczasowych, podstawowych założeń. Powoli zaczął krystalizować się pogląd negujący towarowy charakter pracy i przedmiotowe podejście do osób ją wykonujących.

W ślad za wskazanymi zmianami pojawiają się w pierwszych latach XX w. rozwiązania o charakterze międzynarodowym, których celem jest wyraźne zredukowanie godzin pracy. Na początku zajęła się tą problematyką przede wszystkim Międzynarodowa Organizacja Pracy, której pierwsza konwencja MOP z 1919 r. była poświęcona właśnie temu zagadnieniu, tj. ograniczeniu czasu pracy w przemyśle do ośmiu godzin dziennie i 48 godzin tygodniowo ${ }^{145}$. W kolejnych aktach

145 Konwencja nr 1 MOP z 29 października1919 r. dotycząca ograniczenia czasu pracy do ośmiu godzin dziennie i 48 godzin tygodniowo w zakładach przemysłowych, www.mop.pl. Por. szerzej A.M. Świątkowski, Międzynarodowe prawo pracy, t. 1, Warszawa 2008, s. 381 i n. 
tej organizacji, z uwagi na konieczność ochrony zdrowia i bezpieczeństwa zatrudnionych, ograniczono pracę osób młodocianych i dzieci, a w latach 30. XX w. wprowadzono regulacje dotyczące czasu pracy w handlu i biurach ${ }^{146}$, ograniczając go zasadniczo również do ośmiu godzin dziennie i 48 godzin tygodniowo (art. 3 konwencji) oraz konwencję mającą na celu skracanie czasu pracy do 40 godzin tygodniowo ${ }^{147}$, która miała też pomóc $\mathrm{w}$ walce $\mathrm{z}$ bezrobociem ${ }^{148}$.

Uznanie prawa do odpoczynku było wreszcie bezpośrednim motywem wydania przez MOP w 1921 r. konwencji nr 14 o odpoczynku tygodniowym w zakładach przemysłowych ${ }^{149}$, w której szczególne znaczenie ma zasada cykliczności i nieprzerywalności takiego odpoczynku ${ }^{150}$, oraz konwencji nr 106 z 1957 r. o cotygodniowym odpoczynku w handlu i biurach ${ }^{151}$.

Z konwencji nr 14 wynika prawo wszystkich zatrudnionych w zakładach przemysłowych, niezależnie od tego, czy są one państwowe czy prywatne, do nieprzerwanego 24-godzinnego odpoczynku w każdym siedmiodniowym okresie. Zgodnie z postanowieniami konwencji, odpoczynek ten powinien być $\mathrm{w}$ miarę możliwości udzielany jednocześnie całemu personelowi danego zakładu i przypadać w dniu „uświęconym przez tradycję lub zwyczaj” danego kraju lub regionu. Konwencja dopuszcza jednak, w ramach wyjątków, możliwość ograniczenia owego prawa przez ustawodawców krajowych (włącznie z jego zawieszeniem), wziąwszy pod uwagę wszelkie stosowne względy, w tym ekonomiczne i humanitarne, oraz po zasięgnięciu opinii właściwych organizacji pracodawców i pracowników, jeśli takie istnieją. Ponadto pozwala się na wyłączenie wspomnianej zasady w odniesie-

146 Konwencja nr 30 MOP z 28 czerwca 1930 r. dotycząca uregulowania czasu pracy w handlu i w biurach, www.mop.pl. Zdefiniowano w niej też pojęcie czasu pracy - jest to czas, którym pracownik nie może swobodnie dysponować i gospodarować. W jego zakres nie wchodzą okresy odpoczynku, w których pracownik nie pozostaje do dyspozycji pracodawcy. Podkreśla się jednak, że tego rodzaju okresy będą wliczane do czasu pracy, gdy pracownik pozostaje do dyspozycji pracodawcy, nawet jeśli nie świadczy pracy. Por. A.M. Świątkowski, Międzynarodowe prawo..., s. 399.

147 Konwencja nr 47 MOP z 22 czerwca 1935 r. dotycząca skracania czasu pracy do 40 godzin tygodniowo, www.mop.pl. Wyznaczała ona tym samym pewien standard, do którego należało zmierzać. W połowie XX w. w większości krajów tygodniowy wymiar czasu pracy mieścił się w przedziale 40-48 godzin. Z badań przeprowadzonych w latach 70. XX w. przez Komisję Ekspertów wynikało jednak, że w wielu państwach wymiar ten uległ skróceniu przeciętnie o cztery godziny (a niekiedy nawet osiem). Por. L. Florek, M. Seweryński, Międzynarodowe prawo pracy, Warszawa 1988, s. 204 i n.

148 Por. Z. Góral, O kodeksowym katalogu..., s. 180.

149 Konwencja nr 14 MOP z 17 listopada 1921 r. o odpoczynku tygodniowym w zakładach przemysłowych, Dz. U. 1925, Nr 54, poz. 384.

150 Por. Z. Góral, O kodeksowym katalogu..., s. 180. Zob. też L. Florek, M. Seweryński, Międzynarodowe prawo..., s. 206.

151 Konwencja nr 106 MOP z 5 czerwca 1957 r. dotycząca cotygodniowego odpoczynku w handlu i w biurach, www.mop.pl. Regulowano też czas pracy i odpoczynku wybranych kategorii pracowników, np. zatrudnionych w transporcie drogowym, na statkach czy pracowników plantacji. Por. A.M. Świątkowski, Międzynarodowe prawo......, s. 377 i n. 
niu do zakładów, w których są zatrudnieni tylko członkowie tej samej rodziny ${ }^{152}$.

Analogiczną regułę w zakresie prawa do odpoczynku tygodniowego wprowadzono następnie do znacznie późniejszej konwencji nr 106 MOP. W niej również zagwarantowano wszystkim osobom objętym jej postanowieniami (zakres ten precyzuje art. 2 i 3 konwencji) prawo do cotygodniowego okresu odpoczynku obejmującego co najmniej 24 kolejne godziny w każdym okresie siedmiodniowym, z zachowaniem wymienionych wyżej zasad jego udzielania. Dodatkowo zwrócono jedynie uwagę na potrzebę uwzględnienia, w miarę możliwości, tradycji i zwyczajów mniejszości wyznaniowych.

Nieco inny, bardziej szczegółowy w porównaniu z treścią konwencji nr 14, jest katalog wyjątków sformułowany w konwencji nr 106. Odróżniono w niej modyfikację systemu odpoczynku tygodniowego od dopuszczalności jego ograniczenia ${ }^{153}$.

Przede wszystkim gwarantuje się możliwość wprowadzenia w prawie wewnętrznym poszczególnych państw alternatywnych form wypoczynku tygodniowego w sytuacji, gdy jest to uzasadnione rodzajem pracy lub liczebnością obsługiwanej ludności czy stanem załogi. Art. 7 konwencji wyraźnie stanowi, że gdy rodzaj pracy, rodzaj usług świadczonych przez zakład, liczebność obsługiwanej ludności lub liczba osób zatrudnionych nie pozwalają na stosowanie wcześniej opisanych reguł, właściwa władza lub odpowiedni organ w każdym kraju, po konsultacji z reprezentatywnymi organizacjami zainteresowanych pracodawców i pracowników, jeżeli takie istnieją, będą mogły zastosować środki w celu poddania w razie potrzeby określonych kategorii osób lub określonych zakładów, objętych zakresem działania tej konwencji, specjalnym systemom odpoczynku cotygodniowego, biorąc pod uwagę wszelkie istotne względy społeczne i gospodarcze.

Jednocześnie zastrzega się, że osoby objęte tymi specjalnymi systemami powinny mieć prawo do odpoczynku za każdy siedmiodniowy okres o łącznej długości co najmniej równorzędnej z okresem odpoczynku ustalonym na zasadach ogólnych ${ }^{154}$. Jego odmienność polega zatem na możliwości legalnej kumulacji okresów odpoczynku, które z wymienionych wyżej względów nie mogą być cotygodniowo realizowane ${ }^{155}$.

Ponadto $\mathrm{z}$ art. 8 omawianej konwencji wynika, że tymczasowe, całkowite lub częściowe odstępstwa od jej wcześniejszych postanowień (łącznie z zawieszeniem lub skróceniem odpoczynku) mogą być wprowadzone w każdym kraju bądź przez właściwą władzę, bądź w jakimkolwiek innym trybie zatwierdzonym przez właściwą władzę, zgodnie z ustawodawstwem i praktyką krajową:

152 Komitet do spraw Stosowania Konwencji i Zaleceń MOP interpretuje jednak ten przepis ściśle. Neguje się w szczególności wyłączenie spod omawianej regulacji osób na stanowiskach kierowniczych, zatrudnionych na część etatu czy w małych zakładach pracy. Por. tamże, s. 409.

153 Por. L. Florek, M. Seweryński, Międzynarodowe prawo..., s. 206.

$154 \mathrm{Z}$ zalecenia $\mathrm{nr} 103$ MOP o wypoczynku tygodniowym w handlu i biurach wynika, że w żadnym razie nie powinien on być krótszy niż 12 nieprzerwanych godzin. Por. tamże, s. 207.

155 A.M. Świątkowski, Międzynarodowe prawo..., s. 413. 
a) w razie wypadku, zaszłego lub grożącego, i w razie siły wyższej lub konieczności wykonania pilnych prac przy instalacjach, ale jedynie w stopniu koniecznym do uniknięcia poważnego zakłócenia normalnego funkcjonowania zakładu;

b) w razie nadzwyczajnego nadmiaru pracy, wywołanego szczególnymi okolicznościami, jeżeli nie można normalnie oczekiwać od pracodawcy zastosowania innych środków;

c) dla zapobieżenia stracie towarów ulegających zepsuciu.

Konwencja stanowi jednak, że w razie tymczasowego odstępstwa od omawianego prawa należy zagwarantować objętym nim pracownikom odpoczynek wyrównawczy, który nie może być krótszy od odpoczynku podstawowego, powszechnego przewidzianego w tej konwencji ${ }^{156}$.

Z uwagi na to, że unormowanie dotyczące cotygodniowego odpoczynku ma na celu ochronę zdrowia pracownika, organy kontrolne MOP przyjmują, że nie jest dopuszczalne jego zastąpienie ekwiwalentem pieniężnym ${ }^{157}$.

Z czasem poza ograniczeniem godzin pracy pracowników uznano również ich prawo do płatnego urlopu wypoczynkowego, który dziś jest podstawowym elementem prawa do odpoczynku. Materia ta została jednak dosyć późno uregulowana w aktach MOP, bowiem dopiero w latach 40. XX w. Urlopowi wypoczynkowemu została poświęcona konwencja nr 52 MOP z 1936 r. ${ }^{158}$, która gwarantowała to prawo w raczej skromnym rozmiarze, a która została zrewidowana w 1970 r. ${ }^{159}$.

W art. 2 konwencji z 1936 r. przyjęto, że każda osoba, do której ma zastosowanie ta konwencja, po roku nieprzerwanej pracy będzie uprawniona do corocznego płatnego urlopu w wymiarze co najmniej sześciu dni roboczych, a w odniesieniu do osób poniżej 16 roku życia (w tym też praktykantów) w wymiarze co najmniej $12 \mathrm{dni}{ }^{160}$.

Jest to najniższy dopuszczony przez konwencję wymiar urlopu, który powinien jednak, zgodnie z jej dalszymi postanowieniami, wzrastać wraz ze stażem pracy na warunkach określonych w prawie krajowym.

Z zalecenia nr 47 wynika, że zwiększenie wymiaru urlopu proporcjonalnie do stażu pracy powinno dokonywać się możliwie szybko, w regularnych etapach, tak by po określonej liczbie lat mogło zostać osiągnięte ustalone minimum (np. 12 dni roboczych po siedmiu latach pracy) ${ }^{161}$.

156 Pojęcie odpoczynku wyrównawczego nie zostało w konwencji zdefiniowane. Kwestie te pozostawia się do uregulowania władzom państw członkowskich. Por. tamże, s. 416.

157 Tamże.

158 Konwencja nr 52 MOP z 24 czerwca 1936 r. dotycząca corocznych płatnych urlopów, www. mop.pl. Po wojnie uchwalono też konwencje dotyczące urlopu wypoczynkowego marynarzy oraz urlopu wypoczynkowego w rolnictwie. Por. L. Florek, M. Seweryński, Międzynarodowe prawo..., s. 208.

159 Konwencja nr 132 MOP z 24 czerwca 1970 r. dotycząca corocznych płatnych urlopów, www. mop.pl.

160 Rekomenduje się wręcz stworzenie w odniesieniu do młodocianych i praktykantów poniżej 18. roku życia bardziej korzystnego systemu w omawianym zakresie. Por. ust. 5 zalecenia nr 47 z 1936 r. dotyczącego corocznych płatnych urlopów. Treść zalecenia por. Konwencje i zalecenia Międzynarodowej Organizacji Pracy 1919-2012, t. 1, MPiPS, Warszawa 2014, s. 157 i n.

161 Por. ust. 3 zalecenia $\mathrm{nr} 47$. 
We wspominanym wyżej zaleceniu zostały też określone bardziej szczegółowe wskazania dotyczące zasad ustalania stażu urlopowego. Zgodnie z jego postanowieniami państwa ratyfikujące konwencję, które uzależniają uprawnienia urlopowe pracownika od zachowania ciągłości pracy, mają rozważyć wprowadzenie unormowań, na podstawie których bez wpływu na ową ciągłość wymaganą do nabycia uprawnień urlopowych będą pozostawały przerwy spowodowane chorobą lub wypadkiem, wydarzeniami rodzinnymi, służbą wojskową, realizacją praw obywatelskich, zmianami kierownictwa w przedsiębiorstwie, w którym pracuje zatrudniona osoba, czy mimowolnym bezrobociem, jeśli jego okres nie przekracza określonego limitu oraz jeśli zainteresowana osoba podejmuje ponownie zatrudnienie $^{162}$. Ponadto, jak wynika $\mathrm{z}$ dalszych punktów ust. 1 zalecenia nr 47, w przypadku takich zajęć, w których praca nie jest wykonywana regularnie w ciągu roku, pod warunkiem przepracowania określonej liczby dni w określonym czasie, ciągłość zatrudnienia powinna zostać uznana za zachowaną.

Rekomenduje się również, aby okres roku pracy, mający stanowić przesłankę nabycia prawa do urlopu, był niezależny od ewentualnych zmian zatrudnienia w tym okresie (a więc aby brać pod uwagę ogólny staż pracy ${ }^{163}$ ) oraz by rozłożono obciążenia związane $z$ urlopem pomiędzy poszczególnych pracodawców zatrudniających pracownika w danym roku.

Władze poszczególnych państw zyskały też możliwość dopuszczenia, jako wyjątku, podziału urlopu na części, ale pod warunkiem, że będzie to dotyczyć części urlopu, która jest dłuższa od wskazanego przez konwencję wymiaru minimalnego $^{164}$. Zaleca się jednak wprowadzenie ograniczenia owego podziału do nie więcej niż dwóch części, z których jedna nie powinna być krótsza niż określone wcześniej minimum (ust. 2 zalecenia nr 47). W zaleceniu podkreśla się także, że w szczególnych przypadkach może być wskazane wprowadzenie przepisu o podziale urlopu, jednakże należy wtedy zapewnić, aby takie regulacje nie były sprzeczne z celem urlopu, którym jest umożliwienie zatrudnionej osobie odnowy sił fizycznych i psychicznych, utraconych w ciągu roku.

Zgodnie z ust. 3 art. 2 konwencji nr 52, do płatnych urlopów nie będą wliczane:

- święta ustawowe i zwyczajowe,

- nieobecności w pracy spowodowane chorobą.

W konwencji uwzględniono również fakt, że urlop wypoczynkowy, aby spełniał swoje podstawowe funkcje, musi być świadczeniem płatnym. W związku z tym $\mathrm{w}$ art. 3 konwencji ustanowiono prawo pracownika do wynagrodzenia za cały czas urlopu w wysokości albo normalnie pobieranego wynagrodzenia, obliczanego w sposób ustalony przez ustawodawstwo krajowe (łącznie z prawem do ewentualnego ekwiwalentu za część wynagrodzenia realizowaną w naturze), albo w wysokości ustalonej przez układ zbiorowy pracy obowiązujący u danego pracodawcy.

162 Zdaniem A.M. Świątkowskiego, chodzi więc bardziej o pozostawanie w zatrudnieniu niż rzeczywiste świadczenie pracy. Por. tenże, Międzynarodowe prawo..., s. 507.

163 Tamże, s. 509.

164 O pewnych wątpliwościach na tle interpretacji tego przepisu por. szerzej tamże, s. 512 i n. 
Rekomenduje się przy tym, by osoby, których wysokość wynagrodzenia w poszczególnych miesiącach osiąga zmienną wartość w związku z zastosowaniem akordowego systemu wynagradzania, miały ustalane wynagrodzenie urlopowe $\mathrm{z}$ na tyle długiego okresu, aby możliwie zredukować wpływ wahań zarobków na jego ostateczną wysokośćc 165 .

Jednocześnie twórcy konwencji pozostawili władzom poszczególnych państw możliwość wyłączenia prawa do wynagrodzenia za czas urlopu na zasadach określonych $\mathrm{w}$ ustawie, $\mathrm{w}$ razie podjęcia $\mathrm{w}$ jego trakcie innego płatnego zatrudnienia. Nie sformułowano w niej jednak wyraźnego, adresowanego do pracowników zakazu wykonywania pracy zarobkowej w tym czasie ${ }^{166}$.

$\mathrm{W}$ omawianej konwencji zagwarantowano ponadto prawo do wynagrodzenia za czas urlopu osobom, które go jeszcze nie wykorzystały, a które są zwalniane z pracy z przyczyn leżących po stronie pracodawcy. Zgodnie z art. 6 konwencji, będą one otrzymywały na mocy konwencji za każdy dzień należnego im urlopu wynagrodzenie w wysokości określonej na podstawie opisanych wyżej zasad (takie jakie by uzyskały, będąc na urlopie).

Istotnym postanowieniem konwencji nr 52 (szczególnie w okresie, w jakim była uchwalana) jest zasada niezbywalności prawa do urlopu, wprowadzona w jej art. 4 . Chodziło bowiem o przeciwdziałanie dość powszechnemu wówczas zjawisku komercjalizacji urlopów, a więc ich swoistemu „odsprzedawaniu” za dodatkowym wynagrodzeniem, czemu sprzyjał ogólnie niski poziom płac robotniczych. Chroniąc prawo do odpoczynku w powołanym wyżej przepisie konwencji, wskazano, że tracą ważność wszelkie porozumienia dotyczące rezygnacji z prawa do płatnego urlopu wypoczynkowego lub jego zrzeczenia się przez uprawnionego. Wynika $\mathrm{z}$ tego, że nie tylko zabroniono zawierania tego rodzaju porozumień po ratyfikacji konwencji przez dane państwo, ale pozbawiono również ważności wszelkie tego rodzaju porozumienia, które zostały zawarte wcześniej.

Warto także zauważyć, że przepisy konwencji nr 52 zobowiązują pracodawców do prowadzenia rejestrów, w określonej przez prawo wewnętrzne formie, zawierających m.in. informację o wymiarze przysługującego zatrudnionemu urlopu wypoczynkowego, dacie jego wykorzystania oraz wysokości wypłaconego za ten okres wynagrodzenia.

Kilkanaście lat później, w 1952 r., została też przyjęta konwencja nr 101 dotycząca płatnych urlopów w rolnictwie ${ }^{167}$, w której wskazano na potrzebę zagwarantowania corocznych, płatnych urlopów wypoczynkowych pracownikom zatrudnionym w przedsiębiorstwach rolnych oraz zajęciach pokrewnych, po okresie nieprzerwanej pracy na rzecz danego podmiotu. Pozostawiła ona jednak państwom ratyfikującym konwencję i partnerom społecznym bardzo duży margines

165 Por. ust. 4 zalecenia nr 47.

166 Krytycznie na temat tej części regulacji por. A.M. Świątkowski, Międzynarodowe prawo..., s. 513.

167 Treść konwencji nr 101 por. Konwencje i zalecenia..., t. 1, s. 377 i n. 
swobody w ustaleniu zarówno zakresu podmiotów, do których znajdą zastosowanie stosowne unormowania, warunków nabycia prawa do urlopu (w tym minimalnego wymaganego okresu nieprzerwanej pracy i najniższego dopuszczalnego wymiaru urlopu), jak i wyboru metod, za pomocą których omawiana problematyka zostanie uregulowana (ustawa, układ zbiorowy pracy itp.). Kwestie te powinny być jednak rozstrzygane w procesie konsultacji z pracownikami, pracodawcami i ich organizacjami oraz wszelkimi innymi podmiotami uznanymi za właściwe w tych sprawach z uwagi na posiadane kwalifikacje oraz wykonywaną pracę.

W konwencji nr 101 sformułowano natomiast wyraźny zakaz zrzeczenia się prawa do urlopu oraz gwarancję wypłaty wynagrodzenia urlopowego, które zasadniczo nie powinno być niższe od kwoty wynagrodzenia zwykle uzyskiwanego. Wynagrodzenie to, zgodnie z art. 9 konwencji, należy wypłacić także pracownikom, którzy zostali zwolnieni z pracy z przyczyn od siebie niezależnych przed wykorzystaniem należnego im urlopu (ekwiwalent).

W kontekście pewnej tendencji do zwiększania okresów odpoczynku warto również zwrócić uwagę na art. 5 pkt d omawianego aktu, w którym zaleca się (pozostawiając ostateczne rozstrzygnięcie prawu krajowemu), by przy udzielaniu urlopu nie uwzględniać w nim dni świątecznych, wybranych przerw w pracy, zwłaszcza związanych z chorobą lub wypadkiem, ale też, co istotne, okresów odpoczynku tygodniowego. Celem tego wyłączenia, jak się wydaje, jest z jednej strony dążenie do zwiększenia efektywności odpoczynku rocznego, zabezpieczenia faktycznej realizacji jego podstawowych funkcji (okres choroby trudno uznać za czas temu sprzyjający), ale też wyeliminowania przypadków zachodzenia na siebie poszczególnych przerw w pracy służących wypoczynkowi.

W połowie lat $60 . \mathrm{XX}$ w. zostało także wydane zalecenie dotyczące płatnych urlopów $^{168}$, które obejmowało swym zakresem niemal wszystkich pracowników ${ }^{169}$. Rekomendowano w nim przede wszystkim odstąpienie od rocznych okresów pozostawania w stosunku pracy jako warunku nabycia prawa do urlopu wypoczynkowego na rzecz określenia liczby dni, które pracownik powinien przepracować, aby uzyskać prawo do urlopu lub jego części. Jego istotnym novum, jak wskazuje się w literaturze, było wprowadzenie prawa do urlopu proporcjonalnego ${ }^{170}$. Zawarto w nim bowiem regułę, że czas trwania urlopu powinien być proporcjonalny do okresu pracy wykonanej u jednego lub kilku pracodawców w ciągu danego roku. Jeśli więc stosunek pracy kończy się przed upływem okresu zatrudnienia wymaganego dla uzyskania prawa do pełnego, corocznego płatnego urlopu, pracownik powinien mieć prawo bądź do urlopu proporcjonalnego do przepracowanego czasu, bądź do ekwiwalentu pieniężnego, bądź do równoważnego zaliczenia tego okresu na poczet przyszłego urlopu, stosownie do tego, którą z tych metod uważa się w danym kraju za najodpowiedniejszą.

168 Zalecenie nr 98 MOP z 23 czerwca 1954 r., www.mop.pl.

169 Z wyjątkiem marynarzy, pracowników rolnych i osób zatrudnionych w zakładach, w których zatrudnieni są wyłącznie członkowie rodziny pracodawcy. Por. art. 3 zalecenia.

170 A.M. Świątkowski, Międzynarodowe prawo..., s. 521. 
W zaleceniu tym wzmocniono również zasadę, że do urlopu wypoczynkowego nie należy wliczać pewnych okresów nieświadczenia pracy ${ }^{171}$, a także że przerwy w pracy zasadniczo nie powinny mieć wpływu na nabycie prawa do urlopu i jego wymiar. Chodzi przede wszystkim o przerwy w pracy, w czasie których pracownik zachowuje prawo do wynagrodzenia, ale też okresy zawieszenia stosunku pracy, które nie powinny wpływać na uprawnienia pracownika nabyte przed takim zawieszeniem.

W celu umożliwienia pracownikowi planowania wypoczynku zwraca się w nim ponadto uwagę na konieczność odpowiednio wcześniejszego informowania pracowników o terminie rozpoczęcia udzielonego urlopu wypoczynkowego ${ }^{172}$.

W 1970 r. w wyniku rewizji konwencji z 1936 r. została przyjęta kolejna konwencja dotycząca płatnych urlopów - konwencja nr 132. Wprowadziła ona dość istotne zmiany w stosunku do wcześniej omawianego aktu, podnosząc niewątpliwie ogólne standardy w zakresie prawa do wypoczynku osób zatrudnionych.

Przede wszystkim podkreślono w niej powszechny charakter prawa do odpoczynku w aspekcie urlopów wypoczynkowych, uogólniono bowiem (w kierun$\mathrm{ku}$ jego rozszerzenia) zakres podmiotów uprawnionych do tego urlopu. Zgodnie z art. 2 pkt 1 konwencji nr 132, ma ona zastosowanie do wszystkich osób zatrudnionych, $\mathrm{z}$ wyjątkiem marynarzy. Jest to odmienna regulacja $\mathrm{w}$ porównaniu do konwencji nr 52, która swą ochroną obejmowała osoby zatrudnione w zakładach i przedsiębiorstwach wymienionych w konwencji (mimo że był to bardzo obszerny katalog ${ }^{173}$ ) i pozostawiała władzom poszczególnych państw wyznaczenie, przy udziale partnerów społecznych, linii rozgraniczającej zakłady i przedsiębiorstwa określone w konwencji od tych, do których jej postanowienia nie znajdą zastosowania (art. 1 ust. 2 konwencji nr 52).

W konwencji nr 132, rozciągając prawo do urlopu na niemal wszystkich pracowników, zawarto jednocześnie generalne zezwolenie, aby na zasadzie absolutne-

171 Chodzi nie tylko o dni wolne od pracy (święta, dni odpoczynku tygodniowego), ale też dni niezdolności do pracy spowodowane wypadkiem przy pracy lub chorobą oraz okresy urlopu macierzyńskiego (ust. 5 zalecenia).

172 Por. A.M. Świątkowski, Międzynarodowe prawo..., s. 523.

173 Zgodnie z art. 1 ust. 1 konwencji nr 52, chodziło bowiem o przedsiębiorstwa, w których produkty są wytwarzane, przerabiane, oczyszczane, naprawiane, zdobione, wykańczane, przygotowywane do sprzedaży, rozdrabniane lub niszczone, albo w których materiały ulegają przetwarzaniu, przedsiębiorstwa całkowicie lub częściowo zaangażowane w budowę, odbudowę, utrzymanie, naprawę, przeróbkę lub burzenie jednego bądź więcej obiektów wymienionych w konwencji, zakłady zaangażowane w przewóz osób lub towarów drogą lądową, kolejową, śródlądową drogą wodną lub drogą powietrzną, włączając przeładunek towarów w dokach, przystaniach, na nabrzeżach, w magazynach czy na lotniskach; kopalnie, kamieniołomy i inne przedsiębiorstwa wydobywcze, przedsiębiorstwa handlowe, przedsiębiorstwa i usługi administracyjne, zakłady prasowe, zakłady świadczące usługi lecznicze i opiekuńcze, hotele, restauracje, pensjonaty, kluby, kawiarnie i inne zakłady o podobnym charakterze; teatry i miejsca rozrywki publicznej, a także mieszane zakłady handlowe i przemysłowe niekwalifikujące się w pełni do którejkolwiek z powyższych kategorii. 
go wyjątku właściwe władze, w trybie przyjętym dla danego kraju i po konsultacji z organizacjami zainteresowanych pracodawców i pracowników, w razie konieczności podjęły kroki w celu wyłączenia ze stosowania konwencji ograniczonych kategorii osób zatrudnionych, jeżeli wskutek zastosowania do nich konwencji wynikłyby szczególne problemy, mające istotne znaczenie dla wewnętrznego porządku prawnego, w tym zwłaszcza konstytucyjnego.

Wyłączenia te poddano jednak wyraźnej kontroli organów MOP; każde państwo, które zdecydowało się skorzystać z tej możliwości, jest zobowiązane opisać w sprawozdaniu ze stosowania konwencji jakie grupy, w jakim zakresie i z jakich przyczyn zostały objęte omawianym wyłączeniem oraz podać stan ustawodawstwa i praktyki swego kraju w odniesieniu do tych kategorii osób zatrudnionych.

Nabycie prawa do urlopu wypoczynkowego może być uzależnione od określonego, przyjętego w danym państwie minimalnego stażu pracy, niemniej, jak stanowi art. 5 ust. 2 konwencji, w żadnym razie nie może być to okres dłuższy niż sześć miesięcy ${ }^{174}$. Zasady obliczenia owego minimalnego okresu pracy warunkującego uprawnienia urlopowe pozostawiono do szczegółowego ustalenia władzom państw ratyfikujących konwencję. Wskazuje się jedynie w jej treści, że czas trwania nieobecności w pracy z przyczyn niezależnych od zatrudnionego, takich jak choroba, wypadek lub urlop macierzyński, będzie wliczany do omawianego stażu urlopowego.

Dostrzegana w konwencji nr 132 tendencja do rozszerzania poziomu uprawnień urlopowych pracownika wiąże się niewątpliwie z wydłużeniem minimalnego okresu rocznego wypoczynku. Podwyższono w niej najniższy dopuszczalny wymiar corocznego, płatnego urlopu wypoczynkowego do trzech tygodni (roboczych) ${ }^{175}$. W prawie wewnętrznym należy przyjąć odpowiednie regulacje, z których będzie wynikać minimalny wymiar urlopu dla wszystkich podmiotów podlegających omawianej konwencji (w żadnym wypadku nie niższy od wskazanego w jej przepisach minimum $)^{176}$.

Ponadto, zgodnie $\mathrm{z}$ art. 6 konwencji, przy ustalaniu wymiaru urlopu wypoczynkowego, przynajmniej na jego poziomie minimalnym wskazanym w konwencji, należy pominąć dni uznane urzędowo lub zwyczajowo za wolne od pracy, niezależnie od tego, czy przypadają one podczas corocznego urlopu płatnego czy też

174 Wszelkie przypadki wydłużenia tego okresu są oceniane przez Komitet do spraw Stosowania Konwencji i Zaleceń MOP jako niezgodne z międzynarodowymi standardami. Por. A.M. Świątkowski, Międzynarodowe prawo..., s. 530.

175 Jak wskazuje się w literaturze, posłużenie się pojęciem tygodnia roboczego, a nie dnia pracy, było zabiegiem celowym. Liczba dni roboczych w tygodniu w poszczególnych państwach jest różna, co groziło nierównym traktowaniem pracowników. Ponadto rozwiązuje to problem udzielania urlopu osobom zatrudnionym na część etatu. Por. L. Florek, M. Seweryński, Międzynarodowe prawo..., s. 210. Zob. też A.M. Świątkowski, Międzynarodowe prawo..., s. 525.

176 W innych aktach MOP wskazano dodatkowo na potrzebę zagwarantowania dłuższych urlopów wypoczynkowych dla pracowników młodocianych (co najmniej czterotygodniowych) oraz osób starszych. Por. L. Florek, M. Seweryński, Międzynarodowe prawo......, s. 211. 
nie. Choć sposób sformułowania tego przepisu budzi pewne wątpliwości ${ }^{177}$, to jest to bardzo ważne z punktu widzenia prawa do odpoczynku postanowienie, zapobiega ono bowiem faktycznemu skracaniu czasu wolnego od pracy wynikającego $\mathrm{z}$ różnych tytułów wskutek zbiegu terminu ich wystąpienia.

Proponuje się również, pozostawiając ostateczną decyzję władzom poszczególnych państw ${ }^{178}$, aby z minimalnego okresu płatnego urlopu wypoczynkowego zostały wyłączone okresy niezdolności do pracy, powstałe w wyniku choroby lub wypadku, co też niewątpliwie sprzyja pełniejszej realizacji podstawowej funkcji omawianego świadczenia.

W myśl zasady, że każdemu okresowi pracy powinno odpowiadać prawo do urlopu wypoczynkowego w konwencji nr 132 wprowadzono regułę nabywania uprawnień urlopowych proporcjonalnie do okresu przepracowanego w danym roku, a niewystarczającego do uzyskania pełnego urlopu wypoczynkowego. Wynika ona wprost $\mathrm{z}$ art. 4 konwencji, który stanowi, że osoba, której okres pracy w jakimkolwiek roku jest krótszy niż wymagany do nabycia pełnych uprawnień urlopowych określonych $w$ art. 3 , będzie miała prawo do corocznego płatnego urlopu, $\mathrm{w}$ wymiarze proporcjonalnym do okresu pracy w tym roku.

Wyjaśniono przy tym, że pojęcie roku, jakim posłużono się na gruncie powołanego przepisu, należy zasadniczo odnosić do roku kalendarzowego lub jakiegokolwiek innego okresu tej samej długości, oznaczonego przez właściwe władze lub w trybie przyjętym dla danego kraju (może to być zatem rok pracy) ${ }^{179}$.

W konwencji nr 132 podtrzymano również prawo do wynagrodzenia za cały okres należnego danej osobie urlopu w wysokości zwykle przez nią uzyskiwanej („co najmniej normalne lub średnie wynagrodzenie”), ale wprowadzono wyraźne postanowienie zobowiązujące do wypłaty tego wynagrodzenia przed rozpoczęciem urlopu, chyba że obowiązujący układ zbiorowy pracy stanowi w tym zakresie inaczej (art. 7 ust. 2 konwencji). Wymaga się także zagwarantowania pracownikowi prawa do świadczenia pieniężnego za niewykorzystany urlop wypoczynkowy $\mathrm{w}$ razie ustania stosunku pracy (ewentualnie udzielenia tego urlopu w naturze $\mathrm{w}$ wymiarze proporcjonalnym do przepracowanego okresu - art. 11 konwencji). W innych przypadkach, wszelkie porozumienia, na podstawie których pracownik rezygnuje $\mathrm{z}$ dni wolnych od pracy w zamian za stosowną rekompensatę finansową

177 Zob. A.M. Świątkowski, Międzynarodowe prawo......, s. 530. Słusznie podkreśla się, że dni wolne od pracy, które nie pokrywają się z okresem urlopu, nie mają znaczenia dla tego urlopu.

178 Art. 6 ust. 2 konwencji stanowi bowiem, że w warunkach określonych przez właściwą władzę lub w trybie właściwym dla danego kraju, okresy niezdolności do pracy, powstałe wskutek choroby lub wypadku, mogą nie być zaliczane do minimalnego corocznego urlopu płatnego określonego w ust. 3 art. 3 niniejszej konwencji.

179 Na przykład we Francji prawo do urlopu ustala się według okresu pracy wykonywanej w ramach tzw. okresu referencyjnego, który poprzedza rok przyznania urlopu i obejmuje on czas od 1 czerwca roku poprzedniego do 31 maja roku bieżącego. Por. G. Auzero, E. Dockès, Droit du travail, Paris 2014, s. 868. 
(zamiana urlopu na ekwiwalent pieniężny), należy uznać za nieważne lub zabronione, stosownie do warunków krajowych. W konwencji nr 132 utrzymano też, już wcześniej wyraźnie formułowany w konwencjach MOP, niezwykle istotny z punktu widzenia tytułowej materii, generalny zakaz zrzeczenia się prawa do urlopu wypoczynkowego przez pracownika.

Zrezygnowano natomiast $\mathrm{z}$ regulacji przyjętej we wcześniejszej konwencji nr 52, która wprost dopuszczała możliwość wyłączenia prawa do wynagrodzenia za czas urlopu, na zasadach określonych w ustawie, w razie podjęcia w jego trakcie innego płatnego zatrudnienia. W konwencji nr 132 wprowadzono ogólniejsze postanowienie, na mocy którego państwa ratyfikujące omawiany akt mogą ustanowić specjalne przepisy (ewentualnie rozstrzygnąć te kwestie w innym trybie przyjętym w danym kraju) dotyczące wypadków wykonywania przez osobę zatrudnioną w czasie swego urlopu płatnego zajęcia niedającego się pogodzić z celem urlopu (art. 13 konwencji). Niewątpliwie w przepisach, o których mowa można wprowadzać określone konsekwencje płacowe związane z podjęciem innej pracy zarobkowej w trakcie urlopu, ale też zakazać w ogóle jej podejmowania, jeżeli byłoby to sprzeczne z celem tego urlopu.

Pomijając kwestię odpłatności urlopu, o której wyżej była mowa, konwencja nr 132 zawiera również inne istotne postanowienia odnośnie do zasad udzielania urlopu wypoczynkowego pracownikowi, który nabył do niego prawo.

Śladem konwencji nr 52 zachowano w niej możliwość podziału urlopu na części. Niemniej wymaga się, by zasady tego podziału zostały określone w prawie wewnętrznym poszczególnych państw, z tym zastrzeżeniem, że jedna z części urlopu powinna odpowiadać zasadniczo co najmniej dwóm nieprzerwanym tygodniom pracy, jeżeli okres pracy danej osoby uprawnia do urlopu w tym rozmiarze, a układ zbiorowy pracy nie stanowi inaczej. Tym samym wbrew wcześniejszym sugestiom zawartym w zaleceniu nr 47 dopuszcza się możliwość podziału urlopu wypoczynkowego na więcej niż dwie części (z inicjatywy każdej ze stron stosunku pracy, brak bowiem w konwencji wskazania na pracownika jako stronę wyłącznie uprawnioną do wystąpienia ze stosownym wnioskiem w tej sprawie). Mając jednak na uwadze podstawową funkcję omawianego świadczenia, jaką jest przede wszystkim psychofizyczna regeneracja pracownika, wymaga się, aby jeśli wymiar urlopu na to pozwala, jedna część tego wypoczynku odpowiadała nie mniej niż dwóm nieprzerwanym tygodniom pracy.

Ponadto w omawianej konwencji zawarto również szereg postanowień dotyczących terminu udzielenia urlopu wypoczynkowego przez pracodawcę.

Jak wynika $z$ art. 9 konwencji, jeśli dojdzie do podziału urlopu na części, nieprzerwana część corocznego urlopu, o której wyżej była mowa, powinna być udzielona i wykorzystana nie później niż w ciągu roku, a pozostałej części urlopu wypoczynkowego należy pracownikowi, co do zasady, udzielić nie później niż w ciągu 18 miesięcy, licząc od końca tego roku, za który przysługuje prawo do urlopu ${ }^{180}$.

180 Por. też L. Florek, M. Seweryński, Międzynarodowe prawo..., s. 211. 
Wyjątkowo jednak w odniesieniu do tej części urlopu, która przekracza owo wymagane minimum, możliwe jest dowolne wykroczenie poza podany w konwencji termin, pod warunkiem uzyskania na to zgody pracownika. Szczegółowe warunki i progi obowiązujące $\mathrm{w}$ tym zakresie (okres, o który możliwe jest odroczenie urlopu lub jego części), pozostawiono do regulacji w prawie wewnętrznym państw ratyfikujących konwencję. Konwencja nr 132, jak podkreślono w piśmiennictwie, nie ustanawia międzynarodowych standardów przedawnienia urlopów wypoczynkowych ${ }^{181}$.

Oceniając to unormowanie z punktu widzenia prawa do odpoczynku, ochrony życia i zdrowia osób zatrudnionych, wydaje się ono nazbyt liberalne. Zaprzecza ono bowiem dość wyraźnie eksponowanej w samej konwencji zasadzie coroczności urlopu wypoczynkowego wpisującej się bardzo mocno w podstawowe funkcje tego świadczenia.

Oceny tej nie zmienia istotnie art. 10 konwencji, w którym jej twórcy wymagają, aby termin udzielenia urlopu wypoczynkowego został wyznaczony przez pracodawcę po konsultacji z zainteresowaną osobą zatrudnioną lub jej przedstawicielami, chyba że zostanie on ustalony przez przepisy prawne, układy zbiorowe, orzeczenia arbitrażowe lub w inny sposób zgodny z praktyką krajową. Co istotne, w konwencji zastrzega się wyraźnie, że przy określaniu czasu, w jakim ma być wykorzystany urlop, należy brać pod uwagę z jednej strony potrzeby pracodawcy, ale z drugiej strony możliwość „,wypoczynku i odprężenia” przez osobę zatrudnioną ${ }^{182}$.

W połowie XX w. prawo pracownika do wypoczynku, w podobnym do współczesnego ujęciu ${ }^{183}$, zaczyna być wyraźnie formułowane w ogólnych dokumentach międzynarodowych o charakterze uniwersalnym, a także w prawie europejskim.

W art. 24 Powszechnej Deklaracji Praw Człowieka z 10 grudnia 1948 r. potwierdzono prawo każdego człowieka do urlopu i wypoczynku, włączając w to rozsądne ograniczenie godzin pracy i okresowe płatne urlopy. Tego rodzaju unormowanie wprowadzono następnie do Międzynarodowego Paktu Praw Gospodarczych, Społecznych i Kulturalnych ONZ z 19 grudnia 1966 r., którego art. 7 lit. d stanowi, że w ramach prawa każdego człowieka do korzystnych i sprawiedliwych warun-

181 Tamże, s. 536.

182 Zdaniem jednak A.M. Świątkowskiego, „konsultacja ta nie musi odbywać się na zasadach «wyważonego» udziału pracowników lub ich przedstawicieli" w procesie ustalania terminu urlopów. Są oni uprawnieni jedynie do wyrażenia swej opinii. Por. A.M. Świątkowski, Międzynarodowe prawo..., s. 537.

183 Obecnie prawo do wypoczynku analizuje się najczęściej w trzech wymiarach: dobowym, tygodniowym i rocznym. O jego zakresie decydują zarówno rozwiązania prawne dotyczące urlopów wypoczynkowych, jak i przepisy o czasie pracy (znaczenie tych ostatnich dla realizacji omawianego prawa podkreślał wyraźnie m.in. A. Sobczyk - por. tenże, Zasady..., s. 257). Rozważając prawo do wypoczynku, trzeba ponadto podkreślić, że chodzi już nie tylko o zagwarantowanie pracownikowi czasu biologicznie niezbędnego do regeneracji sił fizycznych, ale wypoczynek umożliwiający uczestnictwo w życiu społeczno-politycznym i kulturalnym. 
ków pracy należy zapewnić wypoczynek, wolny czas i rozsądne ograniczenie czasu pracy, a także okresowe płatne urlopy oraz wynagrodzenie za dni świąteczne ${ }^{184}$.

Zgodnie z postanowieniami omawianego aktu państwo jest zobowiązane do niezwłocznego podjęcia wszelkich możliwych działań i maksymalnego wykorzystania wszystkich dostępnych środków, w tym zwłaszcza ustawodawczych, w celu stopniowej jego realizacji, stosownie do poziomu rozwoju społeczno-gospodarczego (zwłaszcza gdy chodzi o kwestię dalszego skracania czasu pracy). Niewątpliwie ogólny sposób formułowania praw zawartych w analizowanym Pakcie, także gdy chodzi o prawo do odpoczynku, powoduje, że co do zasady nie nadają się one do bezpośredniego stosowania i wymagają odpowiedniej konkretyzacji w prawie wewnętrznym. Państwo zobowiązane, podejmując działania w tym zakresie, powinno jednak czynić to $\mathrm{w}$ sposób, który nie będzie sprzeciwiać się istocie tych praw.

Jak wynika ze stanowiska EAPN Polska w sprawie realizacji Międzynarodowego Paktu Praw Gospodarczych, Społecznych i Kulturalnych w Polsce ${ }^{185}$, jedną z największych bolączek rynku pracy w naszym kraju jest upowszechnienie zawierania umów cywilnoprawnych w sferze zatrudnienia, co przekłada się negatywnie również na realizację ustawowego prawa do odpoczynku. Według szacunków Głównego Urzędu Statystycznego na podstawie takich umów pracuje około 1,087 $\mathrm{mln}$ osób, a $80 \%$ z nich nie z własnego wyboru. Osoby zatrudnione na takich umowach nie są objęte ochroną gwarantowaną przez polskie prawo pracy, zarówno w zakresie regulacji czasu pracy, jak i prawa do urlopu wypoczynkowego.

$\mathrm{Na}$ tę kwestię w ostatnim czasie zwrócił uwagę również Komitet Praw Gospodarczych, Społecznych i Kulturalnych w stosunku do Polski. Komitet wyraził swoje zaniepokojenie stosunkowo wysoką liczbą umów cywilnoprawnych, na podstawie których świadczona jest praca, co ostatecznie może mieć negatywny wpływ na realizację prawa pracownika do sprawiedliwych i korzystnych warunków pracy, $\mathrm{w}$ tym m.in. prawa do odpoczynku ${ }^{186}$. W związku z tym zalecono m.in. zapewnienie osobom zatrudnionym na podstawie takich umów odpowiednich gwarancji w zakresie korzystania z praw pracowniczych („aby prawa pracy i zabezpieczenia społecznego osób pracujących na umowach cywilnoprawnych, zostały w pełni zagwarantowane w prawie i w praktyce") ${ }^{187}$.

184 Dz. U. 1977, Nr 38, poz. 169.

185 Stanowisko Polskiego Komitetu Europejskiej Sieci Przeciwdziałania Ubóstwu (EAPN Polska) w sprawie realizacji Międzynarodowego Paktu Praw Gospodarczych, Społecznych i Kulturalnych w Polsce, Warszawa 2016, s. 7 i n.

186 Uwagi końcowe dotyczące VI Sprawozdania Okresowego Rzeczypospolitej Polskiej, 7.10.2016, E/C.12/POL/CO/6, www.rpo.gov.pl.

187 Tamże. 


\subsubsection{Europejska Karta Społeczna Rady Europy}

Równie szeroką jak w omówionych wyżej aktach formułę prawa do wypoczynku przyjęto wcześniej w Europejskiej Karcie Społecznej z 1961 r. ${ }^{188}$, na gruncie której stało się ono jednym z podstawowych instrumentów ochrony życia i zdrowia ludzkiego, a zarazem istotnym elementem uzupełniającym prawo do bezpiecznych i higienicznych warunków pracy ${ }^{189}$. U podstaw omawianego prawa legło bowiem przekonanie, że praca bez zagwarantowanych odpowiednich przerw dobowych, tygodniowych i rocznych przeznaczonych na odpoczynek generuje m.in. znacznie większe ryzyko występowania wypadków przy pracy ${ }^{190}$.

Art. 2 Karty stanowi, że w celu realizacji prawa do odpowiednich warunków pracy należy m.in. określić „rozsądny” dzienny i tygodniowy czas pracy, z tendencją do skracania tego ostatniego stosownie do wzrostu wydajności pracy oraz innych związanych z tym czynników, zagwarantować pracownikom tygodniowy odpoczynek, który będzie, w miarę możliwości, zbiegał się z dniem uznanym za dzień wolny od pracy zgodnie z tradycją lub zwyczajem danego kraju, płatne dni świąteczne, a także coroczny, co najmniej dwutygodniowy (a w wersji zrewidowanej - czterotygodniowy ${ }^{191}$ ), płatny urlop wypoczynkowy, dążyć do ograniczania czasu pracy osób zatrudnionych przy pracach niebezpiecznych lub szkodliwych dla zdrowia.

Prawo do odpoczynku, jak z powyższego wynika, ma na gruncie Karty dynamiczny charakter. Zwraca się bowiem uwagę na potrzebę stopniowego podwyższania standardów w zakresie odpoczynku, przede wszystkim w obszarze norm czasu pracy oraz urlopów wypoczynkowych, stosownie do możliwości społeczno-gospodarczych danego kraju, w tym szczególnie uwarunkowań dotyczących wydajności pracy.

Prawo do odpoczynku w ujęciu EKS obejmuje niemal wszystkie zasadnicze jego aspekty. Składa się bowiem na to prawo zarówno konieczność ograniczania czasu pracy w skali doby i tygodnia, ze szczególnym uwzględnieniem osób wykonujących prace niebezpieczne lub szkodliwe dla zdrowia (choć nie sformułowano w Karcie, jak to uczyniono w dyrektywie unijnej, wyraźnego prawa do odpoczynku dobowego), zagwarantowanie odpoczynku tygodniowego, który w miarę możliwości powinien przypadać na dzień zwyczajowo wolny od pracy oraz prawo do co najmniej dwutygodniowego (lub czterotygodniowego w wersji zrewidowanej Karty) odpoczynku rocznego.

Powyższe unormowania Karty są stosunkowo ogólne (zwłaszcza gdy chodzi o pojęcie „rozsądnego” czasu pracy czy tygodniowego okresu odpoczynku), stąd doprecyzowaniem minimalnych standardów w zakresie omawianego prawa zajął się Komitet Praw Społecznych Rady Europy.

188 Europejska Karta Społeczna Rady Europy z 18 października 1961 r., Dz. U. 1999, Nr 8, poz. 67. 189 Por. A.M. Świątkowski, Karta Praw Społecznych Rady Europy, Warszawa 2006, s. 100.

190 Por. Konkluzje XIV-2, s. 364.

191 Por. art. 2 pkt 3 Zrewidowanej Europejskiej Karty Społecznej z 3 maja 1996 r. 
Komitet podkreślał niemal od samego początku, że regulacja zawarta w art. 2 ust. 1 Karty, wprowadzająca wymóg określenia rozsądnego dziennego i tygodniowego wymiaru czasu pracy, ma charakter ewolucyjny. Nie ma w związku z tym możliwości określenia konkretnego wymiaru czasu pracy, który można uznać za rozsądny. Kwestia ta musi być bowiem zawsze rozpatrywana na tle sytuacji społeczno-ekonomicznej istniejącej w danym kraju (w tym m.in. ogólnego stanu gospodarki, poziomu bezrobocia) oraz z uwzględnieniem prawa poszczególnych państw do swobodnego wyboru priorytetów w zakresie prowadzonej przez siebie polityki. Stąd, zdaniem Komitetu Rządowego, pojęcie rozsądnego czasu pracy, którym posłużono się w art. 2 EKS, nie może rodzić ściśle sprecyzowanych obowiązków prawnych ${ }^{192}$.

Niemniej Komitet, interpretując pojęcie czasu pracy jako każdego okresu pozostawania $\mathrm{w}$ dyspozycji pracodawcy (a więc $\mathrm{z}$ uwzględnieniem pracy ponadwymiarowej), zwracał w przeszłości uwagę na krajowe regulacje dotyczące pracy w godzinach nadliczbowych, uznając, że przekroczenia pewnej liczby godzin pracy w tygodniu czy w wymiarze dobowym nie można w żadnym razie uznać za „rozsądne”, szczególnie z punktu widzenia zdrowia pracownika, ale też dobra publicznego ${ }^{193}$. Komitet przyjął m.in., że ustawowo dopuszczona możliwość wykonywania pracy przez okres 16 godzin w okresie doby pracowniczej (24 kolejnych godzin) czy 60 i więcej godzin tygodniowo nie jest zgodna z postanowieniami Karty ${ }^{194}$.

Zalecono również władzom poszczególnych państw prowadzenie odpowiedniej polityki na rzecz ograniczania podejmowania przez pracowników dodatkowego zatrudnienia, które, jak ocenił Komitet, może skutkować nadmiernym zwiększeniem faktycznego czasu pracy, a w rezultacie zagrażać zdrowiu i bezpieczeństwu pracowników $^{195}$. Zarówno jednak w Komitecie Rządowym, jak i w Zgromadzeniu Parlamentarnym Rady Europy zauważono, że przyjmowane w tym zakresie przez państwa rozwiązania nie powinny prowadzić do ograniczenia indywidualnych wolności ${ }^{196}$.

Komitet podkreślił także, że dobowe i tygodniowe normy czasu pracy muszą być odrębnie oceniane z punktu widzenia wymogów Karty, zachowanie rozsądnej normy tygodniowej nie oznacza bowiem automatycznie pozytywnej oceny w odniesieniu do normy dobowej ${ }^{197}$.

192 Por. R. Blanpain, M. Matey, Europejskie prawo pracy w polskiej perspektywie, Warszawa 1993, s. 273. Zob. też J. Wratny, Prawo pracy Rady Europy, [w:] Europejskie prawo pracy i ubezpieczeń społecznych, red. L. Florek, Warszawa 1996, s. 133.

193 Wnioski KNE z X cyklu kontroli - por. R. Blanpain, M. Matey, Europejskie prawo..., s. 272.

194 Konkluzje XIV-2 - por. Informacje na temat Europejskiej Karty Społecznej, maj 1999, udostępnione przez Ministerstwo Pracy i Polityki Socjalnej, s. 42. Zob. też J. Wratny, Prawo pracy Rady..., s. 134.

195 Konkluzje III - por. B. Skulimowska, Prawo do odpowiednich warunków pracy, „Europejska Karta Społeczna. Biuletyn Ośrodka Informacji i Dokumentacji Rady Europy Uniwersytetu Warszawskiego" 1997, nr 1-2, s. 29.

196 Tamże, s. 30.

197 A.M. Świątkowski, Karta Praw..., s. 103. 
W kontekście rozsądnych norm czasu pracy, wymaganych przez Radę Europy, Komitet dostrzegał też znaczenie odpowiednich okresów rozliczeniowych, które służą ochronie pracownika przed długotrwałym natężeniem prac. Dopuszczając pewną elastyczność w zakresie kształtowania tygodniowego wymiaru czasu pracy i akceptując przeciętny charakter tej normy, Komitet wymaga z jednej strony ustalenia wyraźnych limitów pracy tygodniowej, ale z drugiej strony przyjęcia odpowiednich okresów rozliczeniowych, zasadniczo nieprzekraczających 4-6 miesięcy. Jak wskazuje się w literaturze, wyjątkowo Komitet aprobował również okresy roczne ${ }^{198}$.

Ponadto dla rzeczywistego wykonania prawa do odpowiednich warunków pracy postuluje się, aby kwestie związane z określaniem maksymalnych norm czasu pracy były regulowane na poziomie prawa powszechnego lub układów zbiorowych pracy (czy innych porozumień zbiorowych), a odpowiednie organy (np. sądowe) zostały wyposażone w stosowne kompetencje kontrolne. Chociaż, zdaniem Komitetu, nawet przy braku jakiejkolwiek regulacji prawnej, omawiane zobowiązanie wynikające $z$ Karty może być spełnione poprzez kształtowanie norm czasu pracy w indywidualnych umowach o pracę, których treść byłaby systematycznie weryfikowana ${ }^{199}$.

W ramach prawa pracowników do odpowiednich warunków pracy sformułowano w Karcie wyraźnie prawo do odpoczynku tygodniowego. Ma być ono realizowane $\mathrm{z}$ jednej strony poprzez zasadę pięciodniowego tygodnia pracy (a więc obowiązek ustanowienia przez pracodawcę w każdym tygodniu jednego dnia dodatkowo wolnego od pracy) ${ }^{200}$, a z drugiej poprzez zakaz świadczenia pracy w dniu zwyczajowo uznanym w danym kraju lub regionie za wolny od pracy, w przeważającej liczbie państw chodzi o niedzielę ${ }^{201}$.

Prawo do odpoczynku tygodniowego, podobnie jak prawo do urlopu wypoczynkowego, ma w świetle konkluzji Komitetu, niezbywalny charakter, pracownik nie może się go zrzec lub odstąpićn 202 .

W odniesieniu do dni dodatkowo wolnych jest to też wymóg bezwzględny. Komitet dopuszcza jedynie, po spełnieniu konkretnych warunków ustalonych w prawie krajowym, aby dni wyznaczone jako dodatkowo wolne od pracy mogły zostać wykorzystane w innym czasie - tygodniu, przy czym nie może to, w ocenie Komitetu, stwarzać zagrożenia dla zdrowia pracownika i powinno nastąpić nie później niż w ciągu 12 kolejnych dni. Wówczas należy udzielić pracowników dwóch następujących po sobie dni wolnych ${ }^{203}$.

198 Tamże.

199 Por. J. Wratny, Prawo pracy Rady..., s. 134.

200 Por. Konkluzje I, s. 20.

201 Por. Konkluzje XI, s. 55. Zob. też: Konkluzje XIV-2, s. 539; J. Wratny, Prawo pracy Rady..., s. 138.

202 Por. J. Wratny, Prawo pracy Rady..., s. 139.

203 Por. Konkluzje XIV-2, s. 387 i n. oraz European Social Charter, European Committee of Social Rights, Konkluzje XIX-3 (Niemcy), Strasbourg 2011, s. 95 i n. 
Nieco inaczej wygląda sytuacja, gdy chodzi o drugi ze wskazanych aspektów prawa do odpoczynku tygodniowego. Dopuszcza się bowiem wyjątkowo możliwość zamiany owego dnia zwyczajowo wolnego od pracy na inny wolny dzień w tygodniu, jeśli specyfika prowadzonej przez dany podmiot działalności czy charakter wykonywanej pracy tego bezwzględnie wymagają. Nie może to jednak prowadzić do swoistego upowszechnienia pracy w niedzielę i zastępowania wolnej niedzieli innym dniem wolnym od pracy w stosunku do znacznej części pracowników (np. ponad 30\% lub 40\%, jak miało to miejsce w Wielkiej Brytanii) ${ }^{204}$.

Prawo do odpoczynku, w ujęciu EKS, gwarantują również płatne i wolne dni świąteczne. Zgodnie z wykładnią Komitetu Praw Społecznych, chodzi o święta przypadające $\mathrm{w}$ dni, w których pracownicy mieli obowiązek świadczyć pracę (a zatem z wyłączeniem dni realizujących prawo do odpoczynku tygodniowego, o których była wcześniej mowa). Z samej Karty, ale także z konkluzji Komitetu, nie wynika żadna minimalna liczba świąt, jaką miałyby ustanowić poszczególne państwa - strony Karty, by uczynić zadość omawianemu wymaganiu. Pozostawia się więc im w tym zakresie bardzo dużą swobodę. Są one jednak zobowiązane do zagwarantowania pracownikom za ten czas wynagrodzenia w takiej wysokości, w jakiej by je uzyskali, gdyby świadczyli pracę.

Podobnie jak w przypadku pracy w niedzielę czy w inny dzień zwyczajowo wolny od pracy, Komitet uznał możliwość odstąpienia od omawianej zasady w stosunku do wąskiej grupy pracowników ze względu na szczególny rodzaj ich pracy. Wymaga się jednak, aby osoby wyjątkowo świadczące pracę w dni świąteczne, miały ten czas należycie zrekompensowany. Regułą jest udzielenie czasu wolnego od pracy w wymiarze nie mniejszym niż odpowiadający okresowi zatrudnienia w dzień świąteczny ${ }^{205}$. Komitet bardzo sceptycznie odniósł się natomiast do regulacji, które jako alternatywę dla owego czasu wolnego w innym dniu przewidywały finansową formę rekompensaty pracy w święto, choć ostatecznie dopuścił taką możliwość po uzyskaniu zgody pracownika ${ }^{206}$.

Wiele istotnych wskazań sformułowanych przez organy kontrolne Rady Europy dotyczy także urlopów wypoczynkowych.

W samej Karcie określono przede wszystkim ich minimalny wymiar wynoszący dwa tygodnie (lub cztery tygodnie według Zrewidowanej EKS). Chociaż, jak wynika z ust. 4 art. 2 Karty, dostrzeżono również konieczność zwiększania tego urlopu pracownikom zatrudnionym przy pracach niebezpiecznych lub szkodliwych. Tym samym uznano urlop na gruncie Europejskiej Karty Społecznej za istotny instrument ochrony przed skutkami narażenia pracowników na czynniki zagrażające ich zdrowiu, a zatem element poprawy stanu bezpieczeństwa i higieny pracy ${ }^{207}$.

204 Por. Konkluzje XIV-2, s. 761.

205 Tamże, s. 631. W odniesieniu do osób zatrudnionych w pełnym wymiarze czasu pracy powinien być to inny dzień wolny, a w sytuacji osób zatrudnionych na część etatu - czas wolny w innym dniu odpowiadający liczbie godzin przepracowanych w dzień świąteczny. Por. Konkluzje XII-2, s. 61.

206 Konkluzje XIV-2, s. 220.

207 Por. m.in. Konkluzje V, s. 15 i n. 
Dłuższe urlopy wypoczynkowe, w świetle postanowień omawianego aktu (art. 7 ust. 7 Karty), należy zagwarantować też pracownikom młodocianym, ze względu na potrzebę szczególnej ochrony zdrowia fizycznego i psychicznego organizmu znajdującego się w okresie rozwoju ${ }^{208}$.

Bezpośrednio z przepisów Karty wynika także zasada odpłatności urlopu oraz coroczności tego świadczenia.

Niemniej prawo do urlopu wypoczynkowego, sformułowane dość ogólnie w art. 2 ust. 3 Karty, zostało rozwinięte w kolejnych cyklach kontrolnych Komitetu Praw Społecznych, który oceniając rozwiązania prawne obowiązujące w tym zakresie w poszczególnych państwach, określił dodatkowo kilka ważnych reguł.

Przede wszystkim uznano za niedopuszczalne zrzeczenie się przez pracownika prawa do urlopu w zamian za określoną gratyfikację finansową, z wyjątkiem przypadków szczególnych, kiedy pracownik nie ma możliwości wykorzystania urlopu w naturze $\mathrm{w}$ związku $\mathrm{z}$ rozwiązaniem stosunku pracy (ekwiwalent pieniężny). Podobną zasadę sformułowano również w zakresie prawa do odpoczynku tygodniowego. Wszelkie porozumienia między stronami stosunku pracy wyłączające omawianą zasadę należy uznać za nieskuteczne ${ }^{209}$.

Niezgodne z postanowieniami Karty jest też faktyczne zmniejszanie wymiaru urlopu w związku z zaliczaniem do niego okresu choroby, która wystąpiła w trakcie korzystania przez pracownika $\mathrm{z}$ tego zwolnienia, czy nawet rozpoczęła się wcześniej. Komitet, rozważając problem wpływu choroby na prawo do urlopu wypoczynkowego, przyjął ostatecznie, że ze względu na funkcję omawianego świadczenia, całości lub części urlopu niewykorzystanej przez pracownika z podanej przyczyny należy mu udzielić $\mathrm{w}$ terminie późniejszym ${ }^{210}$. Konsekwencją powyższego stanowiska musi być uznanie obowiązku przerwania urlopu w razie choroby i udzielenia niewykorzystanej części w terminie późniejszym lub przesunięcia go na inny termin, jeśli choroba uniemożliwia rozpoczęcie urlopu wypoczynkowego w zaplanowanym terminie. Dotyczy to urlopu w minimalnym wymiarze określonym w Karcie ${ }^{211}$.

Komitet Praw Społecznych przyjął natomiast możliwość uzależnienia prawa do urlopu wypoczynkowego od przyjętego w danym państwie stażu pracy, w tym nawet 12-miesięcznego okresu zatrudnienia u danego pracodawcy ${ }^{212}$. Niemniej Komitet wskazywał także na potrzebę nabywania prawa do pierwszego urlopu $\mathrm{w}$ wymiarze proporcjonalnym do okresu zatrudnienia, tj. $\mathrm{w}$ razie nieosiągnięcia

208 Por. szerzej J. Wratny, Prawo pracy Rady..., s. 147.

209 Por.: Konkluzje I, s. 170 lub Konkluzje XIV-2, s. 222. Zob. ponadto L. Samuel, Droits sociaux fondamentaux. Jurisprudence de la Charte sociale européenne, Strasbourg 1997, s. 53 i n.

210 Por. Konkluzja XII-2, s. 62. Por. też: Konkluzje XIV-2 (Norwegia), s. 580 i Konkluzje XVI-2 (Hiszpania), s. 833, a także J. Wratny, Prawo pracy Rady..., s. 137 oraz L. Samuel, Droits sociaux..., s. 55.

211 Por. Konkluzje XIV-2, s. 580. Zob. też L. Samuel, Droits sociaux..., s. 55.

212 Por. Konkluzje I, s. 20 oraz B. Skulimowska, Prawo..., s. 30. Zob. też: J. Wratny, Prawo pracy Rady..., s. 137 oraz L. Samuel, Droits sociaux..., s. 54. 
stażu pracy warunkującego urlop wypoczynkowy w pełnym wymiarze powinien on być odpowiednio skracany, tak aby każdy pracujący miał prawo do odpoczynku rocznego w wymiarze stosownym do liczby przepracowanych miesięcy ${ }^{213}$.

Beneficjentem powyższych postanowień Karty są wszyscy pracownicy (niezależnie od tego, czy zatrudnienie ma charakter terminowy i w pełnym wymiarze czasu pracy czy też nie $\left.{ }^{214}\right)$, a także członkowie rodziny osób współpracujących z przedsiębiorcą prowadzącym działalność rolniczą ${ }^{215}$. Nie gwarantuje ona natomiast prawa do odpoczynku osobom pracującym na własny rachunek.

Trzeba również pamiętać, że warunkiem uznania wykonania omawianego prawa jest objęcie odpowiednią regulacją w tym zakresie znacznej większości wymienionych wyżej osób, tj., jak przyjmuje Komitet, co najmniej 80\% pracowników ${ }^{216}$.

\subsection{Prawo do odpoczynku w prawie Unii Europejskiej}

Stosunkowo późno uregulowania dotyczące wypoczynku pojawiły się w prawie wspólnotowym. W postanowieniach Traktatu Rzymskiego była co prawda mowa o zachowaniu istniejącego systemu płatnych urlopów wypoczynkowych, niemniej przepis ten nie rodził konkretnych praw podmiotowych po stronie pracowników, miał więc raczej programowy charakter ${ }^{217}$. W zasadzie, jeśli chodzi o akty prawnie wiążące, kwestie dotyczące czasu pracy w szerszym ujęciu zamieszczono dopiero w dyrektywie 93/104/WE z 23 listopada 1993 r. w sprawie niektórych aspektów organizacji czasu pracy. Wcześniej w omawianym obszarze wydano jedynie zalecenie, o niewiążącym charakterze, o zasadach 40-godzinnego tygodnia pracy oraz czterotygodniowego płatnego urlopu wypoczynkowego (22 lipca 1975 r. $)^{218}$, a także wprowadzono prawo do wypoczynku cotygodniowego i płatnych urlopów do Wspólnotowej Karty Podstawowych Praw Socjalnych Pracowników ${ }^{219}$. Karta, ostatecznie dokument bardziej polityczny niż prawny, miała w założeniu uzupełniać konwencje MOP oraz Europejską Kartę Społeczną Rady Europy w zakresie m.in. poprawy warunków życia i pracy ${ }^{220}$. W literaturze przedmiotu bywa

213 Por. Konkluzje VII, s. 14. Zob. też L. Samuel, Droits sociaux..., s. 55.

214 Por. w odniesieniu do urlopu wypoczynkowego Konkluzje XIV-2, s. 222 i n.

215 Por. A.M. Świątkowski, Karta Praw..., s. 100. Zob. też L. Samuel, Droits sociaux..., s. 54.

216 Por. Konkluzje I, s. 20.

217 Por. L. Mitrus, Wptyw regulacji wspólnotowych na polskie prawo pracy, Kraków 2006, s. 233 i podana tam literatura.

218 Recommendation concerning the principle of the 40-hour week and the principle of 4 weeks' annual paid vacation, Dz. Urz. WE 1975 (30 lipca), nr L 199. Zob. też L. Florek, Prawo pracy Unii Europejskiej, [w:] Prawo pracy i ubezpieczeń społecznych, red. tenże, Warszawa 1996, S. 51.

219 Por. szerzej: L. Florek, Czas pracy i urlopy wypoczynkowe w prawie europejskim, „PiZS” 1999, nr 2, s. 12 oraz R. Blanpain, M. Matey, Europejskie prawo..., s. 62 i n.

220 R. Blanpain, M. Matey, Europejskie prawo..., s. 60. Por. też C. Barnard, EC Employment Law, Chichester 1995, s. 61 in. 
wyrażany również pogląd, że w zasadzie dopiero od momentu jej uchwalenia Wspólnota Europejska zaczęła postrzegać czas pracy jako kategorię społecznie istotną, służącą do ochrony praw człowieka ${ }^{221}$.

Niewątpliwie podkreśleniem wysokiej rangi prawa do odpoczynku było ostatecznie zamieszczenie go w Karcie Praw Podstawowych Unii Europejskiej z 2000 r. Artykuł 31 ust. 2 tej Karty przewiduje, że każdy pracownik ma prawo do ograniczenia maksymalnego wymiaru czasu pracy, do okresów dziennego i tygodniowego odpoczynku oraz do corocznego płatnego urlopu ${ }^{222}$.

Wszystkie te elementy reguluje szczegółowo wspomniana wyżej dyrektywa poświęcona problematyce czasu pracy i urlopów wypoczynkowych, zmieniona w 2003 r. ${ }^{223}$ Wskazuje ona m.in. na konieczność zagwarantowania minimalnych standardów odpoczynku w trzech wymiarach: dobowym, tygodniowym i rocznym oraz wprowadzenia przerw w pracy.

Przedkładając projekt tego aktu, Komisja zwróciła uwagę, że obserwowana tendencja do uelastyczniania czasu pracy, często bardzo korzystna dla pracodawców, ale i samych zatrudnionych, wymaga jednak zabezpieczenia pracowników przed nadmiernie wydłużonym czasem pracy stanowiącym poważne zagrożenie dla ich zdrowia i bezpieczeństwa. Zdaniem Komisji, bezdyskusyjny jest fakt, że każda praca, nawet lekka, pociąga za sobą pewien wysiłek i zmęczenie, które wzrastają z każdą kolejną godziną pracy, zwłaszcza jeśli przekracza ona ośmiogodzinną normę dobową. W rezultacie rośnie poziom stresu, ryzyko popełniania błędów, ale też zwiększa się znacznie prawdopodobieństwo wystąpienia wypadków przy pracy (w szczególności o charakterze ciężkim). Dotyczy to również tygodniowego wymiaru czasu pracy, który w przekonaniu twórców projektu, jeśli jest zbyt długi (np. przekraczający 50 godzin), może w dłuższej perspektywie stwarzać niebezpieczeństwo dla życia i zdrowia osób świadczących pracę, wywoływać zmęczenie, zaburzenia snu itd. Stąd, jak podkreślono w uzasadnieniu projektu dyrektywy, tak ważne jest zagwarantowanie pracownikom minimalnych okresów odpoczynku ${ }^{224}$.

Ostatecznie zarówno obowiązująca wcześniej dyrektywa 93/104, jak i obecna dyrektywa 2003/88, zastępująca tę pierwotną i przejmująca w gruncie rzeczy jej rozwiązania $\mathrm{w}$ aspekcie szeroko rozumianego czasu pracy, gwarantują pracownikom minimalną ochronę $\mathrm{w}$ zakresie ich bezpieczeństwa i zdrowia $\mathrm{w}$ związku z czasem pracy i opierają się na założeniu, że cele o charakterze gospodarczym nie mogą być jedynym kryterium determinującym kształt przepisów regulujących tę materię 225 . Prawo do odpoczynku stało się przy tym jednym z głównych motywów wydania wymienionych wyżej aktów. Dotyczy to w szczególności dyrektywy

221 Tak por. A.M. Świątkowski, Prawo pracy Unii..., Warszawa 2015, s. 278.

222 Szerzej na ten temat por. L. Mitrus, Karta Praw Podstawowych Unii Europejskiej. Komentarz, red. A. Wróbel, Warszawa 2012, s. 929 i n.

223 Dyrektywa 2003/88/WE z 4 listopada 2003 r., Dz. Urz. UE 2003 (18 listopada), nr L 299, s. 9.

224 Por. Dz. Urz. WE 1990 (9 września), nr C 254/4. Por. też: R. Blanpain, M. Matey, Europejskie..., s. 158 i n. oraz szerzej: D. Schiek, Europaisches Arbeitsrecht, Baden-Baden 1997, s. 223.

225 Zob. preambuła dyrektywy 93/104 oraz pkt 4 preambuły Dyrektywy 2003/88 - www.eur-lex. europa.eu (dostęp 14.02.2017, godz.. 11.15). Por. też L. Mitrus, Wpływ..., s. 222. 
2003/88, w której, jak oceniają niektórzy autorzy, zaprezentowano jednolitą koncepcję czasu pracy, zabezpieczającą pracującym omawiane prawo ${ }^{226}$. Została ona, zdaniem A. Świątkowskiego, osadzona na dwóch elementach: konstrukcji prawnej ograniczania norm czasu pracy oraz zagwarantowaniu osobom świadczącym pracę uprawnień w zakresie odpoczynku ${ }^{227}$.

Ustawodawca wspólnotowy dał temu wyraz już w preambule dyrektywy 2003/88 (a wcześniej też częściowo dyrektywy 93/104), w której zapisano, że wszystkim pracownikom powinny przysługiwać odpowiednie okresy odpoczynku, realizowane w konkretnych jednostkach czasu (dzień, tydzień, rok), a także przerwy w pracy oraz że w celu skuteczniejszego wykonania tego prawa konieczne staje się wyznaczenie maksymalnego limitu tygodniowego wymiaru czasu pracy (pkt 5 preambuły). Zmianie uległa również stosowana w niej terminologia - zrezygnowano z określenia występującego we wcześniejszej dyrektywie, w której posłużono się pojęciem „przerw” dziennych czy tygodniowych, na rzecz wyeksponowania pojęcia odpoczynku.

Dyrektywa reguluje wiele szczegółowych elementów dotyczących organizacji szeroko pojętego czasu pracy. Określono w niej pojęcie czasu pracy oraz pojęcie okresu odpoczynku, ustalono, co szczególnie istotne z punktu widzenia prowadzonych rozważań, minimalne okresy odpoczynku dobowego, tygodniowego i rocznego, przerwy w pracy, a także maksymalny tygodniowy czas pracy, a ponadto uregulowano kwestie pracy w porze nocnej (postrzeganej jako istotne źródło potencjalnych zagrożeń dla zdrowia pracowników ${ }^{228}$ ), pracy zmianowej oraz harmonogramów pracy. W zakresie tych ostatnich wymaga się, aby były one tworzone przez pracodawców przy uwzględnieniu zasady dostosowania organizacji pracy do pracownika - rodzaju wykonywanej przez niego pracy, wymagań bezpieczeństwa oraz zdrowia, m.in. poprzez planowanie określonych przerw w pracy (zwłaszcza jeśli praca ma charakter monotonny).

Pojęcie odpoczynku ma na gruncie prawa wspólnotowego określoną treść, jest pojęciem, jak przyjął Trybunał Sprawiedliwości UE, prawa UE i jest definiowane w bezpośredniej kontrze do pojęcia czasu pracy ${ }^{229}$.

226 Wskazuje się przy tym, że wcześniejsza dyrektywa obejmująca tę materię była bardzo mocno powiązana z problematyką bezpieczeństwa i higieny pracy (w tym z dyrektywą ramową 89/391), ale przede wszystkim z polityką kreowania nowych miejsc pracy dla osób wkraczających na rynek pracy poprzez ograniczanie norm czasu pracy. Opierała się w dużej mierze na przesłankach o charakterze gospodarczym. Tak por. A.M. Świątkowski, Prawo pracy..., s. 277 i n.

227 Tamże, s. 278.

228 W preambule dyrektywy powołano się na badania, które wykazały, że organizm ludzki w porze nocnej jest bardziej podatny na zakłócenia środowiska oraz uciążliwe formy organizacji pracy, a także że dłuższe okresy pracy w porze nocnej mogą być szkodliwe dla zdrowia pracowników i zagrażać ich bezpieczeństwu w miejscu pracy. Dlatego też zwrócono uwagę na potrzebę m.in. ograniczenia okresów pracy w porze nocnej, w tym zwłaszcza w zakresie godzin nadliczbowych.

229 Por. pkt 25 orzeczenia TSUE z 10 września 2015 w sprawie Federacion de Servicios Privados del sindicato Comisiones obreras v „Tyco”, C-266/14, Dz.Urz. UE C 363/16, w którym Trybunał, rozpatrując pytanie prawne zadane przez sąd hiszpański (Audiencia Nacional), dokonał interpretacji wymienionych wyżej pojęć i uznał, że pojęcie czasu pracy i pojęcie odpoczynku 
Okresem odpoczynku, w rozumieniu prawa wspólnotowego, jest każdy okres, który nie jest czasem pracy (a więc nie jest „okresem, podczas którego pracownik pracuje, jest do dyspozycji pracodawcy oraz wykonuje swoje działania lub spełnia obowiązki, zgodnie z przepisami krajowymi lub praktyką krajową" - art. 2 pkt 1 i 2 dyrektywy). Ów odpoczynek można uznać za „odpowiedni”, jeśli pracownikom zagwarantuje się regularne okresy odpoczynku, których wymiar jest wyrażany w jednostkach czasu oraz które są wystarczające długie i nieprzerwane w celu zapewnienia, że w wyniku zmęczenia lub nieregularnych harmonogramów pracy pracownicy nie powodują wypadków, których ofiarami są oni sami lub ich współpracownicy oraz nie doznają uszczerbku na zdrowiu zarówno krótkoterminowo, jak i w dłuższym czasie (art. 2 pkt 9 dyrektywy).

Na podstawie powołanych przepisów Trybunał Sprawiedliwości UE wielokrotnie analizował konkretne sytuacje z punktu widzenia możliwości kwalifikowania ich w kategoriach „odpoczynku”. Szczególnie ważne są orzeczenia, które odnoszą się do dyżurów pracowniczych, w tym w szczególności dyżurów medycznych. Trybunał w licznych swoich wyrokach dotyczących tej materii wyraźnie podkreślał, że czas spędzony przez pracownika $\mathrm{w}$ ramach dyżuru w zakładzie pracy, nawet jeśli w jego trakcie występują godziny poświęcone na sen, nie może być z punktu widzenia postanowień dyrektywy traktowany jako okres wyłączony z czasu pracy, a tym samym zaliczany do okresu odpoczynku. Dyrektywa, jak słusznie zauważył Trybunał, nie przewiduje bowiem innego typu czasookresów - albo coś jest czasem pracy, albo czasem odpoczynku ${ }^{230}$. Trybunału podkreślił przy tym wyraźnie, że „celem dyrektywy jest zapewnienie ochrony zdrowia i bezpieczeństwa pracowników poprzez zapewnienie im minimalnych okresów odpoczynku i odpowiednich przerw. [...] wyłączenie czasu dyżurowania z czasu pracy w sytuacjach, gdy wymaga się od pracownika jego obecności fizycznej w zakładzie pracy, w poważny sposób podważałoby ten cel”231. Dyrektywa nie pozwala państwu członkowskiemu na to, aby w przepisach prawa krajowego traktować czas dyżurowania jako okresu odpoczynku ${ }^{232}$, co niewątpliwie kłóciłoby się $\mathrm{z}$ istotą tego ostatniego oraz funkcją przepisów omawianej dyrektywy.

Poza zdefiniowaniem podstawowych pojęć związanych z odpoczynkiem, w tym zwłaszcza wyjaśnieniem istoty „odpoczynku odpowiedniego"233, w dyrektywie wprowadzono kilka elementów, które odpoczynek ten mają zabezpieczać.

wzajemnie się wykluczają. W dyrektywie nie ma bowiem, zdaniem Trybunału, okresu pośredniego między pracą a odpoczynkiem. Podobnie m.in. L. Mitrus, Wpływ..., s. 225. Zob. ponadto L. Mitrus, Stosunek pracy, Kraków 2005, s. 255 i n. W kontekście problematyki dyżurów pracowniczych pojawiły się propozycje, aby wprowadzić kategorię pośrednią pomiędzy czasem pracy a czasem odpoczynku. Por. szerzej J. Skoczyński, Pojęcie czasu pracy w prawie Unii Europejskiej, [w:] Czas pracy, red. L. Florek, Warszawa 2011, s. 58 i n.

230 Por. m.in.: orzeczenie TSUE z 1 grudnia 2005 r. w sprawie Abdelkader Dellas i in. przeciwko Premier ministre i in., C-14/04, Dz. Urz. UE C 36/8; orzeczenie TSUE z 3 października 2000 r. w sprawie SiMAP, C-303/98; orzeczenie TSUE z 9 września 2003 r. w sprawie Jaeger, C-151/02, www.eur-lex.europa.eu [dostęp 14.02.2017].

231 Tak orzeczenie TSUE z 3 października 2000 r. w sprawie SiMAP.

232 Por. orzeczenie TSUE z 9 września 2003 r. w sprawie Jaeger.

233 Pojęcie to zostało wprowadzone do dyrektywy z $2003 \mathrm{r}$. 
Jak wcześniej wspomniano, prawo pracownika do odpoczynku na gruncie postanowień dyrektywy realizują przede wszystkim przepisy, które określają minimalne standardy w zakresie:

- odpoczynku dobowego - państwa należące do UE zostały zobowiązane do zapewnienia każdemu pracownikowi co najmniej 11 godzin nieprzerwanego odpoczynku w okresie obejmującym 24 godziny.

- odpoczynku tygodniowego - zgodnie z art. 5 dyrektywy państwa członkowskie przyjmują niezbędne środki w celu zapewnienia, by każdy pracownik był uprawniony w okresie siedmiodniowym do minimalnego nieprzerwanego okresu odpoczynku w wymiarze 35 godzin (w tym 11 godzin odpoczynku dobowego). Wyjątkowo odpoczynek ten może być skrócony do 24 godzin, jeśli jest to uzasadnione warunkami obiektywnymi, technicznymi lub organizacyjnymi. W dyrektywie z 2003 r., zgodnie ze stanowiskiem Trybunału Sprawiedliwości UE, nie ma już bezpośredniego zalecenia, jak to było pierwotnie, aby odpoczynek ten przypadał na niedzielę ${ }^{234}$.

- przerw w pracy - w dyrektywie wprowadzono wymóg zagwarantowania pracownikom przerwy na wypoczynek w przypadku, gdy dobowy wymiar czasu pracy jest dłuższy niż sześć godzin. Szczegółowe warunki, na jakich przerwy te będą udzielane, w tym zwłaszcza ich ilość i długość, ma zostać określona w prawie wewnętrznym państw członkowskich (w tym np. w układach zbiorowych pracy).

- urlopu wypoczynkowego, o czym dalej.

Ważne są również te postanowienia dyrektywy, które zmierzają do ograniczenia godzin pracy w porze nocnej, określają tygodniowy limit czasu pracy, tj. że przeciętny wymiar czasu $\mathrm{w}$ okresie siedmiodniowym, łącznie $\mathrm{z}$ pracą $\mathrm{w}$ godzinach nadliczbowych, nie może przekraczać 48 godzin, oraz odnoszą się do okresów rozliczeniowych. Te ostatnie, bowiem, im są krótsze, tym bardziej przeciwdziałają kumulowaniu zmęczenia związanego $\mathrm{z}$ pracą $\mathrm{w}$ dłuższym przedziale czasowym oraz z nieregularnym jej wykonywaniem.

Ocenia się jednak, że postanowienia dyrektywy są w tym obszarze dość liberalne. Przede wszystkim wynikająca $\mathrm{z}$ powoływanego aktu maksymalna tygodniowa norma czasu pracy ma charakter przeciętny, stąd dłuższa niż 48-godzinna pra$\mathrm{ca} \mathrm{w}$ jednych tygodniach będzie rekompensowana krótszą pracą $\mathrm{w}$ innych tygodniach. Stopień dolegliwości takiego wydłużenia tygodnia pracy będzie jednak w dużej mierze uzależniony od okresu rozliczeniowego. Zwraca bowiem uwagę, że przyjmowany zasadniczo czteromiesięczny okres rozliczeniowy (art. 16 pkt b Dyrektywy) może być, choć tylko w szczególnie uzasadnionych przypadkach i na podstawie porozumień zbiorowych oraz przy zachowaniu ogólnych zasad bezpieczeństwa i zdrowia pracowników, ewentualnie też w odniesieniu do wybranych grup pracowniczych ${ }^{235}$, przedłużony nawet do 12 miesięcy (art. 19-21 dyrektywy).

234 Na temat okoliczności rezygnacji z regulacji odpoczynku niedzielnego por. szerzej P. Grzebyk, Ochrona odpoczynku niedzielnego, [w:] Czas pracy, red. L. Florek, Warszawa 2011, s. 200 i n. Zob. też L. Mitrus, Stosunek pracy, s. 263.

235 Zgodnie z dyrektywą, 12-miesięczny okres rozliczeniowy przewidziany dla rozliczenia 48-godzinnej normy dobowej może być stosowany do pracowników na pokładach morskich statków rybackich (art. 21 dyrektywy), a także, przy zachowaniu ogólnych zasad bezpie- 
Ponadto prawo krajowe może dopuścić swego rodzaju uchylenie omawianego tygodniowego limitu na podstawie porozumień zawieranych indywidualnie z poszczególnymi pracownikami (tzw. prawo wyboru), przy zachowaniu określonych dodatkowych warunków wymienionych w art. 22 ust. 1 dyrektywy ${ }^{236}$ oraz wynikających z orzecznictwa Trybunału Sprawiedliwości UE ${ }^{237}$. Zdaniem Europejskiej Konfederacji Związków Zawodowych (ETUC), pozwala to na znaczące wydłużanie godzin pracy części zatrudnionych, co jest sprzeczne z prawem traktatowym zobowiązującym do limitowania maksymalnej długości czasu pracy wszystkich pracowników UE ${ }^{238}$. Dlatego też ETUC domagało się m.in. usunięcia z dyrektywy klauzuli opt-out.

Obawy sformułowane przez wspomnianą wyżej konfederację związków zawodowych znalazły częściowo swe potwierdzenie w opublikowanym przez Komisję Europejską w ostatnich latach raporcie dotyczącym społeczno-gospodarczych aspektów czasu pracy. Potwierdzono w nim negatywny wpływ wielogodzinnej pracy oraz pracy w czasie weekendu i w nocy na zdrowie i dobre samopoczucie pracowników, a za jeden z głównych czynników zagrożenia uznano przedłużanie okresów rozliczeniowych poza podstawowe wielkości wskazane w dyrektywie. W szczególności sformułowano wyraźne ostrzeżenie przed wprowadzeniem 12-miesięcznych okresów rozliczeniowych $\mathrm{w}$ prawie wewnętrznym poszczególnych państw jako potencjalnie niebezpiecznych dla życia i zdrowia ludzkiego. W raporcie tym zaleca się ośmiogodzinny dzień pracy, pięciodniowy tydzień pracy, a tym samym 40-godzinną normę tygodniową, które najpełniej przyczyniają się do zachowania równowagi między życiem zawodowym i prywatnym pracowników ${ }^{239}$.

Z drugiej jednak strony, na fali wyraźnej tendencji do uelastyczniania czasu pracy, zwolennicy „klauzuli opt-out” - w tym też sama Komisja Europejska - wskazują, że zachowanie klauzuli pozwoli krajom słabszym pod względem gospodarczym, w szczególności pracownikom z tych państw, na zniwelowanie róż-

czeństwa i zdrowia oraz w razie wystąpienia przyczyn wskazanych w przepisie (art. 20 dyrektywy), do pracowników, którzy wykonują zasadniczo pracę na urządzeniach oddalonych od brzegu.

236 Chodzi w szczególności o poszanowanie zasad bezpieczeństwa i ochrony zdrowia pracowników, ale też prawa pracownika do odmowy wyrażenia zgody na wprowadzenie takiej klauzuli (przede wszystkim zabezpieczenie przed sankcjami ze strony pracodawcy), prowadzenie aktualnej dokumentacji dotyczącej tego rodzaju przypadków, wprowadzenie prawa stosownych organów do kontroli tej dokumentacji wraz z prawem do wydania zakazu w zakresie wydłużania maksymalnego tygodniowego czasu pracy w danym przypadku.

237 Trybunał w swych rozstrzygnięciach kładzie nacisk przede wszystkim na kwestię wyrażenia zgody przez pracownika. Wymaga on bezwzględnie, aby oświadczenie woli w tej sprawie było dobrowolne, wyraźne oraz by zostało złożone bezpośrednio przez zatrudnionego (a nie np. reprezentującą go organizację związkową). Por. wyrok TSUE w sprawie Pfeifer C-397/01 oraz C-403/01, a także wyrok w sprawie C-303/98.

238 Por. Prawa podstawowe a dyrektywa o czasie pracy, European Trade Union Confederation (ETUC), www.etuc.org [dostęp 14.02.2017].

239 Tamże. 
nic w wydajności pracy bez ograniczania płac i poziomu konsumpcji ${ }^{240}$. Dużą rolę odgrywają także czynniki związane z zachowaniem konkurencyjności gospodarki europejskiej. Ścierają się zatem argumenty o charakterze ekonomicznym ze wskazaniami natury społecznej i zdrowotnej, stanowiącymi podstawę pracowniczego prawa do odpoczynku.

Z powyższych względów, ale też z powodu konieczności uwzględnienia specyficznych warunków wykonywania pracy, większość norm wynikających z dyrektywy w zakresie odpoczynku nie ma bezwzględnego charakteru. Wskazane już wcześniej możliwości wydłużania okresów rozliczeniowych czy wprowadzania klauzuli opt-out nie należą do jedynych wyjątków zawartych w dyrektywie. Pozwala się państwom członkowskim UE (ewentualnie partnerom społecznym) na odstąpienie od opisanych wymogów dyrektywy w innych jeszcze szczególnych sytuacjach lub zawodach oraz rodzajach działalności (np. w stosunku do lekarzy-stażystów). Dotyczy to nie tylko wydłużenia tygodnia pracy lub okresu rozliczeniowego, ale również odejścia od podstawowych reguł związanych z udzielaniem odpoczynku dobowego i tygodniowego. Zgodnie z regulacją rozdziału 5 dyrektywy, z należytym poszanowaniem ogólnych zasad bezpieczeństwa i zdrowia pracowników można bowiem odstąpić od przepisów regulujących odpoczynek dobowy i tygodniowy, m.in.:

- w przypadku, gdy ze względu na szczególny charakter wykonywanych czynności, wymiar czasu pracy nie jest z góry ustalony czy możliwy do sprecyzowania lub może być on określony przez samych pracowników, w tym zwłaszcza w odniesieniu do pracowników zarządzających zakładem pracy, pracowników przedsiębiorstw rodzinnych czy pracowników pełniących obowiązki podczas ceremonii religijnych w kościołach oraz wspólnotach wyznaniowych;

- w stosunku do pracowników wykonujących pracę w specyficznych warunkach lub zakładach wymienionych w ust. 3 art. 17 dyrektywy, w tym np. miejscach oddalonych od miejsca zamieszkania pracownika (włącznie z pracą na urządzeniach oddalonych od brzegu), firmach prowadzących działalność z zakresu ochrony bezpieczeństwa i nadzoru, która wymaga stałej obecności ludzi w celu ochrony osób lub mienia (strażników, dozorców, firm ochroniarskich), zakładach, których funkcjonowanie jest niezbędne ze względu na konieczność zachowania ciągłości usług lub produkcji (w opiece zdrowotnej, portach, lotniskach, transporcie miejskim, środkach masowego przekazu, poczcie, jednostkach badawczo-rozwojowych, gałęziach przemysłu, w których praca ze względu na technologię produkcji nie może być wstrzymana, w gazowniach, wodociągach, elektrowniach, zakładach oczyszczania miasta itp.), w obszarach, w których występują możliwe do przewidzenia działania, np. rolnictwie, turystyce, usługach pocztowych, w przypadku niektórych pracowników zatrudnionych w transporcie kolejowym czy w razie wystąpienia wypadku lub realnego zagrożenia jego wystąpieniem; 
- w odniesieniu do pracowników wykonujących pracę zmianową lub w przerywanym systemie czasu pracy;

- pracowników wykonujących pracę w trasie;

- osób wykonujących pracę na pokładzie morskich statków rybackich pływających pod banderą państwa członkowskiego.

Ponadto, jak wynika z art. 18 dyrektywy, odstępstwa od okresów odpoczynku ustalonych w dyrektywie (ale też m.in. ustalonych okresów rozliczeniowych) mogą być wprowadzane w drodze układów zbiorowych pracy oraz innych porozumień zbiorowych zawieranych przez partnerów społecznych na szczeblu krajowym lub regionalnym. W tym przypadku wymaga się jednak wyraźnie, aby zainteresowanym pracownikom przyznano równoważne okresy odpoczynku, a wyjątkowo, jeśli z obiektywnych powodów nie jest to możliwe, zostali oni objęci właściwą ochroną.

Trzeba też pamiętać, że dyrektywa dotycząca czasu pracy ustanawia minimalny poziom ochrony w tytułowym zakresie, co zawsze pozwala państwu członkowskiemu na przyjęcie lub utrzymanie standardów wyższych od wynikających $\mathrm{z}$ omawianego aktu, m.in. w zakresie urlopu wypoczynkowego ${ }^{241}$.

Odmienne, bardziej precyzyjne zasady odnoszące się do ukształtowania okresów odpoczynku $\mathrm{w}$ określonych zawodach lub rodzajach działalności mogą również wynikać z innych instrumentów prawa wspólnotowego, które wówczas znajdują pierwszeństwo przed dyrektywą (preambuła dyrektywy 2003/88 oraz jej art. 14).

Jak wynika z powyższych rozważań, zakres możliwych odstępstw od reguł odpoczynku dobowego i tygodniowego, określonych w dyrektywie, jest stosunkowo szeroki. Niemniej ich analiza wskazuje, że zwykle są one dość mocno powiązane z obiektywnymi warunkami wykonywania pracy lub specyfiką określonych zawodów, które wymagają często odmiennego ukształtowania tego odpoczynku. Trzeba bowiem zauważyć, że według ogólnych wskazań zawartych w dyrektywie, wynikających m.in. z jej preambuły, zasadą powinno być przyznanie pracownikom objętym opisanymi wyjątkami „wyrównawczych okresów odpoczynku” oraz respektowanie ogólnych norm ochrony życia i zdrowia osób zatrudnionych.

Niemniej sama koncepcja czasu pracy i związanego z nim odpoczynku, przyjęta w dyrektywie, może być uznana, w pewnym sensie, za dość charakterystyczną.

241 Por. m.in. wyrok TSUE z 24 stycznia 2012 r. w sprawie Dominguez, C-282/10, EU: C:2012:33, pkt 47, czy wyrok TSUE z 3 maja 2012 r. w sprawie Neidel, C-337/10, EU:C:2012:263, pkt 3435. Trybunał uznał, że pracownikom może być zagwarantowany wyższy niż określony w dyrektywie wymiar urlopu. Państwa członkowskie muszą, z jednej strony, podjąć decyzję o ewentualnym przyznaniu pracownikom prawa do urlopu wypoczynkowego w większym wymiarze niż minimalny okres przewidziany w art. 7 dyrektywy. Jeśli tak się stanie, państwa członkowskie mogą postanowić, że pracownikowi, który z powodu choroby nie mógł w pełni wykorzystać przysługującego mu urlopu wypoczynkowego przed ustaniem jego stosunku pracy, przysługuje prawo do ekwiwalentu pieniężnego w wymiarze odpowiadającym takiemu dodatkowemu okresowi. $Z$ drugiej strony państwa członkowskie muszą określić warunki przyznawania takiego ekwiwalentu. 
W literaturze przedmiotu zauważono bowiem, że mamy w niej do czynienia z jednej strony $\mathrm{z}$ obowiązkiem pracodawcy zatrudniania pracowników w granicach norm czasu pracy wyznaczonych przepisami dyrektywy, a z drugiej strony z prawem pracowników do odpoczynku (w tym przerw w pracy), które to prawo musi być przez pracodawcę respektowane. Jego poszanowanie, jak zauważa A. Świątkowski, analizując obowiązujące w tym zakresie przepisy unijne oraz orzecznictwo Trybunału Sprawiedliwości UE, oznacza zakaz wydawania poleceń świadczenia pracy w czasie odpoczynku, tj. powyżej ustalonych limitów czasu pracy, ale nie jest równoznaczne $z$ obowiązkiem pracodawcy niedopuszczania pracownika do pracy w tych okresach, jeśli pracownik wyraża taką wolę. Tym samym trzeba przyjąć, że zgodnie z omawianą dyrektywą, na podmiotach zatrudniających nie ciąży obowiązek stworzenia pracownikowi warunków pozwalających na skorzystanie z przysługującego mu prawa do odpoczynku ${ }^{242}$. W świetle powyższego stanowiska, realizacja omawianego prawa leży zatem w dużej mierze w gestii samego zatrudnionego.

Z punktu widzenia tytułowych rozważań podstawowe znaczenie ma prawo pracownika do urlopu wypoczynkowego, które określa się często mianem odpoczynku rocznego. Wydaje się, że tak właśnie jest ono pojmowane w dyrektywie, która reguluje kwestie związane $\mathrm{z}$ urlopem $\mathrm{w}$ ramach problematyki szeroko rozumianego czasu pracy. Urlop wypoczynkowy jest w istocie odpłatną i coroczną przerwą w procesie wykonywania pracy służącą odpoczynkowi ${ }^{243}$.

Na gruncie prawa wspólnotowego urlop wypoczynkowy jest traktowany w sposób szczególny. Świadczy o tym nie tylko fakt, że wspomniano o nim wprost już w prawie traktatowym, a ostatecznie wymieniono prawo do urlopu wypoczynkowego w Karcie Praw Podstawowych UE ${ }^{244}$ (obowiązującej na równi z traktatami ${ }^{245}$ ), ale też brak przewidzianych w dyrektywie jakichkolwiek odstępstw od obowiązku zagwarantowania go każdemu pracownikowi w określonym wymiarze (w przeciwieństwie do innych okresów odpoczynku, o czym pisałam wcześniej). Potwierdza to również orzecznictwo TSUE, w którym świadczenie to uznano za jedną z fundamentalnych zasad prawa socjalnego UE, podstawowy gwarant realizacji prawa pracownika do odpoczynku, wytchnienia i czasu wolnego ${ }^{246}$.

242 Tak zob. A.M. Świątkowski, Prawo pracy..., s. 278 i n.

243 Wskazywał na to już wcześniej L. Florek. Por. tenże, Europejskie prawo pracy, Warszawa 2005, s. 144.

244 Art. 31 Karty Praw Podstawowych Unii Europejskiej z 7 grudnia 2000 r., Dz. Urz. UE 2010 (30 marca) nr C 83, gwarantuje każdemu pracownikowi w ramach należytych i sprawiedliwych warunków pracy m.in. coroczny płatny urlop.

245 Art. 6 ust. 1 Traktatu o Unii Europejskiej. Potwierdzit to wprost TSUE w wyroku z 3 maja 2012 r. w sprawie Neidel, C-337/12, pkt 40.

246 Por. m.in.: wyrok TSUE z 20 stycznia 2009 r. w sprawach połączonych Schultz-Hoff i in., C-350/06 i 520/06, Zb. Orz., s. I-179, pkt 43 i 55; wyrok TSUE z 10 września 2010 r. Vicente Pereda, C-277/08, www.curia.europa.eu, pkt 18 i powołane tam orzecznictwo oraz wyrok TSUE z 30 czerwca 2016 r. w sprawie Alicja Sobczyszyn przeciwko Szkole Podstawowej w Rzeplinie, C-178/15, www.eur-lex.europa.eu. 
W samej dyrektywie uregulowania dotyczące urlopu wypoczynkowego nie należą do rozbudowanych. Wynika z niej jednak bezwzględny obowiązek wszystkich państw członkowskich UE zagwarantowania corocznego, płatnego urlopu każdemu pracownikowi, w wymiarze co najmniej czterech tygodni, na warunkach określonych w prawie wewnętrznym tych państw. Jednocześnie, aby zapewnić jak najpełniejszą realizację funkcji omawianego świadczenia, a zarazem podkreślić wartość czasu wolnego, art. 7 ust. 2 dyrektywy przewiduje zakaz zamiany dni wolnych objętych urlopem na ekwiwalent pieniężny, z wyjątkiem jednej jedynej sytuacji wskazanej w tym przepisie, a mianowicie, gdy urlop ten nie może być wykorzystany z powodu rozwiązania stosunku pracy.

Mimo stosunkowo skromnej regulacji dyrektywy w zakresie prawa urlopowego, trzeba podkreślić, że wiele kwestii szczegółowych decydujących o ostatecznej treści, kształcie tego prawa wynika z europejskiego orzecznictwa. Prawo to było bowiem i jest przedmiotem zainteresowania Trybunału Sprawiedliwości UE, który ocenia obowiązujące w tym obszarze rozwiązania prawne poszczególnych państw z punktu widzenia funkcji urlopu i ogólnych jego celów określonych w dyrektywie.

W licznych swych wyrokach Trybunał, odnosząc się do zakresu podmiotowego tego prawa, podkreślał jego powszechność, tj. fakt, że zgodnie z przepisami dyrektywy są nim objęci wszyscy pracownicy, niezależnie od np. ich płci, wieku, stanu zdrowia $^{247}$ czy zatrudnienia na podstawie terminowych umów o pracę ${ }^{248}$. W szczególności ci ostatni, ze względu na niestabilność ich sytuacji prawnej, powinni zostać otoczeni szczególną ochroną w zakresie uprawnień urlopowych. Za niedopuszczalne należy uznać m.in. wprowadzenie takich warunków nabycia prawa do urlopu wypoczynkowego, jakich osoby zatrudnione na podstawie umów terminowych nie mogą spełnić ${ }^{49}$. Trybunał wyraźnie stwierdził, że ustawodawca unijny przeciwdziała tego rodzaju przepisom lub praktykom, w wyniku których państwa członkowskie jednostronnie ograniczają prawo do corocznego urlopu wypoczynkowego, przysługujące wszystkim pracownikom, poprzez wprowadzenie warunku nabycia tego prawa skutkującego wyłączeniem niektórych pracowników z możliwości skorzystania $\mathrm{z}$ niego ${ }^{250}$.

Powyższe uwagi odnoszą się także do osób zatrudnionych w niepełnym wymiarze czasu pracy, których uprawnienia w zakresie urlopu wypoczynkowego powinny kształtować się proporcjonalnie do tych, jakie mają osoby zatrudnione na cały etat. Zasady tej nie można jednak stosować, jak słusznie zauważył TSUE,

247 Por. m.in. wyrok TSUE z 20 lipca 2016 r. w sprawie Hansa Mascheka, C-341/15, www.curia. europa.eu, pkt 25.

248 Por. wyroki TSUE: z 16 marca 2006 r. w sprawach połączonych Robinson-Steele i in., C-131/04 i C-257/04, Zb. Orz., s. I-2531, pkt 48 (też curia.europa.eu - j.w.), z 18 marca 2004 r. w sprawie Merino Gomez, C-342/01, www.curia.europa.eu, pkt 29 oraz z 6 kwietnia 2006 r. w sprawie Federatie Nederlandse Vakbeweging, C- 124/05, www.ec.europa.eu, pkt 27-28.

249 Por. A.M. Świątkowski, Prawo pracy..., s. 282 oraz L. Mitrus, Stosunek pracy, s. 267 i n.

250 Por. m.in. wyrok TSUE z 26 czerwca 2001 r. w sprawie BECTU, C-173/99, Zb. Orz., s. I-04881, pkt 52 oraz wyrok TSUE z 24 stycznia 2012 r. w sprawie Dominguez, C-282/10, pkt 17. 
ex post, $\mathrm{tj}$. do prawa do urlopu wypoczynkowego nabytego w okresie pracy w pełnym wymiarze. Jeśli więc pracownik był początkowo zatrudniony w pełnym wymiarze czasu pracy i nabył prawo do urlopu, ale go nie wykorzystał, to w razie zmniejszenia etatu w roku następnym zachowuje on prawo do urlopu zaległego w pełnym, niezredukowanym proporcjonalnie wymiarze ${ }^{251}$.

Z orzecznictwa Trybunału wynika również, że ze względu na rangę omawianego uprawnienia i jego znaczenie dla realizacji prawa każdego człowieka do odpoczynku, powinien on być zagwarantowany niezależnie od innych ewentualnych przerw w wykonywaniu pracy, przypadających na rok nabycia prawa do tego urlopu przez daną osobę, jeśli ich cele nie są ze sobą zbieżne. W ten sposób ów sąd niejako zanegował tezę, według której odpoczynek nie jest potrzebny osobom niewykonującym pracy w danym okresie.

Powyższa konstatacja odnosi się m.in. do wszelkich zwolnień chorobowych przypadających w czasie urlopu wypoczynkowego. Trybunał uznał bowiem, że w świetle postanowień dyrektywy, generalnie niedopuszczalne jest wprowadzenie w prawie lub praktyce krajowej rozwiązań, które powodowałyby wygaśnięcie prawa do urlopu wypoczynkowego z upływem roku kalendarzowego jego nabycia lub terminu jego dopuszczalnego przesunięcia w sytuacji braku możliwości wykorzystania go $\mathrm{w}$ tych okresach $\mathrm{z}$ powodu przebywania pracownika na „zwolnieniu chorobowym”252. Wniosek taki opiera się na przekonaniu Trybunału, że generalnie funkcja corocznego, płatnego urlopu, który ma zapewniać pracownikowi odpoczynek, czas wolny jest różna od przeznaczenia prawa do zwolnienia chorobowego, którego celem jest umożliwienie mu powrotu do zdrowia ${ }^{253}$. W związku z tym Trybunał kilkakrotnie już orzekał, że pracownikowi, który przebywał na zwolnieniu chorobowym w czasie ustalonego według określonej procedury terminu urlopu, przysługuje prawo do wykorzystania tego urlopu w innym terminie, choćby wykraczającym poza rok kalendarzowy, za który ten urlop przysługuje ${ }^{254}$. Jednocześnie Trybunał przyznał, że z punktu widzenia respektowania art. 7 dyrektywy, gwarantującego urlop wypoczynkowy, dopuszczalne jest przyjęcie w przepisach wewnętrznych poszczególnych państw zakazu korzystania z urlopu w trakcie zwolnienia lekarskiego, jak to ma miejsce $\mathrm{w}$ prawie polskim, $\mathrm{z}$ jednoczesnym zastrzeżeniem prawa do tego urlopu w innym

251 Por. m.in. wyrok TSUE z 22 kwietnia 2010 r. w sprawie Zentralbetriebsrat der Landeskrankenhäuser Tirols, C-486/08, www.curia.europa.eu., pkt 32 i n.

252 Por. m.in. wyrok TSUE z 20 stycznia 2009 r. w sprawach połączonych Schultz-Hoff i in. Stanowisko Trybunału w tej sprawie było dość krytycznie oceniane nie tylko przez rządy zainteresowanych państw, lecz także przez Komisję Europejską, która zapowiedziała zezwolenie państwom członkowskim na określenie i wprowadzenie górnego limitu zgromadzonych uprawnień w zakresie urlopu wypoczynkowego dla pracowników korzystających z długotrwałych zwolnień lekarskich, na poziomie minimum wskazanego w dyrektywie, tj. czterech tygodni.

253 Por. m.in. wyrok TSUE z 21 czerwca 2012 r. w sprawie ANGED, C-78/11, www.curia.europa.eu.

254 Por. tamże, pkt 20 oraz np. wyrok TSUE z 10 września 2010 r. Vincente Pereda. 
terminie, ale też, co z punktu widzenia celów dyrektywy i ogólnego uzasadnienia prawa do odpoczynku może już budzić pewne wątpliwości, możliwości realizacji urlopu w trakcie zwolnienia lekarskiego ${ }^{255}$.

Art. 7 dyrektywy nie daje natomiast podstaw, na co również zwrócono uwagę $\mathrm{w}$ orzecznictwie unijnym, do uzależnienia przez prawo wewnętrzne państwa członkowskiego nabycia urlopu wypoczynkowego w minimalnym wymiarze czterech tygodni od „rzeczywistego świadczenia pracy” przez wymagany okres w roku, za który ten urlop będzie przysługiwać256. Jak zauważył bowiem Trybunał, przepisy dyrektywy nie wprowadzają żadnego rozróżnienia pomiędzy pracownikami nieobecnymi w pracy podczas okresu rozliczeniowego przyjętego dla urlopu wypoczynkowego ze względu na zwolnienie chorobowe (niezależnie od jego przyczyny, w tym rodzaju choroby, jej pochodzenia, np. jako ewentualnego następstwa wypadku przy pracy itd.) a pracownikami, którzy rzeczywiście świadczyli w tym czasie pracę. Z tego wynika, że „prawo do corocznego płatnego urlopu pracownika nieobecnego podczas okresu rozliczeniowego ze względów zdrowotnych nie może być przez państwo członkowskie uzależnione od obowiązku rzeczywistego wykonania pewnej pracy w tym samym okresie"257.

Szczególne kontrowersje w omawianym wyżej kontekście wywołała kwestia tzw. urlopów zdrowotnych występujących w różnym zakresie na gruncie przepisów wewnętrznych wielu państw, w tym m.in. prawa polskiego. Ostatecznie stanowisko analogiczne do wcześniej powołanego w przedmiocie niezdolności do pracy z powodu choroby zostało przedstawione w wyroku z 2016 r. odnoszącym się do polskiego stanu prawnego, a konkretnie przepisów ustawy - Karta Nauczycie$l a^{258} \mathrm{i}$ uregulowanego $\mathrm{w}$ niej urlopu dla poratowania zdrowia. Zdaniem Trybunału, jeżeli sąd krajowy oceni, że cele urlopu zdrowotnego oraz urlopu wypoczynkowego są odmienne, jest to równoznaczne z obowiązkiem pracodawcy udzielenia pracownikowi tego ostatniego w innym terminie niż ten wcześniej zaplanowany i pokrywający się z okresem korzystania z urlopu zdrowotnego, nawet jeśli termin ten będzie przekraczać okres rozliczeniowy, w jakim należy, zgodnie z prawem krajowym, urlop wypoczynkowy wykorzystać25. Nowy termin urlopu powinien zostać zaproponowany przez pracownika, ale uwzględniać też ważny interes pracodawcy.

255 Por. pkt 29-31 wyroku TSUE z 20 stycznia 2009 r. w sprawach połączonych Schultz-Hoff i in.

256 Por. wyrok TSUE z 24 stycznia 2012 r. w sprawie Dominguez, C-282/10, pkt 21. Chodziło o poddanie urlopu wypoczynkowego wymogowi posiadania minimalnego okresu 10 dni lub miesiąca rzeczywistego świadczenia pracy w okresie rozliczeniowym przyjętym dla omawianego prawa.

257 Tamże, pkt 30. Por. też wyrok TSUE z 26 czerwca 2001 r. w sprawie BECTU, C-173/99, pkt 52-53.

258 Ustawa z 26 stycznia 1982 r. - Karta Nauczyciela, tekst jednolity, Dz. U. 2017, poz. 1189. Art. 73 ust. 1 Karty przewiduje, że urlop ten jest udzielany „w celu przeprowadzenia zalecanego leczenia", co, jak sugeruje Trybunat, pozostawiając ostateczną ocenę sądowi krajowemu, wskazuje na inne funkcje wspominanego świadczenia w porównaniu z celem urlopu wypoczynkowego. Wyrok TSUE z 30 czerwca 2016 r. w sprawie Alicja Sobczyszyn przeciwko Szkole Podstawowej w Rzeplinie, C-178/15.

259 Wyrok TSUE z 30 czerwca 2016 r. 
Przy okazji wydawania tego orzeczenia, ale i we wcześniejszych swych wypowiedziach, Trybunał zwrócił uwagę na zasadę urlopu corocznego. Podkreślił przede wszystkim jej istotne znaczenie dla pełnej realizacji funkcji urlopu wypoczynkowego oraz kwestii bezpieczeństwa i zdrowia zatrudnionego. Niemniej, jak przyjął Trybunał w kontekście zbiegu prawa do urlopu z innymi okresami nieobecności $\mathrm{w}$ pracy, w tym choćby urlopami dla poratowania zdrowia czy zwolnieniami chorobowymi, w tym przypadku czas odpoczynku nie traci swego znaczenia, nawet jeśli ma być wykorzystany w trakcie następnego roku kalendarzowego ${ }^{260}$. Niekiedy, w ocenie Trybunału, jest to wręcz nieuniknione.

Jednakże, aby urlop spełnił swe podstawowe funkcje, a więc z jednej strony umożliwiał odpoczynek od zadań wykonywanych w ramach stosunku pracy, a $z$ drugiej zapewniał wytchnienie i czas wolny, przeniesienie tego urlopu nie może wykraczać poza określone ramy czasowe. Po przekroczeniu bardzo długiego czasu, biorąc pod uwagę moment nabycia prawa do urlopu i moment, kiedy może on być wykorzystany, urlop ten, zdaniem Trybunału, traci bowiem swój wypoczynkowy charakter, utrzymując jedynie swą funkcję związaną z zapewnieniem czasu wolnego ${ }^{261}$.

W związku z tym Trybunał Sprawiedliwości UE zdecydował się nieco zweryfikować opisaną wyżej i potwierdzoną w licznych orzeczeniach zasadę dotyczącą wpływu zwolnień lekarskich na prawo do urlopu wypoczynkowego. Chodzi o sytuację pracownika, który z powodu choroby jest niezdolny do pracy przez kilka następujących po sobie lat. Gdyby w stosunku do niego stosować konsekwentnie wypracowaną regułę, pracownik ten miałby możliwość gromadzenia, w nieograniczonym wymiarze, wszystkich praw do corocznego płatnego urlopu wypoczynkowego nabytych w czasie owej nieobecności w pracy. Takie "gromadzenie urlopu”, w ocenie Trybunału, nie odpowiadałoby już jego celowi, o czym wyżej była mowa. Trybunał w konsekwencji stanął na stanowisku, że jest zgodne z art. 7 dyrektywy ewentualne ograniczenie $\mathrm{w}$ prawie lub praktyce krajowej, poprzez np. ustanowienie 15-miesięcznego okresu dozwolonego przeniesienia, po upływie którego prawo do urlopu wygasa, możliwości gromadzenia uprawnień do urlopu wypoczynkowego przez pracownika niezdolnego do pracy w ciągu kilku następujących po sobie lat ${ }^{262}$. Trybunał zaznaczył jednak, że wyznaczając taki okres dozwolonego przeniesienia urlopu, należy wziąć pod uwagę m.in. jego cel, wysoką rangę tego prawa, a w szczególności zasadę, że okres ten musi „znacznie” wykraczać poza czas trwania okresu rozliczeniowego (rok), za który urlop ten został przyznany (np. 15 miesięcy, jak w stanie faktycznym, którego orzeczenie dotyczyło ${ }^{263}$.

260 Tamże. Por. też orzeczenia wcześniejsze: wyrok TSUE z 6 kwietnia 2006 r. w sprawie Federatie Nederlandse Vakbeweging, C-124/05 oraz wyrok TSUE z 20 stycznia 2009 r. w sprawie Schultz-Hoff $\mathrm{i}$ in.

261 Por. wyrok TSUE z 22 listopada 2011 r. w sprawie KHS AG przeciwko Winfriedowi Schultemu, C-214/10, www.eur-lex.europa.eu, pkt 30-33.

262 Tamże.

263 Tamże. 
Powyższy problem zbiegu prawa do urlopu $\mathrm{z}$ innymi zwolnieniami od pracy był również rozstrzygany w odniesieniu do urlopów związanych $\mathrm{z}$ rodzicielstwem, $\mathrm{w}$ tym zwłaszcza macierzyńskich i wychowawczych. Generalna zasada, jaką w tym zakresie przyjął Trybunał, jest taka, że jeden urlop gwarantowany przez przepisy prawa wspólnotowego nie może wpływać na możliwość skorzystania $\mathrm{z}$ innego urlopu przewidzianego przez to prawo ${ }^{264}$. Zwykle cele tych urlopów, jak zauważa Trybunał, istotnie różnią się bowiem od siebie. Istotą urlopu wypoczynkowego jest zapewnienie pracownikowi określonego odpoczynku, natomiast funkcją np. urlopu macierzyńskiego jest ochrona zdrowia kobiety oraz szczególnej więzi między rodzicami a dzieckiem. Stąd też Trybunał uznał, że pracownicy muszą mieć zagwarantowaną możliwość skorzystania z urlopu wypoczynkowego $\mathrm{w}$ innym okresie niż urlop macierzyński, nawet wówczas jeśli termin, w jakim wykorzystywany jest ten ostatni, koliduje z zaplanowanym wcześniej urlopem wypoczynkowym (choćby ów okres urlopowy był określony w ogólny sposób dla całej załogi w układzie zbiorowym pracy ${ }^{265}$.

Analogiczne podejście należy stosować również do innych urlopów związanych $\mathrm{z}$ rodzicielstwem. W świetle orzecznictwa unijnego ${ }^{266}$, ale też na podstawie przepisów porozumienia ramowego dotyczącego urlopu rodzicielskiego ${ }^{267}$, konieczne jest przyjęcie takiej regulacji prawnej, która zapewni, że pracownicy korzystający $\mathrm{z}$ urlopu rodzicielskiego nie będą tracić prawa do urlopu wypoczynkowego, które nabyli przed tym urlopem. Ze wspomnianego porozumienia wynika bowiem, jak przypomina Trybunał, że jednym z jego celów jest uniknięcie utraty lub ograniczenia praw wynikających ze stosunku pracy, nabytych lub nabywanych, na które pracownik może powoływać się $\mathrm{w}$ momencie rozpoczęcia urlopu rodzicielskiego, i zagwarantowanie, że po jego zakończeniu pozostanie on w odniesieniu do tych praw w identycznej sytuacji, w jakiej znajdował się przed tym urlopem. Do tego rodzaju praw należy bez wątpienia, zdaniem Trybunału Sprawiedliwości UE, prawo do urlopu wypoczynkowego każdego pracownika, niezależnie od jego płci ${ }^{268}$.

264 Por. m.in. wyrok TSUE z 14 kwietnia 2005 r. w sprawie Komisja Europejska przeciwko Luksemburgowi, C-519/03, www.curia.europa.eu.

265 Por. w szczególności wyrok TSUE z 18 marca 2004 r. w sprawie Merino Gomez, C-342/01, tamże.

266 Por. m.in. wyrok TSUE z 22 kwietnia 2010 r. w sprawie Zentralbetriebsrat der Landeskrankenhäuser Tirols, C-486/08, pkt 50 in.

267 Porozumienie ramowe w sprawie urlopu rodzicielskiego z 14 grudnia 1995 r. będące załącznikiem do dyrektywy 96/34/WE z dnia 3 czerwca 1996 r. (Dz. Urz. UE nr L 145, s. 4) zmienionej dyrektywą 97/75/WE z 15 grudnia 1997 r. (Dz. Urz. UE 1998, nr L 10, s. 24). Zgodnie z klauzulą 2 pkt 6 owego porozumienia, uprawnienia nabyte lub nabywane przez pracownika w chwili rozpoczęcia urlopu rodzicielskiego są zachowane w niezmienionej formie do zakończenia urlopu rodzicielskiego i mają zastosowanie po zakończeniu tego urlopu. Analogiczne postanowienie zostało zawarte ostatecznie w klauzuli 5 pkt 2 zmienionego porozumienia ramowego dotyczącego urlopu rodzicielskiego, wdrożonego dyrektywą 210/18/UE z 8 marca 2010 r. w sprawie wdrożenia zmienionego porozumienia ramowego dotyczącego urlopu rodzicielskiego zawartego przez BUSINESSEUROPE, UEAPME, CEEP i ETUC oraz uchylającą dyrektywę 96/34/WE, Dz. Urz. UE 2010 (18 marca), nr L 68, s. 13.

268 Por. wyrok TSUE z 22 kwietnia 2010 r. w sprawie Zentralbetriebsrat der Landeskrankenhäuser Tirols, pkt 54. 
Dlatego też prawo krajowe nie może wprowadzać norm naruszających wspomniane wymogi i przewidujących, że np. pracownicy, którzy korzystają z prawa do urlopu rodzicielskiego w wymiarze dwóch lat, tracą po jego zakończeniu prawo do corocznego płatnego urlopu nabyte w roku poprzedzającym narodziny dziecka (jak to miało miejsce w prawie austriackim na obszarze Tyrolu) ${ }^{269}$.

Zasadą prawa urlopowego, wprost wskazaną w dyrektywie, obok wspomnianej już zasady coroczności, jest odpłatność. W prawie UE i wydawanym na jego podstawie orzecznictwie bardzo mocno ugruntowało się przekonanie, że prawo do przerwy urlopowej i wynagrodzenia za czas jej trwania są to $\mathrm{w}$ istocie dwa aspekty tego samego prawa ${ }^{270}$. Celem wynagrodzenia urlopowego jest bowiem stworzenie realnej możliwości odpoczynku pracownikowi korzystającemu z urlopu wypoczynkowego. Żeby tak się stało, pracownik w okresie tego urlopu musi znajdować się w sytuacji porównywalnej pod względem płacowym do tej, w jakiej znajduje się w okresach pracy ${ }^{271}$. Dlatego też, mimo że przepisy dyrektywy nie zawierają konkretnych wytycznych w przedmiocie obliczania wysokości tego świadczenia, Trybunał przyjmuje jako ogólną regułę, że wynagrodzenie urlopowe powinno odpowiadać „Zwykłemu wynagrodzeniu” pracownika za ten okres ${ }^{272}$.

Trybunał w swych orzeczeniach wielokrotnie podejmował próbę wypracowania określonych kryteriów obliczania tego świadczenia, szczególnie gdy wynagrodzenie pracownika składa się z różnych elementów płacowych. Analiza poszczególnych stanów faktycznych pozwoliła Trybunałowi określić wiele wytycznych umożliwiających, w zależności od przypadku, włączenie niektórych świadczeń do wynagrodzenia za czas urlopu lub też wykluczenie ich z tego wynagrodzenia. Generalną zasadą, którą kieruje się Trybunał w tym obszarze, jest uznanie, że „chociaż struktura zwykłego wynagrodzenia pracownika podlega przepisom krajowym lub praktyce krajowej państwa członkowskiego, to nie może mieć ona wpływu na prawo pracownika do korzystania podczas okresu odpoczynku z warunków ekonomicznych porównywalnych do tych, które stosują się w przypadku, gdy wykonuje on pracę"273. Z orzecznictwa wynika, że wynagrodzenie urlopowe powinno obejmować m.in.:

- kwotę pieniężną stanowiącą rekompensatę niedogodności nierozerwalnie związanych z wykonywaniem zadań wynikających z umowy o pracę, uwzględnianą przy obliczaniu całkowitego wynagrodzenia pracownika, np. w przypadku pilotów

269 Por. tamże, pkt 56. Powyższe stanowisko stało się również elementem uzasadnienia konieczności zmiany w polskim prawie, w zakresie tzw. urlopu proporcjonalnego. Por. druk 909, www.senat.gov.pl.

270 Por. np. wyrok TSUE z 20 stycznia 2009 r. w sprawie Schultz-Hoff i in. oraz wyrok TSUE z 22 maja 2014 r. w sprawie Z.J.R. Locka, C-539/12, www.curia.europa.eu, pkt 17.

271 Por. np. wyroki TSUE: z 16 marca 2006 r. w sprawach połączonych Robinson-Steele i in., C-131/04 i C-257/04, pkt 58 oraz z 20 stycznia 2009 r. w sprawie Schultz-Hoff i in., pkt 60.

272 Por. m.in. wyrok TSUE z 22 maja 2014 r. w sprawie Z.J.R. Locka, C-539/12, pkt 16.

273 Por. m.in. wyrok TSUE z 22 maja 2014 r. w sprawie Williams i in., C-155/10, Zb. Orz., s. I-8409, pkt 23. 
chodzi o czas spędzany w powietrzu ${ }^{274}$. Ocena owego "nieodzownego związku” między poszczególnymi składnikami całkowitego wynagrodzenia a wykonywaniem zadań powierzonych pracownikowi w ramach nawiązanego stosunku pracy należy, zdaniem Trybunału, do sądu krajowego. Ocenę tę należy przeprowadzić mając na uwadze średnią z okresu referencyjnego uznanego za reprezentatywny ${ }^{275}$;

- wszystkie składniki „całkowitego wynagrodzenia”, które wiążą się z osobistym i zawodowym statusem pracownika, np. dodatki funkcyjne, stażowe, dodatki związane z kwalifikacjami zawodowymi ${ }^{276}$;

- wszelkie premie i prowizje pozostające $\mathrm{w}$ bezpośrednim związku z działalnością pracownika (jego zadaniami) w ramach zatrudniającego go przedsiębiorstwa. Sprzeczne z dyrektywą będą zatem takie regulacje i praktyki, w wyniku których pracownik uzyskujący wynagrodzenie składające się z płacy zasadniczej oraz prowizji (np. od sprzedaży) będzie miał prawo z tytułu urlopu wypoczynkowego wyłącznie do wynagrodzenia podstawowego ${ }^{277}$. Tutaj również, jak ocenił Trybunał Sprawiedliwości UE, sąd krajowy powinien w razie wątpliwości dokonać stosownej oceny, na podstawie wcześniej omówionych kryteriów, czy na gruncie prawa danego państwa, opierając się na średniej za okres odniesienia uznany za reprezentatywny, metody obliczania prowizji należnej pracownikowi w okresie korzystania z urlopu wypoczynkowego pozwalają osiągnąć cel wynikający z art. 7 dyrektywy ${ }^{278}$. W szczególności, według Trybunału, sprzeczne z funkcją powołanego przepisu dyrektywy będzie wypłacenie wynagrodzenia urlopowego w wysokości porównywalnej do zwykle uzyskiwanego, a więc z uwzględnieniem prowizji, ale pozbawienie pracownika tego składnika wynagrodzenia po urlopie, $\mathrm{z}$ tego powodu, że w okresie owego urlopu tej prowizji „nie wypracował”. Może to bowiem $\mathrm{w}$ rezultacie zniechęcić do korzystania z prawa do wypoczynku z uwagi na szkodę finansową powstającą później ${ }^{279}$. Tym samym w orzecznictwie unijnym przeciwdziała się nieuzasadnionemu zmniejszeniu wynagrodzenia w związku z urlopem wypoczynkowym nie tylko w trakcie tej przerwy, ale także po jej zakończeniu.

Pominięte przy obliczaniu wynagrodzenia za czas urlopu mogą zostać natomiast te składniki wynagrodzenia, których wyłącznym celem jest pokrycie kosztów, jak to ujął Trybunał, „ponoszonych od czasu do czasu” i „kosztów ubocznych” powstających przy wykonywaniu zadań wynikających z umowy ${ }^{280}$.

Zasadą prawa urlopowego wynikającą pośrednio z samej dyrektywy, której wagę dla realizacji efektywnego odpoczynku podkreślał wielokrotnie Trybunał Sprawiedliwości UE, jest też zasada urlopu w naturze, tj. w postaci dni wolnych. Taki

274 Tamże, pkt 24.

275 Tamże, pkt 26.

276 Tamże, pkt 27-28. Por. też wyrok TSUE z 1 lipca 2010 r. w sprawie Parviainen, C-471/08, Zb. Orz., s. I-6533, pkt 73.

277 Por. wyrok TSUE z 22 maja 2014 r. w sprawie Z.J.R. Locka, C-539/12, pkt 24.

278 Tamże, pkt 32-35.

279 Tamże, pkt 21-23.

280 Por. wyrok TSUE z 22 maja 2014 r. w sprawie Williams i in., C-155/10, pkt 25. 
sposób realizacji wskazanego uprawnienia najpełniej służy bowiem rzeczywistemu wypoczynkowi, sprzyja bezpieczeństwu i ochronie zdrowia zatrudnionego ${ }^{281}$. Od zasady tej dopuszcza się jeden tylko wyjątek, wyraźnie określony w dyrektywie, polegający na możliwości wypłaty ekwiwalentu pieniężnego za niewykorzystany urlop w sytuacji, gdy dochodzi do ustania stosunku pracy. Wynika z tego, po pierwsze, że możliwość zamiany dni wolnych w zakresie urlopu wypoczynkowego na świadczenie pieniężne jest zastrzeżona wyłącznie dla przypadku wprost opisanego w dyrektywie. Tym samym niedopuszczalna będzie zamiana urlopu na ekwiwalent pieniężny w razie przesunięcia terminu urlopu na rok następny, nawet jeśli dochodzi do tego w wyniku porozumienia zawartego między stronami. Wypowiadając się w tej kwestii, Trybunał zwrócił uwagę, że tego rodzaju zamiana świadczenia w naturze na świadczenie pieniężne stwarzałaby swego rodzaju zachętę do rezygnacji z urlopu wypoczynkowego lub namawiania pracowników do takiej rezygnacji, co jest w sposób oczywisty sprzeczne z celami omawianej dyrektywy ${ }^{282}$. Z drugiej strony, pracodawca ma bezwzględny obowiązek wypłacenia ekwiwalentu w razie rozwiązania stosunku pracy i niewykorzystania przez pracownika urlopu wypoczynkowego w całości lub w części, niezależnie od jakichkolwiek innych okoliczności, np. powodu ustania stosunku pracy czy strony inicjującej jego rozwiązanie. Za sprzeczne z postanowieniami prawa wspólnotowego uznano zatem w orzecznictwie Trybunału Sprawiedliwości UE m.in. takie przepisy prawa krajowego, które pozbawiają pracownika rozwiązującego stosunek pracy w związku z przejściem na emeryturę prawa do ekwiwalentu za urlop ${ }^{283}$.

Podobnie formułuje się ogólny zakaz wyłączenia prawa do ekwiwalentu pieniężnego za niewykorzystany urlop wypoczynkowy w razie ustania zatrudnienia w stosunku do pracowników, którzy nie mogli urlopu wykorzystać z przyczyn od nich niezależnych, zwłaszcza gdy przez cały rok (lub okres dopuszczalnego przeniesienia urlopu) przebywali na zwolnieniu lekarskim i z tego powodu nie wykorzystali urlopu. Trybunał zdecydował bowiem, że nikt nie może być pozbawiony prawa do tego świadczenia w razie spełnienia konkretnych warunków jego wypłaty opisanych w art. 7 dyrektywy ${ }^{284}$.

Jednakże, aby zapewnić skuteczność prawa do urlopu wypoczynkowego (effet utile) w orzecznictwie Trybunału Sprawiedliwości UE przyjęto, że pracownik, którego stosunek pracy zostaje rozwiązany, a który na mocy porozumienia zawartego z pracodawcą został zwolniony z obowiązku świadczenia pracy w określonym czasie poprzedzającym to rozwiązanie $z$ zachowaniem prawa do wynagrodzenia, nie nabywa ekwiwalentu za niewykorzystany w tym okresie urlop, chyba że nie mógł tego urlopu wykorzystać z powodu choroby ${ }^{285}$. Wydaje się, że Trybunał doszedł

281 Por. wyrok TSUE z 6 kwietnia 2006 r. w sprawie Federatie Nederlandse Vakbeweging, C- $124 / 05$, pkt 32.

282 Tamże.

283 Por. wyrok TSUE z 20 lipca 2016 r. w sprawie Hansa Mascheka, C-341/15, pkt 28-30.

284 Por. m.in. wyrok TSUE z 20 stycznia 2009 r. w sprawie Schultz-Hoff i in., pkt 62 oraz wyrok TSUE z 20 lipca 2016 r. w sprawie Hansa Mascheka, C-341/15, pkt 31.

285 Wyrok TSUE z 20 lipca 2016 r. w sprawie Hansa Mascheka, C-341/15, pkt 35-37. 
w rozpatrywanej sprawie do przekonania, że cele czy istota zwolnienia z obowiązku wykonywania pracy oraz urlopu wypoczynkowego są może nie zbieżne, ale na tyle zbliżone, że nie ma przeszkód, by w czasie takiego zwolnienia pracownik skutecznie zrealizował wypoczynkową funkcję urlopu, co jednak może rodzić pewne kontrowersje (por. uwagi dotyczące urlopu w okresie wypowiedzenia zawarte w III części opracowania).

W sprawie sposobu obliczania owego ekwiwalentu Trybunał przypominał, że jest on pochodną prawa do urlopu wypoczynkowego i wynagrodzenia za ten okres. Pracownik, który nie mógł wykorzystać corocznego płatnego urlopu wypoczynkowego przed ustaniem zatrudnienia, powinien uzyskać więc ekwiwalent pieniężny w takiej wysokości, która spowoduje, że znajdzie się on w sytuacji porównywalnej do tej, w jakiej znajdowałby się, gdyby skorzystał z urlopu w naturze podczas trwania stosunku pracy. Z tego wynika, że zwykłe wynagrodzenie pracownika, stanowiące podstawę obliczenia wynagrodzenia urlopowego, powinno stać się również decydujące przy ustalaniu kwoty ekwiwalentu pieniężnego za niewykorzystany urlop wypoczynkowy ${ }^{286}$.

Jak wynika z powyższego, prawo do urlopu wypoczynkowego postrzegane jest w orzecznictwie Trybunału Sprawiedliwości UE jako podstawowy gwarant prawa do wypoczynku, bezpieczeństwa i ochrony zdrowia ludzkiego. Z tej perspektywy ocenia się zgodność z prawem wspólnotowym różnych krajowych rozwiązań prawnych w przedmiocie zasad nabycia i udzielania urlopu wypoczynkowego. To do państw członkowskich należy bowiem ustalenie w ich regulacjach krajowych warunków wykonania i transpozycji prawa UE do corocznego płatnego urlopu w drodze sprecyzowania konkretnych okoliczności, w których pracownicy mogą korzystać z tego świadczenia, jednak, jak wielokrotnie podkreślał Trybunał Sprawiedliwości UE, „,bez możliwości poddania jakimkolwiek warunkom samego istnienia tego prawa”287. Stanowi ono bowiem jedną z głównych zasad prawa socjalnego UE, niekwestionowany standard pracowniczej ochrony.

\subsection{Regulacja odpoczynku w konstytucyjnym porządku prawnym państw europejskich}

Wraz z pojawianiem się coraz bardziej rozbudowanych międzynarodowych i europejskich unormowań w obszarze prawa do odpoczynku, zaczyna ono zyskiwać także większe uznanie poszczególnych ustawodawców krajowych. Wypoczynek, obok tak podstawowych praw jak prawo do pracy, wynagrodzenia za pracę, zaczyna być postrzegany jako nieodłączny element procesu pracy, szeroko pojętego życia ludzkiego, a tym samym zasadniczy i konieczny instrument jego ochrony.

286 Por. wyrok TSUE z 20 stycznia 2009 r. w sprawie Schultz-Hoff i in., pkt 61.

287 Por. m.in.: wyrok TSUE z 26 czerwca 2001 r. w sprawie BECTU, C-173/99; wyrok TSUE z 20 stycznia 2009 r. w sprawie Schultz-Hoff i in., pkt 46 czy wyrok TSUE z 24 stycznia 2012 r. w sprawie Dominguez, C-282/10, pkt 18. 
Znalazło to swój wyraz szczególnie w aktach rangi konstytucyjnej, które ze swej istoty odzwierciedlają przyjęte przez dane państwo wiodące idee i wartości, zasady organizacji życia społeczno-politycznego i gospodarczego. Trzeba jednak wyraźnie podkreślić, że konstytucjonalizacja prawa do odpoczynku nastąpiła stosunkowo późno, w zasadzie w drugiej połowie XX w. i nie ma charakteru powszechnego. Konstytucje powstające w XVIII i XIX w. pozostawały bowiem pod silnym wpływem doktryny liberalnej, traktującej pracę jak zwykły towar poddany swobodnej grze sił rynkowych. Taki sposób ujmowania pracy ludzkiej, postrzegania roli państwa jako „nocnego stróża”, stojącego jedynie na straży bezpieczeństwa wewnętrznego i zewnętrznego, ale nie socjalnego, nie sprzyjał normowaniu praw o społeczno-ekonomicznym charakterze.

W związku z powyższym to przede wszystkim w ramach ustawodawstwa zwykłego podejmowano pierwsze wysiłki na rzecz ograniczenia dobowej i tygodniowej normy czasu pracy osób wykonujących pracę zarobkową ze względu na ich zdrowie i bezpieczeństwo ${ }^{288}$. Chodziło więc o odpoczynek fizycznie niezbędny.

Z czasem poza ograniczaniem godzin pracy pracowników uznano również ich prawo do płatnego urlopu wypoczynkowego, który dziś jest podstawowym elementem prawa do odpoczynku. Przed pierwszą wojną światową korzystały z niego jedynie wybrane kategorie pracowników (np. urzędnicy państwowi) i to często, wobec nielicznych jeszcze wówczas ustaw urlopowych, na podstawie dobrej woli pracodawcy $^{289}$. Po pierwszej wojnie światowej wzrasta liczba aktów prawnych gwarantujących przerwę urlopową, a samo prawo do urlopu wypoczynkowego stało się prawem podmiotowym pracownika, mającym swe źródło w ustawie, układzie zbiorowym pracy lub w samej umowie o pracę ${ }^{290}$. Niektórzy dowodzili nawet, że pracownik ma prawo do urlopu w braku odpowiednich regulacji normatywnych na zasadzie prawa zwyczajowego lub też obowiązku pieczy pracodawcy ${ }^{291}$. W literaturze niemieckiej sformułowano też pogląd wskazujący na publicznoprawny charakter prawa urlopowego, oparty na konstytucyjnej zasadzie ochrony godności ludzkiej i na publicznej trosce o zdrowie obywatela ${ }^{292}$. Niemniej upowszechnienie omawianego prawa następuje faktycznie dopiero po drugiej wojnie światowej, początkowo przede wszystkim w państwach socjalistycznych, które zdecydowały się także nadać mu rangę konstytucyjną ${ }^{293}$.

288 Najwcześniej regulacje tego rodzaju pojawiły się w prawie angielskim (bo już w pierwszej połowie XIX w.), zwłaszcza jeśli chodzi o czas pracy młodocianych i kobiet. Nieco później odpowiednie ustawy przyjęły również inne państwa, np. Francja i Niemcy. Por. szerzej m.in. A. Sobczyk, Zasady..., s. 45 i n.

289 Por. J. Loga, Poglądy nauki burżuazyjnej..., s. 53. Por. też tenże, Urlopy wypoczynkowe, Łódź 1963, s. 17 in.

290 Por. J. Loga, Poglądy nauki burżuazyjnej..., s. 53 i n.

291 Tamże, s. 55 i podana tam literatura.

292 Por. L. Schnorr von Carolsfeld, Arbeitsrecht, Göttingen 1954, s. 246, za: J. Loga, Poglądy nauki burżuazyjnej..., s. 56.

293 Por. m.in.: Konstytucja ZSRR z 1936 r. (art. 119); Konstytucja PRL z 22 lipca 1952 r. (art. 59), Konstytucja Bułgarii z 1947 r. (art. 74), Konstytucja Czechosłowacji z 1948 r. (§ 28). 
Konstytucjonalizacji pracowniczego prawa do odpoczynku w początkowym okresie nie sprzyjał również jego charakter. Prawa społeczno-ekonomiczne były bowiem przez bardzo długi czas uznawane za prawa „drugiej kategorii”, tj. stojące niżej w hierarchii niż podstawowe prawa oraz wolności polityczne i osobiste, których konstytucyjne ujęcie, ze względu na ich jedynie deklaratoryjny charakter, byłoby wręcz szkodliwe z punktu widzenia rangi i wiarygodności ustawy zasadniczej ${ }^{294}$. Dlatego też ustawy zasadnicze tego okresu, zwane konstytucjami pierwszej generacji, jak np. konstytucja Belgii z 1831 r., Norwegii z 1814 r., ograniczały się $\mathrm{w}$ zasadzie do formułowania jedynie praw oraz wolności politycznych i osobistych, do których tradycyjnie zalicza się m.in. prawo do życia, wolności, własności ${ }^{295}$. Próżno w nich zatem poszukiwać unormowań z obszaru prawa pracy, w tym również, choćby fragmentarycznie ujętego, prawa do odpoczynku. Również w Szwajcarii, na co zwrócono uwagę w literaturze, wnioski o konstytucjonalizację praw społecznych począwszy od 1894 r. były systematycznie odrzucane ${ }^{296}$.

Mimo obecnej już w XIX w. krytyki doktryny liberalnej, a także obserwowanego z czasem wzrostu roli i znaczenia związków zawodowych oraz propagowanej idei pokoju społecznego jako reakcji na wzmagające się nastroje rewolucyjne i związanej z tym zmiany w podejściu do problemów świata pracy, tendencje do prawnego regulowania minimalnych standardów w zakresie choćby samego czasu pracy nie znalazły też zasadniczo swego wyrazu w postanowieniach nowo uchwalanych po pierwszej wojnie światowej konstytucji, chociaż stanowiono już w nich o pewnych uprawnieniach pracowniczych. Nie normowała tej problematyki m.in. polska Konstytucja z 17 marca 1921 r., zawierająca pewną regulację w zakresie praw o charakterze społecznym ${ }^{297}$, a także np. Konstytucja Republiki Estonii z 1920 r., Łotwy z 1922 r., Litwy z 1922 r., Rumunii z 1923 r. czy Finlandii z 1919 r. ${ }^{298}$

W zachodnioeuropejskiej doktrynie prawa nadal wielu zwolenników miał pogląd, według którego prawa ekonomiczno-społeczne, biorąc pod uwagę ich programowy charakter, nie zawsze sprecyzowaną treść i ścisłą zależność od możliwości finansowych państwa, powinny być regulowane w drodze ustawodawstwa zwykłego $^{299}$. Dlatego też nawet niemiecka Konstytucja z 11 sierpnia 1919 r., wyróżniająca się niewątpliwie na tle treści ówczesnych ustaw zasadniczych bogactwem postanowień adresowanych bezpośrednio do świata pracy, nie formułowa-

294 Por. na ten temat B. Zawadzka, Rozwój konstytucyjnych praw społecznych obywateli, „Studia Prawnicze" 1993, z. 2-3, s. 3.

295 Por też na ten temat M. Nowak, Prawo do godziwego wynagrodzenia w konstytucjach państw europejskich, PiZS 2002, nr 5, s. 11 i n.

296 Kolejne referenda w latach 1946, 1947 i 1970. Por. M. Sobolewski, Prawa i wolności obywatelskie w wysoko rozwiniętych państwach kapitalistycznych, [w:] Prawa i obowiq̨zki obywatelskie w Polsce i świecie, red. M. Szczepaniak, Warszawa 1978, s. 73.

297 Było to przedmiotem krytyki niektórych polityków społecznych. Por. np. G. Simon, Zagadnienie społeczne w Konstytucji polskiej, Warszawa 1928, s. 10 i n.

298 Teksty konstytucji por. Nowe konstytucje, red. J. Makowski, Warszawa 1925, s. 3 i n.

299 Por. szerzej A. Michalska, Podstawowe prawa człowieka w prawie wewnętrznym a pakty praw człowieka, Warszawa 1976, s. 129. 
ła wprost omawianego prawa. Niemiecki ustrojodawca ograniczył się w zasadzie do określenia w art. 151 Konstytucji ogólnej zasady, zgodnie z którą życie gospodarcze należało organizować w taki sposób, aby odpowiadało regułom sprawiedliwości i zmierzało do zapewnienia wszystkim egzystencji godnej człowieka. Jedynie w tych granicach, zgodnie z powołanym przepisem, można było zagwarantować jednostce wolność gospodarczą. Ponadto omawiana ustawa zasadnicza przewidywała, że niedziela i inne uznane przez państwo dni świąteczne pozostają dniami wolnymi od pracy i poświęconymi „podniesieniu ducha” (art. 139 Konstytucji $^{300}$, a także przyznawała osobom związanym stosunkiem służbowym lub stosunkiem najmu pracy prawo do uzyskania czasu wolnego od zajęć, a koniecznego do korzystania z praw obywatelskich oraz w zakresie, w jakim nie zagraża to pracy zakładu, do wykonywania powierzonych im urzędów honorowych. Ustawa miała dookreślić prawo do wynagrodzenia za ten okres. Konstytucja wskazywała również na potrzebę ochrony młodzieży przed zaniedbaniem (art. 122).

Zarówno wykładnia funkcjonalna, jak i systemowa powyższych uregulowań wskazuje, że zagwarantowanie wypoczynku osobom zatrudnionym (w sensie czasu niezbędnego do regeneracji fizycznej i psychicznej) nie było bezpośrednim motywem ich wprowadzenia. Chodziło raczej o zapewnienie faktycznej możliwości realizacji innych praw, takich jak prawo do kultywowania dni świątecznych i prawo do czynnego udziału w życiu publicznym.

Ponadto w literaturze czasami podkreśla się, że Konstytucja weimarska bardziej deklarowała pewne zasady i zadania władz w sprawach społecznych niż ustanawiała „subiektywne prawa społeczne obywateli”301.

Jeszcze bardziej lakoniczną formułę odnaleźć można w Konstytucji Irlandii z 1 lipca 1937 r., której art. 45 ust. 4, określający „przewodnie zasady polityki społecznej”, stanowi jedynie, że „państwo stara się zapewnić takie warunki, by nie nadużywano sił i zdrowia pracowników, mężczyzn i kobiet oraz osób małoletnich”.

Niewątpliwie wyjątkowe, jak na ówczesne czasy, dążenie do konstytucyjnego zabezpieczenia kwestii ograniczania czasu pracy można odnaleźć natomiast w Konstytucji Królestwa Serbów, Kroatów i Słoweńców z 1921 r. ${ }^{302}$ Zgodnie z jej art. 23, pracę objęto opieką państwa i jednocześnie zobowiązano ustawodawcę m.in. do wydania odpowiednich ustaw normujących dzień pracy we wszystkich przedsiębiorstwach. Sama konstytucja nie precyzowała jednak konkretnych warunków czy kryteriów, na podstawie których należało tego dokonać, w szczególności nie wspomina się w niej o potrzebie takiego ograniczenia czasu pracy, które gwarantowałoby zatrudnionym niezbędny wypoczynek.

Zmiany w podejściu ustrojodawców krajowych do kwestii związanych z odpoczynkiem uwidaczniają się po drugiej wojnie światowej, choć nie było to przynajmniej w początkowym okresie zjawisko powszechne, zwłaszcza gdy chodzi o konstytucje państw Europy Zachodniej, np. Francji z 1946 r. czy późniejszą z 1958 r.,

300 Tekst Konstytucji zawarty jest w zbiorze Nowe konstytucje, s. 359 i n.

301 Por. B. Zawadzka, Rozwój konstytucyjnych praw..., s. 7.

302 Tekst Konstytucji zawarty jest w zbiorze Nowe konstytucje, s. 228. 
RFN z 1949 r., a także Danii z 1953 r. czy Holandii z 1956 r., które unikały w zasadzie normowania problematyki pracowniczej i społecznej w swych nowo uchwalanych, powojennych ustawach zasadniczych i pozostawiały te kwestie do uregulowania w obrębie ustawodawstwa zwykłego ${ }^{303}$. Nadal dominowało bowiem przekonanie, że konstytucja nie jest właściwym aktem do uwzględniania w niej materii społeczno-gospodarczej ${ }^{304}$. Dlatego też prawo do odpoczynku w aktach najwyższej rangi uchwalanych w tamtym okresie przez państwa wspomnianego regionu było w zasadzie rzadkością. Do tego rodzaju wyjątków zalicza się niewątpliwie Konstytucja Włoch z 22 grudnia 1947 r., uchwalona jednak przy silnym udziale ugrupowań lewicowych z jednej strony i wyraźnym wpływie społecznej nauki Kościoła $\mathrm{z}$ drugiej. Art. 36 tej Konstytucji w omawianym obszarze zobowiązuje ustawodawcę do określenia maksymalnego czasu trwania dnia pracy, a ponadto gwarantuje każdemu pracownikowi prawo do cotygodniowego wypoczynku i corocznego płatnego urlopu, których ten nie może się zrzec ${ }^{305}$.

Ów konstytucyjnie określony zakaz zrzekania się prawa do odpoczynku, zwłaszcza jeśli chodzi o urlop wypoczynkowy, stanowił bardzo ważny element w walce ze zjawiskiem komercjalizacji urlopów, a więc ich sprzedażą przez pracowników za dodatkowym wynagrodzeniem, czemu sprzyjał ogólnie niski poziom płac.

Próby szerokiego konstytucyjnego ujęcia praw społeczno-ekonomicznych, w tym m.in. prawa do odpoczynku, podjęto także we Francji. W kwietniu 1946 r. Zgromadzenie Narodowe uchwaliło bowiem projekt konstytucji zawierający wyraźnie wyodrębnioną część zatytułowaną "Prawa społeczne i ekonomiczne”, co z pewnością było zupełnym novum jeśli chodzi o przyjęte do tej pory w Europie ustawy zasadnicze ${ }^{306}$. W jej ramach uznano prawo pracownika do zdrowych warunków pracy, wypoczynku i urlopu. Jednak projekt ten w referendum został odrzucony. Ostatecznie w przyjętym w 1946 r. akcie prawnym prawo do wypoczynku zostało zupełnie pominięte, co zostało następnie utrwalone w Konstytucji francuskiej z 1958 r. ${ }^{307}$

Z czasem niektóre kraje, tradycyjnie ograniczające regulację konstytucyjną do praw i wolności politycznych i osobistych, po drugiej wojnie światowej zdecydowały się poszerzyć ją o przynajmniej ogólne zasady czy normy programowe dotyczące kwestii społeczno-ekonomicznych. Pewien akcent socjalny, który może mieć ewentualnie znaczenie w zakresie omawianej problematyki, choć jedynie pośrednio, został wprowadzony do pochodzącej z 1831 r. konstytucji Belgii, w której uznano, że każdy ma prawo prowadzić życie odpowiadające wymogom ludz-

303 Szerzej na ten temat M. Nowak, Przesłanki i zakres konstytucjonalizacji praw pracowniczych, „Studia Prawno-Ekonomiczne” 2002, t. LXV, s. 80 i n.

304 Por. Z. Kędzia, Burżuazyjna koncepcja praw człowieka, Wrocław 1980, s. 215.

305 Por. Konstytucja Republiki Włoskiej, [w:] Nowe konstytucje państw europejskich, red. L. Gelberg, Warszawa 1949, s. 221 i n. Por. też Konstytucja Republiki Włoskiej z 27 grudnia 1947 r., tłum. Z. Witkowski, Warszawa 2004.

306 B. Zawadzka, Rozwój konstytucyjnych praw..., s. 11.

307 Tamże, s. 12. 
kiej godności. W tym celu ustawodawca zwykły powinien zagwarantować, przy uwzględnieniu odpowiednich zobowiązań, prawa ekonomiczne, socjalne i kulturalne, w tym "prawo do odpowiednich warunków zatrudnienia”308. Jednocześnie jednak w Belgii w 1971 r. przerwano prace zmierzające do stosownego rozbudowania deklaracji praw z 1831 r. o uprawnienia natury socjalnej ${ }^{309}$. Także w Szwajcarii w 1970 r. po raz kolejny odrzucono stosowny wniosek ${ }^{310}$.

Jedną z pierwszych ustaw zasadniczych uchwalonych w drugiej połowie XX w., w której prawo do odpoczynku zostało wyraźnie wyeksponowane, była Konstytucja Portugalii z 2 kwietnia 1976 r. ${ }^{311}$, która dodatkowo była uchwalana „na fali rewolucji ludowej”312, co niewątpliwie także zaważyło na jej treści. Art. 59 tej Konstytucji poświęcony bezpośrednio prawom pracowniczym stanowi bowiem wprost, że wszyscy pracownicy, bez względu m.in. na wiek, płeć, rasę czy religię, mają prawo do „wypoczynku i do rozrywki, do ustalenia maksymalnej długości dnia pracy, do cotygodniowego wypoczynku i do okresowych płatnych urlopów”. Warto zwrócić uwagę, że poza odpoczynkiem w wymiarze dobowym, tygodniowym i dłuższym, wynikającym z prawa do urlopu wypoczynkowego (rocznym), w przepisie tym wyeksponowano dodatkowo ogólne prawo zatrudnionych do „wypoczynku i rozrywki”, co nie tylko wzmacnia funkcję ochronną tego przepisu, podnosi rangę omawianego uprawnienia, ale sugeruje również potrzebę pomocy państwa w zakresie sposobu jego realizacji. Potwierdzeniem tego jest ust. 2 omawianego przepisu, w którym dążąc do urzeczywistnienia wymienionych wcześniej gwarancji, zobowiązuje się wprost państwo, aby w omawianym obszarze nie tylko ustaliło, na szczeblu ogólnokrajowym, maksymalne normy czasu pracy (pkt b), ale też systematycznie rozwijało sieć ośrodków wypoczynkowych i urlopowych, we współpracy z organizacjami społecznymi (pkt d). Ponadto władze mają objąć szczególną ochroną pracę kobiet w ciąży i po porodzie, małoletnich, niepełnosprawnych oraz zatrudnionych w warunkach szkodliwych dla zdrowia lub niebezpiecznych.

Z punktu widzenia wprowadzania szczegółowych rozwiązań prawnych realizujących konstytucyjnie gwarantowany odpoczynek pracowniczy, ale też ich oceny pod kątem zgodności z Konstytucją na etapie stosowania prawa, istotne znaczenie mogą mieć również wcześniej sformułowane w omawianym przepisie ogólne wskazania dotyczące m.in. organizowania pracy w warunkach zapewniających godność społeczną, umożliwiających rozwój osobisty oraz pogodzenie życia zawodowego z życiem rodzinnym, a także wykonywania pracy z zachowaniem higieny, bezpieczeństwa i zdrowia (art. 59 ust. 1 pkt b i c Konstytucji Portugalii).

308 Konstytucja Belgii z lutego 1831 r., tekst jednolity z 14 lutego 1994 r., wstęp W. Skrzydło, Warszawa 1996.

309 Por. M. Sobolewski, Prawa i wolności obywatelskie..., s. 73.

310 Tamże, s. 73.

311 Por. Konstytucja Republiki Portugalskiej z 2 kwietnia 1976 r., tłum. A. Wojtyczek-Bonnand, Warszawa 2000.

312 Por. B. Zawadzka, Rozwój konstytucyjnych praw..., s. 19. 
Wydaje się, że Konstytucja Portugalii w sposób niespotykanie szeroki ujmuje analizowane prawo, zwracając uwagę zarówno na względy godności ludzkiej, zagwarantowania bezpieczeństwa osobom pracującym, ochrony ich życia i zdrowia, poprzez zapobieganie negatywnym zjawiskom związanym $\mathrm{z}$ ich przemęczeniem, jak i w pewnym zakresie na jakość tego wypoczynku, a przez to poprawę jakości samego życia.

Kwestie dotyczące odpoczynku pracownika zostały wprowadzone również do hiszpańskiej ustawy zasadniczej z 27 grudnia $1978 \mathrm{r}^{313}$, choć w trochę innym od wyżej zaprezentowanego ujęciu. W konstytucji tej problematykę odpoczynku związanego z pracą ustrojodawca podejmuje $\mathrm{w}$ rozdziale o przewodnich zasadach polityki społecznej i gospodarczej. W zamieszczonym tam art. 40 ust. 2 zobowiązano władze publiczne do czuwania nad bezpieczeństwem i higieną pracy oraz zagwarantowania niezbędnego wypoczynku, przez skrócenie dnia pracy, okresowe płatne urlopy oraz „wspieranie odpowiednich ośrodków”. Nie mówi się tu zatem wprost o subiektywnym prawie pracownika do odpoczynku, ale formułuje obowiązek władz państwowych do wprowadzenia takich rozwiązań prawnych, które tę zasadę będą realizować. $\mathrm{Z}$ omawianego aktu wynika, że chodzi przede wszystkim o odpowiednie regulacje z zakresu czasu pracy (chociaż, inaczej niż w Konstytucji portugalskiej, zwrócono uwagę jedynie na jego wymiar dobowy) oraz urlopów wypoczynkowych. Jednocześnie w Konstytucji tej podkreśla się znaczenie efektywnego wykorzystywania uprawnień urlopowych przez pracownika i jego rodzinę poprzez zwrócenie uwagi na konieczność rozwijania ośrodków wypoczynkowych, co było również eksponowane we wcześniej omawianej ustawie zasadniczej Portugalii.

W przeciwieństwie do Konstytucji Portugalii czy Hiszpanii prawo do wypoczynku nie znalazło swego konstytucyjnego umocowania w pochodzącej mniej więcej z tego samego okresu greckiej ustawie zasadniczej ${ }^{314}$. Zadeklarowano w niej jedynie ogólnie, że praca znajduje się pod ochroną państwa, które czuwa m.in. nad „rozwojem moralnym i materialnym osób aktywnych zawodowo na wsi i w mieście" (art. 22 Konstytucji Grecji).

Także w nowej Konstytucji Szwajcarii z 1999 r. kwestie związane z analizowanym uprawnieniem nie zostały podniesione do rangi konstytucyjnej i nie zostały wyraźnie wymienione nawet $\mathrm{w}$ rozdziale poświęconym tzw. celom socjalnym ${ }^{315}$.

W przeciwieństwie do państw zachodnioeuropejskich prawo do odpoczyn$\mathrm{ku}$, ze zrozumiałych względów, było bardzo szeroko ujmowane w powstających w pierwszej i drugiej połowie XX w. konstytucjach państw socjalistycznych ${ }^{316}$.

313 Tekst aktu: Konstytucja Hiszpanii, tłum. i wstęp T. Mołdawa, Warszawa 1993.

314 Konstytucja Grecji z 9 lipca 1975 r. (zmieniona ustawa z 6 marca 1986 r.), Warszawa 1992.

315 Por. Konstytucja Federalna Konfederacji Szwajcarskiej z 18 kwietnia 1999 r., tłum. i wstęp Z. Czeszejko-Sochacki, Warszawa 2000.

316 Dotyczy to również w dużym stopniu konstytucji pozaeuropejskich państw socjalistycznych lub państw o orientacji socjalistycznej. Przykładem mogą być ustawy zasadnicze Mongolii, Korei lub Kuby, które zobowiązywały m.in. do przestrzegania ośmiogodzinnego dnia pracy 
Wyróżniały one prawa społeczno-ekonomiczne i przyznawały im pod względem merytorycznym prymat nad wolnościami o charakterze politycznym czy społecznym $^{317}$. Dotyczyło to w szczególności prawa do odpoczynku, które postrzegano jako pochodną prawa do pracy i uznawano wraz z nim za „podwalinę" ustroju socjalistycznego ${ }^{318}$.

W Konstytucji ZSRR z 1936 r. już w drugim przepisie zamieszczonym w rozdziale o podstawowych prawach i obowiązkach obywateli (zaraz po prawie do pracy) wprost sformułowano prawo obywateli ZSRR do wypoczynku ${ }^{319}$. Jak wynika z dalszej części art. 119 Konstytucji, prawo to miało być zabezpieczone przez:

- ustanowienie dla robotników i pracowników umysłowych siedmiogodzinnego dnia pracy i skrócenie tej normy do sześciu godzin dla „szeregu zawodów o ciężkich warunkach pracy” oraz do czterech godzin „w oddziałach o szczególnie ciężkich warunkach pracy";

- zagwarantowanie wszystkim pracownikom (zarówno robotnikom, jak i pracownikom umysłowym) corocznych płatnych urlopów;

- „oddanie do użytku ludu pracującego szerokiej sieci sanatoriów, domów wypoczynkowych i klubów”.

Potwierdzono to prawo również w kolejnej konstytucji ZSRR z 1977 r. (art. 41) ${ }^{320}$.

Za przykładem ZSRR również inne kraje tzw. bloku wschodniego normowały omawiane uprawnienia w uchwalanych po drugiej wojnie światowej ustawach zasadniczych. W Konstytucji Ludowej Republiki Bułgarii z 16 maja 1971 r. (a także wcześniejszej, wzorowanej na radzieckiej, z 4 grudnia 1947 r. $^{321}$ ) uznano w art. 42 ust. 1 prawo obywateli do wypoczynku, a następnie w ust. 2 tego przepisu określono szczegółowe warunki jego realizacji, tj. zmniejszenie czasu pracy bez obniżenia

oraz udzielania płatnych urlopów wypoczynkowych, oddawania do użytku społecznego sanatoriów, domów wypoczynkowych, ośrodków kulturalnych. Por. T. Smoliński, Podstawowe prawa, wolności i obowiq̨zki obywateli w pozaeuropejskich państwach socjalistycznych, [w:] Prawa i obowiqzzki obywatelskie w Polsce i świecie, red. M. Szczepaniak, Warszawa 1978, s. 250. Bezpośrednio, a zarazem bardzo ogólnie, sformułowane prawo do odpoczynku zawierały również konstytucje Algierii, Gwinei czy Mali. W Konstytucji Związku Birmańskiego z 1947 r. zostało ono uznane za „dyrektywną zasadę polityki państwa”. Por. D. Wojtkowiak, Podstawowe prawa, wolności i obowiqzzki obywateli w pokolonialnych państwach o orientacji socjalistycznej, [w:] Prawa i obowiązki obywatelskie w Polsce i świecie, red. M. Szczepaniak, Warszawa 1978, s. 136 i n.

317 Por. L. Garlicki, Prawa socjalne w orzecznictwie Trybunału Konstytucyjnego, „Przegląd Sejmowy" 1995, nr 2, s. 54.

318 Zob. Prawo do wypoczynku, [w:] Zagadnienia prawne Konstytucji Polskiej Rzeczypospolitej Ludowej, t. 3, red. S. Grzybowski, Warszawa 1954, s. 492.

319 Konstytucja ZSRR, Warszawa 1975, s. 28.

320 Por. L. Wiśniewski, Podstawowe prawa, wolności i obowiqzzi obywateli PRL na tle nowych konstytucji socjalistycznych, PiP 1977, nr 12, s. 23.

321 Art. 74 Konstytucji stanowił również, że obywatele mają prawo do wypoczynku i że prawo to zabezpiecza ograniczenie dnia pracy, udzielenie corocznie płatnego urlopu i utworzenie szerokiej sieci domów wypoczynkowych, klubów itd. Por. Nowe konstytucje państw europejskich, s. 47. 
wynagrodzenia i uszczuplania innych uprawnień pracowniczych, zapewnienie corocznego płatnego urlopu wypoczynkowego oraz tworzenie „szerokiej sieci domów wypoczynkowych, klubów, czytelni publicznych, domów kultury i innych miejsc wypoczynku i kultury"322. Bardzo podobnie kwestia ta została ujęta m.in. w Konstytucji Czechosłowackiej Republiki Socjalistycznej z 11 lipca 1960 r. (oraz we wcześniejszej ustawie zasadniczej z maja 1948 r. ${ }^{323}$ ), w której również podkreślono (art. 22 ust. 1 i 2 Konstytucji), że wszyscy pracujący mają prawo do wypoczynku po wykonaniu pracy, które to prawo ma zabezpieczać ustawowa regulacja czasu pracy, płatny urlop oraz „troska państwa i organizacji społecznych o najpełniejsze wykorzystanie przez pracujących czasu wolnego na wypoczynek i życie kulturalne". Zbliżone do zaprezentowanych ujęcie prawa do odpoczynku odnaleźć można też w Konstytucji Rumunii z kwietnia 1948 r. ${ }^{324}$ czy w Konstytucji Węgier z 1972 r. ${ }^{325}$

Również w Konstytucji PRL z 22 lipca 1952 r. po raz pierwszy omawiane prawo zostało wyraźnie uwzględnione ${ }^{326}$. Zgodnie z jej art. 59, wszyscy obywatele PRL mieli prawo do wypoczynku (ust. 1), które, zarówno jeśli chodzi o robotników, jak i pracowników umysłowych, miało zapewniać ustawowe skrócenie czasu pracy poprzez urzeczywistnienie ośmiogodzinnego dnia pracy oraz krótszego czasu pracy w przypadkach przewidzianych ustawami, ustawowo określone dni wolne od pracy oraz coroczne płatne urlopy (ust. 2 art. 59 Konstytucji). Ponadto w ust. 3 powołanego przepisu dodano jeszcze zdanie potwierdzające, acz pod względem materialnoprawnym niewiele znaczące, że organizacja wczasów, rozwój turystyki, uzdrowisk, urządzeń sportowych, domów kultury, klubów, świetlic, parków i innych urządzeń wypoczynkowych stwarza możliwość „zdrowego i kulturalnego wypoczynku" dla coraz szerszej rzeszy osób pracujących.

W literaturze tamtego okresu wyrażano nawet pogląd, że konieczność uznania prawa obywateli do wypoczynku można również pośrednio wyprowadzić z konstytucyjnego prawa do ochrony zdrowia, do kultury, nauki i do wszechstronnego rozwoju fizycznego ${ }^{327}$.

W doktrynie prawa pracy podkreślano w kontekście art. 59 Konstytucji PRL, że nastąpiło powszechne zapewnienie wypoczynku w skali dziennej, tygodniowej

322 Por. Konstytucja Ludowej Republiki Bułgarii, wstęp E. Gdulewicz, Wrocław, Warszawa, Kraków, Gdańsk 1979, s. 44.

323 Paragraf 28 tej Konstytucji stanowit, że wszyscy pracujący mają prawo do wypoczynku i że prawo to będzie gwarantowane przez ustawowe ustalenie czasu pracy, zapewnienie płatnego urlopu oraz przez opiekę nad wypoczynkiem pracowników. Por. Nowe konstytucje państw europejskich, s. 69.

324 Art. 20 Konstytucji Rumuńskiej Republiki Ludowej z 13 kwietnia 1948 r. Por. tamże, s. 188.

325 W § 56 Konstytucji Węgierskiej Republiki Ludowej z 1972 r. również sformułowano prawo do wypoczynku urzeczywistniane przez „ustawowe określenie czasu pracy, zapewnienie płatnych urlopów i organizowanie wczasów”. Por. Konstytucja Węgierskiej Republiki Ludowej, red. A. Gwiżdż, Wrocław, Warszawa, Kraków, Gdańsk 1975, s. 56.

326 Konstytucja Polskiej Rzeczypospolitej Ludowej, Dz. U. PRL 1952, Nr 33, poz. 232.

327 D. Wojtkowiak, Podstawowe prawa..., s. 137. Tak też w: Prawo do wypoczynku, [w:] Zagadnienia prawne..., s. 497. 
i rocznej na rzecz wszystkich pracujących, a podstawowe zasady konstytucyjne w omawianym zakresie wskazują na kierunki, w jakim należy rozwijać ustawodawstwo pracy $^{328}$. Przede wszystkim, jak oceniano, z powołanego przepisu wynika konkretny obowiązek ustawodawcy zwykłego w zakresie regulacji czasu pracy. Większą swobodę działania pozostawiono mu natomiast w kwestii ustalania wymiaru urlopu wypoczynkowego ${ }^{329}$. Za podmiot odpowiedzialny za realizację omawianego konstytucyjnego uprawnienia uznawano przy tym przede wszystkim państwo, ale też związki zawodowe, kierownictwo zakładów pracy oraz samych pracowników. Pod adresem tych ostatnich formułowano m.in. obowiązek powstrzymywania się w okresie urlopu wypoczynkowego od wszelkiej pracy zarobkowej ${ }^{330}$.

Sposób konstruowania ówczesnej konstytucyjnej regulacji dotyczącej prawa do wypoczynku był charakterystyczny dla wszystkich praw społeczno-ekonomicznych, jakie wówczas na poziomie ustawy zasadniczej gwarantowano. Jak wynika z przytoczonych wyżej unormowań, przepis składał się zwykle z dwóch części: pierwszej, która zwięźle deklarowała samo prawo, i drugiej, która obejmowała rozbudowane gwarancje materialne służące do jego realizacji ${ }^{331}$. Do gwarancji tych w zakresie prawa do odpoczynku standardowo zaliczano bardziej lub mniej precyzyjne wskazanie na konieczność ograniczenia czasu pracy; płatny urlop wypoczynkowy oraz rozwijanie stosownych urządzeń sprzyjających optymalnemu wykorzystaniu czasu wolnego (sanatoria, ośrodki wczasowe, domy kultury itp.). W późniejszej literaturze przedmiotu, choć z jednej strony podkreślano duże znaczenie konstytucyjnego ujęcia tego rodzaju praw, to jednocześnie krytykowano ich formułę, tzw. fasadowy charakter i wskazywano na kłopoty z ich praktyczną realizacją ${ }^{332}$. Odnosiło się to również do wspomnianego prawa do odpoczynku, które nie było respektowane w zakresie choćby wyraźnie w Konstytucji PRL określonej ośmiogodzinnej normy czasu pracy. Ustawodawstwo pracy wyraźnie dopuszczało w pewnych sytuacjach możliwość wydłużenia tego czasu (sprzyjały temu zwłaszcza liberalizacja regulacji pracy w godzinach nadliczbowych oraz system grupowej organizacji pracy) $)^{333}$. W ocenie J. Wratnego, także przepisy Kodeksu pracy o urlo-

328 Por. Prawo do wypoczynku, [w:] Zagadnienia prawne..., s. 494 i n.

329 Por. A. Michalska, Podstawowe prawa człowieka w prawie wewnętrznym..., s. 136.

330 Por. Prawo do wypoczynku, [w:] Zagadnienia prawne..., s. 494 i n.

331 Por. Z. Jarosz, S. Zawadzki, Prawo konstytucyjne, Warszawa 1980, s. 258.

332 Często ocenia się, że sformułowania zawarte w Konstytucji w obszarze społeczno-ekonomicznym miały małą wartość normatywną. Por. szerzej H. Suchocka, Zakres i sposób realizacji praw ekonomicznych, socjalnych i kulturalnych w przyszłej konstytucji, [w:] Prawa, wolności i obowiq̨zki człowieka i obywatela w nowej polskiej konstytucji, red. Z. Kędzia, Poznań 1990, s. 10 i n. Podobnie Z. Salwa, Praca oraz prawa socjalne obywateli w przyszłej konstytucji, PiP 1990, nr 9, s. 17. Konstytucja PRL, jak ocenia E. Łętowska, nie była traktowana poważnie, ani przez władzę, ani przez samych obywateli. Była to bowiem konstytucja-manifest, a nie konstytucja-zobowiązanie. Por. E. Łętowska, Po co ludziom konstytucja, Warszawa 1994, s. 11 i n.

333 Por. L. Florek, Konstytucyjne gwarancje uprawnień pracowniczych, PiP 1997, nr 12, s. 210. Podobnie J. Wratny, Normy konstytucyjne a prawo pracy i zabezpieczenia społecznego, PiP 1990, nr 2, s. 38 in. 
pach wypoczynkowych nie respektowały konstytucyjnej zasady zobowiązującej do zapewnienia pracownikom corocznego płatnego urlopu ${ }^{334}$. Ponadto polskie sądy, rozpatrując sprawy m.in. z obszaru prawa pracy, orzekały niemal wyłącznie na podstawie ustawodawstwa zwykłego, nawet wówczas, gdy akt stanowiący podstawę rozstrzygnięcia naruszał konstytucyjne prawa pracownika ${ }^{335}$. Przez długi czas nie było również przewidzianych instrumentów, mechanizmów, które umożliwiłyby obywatelom wyegzekwowanie praw i wolności gwarantowanych w konstytucji ${ }^{336}$.

Ugruntowane $\mathrm{z}$ czasem przekonanie o potrzebie kompleksowego ujmowania praw człowieka, naturalne trudności z całkowitym odcięciem się od dotychczasowych, socjalistycznych tradycji konstytucyjnych, ale też oczekiwania społeczne odnośnie do zamieszczenia materii społecznej w przyszłej konstytucji ${ }^{337}$, przesądziły ostatecznie o szerokim uwzględnieniu praw pracowniczych w uchwalanych po 1989 r. postsocjalistycznych ustawach zasadniczych. Dotyczy to też prawa do odpoczynku, któremu, $w$ różnym stopniu, poświęciła swą uwagę zdecydowana większość ustawodawców konstytucyjnych tego regionu ${ }^{338}$. Należy zauważyć jednak, że prawo to nie jest już tak powszechnie i silnie eksponowane jak w konstytucjach państw tzw. bloku wschodniego. Niemal we wszystkich tworzonych regulacjach zwrócono uwagę na dwa aspekty tego prawa, tj. ograniczenie norm czasu pracy oraz prawo do urlopów wypoczynkowych. W szystkie państwa zrezygnowały natomiast $\mathrm{z}$ trzeciego elementu, jakim była w regulacjach okresu komunistycznego zapowiedź rozbudowy ośrodków wypoczynkowo-kulturalnych.

W Konstytucji Ukrainy prawo do wypoczynku wyraźnie wynika z art. 45 tego aktu i poświęcono mu stosunkowo wiele uwagi. W jego ramach ustrojodawca, wychodząc poza standardowe formuły przyjęte $\mathrm{w}$ innych państwach tego regionu, gwarantuje ustawowo określone dni cotygodniowego wypoczynku, corocznego płatnego urlopu, wprowadzenie krótszych dobowych norm czasu pracy dla niektórych zawodów i branż oraz skrócenie czasu pracy w nocy ${ }^{339}$. Jednocześnie w dalszej części przepisu wymaga się, aby w trybie ustawy określono takie kwestie, jak maksymalna liczba godzin pracy, minimalna długość wypoczynku i corocznego płatnego urlopu, dni wolne od pracy i święta, a także „inne warunki realizacji tego prawa”.

334 Por. J. Wratny, Normy konstytucyjne..., s. 38.

335 Por. tak E. Łętowska, Po co ludziom..., s. 12.

336 Trybunat Konstytucyjny istnieje w Polsce od 1982 r., a pierwsze orzeczenie wydał w 1986 r. Nie było też Rzecznika Praw Obywatelskich. Por. E. Łętowska, Po co ludziom..., s. 11 i n.

337 Przeprowadzone przez CBOS w 1993 r. badania wykazały, że opinia publiczna oczekiwała od nowej konstytucji zagwarantowania przede wszystkim praw socjalnych. Por. M. Drozdek, Prawa społeczne w konstytucji, „Tygodnik Solidarność” 1994, nr 41, s. 6.

338 Nie normuje tej problematyki Konstytucja Estonii, przyjęta w referendum z 28 czerwca 1992 r. oraz Konstytucja Słowenii z 23 grudnia 1991 r., a także Konstytucja Albanii z 29 kwietnia 1991 r. Por. Konstytucja Estonii, wstęp L. Garlicki, P. Łossowski, Warszawa 1997; Konstytucja Republiki Słowenii z 23 grudnia 1991 r., tłum. i wstęp P. Winczorek, Warszawa 1994; Konstytucja Albanii, wstęp A. Bosiacki, Warszawa 1997.

339 Konstytucja Ukrainy z 28 czerwca 1996 r., wstęp i tłum. E. Toczek, Warszawa 1999, s. 44 i n. 
Artykuł 49 Konstytucji Litwy także formułuje prawo pracownika do wypoczyn$\mathrm{ku}$, czasu wolnego i corocznego płatnego urlopu. Zobowiązano ponadto władze państwowe do ustawowego określenia czasu pracy ${ }^{340}$. Również w rosyjskiej ustawie zasadniczej prawo do wypoczynku zostało wprost wymienione ${ }^{341}$. Art. 37 ust. 5 Konstytucji Federacji Rosyjskiej stanowi, że „każdy ma prawo do wypoczynku”. Jednocześnie szczegółowe warunki realizacji tego prawa określono tylko w odniesieniu do osób zatrudnionych na podstawie umowy o pracę, które, zgodnie z regulacją konstytucyjną, mają zapewnione określone przez ustawę federalną dopuszczalną długość czasu pracy, dni wolne od pracy i dni świąteczne oraz coroczny płatny urlop. Rangę konstytucyjną omawianemu uprawnieniu zdecydował się nadać bezpośrednio także ustawodawca węgierski, zarówno w Konstytucji z lat $90 .{ }^{342}$, jak i w ustawie zasadniczej Węgier z kwietnia $2011 \mathrm{r}^{343} \mathrm{~W}$ art. XVII ust. 3 tej ostatniej przyznano pracownikowi w pierwszej kolejności prawo do warunków pracy „respektujących jego zdrowie, bezpieczeństwo i godność”, a w ust. 4 uznano prawo pracowników „do codziennego i cotygodniowego wypoczynku” oraz do corocznego płatnego urlopu wypoczynkowego. Tym samym wspomniana Konstytucja gwarantuje to prawo we wszystkich trzech wymiarach, tj. dobowym, tygodniowym i rocznym.

W innych konstytucjach państw Europy Środkowo-Wschodniej nie wymienia się wyraźnie prawa do wypoczynku, ale formułuje pewne gwarancje z tego obszaru w ramach sprawiedliwych czy odpowiednich warunków pracy. Przykładem może być Konstytucja Republiki Słowackiej z 1 września 1992 r., której art. 36 stanowi o prawie pracowników do „sprawiedliwych i zadowalających warunków pracy”, w ramach którego ustawa zwykła ma zagwarantować m.in. „ochronę bezpieczeństwa i zdrowia podczas pracy”, maksymalną długość czasu pracy, „odpowiedni wypoczynek po pracy”, minimalny okres płatnego urlopu wypoczynkowego. W konstytucji Łotwy elementy analizowanego prawa zostały zawarte w art. 107, w którym obok prawa do minimalnego wynagrodzenia wskazuje się, że każdy pracownik ma prawo do „cotygodniowych dni wolnych i corocznego płatnego urlopu" ${ }^{344}$. Wiele kwestii z zakresu prawa do odpoczynku zostało uwzględnionych również w Konstytucji Rumunii ${ }^{345}$. Art. 38 Konstytucji, który gwarantuje pracownikom „społeczną ochronę ich pracy”, do środków służących jej realizacji zalicza m.in. cotygodniowy wypoczynek i płatny urlop wypoczynkowy. Ponadto, w ust. 3

340 Konstytucja Litwy z 25 października 1992 r., www.sejm.gov.pl.

341 Konstytucja Federacji Rosyjskiej z 12 grudnia 1993 r., wstęp A. Bosiacki, Warszawa 2000, s. 49.

342 Por. Konstytucja Republiki Węgierskiej z 1990 r., tłum. i wstęp H. Donath, Warszawa 1996, s. 57 (§ 70/B pkt 4).

343 Ustawa zasadnicza Węgier z 25 kwietnia 2011 r., tłum. J. Snopek, [w:] Konstytucje państw UE, Warszawa 2011.

344 Konstytucja Republiki Łotewskiej z 15 lutego 1922 r., wstęp P. Kierończyk, Warszawa 2001, s. 53. Rozdział o prawach człowieka został wprowadzony do ustawy zasadniczej w latach 90. $\mathrm{XX}$ w.

345 Konstytucja Rumunii z 21 listopada 1991 r., wstęp W. Brodziński, Warszawa 1996, s. 37. 
art. 58 powołanego aktu, stanowi się, że „normalny czas pracy w ciągu doby wynosi średnio najwyżej osiem godzin". Podobna regulacja jest zawarta w chorwackiej ustawie zasadniczej ${ }^{346}$, w której obok prawa do godziwego wynagrodzenia i prawa partycypacji wymieniono prawo zatrudnionych do cotygodniowego odpoczynku i do corocznego płatnego urlopu, ale z zastrzeżeniem ich niezbywalności. Ponadto zobowiązano stanowiących prawo do ustawowego określenia maksymalnych norm czasu pracy. Również w Konstytucji Bułgarii z 12 lipca 1991 r. gwarantuje się „robotnikom i pracownikom umysłowym” prawo do zdrowych i bezpiecznych warunków pracy, do odpoczynku i urlopu na warunkach określonych ustawą ${ }^{347}$. Na lakonicznym sformułowaniu prawa do "zadowalających warunków pracy” poprzestaje natomiast czeski ustrojodawca w art. 28 Karty Podstawowych Praw i Wolności, stanowiącej część porządku konstytucyjnego Republiki Czeskiej34. Szczegółowe warunki jego realizacji w każdym obszarze, a więc i w zakresie szeroko pojętego czasu pracy, ma określić ustawa.

Jak wynika z powyższej prezentacji, sposób ujęcia prawa pracownika do wypoczynku w poszczególnych aktach konstytucyjnych państw postsocjalistycznych, w przeciwieństwie do ich wcześniejszych regulacji, znacznie różni się od siebie. Dotyczy to nie tylko samego sposobu unormowania omawianego prawa, czy jest ono formułowane bezpośrednio, wyodrębnione w osobnym przepisie czy wymieniane w całości lub w części wśród innych podstawowych praw pracowniczych, ale również jego zakresu podmiotowego i przedmiotowego. Warto zwrócić uwagę, że niektóre kraje omawianego regionu gwarantują to prawo na poziomie konstytucyjnym wszystkim obywatelom („każdy ma prawo do wypoczynku”), jak np. Konstytucja Rosji, w innych zaś stanowi się o prawie osób „zatrudnionych” (np. chorwacka ustawa zasadnicza), ale najczęściej kwalifikuje się je jako prawo pracownicze (por. np. konstytucja ukraińska, litewska, węgierska czy rumuńska). Przy ostatecznym ustalaniu podmiotów objętych konstytucyjną ochroną pewną rolę może odgrywać sposób tłumaczenia poszczególnych aktów, ale też przyjęte $\mathrm{w}$ prawie wewnętrznym wymienionych państw definicje pracownika i pracodawcy. Poza płatnym, corocznym urlopem wypoczynkowym różnie też w poszczególnych krajach jest normowana kwestia odpoczynku dobowego i tygodniowego. Węgierska konstytucja wprost ten odpoczynek gwarantuje, konstytucja ukraińska i rumuńska w zasadzie pośrednio też, choć obok urlopu wypoczynkowego wspomina się w nich przede wszystkim o odpoczynku tygodniowym, prawo do odpoczynku tygodniowego (bez wskazania na odpoczynek dobowy) formułuje również ustrojodawca chorwacki, ale już konstytucja litewska czy bułgarska nie rozróżnia wyraźnie, o jaki odpoczynek chodzi. Niektóre unormowania wyżej prezentowane mają charakter bardziej konkretny, wynikają z nich wprost określone zobowiąza-

346 Por. Konstytucja Republiki Chorwackiej z 22 grudnia 1990 r., wstęp A. i L. Garliccy, Warszawa 1995, s. 29.

347 Konstytucja Bułgarii z 12 lipca 1991 r., www.sejm.gov.pl.

348 Por. Konstytucja Republiki Czeskiej z 16 grudnia 1992 r., wstęp i tłum. M. Kruk, Warszawa 2000, s. 77. 
nia dla ustawodawcy zwykłego, np. gwarancja zasadniczo ośmiogodzinnego dnia pracy w rumuńskiej ustawie zasadniczej czy obowiązek skrócenia czasu pracy w nocy wynikający z konstytucji ukraińskiej, inne są raczej dość ogólnym wskazaniem na potrzebę zagwarantowania wypoczynku. Różnie też w poszczególnych regulacjach są rozkładane akcenty. Część ustawodawców zwraca uwagę na odpoczynek i czyni go centralnym punktem konstytucyjnej regulacji, pozostawiając jednocześnie ustawodawcy zwykłemu dobór właściwych instrumentów jego realizacji (np. w Konstytucji węgierskiej), większość zaś koncentruje się na konkretnych aspektach tego prawa, w tym m.in. zobowiązaniu do ustawowego uregulowania maksymalnych norm czasu pracy i płatnych urlopów wypoczynkowych.

Problem konstytucjonalizacji pracowniczego prawa do odpoczynku był przedmiotem dyskusji również w Polsce, w ramach ogólnej debaty na temat celowości zamieszczenia praw społecznych w przyszłej ustawie zasadniczej. Na potrzebę taką zwracało uwage wielu przedstawicieli doktryny prawa pracy ${ }^{349}$. Z. Salwa uznawał, że prawo do wypoczynku, uregulowane w wielu dokumentach międzynarodowych i traktowane jako jedno z praw uniwersalnych, musi znaleźć swe odzwierciedlenie w przyszłej konstytucji. Zdaniem wspomnianego autora, przemawiały za tym jego niezwykle ważna społeczna treść oraz powszechna faktyczna jego realizacja ${ }^{350}$. Chodzi więc nie tyle o ustanowienie tego prawa, co o jego potwierdzenie, utrwalenie i określenie kierunków, w jakich powinno być ono rozwijane w ustawodawstwie zwykłym ${ }^{351}$. Jednocześnie podkreślano, że dotychczasowa konstytucyjna formuła prawa do wypoczynku musi ulec zmianie, przede wszystkim jeśli chodzi o zakres gwarancji materialnych wynikających z powoływanego wcześniej ust. 3 art. 59 Konstytucji PRL ${ }^{352}$. Należało bowiem zerwać z dotychczasowym stanem, w którym normy konstytucyjne miały często charakter jedynie społeczno-politycznej deklaracji na rzecz ich mocniejszej konkretyzacji, nadania większego waloru normatywnego wprowadzanym regulacjom i lepszego wpisania praw pracowniczych w nowe warunki ustrojowe. Część autorów, moim zdaniem słusznie, przestrzegała jednak przed nadmiernym uszczegółowieniem prawa do odpoczynku w przyszłej ustawie zasadniczej ${ }^{353}$. Konstytucja będąca z założenia aktem o charakterze trwałym nie powinna zbyt szczegółowo normować praw, które podlegają ciągłym zmianom, ewoluują, tak jak ma to miejsce w odniesieniu do poszczególnych aspektów prawa do odpoczynku. Przede wszystkim w zakresie czasu pracy poszukuje się nieustannie bardziej efektywnych sposobów gospodarowania nim, nowych rozwiązań m.in. pozwalających jak najpełniej godzić życie

349 Por. ogólnie m.in.: A. Świątkowski, Normy prawa pracy i prawa ubezpieczeń społecznych w przyszłej polskiej konstytucji, „Krakowskie Studia Prawnicze” 1990, s. 41 i n.; W. Nieciuński, Jeśli wejdziesz między wrony, czyli spór o prawa socjalne w konstytucji, „Rzeczpospolita” 1995, 5 listopada, s. 18.

350 Por. Z. Salwa, Praca oraz prawa socjalne..., s. 20.

351 Tamże.

352 Por. J. Wratny, Normy konstytucyjne..., s. 44 i n.

353 Por. m.in. Z. Salwa, Praca oraz prawa socjalne..., s. 20 i n. 
zawodowe z prywatnym czy stanowiących odpowiedź na nowe wyzwania i zjawiska dynamicznie zachodzące we współczesnym świecie. Jednocześnie stale obecna jest pokusa, by liberalizować przepisy o czasie pracy w kierunku jego wydłużania, co ostatecznie może okazać się niebezpieczne dla osób świadczących pracę. Stąd wskazywano w literaturze raczej na celowość konstytucyjnego określenia maksymalnych granic tygodniowego czasu pracy (z pominięciem wymiaru dobowego) oraz minimalnego wymiaru urlopu wypoczynkowego ${ }^{354}$.

Powyższe postulaty w różnym zakresie znalazły swój wyraz w poszczególnych projektach przyszłej polskiej konstytucji.

Formułowano przede wszystkim obowiązek ustawowego określenia najwyższych dopuszczalnych norm czasu pracy, dni wolnych od pracy oraz corocznych płatnych urlopów wypoczynkowych. W projektach SLD i NSZZ „Solidarnośćc zaproponowano ustanowienie maksymalnego 40-godzinnego tygodniowego wymiaru czasu pracy (co niektórzy uznali za zdecydowanie przedwczesne i „ekonomicznie nieodpowiedzialne"355), a w projekcie UW limit ten podwyższono do 42 godzin $^{356}$.

Ostatecznie projekt konstytucji przyjęty przez Komisję Konstytucyjną Zgromadzenia Narodowego uwzględnił prawo do odpoczynku, ale w bardziej ogólnym ujęciu w porównaniu do wyżej zaprezentowanych propozycji. Art. 66 ust. 2 obowiązującej Konstytucji $\mathrm{RP}^{357}$ potwierdza bowiem prawo pracowników do określonych w ustawie dni wolnych od pracy i corocznych płatnych urlopów oraz ustawowego określenia maksymalnych norm czasu pracy. Warto też podkreślić, że regulacja ta została zamieszczona $\mathrm{w}$ przepisie statuującym $\mathrm{w}$ ust. 1 prawo do bezpiecznych i higienicznych warunków pracy, co, jak się wydaje, czyni z omawianego uprawnienia element szeroko pojętej ochrony życia i zdrowia osób świadczących pracę, choć zgadzam się, że nie jest to de facto motyw jedyny. W literaturze przedmiotu zaprezentowano również w tej kwestii nieco inną koncepcję, według której art. 66 ust. 2 Konstytucji chroni zupełnie autonomiczną wartość, niezależną od ochrony zdrowia. Celem tej regulacji jest bowiem urzeczywistnienie wielu innych konstytucyjnych praw i wolności, m.in. możliwości uczestnictwa w życiu społecznym, politycznym, rodzinnym, kultywowania dni świątecznych itp. ${ }^{358}$ Warto zwrócić uwagę, że być może taka właśnie była intencja ustrojodawcy litewskiego, który obok prawa do „wypoczynku” wymienia również prawo do „czasu wolnego”.

354 Tamże, s. 21. Podobnie T. Liszcz, Przyszła Konstytucja Rzeczypospolitej Polskiej a prawo pracy, „Annales UMCS” 1997, t. XLIV, s. 83. Również L. Florek postulował wyeliminowanie z konstytucyjnej regulacji postanowień dotyczących dobowej normy czasu pracy. Przeciwnego zdania był J. Wratny, który uznał, że przepisy konstytucji w każdym wymiarze prawa do odpoczynku powinny przeciwdziałać „ekstensywnym metodom gospodarowania czasem pracy". Por. J. Wratny, Normy konstytucyjne..., s. 44 i podana tam literatura.

355 Tak por. T. Syryjczyk, Granice misji ekonomicznej i socjalnej państwa w konstytucji, [w:] Konstytucja i gospodarka, red. P. Kaczanowski, Warszawa 1995, s. 67 i n.

356 Por. L. Wiśniewski, Zakres i konstrukcja praw socjalnych w przyszłej konstytucji RP, „Ekspertyzy i Opinie Instytutu Nauk Prawnych PAN" 1995, t. I, s. 95.

357 Konstytucja Rzeczypospolitej Polskiej z 2 kwietnia 1997 r., Dz. U. 1997, Nr 78, poz. 483 ze zm. 358 Por. A. Sobczyk, Prawo pracy w świetle Konstytucji RP, t. I, s. 197. 
Wyżej zaprezentowana konstytucyjna formuła pracowniczego prawa do odpoczynku wzbudzała w literaturze pewne wątpliwości. Oceniano, że w gruncie rzeczy jest to okrojone i nie do końca precyzyjne ujęcie prawa do odpoczynku ${ }^{359}$, choć niewątpliwie zbliżone do unormowań przyjętych w ustawach zasadniczych innych państw omawianego regionu. Niektórzy autorzy zwracali uwagę, że w przywołanym artykule nie zawarto zadań państwa w zakresie warunków korzystania z prawa do wypoczynku, w szczególności krytycznie postrzegano brak jakiejkolwiek materialnej zasady w zakresie ustalania norm czasu pracy, pozostawiając te kwestie w całości do rozstrzygnięcia ustawodawcy zwykłemu ${ }^{360}$ (co ostatecznie znalazło też swe potwierdzenie w orzecznictwie Trybunału Konstytucyjnego, o czym mowa dalej). Tym samym w zasadzie zobowiązano go jedynie do wydania i utrzymania w mocy przepisów regulujących kwestie określone w powołanym wyżej art. 66 ust. 2 Konstytucji RP ${ }^{361}$.

Obecnie wiele kontrowersji wywołuje również zakres podmiotowy tego przepisu. O ile w ust. 1 art. 66 Konstytucji ustawodawca posłużył się bowiem zwrotem „każdy ma prawo...”, o tyle w ust. 2 odnoszącym się do analizowanego zagadnienia użyto pojęcia „pracownik” na oznaczenie podmiotu uprawnionego do dni wolnych od pracy, corocznych płatnych urlopów oraz ustawowo określonych maksymalnych norm czasu pracy. Według tradycyjnej wykładni, przyjmuje się w związku z tym, że zakres ust. 2 art. 66 Konstytucji RP został zawężony w stosunku do jego ust. 1 i jego adresatami są wyłącznie osoby zatrudnione na podstawie stosunku $\operatorname{pracy}^{362}$. Nie jest to jednak pogląd powszechnie akceptowany ${ }^{363}$. W szczególności w ostatnim czasie interesującą wykładnię w omawianym obszarze zaprezentował

359 Tak w szczególności T. Liszcz, Przyszła Konstytucja..., s. 83.

360 Por. tamże oraz W. Nieciuński, Jeśli wejdziesz między wrony..., s. 18.

361 Por. L. Florek, Konstytucyjne gwarancje..., s. 209 i n. Por. też W. Sanetra, Prawa (wolności) pracownicze w Konstytucji, PiZS 1997, nr 11, s. 6.

362 Za taką interpretacją zdaje się opowiadać m.in. T. Wyka, która pisze, że „prawo do wypoczynku zostało wyraźnie ograniczone tylko do kręgu pracowników...” - por. taż, Konstytucyjne prawo każdego do bezpiecznych i higienicznych warunków pracy a zatrudnienie na innej podstawie niż stosunek pracy oraz praca na własny rachunek - uwagi de lege ferenda, „Gdańskie Studia Prawnicze” 2007, t. XVII, s. 334. Pogląd podobny wyrażało też szereg autorów zajmujących się prawem konstytucyjnym - por. Konstytucja Rzeczypospolitej Polskiej. Komentarz, t. 3, red. L. Garlicki, Warszawa 2003, s. 5 czy J. Oniszczuk, Konstytucyjne źródła prawa pracy, [w:] System prawa pracy, t. 1: Część ogólna, red. K.W. Baran, Warszawa 2017, s. 759.

363 Odmiennie por. B. Banaszak, Konstytucja Rzeczypospolitej Polskiej. Komentarz, Warszawa 2009, s. 345. Zob. też B. Bury, Dylematy na tle prawa do wypoczynku w zatrudnieniu niepracowniczym typu cywilnoprawnego, [w:] Przemiany prawa pracy. Od kodyfikacji do wspótczesności. Księga Jubileuszowa Prof. T. Liszcz, red. A. Kosut, W. Perdeus, „Studia luridica Lublinensia" 2015, t. XXIV, s. 386. Również w przeszłości, jeszcze w okresie obowiązywania Konstytucji PRL, pojawiały się opinie negujące stricte pracowniczy charakter konstytucyjnego prawa do wypoczynku. Por. np. E. Siemieński, Podstawowe prawa, wolności i obowiq̨zki obywateli w europejskich państwach socjalistycznych, [w:] Prawa i obowiqzki obywatelskie w Polsce i świecie, red. M. Szczepaniak, Warszawa 1978, s. 223. 
A. Sobczyk. Zdaniem wspomnianego autora, należy odejść przy interpretacji art. 66 ust. 2 Konstytucji RP od kodeksowego rozumienie pojęcia "pracownik” na rzecz pracownika w znaczeniu konstytucyjnym. Przede wszystkim autor zwraca uwagę, że odmienna wykładnia nie tylko w pewnym sensie podważa rangę konstytucji, jako aktu o najwyższej mocy prawnej (pozwala bowiem ustawodawcy zwykłemu definiować jej treść), ale też ogranicza istotnie znaczenie samego prawa do odpoczynku (jako właściwego tylko pracy podporządkowanej) oraz prowadzi do nieuzasadnionego uprzywilejowania osób pozostających w stosunku pracy ${ }^{364}$. Ponadto, zdaniem A. Sobczyka, prawo do bezpiecznych i higienicznych warunków pracy, gwarantowane konstytucyjnie każdej osobie, obejmuje wszystkie regulacje mające na celu ochronę życia i zdrowia, co odnosi się do wielu unormowań $\mathrm{z}$ obszaru prawa pracy stanowiących ważny aspekt prawa do odpoczynku ${ }^{365}$. Stąd też konkluzją powyższego rozumowania jest uznanie, że art. 66 ust. 2 Konstytucji stanowi gwarancję prawa do odpoczynku (zwłaszcza prawa do urlopów wypoczynkowych) dla wszystkich osób zarobkowo świadczących pracę, bez względu na podstawę zatrudnienia ${ }^{366}$.

Do pracy podejmowanej w celach zarobkowych, jako kryterium determinującego pojęcie pracownika w ujęciu konstytucyjnym, odwołał się również Trybunał Konstytucyjny w wyroku z 2 czerwca 2015 r. ${ }^{367}$, choć w innym kontekście niż wypoczynek.

W ocenie T. Liszcz, odstąpienie od pojęć kodeksowych w zakresie wykładni przepisów ustawy zasadniczej, jest w pełni uzasadnione, jak wskazuje bowiem autorka, w doktrynie prawa konstytucyjnego uznaje się, że pojęcia konstytucyjne mają autonomiczny charakter i zwykle szerszy zakres zastosowania w stosunku do identycznych określeń funkcjonujących na gruncie ustawodawstwa zwykłego ${ }^{368}$.

Problem, czy mamy do czynienia w omawianym aspekcie regulacji konstytucyjnej z uwagami de lege lata czy de lege ferenda, został podniesiony również przez M. Skąpskiego ${ }^{369}$. Przede wszystkim, w pełni aprobując, podobnie jak powołani przedstawiciele doktryny prawa pracy, tezę o zasadności podmiotowego rozszerzenia ochrony w zakresie prawa do odpoczynku, nie sposób nie podzielić wątpli-

364 Por. szerzej A. Sobczyk, Prawo pracy..., s. 195 i n.

365 Tamże, s. 185.

366 Tamże, s. 196.

367 Według Trybunału Konstytucyjnego, „pracownik jako podmiot wolności zrzeszania się w związkach zawodowych (art. 59 ust. 1 Konstytucji RP) nie może być identyfikowany wyłącznie przez pryzmat rodzaju stosunku prawnego łączącego go z pracodawcą". Ustalając zakres konstytucyjnej definicji pracownika należy, zdaniem TK, wziąć pod uwagę wszystkie osoby, które „wykonują określoną pracę zarobkową”, „pozostają w stosunku prawnym z podmiotem, na rzecz którego ją świadczą” oraz „mają interesy zawodowe związane z wykonywaniem pracy, które mogą być grupowo chronione". Por. wyrok TK z 2 czerwca 2015 r., K 1/13, Dz. U. 2015, poz. 791.

368 Por. T. Liszcz, Kiedy pracownik..., s. 231.

369 M. Skąpski, Funkcje regulacji czasu pracy wobec idei równości i sprawiedliwości, „Annales Universitatis Mariae Curie-Skłodowska" 2015, sectio G, t. LXII, 2, s. 213 i n. 
wości ostatniego autora w kwestii możliwości zupełnego odejścia przy interpretacji norm konstytucyjnych od znaczenia pojęcia „pracownik” przyjętego w prawie pracy, przy braku, jak się wydaje, dostatecznie precyzyjnego sposobu jego rozumienia w języku potocznym ${ }^{370}$. Oznaczałoby to bowiem konieczność w jakimś sensie intuicyjnego tłumaczenia przepisów konstytucyjnych i w ten sposób wyznaczenia zakresu podmiotów objętych prawem do wypoczynku. Niewątpliwie nie może chodzić o wszystkie podmioty świadczące pracę ${ }^{371}$, w ust. 2 art. 66 Konstytucji RP, w odróżnieniu od ust. 1, nie posłużono się bowiem terminem „każdy ma prawo”, ale „pracownik ma prawo”.

Kwestię tę dostrzeżono w literaturze przedmiotu. Niektórzy uznają, że w związku z powyższym uprawnionymi w świetle art. 66 ust. 2 Konstytucji będą wszystkie osoby świadczące odpłatnie pracę na rzecz innego podmiotu, niezależnie od podstawy zatrudnienia, zaś beneficjentami prawa do bezpiecznych i higienicznych warunków pracy, wynikającego z ust. 1 art. 66 Konstytucji, wszyscy wykonujący pracę zorganizowaną przez inny podmiot, niezależnie od celu jej podjęcia - w tym m.in. wolontariusze, uczniowie czy praktykanci ${ }^{372}$.

Z drugiej strony, przekonujące są próby uzasadnienia konieczności rozszerzenia zakresu podmiotowego omawianego prawa w oparciu o ogólne zasady i wartości konstytucyjne, takie jak prawo do równego traktowania oraz obowiązek poszanowania ludzkiej godności oraz prawo wszystkich zatrudnionych do bezpiecznych i higienicznych warunków pracy, sformułowane wprost w art. 66 ust. 1 Konstytucji. W świetle licznych regulacji prawa międzynarodowego i europejskiego, odpoczynek staje się bowiem jednym z ważniejszych elementów ochrony życia i zdrowia ludzkiego, co było wcześniej wyraźnie sygnalizowane. Skoro więc konstytucyjne prawo do bhp obejmuje wszystkie osoby świadczące pracę, być może również prawo do odpoczynku powinno być w takim zakresie realizowane. W doktrynie prawa pracy zwraca się wszak uwagę, że osoba wykonująca pracę w stanie przemęczenia i przeciążenia organizmu nie realizuje prawa, uznawanego za element bezpieczeństwa i higieny pracy, do świadczenia pracy w odpowiednich warunkach psychofizycznych ${ }^{373}$.

Pożądana byłaby tu jednak określona interwencja ustrojodawcy.

Brzmienie art. 66 ust. 2 Konstytucji RP wskazuje, że jej twórcy zdecydowali się zamieścić w ustawie zasadniczej podstawowe gwarancje realizacji prawa do odpoczynku, do których należy z jednej strony płatny urlop wypoczynkowy, a z drugiej dni wolne od pracy oraz ustawowo określone normy czasu pracy. W konsekwencji

370 Tamże, s. 213.

371 Za bardzo szeroką interpretacją pojęcia pracownika w ujęciu konstytucyjnym opowiedziała się A. Musiała, uznając, że obejmuje ono nie tylko osoby świadczące pracę zarobkową, ale również wolontariuszy czy nawet więźniów wykonujących pracę na podstawie skierowania administracyjnoprawnego. Por. taż, Kim jest „pracownik” w ujęciu przepisów Konstytucji?, M.P.P. 2017, nr 4, s. 174 i n.

372 Por. tak T. Liszcz, Kiedy pracownik..., s. 231.

373 Por. B. Bury, Dylematy..., s. 385. 
wymusza to na ustawodawcy zwykłym wprowadzenie rozwiązań, które nie tylko będą gwarantować czas wolny w ciągu danego dnia czy tygodnia, ale też dni zupełnie wolne od pracy. Polska Konstytucja, w przeciwieństwie do aktów przyjętych w wielu innych państwach Europy (zwłaszcza jej części środkowo-wschodniej) oraz dokumentach międzynarodowych, nie formułuje jednak wprost prawa do odpoczynku, co przy dość ogólnej formule wymienionych zobowiązań z tego obszaru można uznać za mankament obowiązującej regulacji. Wskazanie na odpoczynek jako podstawowy cel wprowadzanych rozwiązań, choćby w zakresie kształtowania czasu pracy, narzuca bowiem określoną optykę przy interpretacji i stosowaniu odpowiednich przepisów, co pośrednio zauważono również w orzecznictwie Trybunału Konstytucyjnego ${ }^{374}$. Dotyczy to w szczególności prawa urlopowego, w ramach którego wprowadzono wiele rozwiązań mających z punktu widzenia wypoczynku pracowniczego dysfunkcjonalny charakter. Przykładem może być obowiązek pracownika wykorzystania urlopu wypoczynkowego udzielonego przez pracodawcę $\mathrm{w}$ okresie wypowiedzenia czy instytucja przesunięcia terminu urlopu z powodu szczególnych potrzeb pracodawcy ${ }^{375}$. Wiele wątpliwości wywołuje także kwestia dni wolnych od pracy, na co zwrócono już uwagę w literaturze przedmiotu ${ }^{376}$. Między innymi warto podkreślić, że w zamkniętym formalnie kodeksowym katalogu wyjątków dopuszczających pracę w niedziele i święta są takie regulacje, które w zasadzie ten katalog otwierają. Trudno znaleźć uzasadnienie dla odstąpienia od konstytucyjnego prawa do dni wolnych od pracy, do których zalicza się w świethe polskiego prawa przede wszystkim niedziele i święta, w sytuacji „pracy zmianowej”, stanowiącej, zgodnie z art. $151^{10}$ pkt 3 k.p., samoistną przesłankę zatrudniania pracowników w te dni. Niemniej wspomniany już wcześniej brak jasno określonego prawa pracownika do wypoczynku i dość lakoniczne zwroty użyte w komentowanym przepisie Konstytucji RP mogą w praktyce bardzo utrudniać kontrolę zgodności norm niższej rangi z postanowieniami ustawy zasadniczej, a w konsekwencji egzekwowanie konstytucyjnie określonych praw i wolności (szczególnie że, zgodnie z art. 81 Konstytucji RP, jest to prawo, które w razie jego naruszenia może być dochodzone tylko w granicach wskazanych w ustawie $\left.{ }^{377}\right)$. Za przykład

374 Por. m.in. wyrok TK z 2 października 2012 r., K 27/11, Dz.U. poz. 1110. Przy okazji oceny zgodności art. 130 § 2 (1) k.p. z Konstytucją Trybunał zwrócił uwagę w uzasadnieniu wyroku, że art. 66 ust. 2 Konstytucji nie kategoryzuje dni wolnych ani też nie określa „społecznych, kulturowych czy gospodarczych funkcji takich dni”, co m.in. w efekcie spowodowało, że nie był w tej sprawie podstawą rozstrzygnięcia.

375 Krytyczne uwagi do powyższych regulacji por.: M. Nowak, Kilka uwag na temat planu urlopów wypoczynkowych," Gdańsko-Łódzkie Roczniki Prawa Pracy i Prawa Socjalnego" 2015, nr 5, s. 57 in.

376 Por. m.in.: A. Sobczyk, Prawo pracy..., s. 198 i n.; K. Stefański, Konieczność odpracowania dni wolnych - uwagi dotyczace art. 130 \$ 2 k.p., PizS 2006, nr 4, s. 17; tenże, Problem pracy w dni świq̨teczne, PiZS 2007, nr 12, s. 20 i n.; tenże, Problem świq̨ przypadających w dni wolne od pracy wynikajace z pięciodniowego tygodnia pracy, PiZS 2010, nr 12, s. 16 i n.

377 O ograniczeniach z tego wynikających por. szerzej A. Zieliński, Środki ochrony wolności i praw według nowej Konstytucji, PiP 1997, nr 12, s. 19 i n. 
może posłużyć powoływany już wcześniej wyrok Trybunału Konstytucyjnego z 2 października 2012 r., w którym Trybunał, kwestionując zgodność art. $130 \$ 2^{1}$ k.p. z Konstytucją RP oparł swoje rozstrzygnięcie na zasadzie równości - art. 32 ust. 1 Konstytucji RP, a nie na jej art. 66 ust. 2, uznając, że ten ostatni przepis nie precyzuje ani tego, jakie dni są dniami wolnymi od pracy, ani ile takich dni pracownikowi w danym okresie przysługuje. Konstytucja, zdaniem Trybunału, nie kategoryzuje tych dni i nie określa ich funkcji. Ustalenie uprawnień pracownika w tym obszarze staje się materią ustawową, a ustawodawca „ma w tym zakresie dużą swobodę regulacyjną". Tym samym, jak ocenił Trybunał Konstytucyjny, „nie jest dopuszczalne wysuwanie roszczeń opartych na tym przepisie Konstytucji szerszych niż uprawnienia wynikające z ustawy”. I chociaż podzielam część uwag krytycznych wysuniętych pod adresem Trybunału Konstytucyjnego w kontekście uzasadnienia powyższego orzeczenia ${ }^{378}$, to obrazuje ono pewien sposób postrzegania omawianej regulacji i obnaża jej niedostatki.

Podsumowując, należy stwierdzić, że w kontekście prawa do odpoczynku można mówić o kilku istotnych etapach w procesie tworzenia jego prawnych i faktycznych gwarancji, od nieograniczonego dnia pracy, przez tzw. ustawodawstwo fabryczne, aż do zasadniczo ośmiogodzinnego dnia pracy i powszechne prawo do urlopu wypoczynkowego, mające często swe zakotwiczenie w aktach o najwyższej mocy prawnej. Jednocześnie wydaje się, że współcześnie celem ustawodawcy jest już nie tylko zapewnienie pracownikowi czasu niezbędnego do psychofizycznej regeneracji organizmu, ale wypoczynek umożliwiający uczestnictwo w życiu społeczno-politycznym i kulturalnym.

Warto jeszcze raz podkreślić, że nadanie prawu do odpoczynku rangi konstytucyjnej nie jest zjawiskiem powszechnym w Europie. Część państw tego regionu, szczególnie jego strony zachodniej, nie zdecydowała się wprowadzić tego prawa do obowiązujących na ich obszarze ustaw zasadniczych. Wynika to z różnych czynników, wcześniej wskazanych, i jest bardzo często pochodną okresu, z jakiego dany akt rangi konstytucyjnej pochodzi. Brak określonego prawa do odpoczynku w znacznej części ustaw zasadniczych państw Europy Zachodniej nie oznacza, co oczywiste, że nie prowadzą i nie prowadziły one wówczas aktywnej polityki w tym zakresie i nie podjęły stosownych działań legislacyjnych. Zachowując w niezmienionym stanie swe konstytucje, wprowadzano najczęściej równolegle odpowiednie gwarancje w drodze ustawodawstwa zwykłego. Przykładem mogą być takie kraje jak Francja, Szwajcaria czy Niemcy, które stosunkowo wcześnie podjęły odpowiednie kroki w celu prawnego ograniczenia czasu pracy ${ }^{379}$.

Konstrukcja prawa do odpoczynku przyjęta w pozostałych ustawach zasadniczych państw europejskich jest zróżnicowana, choć w zasadniczych aspektach wykazuje wiele podobieństw. Podstawowym elementem konstytucyjnej regulacji jest ogólnie zagwarantowane prawo do urlopu wypoczynkowego, ale też zwraca się

378 Krytycznie na ten temat zob. K. Stefański, Problem świq̨t..., s. 30 i n.

379 Por. szerzej m.in. A. Sobczyk, Zasady..., s. 45 i n. 
uwagę na kwestie związane $\mathrm{z}$ bieżącą, „codzienną” organizacją pracy, w tym w szczególności często wymusza się określenie maksymalnych norm czasu pracy, choć zwykle, niestety, jak m.in. w Konstytucji RP, bez ustanowienia minimalnej konstytucyjnej ochrony w tym zakresie. Mimo często dużej ogólnikowości w formułowaniu prawa do odpoczynku na poziomie ustawy zasadniczej, samo nadanie mu charakteru normy konstytucyjnej ma generalnie duże znaczenie. Nie można zapominać, że stanowi ono ważny gwarant realizacji całego szeregu innych podstawowych praw i wolności. Konstytucja nie tylko potwierdza, zabezpiecza i utrwala to prawo, ale też podkreśla jego rangę, obrazuje wagę, jaką dane państwo upatruje w jego urzeczywistnieniu. Jednocześnie nie sposób nie dostrzec, że choć regulacja konstytucyjna prawa do odpoczynku ma niepodważalne znaczenie gwarancyjne, to jednak w większości przypadków o realnej wartości praktycznej tego prawa decyduje ustawodawstwo zwykłe. To w nim właśnie, w przepisach o czasie pracy i urlopach wypoczynkowych, określa się bowiem szczegółowe warunki, na jakich prawo to będzie $\mathrm{w}$ istocie realizowane.

\section{Instrumenty realizacji prawa do odpoczynku w polskim prawie pracy}

\subsection{Uwagi wstępne}

Na gruncie polskiej regulacji prawnej znaczenie odpoczynku pracowniczego zostało wyraźnie przez ustawodawcę docenione. Świadczy o tym nie tylko fakt nadania temu prawu rangi konstytucyjnej, o czym była wyżej mowa, ale również uznanie go za jedną z podstawowych zasad prawa pracy, wyrażoną wprost w art. 14 k.p. ${ }^{380}$. Przepis ten stanowi, że pracownik ma prawo do wypoczynku, który zapewniają przepisy o czasie pracy, dniach wolnych od pracy oraz o urlopach wypoczynkowych. Jest to zatem bardzo istotne prawo o charakterze socjalnym, które pozwala oddzielić sferę czasu wolnego pracownika, jako okresu wolnego od wszelkiej ingerencji pracodawcy (strefę jego prywatności), od czasu pracy ${ }^{381}$. I jak słusznie zauważono w literaturze przedmiotu, służy ono ochronie zdrowia pracownika oraz regeneracji jego sił we wszystkich podstawowych, z punktu widzenia świadczenia pracy, jednostkach czasowych ${ }^{382}$. W praktyce jednak jego reali-

380 Na temat samej zasady zob. Z. Góral, O kodeksowym katalogu..., s. 179. Por też A. Świątkowski, Zasady prawa pracy, Warszawa 1997, s. 120 i n.

381 Por. m.in. T. Nycz, Ochronne przepisy o czasie pracy - wybrane zagadnienia, PiZS 1999, nr 3, S. 2.

382 Por. A. Bigaj, Wybrane aspekty..., s. 82. 
zacja, z uwagi na duży stopień ogólności przytoczonego sformułowania ${ }^{383}$, w dużej mierze zależy od konkretnych, przyjętych przez państwo rozwiązań w zakresie czasu pracy oraz urlopów wypoczynkowych. Te zaś zmieniają się wraz z rozwojem cywilizacyjnym i kulturowym.

Warto zauważyć, że tendencje do prawnego uregulowania podstawowych standardów w zakresie czasu pracy sięgają w Polsce końca XIX i początków XX w. Początkowo regulacje w omawianym obszarze były mocno zróżnicowane, obowiązywało bowiem na poszczególnych obszarach prawo państw zaborczych, o czym dalej $^{384}$. Niemniej w zasadzie od 1918 r. w ustawodawstwie polskim zaczęto stosować powszechnie dzienny i tygodniowy miernik czasu pracy ${ }^{385}$. Proces normowania, a zarazem ograniczania czasu pracy po pierwszej wojnie światowej został zapoczątkowany dekretem z 1918 r. o ośmiogodzinnym dniu pracy i 46-godzinnym tygodniu pracy, zastąpionym następnie ustawą z 1919 r. o czasie pracy w przemyśle i handlu ${ }^{386}$, której uchwalenie uznano w Sejmie za warunek poprawy stanu zdrowia całego społeczeństwa, „podniesienia moralnego i duchowego poziomu klasy robotniczej”, upowszechnienia oświaty ${ }^{387}$. Ustawa powtórzyła przyjęte w powołanym dekrecie dwie podstawowe normy czasu pracy, wyznaczając tym samym zasadę w zakresie maksymalnego dnia i tygodnia pracy. Wielokrotnie zmieniana ${ }^{388}$ obowiązywała ona do 1975 r., a więc do momentu wejścia w życie Kodeksu pracy.

Od połowy 1922 r. ustawodawca stworzył również odpowiednie gwarancje w zakresie odpoczynku rocznego. Warto podkreślić, że pierwsza polska ustawa

383 Z. Góral zwraca uwagę, że formuła przyjęta w Kodeksie pracy jest nawet ogólniejsza w stosunku do i tak dość ogólnego sformułowania w zakresie prawa do odpoczynku przyjętego w Konstytucji. Por. tenże, O kodeksowym katalogu..., s. 182. W literaturze bywa też kwestionowana sama zasadność powtarzania w Kodeksie pracy zasad podobnych do tych, które zostały wyrażone w Konstytucji. Por. m.in. L. Florek, [w:] E. Sobótka, Propozycje zmian w Konstytucji PRL dotyczacych prawa pracy i zabezpieczenia społecznego, „Polityka Społeczna” 1988, nr 8, s. 35. Por. też na ten temat B. M. Ćwiertniak, [w:] Prawo pracy, red. K.W. Baran, Kraków 2010, s. 58.

384 Por. m.in. obowiązująca na obszarze Królestwa Polskiego regulacja z 2 czerwca 1897 r. o długości i podziale czasu roboczego w zakładach fabrycznych, według której czas pracy pracowników produkcyjnych wynosił 11,5 godziny, a w nocy, soboty i dni przedświąteczne 10 godzin. Co istotne, wszelkie przerwy w pracy na odpoczynek nie były zaliczane do czasu pracy. Zasadniczo 11-godzinny dzień pracy obowiązywał również w zaborze austriackim na podstawie tzw. patentu cesarskiego z 20 grudnia 1859 r., którym ogłoszono ustawę przemysłową. Tu także odpoczynek nie był wliczany do czasu pracy. Por. szerzej: M. Lewy, Prawo przemystowe..., s. 157 i n. oraz A. Sobczyk, Zasady..., s. 68 i n.

385 Por. W. Masewicz, Czas pracy, Warszawa 1994, s. 15.

386 Ustawa z 18 grudnia 1919 r. o czasie pracy w przemyśle i handlu, Dz. U. 1920, Nr 2, poz. 7 (nieobowiązująca).

387 Cytaty ze stenogramów sejmowych. Por. W. Landau, Ośmiogodzinny dzień pracy, s. 18 i n.

388 W latach 30. XX w. m.in. podwyższono normę tygodniową do 48 godzin oraz obniżono dodatki za pracę w godzinach nadliczbowych. Powrót do pierwotnych, korzystniejszych regulacji nastąpił po drugiej wojnie światowej. 
urlopowa z 16 maja 1922 r. ${ }^{389}$, mimo że nie obejmowała osób zatrudnionych w małych zakładach pracy oraz w rolnictwie, była oceniana jako niezwykle postępowa, zwłaszcza ze względu na to, że czyniła z urlopu wypoczynkowego instytucję ustawową o stosunkowo szerokim zakresie podmiotowym ${ }^{390}$, o czym szerzej w kolejnych punktach.

Ewolucja w zakresie prawa do odpoczynku i docenienie znaczenia jego realizacji dla jednostki oraz prawidłowego ukształtowania życia społecznego-gospodarczego (widoczne zwłaszcza w prawie międzynarodowym), rozwój cywilizacyjny, a także postęp techniczny spowodowały stopniowy wzrost standardów w omawianym obszarze. Przejawia się to m.in. wprowadzeniem do polskiego prawa zasady pięciodniowego tygodnia pracy, instytucji odpoczynku dobowego oraz tygodniowego, które zostaną dalej opisane.

Z drugiej strony warto też mieć na uwadze, że nowe czasy zawsze niosą za sobą nowe zagrożenia i związane $\mathrm{z}$ nimi wyzwania, wymuszają pewne kompromisy, również w zakresie czasu pracy. Znamienne jest, że o ile w XIX w. dążono przede wszystkim do ograniczenia godzin pracy i unormowania tej materii, a w połowie XX w. bardzo silne były postulaty w kierunku skracania czasu pracy, o tyle obecnie zwraca się większą uwagę na swobodę w jego elastycznym kształtowaniu, co może mieć swój wpływ, nie zawsze pozytywny, na sposób realizacji prawa do odpoczynku, szczególnie jeśli chodzi o jego regularność.

Nie ma jednak wątpliwości, że każde ograniczanie czasu pracy w jakiś sposób przekłada się na poszerzenie sfery czasu wolnego, a tym samym czas potencjalnego odpoczynku. Obowiązująca regulacja, wyznaczając pewne zasady prawidłowej organizacji pracy, ma jednocześnie walor stricte ochronny, przeciwdziała nadmiernemu wydłużaniu czasu, w jakim pracownik musi pozostawać w dyspozycji pracodawcy. Chodzi przede wszystkim o:

- ustalenie maksymalnych norm czasu pracy, zwłaszcza maksymalnej normy tygodniowej;

- okresy rozliczeniowe, których celem jest przeciwdziałanie nadmiernej kumulacji pracy w dłuższym okresie i związanego z nią zmęczenia; mają one szczególne znaczenie w systemach równoważnych norm czasu pracy, w których dopuszcza się wydłużenie dobowego wymiaru czasu pracy poza powszechną normę podstawową;

- zasadę nieprzerwanego dobowego wymiaru czasu pracy, przeciwdziałającą wydłużaniu dnia pracy poprzez wprowadzanie przerw w pracy;

- zasadę pięciodniowego tygodnia pracy, która limituje tygodniową liczbę dni pracy i wymusza wyznaczenie dni dodatkowo wolnych od pracy;

- reglamentację pracy w godzinach nadliczbowych, niedziele i święta.

W dalszej części tego podrozdziału, ze względu na temat niniejszego opracowania i przyjęte wcześniej węższe rozumienie prawa do odpoczynku, a także literalne

389 Por. ustawa z 16 maja 1922 r. o urlopach dla pracowników zatrudnionych w przemyśle i handlu, Dz. U., Nr 40, poz. 334 (nieobowiązująca).

390 Por. m.in. W. Szubert, Zarys..., s. 25. 
brzmienie przepisów formułujących podstawową zasadę w tym obszarze, szerzej zostaną omówione tylko te instytucje prawa pracy, których główną, wiodącą funkcją jest zagwarantowanie pracownikom warunków do realizacji omawianego prawa, tj. te, których bezpośrednim celem jest właśnie odpoczynek.

\subsection{Okresy odpoczynku dobowego i tygodniowego}

\subsubsection{Prawne limitowanie dobowego i tygodniowego czasu pracy - rys historyczny}

Prawo do odpoczynku dobowego i prawo do odpoczynku tygodniowego jako powszechne, odrębne instytucje regulacji czasu pracy pojawiły się w prawie polskim stosunku niedawno ${ }^{391}$. Zostały one bowiem wprowadzone pod wpływem prawa UE, w którym odpoczynek dobowy i tygodniowy stał się bardzo ważnym elementem organizacji czasu pracy.

Brak wyraźnie wyodrębnionego prawa do odpoczynku dobowego i tygodniowego nie oznacza, że nie był on w jakiś sposób gwarantowany. Przez długi czas, $\mathrm{w}$ ramach ograniczania czasu przeznaczonego na pracę i poszerzania sfery czasu wolnego pracownika, obowiązywały bowiem przepisy prawne, które pośrednio wymuszały zachowanie okresów potencjalnego odpoczynku.

W zakresie czasu wolnego od pracy w wymiarze dobowym podstawowe znaczenie miała prawna regulacja maksymalnych norm czasu pracy odnoszonych do dnia roboczego oraz przepisy limitujące pracę w godzinach nadliczbowych. Podobnie wyglądała kwestia dotycząca odpoczynku tygodniowego, choć początkowo był on łączony ściśle z dniami ustawowo wolnymi od pracy, o których dalej będzie mowa, i zakazem pracy w niedzielę. Dopiero po 1918 r. przyjęto w prawie polskim maksymalną tygodniową normę czasu pracy, która przez długi czas determinowała w jakiś sposób możliwość odpoczynku tygodniowego.

Normy te, wyznaczając ogólne ramy czasu pracy i czasu od niej wolnego, spełniały zatem pośrednio, jak podkreślano w doktrynie prawa pracy, określoną funkcję społeczną, umożliwiały bowiem nie tylko codzienny i cotygodniowy wypoczynek, ale również wypełnianie wielu pozazawodowych obowiązków, udział w życiu rodzinnym, kształcenie itp. ${ }^{392}$

391 Ustawa z dnia 14 listopada 2003 r. o zmianie ustawy - Kodeks pracy oraz o zmianie niektórych innych ustaw, Dz. U. 2003, Nr 213, poz. 2081. Wcześniej odpoczynek taki był gwarantowany sporadycznie i dotyczył wybranych grup zawodowych. Por. np. ustawa z 24 sierpnia 2004 r. o czasie pracy kierowców, Dz. U. 2004, Nr 123, poz. 1354, ze zm.

392 Por. A. Uklejska, Aktualne kierunki rozwoju prawa urlopowego, PiZS 1974, nr 6, s. 23. 
Pierwotnie ograniczenia, o których wyżej mowa, regulowały przepisy państw zaborczych, choć zwykle jeszcze nie w stosunku do wszystkich zatrudnionych.

Na obszarze Królestwa Polskiego obowiązywała wynikająca z przepisów prawa rosyjskiego ${ }^{393}$ zasadniczo 11,5-godzinna norma dobowa dla pracowników dziennych (ośmiogodzinna lub dziewięciogodzinna przy pracy zmianowej - norma dobowa dla dzieci poniżej 15 roku życia). Norma ta podlegała zmniejszeniu do 10 godzin w soboty i w dzień poprzedzający święto ${ }^{394}$ oraz w stosunku do osób, które choćby częściowo świadczyły pracę w porze nocnej (tj. między godz. 9 a godz. 5 rano lub przy pracy zmianowej - między godz. 10 a godz. 4 rano). Ponadto w zakładach górniczych i hutniczych, w których praca trwała 18 godzin i odbywała się na dwie zmiany można było wydłużyć dobowy wymiar czasu pracy do 12 godzin (średnio w ciągu dwóch tygodni dobowy wymiar czasu pracy robotnika nie mógł jednak przekroczyć dziewięciu godzin ${ }^{395}$.

W zaborze austriackim, podobnie jak w zaborze rosyjskim, robotników zatrudnionych $\mathrm{w}$ „przedsiębiorstwach przemysłowych prowadzonych fabrycznie” obowiązywał, co do zasady, 11-godzinny dzień pracy ${ }^{396}$, choć prawo upoważniało władzę wykonawczą do ustalania dłuższej normy dobowej dla poszczególnych branż.

Prawo niemieckie limitowało natomiast pracę dobową dzieci i kobiet. Te ostatnie nie mogły wykonywać pracy powyżej 10 godzin na dobę, a w dzień poprzedzający niedzielę lub święto więcej niż osiem godzin i dłużej niż do godz. $17^{397}$.

Wówczas też pojawiły się pierwsze unormowania dotyczące pracy w godzinach nadliczbowych, które w połączeniu $\mathrm{z}$ maksymalną normą dobową wyznaczały de facto zakres czasu wolnego pracownika przeznaczonego m.in. na wypoczynek.

W ramach Królestwa Polskiego tzw. robota nadetatowa, a więc przekraczająca wskazane wyżej maksymalne dobowe normy czasu pracy, czy wykonywana $\mathrm{w}$ dniach wolnych od pracy, była dopuszczalna za zgodą pracownika (po zawarciu w tej sprawie stosownego porozumienia). Niemniej wydane w 1897 r. ministe-

393 Chodzi o tzw. ustawę przemysłową stanowiącą cz. II tomu XI Zbioru Praw Państwa Rosyjskiego. W 1915 r. podzielono ją na ustawę przemysłową i ustawę o pracy w przemyśle, do której włączono wszystkie przepisy dotyczące robotników w fabrykach i kopalniach. Por. M. Lewy, Prawo przemysłowe..., s. 13. Bardzo ważna była nowela z 2 czerwca 1897 r. o długości i podziale czasu roboczego w zakładach fabryczno-hutniczych. Por. tekst przepisów Zbiór praw, instrukcyi i przepisów obowiq̨zujących dla prywatnego przemysłu górniczego w guberniach Królestwa Polskiego, Dąbrowa 1899, s. 215 i n. Przepisy te były jednak stosowane do robotników zatrudnionych w przemyśle. Nie obejmowały zatem pracowników umysłowych oraz pracowników zatrudnionych w warsztatach rzemieślniczych. Por. K. Stefański, Elastyczny czas pracy, Warszawa 2016, s. 109.

394 Dodatkowo prawo nakazywało, by w wigilię Bożego Narodzenia pracę zakończyć w południe. Por. Zbiór praw, instrukcyi i przepisów..., s. 215. Zob. też M. Lewy, Prawo przemysłowe..., s. 167.

395 Por. Zbiór praw, instrukcyi i przepisów..., s. 215.

396 Por. na ten temat szerzej: S. Włoszczewski, O czasie pracy z punktu widzenia interesu narodowego, Warszawa 1922, s. 16 oraz A. Sobczyk, Zasady..., s. 72 i n.

397 M. Lewy, Prawo przemystowe..., s. 163. 
rialne przepisy o długości dnia roboczego wprowadziły tzw. obowiązkowe roboty nadetatowe, które musiały być przez pracowników wykonane, niezależnie od ich woli $^{398}$. Dodatkowo brak limitów czasowych tej pracy powodował, że w istocie trudno mówić o realnym, choćby pośrednim, zabezpieczeniu prawa do odpoczynku dobowego na obszarze obowiązywania omawianych przepisów. Wziąwszy pod uwagę fakt, że ustawa rosyjska, w przeciwieństwie do prawa innych państw zaborczych, nie przewidywała żadnych sankcji za naruszenie jej postanowień, nie może dziwić, że w literaturze oceniano ją bardziej jako zbiór zaleceń niż akt normatywny ${ }^{399}$.

Zupełnie inaczej kształtowała się sytuacja na terenach zaboru austriackiego. Tam praca w godzinach nadliczbowych została poddana bowiem wyraźnym ograniczeniom o charakterze zarówno materialnoprawnym jak i administracyjnym. W szczególności pracodawca miał możliwość wydłużenia czasu pracy o dwie godziny (przy normie 12-godzinnej) lub trzy godziny (jeśli norma wynosiła 11 godzin), ale nie częściej niż trzy razy w miesiącu i po zgłoszeniu tego faktu stosownej władzy. Wprowadzenie godzin nadliczbowych w większym wymiarze było możliwe raz w roku po uzyskaniu specjalnego zezwolenia właściwej władzy (wówczas możliwa była taka praca przez okres trzech lub 12 tygodni w wymiarze jednej lub dwóch godzin w zależności od normy czasu pracy) oraz w razie „klęsk elementarnych" lub wypadków zakłócających proces produkcji, kiedy to można było stosować nadgodziny w dłuższych okresach ${ }^{400}$. Tym samym dość mocno, jak na ówczesne warunki, ograniczono zakres swobody pracodawcy w dysponowaniu czasem pracownika.

W prawie polskim znacznie bardziej wyraźnie zarysowała się kwestia prawa do odpoczynku tygodniowego. Na tle regulacji państw zaborczych wspominano o nim jednak w literaturze w kontekście zakazu pracy w niedzielę ${ }^{401}$. Zarówno na terenach Królestwa Polskiego, jak i na pozostałych ziemiach polskich, obowiązywała bowiem zasada jednego dnia wolnego od pracy w tygodniu. Ustawowo uregulowano w związku z tym zakaz pracy w niedziele ${ }^{402}$ i „święta uroczyste” ${ }^{403}$. W tych dniach odpoczynek miał trwać co najmniej 24 godziny ${ }^{404}$. Ponadto na obszarze Królestwa Polskiego przepisami z 1897 r. odpoczynek ten wydłużono do co

398 Por. tamże, s. 145 i n.

399 Tamże, s. 172.

400 Por. A. Sobczyk, Zasady..., s. 72 i n.

401 Por. M. Lewy, Prawo przemysłowe..., s. 165 i n.

402 Wynikał on również ze specjalnie w tym celu wydanej ustawy obowiązującej na terenach zaboru austriackiego (ustawa z 16 stycznia 1895 r. urządzająca wypoczynek niedzielny i świąteczny w przedsiębiorstwach przemysłowych), a także z prawa niemieckiego (§ 105a). Por. tamże, s. 165 i n.

403 Według przepisów obowiązujących w Królestwie Polskim, jeśli święta miały charakter chrześcijański, osobom wyznającym inną wiarę można było zagwarantować inny dzień wolny od pracy.

404 Por. Zbiór praw, instrukcyi i przepisów..., pkt 11, s. 220. Według ustawy austriackiej z 1895 r., niedzielny odpoczynek miał trwać 24 godziny, od godz. 6 rano w niedzielę. 
najmniej 36 godzin w niedzielę, po której występowało święto oraz do 48 godzin w wybrane święta (np. Boże Narodzenie) $)^{405}$.

Obowiązujące na ziemiach polskich przepisy państw zaborczych dotyczące tzw. odpoczynku niedzielnego nie miały jednak bezwzględnego charakteru.

W prawie rosyjskim pozwolono na odstąpienie od wspomnianej reguły po wystąpieniu nadzwyczajnych powodów i uzyskaniu zgody pracownika. Należało również niezwłocznie zawiadomić inspekcję fabryczną o przyczynach pracy $\mathrm{w}$ niedzielę. W takiej sytuacji pracownik uzyskiwał prawo do innego dnia wolnego od pracy w tygodniu ${ }^{406}$.

Gwarancje te nie były jednak szczególnie silnie, biorąc pod uwagę liczbę możliwych odstępstw od przepisów ustawy, a także brak sankcji za nierespektowanie omawianych przepisów.

Również prawo obowiązujące na terenach zaboru austriackiego upoważniało władze administracyjne (namiestnictwa) do wprowadzenia wyjątków od ustawowo gwarantowanego odpoczynku niedzielnego, po uwzględnieniu stosunków miejscowych oraz właściwości poszczególnych gałęzi przemysłu ${ }^{407}$. Ustawa przyznawała też stowarzyszeniom prawo zgłaszania władzy administracyjnej krajowej, za pośrednictwem władzy przemysłowej, wniosków dotyczących ograniczania zasady zakazu pracy w niedzielę ${ }^{408}$.

Odstępstwa od omawianego odpoczynku wprowadzały także tzw. przepisy ministerialne, w tym zwłaszcza rozporządzenie z 24 kwietnia 1885 r. o urządzeniu wypoczynku niedzielnego i świątecznego w przedsiębiorstwach przemysłowych, które dopuszczało pracę w niedzielę ze względu m.in. na niemożność przerwania prac z powodu ich natury lub niezbędność tych prac wynikającą z codziennych potrzeb ludności lub obrotu publicznego ${ }^{409}$.

Prawo do odpoczynku niedzielnego wyraźnie zmodyfikowano też, jeśli chodzi o handel. W odniesieniu do zatrudnionych $\mathrm{w}$ nim pracowników $\mathrm{w}$ zasadzie jedynie limitowano pracę $\mathrm{w}$ niedzielę i święta, obniżając godzinowy wymiar ich czasu pracy do sześciu godzin, z możliwością jednak wydłużenia tej pracy do 10 $\operatorname{godzin}^{410}, \mathrm{z}$ zastrzeżeniem obowiązku pracodawcy poszanowania prawa pracowników do uczestnictwa w praktykach religijnych ${ }^{411}$.

405 M. Lewy, Prawo przemysłowe..., s. 166 i n.

406 Por. Zbiór praw, instrukcyi i przepisów..., s. 216.

407 Korzystając z tego upoważnienia, władze Galicji obwieszczeniem z 30 kwietnia 1895 r. ustanowity takie wyjątki, obejmując nimi m.in. piekarzy, którzy mogli pracować w niedzielę przy wyrobie pieczywa do godz. 10 rano i od godz. 10 wieczorem. Por. Zamach majstrów piekarskich na spoczynek niedzielny, „Naprzód” 1902, nr 96, s. 1.

$408 \mathrm{Na}$ tej podstawie m.in. cech piekarzy w Krakowie w 1902 r. postanowił złożyć wniosek o ograniczenie odpoczynku niedzielnego piekarzy, tak aby mogli oni już od godz. 8 wieczorem w niedzielę rozpocząć prace przygotowawcze do wyrobu pieczywa. Por. tamże.

409 Było to rozporządzenie ministra handlu w porozumieniu z ministrem spraw wewnętrznych oraz ministrem wyznań i oświaty. Por. A. Sobczyk, Zasady..., s. 74.

410 Z uwagi na święta, odpusty, zwyczaje lub ze względu na miejsce świadczenia pracy możliwe było stałe lub okresowe wydłużenie tej pracy.

411 Por. A. Sobczyk, Zasady..., s. 75. 
Ustawa austriacka, choć dopuszczała wiele wyjątków od odpoczynku niedzielnego, jednocześnie wprowadzała kilka dodatkowych obostrzeń związanych z organizowaniem pracy w niedzielę. Należało bowiem uprzednio zgłosić taki fakt właściwym władzom, prowadzić imienny rejestr osób wykonujących pracę w niedzielę, a samym zatrudnionym zagwarantować prawo udziału w praktykach religijnych oraz kolejną niedzielę wolną od pracy (w razie, jeśli czas pracy w niedzielę przekroczył trzy godziny), z wyjątkiem pracy w ruchu ciągłym, gdzie praca mogła być rekompensowana innym dniem wolnym w tygodniu ${ }^{412}$.

Tendencje do prawnego limitowania godzin pracy w wymiarze dobowym i tygodniowym w celu m.in. urzeczywistnienia prawa pracownika do wypoczynku były rozwijane po odzyskaniu przez Polskę niepodległości. Rewolucja październikowa w Rosji, rosnąca siła ruchów robotniczych, a także działalność normotwórcza MOP zaowocowały intensywnym rozwojem ustawodawstwa pracy również w naszym kraju. Jak wskazywano w literaturze, jego rezultatem było m.in. skracanie czasu pracy odpowiadające hasłu „trzech ósemek”, tj. ośmiu godzin pracy, ośmiu godzin snu i ośmiu godzin odpoczynku dobowego ${ }^{413}$. Wspomnianym wcześniej dekretem z 23 listopada 1918 r. ustanowiono ośmiogodzinny dzień pracy, poszerzając tym samym dobową sferę czasu wolnego od pracy, oraz 46-godzinny tydzień pracy obejmujący pracę po osiem godzin przez pięć dni tygodnia oraz sześciogodzinną pracę w sobotę (tzw. sobota angielska) ${ }^{414}$.

Ostatnia norma, stanowiąca novum w polskim prawie, w połączeniu z niedzielą ustawowo wolną od pracy wyznaczała ramy czasu wolnego od pracy w tygodniu, a pośrednio także okres możliwego wypoczynku.

Wprowadzone dekretem maksymalne normy czasu pracy znalazły następnie swoje odzwierciedlenie w ustawie z 18 grudnia 1919 r. o czasie pracy w przemyśle i handlu.

Wymaga zaznaczenia, że obie normy miały charakter sztywny, tj. bez możliwości ich przekroczenia w danym dniu lub tygodniu, poza przypadkami wprost wskazanymi w ustawie, co było wyraźnie podkreślane w orzecznictwie sądo$\mathrm{wym}^{415}$. W rezultacie pracodawcy mieli ograniczoną swobodę w ustalaniu godzin pracy w poszczególnych dniach tygodnia ${ }^{416}$, a pracownicy, w pewnym sensie i zakresie, zyskiwali poczucie pewności omawianego odpoczynku oraz jego znaczną regularność.

W brzmieniu ustalonym przez dekret z 1946 r. ustawa obejmowała wszystkich pracowników zatrudnionych na podstawie umowy w przemyśle, handlu,

412 Tamże.

413 Por. W. Szubert, Zarys..., s. 21.

414 Por. S. Rychliński, Czas pracy w przemyśle polskim, Warszawa 1929, s. 1.

415 Sąd Najwyższy uznawał m.in., że ustalenie przez pracodawcę większej liczby godzin pracy w danym dniu niż dopuszcza norma ustawowa, nawet przy zmniejszonej liczbie godzin pracy w innym dniu i zachowanej normie tygodniowej, jest niedopuszczalne. Por. wyrok SN z 4 lutego 1932 r., IC 1835/31, ZO 1/32/31.

416 Por. W. Masewicz, S. Dzwonkowski, Czas pracy. Komentarz, Warszawa 1968, s. 35. 
górnictwie, komunikacji i przewozie oraz innych zakładach pracy prowadzonych w sposób przemysłowy, niezależnie od tego, czy zakłady te stanowiły własność prywatną czy państwową lub samorządową (art. 1) $)^{417}$. Ponadto w okresie powojennym obecna była w judykaturze tendencja do rozciągania podstawowych, ustawowych norm czasu na pracowników wszystkich zakładów pracy, choćby nie spełniały one warunków wymienionych w art. 1 ustawy ${ }^{418}$.

Nieco gorzej przedstawiała się jednak sytuacja osób zatrudnionych w handlu, nowelą z 14 lutego 1922 r. wprowadzono bowiem możliwość otwarcia sklepów przez okres 10 godzin, co, mimo że pozostawiono zasadę ośmiogodzinnego dnia pracy, było oceniane jako de facto przedłużenie czasu pracy w tym sektorze ${ }^{419}$. Warto też odnotować odmienność w zakresie ukształtowania norm czasu pracy na obszarze Górnego Śląska objętego prawem niemieckim, w szczególności w przemyśle hutniczym, gdzie w zasadzie do 1929 r. czas pracy był wydłużony do 10 godzin ${ }^{420}$.

Ustawa o czasie pracy w przemyśle i handlu ośmiogodzinny dzień pracy i 46-godzinny tydzień pracy czyniła podstawową zasadą, która w pewnych przypadkach podlegała ograniczeniom. Wyjątki zostały jednak wyraźnie przez prawo określone (w samej ustawie oraz w przepisach wydanych na jej podstawie ${ }^{421}$ ). Ustalono bowiem nie tylko przesłanki materialne uzasadniające pracę dłuższą niż normy wyjściowe (dotyczące szczególnego rodzaju prac czy systemów, a także godzin nadliczbowych) oraz towarzyszące im często wymagania formalne, ale również, co niezwykle ważne w zakresie gwarancji odpoczynku dobowego, dopuszczalną, maksymalną liczbę godzin pracy przekraczającej ową ośmiogodzinną normę (wyjątkowo normę tygodniową ${ }^{422}$ ). W zależności od konkretnej przesłanki i okresu obowiązywania ustawy, liczba godzin pracy dodatkowej wahała się przeważnie między jedną a czterema godzinami na dobę. W ruchu ciągłym zaś, gdzie, przypomnijmy, istniała możliwość wydłużenia normy tygodniowej do 56 godzin, wymagano, by w okresie trzytygodniowym każdy pracownik mógł dwukrotnie skorzystać z 24-godzinnego odpoczynku (art. 13 ustawy) ${ }^{423}$.

417 Por. tamże, s. 7. Ustawa nie obejmowała rolnictwa, leśnictwa ani rybołówstwa, gdzie czas pracy był długo regulowany drogą układową, a także marynarzy w żegludze międzynarodowej oraz pracowników służby zdrowia i zakładów, które zostały objęte pragmatykami pracowniczymi. Por. M. Święcicki, Prawo pracy, s. 475.

418 Por. m.in. wyrok SN z 23 maja 1953 r., I.C. 1882/52, niepublikowany. Krytycznie na ten temat W. Masewicz, S. Dzwonkowski, Czas pracy..., s. 22.

419 Tak por. S. Rychliński, Czas pracy..., s. 1.

420 Tamże, s. 10 i n.

421 Por. m.in. rozporządzenie z 26 stycznia 1922 r. czy z 15 stycznia 1924 r. Zob. szerzej: S. Rychliński, Czas pracy..., s. 1 i n.

422 Ustawa dopuszczała możliwość wydłużenia normy tygodniowej w ruchu ciągłym do 56 godzin tygodniowo. Jednocześnie, chroniąc prawo pracownika do wypoczynku, wymagano, by w okresie trzytygodniowym każdy pracownik mógł dwukrotnie skorzystać z 24-godzinnego odpoczynku.

423 Tekst ustawy zob. W. Masewicz, S. Dzwonkowski, Czas pracy..., s. 12. 
Tego rodzaju odpoczynek przypadający bezpośrednio po zakończeniu pracy został zagwarantowany też (w wymiarze 10 lub 12 godzin) określonym pracownikom zatrudnionym w transporcie.

Ponadto, zgodnie $\mathrm{z}$ art. 16 ustawy, wszelka praca w godzinach nadliczbowych musiała być dodatkowo wynagradzana (50-proc. lub 100-proc. dodatek, w zależności od liczby godzin oraz pory i dnia jej wykonywania).

Warunki do realizacji prawa do odpoczynku tygodniowego, poza opisaną już ustawową, tygodniową normą czasu pracy, stwarzały również regulacje dotyczące pracy w soboty, niedziele i święta.

Zasadniczo praca w sobotę nie mogła przekraczać sześciu godzin, a w nielicznych przypadkach, w których możliwe było jej wydłużenie, należało pracownikowi zapewnić odpowiednio dłuższy okres odpoczynku w inne dni (tj. oddać godziny dodatkowo przepracowane w sobotę).

Praca w niedziele i święta wymienione w odrębnych przepisach była natomiast zasadniczo zakazana. Wyjątki od tej reguły były nieliczne i określone bezpośrednio w ustawie. W razie konieczności wykonywania pracy w niedzielę, a tym samym zakłócenia owego odpoczynku tygodniowego, zobowiązano pracodawcę do zawiadomienia o tym facie odpowiednich podmiotów ${ }^{424}$ oraz do udzielenia pracownikowi w zamian za taką pracę innego dnia wolnego od pracy w tygodniu (art. 12 i 13 ustawy).

Jak z powyższego wynika, formalnie ustawa o czasie pracy w przemyśle i handlu, dzięki zawartym w niej instrumentom, zabezpieczała, przynajmniej pośrednio, prawo pracownika do odpoczynku dobowego i tygodniowego na stosunkowo wysokim, jak na ówczesne warunki, poziomie. Niemniej nie zawsze przekładało się to na jego praktyczną realizację i faktyczne zabezpieczenie pracownika przed nadmiernym zmęczeniem. W literaturze przedmiotu zwracano bowiem uwagę na problemy $z$ wyegzekwowaniem respektowania jej postanowień przez pracodawców, nie tylko w pierwszych latach jej obowiązywania, ale też w okresie międzywojennym ${ }^{425}$.

Ukształtowane pośrednio na podstawie przepisów omawianej ustawy prawo do odpoczynku dobowego i tygodniowego, z krótkotrwałymi, niekorzystnymi z punktu widzenia pracownika zmianami wprowadzonymi w latach 30 . XX w. ${ }^{426}$,

424 Urząd Inspekcji Pracy, a po 1954 r. - właściwy terenowo zarząd okręgowy związków zawodowych.

425 Por. m.in. W. Landau, Ośmiogodzinny dzień pracy, s. 31 i n. O praktyce łamania prawa w latach 1926-1934 poprzez nielegalne przedłużanie czasu pracy i pozbawianie pracownika corocznego wypoczynku wspominat też W Szubert, Zarys..., s. 28.

426 Ogólnoświatowy kryzys gospodarczy, który dotknął również polską gospodarkę, stał się jedną z przyczyn wprowadzenia w 1933 r. zmian ustawodawczych polegających m.in. na przedłużeniu tygodniowej normy czasu pracy do 48 godzin oraz obniżeniu dodatków za pracę w godzinach nadliczbowych. Bezpośrednio po drugiej wojnie światowej przywrócono jednak zasadę 46-godzinnego tygodnia pracy oraz podwyższono wysokość wynagrodzenia za godziny nadliczbowe. Por. dekret z 19 września 1946 r. o zmianie ustawy o czasie pracy w przemyśle i handlu, Dz. U. 1946, Nr 51, poz. 285. 
przetrwało w zasadzie aż do uchwalenia w latach 70. ubiegłego wieku Kodeksu pracy. Wspomniana ustawa z 1919 r. utraciła moc obowiązującą, a Kodeks pracy stał się głównym aktem prawnym w zakresie regulacji czasu pracy, w którym prawo do odpoczynku, w ślad za Konstytucją PRL, zostało podniesione do rangi podstawowej zasady prawa pracy. Była ona postrzegana jako dyrektywa skierowana do pracodawców, obejmująca powinność takiego ustalania rozkładów czasu pracy poszczególnych pracowników, aby każdemu zapewnić odpoczynek po pracy. Uznawano nawet, że może ona stać się podstawą odmowy wykonania pracy przez pracownika, zwłaszcza w godzinach nadliczbowych, jeśli nazbyt ograniczona długość przerwy w świadczeniu pracy nie pozwala na pełną regenerację sił ${ }^{427}$.

Biorąc pod uwagę konstrukcję i poziom uprawnień pracownika w obszarze odpoczynku dobowego i tygodniowego Kodeks pracy w początkowej fazie jego obowiązywania nie wprowadził jakichś dalej idących zmian, choć niewątpliwie, zgodnie $\mathrm{z}$ trendami panującymi w całej Europie ${ }^{428}$, podejmowano określone działania legislacyjne na rzecz skracania czasu pracy. Dotyczyło to jednak przede wszystkim ograniczania jego wymiaru tygodniowego. W zakresie maksymalnego dobowego czasu pracy zachowano w zasadzie dotychczasowe reguły, tj. pozostawiono jako podstawową ośmiogodzinną normę dobową oraz uregulowano warunki dopuszczalności wykonywania pracy w godzinach nadliczbowych. Norma ośmiogodzinna była normą główną, powszechnie stosowaną, ale oczywiście nie jedyną. $\mathrm{W}$ ramach poszczególnych systemów czasu pracy, wprowadzanych po spełnieniu wynikających z Kodeksu pracy przesłanek, umożliwiono jej skrócenie ${ }^{429}$ lub wydłużenie, zwykle jednak przy zachowaniu niezmienionej normy tygodniowej ${ }^{430}$. Tym samym pracownik, w ostatnim przypadku, nie tracił zasadniczo na ogólnej ilości czasu wolnego od pracy, ale na jego regularności, co przekładało się bezpośrednio także na kwestię odpoczynku.

Również obowiązek pracy w godzinach nadliczbowych nadal był poddawany licznym prawnym ograniczeniom. Warto jednak podkreślić, że przez wiele lat od wejścia w życie Kodeksu pracy obowiązywał wyłącznie roczny limit pracy w nadgodzinach, organizowanej ze względu na szczególne potrzeby zakładu pracy, co nie stanowiło wystarczającego zabezpieczenia w zakresie odpoczynku dobowe-

427 Por. tak K. Kolasiński, Podstawy prawa pracy, Toruń 1979, s. 32.

428 Dążenia do skracania czasu pracy, jak wskazywał W. Szubert, stały się powszechne po II wojnie światowej. Tenże, Zarys..., s. 23.

429 Normy skróconego czasu pracy dotyczyły prac szczególnie uciążliwych lub wykonywanych w warunkach szkodliwych dla zdrowia. Były stosowane np. w górnictwie, hutnictwie, przemyśle chemicznym. Skrócony czas pracy obejmował również młodocianych.

430 Chodzi o system tzw. równoważnych norm czasu pracy. Obok niego, na podstawie rozporządzenia RM z listopada 1974 r., występował tzw. przedłużony czas pracy; dotyczył on pracowników zatrudnionych przy pilnowaniu, których obowiązywała nie tylko 12-godzinna norma dobowa, ale też 56-godzinna norma tygodniowa. Por. K. Kolasiński, Podstawy..., s. 126 i n. Na szczególnych warunkach uregulowano również pracę w tzw. ruchu ciągłym, w którym również dopuszczono przedłużenie obu norm czasu pracy. Por.: W. Szubert, Zarys..., s. 215 i n. oraz T. Zieliński, Zarys..., cz. II, s. 248. 
go i było pewnym regresem w stosunku do unormowań ustawy z 1919 r., w której praca ta była poddana wyraźnej reglamentacji dobowej. Szczególnie istotna w rozważanym kontekście była w związku z tym gruntowna nowelizacja Kodeksu pracy dokonana w połowie lat 90. ubiegłego wieku, która przywróciła dobowy limit pracy w godzinach nadliczbowych, wykonywanej ze względu na szczególne potrzeby pracodawcy, wynoszący cztery godziny dla każdego pracownika ${ }^{431}$. Ów limit był jednak niezależny od stosowanego w danym przypadku systemu czasu pracy, co w konsekwencji prowadziło do nieuzasadnionego zróżnicowania maksymalnej wielkości dobowego czasu pracy poszczególnych pracowników ${ }^{432}$. Obowiązywał on do czasu daleko idącej zmiany przepisów o czasie pracy i wprowadzenia instytucji odpoczynku dobowego, która niejako „przejęła” funkcję ochronną omawianej normy, usuwając przy tym wspomniane wyżej jej niedoskonałości.

Niewątpliwie większe zmiany po wejściu w życie Kodeksu pracy nastąpiły natomiast w zakresie kształtowania warunków do odpoczynku tygodniowego. Uznano bowiem, że formy odpoczynku sobotnio-niedzielnego mają szczególne znaczenie dla regeneracji sił pracownika ${ }^{433}$. Stąd poza wolną niedzielą i dniami świątecznymi rozszerzano stopniowo uprawnienia pracownika w zakresie wolnej soboty (po 1979 r. było ich $14^{434}$ ), co miało ostatecznie doprowadzić do skrócenia tygodniowego czasu pracy. Do 1981 r. wskazywano je w uchwale Rady Ministrów, o czym szerzej w kolejnych punktach.

Z czasem skróceniu ulegała też podstawowa tygodniowa norma czasu pracy, stając się jednocześnie normą średnią (wydłużenie czasu pracy w jednym tygodniu oznaczało jego odpowiednie skrócenie w innym tygodniu okresu rozliczeniowego). Spowodowało to po stronie pracownika pewną nieregularność w ilości przypadającego mu czasu wolnego od pracy w poszczególnych tygodniach, zwłaszcza wobec braku określenia maksymalnej ilości czasu pracy, jaką łącznie z godzinami nadliczbowymi pracownik może być tygodniowo obciążony (limity godzin nadliczbowych przez długi czas były określane dobowo i one wyznaczały pośrednio tę wielkość).

Norma ta w latach 90. ubiegłego wieku została ukształtowana na poziomie 42 godzin przeciętnie na tydzień ${ }^{435}$, a w wyniku nowelizacji Kodeksu pracy z 2001 r. nastąpiło dalsze jej stopniowe skracanie, aż do 40 godzin począwszy od 1 stycznia 2003 r. $^{436}$.

431 Por. ustawa z dnia 2 lutego 1996 r. o zmianie ustawy - Kodeks pracy oraz o zmianie niektórych ustaw, Dz. U. 1996, Nr 24, poz. 110.

432 Pracownik objęty normą ośmiogodzinną mógł wykonywać pracę maksymalnie 12 godzin na dobę, ale już ten zatrudniony w systemie równoważnym, w którym dopuszczono wydłużenie dobowego czasu pracy do 12 godzin - 16 godzin.

433 Por. tak M. Piątkowski, Uprawnienia socjalne pracowników, Warszawa 1979, s. 23.

434 Tamże.

435 Ustawa z 2 lutego 1996 r. o zmianie ustawy - Kodeks pracy oraz o zmianie niektórych ustaw, Dz. U. 1996, Nr 24, poz. 110, ze zm.

436 Ustawa z 1 marca 2001 r. o zmianie ustawy - Kodeks pracy, Dz. U. 2001, Nr 28, poz. 301. Do końca grudnia 2001 r. obowiązywała norma 42-godzinna, a w 2001 r. obowiązywała norma 41-godzinna. 
Ustawa z 2001 r. wprowadziła również zasadę przeciętnie pięciodniowego tygodnia pracy.

Wszystkie te elementy, a także zachowana jako podstawowa ośmiogodzinna norma dobowa i limitowanie pracy w godzinach nadliczbowych wyznaczały sferę czasu wolnego od pracy pracownika w ujęciu zarówno dobowym, jak i tygodniowym. Niemniej brak było wyraźnie wyodrębnionych instytucji odpoczynku dobowego i tygodniowego.

\subsubsection{Prawo do odpoczynku dobowego i tygodniowego w obowiązujących przepisach polskiego prawa pracy}

Zmiany w opisanym zakresie przyniosła wspomniana już wcześniej ustawa z listopada 2003 r., która w sposób istotny zmodyfikowała dotychczasową kodeksową regulację czasu pracy. $\mathrm{W}$ ustawie tej wprost, zgodnie $\mathrm{z}$ wymogami prawa unijnego, zagwarantowano pracownikom prawo do odpoczynku dobowego i tygodniowego, którego ten, jak słusznie zauważono w doktrynie prawa pracy, nie może się zrzec $^{437}$. Normy te mają bowiem charakter gwarancyjny i strony stosunku pracy nie mogą skutecznie zawrzeć porozumienia wyłączającego lub ograniczającego ich stosowanie.

Zgodnie z art. 132 k.p., pracownikowi przysługuje w każdej dobie prawo do co najmniej 11 godzin nieprzerwanego odpoczynku.

Biorąc pod uwagę zasadę ośmiogodzinnego dnia pracy, oznacza to, że z reguły w każdej dobie, niemal powszechnie utożsamianej z pracownicząa ${ }^{438}$, pracownik

437 Podzielam w tej kwestii pogląd K. Stefańskiego, że mimo braku regulacji analogicznej jak przy urlopie wypoczynkowym, wprost wyrażającej omawianą zasadę, sposób sformułowania przepisów o odpoczynku, o którym wspomina autor, ale też charakter tej instytucji i jej przeznaczenie w pełni przemawiają za przyjęciem takiej wykładni. Por. tenże, Czas pracy, s. 42. Stanowisko takie wyrazit również SN w uzasadnieniu do wyroku z 3 lutego 2011 r., III PK 32/10, Lex nr 1375430. Zdaniem SN, zachodzi bliska analogia między prawem do odpoczynku i prawem do urlopu, którego pracownik nie może się zrzec (art. 152 § 2 k.p.). Obie instytucje służą do ochrony zdrowia pracownika i jego bezpieczeństwa, a ponadto dzienne, tygodniowe i roczne (czyli urlopy) okresy odpoczynku są analogicznie traktowane przez dyrektywę 2003/88 WE dotyczącą niektórych aspektów organizacji czasu pracy, wcześniej poddaną już analizie. Dalej idącą wykładnię zaproponował K. Kulig, który uznał, że na pracowniku spoczywa wręcz obowiązek celowego wykorzystania tego odpoczynku. Por. tenże, Prawo pracownika..., s. 16.

438 To znaczy, zgodnie z art. 128 k.p., liczonej jako 24 kolejne godziny, poczynając od tej godziny, w której pracownik rozpoczyna pracę zgodnie z obowiązującym go rozkładem czasu pracy. Por. tak m.in.: M. Gersdorf, K. Rączka, M. Raczkowski, Kodeks pracy. Komentarz, Warszawa 2014, s. 834; M. Nałęcz, [w:] Kodeks pracy..., 2011, s. 441; K. Stefański, [w:] Kodeks pracy. Komentarz, red. K.W. Baran, Warszawa 2016, s. 874. Odmienną interpretację zaproponował jednak K. Kulig, który uznaje, że pojęcie „odpoczynku dobowego” należy rozpatrywać w oderwaniu od doby pracowniczej zdefiniowanej w powołanym wyżej przepisie. Zdaniem 
będzie miał 16 godzin wolnych od pracy, w tym 11-godzinny okres odpoczynku, w którym z założenia została niemal całkowicie wyłączona swoboda pracodawcy dysponowania osobą pracownika w celu ochrony jego zdrowia oraz przeciwdziałania nadmiernej eksploatacji organizmu w związku z wykonywaną pracą. Odpoczynek dobowy jest zatem ujęty jako minimalny okres przeznaczony na regenerację, który, niezależnie od systemu czasu pracy, ewentualnych dyżurów i dopuszczalności wykonywania pracy w godzinach nadliczbowych, a nawet podróży służbowej ${ }^{439}$, zasadniczo musi być zagwarantowany każdej osobie świadczącej pracę w ramach stosunku pracy.

Obowiązek powyższy nie ma jednak bezwzględnego charakteru. W sytuacjach szczególnych oraz w odniesieniu do specyficznej grupy zatrudnionych ustawodawca polski, korzystając z możliwości, jakie stwarza w tym zakresie unijna dyrektywa, wprowadził możliwość odstąpienia od opisanego wymogu. Dotyczy to pracowników zarządzających zakładem pracy w imieniu pracodawcy oraz konieczności podjęcia akcji ratowniczej w celu ochrony życia lub zdrowia ludzkiego, ochrony mienia lub środowiska albo usunięcia awarii.

W takich jednak przypadkach należy pracownikom zapewnić, w okresie rozliczeniowym, równoważny okres odpoczynku.

Pojęcie „równoważnego odpoczynku” jest dość ogólne, stąd może być różnie interpretowane. Przykładem są odmienne stanowiska zaprezentowane w tej kwestii przez Państwową Inspekcję Pracy oraz Departament Prawa Pracy Ministerstwa Pracy i Polityki Społecznej. W myśl opinii Głównego Inspektoratu Pracy, zrównoważenie skróconego w danej dobie okresu odpoczynku polega na obowiązku jego wydłużenia w innej dobie pracowniczej o tyle godzin, o ile został on zmniejszony, a nie na udzielaniu pracownikowi czasu wolnego od pracy ${ }^{440}$.

Za inną interpretacją omawianej regulacji opowiedziało się Ministerstwo Pracy, zdaniem którego udzielenie równoważnego okresu odpoczynku powinno w każdym przypadku polegać na dopełnieniu skróconego okresu odpoczynku do wymaganych 11 godzin i obniżeniu czasu pracy pracownika. Zrównoważenie okresu

autora, sensem regulacji dotyczącej okresów odpoczynku jest zagwarantowanie pracownikowi 11 godzin wolnych od pracy między zakończeniem pracy a jej rozpoczęciem w tym samym lub kolejnym „harmonogramowym” dniu pracy. Por. K. Kulig, Prawo pracownika..., s. 14. Dla optymalnego zagwarantowania pracownikowi prawa do odpoczynku jest to założenie ze wszech miar słuszne, wydaje się jednak, że jego przyjęcie wymagałoby interwencji ustawodawcy.

439 W przeciwieństwie do dyżuru pracowniczego kwestia ta nie została uregulowana wprost w przepisach Kodeksu pracy. Znalazła natomiast swój wyraz w orzecznictwie SN; por. wyrok SN z 23 czerwca 2005 r., II PK 265/04, OSNP 2006, nr 5-6, poz. 76. Sąd przyjąt, że polecenie wykonania określonych zadań, pociągające za sobą konieczność odbycia podróży służbowej, musi wraz z dobową normą czasu pracy „mieścić się w ramach wyznaczonych wspomnianymi limitami odpoczynku". Por. też uwagi zamieszczone na początku opracowania dotyczące pojęcia i charakteru prawa do odpoczynku.

440 Por. stanowisko Głównego Inspektoratu Pracy z 10 października 2007 r. w sprawie równoważenia odpoczynku, GNP/401/4560-461/07/PE. 
odpoczynku spowoduje zatem zwiększenie okresu odpoczynku przewidzianego $\mathrm{w}$ rozkładzie czasu pracy pracownika w innej dobie pracowniczej ${ }^{441}$.

Również w uzasadnieniu jednego z orzeczeń sądu rejonowego, dotyczącego prawa pracownika do odpoczynku, wyrażono pogląd, że udzielenie pracownikowi równoważnego odpoczynku w "rozkładowym czasie pracy” gwarantowałoby dopiero pełną skuteczność praw przyznanych pracownikom w omawianym zakresie przez normy prawa unijnego oraz polskiego, a także pozwalało zrealizować wytyczne wynikające $z$ orzecznictwa Trybunał Sprawiedliwości UE. Ponadto takie rozwiązanie, jak ocenił sąd, wiąże się z realną dolegliwością dla pracodawcy, zniechęcając go tym samym do naruszania omawianego prawa w przyszłości, a z drugiej strony zapewnia pracownikowi stosowne zwiększenie jego możliwości odpoczynku w zamian za okresy, kiedy to prawo nie było realizowane ${ }^{442}$.

Ostatnia z koncepcji jest niewątpliwie bardziej korzystna dla pracownika i lepiej wpisująca się w zasadę prawa pracownika do odpoczynku, ale wątpliwa, biorąc pod uwagę treść przepisów k.p. w tej materii. Wydaje się jednak, że chodzi tu o obowiązek zapewnienia pracownikowi dodatkowo tylu godzin $\mathrm{z}$ owego 11-godzinnego okresu, o ile ten odpoczynek został uszczuplony ${ }^{443}$. Jednocześnie, według dominującej w doktrynie prawa pracy wykładni, jego realizacja nie polega na skróceniu czasu pracy w innym dniu okresu rozliczeniowego o wskazane godziny, jak postulowało Ministerstwo, ale na gwarancji wydłużenie czasu odpoczyn$\mathrm{ku}, \mathrm{tj}$. w istocie zobowiązaniu się pracodawcy, w zależności od stopnia zakłócenia odpoczynku dobowego, do np. nieprzedłużania czasu pracy ponad obowiązującą pracownika normę w określonym dniu lub dniach ${ }^{444}$.

Biorąc pod uwagę sposób sformułowania przepisów, niewątpliwie powyższa interpretacja jest uprawniona. Niemniej z punktu widzenia znaczenia i funkcji prawa do odpoczynku jako podstawowej zasady prawa pracy konstrukcja ta nie wydaje się w pełni przekonująca. Przede wszystkim pojawia się wątpliwość, czy $\mathrm{w}$ dostatecznym stopniu realizuje ona cel prawa do odpoczynku, jakim jest m.in. ochrona zdrowia i życia ludzkiego, a pośrednio też bezpieczeństwa w miejscu pracy. $\mathrm{W}$ obecnym stanie prawnym, mając na względzie powyższe wyjątki oraz przeciętny charakter maksymalnej 48-godzinnej normy tygodniowej (łącznie z godzinami nadliczbowymi) formalnie nic nie stoi na przeszkodzie, by pracownik w pewnych okolicznościach (często innych niż zagrożenie dla życia człowieka) świadczył pracę

441 Por. pismo Departamentu Prawa Pracy Ministerstwa Pracy i Polityki Społecznej w sprawie równoważenia odpoczynku, DPR-III-079-575/TW/07.

442 Uzasadnienie sądu rejonowego powołane w uchwale siedmiu sędziów SN z 13 marca 2008 r., I PZP 11/07, www.sn.pl.

443 Por. tak m.in.: M. Gersdorf, K. Rączka, M. Raczkowski, Kodeks pracy..., s. 835; M. Nałęcz, [w:] Kodeks pracy..., 2011, s. 442; K. Stefański, [w:] Kodeks pracy. Komentarz, s. 874 i n.

444 Tak por. m.in. A.M. Świątkowski, Kodeks pracy..., s. 581; Odmiennie w tej kwestii E. Szemplińska, [w:] Kodeks pracy. Komentarz, red. L. Florek, Warszawa 2005, s. 797. Autorka uznała, że równoważenie okresu odpoczynku powinno polegać na obniżeniu czasu pracy w innym dniu o liczbę brakujących godzin. 
nieprzerwanie przez okres wykraczający znacznie poza jedną dobę pracowniczą. Na przykład, osoba, która wykonywała pracę w normalnym czasie pracy, a następnie w godzinach nadliczbowych, może zostać m.in. w razie jakiejkolwiek awarii urządzeń wezwana ponownie do pracy lub zobowiązana do pozostania w miejscu pracy aż do czasu jej usunięcia, a następnie ma ona obowiązek przystąpić do pracy z początkiem kolejnej doby pracowniczej, nawet jeśli wykonywała pracę do godzin porannych. Przepisy nie przewidują bowiem w tego typu sytuacjach prawa pracownika do czasu wolnego w okresie bezpośrednio następującym po takiej pracy (choćby w ramach rekompensaty godzin nadliczbowych ${ }^{445}$ ). Sytuacji nie poprawia na pewno w tym zakresie dopuszczona w ostatnim czasie możliwość wydłużania okresów rozliczeniowych, nawet do 12 miesięcy, niezależnie od systemu czasu pracy (art. $129 \$ 2$ k.p.).

Warto rozważyć, czy w przypadkach stanowiących odstępstwo od reguły odpoczynku dobowego, gdy po wielogodzinnej pracy pomiędzy momentem zakończenia tej pracy w jednej dobie a jej planowym rozpoczęciem w kolejnej dobie pracowniczej nie upływa określona przez prawo liczba godzin, nie należałoby, jeśli nie stoją temu na przeszkodzie obiektywne okoliczności, zobowiązać pracodawcę do rekompensaty przerwanego odpoczynku bezpośrednio po zakończeniu takiej pracy, choćby wymagało to skrócenia czasu pracy pracownika w kolejnym dniu lub modyfikacji jego rozkładu. W celu zminimalizowania wystąpienia negatywnych skutków długotrwałej pracy dla organizmu pracownika, być może należałoby w opisanych wypadkach wprowadzić chociaż prawo pracownika do wystąpienia z wiążącym, co do zasady, wnioskiem o udzielenie w zamian za pracę w godzinach nadliczbowych czasu wolnego bezpośrednio po zakończeniu jej wykonywania. Za tego rodzaju regulacjami opowiedział się wyraźnie Trybunał Sprawiedliwości UE, dokonując interpretacji norm wspólnotowych w kwestii równoważnych okresów odpoczynku ${ }^{446}$, zwracając uwagę na potrzebę przeciwdziałania kumulowaniu okresów pracy bez koniecznego odpoczynku.

W takim kierunku szła wspomniana już wcześniej wykładnia przepisu o równoważnym okresie odpoczynku zaproponowana przez Ministerstwo Pracy i Polityki Społecznej. Departament Prawa Pracy wyraził pogląd, zgodnie z którym równoważny okres odpoczynku powinien być udzielany bezpośrednio po ostatnim okresie wykonywania pracy w danej dobie, tj. w tej dobie, w której naruszono odpoczynek dobowy, w wymiarze, który dopełni okres odpoczynku po zakończeniu pracy

445 Dotyczy to w szczególności osób zarządzających zakładem pracy w imieniu pracodawcy, którzy nie nabywają prawa do wynagrodzenia za godziny nadliczbowe (a tym samym i do czasu wolnego za tę pracę). Również inni pracownicy, zasadniczo uprawnieni do takiej rekompensaty, mogą wystąpić o udzielenie czasu wolnego w zamian za pracę w godzinach nadliczbowych, ale wniosek ten nie jest dla pracodawcy wiążący. Por. tak m.in.: K. Rączka, [w:] Kodeks pracy..., s. 578; A.M. Świątkowski, Kodeks pracy. Komentarz, Warszawa 2006, s. 626; M.T. Romer, Prawo pracy. Komentarz, Warszawa 2010, s. 880; S. Driczinski, [w:] Kodeks pracy. Komentarz, red. K.W. Baran, Warszawa 2012, s. 834.

446 Wyrok TSUE w sprawie Jager, pkt 94. 
do 11 godzin. Oznacza to, że pracownik będzie mógł podjąć pracę w następnej dobie dopiero po upływie kolejnych 11 godzin od zakończenia pracy w poprzedniej dobie ${ }^{47}$. Jedynie wyjątkowo, jak wynika $\mathrm{z}$ opinii Ministerstwa, gdy nie ma możliwości udzielenia równoważnego okresu odpoczynku według powyższej reguły, dopuszczalne jest udzielenie równoważnego okresu odpoczynku w innej dobie. Będzie to jednak wówczas dodatkowy okres niezależny od okresu odpoczynku w danej dobie, którego wymiar powinien odpowiadać liczbie godzin, o jaką naruszono dobowy okres odpoczynku. O tę liczbę godzin zostanie wówczas obniżony wymiar czasu pracy w danej dobie ${ }^{448}$.

Powyższe stanowisko, choć $\mathrm{z}$ pewnością $\mathrm{w}$ istotny sposób łagodziłoby wyżej poruszony problem i związane z nim zastrzeżenia, nie znajduje wyraźnego oparcia w kodeksowych przepisach dotyczących instytucji odpoczynku dobowego i tygodniowego. Dla takiego, jak wyżej proponowane, ukształtowania zasad równoważenia przerwanego odpoczynku konieczna wydaje się zatem interwencja ustawodawcy. Ten, jak wynika z art. 136 i 137 k.p., wprowadził bowiem obowiązek udzielenia odpoczynku bezpośrednio po okresie wykonywania pracy tylko w odniesieniu do osób objętych szczególnymi systemami równoważnych norm czasu pracy, w których dopuszcza się przedłużenie dobowego wymiaru czasu pracy do 16 godzin (prace polegające na dozorze urządzeń lub związane z częściowym pozostawaniem w pogotowiu do pracy) lub 24 godzin (pilnowanie mienia i ochrona osób, zakładowe straże pożarne i służby ratownicze). Przepisy te stanowią zarazem swoisty, kolejny wyjątek od ogólnych standardów w zakresie odpoczynku dobowego. Przedłużenie do 16 czy 24 godzin dobowego czasu pracy powoduje automatycznie brak możliwości zrealizowania prawa do 11-godzinnego nieprzerwanego odpoczynku w każdej dobie pracowniczej. Stąd osobom tym przyznano prawo do odpoczynku bezpośrednio po każdym okresie wykonywania pracy w przedłużonym dobowym wymiarze czasu pracy, odpowiadającego co najmniej liczbie przepracowanych godzin.

Obowiązujące normy, biorąc pod uwagę wielość możliwych sytuacji, jakie w praktyce określa się mianem awarii, szczególnie w zakładach produkcyjnych, oraz ograniczenie prawa do odpoczynku osób zarządzających zakładem pracy w imieniu pracodawcy, a także brak jasno sprecyzowanych reguł udzielania „równoważnych” okresów odpoczynku, nie stwarzają, w mojej ocenie, pełnych, faktycznych i powszechnych gwarancji realizacji omawianego prawa, a zarazem realizacji podstawowej dla prawa pracy zasady. Stawia to również pod znakiem zapytania prawidłowość wykonania dyrektywy unijnej poświęconej niektórym aspektom organizacji czasu pracy, gdyż, jak podkreślano w orzecznictwie Trybunału Sprawiedliwości UE, okresy równoważnego odpoczynku powinny przypadać bezpośrednio po okresach pracy, których wyrównaniu one służą, tak by zapobiec

447 Pismo Departamentu Prawa Pracy Ministerstwa Pracy i Polityki Społecznej w sprawie równoważenia odpoczynku, DPR-III-079-575/TW/07.

448 Tamże. 
przemęczeniu i przeciążeniu pracownika w następstwie kumulacji następujących po sobie okresów pracy ${ }^{449}$, czego polskie prawo nie gwarantuje.

Poza odpoczynkiem dobowym, w Kodeksie pracy uregulowano też bezpośrednio prawo do odpoczynku tygodniowego. Zostało ono sformułowane w art. 133 k.p., który stanowi, że pracownikowi przysługuje w każdym tygodniu prawo do co najmniej 35 godzin nieprzerwanego odpoczynku, obejmującego co najmniej 11 godzin nieprzerwanego odpoczynku dobowego. Odpoczynek taki powinien przypadać w niedzielę, rozumianą jako 24 kolejne godziny, poczynając od godz. 6 w tym dniu, chyba że u danego pracodawcy została ustalona inna godzina. W tych przypadkach, w których prawo dopuszcza możliwość wykonywania pracy w niedzielę, wyjątkowo odpoczynek ten może zostać zagwarantowany w innym dniu.

Z powyższego wynika zatem, że polski ustawodawca, podtrzymując dotychczasowe tradycje „odpoczynku niedzielnego” (wcześniej opisane), wpisał niedzielę jako dzień ustawowo wolny od pracy w zakres prawa do odpoczynku tygodniowego.

Prawne pojęcie niedzieli nie pokrywa się jednak z jej powszechnym rozumieniem, tj. niedzielą w znaczeniu kalendarzowym, chyba że odmiennie zostanie to przyjęte u danego pracodawcy ${ }^{450}$. Zasadniczo niedziela obejmuje bowiem 24 kolejne godziny między godz. 6 rano w tym dniu a godz. 6 dnia następnego. Pracodawca może jednak określić inny moment jej rozpoczęcia, dostosowany np. do godzin pracy obowiązujących w danym zakładzie. Ustawodawca pozostawił pracodawcy w tym aspekcie szeroki margines swobody, niemniej w pełni podzielam pogląd K. Rączki, zgodnie z którym niedziela musi zawsze obejmować 24 kolejne godziny (a więc zaczynać się i kończyć o tej samej godzinie), a ponadto, że ustalona przez pracodawcę pora jej rozpoczęcia i zakończenia nie powinna nadmiernie odbiegać od dnia kalendarzowego, na który owa niedziela przypada. Tym samym okres trwania niedzieli musi być tak wyznaczony, aby obejmował całą porę dzienną tego dnia w jego ujęciu kalendarzowym ${ }^{451}$.

Poza prawnym pojęciem niedzieli znacznie więcej kontrowersji budzi ujęcie tygodnia, do którego odnosi się omawiany odpoczynek. Zastosowanie definicji tygodnia określonej w art. $128 \$ 3$ k.p. nastręcza bowiem wiele problemów interpretacyjnych, na co zwracano uwage w doktrynie prawa pracy ${ }^{452}$. Na przykład warto odnotować, że w pewnych przypadkach może dojść do wyraźnej kolizji obowiązku udzielenia odpoczynku w zakresie tak rozumianego tygodnia z prawem

449 Por. orzeczenie TSUE w sprawie Jager, pkt 94.

450 W literaturze wskazano, że pracodawca może postanowić o zrównaniu niedzieli w ujęciu prawnym z niedzielą w znaczeniu astronomicznym. Por. K. Rączka, Dni wolne od pracy, PizS 2001, nr 8, s. 24. Zob. też K.W. Baran, Prawo pracy, Warszawa 2005, s. 428.

451 Por. K. Rączka, Dni wolne..., s. 25.

452 Por. m.in. A. Sobczyk, Zasady..., s. 233. Autor ten zwraca przede wszystkim uwagę, że zastosowanie legalnej definicji tygodnia powoduje występowanie tygodni niepełnych w końcówkach okresów rozliczeniowych, co może skutkować mniejszą od ilości tygodni kalendarzowych ilością odpoczynków tygodniowych. 
do odpoczynku niedzielnego. Jeśli tydzień, zgodnie z powołanym przepisem, oznacza siedem kolejnych dni kalendarzowych, poczynając od pierwszego dnia okresu rozliczeniowego, to jeżeli ów okres rozpoczął się w poniedziałek (godz. 00 ), tydzień kończy się w niedzielę o godz. 24. Zgodnie zaś z omawianym wcześniej prawnym pojęciem niedzieli, ta kończy się o godz. $6.00 \mathrm{w}$ poniedziałek. Tym samym zamknięcie odpoczynku w skali tygodnia, jak przewiduje polskie prawo, nie pozwala rozciągnąć go na cały okres kodeksowo opisanej niedzieli, co narusza $\mathrm{z}$ kolei wymóg wynikający z art. $133 \$ 3 \mathrm{k}$.p.

Stąd w literaturze wyrażono pogląd, że należy uznać, biorąc pod uwagę literalne brzmienie przepisów, że zawarta w Kodeksie pracy definicja tygodnia dotyczy wyłącznie kwestii rozliczania czasu pracy, a nie odpoczynku, do którego powinno się stosować powszechne rozumienie tego terminu ${ }^{453}$.

W świetle przepisów k.p. odpoczynek tygodniowy musi być zapewniony zawsze, choć w niektórych sytuacjach pozwala się na jego skrócenie - maksymalnie do 24 godzin. Chodzi o wymienione wcześniej przesłanki zakłócenia odpoczyn$\mathrm{ku}$ dobowego oraz kwestię zmiany pory wykonywania pracy przez pracownika w związku z jego przejściem na inną zmianę.

Kodeksowa regulacja odpoczynku dobowego i tygodniowego, choć wzorowana w znacznym stopniu na prawie UE, budzi wiele wątpliwości interpretacyjnych, na które wskazywano wielokrotnie w literaturze przedmiotu oraz orzecznictwie sądowym i które częściowo zostały wyżej zasygnalizowane. Wydaje się jednak, że największym mankamentem opisywanej instytucji jest problem niedostatecznie określonych sankcji związanych z naruszeniem omawianych praw, który ujawnił się z całą mocą w kontekście czasu pracy lekarzy, w tym zwłaszcza dyżurów medycznych. Poza odpowiedzialnością związaną z wykroczeniem przeciwko prawom pracownika (art. 281 pkt 5 k.p.), ustawodawca nie wskazał żadnych innych, negatywnych dla pracodawcy skutków wynikających z nierespektowania uprawnień pracowniczych $\mathrm{w}$ analizowanym obszarze. W szczególności $\mathrm{w}$ przepisach prawa pracy brak chociażby wyraźnego zobowiązania pracodawcy do opłacenia czasu wolnego przyznanego pracownikowi $\mathrm{w}$ formie rekompensaty za bezprawne pozbawienie go możliwości odpoczynku. Zgodnie zaś z art. 80 k.p., wynagrodzenie przysługuje za pracę wykonaną, a za czas niewykonywania pracy tylko wtedy, gdy przepisy prawa pracy tak stanowią. W zależności od przyjętej wykładni, w praktyce może to prowadzić do kuriozalnych sytuacji, w których konsekwencje nieprzestrzegania zasady odpoczynku dobowego i tygodniowego będzie ponosić w dużej mierze pracownik. Jeśli wystąpi on bowiem do sądu o udzielenie zaległych okresów odpoczynku, to będą to okresy niepłatne. Pracownik, niejako „odbierając” ów odpoczynek, może w skrajnych przypadkach, przy wysokim stopniu naruszeń, jakich dopuścił się wcześniej pracodawca, zostać pozbawiony prawa do wynagrodzenia przez znaczny okres. Niewątpliwie taka perspektywa nie zachęca do dochodzenia swoich praw w analizowanym zakresie, a w konsekwencji zagraża skutecznej re-

453 Tamże. 
alizacji dobowego i tygodniowego odpoczynku. Sytuacji nie poprawia również odwołanie się do ogólnych przepisów prawa pracy, w tym prawa do rozwiązania niezwłocznego umowy o pracę przez pracownika czy odmowy wykonania polecenia pracodawcy sprzecznego z prawem. W pierwszym przypadku, biorąc pod uwage uwarunkowania gospodarcze i realia rynku pracy (mimo że te w ostatnim czasie zmieniają się), pracownicy rzadko będą decydowali się na skorzystanie z tej możliwości (nawet jeśli są w stanie wykazać ciężkie naruszenie obowiązku zagwarantowania okresów odpoczynku przez pracodawcę). Natomiast w drugim przypadku powstaje chociażby zasadnicza trudność z właściwą interpretacją kodeksowych przepisów regulujących odpoczynek dobowy i tygodniowy, biorąc pod uwagę dość ogólny sposób ich sformułowania oraz często zróżnicowane komentarze specjalistów dotyczące tych norm, a także pewną zawiłość regulacji czasu pracy.

$\mathrm{Z}$ powyższych względów zarówno w literaturze $\mathrm{z}$ zakresu prawa pracy, jak i w orzecznictwie sądowym podjęto liczne próby rozwiązania sygnalizowanego problemu i wskazania dalej idących uprawnień pracownika w omawianym zakresie.

Według pierwszej koncepcji należy przyjąć, że po upływie okresu rozliczeniowego, w którym ów nieudzielony odpoczynek mógł jeszcze zostać zrównoważony czasem wolnym, prawo pracownika do odpoczynku zamienia się w ekwiwalent pieniężny, którego wypłaty może on dochodzić od pracodawcy ${ }^{454}$.

Znalazła ona swój wyraz m.in. w wyroku Sądu Najwyższego z 23 czerwca 2005 r. ${ }^{455}$, w którym przyjęto, że naruszenie prawa do odpoczynku w związku z podróżą służbową pracownika aktualizuje po stronie pracodawcy obowiązek udzielenia pracownikowi równoważnego okresu odpoczynku, a jeśli nie jest to możliwe - wypłaty stosownego ekwiwalentu pieniężnego ${ }^{456}$.

Powyższe stanowisko, chociaż poprawia sytuację pracownika, nie jest pozbawione wad. Przede wszystkim trzeba zwrócić uwagę, że chodzi tu o prawo o szczególnym charakterze, które dla zachowania jego istoty, realizacji podstawowej funkcji powinno być wykorzystywane w naturze, tj. w postaci czasu wolnego od pracy. Celem odpoczynku jest wszak co najmniej przeciwdziałanie nadmiernemu zmęczeniu pracownika mogącemu negatywnie wpływać na jego organizm, a niekiedy nawet zagrażać jego zdrowiu i życiu, ale też bezpieczeństwu innych osób. W przeciwieństwie do prawa do urlopu wypoczynkowego, nie ma w Kodeksie pracy (ani też w dyrektywie unijnej) normy, która pozwalałaby, przynajmniej w określonych, wyjątkowych przypadkach, zastąpić to uprawnienie prawem do świadczenia pieniężnego. Przyjęcie tego rodzaju rozwiązania rodzi bowiem niebezpieczeństwo odchodzenia w praktyce od prawa w naturze na rzecz wypłaty pracownikom stosownych świadczeń, zarówno z inicjatywy pracodawcy, jak i samych pracowników, co w konsekwencji może prowadzić do braku jego faktycznej realizacji. Eksponował to wielokrotnie w swych orzeczeniach Trybunał Sprawiedliwości UE (patrz

454 Por. K. Jaśkowski, E. Maniewska, Kodeks pracy. Komentarz, Zakamycze 2006, s. 456 i n. 455 II PK 265/04, OSNP 2006, nr 5-6, poz. 76.

456 Tamże. 
wcześniejsze rozważania), ale dostrzegł również Sąd Najwyższy ${ }^{457}$, który w ostatnich latach dość konsekwentnie uznaje, że w razie nieudzielenia przez pracodawcę odpoczynku wynikającego z art. 132 i 133 k.p. pracownik nie ma roszczenia o dodatkowe wynagrodzenie z tego tytułu ${ }^{458}$.

W orzecznictwie Sądu Najwyższego potwierdzono brak wątpliwości co do tego, że pracownikom zasadniczo służy roszczenie o udzielenie czasu wolnego $\mathrm{w}$ celu urzeczywistnienia wynikających z przepisów Kodeksu pracy okresów odpoczynku ${ }^{459}$.

Niemniej powzięto wątpliwość, czy realizacja tego roszczenia jest ograniczona czasowo czy też nie (poza ogólnymi przepisami Kodeksu pracy dotyczącymi przedawnienia roszczeń). $\mathrm{Z}$ orzecznictwa wynika, że bezsprzecznie pracownik może dochodzić równoważnego okresu odpoczynku, czy w razie nielegalnych zachowań pracodawcy, kompensacyjnego czasu wolnego ${ }^{460}$, do końca okresu rozliczeniowego. Sytuacja nie jest tak jednoznaczna, w ocenie sądu, gdy żądanie pracownika wykracza poza ten okres. Zwrócono tu bowiem słusznie uwagę, że w zasadzie ani świadczenie pieniężne, o jakim była wcześniej mowa, ani też skomasowana ilość czasu wolnego udzielonego $\mathrm{w}$ zamian za pozbawienie pracownika odpoczynku w okresach wcześniejszych, zwłaszcza znacznie oddalonych czasowo od chwili dochodzenia przez niego swych praw, nie gwarantują optymalnej realizacji celu omawianej instytucji. Instrumenty te nie zapewniają pracownikowi zarówno należytej ochrony przed przemęczeniem i przeciążeniem pracą, jak i faktycznego wykonania prawa pracownika do ochrony zdrowia i bezpieczeństwa pracy ${ }^{461}$. W związku z tym w powoływanej uchwale siedmiu sędziów SN z marca 2008 r. ostatecznie podważono interpretację dopuszczającą „,kumulowanie wszystkich niewykorzystanych przez pracownika okresów odpoczynku i przyznanie po dłuższym (długim) okresie pracy czasu wolnego, stanowiącego sumę niewykorzystanych okresów odpoczynku" jako sprzeczną z istotą i funkcją tego prawa, jak również celem dyrektywy unijnej poświęconej analizowanej problematyce ${ }^{462}$.

457 Por. w szczególności wątpliwości jednego ze składów orzekających SN podane w uzasadnieniu uchwały siedmiu sędziów SN z 13 marca 2008 r. (I PZP 11/07), z których wynika, że „Sąd Najwyższy dostrzega niebezpieczeństwo dążenia pracowników do uzyskiwania dodatkowego, wysokiego wynagrodzenia kosztem zdrowia i bezpieczeństwa pracy [...], a także niebezpieczeństwo uwalniania się pracodawców od obowiązku takiego organizowania pracy, który zapewniałby przestrzeganie wymaganych okresów odpoczynku pracowników przez zapłatę odszkodowań".

458 Por. m.in. wyrok SN z 11 sierpnia 2009 r., III PK 22/09, niepublikowany oraz wyrok SN z 11 sierpnia 2009 r., III PK 21/09, niepublikowany.

459 Por. uchwała siedmiu sędziów SN z 13 marca 2008 r., I PZP 11/07. Por. też wyrok SN z 6 czerwca 2006 r., I PK 263/05, www.sn.pl.

$460 \mathrm{Na}$ temat pojęcia „kompensacyjnego czasu wolnego” i konieczności odróżnienia go od pojęcia „równoważnego okresu odpoczynku” czy „równoważnego czasu wolnego” - por. Z. Kubot, Kompensacyjny czas wolny - analiza pojęcia, PiZS 2008, nr 9, s. 26 i n. Autor przekonuje, że termin ten powinien być stosowany na oznaczenie świadczenia przysługującego pracownikowi w sytuacji nieudzielonych okresów odpoczynku.

461 Por. uzasadnienie wyroku SN z 21 czerwca 2011 r., III PK 96/10, www.sn.pl.

462 Tamże. Tak też por.: wyrok SN z 11 sierpnia 2009 r., III PK 22/09; wyrok SN z 11 sierpnia 2009 r., III PK 21/09 oraz wyrok SN z 8 października 2009 r., II PK 110/09, LEX nr 558295. 
Przedmiotem kontrowersji jest również kwestia ewentualnej odpłatności czasu wolnego stanowiącego rekompensatę niewykorzystanych okresów odpoczynku.

Zdaniem części autorów, kompensacyjny czas wolny, o którym wyżej mowa, jest płatny ${ }^{463}$. Staje się on bowiem rekompensatą skumulowanych okresów odpoczynku, jakie z mocy prawa przysługują pracownikowi ${ }^{464}$.

Inną ocenę wyraził w tej kwestii Sąd Najwyższy, który zauważył, że czas nieprzerwanego odpoczynku, przewidziany w Kodeksie pracy, nie jest czasem pracy. Tym samym również kompensacyjny czas wolny nie może zostać zrównany z okresem pracy. Jednocześnie brak jest wyraźnej podstawy prawnej uzasadniającej odstąpienie od sformułowanej w art. 80 k.p. zasady wypłaty wynagrodzenia za pracę wykonaną, a zarazem podstawy statuującej obowiązek pracodawcy opłacenia nieprzerwanego odpoczynku dobowego i tygodniowego ${ }^{465}$.

Rozważając powyższe wątpliwości, Sąd Najwyższy doszedł ostatecznie do przekonania (jak się wydaje, bardziej w celu wymuszenia na pracodawcach realizacji ich prawnego obowiązku dbałości o życie i zdrowie pracowników oraz respektowania ich prawa do odpoczynku), że pracownik ma prawo do odszkodowania na zasadach określonych $\mathrm{w}$ prawie cywilnym ${ }^{466}$. Jak przyjęto bowiem w orzecznictwie, „nieudzielenie przez pracodawcę przewidzianych prawem okresów odpoczynku stanowi naruszenie jego obowiązków ze stosunku pracy. W razie spełnienia pozostałych przesłanek, w szczególności zaistnienia po stronie pracownika szkody, pracownik mógłby wystąpić z roszczeniem odszkodowawczym na podstawie art. 471 k.c. w związku z art. 300 k.p." ${ }^{467}$. Nierespektowanie prawa do odpoczynku samo w sobie, jak uznał Sąd Najwyższy, nie stanowi jednak szkody. Niemniej może ona polegać na utracie korzyści majątkowych w wyniku nieudzielenia czasu wolnego czy na rozstroju zdrowia, jakiego wskutek niedostatecznych przerw w pracy doznał pracownik.

Ponadto zachowanie pracodawcy, naruszające prawem określony wymóg gwarantowania okresów odpoczynku, stanowi równocześnie, zdaniem Sądu Najwyższego, czyn niedozwolony w rozumieniu art. 417 k.c., w związku z tym zachodziłby zbieg odpowiedzialności kontraktowej i deliktowej (art. 443 k.c.). „Przepisy Kodeksu pracy wprowadzające minimalne normy odpoczynku mają na celu ochronę zdrowia pracowników. Skoro zdrowie stanowi dobro chronione powszechnie, wyrządzenie szkody na zdrowiu stanowi czyn niedozwolony" ${ }^{468}$.

Uznając okresy odpoczynku za istotny element prawa pracownika do ochrony zdrowia, co czynił też wyraźnie Trybunał Sprawiedliwości UE ${ }^{469}$, Sąd Najwyższy

463 Por. m.in. H. Lewandowski, Dyżur medyczny - uwagi na kanwie wyroku SN z 6 czerwca 2006 r., M.P.P. 2008, nr 1, s. 49.

464 Tamże.

465 Por. uzasadnienie uchwały siedmiu sędziów SN z 13 marca 2008 r., I PZP 11/07, tamże.

466 Tamże. Podobnie w kolejnych wyrokach SN, np.: z 8 października 2009 r., II PK 110/09, z 3 września 2009 r., III PK 33/09, LEX nr 560865.

467 Tamże.

468 Tamże.

469 Por. m.in. orzeczenie TSUE z 12 listopada 1996 r. w sprawie Zjednoczone Królestwo przeciwko Radzie, C-84/94, Rec. s. I-5755, pkt 92 i n. Trybunał uznał, że pojęcia „bezpieczeństwo” i „zdro- 
przyjął również możliwość dochodzenia przez zatrudnionego roszczeń z tytułu naruszenia dóbr osobistych, do których zdrowie należy. W szczególności chodzi o możliwość żądania przez uprawnionego zadośćuczynienia pieniężnego, którego celem jest wyrównanie uszczerbku w dobrach prawnie chronionych i przywrócenie ich poprzedniego stanu oraz świadczenia na określony cel społeczny ${ }^{40}$.

Zwrócono przy tym uwagę, że ochrona dóbr osobistych, przewidziana w art. 24 k.c., przysługuje nie tylko $\mathrm{w}$ razie dokonanego już naruszenia, ale także $\mathrm{w}$ razie samego zagrożenia tym naruszeniem.

Z czasem jednak Sąd Najwyższy słusznie zdecydował, że samo prawo do odpoczynku, mające konstytucyjne umocowanie i stanowiące podstawową zasadę prawa pracy, należy zaliczyć do dóbr osobistych pracownika podlegających prawnej ochronie, niezależnie od zdrowia oraz bezpiecznych i higienicznych warunków pracy ${ }^{471}$.

Brak w przepisach Kodeksu pracy sankcji związanych z naruszeniem przez pracodawcę prawa do odpoczynku dobowego i tygodniowego zdecydowanie osłabia jego rolę oraz możliwość optymalizacji celu, dla którego zostało ono ustanowione. Warto zauważyć bowiem, że zaprezentowana wyżej, przyjęta w orzecznictwie Sądu Najwyższego wykładnia, zgodnie z którą pracownik może dochodzić odszkodowania czy zadośćuczynienia na podstawie przepisów prawa cywilnego, jest istotna i przydatna przede wszystkim w aspekcie przeciwdziałania tego rodzaju zachowaniom w przyszłości oraz swoistego „wymierzenia pracodawcy kary” za naruszenia, jakich dopuścił się w omawianym obszarze. $Z$ punktu widzenia funkcji odpoczynku rozwiązanie to musi zostać natomiast ocenione jako mało efektywne.

Prawnie gwarantowane dobowe i tygodniowe okresy odpoczynku są niewątpliwie bardzo istotnym elementem ochrony prawa pracownika do odpoczynku w jego szerszym, ogólnym ujęciu. W sposób bezpośredni limitują czas, w skali doby i tygodnia, w jakim pracownik może zostać zobowiązany do pozostawania w dyspozycji pracodawcy (uwzględniając godziny nadliczbowe, dyżury czy nawet podróż służbową ${ }^{472}$ ), tak aby zapewnić temu pracownikami co najmniej możliwość

wie" w znaczeniu art. 118a Traktatu o utworzeniu EWG, stanowiącego podstawę dyrektywy 93/1004, należy wykładać tak szeroko, że obejmują one całość fizycznych oraz innych czynników wpływających bezpośrednio lub pośrednio na zdrowie i bezpieczeństwo pracowników w środowisku pracy, a w szczególności określone aspekty kształtowania czasu pracy.

470 Por. wyrok SN z 21 czerwca 2011 r., III PK 96/10, ale też wcześniejsze orzeczenia: uchwała SN z 3 czerwca 2008 r., I PZP 10/07, OSNP 2008, nr 23-24, poz. 342; wyrok SN z 23 lipca 2009 r., II PK 26/09, LEX nr 533037; wyrok SN z 3 września 2009 r., III PK 33/09 oraz wyrok SN z 8 października 2009 r., II PK 110/09.

471 O odpoczynku jako elemencie dobra osobistego w postaci bezpiecznych i higienicznych warunków pracy oraz o możliwości uznania odpoczynku jako dobra osobistego niezależnego od zdrowia i prawa do bezpiecznych i higienicznych warunków pracy por. uzasadnienie do wyroku SN z 21 czerwca 2011 r., III PK 96/10.

472 Por. np. wyrok SN z 23 czerwca 2005 r., II PK 265/04. W uzasadnieniu tego wyroku SN uznat, że „[...] polecenie wykonania zadań (czynności) wymagających odbycia podróży służbowej musi wraz z dobową normą czasu pracy mieścić się w ramach wyznaczonych wspomnianymi limitami odpoczynku". 
regeneracji sił i zminimalizować ryzyko przeciążenia pracą. Z powyższej analizy wynika jednak, że przyjęta w prawie polskim konstrukcja, biorąc pod uwagę prawo do odpoczynku jako podstawową zasadę prawa pracy, nie jest pozbawiona istotnych wad, które w pewnych sytuacjach stawiają pod znakiem zapytania zdolność realizacji wspomnianego wyżej głównego celu, dla którego omawiane przepisy były ustanowione.

\subsection{Przerwy w pracy}

Kolejnym instrumentem mogącym przyczyniać się w pewnym stopniu do urzeczywistniania prawa pracownika do odpoczynku są przerwy w pracy. Nie chodzi tu o pojęcie „przerwy w wykonywaniu pracy” w ujęciu szerokim, tj. wszelkie przewidziane przez prawo okresy nieświadczenia pracy, do których można zaliczyć dni wolne od pracy, urlopy, zwolnienia od pracy czy przerwy z przyczyn uniemożliwiających stawienie się do pracy $^{473}$. Na potrzeby przyjętego podziału termin ten zostanie ograniczony do tych krótkotrwałych okresów nieświadczenia pracy, które zostały tak nazwane bezpośrednio przez ustawodawcę, są zwykle wliczane do czasu pracy i których celem jest zapewnienie czasowego „oderwania się od pracy” i możliwości regeneracji sił czy zniwelowania skutków przeciążenia pracą, zwłaszcza monotonną. Mowa tutaj zatem o „przerwach w czasie pracy” ${ }^{474}$. Ich wprowadzenie przekłada się bezpośrednio na zmniejszenie rozmiarów pracy faktycznie wykonywanej w danej dobie.

Tego rodzaju przerwy w wykonywaniu pracy były stosowane na ziemiach polskich już w okresie zaborów.

Początkowo przerwy w pracy zagwarantowano przede wszystkim osobom poniżej 15 roku życia. Mogły one wykonywać pracę maksymalnie osiem godzin na dobę, ale z przerwą po czterech godzinach pracy, lub dziewięć godzin przy pracy zmianowej, z przerwą po czterech i pół godzinach pracy. Jedynie wyjątkowo dopuszczano możliwość świadczenia pracy przez dzieci przez okres sześciu godzin bez przerwy, jeśli było to konieczne ze względu na rodzaj produkcji ${ }^{475}$.

W prawie niemieckim z kolei wprowadzono jednogodzinną przerwę obiadową dla wszystkich kobiet oraz półtoragodzinną przerwę obiadową dla kobiet prowadzących gospodarstwo ${ }^{476}$.

Po 1897 r. na obszarze Królestwa Polskiego do przerwy w pracy zostali uprawnieni wszyscy pracownicy. Zgodnie z obowiązującymi przepisami, nie rzadziej niż co sześć godzin miała zostać wprowadzona przerwa na posiłek. Ponadto prawo

473 Tak por. T. Zieliński, Zarys..., cz. II, s. 275.

474 Takie rozróżnienie zaproponowano w podręczniku L. Florek, T. Zieliński, Prawo pracy, Warszawa 2004, s. 169.

475 Por. m.in. M. Lewy, Prawo przemysłowe..., s. 159.

476 Tamże, s. 163. 
przewidywało również, że praca powyżej 10 godzin na dobę powinna zostać zasadniczo przerwana przez co najmniej jedną, minimum godzinną „pauzę”, w czasie której pracownicy mieli możliwość dodatkowo opuszczenia fabryki ${ }^{477}$. Niemniej tzw. przerwy wolne, tj. przerwy w pracy wynikające z rozkładu czasu pracy, w ciągu których pracownik mógł wyjść z zakładu pracy i dowolnie rozporządzać swym czasem, nie były wliczane do czasu pracy ${ }^{478}$.

Obowiązek udzielania przerw w pracy istniał też na terenach zaboru austriackiego. Zasadniczo miała ona wynosić co najmniej półtorej godziny, w tym przynajmniej jedna godzina winna mieścić się w tzw. „czasie południowym”. Zgodnie z ustawą przemysłową obowiązek taki nie powstawał, jeśli czas pracy nie przekraczał pięciu godzin, a godziny te przypadały w całości przed południem lub po południu. Liczne wyjątki od opisanej wyżej reguły wprowadzono jednak w przepisach wykonawczych, w których dopuszczano możliwość dzielenia przerwy na krótsze odcinki czasowe, albo też pozwalano na odstąpienie od jej udzielenia.

Również pierwsza polska ustawa regulująca kwestie czasu pracy z 1919 r., wcześniej powoływana, gwarantowała w art. 17, że „najdalej po każdych sześciu godzinach pracy ma nastąpić przerwa, nie krótsza niż jednogodzinna, podczas której ruch maszyn powinien być tam, gdzie na to zezwalają techniczne warunki pracy, wstrzymany, a pracownik wedle swej woli może opuścić miejsce pracy". Jeśli natomiast $\mathrm{z}$ powodu charakteru pracy nie ma możliwości opuszczenia miejsca pracy przez pracownika, szczególnie w ruchu ciągłym, ustawowo zobowiązano pracodawców do zagwarantowania pracownikowi możliwości spożycia posiłku „podczas ruchu zakładu pracy". Owa godzinna przerwa na odpoczynek mogła jednak zostać skrócona lub w ogóle nieudzielona w poszczególnych zakładach pracy, całych gałęziach pracy lub kategoriach zakładów na podstawie zezwolenia wydanego przez upoważnionego do tego ministra, ewentualnie inspekcję pracy.

W literaturze wskazywano jednak, że owa godzinna przerwa na odpoczynek i spożycie posiłku w praktyce nie była stosowana. W układach zbiorowych pracy oraz regulaminach pracy poprzestawano bowiem często jedynie na stwierdzeniu, że dzienny rozkład czasu pracy ustala kierownik zakładu i że rozkład ten może przewidywać przerwę na spożycie posiłku ${ }^{47}$.

Krótkie przerwy w pracy, wliczane do czasu pracy, określane w literaturze mianem „wypoczynkowych" 480 lub „na regenerację sił” ${ }^{481}$, konkretyzowane w regulaminach pracy, zostały ustanowione w przepisach uchwalonego w 1974 r. Kodeksu pracy.

Były to przerwy nie dłuższe niż 15-minutowe przeznaczone na odpoczynek, przerwy na spożywanie posiłku, ale taki charakter miały również specjalne przerwy wprowadzane dla pracowników zatrudnionych przy pracach szczególnie

477 Tamże, s. 168.

478 Por. Zbiór praw, instrukcyi i przepisów..., s. 219.

479 Por. tak W. Masewicz, S. Dzwonkowski, Czas pracy..., s. 173 i n.

480 Por. W. Szubert, Zarys..., s. 211.

481 Por. K. Kolasiński, Podstawy..., s. 125. 
uciążliwych lub szkodliwych dla zdrowia. W ostatnim przypadku stawały się one instrumentem skracania czasu pracy tej grupy zatrudnionych. Rada Ministrów została upoważniona do uregulowania zasad i zakresu stosowania takiego skróconego czasu pracy ${ }^{482}$.

Także na gruncie obowiązującego prawa można wskazać kilka przykładów przerw w pracy, które, biorąc pod uwagę ich charakter, służą odpoczynkowi, regeneracji, przeciwdziałają znużeniu i przeciążeniu pracą.

Przede wszystkim, zgodnie z art. 134 k.p., jeśli dobowy wymiar czasu pracy pracownika wynosi co najmniej sześć godzin, pracownik ma prawo do przerwy w pracy trwającej co najmniej 15 minut, wliczanej do czasu pracy. Mimo że prawo nie określa bezpośrednio jej przeznaczenia, to powszechnie funkcjonuje ona jako tzw. przerwa śniadaniowa, a więc okres przeznaczony na krótki odpoczynek, regenerację sił ${ }^{483}$ i spożycie posiłku.

Zdaniem K. Rączki, prawo do niej nie jest powiązane z obowiązującą pracownika normą czasu pracy, ale $\mathrm{z}$ faktycznym okresem świadczenia pracy w danym $\mathrm{dniu}^{484}$. Stanowisko takie w pełni odpowiada jej celowi, chodzi bowiem o możliwość choćby jednorazowego i krótkotrwałego przerwania pracy, jeśli ma być ona świadczona przez dłuższy czas, tj. minimum sześć godzin, co jest bardzo ważne z punktu widzenia ochrony zdrowia ludzkiego i bezpieczeństwa w pracy.

Należy podzielić również pogląd, zgodnie z którym przerwy te nie mogą być dzielone na krótsze odcinki czasowe oraz powinny przypadać po rozpoczęciu pracy, a przed jej zakończeniem ${ }^{485}$.

Ponadto, zdaniem A. Świątkowskiego, pracownik może powstrzymać się od wykonywania pracy w okresie 15-minutowym, w godzinach podanych pracodawcy, jeśli ten ostatni nie dopełnił ciążącego na nim obowiązku zapewnienia pracownikowi takiej przerwy ${ }^{486}$.

W przeszłości w orzecznictwie Sądu Najwyższego uznano, że pracownikowi przysługuje w takiej sytuacji roszczenie o odszkodowanie ${ }^{487}$, co, biorąc pod uwage jego prawo do odpoczynku realizowane m.in. za pomocą przerw w pracy, wydaje się rozwiązaniem mało efektywnym (por. uwagi dotyczące okresów odpoczynku).

Dodatkowa przerwa na gimnastykę usprawniającą lub wypoczynek została zagwarantowana osobom niepełnosprawnym. Przerwa taka wynosi 15 minut i, jak wynika z art. 17 ustawy o rehabilitacji zawodowej i społecznej oraz zatrudnianiu osób niepełnosprawnych ${ }^{488}$, nie narusza ona omawianego wyżej przepisu Kodeksu

482 Por. W. Szubert, Zarys..., s. 211.

483 Por. tak m.in. M. T. Romer, Prawo pracy..., s. 833.

484 Por. K. Rączka, [w:] Kodeks pracy..., s. 470. Odmiennie A.M. Świątkowski, Kodeks pracy..., S. 582 i n.

485 A.M. Świątkowski, Kodeks pracy..., s. 583.

486 Por. tamże, s. 583.

487 Por. wyrok SN z 16 stycznia 1973 r., I PR 25/73, OSNC 1974, nr 1, poz. 7.

488 Ustawa z 27 sierpnia 1997 r. o rehabilitacji zawodowej i społecznej oraz zatrudnianiu osób niepełnosprawnych, tekst jednolity: Dz. U. 2018, poz. 511, ze zm. 
pracy. Oznacza to, że w istocie jest to przerwa niezależna od tej przewidzianej przepisami kodeksowymi.

Do przerw mających pewne znaczenie z punktu widzenia podjętego tematu należy zaliczyć również przerwy, które mogą stać się elementem skracania czasu pracy osób zatrudnionych w warunkach szczególnie uciążliwych lub szkodliwych dla zdrowia (jako alternatywa dla obniżania norm czasu pracy). Z art. 145 k.p. wynika, że dotyczy to w szczególności pracowników wykonujących pracę monotonną lub pracę $\mathrm{w}$ ustalonym $\mathrm{z}$ góry tempie, $\mathrm{w}$ przypadku których wprowadzenie przerw w pracy stanowi jedyny możliwy instrument ograniczania ich czasu pracy. Przerwy te stanowią przede wszystkim realizację prawa pracownika do bezpiecznych i higienicznych warunków pracy, ale pełnią też ważną rolę w zakresie prawa do odpoczynku. Niewątpliwie praca w trudnych warunkach, szkodliwa, monotonna znacznie bardziej wyczerpuje bowiem organizm człowieka i wymaga w związku z tym znacznie większej ilości czasu na regenerację, na przynajmniej częściowe zniwelowanie negatywnych skutków jej oddziaływania na pracownika.

Wspomnieć należy również o pięciominutowej przerwie po każdej godzinie pracy przy monitorach ekranowych. Jej celem jest ochrona zdrowia pracownika, ale też odpoczynek, w tym przypadku konkretnie od monitora.

Wszystkie wymienione wyżej przerwy są wliczane do czasu pracy. Pod takim też warunkiem, biorąc pod uwagę wspomnianą wcześniej zasadę nieprzerwanego dobowego wymiaru czasu pracy, wprowadzenie dodatkowych przerw lub wydłużanie przerw już gwarantowanych ustawowo może być dokonywane na poziomie aktów wewnątrzzakładowych, takich jak układy zbiorowe pracy czy regulaminy ${ }^{489}$. Jak wynika bowiem z Kodeksu pracy, jedynie wyjątkowo ustawodawca dopuszcza możliwość wprowadzenia przerw niewliczanych do czasu pracy.

W zakresie prowadzonych rozważań znaczenie ma na pewno przerwa, o której stanowi art. 141 k.p. ${ }^{490}$, a więc jedna, maksymalnie godzinna przerwa w pracy na spożycie posiłku lub załatwienie spraw osobistych, nieobjęta czasem pracy, która może być wprowadzona przez pracodawcę w układzie zbiorowym pracy, regulaminie pracy, albo, w razie braku tych aktów, w umowie o pracę.

Wypoczynkowy charakter tej przerwy jest jednak sprawą dyskusyjną. Warto zauważyć, że sam ustawodawca nie określa konkretnie jej przeznaczenia. Może ona bowiem zostać spożytkowana na posiłek i w tym sensie posiadać walor, o którym wyżej mowa, ale może też służyć do załatwienia ogólnie określonych „spraw osobistych", a więc np. realizacji obowiązków pozazawodowych, których pracownik nie

489 Stanowisko takie jest raczej powszechne w doktrynie prawa pracy. Por. m.in.: K. Rączka, [w:] Kodeks pracy..., s. 471 oraz A.M. Świątkowski, Kodeks pracy..., s. 583. Odmienny pogląd został wyrażony przez M.T. Romer, która uznała, że pracodawca może wprowadzić dłuższą przerwę, której wliczenie lub niewliczenie do czasu pracy, powyżej ustawowych 15 minut, będzie uzależnione od decyzji pracodawcy i ewentualnych uzgodnień z załogą. Por. taż, Prawo pracy..., s. 833.

490 Przerwa ta została wprowadzona do Kodeksu pracy ustawą nowelizującą Kodeks pracy z 26 lipca 2002 r. 
jest w stanie wypełnić po zakończeniu pracy. Wówczas z wąsko pojętym prawem do odpoczynku będzie ona miała, nie tylko faktycznie, ale i ze swej istoty, niewiele wspólnego.

Ponadto przerwa ta nie jest wliczana do czasu pracy, co powoduje, że de facto prowadzi ona do wydłużenia dnia pracy, a to zwykle jest oceniane jako rozwiązanie niekorzystne dla pracownika. Bilans wychodzi niby na zero (dobowa norma czasu pracy się nie zmienia), niemniej świadomość konieczności powrotu do pracy po odbytej przerwie powoduje, nawet jeśli służy ona wypoczynkowi, że efektywność takiego odpoczynku jest mniejsza niż tego przypadającego po godzinach pracy. Być może z tych właśnie względów ustawodawca ograniczył swobodę pracodawcy w zakresie możliwości jej wprowadzenia. Decyzję w tym przedmiocie będzie on bowiem podejmował wspólnie $\mathrm{z}$ reprezentacją pracowniczą, ewentualnie $\mathrm{w}$ porozumieniu $\mathrm{z}$ indywidualnym pracownikiem.

Również przerwa w zakresie przerywanego systemu czasu pracy, jak słusznie zauważył Z. Góral, może być rozpatrywana w kontekście prawa do odpoczynku tylko w aspekcie określenia maksymalnych granic jej trwania (nie jest ona bowiem wliczana do czasu pracy). Generalnie jednak system ten, ze swej natury, optymalnemu wypoczynkowi nie służy ${ }^{491}$.

\subsection{Dni wolne od pracy}

Kolejnym instrumentem realizującym prawo pracownika do odpoczynku, co wynika wprost z Konstytucji oraz art. 14 k.p., są dni wolne od pracy.

Dni te nie mają jednorodnego charakteru. W literaturze $\mathrm{z}$ zakresu prawa pracy wskazuje się bowiem na trzy podstawowe rodzaje tych dni. Będą to niedziele i święta, które są dniami ustawowo wolnymi od pracy, dni dodatkowo wolne od pracy wynikające z zasady pięciodniowego tygodnia pracy oraz dni wolne od pracy wynikające $z$ wyrównywania przeciętnej tygodniowej normy czasu pracy ${ }^{492}$.

Ponadto o dniach wolnych od pracy stanowi się również w kontekście rekompensaty pracy w niedziele i święta oraz godzin nadliczbowych występujących $\mathrm{w}$ dniu wolnym od pracy wynikającym z rozkładu czasu pracy w przeciętnie pięciodniowym tygodniu pracy.

Dodatkowo mogą występować też tzw. święta branżowe lub zakładowe.

Dni wolne od pracy ze względu na swoje zróżnicowanie będą mieć również niejednakowy udział w realizacji prawa pracownika do odpoczynku. Choć wszystkie one ze swej natury oraz woli ustawodawcy (o czym była mowa) służą bowiem temu celowi $^{493}$, to jednak z powyższego wynika, że część dni będzie zwiększać wyraźnie

491 Por. Z. Góral, Podstawowe zasady indywidualnego prawa pracy, [w:] System prawa pracy, t. 1: Część ogólna, red. K.W. Baran, Warszawa 2017, s. 1119.

492 Por. K. Rączka, Dni wolne..., s. 23 i n.

493 Por. na ten temat M.A. Mielczarek, Charakter prawny dni wolnych od pracy, „Gdańsko-Łódzkie Roczniki Prawa Pracy i Prawa Socjalnego" 2014, nr 4, s. 48 i n. 
ogólną pulę czasu wolnego od pracy, w tym przeznaczonego na wypoczynek (niedziele i święta, dni dodatkowo wolne od pracy, święta branżowe), część zaś stanowi jedynie rekompensatę pracy $\mathrm{w}$ dniu $\mathrm{z}$ zasady wolnym czy pracy wydłużonej $\mathrm{w}$ innym dniu i tygodniu.

Poza tym o terminie wykorzystania większości dni wolnych, zwłaszcza dni dodatkowo wolnych od pracy oraz bilansujących przeciętną normę tygodniową, decyduje z założenia pracodawca, co przy wydłużonych okresach rozliczeniowych (nawet 12-miesięcznych) ${ }^{494}$ daje mu szeroki margines swobody, osłabiając niewątpliwie znacznie ich funkcję ochronną.

Idea dni wolnych od pracy ma niewątpliwie długą tradycję, chociaż w ujęciu normatywnym sprowadzała się początkowo przede wszystkim do zagwarantowania pracownikom niedzieli wolnej od pracy ${ }^{495}$ oraz wolnych dni świątecznych. W Polsce tego rodzaju unormowania występowały w regulacjach prawnych państw zaborczych (por. uwagi na temat odpoczynku tygodniowego w ujęciu historycznym). Na obszarze Królestwa Polskiego ustawowo wprowadzono zakaz pracy w niedziele i ,święta uroczyste" wymienione w przepisach (około $14 \mathrm{dni})^{496}$, z zastrzeżeniem możliwości wyznaczenia innego dnia zamiast niedzieli dla osób odmiennego wyznania.

Niedziele i święta jako dni z zasady wolne od pracy zostały również wskazane w powoływanej już wcześniej ustawie z 18 grudnia 1919 r. o czasie pracy w przemyśle i handlu, a następnie w przepisach Kodeksu pracy.

Obecnie zasadę tę formułuje art. $151^{9}$ k.p., a w stosunku do niedzieli także przepis dotyczący odpoczynku tygodniowego, którego zasadnicza część powinna właśnie, zgodnie z wolą ustawodawcy, przypadać w niedzielę (por. wcześniejsze rozważania).

Mając powyższe na względzie wydaje się, że w polskich warunkach w pełni uprawnione jest posługiwanie się pojęciem odpoczynku niedzielnego i świątecznego. Jego formalne uznanie przez naszego ustawodawcę ma jednak również głębokie uzasadnienie merytoryczne i światopoglądowe.

Wypoczynkowa funkcja wolnej niedzieli, która bywa niekiedy kwestionowana ${ }^{497}$, nie może budzić wątpliwości, choć z pewnością nie jest to jej jedyna funk-

$494 \mathrm{Na}$ temat roli i znaczenia okresów rozliczeniowych por. szerzej M. Latos-Miłkowska, Okresy rozliczeniowe czasu pracy, [w:] Czas pracy, red. L. Florek, Warszawa 2011, s. 164 i n.

495 Odpoczynek niedzielny został po raz pierwszy prawnie zagwarantowany w edykcie Konstantyna Wielkiego z 321 r. Por. B. Nadolski, Niedziela. Historia, znaczenie, symbolika, Kraków 2010, s. 46 in.

496 Za święta wolne od pracy uznano: 1 i 6 stycznia, 25 marca, 6 i 15 sierpnia, 8 września, 25 i 26 grudnia, a także Wielki Piątek i Wielką Sobotę, poniedziałek i wtorek Wielkanocny, Wniebowstąpienie Pańskie i drugi dzień Zesłania Ducha Świętego. Por. Zbiór praw, instrukcyi i przepisów..., s. 220.

497 Chodzi w szczególności o sprzeciw niektórych państw UE wobec funkcjonującego pierwotnie w dyrektywie dotyczącej czasu pracy przepisu o odpoczynku tygodniowym obejmującym niedzielę. Wypowiadający się w tej sprawie Trybunał uznał, że nie ma argumentów, które przemawiałyby za niedzielą jako dniem szczególnie predestynowanym do takiego 
cja. W literaturze słusznie zwrócono bowiem uwagę, że geneza niedzieli jako dnia wolnego od obowiązku świadczenia pracy ma charakter religijny i to niedziela jako święto stała się ostatecznie podstawą do odpoczynku niedzielnego z czasem prawnie zabezpieczonego ${ }^{498}$. Niemniej, biorąc pod uwagę aspekt kulturowy oraz zwyczajowy, niedziela odgrywa bardzo istotną rolę w realizacji prawa pracownika do odpoczynku, w urzeczywistnianiu celów leżących u jego podstaw, w tym tak podstawowych jak ochrona życia i zdrowia ludzkiego. Potwierdzają to przeprowadzone w tym obszarze badania, na które wskazano w literaturze przedmiotu. Wynika z nich, że u pracowników wykonujących pracę w omawianym dniu rośnie ryzyko występowania chorób i związanej z nimi nieobecności w pracy, a także prawdopodobieństwo spadku wydajności pracy ${ }^{499}$.

Dla pełnej realizacji prawa do odpoczynku ważne są również kwestie możliwości jego spędzania w gronie rodzinnym. Takie szanse daje właśnie niedziela, jako dzień powszechnie wolny nie tylko od pracy, ale też, zasadniczo, od obowiązków szkolnych.

Nie może więc dziwić, że mimo zmian zachodzących w stosunkach społecznych nadal w Polsce powszechne jest przekonanie i oczekiwanie, że niedziele i święta powinny być dniami wolnymi od pracy ${ }^{500}$.

Wypoczynkowy charakter niedzieli został też potwierdzony w judykaturze. W szczególności w uzasadnieniu uchwały składu siedmiu sędziów Sądu Najwyższego z 14 listopada 2001 r. ${ }^{501}$ uznano, że niedziela jako dzień wolny od pracy stanowi ustawową gwarancję prawa do wypoczynku.

Jednocześnie jednak, w owej uchwale zakwestionowano analogiczną rolę świąt. Sąd Najwyższy podkreślił bowiem „różną funkcję niedziel oraz innych dni świątecznych”, które, w jego ocenie, służą „świętowaniu świąt państwowych i religijnych". Ich przeznaczeniem jest zatem udział w uroczystościach, celebrowaniu pewnych rocznic, a w przypadku świąt kościelnych uczestniczenie w obrzędach religijnych ${ }^{502}$.

Taki sposób postrzegania roli niedziel oraz świąt został następnie przyjęty przez Trybunał Konstytucyjny w wyroku z 2 października 2012 r. ${ }^{503}$, co w doktrynie prawa pracy zostało odebrane jako zrównywanie roli niedzieli z dniami dodatkowo wolnymi od pracy ${ }^{504}$.

odpoczynku z punktu widzenia ochrony zdrowia i bezpieczeństwa pracowników. Por. wyrok ETS (obecnie TSUE) z 12 listopada 1996 r. w sprawie Zjednoczone Królestwo Wielkiej Brytanii i Irlandii Północnej przeciwko Radzie, C-84/94, Zb. Orz. 1996, s. I-05755.

498 Por. M.A. Mielczarek, Charakter prawny..., s. 49.

499 Por. P. Grzebyk, Ochrona..., s. 203.

500 Por. K. Łapiński, Wynagrodzenie za pracę w niedzielę i święto, [w:] Z aktualnych zagadnień prawa pracy i zabezpieczenia społecznego. Księga Jubileuszowa Profesora W. Sanetry, red.

B. Cudowski, J. Iwulski, Białystok 2013, s. 254.

501 Uchwała składu siedmiu sędziów SN z 14 listopada 2001 r., III ZP 20/01, www.sn.pl.

502 Tamże.

503 Por. wyrok TK z 2 października 2012 r., K 27/11.

504 Por. K. Stefański, Problem świąt..., s. 31. 
Trudno w pełni zaakceptować wymieniony wyżej pogląd. Chociaż święta, podobnie zresztą jak w tradycji chrześcijańskiej niedziela ${ }^{505}$, mają swoje dodatkowe, szczególne przeznaczenie, to jednak słusznie w literaturze zauważono, że nie można rozpatrywać dni świątecznych wolnych od pracy w oderwaniu od prawa do wypoczynku, zwłaszcza w kontekście art. 66 ust. 2 Konstytucji oraz art. 14 k.p. ${ }^{506}$ Gwarantem prawa do odpoczynku uczynił je bowiem bezpośrednio sam ustawodawca. Tym samym pełniąc, co oczywiste, również inne funkcje (religijne, państwowe, społeczne), ich celem jest także odpoczynek. Uwidacznia się to bezpośrednio w przypadku takich świąt jak Nowy Rok.

Podobnie jak w przypadku niedziel, uznanie wypoczynku świątecznego ma swoje uzasadnienie społeczne i kulturowe.

Na ów społeczny i rodzinny aspekt niedzieli i świąt zwrócono uwagę m.in. w wydanym 20 stycznia 2015 r. dokumencie podpisanym przez przedstawicieli Kościołów zrzeszonych w Polskiej Radzie Ekumenicznej, w którym apelowano do wszystkich „ludzi dobrej woli o poszanowanie niedzieli i świąt z uwagi na społeczny pożytek należnego odpoczynku i świętowania - dla dobra naszych rodzin, dla dobra obywateli naszego państwa" ${ }^{507}$.

Niedziela była i, jak wykazano $\mathrm{w}$ literaturze przedmiotu ${ }^{508}$, jest najstarszym świętem chrześcijańskim, stąd nie może być odmiennie niż one postrzegana, a już szczególnie im przeciwstawiana.

Warto podkreślić też, że niedziele i święta, jako dni z zasady wolne od pracy, zostały objęte generalnie analogiczną regulacją prawną w zakresie dopuszczalności odstąpienia od tej reguły, tj. nieświadczenia pracy w te dni (z pewnymi modyfikacjami wynikającymi z mniejszej częstotliwości występowania tych ostatnich). W szczególności ustawodawca, dążąc do zachowania właśnie wypoczynkowej funkcji omawianych dni, zobowiązuje pracodawcę do zapewnienia pracownikowi, który wyjątkowo świadczył pracę w niedzielę lub w święto, innego dnia wolnego od pracy w tygodniu i to w określonym czasie (art. $151^{11}$ k.p.). Jedynie w wyjątkowych przypadkach, w których nie jest możliwe udzielenie takiego dnia wolnego w przewidzianym przez prawo terminie, pozwala się zastąpić go formą świadcze-

505 Por. apel Kościołów w Polsce o poszanowanie i świętowanie niedzieli z 20 stycznia 2015 r., w którym zwrócono uwagę, że niedziela, jako „dzień zmartwychwstania Jezusa Chrystusa”, powinna być dniem „modlitwy, świętowania i świadectwa”. Realizacja powyższego zalecenia jest jednak zależna, jak przyjęto w cytowanym dokumencie, od zagwarantowania pracującym wypoczynku fizycznego, duchowego i intelektualnego. Por. M.A. Mielczarek, Praca w niedziele i święta w ujęciu aksjologicznym (aspekt ekumeniczny i legislacyjny), [w:] 40 lat Kodeksu pracy, red. Z. Góral, M.A. Mielczarek, Warszawa 2015, s. 255.

506 Por. M.A. Mielczarek, Charakter prawny..., s. 49. Również A. Sobczyk uznawał, że urzeczywistnienie prawa do wypoczynku następuje m.in. poprzez ograniczenie dopuszczalności wykonywania pracy w niedziele i święta. Por. tenże, Zasady..., s. 238.

507 Apel Kościołów w Polsce o poszanowanie i świętowanie niedzieli, za: M.A. Mielczarek, Praca w niedziele..., s. 256.

508 Por. M.A. Mielczarek, Charakter prawny..., s. 54. 
nia pieniężnego ${ }^{509}$, co notabene, z punktu widzenia ochrony prawa do odpoczynku, też nie wydaje się rozwiązaniem w pełni właściwym ${ }^{510}$. Zbyteczne byłyby jednak tego rodzaju obostrzenia zasad rekompensaty pracy w święto, gdyby nie było ono łączone z prawem do odpoczynku. Jest oczywiste, że w dniu wolnym udzielonym za pracę w święto dezaktualizuje się już jego funkcja celebracyjna.

Ze względu na wyraźnie większą liczbę niedziel niż świąt, ustawodawca zdecydował również o przyznaniu pracownikom, którzy w przypadkach przewidzianych w Kodeksie pracy świadczą pracę w niedzielę (z wyjątkiem tzw. weekendowego systemu czasu pracy), prawa do jednej niedzieli wolnej od pracy co najmniej raz na cztery tygodnie.

Sformułowana w art. $151^{9}$ k.p. zasada, że niedziele i święta określone w odrębnych przepisach ${ }^{511}$ są dniami wolnymi od pracy, nie ma, jak już z powyższego wynika, bezwzględnego charakteru.

W przepisach Kodeksu pracy, w teoretycznie zamkniętym katalogu, sformułowano wiele wyjątków o charakterze przedmiotowym, uzasadniających zarządzenie pracy w te dni. Niektóre z nich są oczywiste i nie mogą budzić zastrzeżeń, w pewnych sytuacjach praca w niedziele czy święta staje się bowiem po prostu koniecznością. Dotyczy to takich przypadków, jak np. prowadzenie akcji ratowniczej, praca w ruchu ciągłym, transporcie i komunikacji, zakładach opieki zdrowotnej, zakładach hotelarskich.

Sam sposób uregulowania omawianych odstępstw, a niekiedy też ich rodzaj, wywołuje jednak poważne wątpliwości, w szczególności w kontekście urzeczywistniania konstytucyjnej i kodeksowej zasady prawa do odpoczynku. Skoro dni wolne od pracy zostały uznane za jeden $\mathrm{z}$ istotnych środków realizacji tej zasady, to odstępstwa od wyłączenia pracy w te dni powinny być ściśle określone, ograniczone do prac naprawdę niezbędnych, przypadków wyjątkowych. Tymczasem aktualny stan prawny w Polsce jest raczej daleki od wskazanego.

Przede wszystkim trudno nie podzielić oceny, często formułowanej przez przedstawicieli doktryny prawa pracy ${ }^{512}$, że katalog przesłanek dopuszczających polecenie wykonywania pracy w niedziele i święta został określony zbyt szeroko, co w rezultacie prowadzi do wypaczenia samej zasady. Najbardziej rażącym, według mnie, przykładem takiego działania ustawodawcy jest pkt 3 art. $151^{10}$ k.p. dotyczący pracy zmianowej ${ }^{513}$. W świetle powołanego przepisu stanowi ona samodzielną

509 Szerzej na temat zasad rekompensaty pracy w niedziele i święto por. K. Łapiński, Wynagrodzenie za pracę..., s. 257.

510 Por. uwagi dotyczące ewentualnej finansowej rekompensaty niezagwarantowanego odpoczynku dobowego i tygodniowego i podane tam argumenty. Taki „zamiennik” czasu, który w założeniu ma być przeznaczony na odpoczynek, jest sprzeczny z jego istotą.

511 Por. ustawa z 18 stycznia 1951 r. o dniach wolnych od pracy, tekst jednolity: Dz. U. 2015, poz. 90.

512 Por. m.in. T. Liszcz, Kiedy pracownik..., s. 238 i n.

513 Kwestię tę podnosi również A. Sobczyk. Por. tenże, Prawo pracy..., s. 201. Por. również: T. Liszcz, Kiedy pracownik..., s. 239 oraz A. Więcek, Praca w handlu i usługach w niedziele i święta-problem nadal aktualny, PiZS 2013, nr 10, s. 29 i n. 
przesłankę wykonywania pracy w niedziele i święta, zupełnie niezależną od charakteru tej pracy czy rodzaju prowadzonej działalności. W konsekwencji formalnie każdy pracodawca będzie mógł zatrudniać swoich pracowników w dni z zasady ustawowo wolne, jeśli tylko przyjmie w swoim zakładzie pracy system pracy zmianowej (choćby dwuzmianowej ${ }^{514}$ ), który z kolei, zgodnie z art. 146 k.p., może być stosowany w każdym systemie czasu pracy, a więc powszechnie.

Wątpliwości, zgłaszane w doktrynie prawa pracy, dotyczą również mało precyzyjnego ujęcia wyjątku, wskazanego w punkcie 9 art. $151^{10}$ k.p., tj. prac koniecznych ze względu na ich użyteczność społeczną i codzienne potrzeby ludności, wymienionych przykładowo przez ustawodawcę. Jest to klauzula generalna, której wykładnia będzie wymagała sięgnięcia do reguł i ocen pozaprawnych w zakresie ustalenia użyteczności społecznej poszczególnych prac i ich niezbędności dla zaspokajania codziennych potrzeb ludności (katalog takich prac, podany w przepisie, jest otwarty $)^{515}$. Bywa, że taki sposób regulacji jest oceniany jako zagrażający realizacji prawa pracowników do dni ustawowo wolnych od pracy, a tym samym i pełnemu urzeczywistnieniu ich prawa do wypoczynku ${ }^{516}$.

Ponadto nawet $\mathrm{w}$ tych przypadkach, w których praca w niedziele i święta jest obiektywnie uzasadniona, ustawodawca powinien zastrzec, że chodzi nie o wszystkich zatrudnionych $\mathrm{w}$ danej sferze czy w danym systemie organizacji pracy, np. transporcie, ale o te stanowiska, na których praca w niedziele czy święto jest niezbędna z punktu widzenia celu ich wyłączenia spod ogólnej reguły nieorganizowania pracy w te dni.

Sytuacji w omawianym obszarze nie poprawia z pewnością orzecznictwo Sądu Najwyższego, w którym dokonuje się często analizy obowiązujących przepisów, bez szerszej refleksji na temat istoty zakazu zatrudniania w niedziele i święta oraz jego znaczenia dla realizacji konstytucyjnie gwarantowanej zasady prawa do odpoczynku ${ }^{517}$.

Z punktu widzenia prawa do odpoczynku niedzielnego i świątecznego generalnie uzasadnione wydają się natomiast wprowadzane przez ustawodawcę regulacje wyłączające dopuszczalność zatrudnienia w te dni w placówkach handlowych ${ }^{518}$, postulowane od dłuższego czasu przez niektórych przedstawicieli doktryny prawa

514 Por. K. Rączka, Kodeks pracy..., 2005, s. 588.

515 Por. K. Stefański, Problemy pracy..., s. 21.

516 Por. A. Więcek, Praca w handlu..., s. 30. Autorka stawia wręcz tezę, że liczba wyjątków i sposób, w jaki zostały unormowane, pozwala przyjąć, że na gruncie polskiego prawa mamy w istocie do czynienia z zasadą ograniczonej dopuszczalności pracy w niedziele i święta.

517 Por. na ten temat P. Grzebyk, Ochrona..., s. 208. Por. też M. Latos-Miłkowska, Czas pracy. Między gospodarkq a ochrona pracy, [w:] Prawo pracy. Między gospodarka a ochrona pracy. Księga jubileuszowa Profesora Ludwika Florka, red. M. Latos-Mitkowska, Ł. Pisarczyk, Warszawa 2016, S. 225 i n. Autorka krytycznie odnosi się do kontrowersyjnej uchwały SN z 15 lutego 2016 r. (II PZP 11/05), zgodnie z którą w razie nieudzielenia przez pracodawcę w okresie rozliczeniowym innego dnia wolnego od pracy w zamian za pracę w niedzielę i święto, pracownikowi za każdą godzinę takiej pracy przysługuje tylko jeden dodatek przewidziany w art. $151^{11}$ k.p., słusznie podnosząc, że wykładnia ta przyczynia się do osłabienia ochrony czasu wolnego pracownika.

518 Por. ustawa z 24 sierpnia 2007 r. o zmianie ustawy - Kodeks pracy, Dz. U. 2007, Nr 176, poz. 1239. 
$\operatorname{pracy}^{519}$. Niemniej wiele zastrzeżeń można sformułować w zakresie sposobu, w jaki zostało to ostatecznie zrealizowane, m.in. odnośnie do techniki legislacyjnej ${ }^{520}$.

Zakaz zatrudniania w niedziele i święta, obejmujący wszystkich pracowników handlu, bez względu na rodzaj wykonywanej przez nich pracy ${ }^{521}$, wynika $\mathrm{z}$ art. $151^{\text {9a }}$ k.p., a więc przepisu zamieszczonego przed tym określającym wyjątki „typowe”, i w odniesieniu do świąt ma charakter bezwzględny, natomiast w stosunku do niedziel - ograniczony. Zobowiązanie pracowników do świadczenia pracy w niedziele jest bowiem w handlu wyjątkowo dopuszczone przy pracach koniecznych ze względu na ich użyteczność społeczną oraz codzienne potrzeby ludności. Duży stopnień ogólności przyjętej w omawianej normie formuły w praktyce może wywoływać liczne wątpliwości co do rzeczywistego zakresu zastosowania tego wyjątku ${ }^{522}$. Powinny być one jednak zawsze rozstrzygane $\mathrm{z}$ uwzględnieniem podstawowej zasady prawa pracownika do wypoczynku i jak najpełniejszych gwarancji jej realizacji ${ }^{523}$.

Z przyczyn, o których wyżej była mowa, rodzi się również pytanie, czy powyższe ograniczenie swobody działania pracodawcy w omawianym zakresie nie powinno zostać jednak rozszerzone także na inne sfery gospodarki, w tym zwłaszcza usługi ${ }^{524}$.

Tymczasem ustawodawca, niejako wbrew postulatom doktryny prawa pracy, w ostatnim czasie rozszerzył jeszcze katalog prac dopuszczalnych w niedziele i święta o prace polegające na świadczeniu usług z wykorzystaniem środków komunikacji elektronicznej lub urządzeń telekomunikacyjnych odbieranych poza terytorium RP, jeśli zgodnie z przepisami obowiązującymi odbiorcę takiej usługi, dni, o których mowa, są u niego dniami pracy, oraz o prace zapewniające możliwość świadczenia takich usług ${ }^{525}$. Charakter tego wyjątku uzasadnia

519 W przeszłości m.in. T. Liszcz kwestionowała zgodność przepisów prawa pracy dopuszczających pracę w niedziele i święta w placówkach handlowych z art. 66 ust. 2 Konstytucji. Por. taż, Prawo pracy, Warszawa 2004, s. 341.

520 Por. szeroko na ten temat K. Stefański, Problemy pracy..., s. 21 i n. Zob. też M.A. Mielczarek, Praca w niedziele..., s. 263 i n.

521 Kwestia ta jest w doktrynie prawa pracy przedmiotem dyskusji. W tym zakresie odmienny pogląd wyraził m.in. A. Sobczyk, według którego wykładnia funkcjonalna przemawia za wyłączeniem spod omawianego zakazu czynności niezwiązanych bezpośrednio z prowadzeniem sprzedaży. Por. tenże, Praca w placówkach handlowych w święta i w niedzielę, M.P.P. 2007, nr 12, s. 620.

522 W szczególności wiele wątpliwości, zarówno w teorii, jak i praktyce, wywołuje pojęcie handlu, które nie zostało przez ustawodawcę zdefiniowane w Kodeksie pracy.

523 Generalnie przychylam się w związku z tym do stanowiska zajętego przez A. Więcek, że „potrzeba ochrony prawa pracownika do wypoczynku powinna skłaniać ku restrykcyjnej wykładni omawianej regulacji i uznania bezwzględnego zakazu zatrudniania pracowników placówek handlowych w święta", a w przypadku pracy w niedziele - ograniczenia możliwości jej świadczenia do osób związanych ze sprzedażą i czynnościami handlowymi. Por. taż, Praca w handlu..., s. 30 i n.

524 Por. tak K. Stefański, Problemy pracy..., s. 21.

525 Ustawa z 24 stycznia 2014 r. o zmianie ustawy - Kodeks pracy, Dz. U. 2014, poz. 208. 
tezę, że względy gospodarcze wzięły kolejny raz górę nad aspektami społecznymi oraz argumentami prawnymi wynikającymi z prawa do wolnej niedzieli i święta jako dni wpisanych w konstytucyjną i kodeksową zasadę prawa do odpoczynku. Niewątpliwie nie chodzi tu bowiem o żadne szczególne motywy, nadzwyczajne okoliczności (praca taka w większości wypadków może być realizowane w inne niż niedziele i święta dni tygodnia), które uzasadniałyby odstąpienie od tej podstawowej zasady.

Uznanie niedzieli i świąt jako dni ustawowo wolnych od pracy, realizujących prawo pracownika do odpoczynku uzasadnia pytanie o legalność praktyk polegających na zobowiązywaniu pracownika do pozostawania "pod telefonem” w te dni. Udzielenie na nie odpowiedzi wymaga, jak się wydaje, ustalenia relacji między przepisami dotyczącymi dopuszczalności pracy w niedziele i święta a regulacją dyżuru pracowniczego, o którym stanowi art. $151^{5}$ k.p. i o który w istocie w powyższym przypadku chodzi. Problemu tego ustawodawca jednoznacznie nie rozstrzygnął.

Z Kodeksu pracy wynika, że pracodawca może zobowiązać pracownika do pozostawania poza normalnymi godzinami pracy $\mathrm{w}$ gotowości do wykonywania pracy wynikającej z umowy o pracę $\mathrm{w}$ zakładzie pracy lub innym miejscu wyznaczonym przez tego pracodawcę (dyżur domowy, pod telefonem) i że tak zdefiniowany dyżur nie może naruszać prawa pracownika do odpoczynku dobowego i tygodniowego, wcześniej opisywanego. Z uwagi na to, że odpoczynek tygodniowy, zgodnie z art. 133 k.p., ma obejmować niedzielę, wydaje się, że dyżur powinien być planowany $\mathrm{z}$ poszanowaniem owego dnia wolnego od pracy (w szczególnych przypadkach, wymienionych wcześniej, odpoczynek ten może być co najwyżej ograniczony do maksymalnie 24 godzin).

Ustawodawca nie rozstrzygnął natomiast jednoznacznie problemu dopuszczalności ustanowienia dyżuru w obrębie święta wolnego od pracy.

Przede wszystkim warto zauważyć, że wątpliwości wywołuje już sama definicja dyżuru, a w szczególności użyty przez ustawodawcę zwrot, z którego wynika, że ma on przypadać "poza normalnymi godzinami pracy”. W doktrynie prawa pracy wskazano argumenty przemawiające za wąską wykładnią tego pojęcia, ograniczającą prawo pracodawcy do ustanowienia dyżuru tylko w dniu, w którym pracownik, zgodnie $z$ rozkładem czasem pracy, miał zaplanowaną pracę ${ }^{526}$. Przyjęcie takiego stanowiska oznacza m.in. brak możliwości jego wyznaczenia w święto, będące dla danego pracownika dniem wolnym od pracy.

Ze względu na drugi pogląd, chyba dominujący, że zwrot ten nie jest równoznaczny z koniecznością wyznaczenia dyżuru w tej dobie pracowniczej, w której zaplanowano już pracę̨27, należy zastanowić się, czy dyżur może być zaplanowany na święto będące dla danego pracownika dniem wolnym od pracy i święto będące

526 Por. K. Stefański, Czas pracy, s. 28.

527 Por. np. W. Ostaszewski, M. Raczkowski, Konstrukcja instytucji dyżuru pracowniczego i jej praktyczne wykorzystanie, PiZS 2012, nr 4, s. 26. 
dniem pracy, a jeśli tak, to na jakich warunkach. W szczególności trzeba zadać pytanie, czy będą tu stosowane w pierwszej kolejności przesłanki pracy w święta czy też należy odnieść się do przesłanek wykonywania pracy w godzinach nadliczbowych, w istocie ustanowienie dyżur może skutkować bowiem powstaniem godzin nadliczbowych ${ }^{528}$. Problem potęguje fakt, że dyżur w zakresie, w jakim pracownik nie podjął w jego czasie pracy, nie jest wliczany do czasu pracy. Reguła ta, wynikająca wprost z Kodeksu pracy, wydaje się jednak nie do przyjęcia, nie tylko z punktu widzenia konstytucyjnej i kodeksowej zasady prawa do odpoczynku, ale również norm prawa wspólnotowego, o czym była mowa już wcześniej.

Biorąc powyższe pod uwagę, a także to, że charakter prawny świąt i niedziel jest podobny (są to dni ustawowo wolne od pracy, pełniące bardzo zbliżone funkcje, w tym m.in. urzeczywistniają podstawową zasadę prawa pracy, tj. prawa do odpoczynku), wszelka praca $\mathrm{w}$ te dni, również ta zlecana w ramach dyżurów, wymaga uprzedniego spełnienia przesłanek jej dopuszczalności, wymienionych w art. $151^{10}$ k.p., zwłaszcza że ustawodawca uwzględnił też sytuacje nadzwyczajne, ujęte analogicznie do warunkujących pracę w godzinach nadliczbowych, tj. konieczność prowadzenia akcji ratowniczej w celu ochrony życia lub zdrowia ludzkiego, ochrony mienia lub środowiska albo usunięcia awarii. Jednocześnie można chyba uznać, że przesłanka ta, aby ograniczyć, chociażby częściowo, prawo pracownika do odpoczynku, w tym swobodę rozporządzania swym czasem, szczególnie jeśli nie jest to pracownik, który ma zaplanowaną pracę w święto, musi zaktualizować się $\mathrm{w}$ momencie zlecania takiej pracy ( $\mathrm{w}$ tym przypadku w dniu ustanowienia dyżuru), ewentualnie, jej wystąpienie w święto musi być wysoce prawdopodobne. W przeciwnym razie dochodziłoby do nieuzasadnionego często ingerowania w sferę odpoczynku pracownika, wbrew jego woli, np. poprzez uniemożliwienie wyjazdu poza miejscowość, w której mieszka, niejako „na wszelki wypadek” wystąpienia okoliczności uchylającej zakaz organizowania pracy w niedziele czy święta, co w kontekście powołanej zasady jest, moim zdaniem, niedopuszczalne. W tym zakresie powinna znaleźć zastosowanie reguła, w myśl której wszelkie wątpliwości na tle prawnej regulacji czasu pracy muszą być rozstrzygane na rzecz pracownika, a konkretnie ochrony jego czasu wolnego ${ }^{529}$.

Warto mieć również na uwadze pogląd A. Sobczyka, który w pełni podzielam, o ograniczonej częstotliwości i wyjątkowości dyżurów, oparty m.in. na zasadzie prawa pracownika do odpoczynku. Konsekwencją jego przyjęcia jest negacja praktyk polegających na uczynieniu dyżuru stałym elementem organizacji czasu pracy w danym zakładzie, które należy oceniać w kategoriach naruszenia przepisów o czasie pracy ${ }^{530}$.

Kwestią nie do końca oczywistą jest, czy aspekt woli pracownika odnośnie do świadczenia pracy w niedziele lub w święto może w jakiejś mierze legalizować

528 Zwłaszcza wtedy, gdy jest niemal pewne, że wystąpi konieczność wykonania określonej pracy w danym dniu, ale trudno dokładnie określić w jakich godzinach.

529 Por. W. Uziak, Czas pracy..., s. 290.

530 Por. A. Sobczyk, Zasady..., s. 255. 
działania pracodawcy w tym zakresie. W doktrynie prawa pracy podnosi się bowiem ostatnio, że w Kodeksie pracy ustawodawca nie zdecydował się ostatecznie na sformułowanie wyraźnego zakazu pracy w te dni, ale poprzestał na ustanowieniu ich dniami wolnymi od pracy ${ }^{531}$. Możliwa jest $\mathrm{w}$ związku $\mathrm{z}$ tym taka interpretacja omawianej normy, która ogranicza swobodę działania pracodawcy w tym obszarze, ale pracownikowi pozostawia prawo podjęcia decyzji w przedmiocie rezygnacji z niedzieli czy święta jako dnia wolnego od pracy ${ }^{532}$. Nawet jeśli przyjmie się, co w kontekście powyższej wykładni nie jest jednoznaczne, że pracownik uzyska prawo do dnia wolnego w innym terminie, wówczas co prawda nie dochodzi do zrzeczenia się prawa do odpoczynku w ogóle, ale prawa do odpoczynku niedzielnego bądź świątecznego.

Powyższa konstrukcja prawa do niedzieli i świąt wolnych od pracy może budzić jednak wątpliwości, jeśli skonfrontuje się ją z zaproponowaną w literaturze szeroką, a jednocześnie bardzo restrykcyjną, wykładnią ustawy o dniach wolnych od pracy.

Pojęcie świąt, wielokrotnie wyżej powoływane, nie zostało w Kodeksie pracy zdefiniowane (analogicznie jak w przypadku niedzieli określa się jedynie jego ramy czasowe). Ustawodawca odsyła w tym zakresie do ustawy o dniach wolnych od pracy, w której poza niedzielami wymieniono z nazwy i daty inne dni ustawowo wolne od pracy (potocznie nazywane świętami).

W świetle występującej obecnie tendencji do poszukiwania podstaw rozszerzenia prawa do odpoczynku na inne niż pracownicy (w rozumieniu kodeksowym) osoby świadczące pracę, w literaturze przedmiotu zwrócono uwagę na wiele argumentów uzasadniających tezę o wykraczającym poza stosunek pracy zakresie oddziaływania powołanej ustawy ${ }^{533}$. W ocenie A. Sobczyka, ustawa ta ogranicza swobodę wykonywania każdej pracy, bez względu na jej podstawę prawną oraz zarobkowy lub niezarobkowy cel jej podjęcia, „o ile przepis szczególny lub szczególnie istotna wartość chroniona tego nie dopuszcza (kontratyp)" ${ }^{334}$. W praktyce oznacza to, że m.in. również osoby zatrudnione na podstawie umów prawa cywilnego powinny mieć zagwarantowany odpoczynek niedzielny i świąteczny ${ }^{535}$.

Trudno odmówić trafności spostrzeżeniu autora, że ustawa ta, wbrew tradycyjnemu sposobowi jej odczytywania, nie jest ustawą z zakresu prawa pracy (stosowana na zasadzie odesłania), ani też z jej treści nie wynika, aby była ona adreso-

531 Z wyjątkiem przepisów dotyczących pracy w placówkach handlowych, gdzie, trudno powiedzieć na ile celowo, wziąwszy pod uwagę liczbę mankamentów legislacyjnych tej regulacji, wskazuje się, że praca w takich placówkach w niedziele i święta jest „niedozwolona”.

$532 \mathrm{Na}$ kwestię tę zwrócił uwagę m.in. K. Stefański. Por. tenże, Problem pracy..., s. 20. Szersze uzasadnienie por. K. Kulig, Aksjologia..., s. 298 i n.

533 Por. A. Sobczyk, Prawo pracy..., s. 198 i n.

534 Tamże, s. 200.

535 Zdaniem A. Sobczyka, adresatem omawianej ustawy są również przedsiębiorcy, podmioty „samozatrudniające się", ale ogranicza ona też swobodę wykonywania pracy dla celów własnych, tj. podejmowania czynności naruszających „świąteczną ciszą”. Por. tamże, s. 200 i n. 
wana wyłącznie do pracowników (ostatnie pojęcie w ustawie nie występuje). Być może zatem należy uznać, że wyznacza ona pewną sferę czasu wolnego od pracy dla wszystkich osób wykonujących pracę zarobkową, zwłaszcza że ustawy tej, obowiązującej jeszcze w okresie przedkodeksowym, nie włączono do tego aktu prawnego po jego uchwaleniu, mimo że normowano w nim omawiane kwestie.

Niemniej, zdaniem A. Sobczyka, ustawa ta ogranicza „wolność wykonywania” wszelkiej pracy, z pracą niezarobkową włącznie, „o ile przepis szczególny lub szczególnie istotna wartość chroniona tego nie dopuszcza”536. Oznacza to zakaz świadczenia pracy przez przedsiębiorców, samozatrudnionych, ale również pracy dla celów własnych, tj. podejmowania czynności naruszających „świąteczną ciszę”. Nawet jeśli uznać, jak proponuje autor, że Kodeks pracy stanowi tu lex specialis, to okazuje się, że wyjątkiem od owego zakazu jest nie tylko katalog prac, do których wykonywania w niedziele i święta pracodawca może zobowiązać pracownika, ale też sama konstrukcja prawa do odpoczynku niedzielnego i świątecznego, w ramach której, jak była wyżej mowa, pozwala się na dobrowolne wykonywanie przez pracownika pracy w te dni. Wówczas jednak, zważywszy na fakt, że pracownicy stanowią w społeczeństwie dominującą grupę, wypacza się poniekąd sens regulacji omawianej ustawy. Powstaje również pytanie o celowość tego rodzaju rozszerzenia praw osób pozostających w stosunku pracy w relacji do wszystkich innych obywateli danego kraju, którzy, jak przekonuje autor, nie powinni nawet podejmować czynności faktycznych zakłócających świąteczny spokój. Albo więc należy odrzucić interpretację zakładającą swobodę podjęcia przez pracownika decyzji w kwestii wykorzystania odpoczynku świątecznego, bądź tę dotyczącą zakazu pracy w te dni formułowaną na gruncie ustawy o dniach wolnych, bądź też, akceptując oba przedstawione wyżej stanowiska, przyjąć, że doszło w zakresie wyjaśnianej kwestii do pewnej kolizji norm zawartych w aktach o jednakowej mocy prawnej.

Analiza literatury z zakresu prawa pracy pozwala uznać, że w doktrynie prawa pracy jednak dominuje pogląd o istnieniu zakazu pracy w niedziele i święta, mimo braku jego bezpośredniego wyrażenia w przepisach Kodeksu pracy. Oznacza to w istocie przeciwstawienie się koncepcji, w myśl której pracownik może się zrzec swych uprawnień w omawianym zakresie.

Kluczowe staje się w tym przypadku odwołanie do użytej w art. $151^{9} \mathrm{k}$.p. formuły „praca w niedziele i święta jest dozwolona”, która poprzedza wyjątki od zasady, że niedziele i święta są dniami ustawowo wolnymi od pracy. Skoro praca, a nie, jak podkreślono w piśmiennictwie, zatrudnianie, tylko wówczas może być wykonywana, to znaczy, że w pozostałych sytuacjach jest niedopuszczalna ${ }^{537}$.

Istotne znaczenie ma również cel omawianego prawa, którym jest indywidualny odpoczynek, ale także możliwość łączenia go z życiem rodzinnym. Są to dni, w ramach których w dużej mierze organizuje się życie rodzinne i społeczne ${ }^{538}$.

536 Tamże, s. 200.

537 Tak por. T. Liszcz, Kiedy pracownik..., s. 241.

538 Tamże. 
Mają one też, jako dni wolne od pracy, ważne znaczenie dla samego pracodawcy, sprzyjając wydajniejszej i bezpieczniejszej pracy pracownika po powrocie do niej ${ }^{539}$.

Taka interpretacja wpisuje się również w charakter prawa do odpoczynku tygodniowego, który, jak wynika z przepisów Kodeksu pracy, powinien przypadać w niedzielę, i którego, jak się często przyjmuje, pracownik nie może się zrzec (zob. wcześniejsze rozważania).

Poza niedzielami i świętami, stanowiącymi punkt wyjścia w zakresie prawnej regulacji dni wolnych od pracy, z czasem katalog tych dni zaczął się rozszerzać o dni dodatkowo wolne od pracy. Jak wskazuje się w literaturze przedmiotu, dodatkowe dni wolne od pracy zostały w Polsce po raz pierwszy wprowadzone dekretem Rady Państwa z $1972 \mathrm{r}^{540}$, rozwijając tym samym pracownicze prawo do odpoczynku $^{541}$. Dekret ten upoważniał Radę Ministrów do wprowadzenia, w porozumieniu z Centralną Radą Związków Zawodowych, dwóch dodatkowych dni wolnych od pracy, które miały być jednak „wyrównywane przez odpowiednią zmianę wymiaru czasu pracy w dniach poprzedzających dodatkowe dni wolne od pracy" (art. 1 ust. 1 dekretu). W związku $\mathrm{z}$ tym dopuszczono możliwość podwyższenia dobowego wymiaru czasu pracy w tych dniach do dziewięciu godzin (a w sobotę do ośmiu godzin) - art. 3 dekretu.

Dni dodatkowo wolne od pracy (przede wszystkim chodziło o wolne soboty) zaczęły być także postrzegane jako jedna z dróg prowadzących do realizacji wyraźnej już w połowie XX w. tendencji skracania czasu pracy. W uchwalonym w latach 70. Kodeksie pracy upoważniono Radę Ministrów do wprowadzenia takich dni. Delegację tę wykorzystano i w 1974 r. ustanowiono sześć, a od 1975 r. 12 wolnych sobót, co istotne, już bez obowiązku ich odpracowywania ${ }^{542}$. Zwykle był to jeden dzień dodatkowo wolny od pracy w miesiącu, ustalony na szczeblu centralnym w sposób jednolity dla całego kraju ${ }^{543}$. Uzyskiwały go zakłady, które wykonały zadania planowe.

W kolejnych aktach wykonawczych liczbę tych dni stopniowo zwiększano. Istotne w tym zakresie było zwłaszcza rozporządzenie Rady Ministrów z 8 października $1984 \mathrm{r}^{544}$, w którym upoważniono kierowników zakładów pracy do wprowadzenia dni dodatkowo wolnych od pracy w wymiarze:

- 38 dni w roku kalendarzowym - przy zastosowaniu stałej normy dobowej maksymalnie ośmiogodzinnej;

- 34 dodatkowych dni wolnych - przy zastosowaniu ośmiogodzinnej normy dobowej przez pięć dni roboczych i normy sześciogodzinnej w szóstym dniu roboczym, wynikającym z rozkładu czasu pracy;

539 Tamże, s. 242.

540 Dekret z 20 lipca 1972 r. o dodatkowych dniach wolnych od pracy, Dz. U. 1972, Nr 29, poz. 203.

541 Por. T. Zieliński, Zarys..., cz. I, s. 112.

542 Por. W. Szubert, Zarys..., s. 212.

543 Por. W. Muszalski, Czas pracy..., s. 418.

544 Rozporządzenie w sprawie zasad stosowania czasu pracy w uspołecznionych zakładach pracy oraz zmian niektórych przepisów o czasie pracy, Dz. U. 1984, Nr 51, poz. 263, ze zm. 
- 52 dodatkowych dni wolnych od pracy w roku kalendarzowym - przy zastosowaniu przedłużonej normy dobowej - ośmioipółgodzinnej - we wszystkie dni robocze.

Rozporządzenie regulowało ponadto kwestię dni wolnych udzielonych w zamian za pracę w dniu wyznaczonym jako dodatkowo wolny od pracy (por. np. $\$ 14$ rozporządzenia) czy dni dodatkowo wolnych w zakładach prowadzących działalność produkcyjną lub usługową przez sześć lub siedem dni w tygodniu.

Niewątpliwie z punktu widzenia prawa do wypoczynku za mankament należy uznać wynikającą $\mathrm{z}$ rozporządzenia regułę wliczania dni dodatkowych wolnych od pracy przypadających $\mathrm{w}$ czasie urlopu wypoczynkowego do jego wymiaru, z wyjątkiem dni dodatkowo wolnych pokrywających się z pierwszym i ostatnim dniem urlopu ( $\$ 13$ rozporządzenia).

Kolejnym ważnym w omawianym zakresie aktem, wprowadzającym dość istotne zmiany zasad udzielania dni dodatkowo wolnych od pracy, było rozporządzenie Rady Ministrów z 1988 r. ${ }^{545}$, w którym przyjęto, że we wszystkich uspołecznionych zakładach pracy zostanie wprowadzonych 38 dni dodatkowo wolnych od pracy rocznie, w terminach określonych przez Ministra Pracy i Polityki Socjalnej po porozumieniu z ogólnokrajową organizacją międzyzwiązkową ${ }^{546}$. Jednocześnie z rozporządzenia wynikała dość duża swoboda kierowników zakładów pracy do ustalenia innego terminu wykorzystania tych dni, na zasadach wskazanych w rozporządzeniu.

W omawianym rozporządzeniu podtrzymano również zasadę, zgodnie z którą wszystkie dni dodatkowo wolne przypadające na okres urlopu wypoczynkowego należy do tego urlopu wliczyć. Urlop nie mógł jedynie ani rozpoczynać się, ani też kończyć w dniu wyznaczonym jako dodatkowo wolny od pracy.

Reguła powyższa nie dotyczyła jednak dnia udzielonego w zamian za pracę $\mathrm{w}$ dniu dodatkowo wolnym. Jeśli pracownik nie mógł bowiem takiego dnia wykorzystać z powodu urlopu, choroby czy innej usprawiedliwionej nieobecności, nakazywano udzielenie dnia wolnego w innym terminie lub na wniosek pracownika wypłatę zwiększonego wynagrodzenia.

Udzielenie zaległego dnia wolnego $\mathrm{w}$ zamian za pracę $\mathrm{w}$ dniu dodatkowo wolnym następowało $\mathrm{w}$ wyznaczonym $\mathrm{z}$ góry terminie $\mathrm{i}$, co ważne, rozporządzenie przewidywało, że tego rodzaju dni wolne mogą być udzielone, za zgodą pracownika lub na jego wniosek, łącznie z urlopem wypoczynkowym. Ostatecznie dopuszczono również możliwość zastąpienia zaległego dnia wolnego świadczeniem pieniężnym, co nie do końca przystawało do charakteru tych dni i ich podstawowej funkcji.

Zarządzenie pracy $\mathrm{w}$ dniu dodatkowo wolnym mogło nastąpić tylko po uzgodnieniu z zakładową organizacją związkową oraz pod warunkiem racjonalnego

545 Rozporządzenie Rady Ministrów z 23 grudnia 1988 r. w sprawie czasu pracy w uspołecznionych zakładach pracy w latach 1989-1992, Dz. U. 1988, Nr 42, poz. 329.

546 W literaturze wyrażono pogląd o dopuszczalności ustalenia większej liczby takich dni w zakładach pracy o charakterze prywatnym. Por. W. Masewicz, Czas pracy, s. 191. 
wykorzystania czasu pracy w poprzednich dniach tygodnia i należytego przygotowania pracy (pod względem organizacyjno-technicznym i materiałowo-kooperacyjnym) przypadającej na dzień dodatkowo wolny.

Rozporządzenie przewidywało także bilansowanie w systemie równoważnym przedłużonej normy czasu pracy dniami wolnymi.

Zmiany ustrojowe po 1989 r. przyniosły również liczne modyfikacje w zakresie sposobu organizacji dni dodatkowo wolnych od pracy. W szczególności należy wskazać na ustawę nowelizującą Kodeks pracy z 1996 r. ${ }^{547}$, w której wprowadzono dni dodatkowo wolne od pracy w wymiarze 39 dni rocznie, przy czym w każdym okresie obejmującym kolejne trzy miesiące liczba tych dni nie mogła być mniejsza niż dziewięć.

Jednocześnie przepisy dopuszczały możliwość wprowadzenia większej liczby dni dodatkowo wolnych, a więc wariant pięciodniowego tygodnia $\operatorname{pracy}^{548}$, nie większej jednak niż 52, przy jednoczesnym wydłużeniu normy dobowej do dziewięciu godzin.

Kodeks pracy podtrzymywał wcześniejszy obowiązek rekompensaty dnia dodatkowo wolnego od pracy, w którym pracownik na polecenie pracodawcy świadczył pracę, innym dniem wolnym, udzielonym zasadniczo do końca okresu rozliczeniowego, a za zgodą pracownika lub na jego wniosek - najpóźniej do końca następnego okresu rozliczeniowego.

Obowiązek akceptacji ze strony pracownika wydaje się przy tym dość istotny, w zależności od jego własnej oceny kondycji psychofizycznej, poziomu zmęczenia, mógł on sprzeciwić się bowiem odsunięciu w czasie należnego mu dnia wolnego realizującego jego prawo do odpoczynku.

Skuteczność decyzji pracownika podważała jednak dalsza regulacja, z której wynikało, że w razie jeśli i ten dzień wolny nie mógł zostać wykorzystany przez pracownika (a więc ustawodawca pośrednio dopuścił możliwość wezwania pracownika do pracy w ten dzień), należy mu udzielić dnia wolnego $w$ innym terminie, a w razie jego nieudzielenia - wypłacić wynagrodzenie w wysokości obliczonej analogicznie jak za pracę w święto.

Co istotne, doszło również wówczas do decentralizacji procesu wyznaczania dni dodatkowo wolnych od pracy; terminy ich wykorzystania miały być określane $\mathrm{w}$ układzie zbiorowym pracy lub regulaminie, a w razie braku takich aktów dokonywali tego bezpośrednio pracodawcy, dysponując w tym zakresie dość szeroką swobodą ${ }^{549}$.

Ostatecznie regulację dotyczącą dni wolnych od pracy zastąpiła wprowadzona do Kodeksu pracy zasada pięciodniowego tygodnia pracy. Jej realizacja następuje bowiem poprzez wskazanie średnio dwóch dni wolnych w tygodniu. Z uwagi

547 Ustawa z 2 lutego 1996 r. o zmianie ustawy Kodeks pracy oraz o zmianie niektórych ustaw, Dz. U. 1996, Nr 24, poz. 110.

548 Por. K. Kolasiński, Prawo pracy znowelizowane, Toruń 1996, s. 203.

549 Por. K. Rączka, Dodatkowe dni wolne od pracy, PiZS 1997, nr 12, s. 32 i n. 
na to, że jednym z tych dni jest niedziela, dzień ustawowo wolny od pracy, pracodawca powinien wyznaczyć średnio w każdym tygodniu jeden dzień dodatkowo wolny od pracy. Może być to sobota lub inny, poza niedzielą, dzień tygodnia. Jak słusznie zauważył Sąd Najwyższy, decydując o pięciodniowym tygodniu pracy, ustawodawca nie określił, który dzień tygodnia (poza niedzielą) ma być dniem wolnym od pracy. W szczególności brak jest reguły, według której praca miałaby być wykonywana przez pięć dni w tygodniu od poniedziałku do piątku. „Nowelizacja przepisów Kodeksu pracy o czasie pracy nie wprowadziła zatem powszechnie wolnych sobót jako drugiego - obok niedzieli - dnia wolnego od pracy w każdym kolejnym tygodniu pracy. Drugim - poza niedzielą - dniem wolnym od pracy może być każdy dzień tygodnia od poniedziałku do soboty. Nie musi być to również dzień stały w poszczególnych tygodniach okresu rozliczeniowego" ${ }^{550}$.

Charakter dni dodatkowo wolnych od pracy różni się zdecydowanie od niedziel oraz świąt przede wszystkim ze względu na to, że dni te nie są ustalane jednolicie w skali kraju, ale są odmiennie kształtowane u poszczególnych pracodawców, a nawet, jak przyjmuje K. Rączka, mogą być różne dla poszczególnych grup pracowniczych czy nawet pojedynczych pracowników jednego pracodawcy ${ }^{551}$. Ze względu na to, że pięciodniowy tydzień pracy jest normą przeciętną, liczba dni dodatkowo wolnych może być też bardzo różna w poszczególnych tygodniach okresu rozliczeniowego. Dlatego przyjmuje się, że w przeciwieństwie do niedziel i świąt, dni te są elementem organizacji czasu pracy podporządkowanym jej potrzebom ${ }^{552}$.

Nie zmienia to jednak faktu, że w świetle zasady prawa do odpoczynku, obok niedziel i świąt, stają się one istotnym gwarantem jej realizacji. Ustawodawca stanowiąc o prawie pracownika do odpoczynku, wprost przewiduje bowiem, że zapewnić go mają „dni wolne od pracy”, a zatem wszystkie dni wolne, bez względu na ich charakter oraz podstawę. W przypadku dni dodatkowo wolnych, jak się wydaje, ich funkcja wypoczynkowa staje się przy tym funkcją wiodącą. Generalnie odpada bowiem w tym przypadku aspekt religijny czy patriotyczny, jaki z założenia towarzyszy dniom ustawowo wolnym od pracy. Ich geneza, o czym była mowa wyżej, wiąże się bezpośrednio z dążeniem do skracania czasu pracy czy jego optymalizowania, a tym samym poszerzania sfery wolności od pracy zawodowej.

Wiele kontrowersji w doktrynie i orzecznictwie wywoływała kwestia zbiegu dnia dodatkowo wolnego od pracy oraz święta. Zastanawiano się przede wszystkim, czy wspomniana zasada pięciodniowego tygodnia pracy może być realizowana przy udziale świąt występujących w innym dniu niż niedziela, co oznaczałoby w praktyce, że będzie ono niejako pochłaniać dzień dodatkowo wolny ${ }^{553}$.

550 Por. uchwała składu siedmiu sędziów SN z 14 listopada 2001 r., op. cit. Na ten temat też K. Rączka, Czas pracy - nowa regulacja prawna, PiZS 2001, nr 4, s. 25.

551 Por. K. Rączka, Praca w dni wolne, s. 304.

552 Tamże.

$553 \mathrm{Na}$ kwestię tę jeszcze przed wejściem w życie nowych przepisów zwracał uwagę m.in. K. Rączka, Czas pracy..., s. 25 i n. 
W zasadzie od początku w orzecznictwie Sądu Najwyższego podkreślano, że występowanie święta $\mathrm{w}$ innym dniu niż niedziela powoduje $\mathrm{w}$ okresie rozliczeniowym odpowiednie zmniejszenie liczby dni, a tym samym godzin pracy, a zatem zasada pięciodniowego tygodnia pracy powinna być odnoszona do tych tygodni, w których nie ma święta przypadającego w innym dniu tygodnia niż niedziela ${ }^{554}$. Ostatecznie powyższe stanowisko znalazło swój wyraz w art. $130 \$ 2$ k.p., na podstawie którego należy przyjąć, że jeśli dochodzi do zbiegu święta i dnia dodatkowo wolnego od pracy pracownik powinien mieć zapewniony jeszcze inny dzień wolny od pracy. Kontrowersje budziły zatem te regulacje (jako że przepisy, które zostały wprowadzone w omawianym zakresie zmieniały się w poszczególnych latach), w ramach których starano się zmniejszyć rozmiar czasu wolnego pracownika poprzez ograniczenie stosowania omawianej reguły ${ }^{555}$. W mojej ocenie nie ma wątpliwości, że tego rodzaju działania ustawodawcze należy uznać za niedopuszczalne w kontekście zasady prawa pracownika do odpoczynku. Jest to podstawowe prawo wszystkich pracowników, a regulacje o czasie pracy mają służyć jego realizacji. Ustawodawca nie może zatem gwarantować zastosowania jednego instrumentu kosztem drugiego, zwłaszcza jeśli mają one odmienne podstawy prawne (tak jak w przypadku dni ustawowo i dodatkowo wolnych od pracy), co potwierdza m.in. wyłączenie tych dni z urlopu wypoczynkowego, czy de facto upoważniać do jednostronnego ograniczenia zakresu zastosowania instytucji służących do urzeczywistniania tego prawa (o terminie dni dodatkowo wolnych decyduje bowiem pracodawca, który mógł przynajmniej część tych dni wyznaczyć w terminach świąt, ograniczając w ten sposób znacznie ilość czasu wolnego pracownika). Na prawo do wypoczynku składa się określona pula dni wolnych - niedziel, świąt oraz dni dodatkowo wolnych, która stanowi o jego zakresie i niezależnie od rozkładów czasu pracy powinna być jednakowa dla wszystkich pracowników. Stąd wynika bowiem m.in. obowiązek, dalej opisany, rekompensaty pracy świadczonej wyjątkowo $\mathrm{w}$ dniu dodatkowo wolnym od pracy innym dniem wolnym od pracy $\mathrm{w}$ okresie rozliczeniowym.

Słusznie też podkreślano w literaturze przedmiotu, że trudno mówić o dniach wolnych od pracy, jeśli pracownik musi je następnie de facto odpracować, a więc nie zostaje zwolniony z obowiązku świadczenia pracy w te dni, ale obowiązek ten przesuwa się na inny dzieńn ${ }^{556}$.

554 Por. uchwała SN z 14 listopada 2001 r., III ZP 20/01. Krytycznie o tym wyroku, nie w kontekście samej tezy, ale jej uzasadnienia por. M.A. Mielczarek, Charakter prawny..., s. 48 i n.

555 Przypomnieć wystarczy obowiązującą w latach 2004-2006 normę, która przewidywała, że jeśli w tygodniu poza niedzielą występowały dwa święta, obniżenie wymiaru czasu pracy następowało tylko z tytułu jednego z nich, czy uznany za niekonstytucyjny przepis wprowadzony nowelą z 24 września 2010 r. (Dz. U. 2010, Nr 224, poz. 1459), który w zamian za dodane Święto Trzech Króli, stanowit, że święto przypadające w wynikającym z rozkładu czasu pracy dodatkowym dniu wolnym nie obniża wymiaru czasu pracy. Szerzej na temat ewolucji przepisów w omawianym zakresie por. K. Stefański, Problem świq̨t..., s. 28 i n.

556 Por. K. Stefański, Konieczność..., s. 17. 
Dni wolne od pracy ze swej natury są okresem, w którym pracownik nie ma obowiązku pozostawania w dyspozycji pracodawcy. Niemniej z przepisów prawa pracy wynika, że w szczególnych przypadkach, związanych z pracą w godzinach nadliczbowych, pracownik może zostać zobowiązany do świadczenia pracy w te dni. Wówczas jednak, zgodnie $\mathrm{z}$ art. $151^{3}$ k.p., przysługuje mu inny dzień wolny od pracy, który musi być udzielony przez pracodawcę $\mathrm{w}$ terminie uzgodnionym z pracownikiem, nie później niż do końca okresu rozliczeniowego.

Zlecenie pracy w dniu dodatkowo wolnym ma zatem wyjątkowy charakter, wymaga spełnienia przesłanek pracy w godzinach nadliczbowych, a ponadto, w celu zabezpieczenia wypoczynkowej funkcji tych dni, wyłącza się finansową formę ich rekompensaty. Pracownik musi mieć możliwość zneutralizowania większego zmęczenia w jednym czasie dłuższym okresem odpoczynku w tym samym jeszcze lub innym tygodniu okresu rozliczeniowego.

Nie jestem natomiast przekonana, czy odwołanie się ustawodawcy do okresu rozliczeniowego, również $\mathrm{w}$ innych przepisach związanych $\mathrm{z}$ bilansowaniem odpoczynku, jest zabiegiem właściwym. Być może lepszą formułą byłoby ustalenie konkretnej liczby tygodni (stosunkowo niskiej), w ramach której powinno nastąpić wymagane przez ustawodawcę zrównoważenie zwiększonej ilości pracy w danym czasie, w tym przypadku udzielenie innego niż planowany dnia wolnego od pracy. $\mathrm{Z}$ jednej strony, jeśli pracownik świadczy pracę w dniu dodatkowo wolnym przypadającym na koniec okresu rozliczeniowego, pracodawca nie ma obiektywnych możliwości zrealizowania wymogu wynikającego z powołanej normy, a z drugiej strony, odwołanie się do końca okresu rozliczeniowego nie we wszystkich przypadkach stanowi wystarczającą gwarancję efektywnej realizacji prawa do odpoczynku. W wyniku wprowadzonych do Kodeksu pracy w ostatnich latach zmian, okresy rozliczeniowe mogą bowiem zostać wydłużone nawet do 12 miesięcy. I choć prawdą jest, że pracownicy muszą mieć świadomość występowania okresów zwiększonego natężenia pracy, a tym samym zakłócenia określonego rytmu wypoczynku, to jednak, jak słusznie zauważył Z. Góral, dla zachowania istoty omawianej zasady konieczne jest ustalenie wyraźnych granic takiej elastyczności ${ }^{557}$.

$\mathrm{Z}$ perspektywy prawa pracownika do wypoczynku istotnym mankamentem w zakresie obowiązującej regulacji zasady pięciodniowego tygodnia pracy jest także, dostrzeżony w doktrynie prawa pracy, brak wyraźnie określonych konsekwencji bezprawnego jej naruszenia w sytuacji, gdy nie dojdzie do przekroczenia tygodniowej normy czasu pracy (zorganizowanie pracy przez sześć dni w tygodniu, przy niższej niż ośmiogodzinna normie dobowej). Zdaniem M. Latos-Miłkowskiej, pracownik po upływie okresu rozliczeniowego „ «nie odzyska» dni wolnych od pracy”, wątpliwa jest również ich rekompensata finansowa ${ }^{558}$. Problemem jest tu więc brak konkretnego przepisu, który by prawo do innego dnia wolnego i w tym przypadku w określonym terminie gwarantował. Nawet uznanie, że ze względu

557 Por. Z. Góral, Podstawowe zasady..., s. 1118.

558 Por. M. Latos-Miłkowska, Czas pracy..., s. 225. 
na podniesienie prawa do dni wolnych od pracy do rangi podstawowej zasady prawa pracy, pracownik ma roszczenie o dni wolne nieograniczone upływem okresu rozliczeniowego do końca problemu nie rozwiązuje. Upływ długiego czasu pomiędzy momentem nieuzyskania dnia dodatkowego wolnego a momentem jego rekompensaty innym dniem wolnym może bowiem podważać celowość udzielenia takiego dnia wolnego. Należałoby zatem uznać na gruncie aktualnego stanu prawnego, że ponieważ reguła pięciodniowego tygodnia pracy ma charakter przeciętny, w opisanym przypadku pracownik powinien uzyskać prawo do powstrzymania się od pracy w ostatnich dniach okresu rozliczeniowego, w którym prawo do dni dodatkowo wolnych może być jeszcze przez pracodawcę zrealizowane.

Docelowo zaś, z uwagi na należyte zabezpieczenie prawa do odpoczynku związanego z pracą, należy albo rozważyć zasadność utrzymania przepisów pozwalających na tak znaczne i stosunkowo łatwe wydłużanie okresów rozliczeniowych, jak to występuje obecnie, albo też powiązać zasadę pięciodniowego tygodnia pracy $\mathrm{z}$ innymi czasookresami, $\mathrm{w}$ jakich powinno nastąpić jej rozliczenie i ustalić skutki niedopełnienia tego obowiązku. Tylko wówczas wypoczynkowa funkcja dni dodatkowo wolnych od pracy oraz tych udzielonych $\mathrm{w}$ zamian za pracę $\mathrm{w}$ dniu dodatkowo wolnym będzie mogła zostać w pełni zrealizowana.

Z drugiej strony, powstaje również kwestia oceny możliwości wykonywania pracy $\mathrm{w}$ dniach dodatkowo wolnych od pracy $\mathrm{z}$ woli pracownika. W przeszłości $\mathrm{w}$ literaturze prawa pracy wyrażono pogląd, zgodnie z którym dni te stanowią uprawnienie pracowników, a zatem mogą oni nimi swobodnie dysponować. Dopuszczalne jest zatem podejmowanie pracy $\mathrm{w}$ te dni, jeśli tylko ma to charakter dobrowolny ${ }^{55}$.

Teza ta, moim zdaniem, pozostaje w jakiejś mierze aktualna także na gruncie obecnego stanu prawnego. Ustawodawca nie wprowadza zakazu pracy w te dni, ale zasadę, według której praca powinna być organizowana w sposób dający pracownikowi możliwość odpoczynku średnio w ciągu dwóch dni w tygodniu. Tym samym w charakter dni dodatkowo wolnych od pracy jest wpisana niejako pewna fluktuacja tego odpoczynku - dni te wyznacza pracodawca, przy czym nie musi to być jeden dzień dodatkowo wolny w każdym tygodniu (zasada pięciodniowego tygodnia pracy jest bowiem normą przeciętną). Mimo że pracownik dobrowolnie podejmuje pracę $\mathrm{w}$ tym dniu, $\mathrm{w}$ jej wyniku powstaną zwykle godziny nadliczbo$\mathrm{we}^{560}$. Wówczas godząc się na pracę $\mathrm{w}$ dniu dodatkowo wolnym od pracy, pracownik de facto akceptuje jedynie przesunięcie dnia wolnego na inny termin $\mathrm{z}$ nim uzgodniony. Analizowany wyżej art. $151^{3}$ k.p. i w tym przypadku powinien znaleźć swoje zastosowanie. Użyty w nim zwrot „pracownikowi, który ze względu na oko-

559 Tak por. W. Masewicz, Czas pracy, s. 192.

560 W kontekście podstawy wykonywania takiej pracy SN przyjmuje szeroką interpretację, uznaje bowiem, że pracą w godzinach nadliczbowych jest nie tylko praca wykonywana na wyraźne polecenie pracodawcy, ale też praca wykonywana za wiedzą (milczącą aprobatą) pracodawcy, a w szczególnych przypadkach nawet bez takiej wiedzy, jeśli została podjęta bezpośrednio w celu ochrony jego interesów. 
liczności przewidziane w art. $151 \$ 1$ wykonywał pracę w dniu wolnym” nie może być bowiem odnoszony wyłącznie do pracy w nadgodzinach, wykonywanej na polecenie pracodawcy uzasadnione jedną z dwóch przesłanek wymienionych w tym przepisie, ale należy go raczej odnosić do pracy, którą w świetle art. 151 k.p. można kwalifikować jako wykonywaną w godzinach nadliczbowych, abstrahując od przyczyn jej wykonywania (w przeciwnym razie polecenie sprzeczne $\mathrm{z}$ prawem $\mathrm{w}$ zakresie przesłanek przekreślałoby nadliczbowy charakter takiej pracy). Ponadto nie można wykluczać w razie dobrowolnego wykonywania pracy w dniu dodatkowo wolnym istnienia np. szczególnych potrzeb pracodawcy. Takie stanowisko jest też niewątpliwie najbardziej kompatybilne $\mathrm{z}$ art. 14 k.p. i wyrażoną w nim podstawową zasadą prawa pracy.

Niemniej sposób sformułowania art. $151^{3}$ k.p. powoduje, że może być on też inaczej rozumiany, a mianowicie, że odwołując się do okoliczności przewidzianych w art. 151 k.p., dotyczy on wyłącznie tych przypadków, w których pracownik świadczy pracę $\mathrm{z}$ jednego $\mathrm{z}$ dwóch powodów, o których mowa $\mathrm{w}$ tym przepisie, zwykle na polecenie pracodawcy. W konsekwencji pracownik, który zgodził się świadczyć pracę w godzinach nadliczbowych w innych okolicznościach, będzie mieć prawo do jej rekompensaty na zasadach ogólnych, tj. wynagrodzenia lub czasu wolnego. Zawężeniu obowiązku udzielenia innego dnia wolnego nie stoi na przeszkodzie art. 131 k.p., według którego tygodniowy czas pracy łącznie z godzinami nadliczbowymi nie może przekraczać przeciętnie 48 godzin w przyjętym okresie rozliczeniowym. Akceptacja powyższego stanowiska jest jednak równoznaczna $\mathrm{z}$ dopuszczeniem zrzeczenia się przez pracownika prawa do dnia dodatkowo wolnego od pracy, a tym samym korzystania z zasady pięciodniowego tygodnia pracy, z której wynika, że jeśli w jednym tygodniu okresu rozliczeniowego pracownik świadczył pracę sześć dni, w innym tygodniu powinien ją wykonywać cztery dni, co wydaje się już wątpliwe.

W przeciwieństwie do urlopów wypoczynkowych, niewykorzystane dni dodatkowo wolne od pracy (np. z powodu choroby), zarówno obecnie, jak i w przeszłości, nie podlegają rekompensacie innym dniem wolnym czy w jakiejkolwiek innej formie, zwłaszcza finansowej, co wynika poniekąd z charakteru tych dni jako elementu organizacji czasu pracy chroniącego przed przeciążeniem związanym $\mathrm{z}$ aktualnie wykonywaną pracą.

\subsection{Prawo do odpoczynku a urlopy pracownicze}

Pojęcie urlopu, choć często stosowane w przepisach prawa pracy, nie zostało w nich zdefiniowane. W literaturze wskazuje się jednak, że urlop jest to okresowa przerwa w wykonywaniu pracy, przysługująca pracownikowi indywidualnie w sytuacjach określonych w ustawie ${ }^{561}$. W bardziej opisowym ujęciu urlop pracowniczy

561 Por. T. Zieliński, Zarys..., cz. II, s. 277. 
postrzega się natomiast jako przewidziane w przepisach prawa przypadki, kiedy pracownik jest zwolniony $\mathrm{z}$ obowiązku pozostawania $\mathrm{w}$ dyspozycji pracodawcy w zakładzie pracy lub w innym miejscu przeznaczonym do jej wykonywania, z powodów leżących po jego stronie, które sprawiają, że pracownik ma prawo do takiego zwolnienia, oznaczające albo roszczenie wobec pracodawcy (udzielenie urlopu staje się wówczas obowiązkiem tego ostatniego), albo przynajmniej możliwość wystąpienia do niego ze stosownym wnioskiem (przy urlopach udzielanych fakultatywnie), a zwolnienie to obejmuje określoną, względnie dużą liczbę dni i jest przez ustawodawcę wprost nazwane urlopem ${ }^{562}$.

Obok urlopów na gruncie przepisów prawa pracy można wyróżnić również zwolnienia od pracy, potocznie określane „urlopami okolicznościowymi”, wymienione głównie w rozporządzeniu Ministra Pracy i Polityki Socjalnej z 15 maja $1996 \mathrm{r}$. w sprawie sposobu usprawiedliwiania nieobecności w pracy oraz udzielania pracownikom zwolnień od pracy ${ }^{563}$, ale formułowane też $w$ aktach rangi ustawowej (np. wynikające z Kodeksu pracy zwolnienie na poszukiwanie pracy). Trudno wskazać na istotniejsze różnice pomiędzy nimi a instytucją urlopu, poza tym, że zwolnienia mają charakter krótkotrwały, obejmują zwykle część dnia roboczego lub pojedyncze dni, tymczasem mianem urlopów ustawodawca wydaje się określać z założenia dłuższe przerwy w wykonywaniu pracy. Ich cel, podobnie jak urlopów pracowniczych, jest zróżnicowany, ale co istotne z punktu widzenia zakresu prowadzonych rozważań, niepowiązany jednak bezpośrednio z funkcją wypoczynkową. Nie zawsze też towarzyszy im gwarancja wynagrodzenia.

Wbrew zgłaszanym w przeszłości postulatom, aby terminem „urlop”, ze względów historycznych, społecznych i prawnych, objąć tylko urlop wypoczynkowy ${ }^{564}$, w prawie pracy wyróżnia się kilka co najmniej typów urlopów pracowniczych. Obok urlopu wypoczynkowego występują również urlopy bezpłatne, szkoleniowe, urlopy związane z rodzicielstwem czy gwarantowane na gruncie określonych pragmatyk pracowniczych - urlopy dla poratowania zdrowia oraz urlopy tzw. naukowe. Urlopy te, oprócz różnych źródeł regulacji, odmiennych przesłanek ich nabycia i długości, mają zasadniczo, w zależności od ich rodzaju, w miarę precyzyjnie określony cel prawny i tylko w jednym przypadku jest to bezpośrednio wypoczynek. Funkcja urlopu wypoczynkowego, jak podkreślano w literaturze, jest jednocześnie jego immanentną cechą pozwalającą odróżnić go od innych zwolnień od pracy $^{565}$. Nie oznacza to, że również inne urlopy nie mogą w jakiejś mierze tej funkcji realizować, skoro wszystkie stanowią zwolnienie od obowiązku świadczenia pracy u danego pracodawcy, w tym zwłaszcza urlop bezpłatny czy urlop dla poratowania zdrowia, niemniej z całą pewnością nie wypoczynek jest ich zasadniczym przeznaczeniem. Chodzi bowiem najczęściej o przesunięcie ca-

562 Por. Z. Góral, Wprowadzenie, [w:] M. Kuba, M. Nowak, E. Staszewska, Urlopy pracownicze, red. Z. Góral, Warszawa 2016, s. 18.

563 Tekst jednolity: Dz. U. 2014, poz. 1632.

564 Por. tak M. Święcicki, Prawo pracy, s. 442.

565 Por.: J. Loga, Poglądy nauki burżuazyjnej..., s. 53 oraz W. Szubert, Zarys..., s. 225. 
łej energii i wysiłku w innym niż praca kierunku, np. na opiekę nad dzieckiem, przygotowanie do egzaminów, przygotowanie pracy, m.in. habilitacyjnej, powrót do zdrowia i związaną z nim np. niezbędną rehabilitację.

W odniesieniu do urlopów bezpłatnych, które ewentualnie mogą być rozważane w kontekście wypoczynku, warto podkreślić, że one też stanowią grupę wewnętrznie niespójną pod względem celu, któremu służą, są bowiem wśród nich przecież urlopy, których celem z definicji jest praca czy pełnienie określonych funkcji, bądź realizacja określonych zadań (np. urlop udzielany za zgodą pracownika w celu wykonywania pracy u innego pracodawcy - art. $174^{1}$ k.p., urlop dla pracownika powołanego do pełnienia $\mathrm{z}$ wyboru funkcji związkowej ${ }^{566}$, dla członka zarządu komisarycznego na czas pełnienia tej funkcji ${ }^{567}$ czy dla posłów i senatorów ${ }^{568}$ ). W zasadzie ewentualnie urlop bezpłatny udzielany na wniosek pracownika, który nie ma szczególnego charakteru, oraz urlop udzielany młodocianym mogą mieć dla realizacji prawa do odpoczynku pewne znaczenie.

Jeśli chodzi o pierwszy z wymienionych urlopów, ustawodawca nie precyzuje przyczyn jego udzielenia, wymaga jedynie w tej sprawie pisemnego wniosku pracownika. Nie można wykluczyć zatem, że powodem wystąpienia z takim wnioskiem będzie nadmierne zmęczenie i związana z nim chęć odpoczynku, choć mogą to też być zupełnie inne motywy. O uwzględnieniu lub nie wniosku pracownika decyduje pracodawca, stąd ewentualne gwarancje prawa do odpoczynku w tym zakresie są mocno ograniczone. Trzeba mieć również na uwadze, że nie jest on wliczany do stażu pracy, stosunek pracy ulega swego rodzaju zawieszeniu, pracownik nie nabywa więc prawa do różnych świadczeń w jego trakcie, w szczególności nie uzyskuje wynagrodzenia. Skorzystanie z tego urlopu (jak i, co do zasady, z innych bezpłatnych) może także doprowadzić do proporcjonalnego obniżenia wymiaru urlopu wypoczynkowego, na zasadach określonych w art. $155^{2}$ k.p., co będzie przedmiotem analizy w kolejnej części niniejszego opracowania ${ }^{569}$. Nie jest to zatem instytucja, która sprzyjałaby wypoczynkowi, pozwalała w szerszej skali skutecznie realizować sformułowaną w tym zakresie zasadę.

Niewątpliwie natomiast znaczenie prowypoczynkowe można przypisać urlopowi bezpłatnemu dotyczącemu pracowników młodocianych. Zgodnie z art. $205 \$ 4$ k.p. urlop taki jest bowiem udzielany młodocianemu będącemu uczniem szkoły

566 Art. 25 ustawy z 23 maja 1991 r. o związkach zawodowych, tekst jednolity: Dz. U. 2015, poz. 1881. Por. szerzej o tym urlopie K. Rączka, Urlopy bezpłatne i zwolnienia od pracy działaczy zwiqzzkowych, PiZS 2013, nr 11, s. 19 i n.

567 Art. 146 ustawy z 29 sierpnia 1997 r. - Prawo bankowe, tekst jednolity: Dz. U. 2015, poz. 128, ze zm.

568 Art. 29 i 30 ustawy o wykonywaniu mandatu posła i senatora, tekst jednolity: Dz. U. 2016, poz. 1510, ze zm.

569 Wydawać by się mogło, że cele tych urlopów zostały przez ustawodawcę uznane za zbieżne, skoro skorzystanie z urlopu bezpłatnego redukuje wymiar urlopu wypoczynkowego. Wniosek taki należy jednak zdecydowanie odrzucić, biorąc pod uwagę, że przepis dotyczący proporcjonalnego obniżania wymiaru urlopu dotyczy z zasady wszystkich urlopów bezpłatnych, nawet tych, które mają wyraźnie sprecyzowane przeznaczenie, inne niż odpoczynek. 
dla pracujących, w okresie ferii szkolnych łącznie z urlopem wypoczynkowym, w wymiarze nieprzekraczającym dwóch miesięcy. Przyjmuje się, że jego celem jest właśnie umożliwienie młodocianemu „skorzystania z wypoczynku” obejmującego cały okres ferii szkolnych, w sytuacji gdy są one dłuższe niż przysługujący $\mathrm{mu}$ urlop wypoczynkowy ${ }^{570}$. Urlop ten stanowi zatem nieodpłatne przedłużenie czasu przeznaczonego na odpoczynek pracownika młodocianego, uzasadnione jego wiekiem.

Szczególna jest również konstrukcja tego urlopu, podporządkowana, jak można domniemywać, wskazanemu celowi. Pracodawca jest bowiem zobowiązany do jego udzielenia, jeśli z takim wnioskiem wystąpi młodociany, a ponadto wlicza się on do okresu pracy, od którego zależą uprawnienia pracownicze. Pracodawca nie ma też żadnych możliwości odwołania pracownika młodocianego z takiego urlopu bezpłatnego, a poza tym należy przyjąć, że skorzystanie z niego nie może powodować proporcjonalnego zmniejszenia rocznego wymiaru urlopu wypoczynkowego, jak to było w przypadku wcześniejszym, pozostawałoby to bowiem w sprzeczności z funkcją i charakterem tego urlopu ${ }^{571}$.

W przypadku urlopu zdrowotnego, który bywa w praktyce niesłusznie postrzegany jako realizujący cele wypoczynkowe ${ }^{572}$, jego różne od urlopu wypoczynkowego funkcje były szczególnie eksponowane w orzecznictwie Trybunału Sprawiedliwości UE, wcześniej omawianym. Jest to urlop, który choć stanowi zwolnienie z obowiązku świadczenia pracy, jak wszystkie wyżej wskazane urlopy, to jednak $\mathrm{w}$ założeniu jego głównym motywem jest umożliwienie powrotu do zdrowia w związku z trwającą lub przebytą chorobą. Wysiłek organizmu ma zatem zostać skierowany na walkę z nią oraz jej skutkami, a nie na odpoczynek w rozumieniu wcześniej przyjętym.

Tym samym realizując cele dyrektywy UE w sprawie niektórych aspektów organizacji czasu pracy, należy mieć na uwadze, że urlop wypoczynkowy nie powinien pokrywać się z innymi zwolnieniami od pracy, których przeznaczeniem nie jest wypoczynek w rozumieniu wcześniej przyjętym, w tym m.in. właśnie urlopem zdrowotnym, macierzyńskim czy zwolnieniem od pracy, np. z powodu choroby. Jeśli pracownik nie może wykorzystać urlopu wypoczynkowego ze względu na nieobecność w pracy wywołaną wskazanymi wyżej przykładowo okolicznościa$\mathrm{mi}$, należy udzielić mu tego urlopu w innym terminie.

Tym bardziej urlop wypoczynkowy nie może przypadać na przerwy w pracy powstałe z przyczyn od pracownika niezależnych, w których ten ostatni powinien pozostawać w gotowości do jej świadczenia (np. na czas przestoju).

570 Por. E. Staszewska, [w:] M. Kuba, M. Nowak, E. Staszewska, Urlopy..., s. 171 i podana tam literatura.

571 Tamże, s. 172. Por. też E. Chmielek-Łubińska, Pracownicze urlopy bezpłatne i zwolnienia od pracy, Warszawa 1999, s. 62 i n.

572 Por. m.in. wyrok SN z 10 lutego 1988 r., I PR 7/88, „Służba Pracownicza” 1988, nr 5, s. 28. Sąd, moim zdaniem, błędnie uznał w nim, że pracownikowi korzystającemu z urlopu zdrowotnego, który z tego powodu nie świadczył w danym roku pracy, nie przysługuje urlop wypoczynkowy, gdyż cele tych urlopów są zbieżne. 
Zgodnie z Konstytucją oraz art. 14 k.p. nadającym prawu do odpoczynku rangę prawa podstawowego, urlop wypoczynkowy jest kolejną z bezpośrednich form jego realizacji.

Z perspektywy prawa do odpoczynku jest jednocześnie instytucją szczególną. W przeciwieństwie do wcześniej wskazanych instrumentów urzeczywistniających zasadę wyrażoną w art. 14 k.p., urlop jest stosunkowo długą przerwą w świadczeniu pracy, wykorzystywaną z zasady w skali roku kalendarzowego, której celem jest pełna regeneracja psychofizyczna organizmu, a nie tylko krótkotrwałe zabezpieczenie przed przeciążeniem pracą, nadmiernym zmęczeniem w danym dniu czy tygodniu. Ma on zatem przyczynić się do zniwelowania swego rodzaju strat stanowiących naturalne następstwo pracy wykonywanej przez wiele miesięcy niemal codziennie ${ }^{573}$. Ze swej natury powinien on umożliwić pracownikowi zmianę miejsca pobytu, otoczenia, klimatu, oderwanie się od codziennej rutyny, a przez to sprzyjać osiągnięciu możliwie największego odprężenia koniecznego dla całkowitej regeneracji si1574. Z tego punktu widzenia można zaryzykować twierdzenie, że stanowi on podstawowy, wiodący instrument ochrony prawa do odpoczynku od wykonywanej pracy ${ }^{575}$.

Niemniej nie ulega wątpliwości, że pełne, skuteczne zagwarantowanie tego prawa wymaga łączenia różnych, uzupełniających się elementów, a więc obok urlopu również takich, które służą skracaniu czy odpowiedniemu rozłożeniu czasu pracy ${ }^{576}$.

Współcześnie w zasadzie nie powinno budzić większych zastrzeżeń, że urlop wypoczynkowy, biorąc pod uwagę jego pojęcie i funkcje, wpisuje się też bardzo mocno w problematykę szeroko postrzeganej ochrony pracy ${ }^{577}$, której głównym celem jest ochrona życia i zdrowia osób zatrudnionych, czy nawet pośrednio w zagadnienia szeroko rozumianego bezpieczeństwa i higieny pracy, definiowanego jako konieczność wyeliminowania ze środowiska pracy czynników zagrożenia dla życia i zdrowia ludzkiego ${ }^{578}$, a więc także np. nadmiernego zmęczenia. Źródłem owych zagrożeń może być m.in. zbyt duża uciążliwość pracy, zwłaszcza jeśli nie jest ona odpowiednio rekompensowana czasem wolnym od pracy, czy niewłaściwa organizacja pracy $^{579}$, w tym nieodpowiednie gospodarowanie czasem pracy zatrudnionych w zakładzie osób.

573 Por. A. Uklejska, Aktualne kierunki..., s. 23.

574 Tamże.

575 Nieco inaczej na tę kwestię zapatruje się A. Kosut. Autorka uznała, że zmiany dokonane w ostatnich latach w obszarze czasu pracy, dotyczące m.in. okresów odpoczynku czy maksymalnej tygodniowej normy czasu pracy, nadają tym instrumentom pierwszorzędne znaczenie w zakresie realizacji zasady wyrażonej w art. 14 k.p. Por. taż, Przemiany regulacji prawnej urlopów wypoczynkowych w Kodeksie pracy, [w:] Przemiany prawa pracy..., s. 194.

576 Por. A. Uklejska, Aktualne kierunki..., s. 23. Teza ta słusznie znalazła aprobatę we współczesnych analizach prawa urlopowego; por. A. Kosut, Przemiany..., s. 194.

577 Ochrona pracy w znaczeniu szerszym to „wszystkie normy prawa pracy, które służą interesom życiowym pracowników”. Por. L. Florek, T. Zieliński, Prawo pracy, s. 225 i n.

578 Por. A. Nałęcz, Ochrona pracy, [w:] Polityka społeczna, red. A. Rajkiewicz, Warszawa 1979, s. 399. L. Florek ujmuje to jako „wyłączenie lub zmniejszenie niekorzystnego wpływu pracy” na zdrowie fizyczne i psychiczne pracownika. Por. L. Florek, T. Zieliński, Prawo pracy, s. 225.

579 Por. M. Święcicki, Prawo pracy, s. 493. 
Aspekt ten jest szczególnie eksponowany na gruncie prawa UE oraz towarzyszącego mu orzecznictwa (por. wcześniejsze rozważania).

Posługując się pojęciem ochrony zdrowia, należy je interpretować szeroko, zwłaszcza w kontekście problematyki czasu pracy i urlopów wypoczynkowych. Zdrowie, zgodnie z Konstytucją Światowej Organizacji Zdrowia, jest „stanem zupełnej pomyślności fizycznej, umysłowej i społecznej, a nie jedynie brakiem choroby lub ułomności” ${ }^{880}$. Korzystanie z „najwyższego, osiągalnego poziomu zdrowia jest jednym z podstawowych praw każdej istoty ludzkiej" ${ }^{381}$.

Tymczasem w zakresie fizjologii pracy, o czym była mowa na początku niniejszego opracowania, $\mathrm{z}$ całą mocą podkreśla się negatywny wpływ na tak rozumiane zdrowie człowieka braku równowagi pomiędzy wydatkowaniem sił w związku z pracą a czasem na ich regenerację $e^{582}$. Odpoczynek jest jednym z podstawowych warunków utrzymania dobrej kondycji psychicznej i fizycznej organizmu, jego wysokiej odporności na stres i inne związane z pracą czynniki. Jego niedostatek stanowi zagrożenie nie tylko dla samego zatrudnionego, ale także współpracujących z nim osób, może bowiem zwiększać ryzyko wypadku przy pracy w związku z nadmiernym zmęczeniem pracownika i osłabieniem jego refleksu i koncentracji.

Bywa jednak, że poza główną funkcją urlopu wypoczynkowego, tj. funkcją wypoczynkową, ustawodawcy starali się poprzez tę instytucję realizować również inne cele, niekiedy pozostające nawet $\mathrm{z}$ nią $\mathrm{w}$ sprzeczności. Urlop był bowiem, szczególnie w przeszłości, również w polskim prawie, wykorzystywany jako środek służący do dyscyplinowania pracowników czy mający skłaniać ich do pozostawania w stałym zatrudnieniu. Znajdowało to wyraz przede wszystkim w konstrukcji przesłanek nabycia prawa do urlopu oraz jego wymiaru.

\section{Urlop wypoczynkowy jako podstawowy instrument realizacji prawa do odpoczynku w ujęciu ewolucyjnym}

Urlop wypoczynkowy, mimo istotnych funkcji, jakie spełnia, na poziomie ustawowym został zagwarantowany osobom pracującym stosunkowo późno, w zasadzie dopiero w pierwszej połowie XX w., kiedy to w myśli społecznej i prawnej zaczęła przebijać się idea wypoczynku dla wypoczynku, a nie jedynie ochrony mas

580 Konstytucja Światowej Organizacji Zdrowia. Porozumienie zawarte przez Rządy reprezentowane na Międzynarodowej Konferencji Zdrowia i Protokół dotyczący Międzynarodowego Urzędu Higieny Publicznej, podpisane w Nowym Jorku 22 lipca 1946 r., Dz. U. 1948, Nr 61, poz. 477. Por. też wyrok TSUE z 12 listopada 2006 r. w sprawie Wielka Brytania przeciwko Radzie UE, C-84/94, pkt 15.

581 Tamże.

582 Por. G. Lehmann, Praktyczna fizjologia..., s. 42 i n. 
robotniczych przed ich fizycznym wyniszczeniem związanym z pracą przekraczającą granice ludzkiej wytrzymałości. Stał się on zatem swego rodzaju kwintesencją ewolucji rozwiązań prawnych w analizowanym zakresie.

Ustawowa regulacja urlopów wypoczynkowych ma w Polsce bogatą tradycję.

Warto podkreślić, że cząstkowe unormowania w tym zakresie, obejmujące najczęściej wybrane tylko grupy pracowników, obowiązywały już w okresie zaborów. Na podstawie przepisów państw zaborczych z urlopów wypoczynkowych mogli korzystać urzędnicy administracji państwowej oraz urzędnicy komunalni, pracownicy nauki, a także część pracowników umysłowych zatrudniona w handlu ${ }^{583}$. Na terenach zaboru austriackiego podstawę udzielenia urlopu pomocnikom handlowym stanowiła ustawa z 16 stycznia 1910 r., która przyznawała ten urlop w wymiarze zależnym od stażu pracy w danym zakładzie pracy wynoszącym minimum $10 \mathrm{dni}^{584}$.

W pozostałych przypadkach urlop mógł być ewentualnie udzielany na podstawie zawieranych układów zbiorowych pracy bądź umów o pracę. Na umowne zastrzeżenie prawa do urlopu mogli sobie jednak pozwolić tylko nieliczni - zwykle pracownicy na stanowiskach kierowniczych, blisko związani z pracodawcą ${ }^{585}$.

W XIX i początkach XX w. prawo do dłuższego, cyklicznego urlopu było w zasadzie rzadkością, a możliwość skorzystania z niego postrzegano jako wyraz szczególnego uznania, czy wyróżnienia ${ }^{586}$. Problem ten podnoszono m.in. w ówczesnej prasie, w której zwracano uwagę na konieczność zmiany istniejącego stanu rzeczy i rozszerzenia uprawnień urlopowych przynajmniej na przedstawicieli klasy średniej ${ }^{587}$.

W świetle powyższego nie może dziwić, że pierwsza polska ustawa urlopowa z 16 maja 1922 r. ${ }^{588}$ była oceniana jako niezwykle postępowa, zwłaszcza ze względu

583 Por. szerzej S. Roszkowski, Urlopy wypoczynkowe pracowników najemnych, Warszawa 1929, s. 12.

584 Tamże.

585 Por. M. Święcicki, Prawo pracy, s. 443.

586 Por. tak M. Olkuśnik, Podróż, turystyka i wypoczynek pozamiejski w świadomości społeczeństwa Warszawy na przełomie XIX i XX w., Warszawa 2013, s. 188.

587 Szczególnie w „Kurierze Warszawskim” kwestia ta była często podnoszona. Z jednej strony donoszono o szczególnie istotnej sprawie społecznej i etycznej, rozważanej w wielu państwach europejskich, jaką jest to, „żeby ludzie wszelkich stanów spędzali czas, wolny od zajęć obowiązkowych, w odpowiednich miejscach i w odpowiedni sposób”, a z drugiej zaś popierano mocno inicjatywę grona aptekarzy, którzy „urządzili dla swych pracowników [...] wakacje w formie 7-10-dniowego odpoczynku". Na ten czas zwolniono pracowników z obowiązku świadczenia pracy, a w ich miejsce zorganizowano zastępstwo, którego koszty pokrywał pracodawca. Dziennikarze ocenili, że: „Byłoby wielce pożądane, aby ten dobry przykład znalazł jak najszersze naśladownictwo". O ówczesnej sytuacji pisano zaś m.in. w jednym z tygodników w następujący sposób: „Dzięki warunkom, jakie się w ostatnich latach wytworzyły, tak zwane urlopy mężczyzn, pracujących, rozumie się po instytucjach i biurach prywatnych, należą do rzadkości. Albo się dostaje tego rodzaju łaskę raz na kilka lat nb. w żadnym wypadku dłużej jak na przeciąg pięciu lub sześciu tygodni, albo dla niepsucia sobie marki u zwierzchności, nie upomina się o nią wcale” (tygodnik „Miód i Powieści” 1903, nr 7, s. 77 i n.), za: M. Olkuśnik, Podróż..., s. 188 i n.

588 Por. ustawa z 16 maja 1922 r. o urlopach dla pracowników zatrudnionych w przemyśle i handlu, Dz. U. 1922, Nr 40, poz. 334 (nieobowiązująca). 
na to, że czyniła $\mathrm{z}$ urlopu wypoczynkowego instytucję ustawową o stosunkowo szerokim zakresie podmiotowym ${ }^{59}$. Ocenia się, że pod tym względem Polska wyprzedziła większość innych krajów europejskich oraz regulacje międzynarodo$\mathrm{we}^{590}$. Jeszcze w $1935 \mathrm{r}$. urlop wypoczynkowy dla robotnika gwarantowało prawnie bowiem zaledwie 12 państw ${ }^{591}$.

Prawo do corocznego, płatnego urlopu wypoczynkowego, sformułowane wprost $\mathrm{w}$ powołanej ustawie, obejmowało dość szeroki, jak na ówczesne czasy, krąg podmiotów, byli to bowiem pracownicy zatrudnieni na podstawie umowy o pracę w przemyśle, górnictwie, handlu, biurowości, komunikacji i przewozie, szpitalnictwie, instytucjach opieki społecznej oraz użyteczności publicznej, a także w innych zakładach pracy, „choćby na zysk nieobliczonych”, bez względu na to czy stanowily one własność prywatną, państwową czy samorządową, jeśli tylko zatrudniano w nich pokrewne wymienionym kategorie „pracowników najemnych". Przepisom ustawy nie podlegały jednak zakłady przemysłowe rzemieślnicze, zatrudniające czterech lub mniej pracowników ${ }^{592}$; dodatkowo ustawodawca wyłączył również spod jej stosowania pracowników przedsiębiorstw sezonowych, w których praca trwała krócej niż 10 miesięcy. Wyjątki te stwarzały pole do licznych nadużyć w praktyce i były przedmiotem krytyki w ówczesnej literaturze przedmiotu ${ }^{593}$. Ostatecznie wypoczynek w tym zakresie zagwarantowano niemal

589 Por. m.in. W. Szubert, Zarys..., s. 25. Por. też J. Loga, Polskie prawo pracy w okresie międzywojennym, Łódź 1980, s. 4. Wcześniejsze od polskiej regulacje urlopowe, przyjęte np. w Niemczech, Szwajcarii, Francji i Danii, zwykle dotyczyły jedynie wybranych grup zatrudnionych (np. urzędników, pracowników określonych służb, pomocników handlowych czy młodocianych) i nie przyznawały pracownikom roszczenia o urlop, ale uzależniały jego udzielenie od względów służbowych lub wystąpienia szczególnych okoliczności po stronie pracownika, wskazujących na potrzebę skorzystania z tego świadczenia. Por. w szczególności ustawa szwajcarska z 1879 r. Na przykład wcześniejsza od polskiej ustawa niemiecka z 1873 r. regulowała prawo do urlopu tylko w stosunku do urzędników państwowych. Z czasem, w 1938 r., prawo to zagwarantowano też młodocianym. Por. J. Loga, Urlopy wypoczynkowe, s. 17 i n.

590 Por. J. Loga, Polskie prawo..., s. 3.

591 Por. A. Uklejska, Aktualne kierunki..., s. 22.

592 Nie dotyczyło to jednak prawa do urlopu „terminatorów i uczniów”, którzy nabywali urlop niezależnie od wielkości zatrudnienia w danym zakładzie.

593 Por. m.in.: S. Roszkowski, Urlopy wypoczynkowe..., s. 51 i n.; M. Święcicki, Instytucje polskiego prawa pracy w latach 1918-1939, Warszawa 1960, s. 73; J. Loga, Urlopy wypoczynkowe, s. 30. Chodziło o to, że na podstawie powyższych wyjątków próbowano wyłączyć spod zakresu działania ustawy całe grupy przedsiębiorstw, np. tartaki, uznając je za przedsiębiorstwa sezonowe. Tego rodzaju unormowania powodowały również, że manipulowano stanem zatrudnienia lub czasem trwania prac w określonych przedsiębiorstwach, aby obejść przepisy ustawy. Problem rozwiązywały tylko częściowo przepisy wykonawcze do ustawy, w których przyjęto, że małe zakłady są zwolnione z obowiązku udzielania urlopów tylko wówczas, gdy w roku poprzednim co najmniej przez sześć miesięcy nie zatrudniały więcej niż czterech pracowników (§ 3 rozporządzenia Ministra Pracy i Opieki Społecznej z 11 czerwca 1923 r. wydane w porozumieniu z Ministrem Przemysłu i Handlu w przedmiocie wykonania ustawy z 16 maja 1922 r. o urlopach dla pracowników zatrudnionych w przemyśle i handlu, Dz. U. 1923, Nr 62, poz. 464. 
wszystkim robotnikom, z wyjątkiem zatrudnionych w małych zakładach pracy oraz w rolnictwie ${ }^{594}$, co i tak na ówczesne warunki było dużym osiągnięciem. Niemniej ogólne zasady prawa urlopowego rozciągnięto także na rolnictwo i leśnictwo, tyle że w drodze układu zbiorowego pracy ${ }^{595}$.

Ponadto, z czasem w odniesieniu do części pracowników nieobjętych postanowieniami analizowanej ustawy, zastosowanie znalazł art. 465 Kodeksu zobowia$z a n^{596}$, który stanowił, że pracownikowi, dla którego stosunek pracy jest wyłącznym lub głównym źródłem utrzymania, pracodawca po rocznym trwaniu tego stosunku jest zobowiązany corocznie, w terminie przez siebie oznaczonym, udzielić urlopu tygodniowego.

Niektóre grupy zatrudnionych zostały też objęte odrębnymi systemami urlopowymi na podstawie odpowiednich pragmatyk (w tym m.in. nauczyciele oraz urzędnicy służby cywilnej) ${ }^{597}$.

Ustawa poświęcona urlopom wypoczynkowym z 1922 r. wprowadzała wiele istotnych gwarancji, optymalizujących podstawowe funkcje urlopu wypoczynkowego, w tym przede wszystkim coroczność omawianego świadczenia i jego nieprzerwany charakter, odpłatność urlopu, z zastrzeżeniem jednak utraty wynagrodzenia za czas urlopu w razie podjęcia innego zatrudnienia w jego trakcie, planowe jego udzielanie, czy przesunięcie urlopu, na wniosek pracownika, w razie niemożności jego rozpoczęcia z powodu choroby. Ponadto ustawodawca ustalił również, że w miesiącach szczególnie sprzyjających wypoczynkowi, tj. od 1 maja do 30 września, z urlopu powinno korzystać nie mniej niż 50\% ogólnej liczby zatrudnionych w danym przedsiębiorstwie. Upoważniono jednak właściwego ministra do ustalenia innej relacji procentowej dla poszczególnych gałęzi produkcji lub przedsiębiorstw, jeśli konieczność taka wynikała z natury produkcji (art. 5 ustawy). Co istotne, sformułowano też sankcje za naruszenie przepisów tej ustawy, w postaci kary grzywny lub kary aresztu do jednego miesiąca.

Dodatkowo, mimo że ustawa o urlopach z 1922 r. wprost tej kwestii nie regulowała, w orzecznictwie Sądu Najwyższego z okresu międzywojennego konsekwentnie przyjmowano, że urlop wypoczynkowy nie powinien być udzielany w okresie wypowiedzenia ${ }^{598}$.

Jednocześnie na gruncie ustawy urlopowej z 1922 r. funkcjonowało również kilka rozwiązań mocno dyskusyjnych, nieznajdujących oparcia w podstawowych

594 W. Szubert, Zarys..., s. 25. Niemniej nie dotyczyło to, zdaniem Logi, wszystkich osób zatrudnionych w rolnictwie. Poprzez to, że ustawa miała zastosowanie do pracowników „biurowości”, obejmowała ona także pracowników umysłowych zatrudnionych w rolnictwie. Por. J. Loga, Polskie prawo..., s. 3.

595 Por. M. Święcicki, Prawo pracy, s. 445.

596 Rozporządzenie Prezydenta Rzeczypospolitej z 27 października 1933 r. - Kodeks zobowiq zań, Dz. U. 1933, Nr 82, poz. 598.

597 Por. M. Święcicki, Prawo pracy, s. 445.

598 Por. uchwała SN z 7 stycznia 1932, C 1599/ 31, „Głos Kupiectwa” 1936, nr 8, s. 12. Por. też: orzeczenie SN z 11 maja 1932 r., III Rw. 435/32, OSP XII, poz. 85 oraz orzeczenie SN z 21 grudnia 1931 r., C 1929/31, OSP XI, poz. 158. 
funkcjach urlopu wypoczynkowego. Przede wszystkim ustawa ta wprowadziła podział na pracowników umysłowych, którzy nabywali prawo do urlopu w zależności od okresu pracy w wymiarze dwóch tygodni lub jednego miesiąca, oraz robotników, którzy uzyskiwali prawo do urlopu w wymiarze tylko ośmiu lub 15 dni. Tym samym ustawodawca, bez głębszej refleksji, usankcjonował istniejący w omawianym zakresie stan, ukształtowany przed wejściem w życie ustawy postanowieniami układów zbiorowych pracy, które właśnie pracownikom umysłowym przyznawały zwykle miesięczne urlopy wypoczynkowe ${ }^{599}$. Takie rozróżnienie wymiaru urlopu było podyktowane, jak się wydaje, przekonaniem, że pracownicy umysłowi „pracowali” już na swój urlop, zdobywając wykształcenie, co jednak, z punktu widzenia prawa każdego pracownika do odpoczynku, nie uzasadnia trwałego obniżenia tego wymiaru drugiej grupy zatrudnionych, jak to uczyniono na gruncie analizowanej ustawy. Osoby z podobnym stażem pracy, nawet uwzględniając w nim okres nauki, nabywały bowiem prawo do urlopu w różnym wymiarze.

Zróżnicowane były również warunki nabycia prawa do pierwszego urlopu wymienionych kategorii pracowników - robotnicy uzyskiwali to prawo po rocznym okresie zatrudnienia, natomiast pracownicy umysłowi mogli z niego korzystać już po sześciu miesiącach pracy.

Ponadto w doktrynie prawa pracy zwracano uwagę, że zasada nieprzerwanego urlopu miała dotyczyć tylko pracowników umysłowych, co skutkowało, przy stosunkowo niskim wymiarze urlopu robotnika, brakiem faktycznych gwarancji w zakresie wypoczynku tych ostatnich ${ }^{600}$.

Dość istotnym mankamentem ówczesnej regulacji, wzmacnianym jeszcze orzecznictwem Sądu Najwyższego ${ }^{601}$, było także ujęcie urlopu jako uprawnienia, do którego pracownik traci prawo, jeśli nie wystąpi w tym zakresie z odpowiednim żądaniem ${ }^{602}$. Okólnik nr 42-44 Głównego Inspektora Pracy stwierdzał dodatkowo, że „ustawa daje prawo korzystania co rok z płatnego urlopu, lecz nie czyni $\mathrm{z}$ tego obowiązku; wobec czego pracownik może z prawa swego w pewnym roku nie skorzystać [...]. Pracownik zrzekający się przyznanego prawa do urlopu nie może z tego tytułu żądać żadnego wynagrodzenia" ${ }^{003}$.

Pochodną powyższej zasady była też utrata prawa do urlopu w sytuacji rozwiązania przez pracownika stosunku pracy w drodze wypowiedzenia ${ }^{604}$, co było tym

599 Por. J. Loga, Polskie prawo..., s. 4.

600 Por. M. Święcicki, Instytucje..., s. 70. Por. też J. Loga, Urlopy wypoczynkowe..., s. 32.

601 Sąd Najwyższy przyjmował, że pracownik traci prawo do urlopu, jeśli tego urlopu „z góry nie zażąda”. Por. J. Loga, Polskie prawo..., s. 4.

602 Por. M. Święcicki, Prawo pracy, s. 444.

603 Okólnik Głównego Inspektora Pracy z 3 lipca 1922 r., „Praca i Opieka Społeczna” 1921-1922, s. 226 in.

604 J. Loga, Polskie prawo..., s. 4. Przyjmowano, że takiego skutku nie wywoła rozwiązanie umowy przez pracownika, ale z przyczyn leżących po stronie pracodawcy. Niemniej zdarzały się również orzeczenia Sądu Najwyższego, które uznawały utratę prawa do urlopu bez względu na przyczynę rozwiązania umowy przez pracownika, tj. nawet z przyczyn zawinionych przez pracodawcę. Por. wyrok SN z 5 lutego 1931 r., III Rw. 1691/30, „Głos Prawa” 1931, nr 10, s. 500 i n. 
bardziej dyskusyjne, że ustawa nie odnosiła się bezpośrednio w ogóle do przyczyn takiego rozwiązania. Według art. 3 ustawy, pracownik tracił również to prawo, jeżeli rozwiązanie stosunku pracy nastąpiło z powodów uzasadniających rozwiązanie przez pracodawcę umowy bez wypowiedzenia.

Okresowy regres w zakresie uprawnień urlopowych pracowników przyniosły lata 30. XX w., kiedy to de facto obniżono wymiar urlopu pracowniczego, poprzez uznanie za dni urlopu wszystkich, następujących po sobie dni kalendarzowych przypadających na czas jego udzielenia, z uwzględnieniem niedziel i świąt, oraz wprowadzono niekorzystne reguły obliczania wynagrodzenia urlopowego. Obniżeniu standardów ustawowych w aspekcie wypoczynku rocznego towarzyszyła też praktyka łamania prawa poprzez pozbawianie pracowników urlopu wypoczynkowego $^{605}$.

Znaczne zmiany prawa urlopowego w kierunku wzmacniania jego funkcji wypoczynkowej nastąpiły w polskim prawie po 1945 r., kiedy to w szczególności wydłużono wymiar urlopu robotników ${ }^{606}$ oraz wprowadzono instytucję ciągłości pracy, łagodząc tym samym warunki nabycia prawa do omawianego świadczenia. Instytucja ta pozwalała bowiem na sumowanie okresów zatrudnienia u różnych pracodawców przy ustalaniu uprawnień urlopowych pracownika ${ }^{607}$.

Wyjątek stanowiły miesięczne urlopy wypoczynkowe, które przysługiwały pracownikom po 10 latach pracy u danego pracodawcy, wprowadzone w 1950 r. Były one jednak oceniane jako rozwiązanie niezwykle postępowe w skali światowej, tak długie, jak na owe czasy, urlopy należały jeszcze bowiem do rzadkości ${ }^{608}$.

Decydujące znaczenie w omawianym zakresie miało jednak uchwalenie 29 kwietnia 1969 r. nowej ustawy o pracowniczych urlopach wypoczynkowych, która wprowadziła, od lat postulowany w doktrynie prawa pracy, jednolity wymiar urlopów dla wszystkich pracowników uwarunkowany okresami zatrudnienia oraz, po raz pierwszy, okresami nauki ${ }^{609}$.

Wymiar ten był określany w dniach roboczych i wynosił 14 dni po roku pracy, 17 dni po trzech latach, 20 dni po sześciu latach i 26 dni - po 10 latach pracy. Dzień roboczy, zgodnie z ustawą, stanowiły wszystkie dni z wyjątkiem ustawowo wolnych od pracy.

Ustawa ujednolicała również zasady nabywania prawa do pierwszego urlopu - każdy pracownik nabywał do niego prawo po przepracowaniu jednego roku.

605 Por. W. Szubert, Zarys..., s. 28.

606 Dekretem z 8 stycznia 1946 r. najpierw przywrócono stan prawny sprzed okresu kryzysu gospodarczego. tj. powrócono do zasady, że urlop ma być udzielany w dniach roboczych, a następnie wymiar ten podwyższono dla robotników nowelą do ustawy urlopowej z 20 marca 1950 r., Dz. U. 1950, Nr 12, poz. 123.

607 Por. dekret z 18 stycznia 1956 r. o ograniczeniu dopuszczalności rozwiązywania umów o pracę bez wypowiedzenia oraz o zabezpieczeniu ciągłości pracy, Dz. U. 1956, Nr 2, poz. 11.

608 Por. W. Muszalski, Czas pracy..., s. 426.

609 Por. ustawa z 29 kwietnia 1969 r. o pracowniczych urlopach wypoczynkowych, Dz. U. 1969, Nr 12, poz. 85. 
Realizowała też zasadę powszechności urlopu, którą po drugiej wojnie światowej ustawodawca polski starał się stopniowo rozwijać (m.in. dekretem z 1948 r. $^{610}$ przepisy o urlopach wypoczynkowych zostały rozciągnięte także na pracowników zatrudnionych u małych pracodawców, a w latach 50. prawo do płatnego urlopu przyznano też chałupnikom ${ }^{611}$ ). Obejmowała ona zasadniczo wszystkich pracowników, w ustawie nie wprowadzono bowiem już żadnych wyłączeń podmiotowych.

Co istotne z punktu widzenia prawa do odpoczynku, podtrzymano w ustawie coroczny, odpłatny i nieprzerwany charakter urlopu wypoczynkowego. Uregulowano kwestię planowego jego udzielenia, z zastrzeżeniem obowiązku pracodawcy poinformowania pracownika o terminie urlopu nie później niż na miesiąc przed dniem jego rozpoczęcia. Możliwość przesunięcia terminu urlopu, w przypadkach wskazanych w ustawie, uzależniono wprost od zawarcia $\mathrm{w}$ tej sprawie $\mathrm{z}$ pracownikiem stosownego porozumienia oraz uprzedniej zgody rady zakładowej. Określono również, w sposób zbliżony do unormowań zawartych w ustawie z 1922 r., maksymalny termin dotyczący przesunięcia urlopu $\mathrm{w}$ związku $\mathrm{z}$ wystąpieniem zdarzeń prawnych powodujących niemożność rozpoczęcia urlopu przez pracownika w dacie wcześniej zaplanowanej.

Warto też podkreślić, że na gruncie omawianej regulacji obok urlopu podstawowego i uzupełniającego (art. 4 ustawy) wyróżniono również urlopy dodatkowe. Upoważniono bowiem Radę Ministrów do wprowadzenia dodatkowych urlopów wypoczynkowych dla poszczególnych grup pracowników w przypadkach uzasadnionych rodzajem pracy albo szczególnie uciążliwymi lub szkodliwymi warunkami jej wykonywania.

Ustawa ta przewidywała jednak, w stopniu nawet szerszym niż ustawa wcześniejsza, wiele negatywnych konsekwencji w obszarze prawa urlopowego, zarówno pod względem wymiaru urlopu, jak i nabycia do niego prawa, związanych z porzuceniem pracy przez pracownika, wypowiedzeniem przez niego stosunku pracy lub jego rozwiązaniem przez pracodawcę bez wypowiedzenia $\mathrm{z}$ winy pracownika oraz przerwą w zatrudnieniu trwającą dłużej niż trzy miesiące. Między innymi wymiar urlopu podlegał czasowemu obniżeniu w przypadku, gdy pracownik podjął pracę $\mathrm{u}$ nowego pracodawcy po rozwiązaniu stosunku pracy bez wypowiedzenia $\mathrm{z}$ jego winy w poprzednim zakładzie lub gdy doszło do porzucenia pracy. Wówczas pracownik musiał przepracować rok, żeby nabyć ponownie prawo do urlopu, a urlop ten uzyskiwał $\mathrm{w}$ wymiarze bezpośrednio niższym od przysługującego mu przed wystąpieniem wskazanych wyżej sytuacji. Ta swoista sankcja była jednak ograniczona do jednego roku kalendarzowego (art. 7 ustawy).

Obowiązek ponownego nabycia prawa do urlopu dotyczył również pracownika, który rozwiązał stosunek pracy w poprzednim zakładzie pracy za wypowie-

610 Dekret z 28 lipca 1948 r. o zmianie ustawy z 16 maja 1922 r. o urlopach dla pracowników zatrudnionych w przemyśle i handlu, Dz. U. 1948, Nr 36, poz. 258.

611 Por. najpierw zarządzenie Ministra Przemysłu Drobnego i Rzemiosła, w 1960 r. kwestię tę uregulowano uchwałą nr 204 RM z 28 czerwca 1960 r. w sprawie urlopów wypoczynkowych dla chałupników, M.P. 1960, Nr 58, poz. 273. 
dzeniem lub podejmował pracę po przerwie w zatrudnieniu trwającej dłużej niż trzy miesiące. Towarzyszyło temu wyraźnie restrykcyjne orzecznictwo, w którym przyjmowano, że właściwie każda przerwa w zatrudnieniu dłuższa niż trzy miesiące, bez względu na jej przyczynę, pociąga za sobą konieczność przepracowania przez pracownika jednego roku w celu nabycia prawa do urlopu (np. w związku z pobieraniem renty chorobowej) $)^{612}$.

W analizowanej ustawie wprost wskazano również na możliwość, a wręcz obowiązek pracodawcy, udzielenia pracownikowi urlopu w okresie wypowiedzenia, jeżeli stroną wypowiadającą umowę był pracodawca, a okres wypowiedzenia wynosił co najmniej trzy miesiące. W ten sposób ustawodawca zanegował wypracowane przez Sąd Najwyższy w okresie międzywojennym wyżej opisane stanowisko dotyczące omawianej kwestii.

Regulacje ustawy urlopowej z 1969 r. zostały następnie „wchłonięte” i uzupełnione przez Kodeks pracy. Przede wszystkim wprowadzono w nim, trudną do przecenienia dla skutecznej realizacji prawa do odpoczynku, zasadę niezbywalności prawa do urlopu oraz regułę, według której pracownik za czas urlopu miał prawo do takiego wynagrodzenia, jakie by otrzymał, gdyby w tym czasie normalnie pracował.

Korzystne dla pracownika było też odejście w zakresie liczenia stażu pracy decydującego o wymiarze urlopu od reguły, że okresy poprzedniego zatrudnienia mogą być uwzględniane tylko wówczas, jeśli przerwa w zatrudnieniu trwała nie więcej niż trzy miesiące (warunek ten pozostawiono jedynie w kwestii nabycia prawa do urlopu).

Ustawodawca rozszerzył również katalog przesłanek powodujących przerwanie urlopu pracownika i obowiązek udzielenia niewykorzystanej jego części w innym terminie. Obok czasowej niezdolności do pracy wywołanej chorobą trwającą co najmniej trzy dni oraz odosobnienia w związku z chorobą zakaźną, sformułowanych w uchylonej ustawie, wśród okoliczności pociągających za sobą przerwanie urlopu wymieniono bowiem jeszcze odbywanie ćwiczeń wojskowych lub przeszkolenia wojskowego przez czas do trzech miesięcy oraz urlop macierzyński.

Jednocześnie odstąpiono od obowiązku zawarcia porozumienia z pracownikiem w sprawie ewentualnego przesunięcia terminu urlopu, m.in. z powodu szczególnych potrzeb zakładu, rozszerzając w tym zakresie uprawnienia pracodawcy, a także wyeliminowano z przepisów ustawy określenie terminu, w jakim urlop, do którego przesunięcia prawo zobowiązywało pracodawcę, musiał być wyznaczony (trzy miesiące od ustania przyczyny uzasadniającej przesunięcie). W Kodeksie pracy obowiązywał w tym zakresie ogólny wymóg, że urlopu niewykorzystanego zgodnie z planem urlopów, bez względu na okoliczności, należy pracownikowi udzielić najpóźniej do końca pierwszego kwartału roku następnego ${ }^{613}$.

612 Por. uchwała SN z 12 grudnia 1978 r., I PZP 25/78, OSPiKA 1980, nr 4. Szerzej A. Małysz, Pracownicze urlopy wypoczynkowe, Warszawa 1987, s. 44 i n.

613 W ustawie z 1969 r. taki termin odnoszono tylko do przypadków przesunięcia terminu urlopu z woli stron (por. art. 12 ust. 3 ustawy). 
Niemniej kwestia ta została uwzględniona $\mathrm{w}$ rozporządzeniu urlopowym z 1974 r. ${ }^{614}$, które obligowało m.in. pracodawcę do przesunięcia niewykorzystanej części urlopu, w związku z chorobą lub odosobnieniem ze względu na chorobę zakaźną trwających nieprzerwanie co najmniej trzy dni kalendarzowe i nieobejmujących części urlopu większej niż siedem dni, na okres przypadający bezpośrednio po terminie zakończenia urlopu, chyba że pracownik wnioskował inaczej. Jeżeli okres takiej niezdolności przekraczał siedem dni urlopu, wówczas niewykorzystaną część urlopu wynoszącą siedem dni należało udzielić bezpośrednio po terminie zakończenia urlopu, a pozostałą część na ogólnych zasadach kodeksowych.

W Kodeksie pracy rozszerzono ponadto obowiązek udzielenia pracownikowi urlopu w okresie wypowiedzenia. Poza przypadkiem wymienionym we wcześniejszej ustawie, w art. 170 k.p. sformułowano bowiem obowiązek udzielenia urlopu w okresie wypowiedzenia również wówczas, gdy umowę o pracę wypowiadał pracownik, choćby okres wypowiedzenia był krótszy niż trzy miesiące. Jest to rozwiązanie, które, choć zmodyfikowane, obowiązuje także na gruncie obecnego stanu prawnego i w mojej ocenie jest dysfunkcjonalne z punktu widzenia skutecznej realizacji prawa do odpoczynku (por. szerzej dalsze rozważania).

Ograniczono jednak w Kodeksie pracy dotychczasowe przesłanki utraty prawa do urlopu, co z pewnością należy ocenić pozytywnie w kontekście omawianej zasady. Zrezygnowano bowiem $\mathrm{z}$ rozwiązania stosunku pracy przez pracownika $\mathrm{w}$ drodze wypowiedzenia jako jednego $\mathrm{z}$ przypadków wywołujących wskazane wyżej konsekwencje. Nadal jednak rozwiązanie stosunku pracy przez pracodawcę $\mathrm{w}$ trybie niezwłocznym $\mathrm{z}$ winy pracownika oraz porzucenie pracy skutkowały koniecznością ponownego nabycia prawa do urlopu u kolejnego pracodawcy.

Tego rodzaju regulacje, zwłaszcza jeżeli chodzi o rozwiązanie umowy za wypowiedzeniem, w zakresie prawa urlopowego niewątpliwie nie służyły realizacji prawa pracownika do corocznego odpoczynku i pozostawały w pewnej sprzeczności w stosunku do podstawowych funkcji omawianej przerwy w pracy. Stanowiły bowiem swoistą karę za określony sposób zakończenia stosunku pracy, nawet prawem dopuszczany, a pośrednio także za naruszenie przez pracownika określonych obowiązków wobec pracodawcy. Wypoczynek zapewniający co najmniej czas na regenerację psychofizyczną organizmu w związku z wykonywaną pracą jest jednak i był podstawowym prawem każdego człowieka-pracownika, konstytucyjnie gwarantowanym, a zatem nie może być rozpatrywany w kategoriach kary i nagrody czy uzależniany od zachowania określonej lojalności wobec pracodawcy. Służy on bowiem, jak wcześniej wskazywano, ochronie życia i zdrowia ludzkiego, a w pewnym stopniu też zagwarantowaniu bezpieczeństwa pracy, stąd nie powinien zasadniczo podlegać ograniczeniom, nawet w przypadku naruszającego prawo zachowania pracownika. Ewentualnie takie ograniczenia powinny być zastrzeżone dla sytuacji naprawdę wyjątkowych.

614 Rozporządzenie Ministra Pracy, Płac i Spraw Socjalnych z 21 października 1974 r. w sprawie pracowniczych urlopów wypoczynkowych, Dz. U. 1974, Nr 43, poz. 259. 
Szczególne warunki nabycia prawa do urlopu i jego wymiaru dotyczyły pracowników sezonowych i młodocianych. Ci ostatni uzyskiwali to prawo po upływie sześciu miesięcy od rozpoczęcia pierwszej pracy, natomiast pracownikom sezonowym urlop przysługiwał w wymiarze jednego dnia za każdy przepracowany miesiąc. O ile dla pracowników młodocianych były to z pewnością warunki korzystniejsze, o tyle w przypadku drugiej grupy można mówić o faktycznym zmniejszeniu wymiaru ich urlopu (maksymalnie 12 dni rocznie), na który nie miał wpływu ani staż pracy, ani rodzaj ukończonej szkoły. Z drugiej jednak strony, jak podkreślano w ówczesnej literaturze przedmiotu, umożliwiono im w ten sposób w ogóle korzystanie z odpoczynku związanego z urlopem. Poddanie ich bowiem ogólnym regułom kodeksowym dotyczącym nabycia prawa do urlopu (w tym w szczególności wymogowi legitymowania się rocznym stażem pracy oraz zachowania ciągłości pracy) doprowadziłoby w praktyce do pozbawienia ich omawianego uprawnienia ${ }^{615}$.

W dość trudnym położeniu znajdowały się również osoby podejmujące dodatkowe zatrudnienie. $\mathrm{Z}$ powodu braku regulacji szczególnej w Kodeksie pracy, w orzecznictwie Sądu Najwyższego przyjmowano ogólną regułę, że do okresów zatrudnienia warunkujących nabycie prawa i wymiar urlopu wypoczynkowego w tym zatrudnieniu nie wlicza się okresu trwania zatrudnienia u macierzystego pracodawcy ${ }^{616}$. W praktyce oznaczało to najczęściej wymóg przepracowania rocznego okresu dla nabycia prawa do urlopu w dodatkowym zatrudnieniu oraz uzyskiwanie urlopu w najniższym z możliwych wymiarze, co znacznie utrudniało skuteczną realizację prawa do wypoczynku w zatrudnieniu podstawowym.

Poważne zmiany w zakresie prawa urlopowego nastąpiły w latach 90. XX w., w wyniku gruntownej nowelizacji Kodeksu pracy mającej przystosować zawarte w nim unormowania do nowych warunków ustrojowych. Chodziło z jednej strony o adaptację obowiązujących przepisów do kształtującego się odmiennego układu społeczno-ekonomicznego, a z drugiej o przeciwdziałanie narastającemu zjawisku naruszania zawartych w Kodeksie pracy norm formułujących określone uprawnienia pracownicze. Głównym motywem nowelizacji dokonanej w obszarze urlopów wypoczynkowych była jednak potrzeba dostosowania lub przynajmniej zbliżenia regulujących je przepisów do standardów wynikających z prawa międzynarodowego i europejskiego, w tym zwłaszcza konwencji MOP oraz Europejskiej Karty Społecznej ${ }^{617}$. Miała ona w rezultacie służyć skuteczniejszej realizacji prawa pracownika do wypoczynku, m.in. dzięki usunięciu norm, które pełniły inne jeszcze, niepowiązane z wypoczynkiem, funkcje (przede wszystkim dyscyplinujące i stabilizujące zatrudnienie $)^{618}$. Jak oceniano bowiem w literaturze, dotychczasowe

615 Por. J. Wratny, Sytuacja prawna pracowników sezonowych, „Studia i Materiały IPiSS” 1977, z. 2, s. 36.

616 Por. uchwała składu 7 sędziów SN z 27 stycznia 1977 r., V PZP 5/76, OSNCP 1977, nr 4, poz. 63.

617 Por. Z. Salwa, Założenia i kierunki nowelizacji Kodeksu pracy, [w:] Prawo pracy po zmianach, red. K. Rączka, Warszawa 1997, s. 26.

618 Por. A. Kosut, Przemiany..., s. 182. 
przepisy pozostawały niekiedy $\mathrm{w}$ sprzeczności $\mathrm{z}$ konstytucyjną zasadą prawa do corocznego wypoczynku ${ }^{619}$.

Dokonane w omawianym okresie zmiany objęły zarówno kwestie nabycia prawa do urlopu oraz jego wymiaru, jak i reguły udzielania urlopów wypoczynkowych w celu pełniejszego urzeczywistnienia wypoczynku stanowiącego ich podstawowe przeznaczenie.

Przede wszystkim, zgodnie z wymogami MOP, oraz pod wpływem zgłaszanych $\mathrm{w}$ doktrynie prawa pracy wątpliwości ${ }^{620}$, zmodyfikowano konstrukcję nabycia prawa do pierwszego urlopu. Pracownik nadal nabywał to prawo w pełnym wymiarze po upływie roku pracy, niemniej po przepracowaniu sześciu miesięcy uzyskiwał uprawnienie do urlopu wypoczynkowego $\mathrm{w}$ wymiarze połowy wymiaru urlopu przysługującego mu po przepracowaniu roku ${ }^{621}$. Ostatni urlop był zaliczany na poczet urlopu rocznego.

Zwiększeniu uległ przy tym minimalny wymiar urlopu pracowniczego, który wynosił 18 dni. Miało to zagwarantować zgodność polskiego prawa z wymogami opisanej wcześniej Konwencji MOP nr 132, która zobowiązywała do wprowadzenia co najmniej trzytygodniowych urlopów wypoczynkowych.

Również urlop pracowników sezonowych został powiększony. Za każdy miesiąc pracy nabywali oni bowiem prawo do urlopu w wymiarze półtora dnia, co pozwalało im przynajmniej po roku pracy osiągnąć minimalną wielkość urlopu gwarantowaną pozostałym pracownikom (18 dni). Jednocześnie zdecydowano też o zaliczeniu tego urlopu na poczet urlopu wypoczynkowego uzyskiwanego $\mathrm{w}$ danym roku kalendarzowym z tytułu pracy niesezonowej ${ }^{622}$.

Przejawem podwyższenia wymiaru urlopu wypoczynkowego było również przyjęcie określonej definicji „dnia urlopu”. Dniami urlopu, zgodnie ze zmienionymi przepisami, były tylko dni robocze. A zatem niedziele i święta, ale też dni dodatkowo wolne od pracy, nie podlegały zasadniczo uwzględnieniu w wymiarze urlopu wypoczynkowego. Problemem były jednak prace wykonywane w niedziele i święta, np. w ruchu ciągłym. Choć były to dni faktycznie świadczonej pracy, to jednak, jak wynikało z przyjętej definicji dnia roboczego, nie mieściły się w jej zakresie, a zatem nie mogły zostać wliczone do urlopu.

619 Tamże, s. 26.

620 Por. w szczególności: L. Florek, Staż pracy, Warszawa 1980, s. 155 i n. Autor ten wskazywał w szczególności, że zarówno roczny okres wyczekiwania na pierwszy urlop, jak i sposób uzależnienia od niego prawa do pierwszego urlopu budzi uzasadnione zastrzeżenia z punktu widzenia skutecznej realizacji podstawowej funkcji tej instytucji.

621 Urlop pierwszy był to zatem urlop po roku pracy w pełnym wymiarze wraz z urlopem cząstkowym po sześciu miesiącach pracy. Por. tak: E. Chmielek-Łubińska, Pierwszy urlop wypoczynkowy, „Studia z zakresu prawa pracy i polityki społecznej”, red. A. Świątkowski, Kraków 2001/2002, s. 373 i n. oraz I. Boruta, Urlopy wypoczynkowe po zmianie Kodeksu pracy, Warszawa 1997, s. 12. Trochę inaczej pojęcie pierwszego urlopu postrzegał Z. Salwa, który uznawat, że jest nim tylko urlop po sześciu miesiącach zatrudnienia. Por. tenże, Nabycie prawa do urlopu wypoczynkowego, [w:] Prawo pracy po zmianach, s. 279 i n.

622 Kwestia ta była podnoszona w literaturze przedmiotu już znacznie wcześniej. Por. J. Wratny, Sytuacja prawna..., s. 36. 
Zwiększeniu dostępności pracowników do odpoczynku rocznego służyły również zmiany w zakresie ustalania stażu warunkującego nabycie prawa i wymiar urlopu wypoczynkowego. Według nowych przepisów w stażu tym uwzględniano bowiem wszystkie wcześniejsze okresy pozostawania w stosunku pracy, bez względu na przerwy w zatrudnieniu, ale też sposób ustania stosunku pracy. W rezultacie uchylono wcześniejsze, restrykcyjne unormowania statuujące wymóg zachowania określonej ciągłości pracy dla nabycia prawa do urlopu wypoczynkowego oraz przepisy, które $\mathrm{z}$ określonym sposobem ustania stosunku pracy wiązały skutek w postaci utraty prawa do urlopu i obowiązek ponownego jego nabycia u kolejnego pracodawcy. Nowe przepisy urlopowe ustanowiły tym samym zasadę, że pracownik nabywał prawo do pierwszego urlopu wypoczynkowego tylko raz w swoim życiu zawodowym, w pierwszym okresie zatrudnienia w ramach stosunku pra$\mathrm{cy}^{623}$. Sprzyjały one też szybszemu osiągnięciu wyższego wymiaru tego urlopu.

Jak słusznie zauważono w literaturze przedmiotu, w ten sposób wzmocniono podmiotowe prawo pracownika do wypoczynku, a przepisy urlopowe przestały w końcu pełnić funkcje sprzeczne $\mathrm{z}$ istotą omawianego świadczenia, tj. dyscyplinujące pracownika i stabilizujące zatrudnienie ${ }^{624}$.

W każdym następnym roku kalendarzowym, po roku nabycia prawa do pierwszego urlopu w pełnym wymiarze, pracownicy uzyskiwali prawo do kolejnego urlopu.

Powyższa konstrukcja nabycia prawa do urlopu, chociaż znacznie korzystniejsza dla pracownika niż wcześniejsze rozwiązania przyjęte w tym zakresie, nie była jednak pozbawiona pewnych wad. Jak z powyższego wynika, na jej gruncie mogły wystąpić bowiem nawet kilkumiesięczne okresy zatrudnienia nierekompensowane odpoczynkiem w postaci dni urlopowych. Taka sytuacja miała miejsce w przypadku nabycia prawa do pierwszego urlopu w pełnym wymiarze w początkowych miesiącach danego roku kalendarzowego, przy jednoczesnym kontynuowaniu zatrudnienia ${ }^{625}$.

W celu lepszego rozłożenia obciążeń urlopowych pracodawców oraz większego dostosowania wielkości przysługującego pracownikowi urlopu do liczby przepracowanych w danym roku miesięcy, wprowadzono również reguły dotyczące tzw. urlopu proporcjonalnego ${ }^{626}$. Jego istotą jest proporcjonalne obniżanie wymiaru

623 Por. Z. Salwa, Nabycie..., s. 279.

624 Por. A. Kosut, Przemiany..., s. 185 i n. W doktrynie prawa pracy wyrażono jednocześnie wątpliwości dotyczące wpływu faktycznego porzucenia pracy, w świetle nowych przepisów, na wymiar urlopu wypoczynkowego pracownika (co zostanie szerzej omówione w dalszych fragmentach niniejszego opracowania). Por. A. Sobczyk, „Porzucenie” pracy a urlop proporcjonalny, „Przegląd Sądowy” 1998, nr 11-12, s. 168 i n.

625 W literaturze dość powszechnie przyjmowano bowiem, że reguła urlopu proporcjonalnego nie znajduje swego zastosowania do okresu „wyczekiwania na «drugi» urlop wypoczynkowy". Por. E. Chmielek-Łubińska, Urlop proporcjonalny, s. 258.

626 Urlop proporcjonalny był wcześniej regulowany w przepisach wykonawczych dotyczących urlopów wypoczynkowych, ale w bardzo ograniczonym zakresie. Był on związany m.in. z korzystaniem przez pracownika z urlopu bezpłatnego czy wychowawczego. Por. M. Łajeczko, Urlop wypoczynkowy, „Prawo Pracy” 1999, nr 3, s. 15. 
rocznego urlopu wypoczynkowego przysługującego pracownikowi w związku $\mathrm{z}$ ustaniem i nawiązaniem stosunku pracy w części roku kalendarzowego oraz wystąpieniem pewnych okresów nieobecności w pracy, nie krótszych niż miesiąc, w czasie których pracownik nie nabywa prawa do urlopu wypoczynkowego (w szczególności urlopów bezpłatnych). Odstąpiono w związku z tym od dotychczasowej zasady, z której wynikało, że w przypadku rozwiązania stosunku pracy następuje realizacja prawa do urlopu w całości wyłącznie u pracodawcy, który zatrudniał pracownika w dniu nabycia prawa do tego urlopu ${ }^{627}$.

W pierwotnym brzmieniu nowy przepis kodeksowy dotyczył jednak tylko wpływu na wymiar urlopu ustania i ewentualnego nawiązania stosunku pracy w tym samym roku kalendarzowym, co budziło liczne wątpliwości w literaturze przedmiotu ${ }^{628}$. Oznaczało bowiem m.in., że pracownik podejmując zatrudnienie w kolejnym roku kalendarzowym, po roku ustania poprzedniego stosunku pracy, nabywał, w świetle literalnego brzmienia przepisów, u kolejnego pracodawcy urlop w pełnym wymiarze, nawet jeśli nawiązał stosunek pracy pod koniec roku.

Ustawodawca nie określał też precyzyjnie, do jakich pracowników powyższe zasady znajdują swoje zastosowanie, posłużono się bowiem w przepisie dość ogólnym pojęciem „pracownika uprawnionego do urlopu” ${ }^{29}$, oraz, jeśli chodzi o drugą grupę przesłanek zastosowania reguły proporcjonalności, jakie okresy nieobecności w pracy, dłuższe niż miesięczne, będą powodować obniżenie wymiaru urlopu wypoczynkowego pracownika ${ }^{630}$.

Zastosowanie reguły proporcjonalności nie mogło prowadzić do zwiększenia wymiaru urlopu przysługującego pracownikowi za dany rok. Jeśli dotychczasowy pracodawca udzielił urlopu w pełnym wymiarze, mimo ustania stosunku pracy w części roku kalendarzowego, lub urlopu w wymiarze wyższym niż wynikający z zastosowania omawianych przepisów, nie miał żadnych roszczeń wobec pracownika, ale fakt ten dawał kolejnemu pracodawcy, zatrudniającemu pracownika $\mathrm{w}$ tym samym roku kalendarzowym, podstawę do odpowiedniego zmodyfikowania ilości udzielonego pracownikowi urlopu za ten rok, tak aby by nie przekroczyć wymiaru ustawowo określonego.

627 Por. J. Iwulski, [w:] Kodeks..., s. 451.

628 Por. m.in. Z. Salwa, Nabycie..., s. 283 i n.

629 Jak podkreślała M. Łajeczko, zasada proporcjonalności nie dotyczy urlopów wymienionych w art. 153 § 1 i 2 k.p., tj. urlopu pierwszego po sześciu miesiącach pracy i urlopu w pełnym wymiarze po rocznym okresie zatrudnienia - taż, Urlop..., s. 12. Podobnie: I. Boruta, Urlopy..., s. 41 oraz E. Chmielek-Łubińska, Urlop proporcjonalny, s. 258. Były jednak wyrażane opinie odmienne. Na temat kontrowersji dotyczących zakresu zastosowania omawianego przepisu szeroko Z. Salwa, Urlop proporcjonalny, PiZS 1997, nr 10, s. 28. O wątpliwościach związanych z urlopem proporcjonalnym zob. też: A. Wypych-Żywicka, Problem praktycznego stosowania art. 155(2) § 1 k.p., PiZS 1997, nr 2, s. 27 i n.

630 Por. na ten temat szerzej A. Dubowik, Zasady udzielania urlopów wypoczynkowych według nowych przepisów, PiZS 1997, nr 4, s. 17 i n. 
Przepisy wprowadzające urlop proporcjonalny, choć można wskazać ich obiektywne uzasadnienie, prowadziły do pogorszenia sytuacji pracowników w stosunku do dotychczasowego stanu prawnego. Ujawniało się to w szczególności w przypadku wystąpienia przerwy, np. dwumiesięcznej, pomiędzy rozwiązaniem jednego a nawiązaniem kolejnego stosunku pracy. Wówczas roczny wymiar urlopu pracownika ulegał bowiem obniżeniu o $2 / 12$ z przysługującego mu wymiaru ${ }^{631}$.

Po nowelizacji Kodeksu pracy z 1996 r. odstąpiono również od regulacji płatnych urlopów dodatkowych związanych z pracą uciążliwą lub szkodliwą dla zdrowia w drodze aktu wykonawczego (rozporządzenia RM), na rzecz pozostawienia tych kwestii do rozstrzygnięcia partnerom społecznym w układach zbiorowych pracy.

W zakresie zasad prawa urlopowego, w kontekście prowadzonych rozważań, na uwagę zasługuje zaostrzenie warunków podziału urlopu na części, poprzez wprowadzenie wymogu, że przynajmniej jedna $z$ nich ma obejmować nie mniej niż 14 dni kalendarzowych oraz uznanie, że każda niezdolność do pracy z powodu choroby, niezależnie od czasu jej trwania, przerywa urlop wypoczynkowy i stanowi okoliczność uzasadniającą jego przesunięcie na inny termin, a także uchylenie przepisu, w którym sformułowano nakaz wykorzystania urlopu w okresie wypowiedzenia.

Przyznano również zakładowej organizacji związkowej znaczący wpływ na ostateczny kształt planu urlopowego tworzonego przez pracodawcę. Miał on być bowiem z tą organizacją „uzgadniany”. Jednocześnie jednak uchylono część przepisu zobowiązującego pracodawcę do zawiadomienia pracownika o terminie urlopu, nie później niż na miesiąc przed jego rozpoczęciem. Pomijając sytuacje szczególne, rozwiązanie takie można oceniać jako utrudniające w niektórych przypadkach proces należytej organizacji wypoczynku przez pracownika.

Kolejne poważne modyfikacje prawa urlopowego następowały po $2000 \mathrm{r}$.

Pierwsza z przeprowadzonych zmian, dokonana ustawą z 2002 r., nie była obliczona bezpośrednio na wprowadzanie jakichś istotniejszych regulacji w aspekcie realizacji prawa pracownika do wypoczynku. Chodziło raczej o uwzględnienie zgłaszanych wcześniej w doktrynie prawa pracy wątpliwości dotyczących brzmienia określonych przepisów i trudności z ich praktycznym stosowaniem. Dotyczyło to m.in. udzielania urlopu osobom zatrudnionym w niedziele i święta, objętym szczególnymi systemami czasu pracy oraz pracującym na część etatu, czy doprecyzowania zasad udzielania urlopu w wymiarze proporcjonalnym.

$\mathrm{W}$ związku $\mathrm{z}$ powyższym $\mathrm{w}$ zmienionych przepisach pozostawiono zasadę udzielania urlopu wypoczynkowego w dniach roboczych, ale ustanowiono również wyjątek obejmujący osoby wykonujące dozwoloną pracę w niedziele i święta, którym należało udzielać urlopu na te dni kalendarzowe, które zgodnie z rozkładem ich czasu pracy są dla tych pracowników dniami pracy. Wprowadzono też odpowiednią regulację o porządkującym charakterze w odniesieniu do pracowników

631 Por. E. Chmielek-Łubińska, Urlopy wypoczynkowe po nowelizacji Kodeksu pracy, „Służba Pracownicza" 1997, nr 1, s. 2. 
zatrudnionych w systemie równoważnych norm czasu pracy, w tym przy dozorze urządzeń lub w częściowym pogotowiu do pracy, oraz wykonujących pracę w niepełnym wymiarze czasu pracy ${ }^{632}$. Uzupełniono w ten sposób obowiązującą regulację prawa urlopowego o „sytuacje nietypowe”, w celu wyeliminowania takiej jej wykładni, która prowadziłaby do nieuwzględniania w urlopach wskazanych grup pracowników dni dodatkowo wolnych od pracy rekompensujących dłuższą pracę $\mathrm{w}$ inne dni, a w efekcie do faktycznego ich wydłużania ${ }^{633}$. Wprowadzone rozwiązania były jednak dość skomplikowane i nie usunęły wszystkich kontrowersji związanych z udzielaniem urlopu omawianym grupom pracowniczym ${ }^{634}$.

Rozstrzygając wątpliwości interpretacyjne $\mathrm{w}$ zakresie urlopu proporcjonalnego ustawodawca z kolei wyraźnie dookreślił, że ma on zastosowanie wyłącznie do pracowników uprawnionych do kolejnego urlopu wypoczynkowego, a z drugiej strony, że udzielanie urlopu w wymiarze proporcjonalnym następuje również w przypadkach nawiązania stosunku pracy w części kolejnych lat kalendarzowych, w stosunku do roku, w którym ustało poprzednie zatrudnienie. Uszczegółowiono też kwestię zasad udzielania tego urlopu u kolejnego pracodawcy w sytuacji, gdy pracownik jest zatrudniony na podstawie umowy terminowej, której koniec przypada na ostatni dzień danego roku kalendarzowego lub wykracza poza ten dzień. Ponadto wyszczególniono w katalogu zamkniętym wszystkie okresy, których wystąpienie może powodować proporcjonalne zmniejszenie urlopu pracownika w roku, za który urlop przysługuje.

Ustawodawca zauważył również sygnalizowane wcześniej niejasności dotyczące pojęcia i charakteru pierwszego urlopu ${ }^{635}$. Nowe brzmienie przepisu w zasadzie przesądziło, że urlop po sześciu miesiącach pracy nie jest urlopem samodzielnym, ale ma charakter zaliczkowy, tzn., że jest udzielany na poczet urlopu w pełnym wymiarze przysługującego po przepracowaniu roku (stanowi jego część).

Doprecyzowano także wyjątek polegający na możliwości podziału urlopu na części, jeśli z takim wnioskiem wystąpi pracownik. Ustawodawca, uwzględniając postulaty przedstawicieli doktryny prawa pracy, wyraźnie wskazał, że jedna część nie urlopu, ale wypoczynku, nie może być krótsza niż 14 kolejnych dni kalendarzowych.

$\mathrm{Z}$ drugiej strony, wprowadzono jednak w ramach urlopu wypoczynkowego zupełnie nową formę jego realizacji, tzw. urlop na żądanie, którego charakter i znaczenie z punktu widzenia zasadniczego tematu rozważań będą poddane analizie w dalszych częściach niniejszego opracowania.

632 Z przepisów wynikało, że takim pracownikom, jeśli w ich rozkładach czasu pracy była przewidziana większa liczba dni wolnych od pracy w okresie rozliczeniowym niż przypadająca w tym okresie łączna liczba niedziel, świąt i dni wolnych od pracy wynikających z zasady pięciodniowego tygodnia pracy, należało udzielić urlopu w dni, które są dla nich dniami pracy i dniami wolnymi od pracy, w takiej proporcji, w jakiej dni te występują w czasie wykonywania pracy, zgodnie z ustalonym rozkładem czasu pracy.

633 Por. K. Rączka, [w:] Kodeks pracy..., 2003, s. 513 i n.

634 Por. A. Kosut, Przemiany..., s. 186.

635 Szerzej zob. E. Chmielek-Łubińska, Pierwszy urlop..., s. 373 i n. 
Z perspektywy prawa do odpoczynku istotne było również ponowne ustanowienie dość kontrowersyjnego przepisu pozwalającego na skierowanie pracownika na urlop w okresie wypowiedzenia, a także, co ma stosunkowo mniejsze znaczenie, osłabienie obowiązku wydania planu urlopów oraz wpływu organizacji związkowej na jego kształt.

Zmianą we właściwym kierunku było natomiast dopuszczenie możliwości odstąpienia od obowiązku wypłaty ekwiwalentu za niewykorzystany urlop wypoczynkowy, na podstawie porozumienia stron stosunku pracy, w przypadku, gdy pracownik ma jeszcze możliwość zrealizowania tego świadczenia w naturze, w związku z nawiązaniem kolejnej umowy o pracę z tym samym pracodawcą bezpośrednio po ustaniu poprzedniej.

Druga bardzo poważna zmiana prawa urlopowego, mająca miejsce $\mathrm{w}$ obecnym stuleciu, została przeprowadzona ustawą z 14 listopada 2003 r. ${ }^{636}$ i de facto zdeterminowała kształt obowiązującej regulacji. Jej bezpośrednim motywem była konieczność dostosowania polskich rozwiązań prawnych w zakresie urlopu wypoczynkowego do wymogów wspólnotowych i podstawowych celów wynikających z omawianej wcześniej dyrektywy dotyczącej niektórych aspektów organizacji czasu pracy. Wskazana nowelizacja przyczyniła się zatem w dużym stopniu do pełniejszej realizacji zasady prawa pracownika do wypoczynku, co przejawia się szczególnie w dwóch aspektach:

1. zasadach nabycia prawa do urlopu, które umożliwiają obecnie szybsze uzyskiwanie uprawnień urlopowych przez pracownika. Ustawodawca zmienił bowiem zupełnie konstrukcję prawną $\mathrm{w}$ omawianym zakresie, odstępując od obowiązku przepracowania dłuższego okresu przez pracownika w celu nabycia przynajmniej części urlopu wypoczynkowego. Według aktualnych reguł, które będą dalej analizowane, „pierwszy urlop” został ograniczony wyłącznie do roku kalendarzowego, w którym dana osoba podjęła po raz pierwszy w swym życiu zawodowym pracę w ramach stosunku pracy, choć początkowo było to przedmiotem pewnych wątpliwości ${ }^{637}$, przy braku okresów zaliczanych, i jest nabywany cząstkowo z upływem każdego miesiąca pracy. Może to prowadzić do pewnego rozdrobnienia urlopu (choć pracownik nie musi wykorzystać nabytego prawa po każdym miesięcznym okresie pracy), gwarantuje jednak możliwość szybszego skorzystania z odpoczynku i lepsze, proporcjonalne jego dostosowanie do przepracowanego $\mathrm{w}$ tym roku czasu oraz związanego $\mathrm{z}$ nim narastającego zmęczenia. W większości przypadków pozwala też na skrócenie okresu wymaganego do nabycia prawa do kolejnego urlopu ${ }^{638}$.

W efekcie doszło do oderwania zasad nabycia prawa do urlopu pierwszego od rocznego stażu pracy, tradycyjnie obecnego w prawie polskim, i powiązania ich $\mathrm{z}$ miesięcznym okresem pracy oraz tzw. urlopem ułamkowym.

636 Ustawa z 14 listopada 2003 r. o zmianie ustawy - Kodeks pracy oraz o zmianie niektórych innych ustaw, Dz. U. 2003, Nr 213, poz. 2081.

637 Por. na ten temat E. Chmielek-Łubińska, Urlop wypoczynkowy po nowelizacji, PiZS 2004, nr 1, s. 20 in.

638 Tamże, s. 20. 
2. podwyższeniu wymiaru urlopu wypoczynkowego - poprzez rezygnację z jego najniższego dotąd progu, wynoszącego 18 dni. W ten sposób obowiązujący stan prawny został dostosowany do wspomnianej dyrektywy unijnej, w której wymaga się, by minimalny wymiar urlopu nie był niższy niż cztery tygodnie. Przy urlopie w wymiarze co najmniej $20 \mathrm{dni}$, udzielanym tylko na dni pracy, i zasadzie pięciodniowego tygodnia pracy, przepis dyrektywy został wykonany.

Co ważne, zrezygnowano z odmiennego ukształtowania, jak to było dotychczas, wymiaru urlopu i warunków jego nabycia zatrudnionych przy pracy sezonowej. Po nowelizacji zostali oni zatem poddani ogólnym wymogom w tym zakresie, dotyczącym wszystkich pracowników objętych regulacją kodeksową.

Ponadto ustawodawca uporządkował kwestie dotyczące ustalania wymiaru urlopu osób zatrudnionych w niepełnym wymiarze czasu pracy, ale też uregulował uprawnienia urlopowe pracowników podejmujących dodatkowe zatrudnienie, przez co przyczynił się niewątpliwie w znacznym stopniu do zagwarantowania tym ostatnim warunków do rzeczywistego wypoczynku, co zostanie jeszcze szerzej wyjaśnione.

Daleko idącym modyfikacjom zostały poddane także zasady udzielania urlopów wypoczynkowych w ich wymiarze "technicznym”. Obecnie urlop jest udzielany bowiem w dniach, które są dla danego pracownika dniami pracy, zgodnie z obowiązującym go rozkładem czasu pracy i w wymiarze godzinowym, przy założeniu, że jeden dzień urlopu równa się ośmiu godzinom pracy. Pozwoliło to na pewne uproszczenie i uogólnienie reguł udzielania urlopów wypoczynkowych, w tym zwłaszcza w stosunku do osób zatrudnionych w systemach równoważnych norm czasu pracy oraz zatrudnionych na część etatu. Jednocześnie w omawianym zakresie ustawowo zabezpieczono funkcję wypoczynkową urlopu poprzez ograniczenie możliwości jego udzielania na część dnia roboczego, tj. pojedyncze godziny.

Do zmian mających istotne znaczenie z punktu widzenia dostosowania polskiego prawa do standardów unijnych i optymalizowania warunków do urzeczywistniania podstawowego celu urlopu należy zaliczyć również zawężenie przypadków dopuszczalnego odstąpienia od zasady udzielania urlopu w naturze i zastępowania go ekwiwalentem pieniężnym ${ }^{639}$. Wyeliminowano bowiem z Kodeksu pracy przesłankę wypłaty tego świadczenia w postaci powołania pracownika do zasadniczej, okresowej lub zawodowej służby wojskowej, do służby w charakterze kandydata na żołnierza zawodowego, albo do odbycia przeszkolenia wojskowego trwającego dłużej niż trzy miesiące. Obecnie tylko ustanie stosunku pracy daje możliwość wypłaty takiego ekwiwalentu, jeśli pracownik wcześniej należnego mu urlopu nie wykorzystał.

Zagwarantowano też pracodawcy zwolnienie z obowiązku wypłaty wynagrodzenia za czas urlopu czy ekwiwalentu za niewykorzystany urlop bądź ograniczenie go do ewentualnego wyrównania, jeśli na podstawie odrębnych przepisów został on zobowiązany do objęcia pracownika obowiązkowym ubezpieczeniem

639 Zwracał na to uwagę L. Florek, Prawo pracy Unii Europejskiej, s. 59. 
zapewniającym mu otrzymanie świadczenia pieniężnego za czas urlopu. Przepis ten nie ma jednak większego, w sensie powszechnego, znaczenia praktycznego.

Urlop wypoczynkowy, na co wprost wskazuje choćby jego nazwa, stając się instytucją prawną, miał od początku urzeczywistniać ogólniejsze prawo pracownika do odpoczynku. Niemniej, jak wynika z powyższej analizy, wraz z rozwojem poglądów na istotę wypoczynku oraz jego jednostkowe i społeczne znaczenie, ewoluowała również prawna regulacja dotycząca tego urlopu. W pierwszym okresie jej rozwoju wartością było już samo ustawowe zagwarantowanie pracownikom omawianego świadczenia. Z czasem jednak zaczęto podejmować wysiłki na rzecz stworzenia możliwie najbardziej optymalnych warunków jego wykorzystywania, aby w maksymalnym stopniu zrealizować cel, dla którego urlop ten został ustanowiony. Jak na tym tle prezentuje się obecna regulacja, będzie to przedmiotem analizy i oceny w kolejnych częściach niniejszego opracowania. Niemniej warto pamiętać, że procesu doskonalenia omawianego prawa nie można uznawać za skończony. Zmienia się bowiem świat, a wraz z nim warunki społeczno-gospodarcze i związane z nimi procesy, które wymuszają również określone reakcje prawne. Kwestia prawnie zagwarantowanego odpoczynku staje się obecnie niezwykle ważna, do czego przyczynił się niewątpliwie gwałtowany wzrost tempa życia, a zwłaszcza samej pracy. 



\section{Część II}

\section{Elementy konstrukcyjne prawa do urlopu wypoczynkowego sprzyjające realizacji prawa do odpoczynku}

\section{Pojęcie urlopu wypoczynkowego i jego charakter prawny}

Urlop wypoczynkowy, z punktu widzenia jego istoty, w zasadzie nie został zdefiniowany zarówno w przepisach Kodeksu pracy, jak i we wcześniejszych ustawach regulujących to prawo. Wskazano jedynie na pewne jego cechy podstawowe, specyficzne dla tej instytucji, zabezpieczające faktyczną realizację jej zasadniczego celu wpisanego w nazwę omawianego prawa, jakim jest wypoczynek.

$\mathrm{W}$ doktrynie prawa pracy podjęto jednak próby wyjaśnienia charakteru tytułowego urlopu i w zasadzie zgodnie przyjmuje się, że urlop ten stanowi w sensie prawnym coroczne zwolnienie pracownika $\mathrm{z}$ obowiązku świadczenia pracy, z zachowaniem jego prawa do wynagrodzenia za ten okres, w celu umożliwienia mu wypoczynku'.

Jest to zatem z natury pewien dłuższy czas wolny od pracy zawodowej - obowiązku pozostawania w dyspozycji pracodawcy - oddany do swobodnej dyspozycji pracownika, przeznaczony w założeniu nie na bieżący odpoczynek, ale na pełną regenerację sił fizycznych i psychicznych organizmu nadwyrężonych po wielomiesięcznej pracy, na odprężenie, relaks i rozwój osobisty.

Urlop ten różni się zatem nie tylko od pozostałych form realizacji prawa do odpoczynku, wcześniej omówionych (które, poza innymi różnicami, bardzo często wyznaczają granicę zobowiązania pracownika, nie są więc zwolnieniem $\mathrm{z}$ obowiązku wykonywania pracy), ale też generalnie od innych przerw w wykonywaniu

1 Por. W. Szubert, Zarys prawa pracy. Warszawa 1976, s. 225 oraz J. Loga, Urlopy wypoczynkowe, Łódź 1963, s. 46. Podobnie też M. Święcicki, Prawo pracy, Warszawa 1968, s. 442 i n. 
pracy przewidzianych prawem, $\mathrm{w}$ tym $\mathrm{m}$.in. i tych określonych przez ustawodawcę mianem urlopu (por. wcześniejsze uwagi). Stanowi on również instytucję jakościowo odmienną od przypadków określanych mianem usprawiedliwionej nieobecności w pracy, które mają w swą istotę wpisany obowiązek świadczenia pracy, ale z jakichś przyczyn, uznanych za usprawiedliwione, nie zostaje on zrealizowany. W przypadku urlopu wypoczynkowego jest to czas, w którym pracownik nie ma takiego obowiązku, zostaje z niego zwolniony, co nie zawsze przy formułowaniu przepisów prawnych jest przez ustawodawcę dostrzegane ${ }^{2}$.

$\mathrm{Z}$ uwagi na to, że jest to „Zwolnienie od pracy”, na podmiocie zatrudniającym spoczywa obowiązek umożliwienia uprawnionemu korzystania $z$ urlopu, a więc udzielenia owego czasu wolnego w odpowiednim rozmiarze i wypłaty za ten okres wynagrodzenia.

Niekiedy akcentuje się dodatkowo, że jest to uprawnienie pracownika szczególnego rodzaju, o charakterze ustawowym, przysługujące mu w wymiarze określonym przepisami prawa pracy i $\mathrm{w}$ czasie ustalonym przez pracodawcę ${ }^{3}$ oraz że urlop wypoczynkowy ma charakter prawa osobistego $0^{4}$, a nawet prawa pierwotnego stanowiącego obligatoryjny element stosunku pracy już od momentu jego powstania 5 .

Niemniej wszyscy autorzy zgodnie przyjmują, że celem omawianego zwolnienia jest wypoczynek, niekiedy ujmowany jako regeneracja sił ${ }^{6}$ czy regeneracja „zdolności psychofizycznej do pracy"' . Owa regeneracja współcześnie nie może być jednak sprowadzana wyłącznie do aspektu biologicznego, konstrukcja urlopu, a także mnogość różnorodnych form wypoczynku wskazują bowiem, że jest to czas, który może być również wykorzystany do rozwoju osobistego danej jednostki ${ }^{8}$, a nie jedynie odtworzenia sił zużytych pracą.

Cel analizowanego urlopu, a także jego regularność, stają się zatem jednocześnie jego immanentną cechą pojęciową, pozwalającą odróżnić urlop od innych zwolnień z obowiązku wykonywania pracy gwarantowanych prawem. Nie są one bowiem zwykle udzielane cyklicznie i mają odmienne od urlopu wypoczynkowego przeznaczenie, co było wcześniej szerzej wyjaśniane.

2 Za zbytnie uproszczenie należy uznać posłużenie się w art. 41 k.p. pojęciem „urlopu pracownika, a także [...] innej usprawiedliwionej nieobecności pracownika w pracy”.

3 Por. tak: W. Muszalski, Kodeks pracy. Komentarz, Warszawa 2009, s. 713. Podobnie E. Chmielek-Łubińska, [w:] Kodeks pracy. Komentarz, red. L. Florek, Warszawa 2009, s. 955.

4 Por. Z. Masternak, [w:] Prawo pracy. Zarys wykładu, Warszawa 2005, s. 237.

5 Por. T. Liszcz, Prawo pracy, Warszawa 2004, s. 362. Por. też A. Wypych-Żywicka, Prawa podmiotowe w prawie pracy, [w:] System prawa pracy. Część ogólna, t. 1, red. K.W. Baran, Warszawa 2017, s. 1335.

6 Por. K. Kolasiński, Podstawy prawa pracy, Toruń 1979, s. 133. Tak też: T. Zieliński, Zarys wykładu prawa pracy, cz. II, Katowice 1984, s. 278 oraz W. Dyląg, Prawo do wypoczynku jako przejaw funkcji ochronnej prawa pracy, [w:] Funkcja ochronna prawa pracy a wyzwania współczesności, red. M. Bosak, Warszawa 2014, s. 32.

7 Por. K. Rączka, [w:] Kodeks pracy. Komentarz, Warszawa 2005, s. 591.

8 Por. też M. Święcicki, Prawo pracy, s. 442. 
Konstrukcja omawianego urlopu jest w dużej mierze do celu tego dostosowana, w szczególności poprzez określony wymiar tego świadczenia, który ma zapewniać odpowiednią długość wypoczynku, ale też wpływać na jego jakość ${ }^{9}$, jak i podstawowe zasady prawa urlopowego, dalej analizowane, służące bezpośrednio jego realizacji. Chodzi m.in. o osobisty charakter tego prawa, ale przede wszystkim obowiązek wypłaty wynagrodzenia za ten okres, który powoduje m.in., że pracownik może swój wypoczynek odpowiednio zorganizować oraz powstrzymać się od pracy zarobkowej w tym czasie i który, zdaniem J. Logi, współdecyduje o istocie tego urlopu $^{10}$.

Odpłatność, obok coroczności i nieprzerwanego charakteru omawianego prawa, stała się przy tym elementem definicyjnym urlopu wypoczynkowego, wynikającym z art. 152 k.p.

Zwykle przyjmuje się, że obowiązek pracodawcy wypłaty wynagrodzenia wynika $\mathrm{z}$ faktu ponoszenia przez niego ryzyka socjalnego w stosunku pracy, niemniej na gruncie innych teorii wynagrodzenie to jest formą odroczonej wypłaty części wynagrodzenia za miesiące poprzedzające nabycie prawa do urlopu ${ }^{11}$.

Warto bowiem przypomnieć, że w związku z rozwojem prawa urlopowego wykształciły się w przeszłości różne teorie dotyczące jego prawnej natury. Teorie te, wywodzone z określonych rozwiązań prawnych przyjmowanych w zakresie prawa urlopowego, stanowiące jednocześnie ich uzasadnienie, bądź formułowane w okresie braku takich regulacji, w jakiejś mierze rzutują również na sposób i zakres realizacji podstawowej funkcji omawianego urlopu, mocniej lub słabiej ją zabezpieczając.

J. Loga wskazywał na co najmniej pięć wyodrębnionych w tym zakresie koncepcji ${ }^{12}$.

W początkowym okresie kształtowania się praktyki udzielania urlopów wypoczynkowych dominujący charakter miały dwie, wywodzone z przepisów prawa cywilnego, koncepcje: teoria darowizny oraz urlopu jako prawa idealnego z pośrednią wartością majątkową.

W ramach teorii darowizny zakładano, że urlop, a w szczególności wynagrodzenie za ten czas, jest formą darowizny dokonywanej przez pracodawcę na rzecz pracownika. Z łączącej strony umowy wynika bowiem, że pracodawca ma obowiązek wypłacać wynagrodzenie za wykonaną przez pracownika pracę. Jeśli wskutek dobrowolnego (czy nawet zwyczajowego) zwolnienia pracownika z obowiązku wykonywania pracy ten ostatni nie świadczy pracy, to pracodawca, wypłacając mimo wszystko wynagrodzenie, przy braku świadczenia wzajemnego ze strony pracownika, staje się darczyńcą - przysparza temu pracownikowi korzyść majątkową.

9 A. Uklejska, Aktualne kierunki rozwoju prawa urlopowego, PiZS 1974, nr 6, s. 23.

10 Por. J. Loga, Urlopy wypoczynkowe, s. 47.

11 Por. K. Kolasiński, Prawo pracy znowelizowane, Toruń 1996, s. 209.

12 Por. J. Loga, Urlopy wypoczynkowe, s. 42 i n.; por też: tenże, Poglądy nauki burżuazyjnej na charakter prawny urlopu wypoczynkowego, „Zeszyty Naukowe Uniwersytetu Łódzkiego” 1958, seria I, z. 14, s. 57 i n. 
Umowne zastrzeżenie prawa do urlopu zwolennicy tej koncepcji postrzegali z kolei jako „przyrzeczenie darowizny”, choć wyrażano w tym konkretnym przypadku również zdania odrębne (tj. że wówczas urlop traci taki charakter $)^{13}$.

W dominującej do około pierwszej wojny światowej, przy braku rozwiązań ustawowych, teorii darowizny urlopu w zasadzie zależał on w dużej mierze od dobrej woli pracodawcy. Nawet bowiem, jeśli urlop wypoczynkowy był gwarantowany $\mathrm{w}$ umowie o pracę, to ta nie była zawierana $\mathrm{w}$ formie wymaganej dla dochodzenia roszczeń z tytułu dokonanej darowizny, często np. aktu notarialnego.

$\mathrm{Na}$ jej gruncie urlop wypoczynkowy nie był de facto prawem pracownika, ale świadczeniem, z którego ten korzystał dzięki zgodzie pracodawcy.

Ponadto teoria ta bardzo słabo odzwierciedlała podstawowe funkcje omawianego urlopu, jego celem nie jest bowiem przysporzenie pracownikowi korzyści majątkowej, jak zakładali jej zwolennicy, ale odpoczynek przekładający się na ochronę jego życia i zdrowia.

W ramach drugiej grupy poglądów dotyczących istoty urlopu wypoczynkowego podkreślano z kolei jedynie obowiązek pracodawcy zwolnienia pracownika od pracy. A zatem elementem tak pojętego prawa do urlopu nie był obowiązek wypłaty wynagrodzenia za ten czas.

Tym samym również drugi z wstępnie formułowanych poglądów na temat charakteru prawnego urlopu wypoczynkowego, jako „prawa idealnego”, w rezultacie zaprzeczał jego głównemu przeznaczeniu, a nawet podważał w istocie prawo do urlopu wypoczynkowego ${ }^{14}$. Roszczenia pracownika w omawianym zakresie ograniczały się bowiem wyłącznie do czasu wolnego. Brak było natomiast gwarancji, niezwykle ważnej z punktu widzenia faktycznej realizacji prawa do odpoczynku, wypłaty wynagrodzenia za ten czas czy obowiązku uiszczenia ekwiwalentu pieniężnego (odszkodowania) w razie odmowy udzielenia urlopu przez pracodawcę ${ }^{15}$.

W okresie międzywojennym pojawiła się również koncepcja urlopu jako elementu obowiązku pieczy pracodawcy. Wywodzi się ona ze szczególnego sposobu postrzegania stosunku pracy jako stosunku wspólnoty, w którym wszyscy jej członkowie troszczą się o dobro zakładu oraz działają na rzecz poszanowania swoich wzajemnych interesów. Po stronie pracownika przybiera to postać obowiązku wierności, a po stronie pracodawcy, jako podmiotu kierującego pracą, obowiązku pieczy nad pracownikami, w tym przede wszystkim szczególnej dbałości o ich życie i zdrowie. Nie ulega wątpliwości, że wypoczynek realizowany poprzez instytucję urlopów wypoczynkowych znacznie się do tego przyczynia.

13 Por. J. Loga, Urlopy wypoczynkowe, s. 49 i n.

14 Por. A. Walas, Prawo do wypoczynku. Zagadnienia prawne Konstytucji PRL, t. 3, Warszawa 1954, s. 486.

15 W literaturze wskazywano na konieczność udowodnienia przez pracownika szkody majątkowej, stanowiącej bezpośrednie następstwo braku realizacji prawa do czasu wolnego jako konieczną przesłankę dochodzenia ewentualnie takiego odszkodowania. Uznawano, że może ona przybrać postać rozwiązania przez pracownika stosunku pracy w związku z koniecznością wypoczynku. Por. A. Walas, Prawo do wypoczynku..., s. 486. 
Koncepcja ta, jak podkreślał J. Loga, stwarzała podstawy roszczenia pracownika o urlop, zwłaszcza w sytuacji braku odpowiednich regulacji prawnych czy umownych, ale nie do końca wyjaśniała jego charakter prawny ${ }^{16}$. Ponadto osłabiała ona znacznie wypoczynkową funkcję omawianego urlopu poprzez uzasadnienie możliwości odmowy jego udzielenia m.in. w sytuacjach ciężkiego naruszenia przez pracownika swoich podstawowych obowiązków, czy ujmując rzecz ogólniej, niedopełnienia obowiązku wierności i lojalności wobec podmiotu zatrudniającego.

Dokonana $\mathrm{z}$ czasem ustawowa (ewentualnie układowa) regulacja prawa do urlopów wypoczynkowych spowodowała pewną dezaktualizację wspomnianych wcześniej teorii, choć niektórzy również w obowiązujących przepisach dostrzegają jeszcze ich ślady ${ }^{17}$. Po wydaniu konkretnych aktów ustawowych poświęconych urlopom, na gruncie prawa polskiego, szczególną rolę odegrały jednak dwa konkurujące ze sobą ujęcia teoretyczne istoty urlopu: urlopu jako świadczenia społecznego i urlopu jako odpłaty za świadczoną pracę.

Pierwsza z tych koncepcji zakłada, że urlop wypoczynkowy jest świadczeniem społecznym, a więc świadczeniem, które nie pozostaje w bezpośrednim związku z pracą na rzecz danego pracodawcy. Teoria ta zyskała na znaczeniu po drugiej wojnie światowej, znajdując oparcie w tych przepisach prawa, w których zaczęto wprowadzać zasadę prawa do urlopu corocznego niezwiązanego z pracą na rzecz jednego pracodawcy, lecz z pracą w ogóle, bez względu na miejsce jej wykonywania ${ }^{18}$. W latach 80 . XX w. opowiadał się za nią, uwzględniając ówczesne rozwiązania prawne, T. Zieliński, uznając, że sposób unormowania przesłanek nabycia prawa do urlopu wpisuje się w zasadę „przyznawania świadczeń socjalnych według potrzeb" ${ }^{\prime 1}$. Urlop nie jest zatem świadczeniem wzajemnym spełnianym przez pracodawcę jako forma pewnej odpłaty za wykonywaną przez pracownika w danym okresie pracę, przysługuje mu bowiem w związku z samą potrzebą wypoczynku po corocznej pracy. Tym samym, zdaniem Zielińskiego, wymóg przepracowania określonego czasu jako przesłanka nabycia prawa do urlopu jest spowodowany wyłącznie tym, że wykonywanie pracy przez pewien okres pociąga za sobą konieczność „rekreacji”, „przerwy w wydatkowaniu energii dla nabycia nowych sił"20.

W tym miejscu nie sposób nie wspomnieć, że współcześnie również w polskim prawie pewne elementy tej koncepcji znalazły ostatecznie swoje odzwierciedlenie, o czym świadczy art. $154^{1}$ k.p., nakazujący, częściowo odmiennie niż w okresie

16 Por. J. Loga, Urlopy wypoczynkowe, s. 54 i n.

17 W ocenie A. Bigaja można dostrzec w obowiązującej regulacji urlopowej elementy teorii pieczy, chociaż z innym rozłożeniem akcentów. Por. tenże, Charakter prawny urlopu wypoczynkowego, „Studia z zakresu prawa pracy i polityki społecznej”, red. A. Świątkowski, Kraków 2012, s. 176.

18 Por. J. Loga, Urlopy wypoczynkowe, s. 59 i n.

19 Por. T. Zieliński, Zarys..., cz. II, s. 280.

20 Tamże, s. 280. 
PRL ${ }^{21}$, wliczać do stażu urlopowego wszystkie okresy zatrudnienia, bez względu na przerwy w zatrudnieniu czy sposób ustania stosunku pracy.

Należy też w tym kontekście zauważyć, że poza pewnymi okresami wymienionymi w art. $155^{2}$ k.p., dla nabycia prawa do urlopu wypoczynkowego istotne jest zasadniczo samo pozostawanie w stosunku pracy, a nie wykonywanie w tym czasie pracy, stąd np. okres przebywania na zwolnieniu lekarskim nie wpływa w żadnej mierze na nabycie prawa i wymiar tego urlopu (w szczególności nie ma absolutnie podstaw prawnych do odliczania dni owej nieobecności w pracy od okresu warunkującego ten urlop).

Z punktu widzenia prawa pracownika do wypoczynku niewątpliwą zaletą omawianej teorii jest to, że sprzyja ona szybszemu nabywaniu uprawnień urlopowych. $\mathrm{Z}$ jej podstawowych założeń wynika bowiem brak uzasadnienia dla takich unormowań prawnych, które wprowadzają dłuższy okres zatrudnienia jako warunek roszczenia o urlop ${ }^{22}$.

Ponadto koncepcja ta stwarza silniejsze podstawy do zachowania prawa do urlopu wypoczynkowego $\mathrm{w}$ sytuacji, gdy pracownik $\mathrm{w}$ danym roku pracy na rzecz danego podmiotu faktycznie nie świadczył, choćby ze względu na niezdolność do pracy z powodu choroby.

Występujące w tej koncepcji rozluźnienie związków między urlopem a wykonywaną pracą może mieć też istotny wpływ na kwestię oceny sposobu jego wykorzystywania przez pracownika, w kierunku uznania jego większej swobody w dysponowaniu udzielonym mu czasem wolnym.

Teoria ta znajduje swoich zwolenników również we współczesnej literaturze przedmiotu. Warto zwrócić uwagę na koncepcję A. Sobczyka, który oceniając prawo do urlopu wypoczynkowego w kontekście regulacji konstytucyjnych, opowiada się zdecydowanie za socjalnym, a w niektórych aspektach nawet więcej - społecznym, publicznym (jeśli wziąć pod uwagę odpłatność urlopu) charakterem tego świadczenia ${ }^{23}$.

21 Kodeks pracy w swej pierwotnej wersji wprowadził zasadę, według której do stażu warunkującego nabycie prawa do urlopu wypoczynkowego wliczało się okresy „przedniego zatrudnienia”, ale pod warunkiem, że przerwa w zatrudnieniu nie trwała dłużej niż trzy miesiące lub że nie doszło do rozwiązania stosunku pracy przez pracownika za wypowiedzeniem (art. 156 k.p.). Ponadto, art. 169 k.p. określał przesłanki utraty prawa do urlopu wypoczynkowego, która następowała w roku rozwiązania lub wygaśnięcia stosunku pracy z powodu: a) jego rozwiązania przez pracodawcę $w$ trybie niezwłocznym z winy pracownika; b) porzucenia przez pracownika pracy. Por. ustawa z 26 czerwca 1974 r. Kodeks pracy, Dz. U. 1974, Nr 24, poz. 141.

22 J. Loga, Urlopy wypoczynkowe, s. 69.

23 Por. A. Sobczyk, Prawo pracy w świetle Konstytucji RP, t. 1: Teoria publicznego i prywatnego indywidualnego prawa pracy, Warszawa 2013, s. 203 i n. W związku z tym, co warto przypomnieć, przywołany autor postuluje m.in. przyznanie prawa do urlopu nie tylko pozostającym w stosunku pracy, jak to jest obecnie, ale każdej osobie pracującej w warunkach ekonomicznej zależności, jeśli łączący strony stosunek, np. cywilnoprawny, ma długotrwały charakter; tworzy on pewną koncepcję - „pracownika konstytucyjnego”. 
Trzeba bowiem zaznaczyć, że różnie postrzega się również kwestię natury źródła, z którego prawa do urlopu się wywodzi. Większość doktryny prawa pracy uznaje, że urlop wypoczynkowy wchodzi w zakres umownego prawa pracy, niemniej niektórzy autorzy dostrzegają w nim także elementy publicznoprawne, co oznaczałoby, że udzielając urlopu, pracodawca realizuje swój obowiązek nie tylko wobec pracownika, ale również państwa.

Twórcy drugiej z wymienionych koncepcji - urlopu jako odpłaty za świadczoną pracę - przyjęli, że udzielenie urlopu i zapłata za urlop są świadczeniami wzajemnymi pracodawcy na rzecz pracownika za spełnioną przez niego pracę. Eksponuje się w niej zatem wyraźny związek między nabyciem prawa do urlopu i jego wymiarem a okresem zatrudnienia. Tym samym w myśl tej teorii pracownik nabywa prawo do urlopu stopniowo, w miarę trwania stosunku pracy, a realizacja tego prawa jest możliwa w każdej chwili jego powstania ${ }^{24}$. Jak wskazywał Loga, przyjęcie takiej konstrukcji w odniesieniu do urlopu jako świadczenia wzajemnego daje „najmocniejsze oparcie dla podmiotowego prawa pracownika do wypoczynku”25 i uniezależnia je od takich kwestii, jak np. sposób rozwiązania stosunku pracy.

$\mathrm{Z}$ drugiej jednak strony, dopuszczana w tej teorii możliwość zdeterminowania uzyskania tego prawa, przynajmniej w zakresie pierwszego urlopu, upływem określonego czasu, zwłaszcza jeśli byłby on wielomiesięczny, stanowi istotne zagrożenie dla skutecznej realizacji jego podstawowej funkcji.

Funkcja ta schodzi zresztą w omawianej teorii na dalszy plan, skoro urlop stanowi swego rodzaju formę ,wynagrodzenia za pracę"26.

Po kilku latach obowiązywania przepisów k.p. pogląd na temat charakteru prawnego urlopu wypoczynkowego zbliżony do założeń teorii odpłaty formułował W. Piotrowski, uznając, że prawo do urlopu jest zależne od „wysługi na rzecz zakładu lub gospodarki narodowej”27.

$\mathrm{W}$ istocie obowiązująca po wejściu w życie k.p. regulacja dotycząca nabycia prawa i wymiaru urlopu wypoczynkowego w wielu swych fragmentach takie stanowisko uzasadniała. Pierwszy urlop pracownik nabywał bowiem dopiero z upływem roku pracy, a jego wymiar wzrastał sukcesywnie (od 14 do maksymalnie $26 \mathrm{dni}$ ) wraz ze wzrostem stażu pracy.

Elementy tej koncepcji w kodeksowej konstrukcji prawa urlopowego dostrzegał także W. Szubert. Niemniej autor ten podkreślał, że prawo do urlopu wypoczynkowego nie jest determinowane wyłącznie świadczeniem pracy na rzecz pracodawcy, ale wpływają na nie (zwłaszcza jego wymiar) też okoliczności, które nie są związane z samą pracą, np. okresy nauki czy służby wojskowej. Z tego względu, zdaniem Szuberta, ciążący na pracodawcy kodeksowy obowiązek udzielenia urlopu

24 Por. J. Loga, Poglady nauki burżuazyjnej..., s. 64.

25 Tamże, s. 70.

26 Por. J. Loga, Urlopy wypoczynkowe..., s. 58.

27 Por. W. Jaśkiewicz, C. Jackowiak, W. Piotrowski, Prawo pracy w zarysie, Warszawa 1980, s. 345. 
wypoczynkowego wykracza poza ramy ekwiwalentności świadczeń i staje się bardziej obowiązkiem nałożonym „w interesie społecznym”, ale „przy uwzględnieniu przesłanek, które decydują o potrzebie wypoczynku i uzasadniają zróżnicowanie jego wymiaru"28.

Różne wypowiedzi przedstawicieli doktryny prawa pracy w omawianej sprawie wskazują na złożoność problemu i liczne wątpliwości, jakie już w przeszłości wywoływała ocena charakteru prawnego urlopu wypoczynkowego w prawie polskim.

Jeśli jednak rozważać prawo do urlopu jako formę odpłaty ze strony pracodawcy za świadczoną przez pracownika pracę, to należy zwrócić uwagę na kilka rozwiązań przyjętych w obowiązującym prawie, które zdają się w tę teorię wpisywać. Najbardziej przełomowym było z pewnością wprowadzenie w 1996 r. instytucji urlopu proporcjonalnego. Tym samym odstąpiono od wcześniej stosowanej zasady, zgodnie z którą w przypadku rozwiązania stosunku pracy obowiązkiem udzielenia całego, przysługującego pracownikowi urlopu w naturze lub wypłaty ekwiwalentu pieniężnego za ten urlop obciążony był wyłącznie dotychczasowy pracodawca. Istotą zaś urlopu proporcjonalnego jest bardziej równomierne rozłożenie tych obciążeń pomiędzy pracodawców zatrudniających pracownika w danym roku kalendarzowym, stosownie do rzeczywistego okresu trwania stosunku pracy czy okresu pracy (art. $155^{2}$ k.p.) na ich rzecz w tym roku. W pewnym uproszczeniu powoduje to, że pracownik niejako dostaje tyle urlopu od danego pracodawcy, ile miesięcy u niego wypracowat.

$\mathrm{Z}$ omawianą teorią współgrają niewątpliwie w jakimś zakresie również unormowania odnoszące się do różnicowania wymiaru urlopu w zależności od stażu pracy.

W związku z powyższym na niejednorodny charakter prawa do urlopu wypoczynkowego, zawierający w sobie przejawy obu zarysowanych wyżej koncepcji, wskazywał m.in. K. Rączka ${ }^{29}$.

Obecnie bywa jednak prezentowane, jak wcześniej wspominano, również zupełnie odmienne od dotychczasowego podejście w kwestii oceny charakteru prawnego urlopu wypoczynkowego, w ramach którego odchodzi się od tradycyjnie wymienianych teorii na rzecz koncepcji urlopu jako „powszechnego prawa człowieka, powiązanego z pracą in abstracto" 30 . Jej główną wartością jest uznanie prawa do odpoczynku, a co za tym idzie, prawa do urlopu wypoczynkowego za podstawowe prawo każdego człowieka, przez co dostarcza ona argumentów na rzecz rozszerzenia zakresu podmiotowego omawianego prawa ${ }^{31}$.

Takie postrzeganie prawa do urlopu wypoczynkowego, jako instytucji realizującej jedno z podstawowych praw człowieka, ale też chroniącej jego dobra osobiste, uzasadnia też priorytet wypoczynkowej funkcji omawianego urlopu nad względa-

28 Por. W. Szubert, Zarys..., s. 225 i n.

29 Por. K. Rączka, [w:] Kodeks pracy. Komentarz, Warszawa 2003, s. 505.

30 Por. A. Bigaj, Charakter..., s. 176 i n.

31 Tak: A. Świątkowski, za: A. Bigaj, Charakter..., s. 177. 
mi związanymi z pracą na rzecz danego pracodawcy, czego rezultatem jest m.in. odejście od zasady warunkującej nabycie prawa do urlopu i jego utrzymanie posiadaniem określonego stażu pracy u danego pracodawcy.

Prawo do urlopu jawi się zatem współcześnie jako coroczne, odpłatne i nieprzerwane zwolnienie pracownika od obowiązku świadczenia pracy w celu zapewnienia mu możliwości wypoczynku, które nie jest kwestią swoistej zapłaty za pracę, dobrej woli pracodawcy czy bezpośrednim wynikiem sprawowania przez niego pieczy nad pracownikiem. Prawo to jest bowiem środkiem realizacji jednego z podstawowych praw człowieka, elementem wpisanym w naturalny cykl życia ludzkiego.

Jak z powyższego wynika, do cech swoistych omawianego zwolnienia od pracy należą przede wszystkim jego odpłatność, periodyczność oraz szczególny cel, któremu powinna być podporządkowana zarówno sama konstrukcja tego urlopu, jak i zasady jego udzielania.

Z istotą urlopu wypoczynkowego w ścisłym związku pozostaje kwestia oceny charakteru tego prawa w kontekście możliwości czy obowiązku określonego postępowania. Chodzi przede wszystkim o ustalenie czy z urlopem wypoczynkowym wiąże się jedynie obowiązek pracodawcy udzielenia czasu wolnego od pracy na warunkach prawem przewidzianych, a zarazem roszczenie pracownika o zwolnienie go z obowiązku świadczenia pracy, czy też dodatkowo po stronie tego ostatniego powstaje powinność wykorzystania owego czasu w sposób w pełni zgodny z jego celem, a zatem, czy na pracowniku ciąży prawny obowiązek odpoczywania w tym czasie.

Kwestia ta jest trudna do jednoznacznej oceny. Niemniej z uwagi na to, że urlop wypoczynkowy stanowi istotną część szerszego uprawnienia pracownika - prawa do odpoczynku - znaleźć tu muszą zastosowanie ogólne ustalenia wcześniej dokonane, dotyczące charakteru tego prawa. Z nich zaś wynika, że prawna konstrukcja odpoczynku polega raczej na obowiązku stworzenia pracownikowi odpowiednich warunków do psychofizycznej regeneracji organizmu po wysiłku związanym z wykonywaną pracą, a nie na powinności odpoczywania, której niedopełnienie przez pracownika będzie prawnie sankcjonowane. Sam ustawodawca nie wprowadza przecież szczególnych instrumentów w zakresie prawa urlopowego, które gwarantowałyby pracodawcy możliwość kontrolowania sposobu realizacji tego urlopu przez pracownika ani też specjalnych sankcji z tym związanych, co byłoby niewątpliwie argumentem za przyjęciem tezy o obligatoryjności wypoczynku w rozumieniu wskazanym wyżej.

Analogiczna do powyższej filozofia legła również u podstaw koncepcji odpoczynku przyjętej w prawie Unii Europejskiej, o czym była wcześniej mowa.

Z drugiej strony, biorąc pod uwagę szczególny charakter urlopu wypoczynkowego jako instytucji, która ma służyć odpoczynkowi od pracy, ale też ochronie życia i zdrowia ludzkiego, jak również bezpieczeństwu innych osób, można mieć wątpliwości, czy mimo zasadniczo konieczności uznania swobody pracownika w zakresie sposobu jego realizacji, nie powinno się zastrzegać jednocześnie braku 
całkowitej dowolności w korzystaniu przez pracownika ze swych uprawnień, zwłaszcza wykorzystywaniu pewnych instytucji w sposób oczywiście sprzeczny $\mathrm{z}$ ich przeznaczeniem.

W tym aspekcie bywa jednak wyrażany pogląd, że swoboda pracownika w zakresie czynienia użytku ze swego prawa do odpoczynku nie podlega zasadniczo ograniczeniu z mocy art. 8 k.p. Prawo do urlopu wypoczynkowego będące prawem podmiotowym nie musi być, zdaniem T. Zielińskiego, wykorzystywane w sposób zgodny ze społeczno-gospodarczym przeznaczeniem prawa do odpoczynku ${ }^{32}$.

Nie bez znaczenia dla analizowanego zagadnienia jest też podstawowy obowiązek pracownika dbałości o dobro pracodawcy (art. $100 \$ 2$ pkt 4 k.p.), pozwalający, jak wskazuje się w literaturze przedmiotu, nie tylko na precyzowanie sposobu wykonania innych obowiązków, ale też sposobu korzystania z uprawnieńn ${ }^{33}$. I choć słusznie zauważono, że obowiązek ten nie może być współcześnie traktowany jako „odpowiednik pracowniczego wszechobowiązku czynienia wszystkiego, co służy dobru pracodawcy" ${ }^{34}$, to niewątpliwie jednak brak odpoczynku w okresie urlopu może wpłynąć pośrednio na obniżenie jakości świadczonej pracy po jego zakończeniu i powrocie do pracy, a tym samym naruszenie obowiązku wyżej wymienionego.

W tym kontekście wiele wątpliwości wywołuje szczególnie kwestia dopuszczalności podjęcia przez pracownika w okresie urlopu wypoczynkowego innej pracy zarobkowej ${ }^{35}$, która, odmiennie niż np. w prawie niemieckim ${ }^{36}$, nie została bezpośrednio rozstrzygnięta przez ustawodawcę ${ }^{37}$. Rozważając ten problem w powiązaniu z tytułową materią, jest oczywiste, że takie zachowanie pracownika może kolidować z podstawową funkcją omawianego zwolnienia, a w niektórych przypadkach przyczyniać się do pogorszenia stanu zdrowia zatrudnionej osoby. Nie-

32 Por. T. Zieliński, Klauzule generalne w prawie pracy, Warszawa 1988, s. 149 i n.

33 Por. M. Skąpski, Wpływ pracowniczego obowiq̨zku dbałości o dobro zakładu pracy na zakres kompetencji pracodawcy do kontrolowania pracownika, [w:] Kontrola pracownika. Możliwości techniczne i dylematy prawne, red. Z. Góral, Warszawa 2010, s. 73.

34 Por. A. Chobot, Pracowniczy obowiq̨zek dbałości o dobro zakładu a ograniczenia zasady wolności pracy, Poznań 1983, s. 36. Zob. też M. Skąpski, Wpływ pracowniczego obowiq̨zku..., s. 74.

35 Pomijam tu przypadki, w których pracownik jest wprost związany zakazem podejmowania dodatkowego zatrudnienia. W tym względzie w pełni zgadzam się z B. Cudowskim, że zakaz ten wówczas obowiązuje również w okresie urlopu wypoczynkowego. Por. szerzej: B. Cudowski, Urlop wypoczynkowy i bezpłatny a dodatkowe zatrudnienie, [w:] Człowiek, obywatel pracownik. Studia z zakresu prawa. Księga Jubileuszowa poświęcona Profesor U. Jackowiak, red. J. Stelina, A. Wypych-Żywicka, „Gdańskie Studia Prawnicze” 2007, t. XVII, s. 46 i n.

36 Według ustawodawstwa niemieckiego, podczas urlopu wypoczynkowego pracownik nie może podejmować żadnej działalności zarobkowej, ani w ramach stosunku pracy, ani na innej podstawie, z wyjątkiem kształcenia zawodowego. Zakaz ten nie dotyczy prac podejmowanych przez pracownika na swoją rzecz, tj. np. domowych czy ogrodowych. Por. M. Henssler, H.J. Willemsen, H.-J. Kalb (Hrsg.), Arbeitsrecht Kommentar, Köln 2016, s. 1901 i n.

37 Szerzej zob. M. Nowak, Kilka uwag na temat charakteru prawnego i funkcji urlopu wypoczynkowego w świetle zmieniających się przepisów kodeksu pracy, [w:] 40 lat Kodeksu pracy, red. Z. Góral, M.A. Mielczarek, Warszawa 2015, s. 278 i n. oraz przywołana tam literatura. 
mniej, jak się wydaje, obowiązująca regulacja prawna nie daje podstaw do sformułowania jakiegoś ogólnego, kategorycznego zakazu w tym zakresie ${ }^{38}$, zwłaszcza że pracownik może pozostawać jednocześnie w więcej niż jednym stosunku pracy, a nie tylko doraźnie podjąć pracę w czasie urlopu. Co więcej, w przepisach k.p. uregulowano uprawnienia urlopowe pracownika w zatrudnieniu dodatkowym, nie zastrzegając przy tym, że urlop ten musi być wykorzystywany w tym samym czasie co w zatrudnieniu podstawowym. Nie zawsze zresztą byłoby to w pełni możliwe, zważywszy chociażby na tzw. urlop proporcjonalny związany z podjęciem dodatkowego zatrudnienia w części roku kalendarzowego czy występującą po stronie pracodawcy konieczność zapewnienia normalnego toku pracy.

Ustawodawca nie określił również sankcji związanych z takim zachowaniem pracownika w czasie urlopu wypoczynkowego, co więcej, dawno zrezygnowano z pierwotnie wprowadzonej w prawie urlopowym normy, z której wynikała utrata prawa do wynagrodzenia za czas urlopu w razie podjęcia w jego trakcie pracy zarobkowej w innym przedsiębiorstwie (por. art. 3 ustawy urlopowej z 1922 r.). Nawet w przypadku stwierdzenia wykonywania innej pracy zarobkowej przez pracownika w okresie urlopu pracodawca nie może zatem np. odwołać pracownika $\mathrm{z}$ urlopu z tego powodu czy odmówić mu wypłaty wynagrodzenia gwarancyjnego za ten czas.

Niemniej, jeśli pracownik podjął w czasie urlopu inne zatrudnienie, a macierzysty pracodawca odwoła go z urlopu ze względu na wystąpienie przyczyn określonych w przepisach prawa pracy dopuszczających takie odwołanie, pracownik musi liczyć się z utratą korzyści, których nie będzie mógł osiągnąć w związku z takim odwołaniem (np. utratą dodatkowego zarobku). Nie są to bowiem koszty bezpośrednie, które będzie musiał w takiej sytuacji pokryć pracodawca.

W swoim czasie w literaturze formułowano również pogląd, że pracodawca mógłby dochodzić ewentualnie od pracownika wykorzystującego urlop w sposób sprzeczny z jego przeznaczeniem, np. podejmującego w tym czasie inne zatrudnienie, zwrotu wypłaconego za czas urlopu wynagrodzenia na podstawie przepisów o bezpodstawnym wzbogaceniu ${ }^{39}$, co jest jednak bardzo wątpliwe $z$ uwagi na brak wyraźnego zakazu wykonywania pracy w tym okresie, a nawet domniemane założenie dopuszczalności jej świadczenia ze względu na regulację prawną urlopu wypoczynkowego w dodatkowym zatrudnieniu.

Ponadto podnoszono już wcześniej w doktrynie prawa pracy, że wprowadzenie tego rodzaju sankcji związanych z podjęciem pracy, zwłaszcza zarobkowej, w czasie urlopu byłoby niecelowe. Ich ewentualne zastosowanie nie zapewnia bowiem prawidłowego wykorzystania urlopu wypoczynkowego, poza ewentualną funkcją

38 W literaturze bywa jednak wyrażany pogląd odmienny, tj. że istnieje zakaz podejmowania pracy zarobkowej, nawet jeśli nie wynika to wprost z przepisów prawa. Por. W. Dyląg, Prawo do odpoczynku..., s. 32. Jednocześnie dalej autor przyznaje, że kwestia ewentualnego obowiązku odpoczywania w czasie urlopu jest sprawą dyskusyjną. Tamże, s. 35.

39 Por. J. Loga, Poglądy nauki burżuazyjnej..., s. 68 i n. 
odstraszającą, a wręcz przeciwnie, może skorzystanie $\mathrm{z}$ tego prawa skutecznie uniemożliwić (np. w razie odwołania z urlopu czy rozwiązania stosunku pracy) ${ }^{40}$.

W piśmiennictwie zwraca się przy tym też uwagę na ograniczone praktyczne możliwości kontroli formy i efektywności wypoczynku pracownika ${ }^{41}$. Formy te mogą być zresztą rozmaite, zwłaszcza w odniesieniu do szeroko rozumianego obecnie pojęcia wypoczynku, co było wyjaśniane w początkowych fragmentach niniejszego opracowania. Nie jest w szczególności wykluczona realizacja omawianej funkcji wypoczynkowej urlopu w sytuacji podjęcia pracy fizycznej, po intensywnej pracy umysłowej ${ }^{42}$. Wywodzony ewentualnie $\mathrm{z}$ omawianego prawa nakaz odpoczynku byłby zatem w codziennym życiu w zasadzie nieweryfikowalny.

Ponadto próba ingerencji w sposób wykorzystywania zwolnienia od pracy, do którego pracodawca został zobligowany przepisami prawa może być również postrzegana jako bezpodstawne wkraczanie w sferę życia prywatnego pracownika. Wynagrodzenie, które za czas urlopu pracodawca wypłaca, i które bywa wykorzystywane jako argument na rzecz niedopuszczalności podejmowania w tym czasie innej pracy zarobkowej, ma ze swej natury umożliwiać faktyczną realizację celu omawianego zwolnienia, a nie stanowić podstawę do jednak pewnego rodzaju „Zawłaszczania” owego czasu przez pracodawcę, choćby w aspekcie koniecznego od pracy zarobkowej wypoczynku.

Stąd należy raczej uznać, że poza przypadkami rażących zachowań po stronie pracownika, na gruncie obowiązującego prawa, decyzja dotycząca skorzystania z prawa do odpoczynku oraz sposobu wykorzystania urlopu wypoczynkowego należy zasadniczo do uprawnionego ${ }^{43}$.

Wydaje się, że w podobny sposób, choć mocniej akcentując powinność określonego zachowania się korzystającego z urlopu, ocenia ową sytuację A. Sobczyk. Uznaje on bowiem, że zachowanie pracownika w czasie urlopu powinno jednak odpowiadać jego celom, co nie wyklucza jednak zupełnie możliwości wykonywania w jakimś wymiarze pracy, szczególnie na potrzeby własne. Chodzi natomiast, zdaniem autora, o wyeliminowanie zachowań zaprzeczających wręcz podstawowej funkcji urlopu, jaką jest odpoczynek. Wywodząc z obwiązujących przepisów, m.in. $z$ regulacji konstytucyjnej, socjalny charakter omawianego prawa, A. Sobczyk uznaje, że w tym przypadku „wolność pracy” powinna być ograniczona celem finansowanej przez pracodawcę ,wolności od pracy”. Tym samym, zdaniem powołanego autora, świadczeniu socjalnemu pracodawcy, jakim jest urlop wypoczynkowy, odpowiada obowiązek lojalności pracownika, który zostaje naruszony w sytuacji, gdy pracownik wykorzystuje udzielony mu czas wolny w sposób sprzeczny z jego prze-

40 Por. B. Cudowski, Urlop wypoczynkowy..., s. 51.

41 Tamże, s. 50.

42 Już w przeszłości w literaturze przekonywano, że np. pracownik umysłowy podejmując pracę w rolnictwie, postępuje zgodnie z zasadami aktywnego wypoczynku; za: B. Cudowski, Urlop wypoczynkowy..., s. 47.

43 Podobnie: A. Bigaj, Prawo do urlopu wypoczynkowego, Warszawa 2015, s. 141. Autor uznaje, że pracodawca w świetle obowiązującego prawa nie ma możliwości ingerowania w sposób wykorzystywania przez pracownika urlopu wypoczynkowego. 
znaczeniem, godząc jednocześnie w interesy pracodawcy, np. wraca przemęczony po urlopie w związku z wykonywaniem innego zatrudnienia w tym czasie $^{44}$.

Konsekwencją takiego zachowania pracownika mogłoby być rozwiązanie z nim stosunku pracy przez pracodawcę.

$\mathrm{Z}$ punktu widzenia ochrony interesów pracodawcy jest to $\mathrm{z}$ pewnością interpretacja korzystna, niemniej nie przyczynia się bezpośrednio do zabezpieczenia realizacji rzeczywistego celu urlopu wypoczynkowego, pomijając aspekt działania w sposób zniechęcający na podmiot uprawniony do tego urlopu.

Bywają w związku z tym wyrażane również takie opinie, według których sposób wykorzystania urlopu wypoczynkowego (jak i dni wolnych od pracy) pozostawiony jest całkowicie uznaniu podmiotu uprawnionego do takiego zwolnienia. W obecnym stanie prawnym nie traktuje się bowiem urlopu, jako świadczenia, które pracownik powinien realizować również w interesie pracodawcy, tj. przeznaczać ten czas na regenerację sił w celu osiągnięcia większej wydajności w pracy. Jego wykorzystywanie nie podlega również ograniczeniu, o którym mowa w art. 8 k.p. Stąd pracodawca nie może też skutecznie sprzeciwić się wykonywaniu przez pracownika pracy na rzecz innego podmiotu w okresie urlopowym ${ }^{45}$.

\section{Nabycie prawa do urlopu wypoczynkowego}

\subsection{Nabycie prawa do urlopu wypoczynkowego w świetle powszechnego prawa pracy}

Kwestia warunków nabycia prawa do urlopu wypoczynkowego oraz ustalenia jego minimalnego wymiaru bardzo istotnie wpływa na ocenę stopnia, w jakim prawo do wypoczynku jest faktycznie w danym kraju urzeczywistniane. Decyduje bowiem bezpośrednio zarówno o długości tego odpoczynku, jak i o momencie, w jakim osoba pracująca będzie mogła z tego prawa korzystać. Generalnie należy w tym zakresie sformułować zasadę, że każdemu okresowi pracy powinien odpowiadać ekwiwalenty okres wypoczynku, a także że przyjmowany niemal powszechnie okres wyczekiwania na urlop nie powinien być zbyt rozciągnięty w czasie, biorąc pod uwagę moment podjęcia zatrudnienia, tak aby stworzyć jednak pracownikowi szanse na stosunkowo szybką regenerację sił wydatkowanych w związku z wypełnianiem swoich obowiązków zawodowych, choćby w zakresie proporcjonalnym do okresu trwania tego zatrudnienia. W szczególności MOP przyjmuje, że okres ten nigdy nie powinien być dłuższy niż 6 miesięcy (por. wcześniejsze rozważania),

44 Por. A. Sobczyk, Prawo pracy..., s. 205 i n.

45 Por. tak: G. Goździewicz, T. Zieliński, [w:] Kodeks pracy. Komentarz, red. L. Florek, LEX 2011, komentarz do art. 14 k.p. 
co jest w pełni przekonujące, zważywszy na fakt, że pracownik zwykle realizuje swe uprawnienia znacznie później niż je nabywa, o terminie udzielenia urlopu decyduje przede wszystkim pracodawca. Chodzi zatem też o to, aby nabycie prawa do urlopu wypoczynkowego dokonywało się w obrębie okresu rozliczeniowego tego prawa, a zatem roku kalendarzowego, i tak, aby pracownik w tym roku mógł jeszcze z tego prawa skorzystać.

Samo uwarunkowanie nabycia prawa do urlopu wypoczynkowego osiągnięciem określonego stażu pracy jest bowiem powszechne ${ }^{46} \mathrm{i}$ daje się logicznie uzasadnić. Jak trafnie zauważył L. Florek, wypoczynek, któremu ma służyć omawiana instytucja, powinien być zasadniczo poprzedzony jakimś wydatkowaniem sił pracownika w związku z wykonywaną pracą, co następnie uzasadniałoby potrzebę ich regeneracji w czasie urlopu. Okres wyczekiwania na urlop nie powinien być jednak zbyt długi, np. roczny, choćby poprzez wzgląd na fakt, że dotyczy on przeważnie pierwszej pracy pracownika, która może skutkować potrzebą szybszego odpoczynku związanego z tym, że osoba, która podjęła zatrudnienie w założeniu nie jest jeszcze do pracy przyzwyczajona, a zatem szybciej ulega zmęczeniu fizycznemu i psychicznemu ${ }^{47}$. Z tego względu za właściwe uznano wprowadzenie proporcjonalnego nabywania prawa do urlopu w pierwszym roku pracy ${ }^{48}$.

Powyższe, ogólnie zakreślone wymagania pomogła zrealizować na gruncie prawa polskiego nowelizacja przepisów k.p. dokonana w 2003 r., o której była wcześniej mowa.

Ustalone ostatecznie w jej wyniku powszechne reguły nabycia przez pracownika prawa do urlopu wypoczynkowego są zróżnicowane w zależności od tego, czy jest to urlop nabywany po raz pierwszy w życiu zawodowym (w ramach stosunku pracy) czy też chodzi o tzw. urlopy kolejne.

Zgodnie $\mathrm{z}$ art. $153 \$ 1$ k.p., pracownik podejmujący po raz pierwszy pracę, w roku kalendarzowym, w którym to nastąpiło, uzyskuje prawo do urlopu wypoczynkowego $\mathrm{z}$ upływem każdego miesiąca pracy, w wymiarze 1/12 wymiaru urlopu przysługującego mu po przepracowaniu roku.

W początkowym okresie obowiązywania tego przepisu budził on określone wątpliwości, zwłaszcza jego końcowy zwrot „urlopu przysługującego po przepracowaniu roku". Zastanawiano się bowiem, czy zrywa on zupełnie z wcześniejszą koncepcją tzw. urlopu pierwszego po roku pracy (a zwrot ten dotyczy jedynie liczenia wymiaru urlopu) czy też modyfikuje jedynie zasady jego nabywania ${ }^{49}$.

46 Na przykład w Niemczech pracownik uzyskuje prawo do pełnego urlopu po 6 miesiącach pracy. Por. M. Henssler, H. J. Willemsen, H.-J. Kalb (Hrsg.), Arbeitsrecht..., s. 1871.

47 Por. L. Florek, Staż pracy, Warszawa 1980, s. 155.

48 Propozycja ta była formułowana już w latach 70. XX w. Por. A. Malanowski, Niektóre zagadnienia prawa do urlopu wypoczynkowego, „Studia Prawnicze” 1976, nr 3, s. 306. Por. też: L. Florek, Staż pracy, s. 158.

49 Tego rodzaju wątpliwości zgłaszała m.in. E. Chmielek-Łubińska, Urlop wypoczynkowy po nowelizacji, PiZS 2004, nr 1, s. 20 i n. Autorka wskazywała na niejasną formułę omawianego przepisu, z której może wynikać, że jest jednak jakiś urlop przysługujący po przepracowaniu roku. 
Ostatecznie słusznie przyjęto, że w omawianym zakresie ustawodawca dokonał gruntownej zmiany obowiązującego dotychczas prawa łączącego pierwszy urlop wypoczynkowy pracownika $z$ upływem zasadniczo rocznego stażu pracy (por. szerzej wcześniejsze rozważania) na rzecz urlopu uzyskiwanego cząstkowo w roku kalendarzowym podjęcia pierwszej pracy, określanego też jako „ułamkowy pierwszy urlop" ${ }^{\prime \prime}$.

W świetle obowiązującej regulacji kodeksowej przesłanką powstania prawa do urlopu w roku kalendarzowym podjęcia pierwszej pracy jest upływ każdego miesiąca pracy. Oznacza to, że urlop ten jest nabywany z dołu, po każdym miesięcznym okresie zatrudnienia $\mathrm{w}$ ramach stosunku pracy. Jeśli zatem stosunek pracy ustał przed zakończeniem takiego miesiąca, pracownik urlopu u tego pracodawcy za ten niepełny miesiąc pracy nie nabywa, ale ten okres zatrudnienia musi być wzięty pod uwagę przez kolejnego pracodawcę zatrudniającego pracownika w tym samym roku kalendarzowym ze względu na zasadę ogólnego stażu pracy warunkującego zarówno nabycie prawa, jak i wymiar urlopu wypoczynkowego.

Nie znajdzie tu zastosowania obowiązek zaokrąglania niepełnego miesiąca pracy w górę, który występuje przy urlopach proporcjonalnych ${ }^{51}$, gdyż reguły te odnoszą się wyłącznie do urlopu kolejnego, nabywanego na innych warunkach, a zatem, przy braku odpowiednich unormowań kodeksowych wprost odsyłających do wskazanych przepisów, nie do urlopu w pierwszym kalendarzowym roku pracy.

Ustawodawca nie wprowadza tu również obowiązku, w przeciwieństwie do innych sytuacji urlopowych opisanych w k.p. (np. urlopu osób zatrudnionych na część etatu czy urlopu proporcjonalnego), zaokrąglania niepełnego dnia urlopu w górę do pełnego dnia, co zwykle powoduje potrzebę wyliczania tego urlopu nie tylko w godzinach, ale i minutach ${ }^{52}$. Większość podejmujących pracę po raz pierwszy będzie uzyskiwać urlop w najniższym możliwym wymiarze, tj. 20 dni. Jedna z dwudziestu części tego wymiaru wynosi 1 i 2/3, co w przeliczeniu na godziny wynosi około 13,5 godz. Przy założeniu, że dobowa norma czasu pracy pracownika wynosi zwykle 8 godzin, daje to 1 dzień urlopu, 5 godzin i 33 minuty.

Z pewnością nie jest to rozwiązanie szczególnie szczęśliwe zarówno ze względów technicznych dotyczących ustalania uprawnień urlopowych pracownika, jak

50 Por. A. Kosut, Przemiany regulacji prawnej urlopów wypoczynkowych w Kodeksie pracy, [w:] Przemiany prawa pracy. Od kodyfikacji do współczesności. Księga Jubileuszowa Prof. T. Liszcz, red. A. Kosut, W. Perdeus, „Studia luridica Lublinensia” 2015, t. XXIV, s. 183.

51 Tak m.in. A. Wypych-Żywicka, Kilka uwag o urlopie wypoczynkowym z art. 153 § 1 k.p., PiZS 2004, nr 6, s. 20 oraz K. Rączka, Kodeks pracy..., 2005, s. 593. Inaczej na kwestię tę zapatrywała się po wejściu w życie omawianych zmian E. Chmielek-Łubińska, która odsyłała w tym zakresie do reguł dotyczących urlopu proporcjonalnego, a zatem zaokrąglania niepełnego miesiąca pracy w górę. Por. taż, Urlop..., s. 21 lub [w:] Kodeks pracy. Komentarz, red. B. Wagner, Gdańsk 2004, s. 575.

52 W praktyce bywają w tego typu sytuacjach wykorzystywane przepisy o urlopie proporcjonalnym i zaokrągla się w górę niepełny miesiąc pracy, ale też niepełny dzień urlopu do pełnego dnia. Por. I. Jaroszewska-Ignatowska, [w:] Prawo pracy dla sędziów i pełnomocników, red. K. Walczak, M. Wojewódka, Warszawa 2017, s. 500. 
i jego udzielania, należy bowiem dążyć do tego, aby urlop obejmował jednak całą dniówkę roboczą, przeciwnie bowiem osłabia to znacząco funkcję wypoczynkową omawianego prawa. Ustawodawca generalnie, wprowadzając zasadę przeliczania dni urlopu na godziny, dostrzegł ten problem. Zastrzeżono bowiem, jak się wydaje, właśnie z uwagi na szczególne przeznaczenie omawianego urlopu, że urlop ten udzielany w wymiarze godzinowym jedynie wyjątkowo może obejmować część dobowego wymiaru czasu pracy, tj. wówczas gdy część urlopu pozostała do wykorzystania jest mniejsza niż pełny dobowy wymiar czasu pracy pracownika w danym dniu, którego urlop dotyczy. Regulacja ta, która miała mieć charakter wyjątku, w zakresie urlopu pierwszego staje się w istocie regułą, zwłaszcza jeśli pracownik będzie chciał wykorzystać urlop po każdym miesiącu pracy, a nie, jeśli jest taka możliwość i zatrudnienie trwa, łącznie, np. po kilku miesiącach pozostawania $\mathrm{w}$ stosunku pracy u danego pracodawcy.

Wydaje się bowiem, że w zależności od sytuacji, woli pracownika oraz ostatecznej decyzji pracodawcy podyktowanej względami organizacyjnymi, pierwszy urlop może być wykorzystywany sukcesywnie, bezpośrednio po momencie jego nabycia (czy w krótkim czasie od tego momentu), pracownikowi służy bowiem roszczenie o jego udzielenie, ale może również, zwłaszcza z inicjatywy pracownika, zostać udzielony łącznie, tj. w odpowiednio wyższym wymiarze, po dłuższym okresie trwania stosunku pracy.

$\mathrm{Z}$ uwagi na to, że reguły dotyczące nabywania pierwszego urlop powodują $\mathrm{w}$ rezultacie jego bardzo duże rozdrobnienie (co nie przyczynia się zasadniczo do skutecznej realizacji prawa do odpoczynku), a także ze względów, o których była mowa wyżej, z pewnością należy postulować uwzględnianie wniosku pracownika, w sytuacji, gdy jest to tylko możliwe, o udzielenie urlopu w większym wymiarze, po dłuższym niż miesięczny okresie trwania pierwszego zatrudnienia. Choć trzeba jednocześnie podkreślić, że o terminie wykorzystania urlopu wypoczynkowego, niewątpliwie również pierwszego, decyduje ostatecznie pracodawca, a zatem, $\mathrm{z}$ braku odmiennych unormowań, nie jest on związany wnioskiem pracownika dotyczącym terminu wykorzystaniu urlopu.

Z prawem do pierwszego urlopu łączy się również kwestia sposobu wyznaczenia konkretnego terminu jego nabycia (a zatem dnia upływu miesiąca pracy), która nie została bezpośrednio rozstrzygnięta na gruncie przepisów k.p. W związku z tym w doktrynie prawa pracy oraz orzecznictwie sądowym są formułowane różne koncepcje $e^{53}$, których wpływ na realizację funkcji urlopu wypoczynkowego nie jest znaczący i raczej pośredni, ale daje się zauważyć poprzez ich przełożenie na faktyczny okres wyczekiwania na pierwszy urlop.

Z tego punktu widzenia niewątpliwie korzystną dla pracowników interpretację, najpełniej zabezpieczającą ich interesy, zaprezentował Sąd Najwyższy, który odno-

53 Por. szeroko na ten temat E. Staszewska, Kontrowersje wokół sposobów liczenia terminów określonych w kodeksie pracy w świetle orzecznictwa Sądu Najwyższego, [w:] 40 lat Kodeksu pracy, s. 318 i n. Zob. też K. Stefański, Pojęcie miesiq̨ca w kodeksie pracy w świetle orzecznictwa Saqdu Najwyższego, PizS 2016, nr 2, s. 33 i n. 
śnie do liczenia w prawie pracy terminów i ewentualnego wykorzystania do tego przepisów k.c. uznał, że rozważany w tym zakresie często art. 112 k.c. nie ma zastosowania do obliczania okresów, od których zależą uprawnienia pracownicze, w tym m.in. decydujących o prawie do urlopu wypoczynkowego ${ }^{54}$. Zdaniem Sądu Najwyższego, okresy te powinny być ustalane w sposób swoisty dla prawa pracy, w oparciu o potoczne zasady liczenia terminów, co oznacza, że termin taki upływa ostatniego dnia okresu wymaganego do nabycia prawa ( $\mathrm{tj}$. w przeddzień dnia odpowiadającego nazwie dnia początkowego), przy jednoczesnym założeniu, że w przypadku sumowania pojedynczych dni pracy i przeliczania ich na miesiące za miesiąc uznaje się upływ $30 \mathrm{dni}^{55}$.

Ostatnia reguła ma szczególne znaczenie w sytuacji nieprzepracowania przez pracownika pełnego miesiąca kalendarzowego i zmiany zatrudnienia w tym roku kalendarzowym, w którym po raz pierwszy podjął zatrudnienie w ramach stosunku pracy; wówczas bowiem, jak wynika z powyższej wykładni, roszczenie pracownika o urlop powstanie u tego pracodawcy i w tym dniu, w którym upływa 30. dzień jego pracy ${ }^{56}$. Jeśli natomiast pracownik pozostaje w stosunku pracy od pierwszego dnia miesiąca, wówczas nabędzie on prawo do urlopu ostatniego dnia tego miesiąca (tj. np. 31 marca czy 30 kwietnia), a w przypadku, gdy nawiązał stosunek pracy w części miesiąca kalendarzowego jego prawo do urlopu w wymiarze $1 / 12$ powstanie $\mathrm{w}$ następnym miesiącu kalendarzowym, $\mathrm{w}$ dacie poprzedzającej dzień, w którym to nawiązanie nastąpiło ${ }^{57}$.

Nieco później natomiast nabędzie prawo do urlopu w pierwszym kalendarzowym roku pracy ten pracownik, do którego zastosuje się, jak postulują niektórzy ${ }^{58}$, odrzucony przez Sąd Najwyższy art. 112 k.c. Z przepisu tego wynika, że termin oznaczony m.in. w miesiącach kończy się z upływem dnia, który nazwą lub datą odpowiada początkowemu dniowi terminu, a jeśli takiego dnia w danym miesiącu nie ma - w ostatnim dniu tego miesiąca. Wymagałoby to zatem pozostawania

54 Por. wyrok SN z 19 grudnia 1996 r., I PKN 47/96, OSNP 1997, nr 17, s. 310. Aprobująco A. Wypych-Żywicka, Kilka uwag..., s. 18 i n.

55 Por. wyrok SN z 17 listopada 2004 r., II PK 64/04, M.P.P. 2005, nr 1, s. 342. Zob. też postanowienie SN z 11 grudnia 2009 r., II PK 223/09, LEX nr 585777.

56 Do podobnych efektów w tym zakresie, przy zastosowaniu art. 114 k.c. w związku z art. 300 k.p., doszedł K. Rączka. Autor powołując się na wskazany przepis k.c. przyjmuje, że termin liczony w miesiącu, gdy nie jest wymagana jego ciągłość, tak jak to się dzieje w prawie urlopowym, wynosi 30 dni. Por. K. Rączka, Kodeks pracy..., 2005, s. 593. Nie jest jednak do końca jasne, czy, według autora, ta reguła będzie miała zastosowanie również do innych sytuacji związanych z nabyciem prawa do urlopu „pierwszego”, w tym zwłaszcza podjęcia zatrudnienia pierwszego dnia danego miesiąca kalendarzowego. Na art. 114 k.c. powołuje się również w tym konkretnym przypadku A. Wypych-Żywicka, Kilka uwag..., s. 21.

57 Por. m.in.: E. Staszewska, [w:] M. Kuba, M. Nowak, E. Staszewska, Urlopy pracownicze, red. Z. Góral, Warszawa 2016, s. 38. Zob. też A. Martuszewicz, K. Piecyk, Urlopy pracownicze i inne zwolnienia od pracy, Warszawa 2007, s. 22.

58 Por. E. Chmielek-Łubińska, Urlop wypoczynkowy..., s. 21. Podobnie A. Malinowski, Urlopy pracownicze. Komentarz, Warszawa 2010, s. 55. 
przez pracownika w stosunku pracy de facto przez okres miesiąca i jednego dnia dla uzyskania omawianego uprawnienia, co, moim zdaniem, nie do końca przystaje do treści art. $153 \$ 1$ k.p., w którym jednak przewiduje się prawo do urlo$\mathrm{pu}, \mathrm{z}$ upływem miesiąca pracy”, a nie po upływie takiego miesiąca. Koncepcja ta, opóźniając w istocie możliwość skorzystania przez pracownika z prawa do odpoczynku rocznego, jest również mniej korzystna z punktu widzenia realizacji podstawowej w tym zakresie zasady sformułowanej w art. 14 k.p., a przez to, w związku z treścią art. 300 k.p., wątpliwa.

Istotną wartością $\mathrm{w}$ polskim prawie urlopowym $\mathrm{z}$ uwagi na temat prowadzonych rozważań jest z pewnością reguła, według której prawo do urlopu wypoczynkowego $\mathrm{z}$ dołu nabywa się tylko w pierwszym kalendarzowym roku pracy i raz nabytego już się nie traci. Wynika to przede wszystkim z art. $153 \$ 2$ k.p., który stanowi, że w każdym następnym roku kalendarzowym, po roku podjęcia pierwszego zatrudnienia w ramach stosunku pracy, pracownik uzyskuje prawo do urlopu kolejnego. Jest to urlop przysługujący „z góry”, a więc bez potrzeby przepracowania jakiegokolwiek okresu, nabywany już w pierwszym dniu istnienia stosunku pracy (jego powstania lub trwania), niezależnie od podstawy nawiązania stosunku pracy, rodzaju pracy, wymiaru czasu pracy, przerw w pracy czy sposobu zakończenia poprzedniego zatrudnienia.

Brak okresu „wyczekiwania” na kolejny urlop pozwala, w założeniu, na natychmiastową realizację prawa do odpoczynku rocznego, co jest szczególnie ważne w przypadku, gdy dany pracownik kontynuuje zatrudnienie w następnych latach z tym samym lub innym pracodawcą. Wówczas bowiem, w zależności od potrzeb i zaistniałych warunków, może on wystąpić $\mathrm{z}$ wnioskiem o urlop w zasadzie już w pierwszym dniu takiego zatrudnienia (inną kwestią jest, czy termin urlopu zaproponowany przez pracownika uzyska aprobatę pracodawcy, o czym w kolejnych punktach niniejszego opracowania).

Sama konstrukcja nabycia prawa do urlopu wypoczynkowego, pomijając określone mankamenty wskazane powyżej, niewątpliwie odpowiada zatem jego głównemu celowi, zwłaszcza po zmianach reguł uzyskania tzw. „pierwszego urlopu”. Obecnie bowiem, pomijając zupełnie wyjątkowy przypadek podjęcia przez daną osobę pierwszego zatrudnienia $\mathrm{w}$ ramach stosunku pracy po pierwszym grudnia ${ }^{59}$, gdy, zgodnie z wcześniej przyjętymi założeniami, pracownik nie ma już szans na miesięczny okres zatrudnienia w tym roku kalendarzowym, w zasadzie nie występują okresy pracy, którym nie odpowiadałyby określone uprawnienie urlopo-

59 Przesłanką nabycia prawa do urlopu „pierwszego”, odnoszącego się do roku kalendarzowego, w którym podjęto pierwszy raz zatrudnienie w ramach stosunku pracy, jest bowiem, jak była wcześniej mowa, upływ miesiąca pracy(art. $153 \S 1$ k.p.). Stąd, przy braku możliwości zaokrąglania niepełnych miesięcy pracy, w świetle art. 153 § 1 i 2 k.p. należy przyjąć, że pracownik, który podjął pracę w ramach stosunku pracy np. 15 grudnia nie nabędzie w tym roku kalendarzowym urlopu cząstkowego (brak spełnienia przesłanki nabycia prawa do $1 / 12$ urlopu), ale $z$ dniem 1 stycznia, jeżeli nadal pozostaje w zatrudnieniu, uzyskuje już prawo do urlopu kolejnego w pełnym wymiarze. 
we. Taka sytuacja miała miejsce w przeszłości, w okresie obowiązywania zasady nabywania prawa do urlopu z upływem roku pracy, kiedy to mogły zdarzyć się nawet kilkumiesięczne okresy zatrudnienia nierekompensowane odpoczynkiem w postaci dni urlopowych. Jeśli pracownik nabył bowiem prawo do pierwszego urlopu w początkowych miesiącach danego roku kalendarzowego, to, zgodnie z obowiązującymi wówczas przepisami, kolejny urlop uzyskiwał dopiero w następnym roku kalendarzowym. W rezultacie okresowi pracy od miesiąca nabycia prawa do pierwszego urlopu aż do końca tego roku nie odpowiadały żadne uprawnienia urlopowe pracownika ${ }^{60}$.

Ponadto obowiązujące wcześniej warunki nabycia prawa do urlopu wypoczynkowego powodowały niekiedy, że pierwszy urlop w pełnym wymiarze stawał się automatycznie urlopem zaległym; nabyty $\mathrm{z}$ końcem roku kalendarzowego musiał być udzielony w kolejnym roku' ${ }^{61}$.

Zasadę zachowania raz nabytego prawa do urlopu, o której wyżej była mowa, wzmacnia również art. $154^{1} \$ 1$ k.p. dotyczący warunków ustalania stażu urlopowego, wpływającego zarówno na nabycie prawa do urlopu, jak i jego wymiar.

Sposób uregulowania okresów warunkujących prawo do urlopu wypoczynkowego ma niewątpliwie duże znaczenie dla realizacji prawa pracownika do wypoczynku, może bowiem znacznie to prawo ograniczyć bądź też spowodować wydłużenie procesu jego nabywania, w szczególności konieczność czynienia tego kilkakrotnie.

Z tej perspektywy konstrukcja okresów zatrudnienia warunkujących nabycie prawa do urlopu wypoczynkowego, ważna zwłaszcza w pierwszym kalendarzowym roku pracy w ramach stosunku pracy, jest dla pracowników bardzo korzystna.

Przede wszystkim instytucja urlopów wypoczynkowych jest bowiem jedną z nielicznych już w polskim prawie, gdzie zachowano zasadę ogólnego stażu pracy. Oznacza to, że ustalając okres niezbędny dla nabycia prawa do urlopu (jak też jego wymiaru), sumuje się wszystkie okresy pozostawania w stosunku pracy, a nie tylko okres pracy u danego pracodawcy.

W kontekście pierwszego urlopu, gdzie, jak wspomniano, kwestia ta ma zasadnicze znaczenie, $\mathrm{z}$ uwagi na to, że urlop kolejny przysługuje już z „góry”, od pierwszego dnia istnienia stosunku pracy w danym roku kalendarzowym, może to znacznie przyspieszyć nabycie prawa do urlopu cząstkowego, a nawet w ogóle to umożliwić, zwłaszcza jeśli pracownik często w tym roku zmienia zatrudnienie i u żadnego pracodawcy nie wypracowuje pełnych miesięcy.

60 Taka sytuacja miała miejsca w przypadku nabycia prawa do pierwszego urlopu za przepracowany rok, np. 15 marca następnego roku. Prawo do kolejnego urlopu nabywało się bowiem w każdym następnym, w stosunku do roku nabycia pierwszego urlopu, roku kalendarzowym. Tym samym w podanym przykładzie okresowi pracy od połowy marca do końca grudnia nie odpowiadało prawo pracownika do urlopu za ten czas. Zdarzało się, że jeden urlop przysługiwat na okres 23 miesięcy pracy. Por. F. Małysz, Pracownicze urlopy wypoczynkowe, Warszawa 1987, s. 38 i n. Tak też I. Boruta, Urlopy wypoczynkowe po zmianie Kodeksu pracy, Warszawa 1997, s. 15.

61 Por. F. Małysz, Pracownicze urlopy wypoczynkowe, s. 52 i n. 
Nie wymaga się również zachowania określonej ciągłości pracy, jak to bywało wcześniej, tj. w razie nawiązania kolejnego stosunku pracy ustawodawca nie warunkuje możliwości wliczenia okresów zatrudnienia u poprzedniego pracodawcy koniecznością podjęcia tego zatrudnienia w określonym terminie od ustania poprzedniego. Ma to szczególne znaczenie, podkreśla bowiem stricte wypoczynkowe przeznaczenie omawianego urlopu. Prawo do wypoczynku realizowane przez instytucję urlopu wypoczynkowego przestaje być zatem instrumentem do realizacji innych celów, tj. przede wszystkim zachęcania pracowników do pozostawania w stałym zatrudnieniu. Abstrahując od sprzeczności tego rodzaju regulacji z istotą samego prawa do odpoczynku, u podstaw którego leży ochrona szeroko pojętego życia i zdrowia ludzkiego, mogą być one postrzegane także jako pośrednio naruszające zasadę wolności pracy w jej ujęciu negatywnym. Ponadto nie przystają do współczesnych uwarunkowań rynku pracy, na którym występuje dość duża fluktuacja zatrudnienia i okres pozostawania bez pracy często nie musi wynikać $\mathrm{z}$ decyzji samego zainteresowanego.

W związku z tym ustawodawca nakazuje ustalać uprawnienia urlopowe pracownika na podstawie ogólnego stażu pracy, bez względu na przerwy, jakie występowały pomiędzy kolejnymi okresami pozostawania w stosunku pracy, a raz nabytego prawa do urlopu pracownik nie traci, nawet jeśli podejmie pracę wiele lat po ustaniu poprzedniej umowy o pracę (czy innej podstawy kreującej stosunek pracy).

Co niezwykle ważne z punktu widzenia prawidłowej realizacji podstawowego celu omawianej instytucji, po $2000 \mathrm{r}$. zmianie uległy warunki ustalania stażu urlopowego, zarówno w zakresie nabycia prawa, jak i jego wymiaru, osób podejmujących dodatkowe zatrudnienie. Wprowadzając $\$ 2$ do art. $154^{1}$ k.p. ustawodawca zadbał, aby również $\mathrm{w}$ tym przypadku pracownicy zachowali prawo do urlopu na takim samym poziomie, na jakim korzystają z niego w zatrudnieniu podstawowym. Jeśli pracownik pozostaje bowiem $\mathrm{w}$ dwóch lub więcej stosunkach pracy, ustalając jego uprawnienia urlopowe, należy uwzględnić też okres niezakończonego zatrudnienia, ale w części przypadającej przed nawiązaniem drugiego lub kolejnego stosunku pracy $^{62}$, co prowadzi do zrównania uprawnień urlopowych pracownika w zatrudnieniu dodatkowym $\mathrm{z}$ tymi uprawnieniami, jakie uzyskuje $\mathrm{w}$ podstawowym stosunku pracy. Kwestia ta w przeszłości wywoływała liczne wątpliwości. Z brzmienia przepisów wynikało bowiem, że do okresu pracy decydującego o nabyciu prawa i wymiarze urlopu wypoczynkowego wliczeniu podlegały jedynie okresy „poprzedniego zatrudnienia", a zatem, jak uznawano w orzecznictwie Sądu Najwyższego ${ }^{63}$, okresy zatrudnienia zakończonego. Jeśli pracownik po kilku latach od nabycia prawa do pierwszego urlopu wypoczynkowego, wykorzystywanego już w najwyższym

62 Chodzi o zachowanie warunku niedublowania okresów pracy. Dlatego też wlicza się do stażu urlopowego w całości okresy zatrudnienia zakończonego oraz okres zatrudnienia dotychczasowego, ale w tym ostatnim przypadku tylko w części przypadającej bezpośrednio przed nawiązaniem dodatkowej umowy o pracę.

63 Por. m.in. uchwała SN z 27 stycznia 1977 r., V PZP 5/76; uchwała SN z 6 lutego 1979 r., V PZP 5/78, OSNCP 1979, nr 6, poz. 109. Zob. też M. Łajeczko, Urlop wypoczynkowy, „Prawo Pracy” 1999, nr 3, s. 13. 
możliwym wymiarze w podstawowym miejscu pracy, podjął dodatkowe zatrudnienie, to z braku odmiennych unormowań, jeśli nie posiadał żadnych zakończonych okresów pracy w ramach stosunku pracy czy okresów zaliczanych, był w nim traktowany tak, jak osoba podejmująca pracę po raz pierwszy, tzn. musiał ponownie (odrębnie) nabyć prawo do urlopu i uzyskiwał ten urlop w wymiarze często znacznie niższym niż u macierzystego pracodawcy. W literaturze przedmiotu podkreślano wadliwość takiego rozwiązania jako zakłócającego właściwy przebieg funkcji wypoczynkowej omawianego urlopu ${ }^{64}$. Pracownik nie mógł bowiem swojego prawa zrealizować u obu pracodawców na jednakowych warunkach, nawet jeśli osiągnięto porozumienie co do terminu jego wykorzystania, a ponadto świadcząc pracę wiele lat, był zmuszany często, nawiązując dodatkową umowę o pracę, nabywać na nowo uprawnienia urlopowe, co trudno racjonalnie uzasadnić. Wprowadzenie przywołanej powyżej regulacji należy ocenić w związku z tym jako istotną poprawę gwarancji w zakresie pracowniczego odpoczynku rocznego w sytuacji pozostawania w więcej niż jednym stosunku pracy.

W celu pełnego zobrazowania powyższego wątku dotyczącego stażu warunkującego nabycie prawa do urlopu wypoczynkowego nie sposób nie wspomnieć o obowiązku zaliczania do niego pewnych okresów świadczenia pracy poza stosunkiem pracy. Mając na względzie fakt, że stosunek pracy może zostać podjęty na pewnym etapie drogi zawodowej, która dotąd była realizowana na podstawie innych stosunków zatrudnienia, w których dana osoba korzystała już z pozapracowniczego urlopu wypoczynkowego, oraz dążąc do umożliwienia w miarę płynnego przejścia do zatrudnienia pracowniczego, bez zasadniczej zmiany poziomu uprawnień (szczególnie tych podstawowych), ustawodawca w art. 302 k.p. umożliwił wyraźnie wliczanie okresów pracy w służbach mundurowych, wymienionych w tym przepisie ${ }^{65}$, do okresu zatrudnienia warunkującego uprawnienia pracownicze. Odbywa się to $\mathrm{w}$ zakresie i na zasadach określonych odrębnymi przepisami. Zwykle jest to uzależnione od podjęcia pracy w określonym terminie od zakończenia służby (np. w policji czy straży pożarnej) ${ }^{66}$, choć w wielu ustawach nie

64 Por. K. Rączka, [w:] Kodeks pracy..., 2003, s. 515. Na ten temat też B. Cudowski, Urlop wypoczynkowy i bezpłatny..., s. 49 oraz T. Nycz, Urlop w dodatkowym miejscu pracy, PizS 1999, nr 9, s. 24 i n. Ostatni z wymienionych autorów zaprezentowat także odmienną propozycję interpretacji obowiązujących wówczas przepisów, tj. szereg argumentów za wliczaniem do stażu urlopowego w dodatkowym zatrudnieniu również trwającego okresu pracy.

65 Zgodnie z art. 302 k.p. chodzi o okres służby w Policji, Urzędzie Ochrony Państwa, Agencji Bezpieczeństwa Wewnętrznego, Agencji Wywiadu, Służbie Kontrwywiadu Wojskowego, Służbie Wywiadu Wojskowego, Centralnym Biurze Antykorupcyjnym, Służbie Więziennej, Straży Granicznej i Państwowej Straży Pożarnej.

66 Por. art. 80 ustawy z dnia 6 kwietnia 1990 r. o Policji (tekst jednolity Dz. U. 2016, poz. 1782, ze zm.); wymaga się, co do zasady, podjęcia pracy w okresie roku od zwolnienia ze służby lub w ciągu trzech miesięcy, jeśli policjant pełnił służbę przygotowawczą. Jeżeli natomiast niemożność nawiązania stosunku pracy jest związana z chorobą lub inwalidztwem, okres służby podlega wliczeniu, gdy były policjant podjął zatrudnienie w ciągu trzech miesięcy od ustania wskazanych wyżej przyczyn. Analogicznie por. art. 70 ustawy z dnia 24 sierpnia 1991 r. o Państwowej Straży Pożarnej, tekst jednolity: Dz. U. 2016, poz. 603, ze zm. 
formułuje się takiego obostrzenia ${ }^{67}$, z wyłączeniem przypadków zwolnienia z niej będących następstwem skazania prawomocnym orzeczeniem sądu lub orzeczenia kary dyscyplinarnej wydalenia ze służby ${ }^{68}$.

Taka osoba zatem, jeśli nie wystąpiła w stosunku do niej ustawowo sformułowana przesłanka negatywna wyżej wymieniona, w pewnym uproszczeniu, jest w dniu zawarcia umowy o pracę traktowana jak wieloletni pracownik, czego skutkiem jest m.in. nabycie prawa do urlopu wypoczynkowego z pierwszym dniem takiego zatrudnienia.

Odmiennie w tym zakresie uregulowano jednak status prawny żołnierzy zawodowych, którzy choć mają okres służby wliczany do stażu pracy w zakresie wszelkich uprawnień pracowniczych, to jednak w sytuacji, gdy podejmują pracę w ramach stosunku pracy w tym samym roku kalendarzowym, w którym wystąpili ze służby, nabywają oni prawo do urlopu wypoczynkowego w następnym roku kalendarzowym ${ }^{69}$.

Biorąc pod uwagę nowe zasady nabywania prawa do urlopu wypoczynkowego przez pracownika, regulacja ta wydaje się archaiczna, niezrozumiała i w zasadzie zbędna. Nie tylko bowiem pogarsza ona w sposób, który trudno uznać za obiektywnie uzasadniony, sytuację byłego żołnierza w stosunku do innych osób pozostających w zatrudnieniu administracyjnoprawnym, o których wyżej była mowa, ale również w odniesieniu do samych pracowników. Bez względu bowiem na moment zwolnienia żołnierza ze służby i datę nawiązania stosunku pracy, nawet jeśli nastąpi to na początku danego roku kalendarzowego, nabędzie on prawo do urlopu wypoczynkowego, zgodnie z art. 121 powołanej ustawy, dopiero w roku następnym. Tymczasem osoba podejmująca pracę po raz pierwszy jako pracownik będzie ten urlop do końca danego roku nabywała systematycznie, w wymiarze 1/12 za każdy przepracowany miesiąc. Tym samym omawiany przepis, korzystny w zakresie ustalania wymiaru urlopu wypoczynkowego, pod względem uzyskania prawa do urlopu w zasadzie, $z$ uwagi na drugą jego część, jest sprzeczny w obecnym ujęciu z celem omawianych unormowań szczególnych oraz wspomnianą na wstępie tego podpunktu podstawową zasadą prawa urlopowego, zgodnie z którą każdemu okresowi pracy powinien odpowiadać okres odpoczynku. W tym przypad-

67 Por. art. 84 ustawy z dnia 12 października 1990 r. o Straży Granicznej, tekst jednolity: Dz. U. 2016, poz. 1643. Tak też w art. 92 ust. 2 ustawy z dnia 24 maja 2002 r. o Agencji Bezpieczeństwa Wewnętrznego oraz Agencji Wywiadu, tekst jednolity: Dz. U. 2016, poz. 1897.

68 Zgodnie z art. 80 ustawy o Policji, przepisy te nie mają zastosowania do policjantów zwolnionych ze służby w związku ze skazaniem prawomocnym wyrokiem sądu lub orzeczeniem kary dyscyplinarnej wydalenia ze służby. Analogicznie por. art. 70 ustawy o Państwowej Straży Pożarnej; art. 92 ust. 3 ustawy o Agencji Bezpieczeństwa Wewnętrznego i Agencji Wywiadu. Inaczej w art. 84 ustawy z dnia 12 października 1990 r. o Straży Granicznej, w którym wymaga się, by skazanie dotyczyło przestępstwa umyślnego, ściganego z oskarżenia publicznego lub przestępstwa skarbowego popełnionego umyślnie (art. 84 w związku z art. 45 ust. 1 pkt 3 i 4$)$.

69 Art. 121 ustawy z dnia 11 września 2003 r. o służbie wojskowej żołnierzy zawodowych, tekst jednolity: Dz. U. 2014, poz. 1414, ze zm. 
ku były żołnierz zawierający umowę o pracę w tym samym roku kalendarzowym, w którym wystąpił ze służby, w skrajnych przypadkach będzie pozbawiony prawa do urlopu wypoczynkowego przez niemal cały rok lub znaczną jego część.

Dlatego też należy, moim zdaniem, uznać, że regulacja ta jako mniej korzystna dla pracownika, ograniczająca w znaczący sposób jego prawo do odpoczynku rocznego, jest sprzeczna $z$ art. 14 k.p. i w związku z tym do czasu odpowiedniego zmodyfikowania omawianego przepisu ustawy o służbie wojskowej żołnierzy zawodowych trzeba stosować do nich ogólne zasady nabycia prawa do urlopu wynikające z przepisów k.p.

Wliczeniu do stażu warunkującego urlop wypoczynkowy, w tym również nabycie prawa do urlopu, podlega również okres czynnej służby wojskowej, zgodnie $\mathrm{z}$ art. 120 ustawy o powszechnym obowiązku obrony $\mathrm{RP}^{70}$, a także niektóre inne jeszcze okresy szczególne ${ }^{71}$, które zostaną szerzej omówione w kontekście wymiaru urlopu wypoczynkowego.

Wydaje się, że w razie realizacji postulatu rozszerzenia zakresu podmiotowego urlopu wypoczynkowego, często ostatnio zgłaszanego, podmioty objęte umowami prawa cywilnego, ale świadczące pracę w warunkach zbliżonych do zatrudnienia pracowniczego, również powinny taką gwarancję uzyskać.

Drugim, nie mniej ważnym aspektem omawianego zagadnienia jest sposób, w jaki interpretuje się pojęcie „miesiąca pracy”, od którego zależy nabycie prawa do poszczególnych części urlopu w pierwszym kalendarzowym roku, w którym nawiązano stosunek pracy.

Generalnie przyjmuje się bowiem, zarówno w doktrynie, jak i orzecznictwie sądowym $^{72}$, że w odniesieniu do urlopu pierwszego, jak też urlopu kolejnego, nie chodzi o czas efektywnie, czynnie wykonywanej pracy, ale o okres faktycznego pozostawania w stosunku pracy ${ }^{73}$, z wyjątkiem przypadków, w których stosunek ten

70 Ustawa z 21 listopada 1967 r. o powszechnym obowiązku obrony Rzeczypospolitej Polskiej, tekst jednolity: Dz. U. 2016, poz. 1534, ze zm.

71 Jest ich zdecydowanie mniej niż okresów wliczanych do stażu decydującego o wymiarze urlopu. Chodzi przede wszystkim o okres studiów doktoranckich, okres niektórych urlopów bezpłatnych, np. udzielanych młodocianym czy w celu wykonywania pracy u innego pracodawcy w związku z porozumieniem zawartym między pracodawcami, okres pobierania świadczeń z ubezpieczenia społecznego przez kobietę w ciąży po ustaniu zatrudnienia, okres wykonywania pracy nakładczej, po spełnieniu dodatkowych warunków, czy okres pracy za granicą.

72 Por. m.in. wyrok SN z 14 lutego 1991 r., I PRN 1/91, OSNCP 1992, nr 11, poz. 207. Sąd uznat, że pracownik nabywa prawo do urlopu także wówczas, gdy wymagany okres „pracy” upływa w czasie usprawiedliwionej nieobecności w pracy. Zob. też uchwała SN z 4 kwietnia 1995 r., I PZP 10/95, OSNAPiUS 1995, nr 18, poz. 228, w której uznano, że pracownik nabywa prawo do urlopu, mimo że pozostając w stosunku pracy, nie przepracował ani jednego dnia w związku z pobieraniem świadczenia rehabilitacyjnego.

73 Por. m.in.: K. Rączka, Kodeks pracy..., 2005, s. 593; M. Nałęcz, [w:] Kodeks pracy. Komentarz, red. W. Muszalski, Warszawa 2007, s. 712; P. Walorska, Staż pracy, Warszawa 2014, s. 163. Tym samym jednak urlopu pracownik nie nabędzie za okres przypadający po zakończeniu istnienia stosunku pracy, nawet jeśli za ten czas przyznano mu odszkodowanie i wlicza się 
ulega czasowemu zawieszeniu i sam ustawodawca wyłącza możliwość zaliczenia ich do stażu pracy, np. urlop bezpłatny, o którym stanowi art. 174 k.p. ${ }^{74}$. Art. 152 k.p. gwarantuje bowiem to prawo wszystkim pracownikom, a nie tylko tym, którzy aktywnie pracę świadczą ${ }^{75}$.

Uznanie zasadniczo samego faktu pozostawania w zatrudnieniu, postrzegane $\mathrm{w}$ literaturze przedmiotu jako ważny przejaw postępu w prawie urlopowym ${ }^{76}$, przyczynia się do pełniejszej realizacji prawa do odpoczynku. W ramach takiej konstrukcji stażu urlopowego eliminuje się bowiem przypadki, kiedy pracownik nie mógłby uzyskać odpoczynku rocznego w związku np. z chorobą, co do której trudno uznać, aby ten cel zastępczo realizowała ${ }^{77}$. W pewnym sensie jest to więc konsekwencja przyjęcia założenia, o którym wcześniej była mowa, niewpływania na urlop wypoczynkowy innych przerw w świadczeniu pracy ${ }^{78}$, które zasadniczo nie pokrywają się pod względem funkcji, jakie pełnią, z tym urlopem. Jest to też częściowo podyktowane samą specyfiką zatrudnienia pracowniczego, które choć z definicji ma charakter ciągły, polega na zobowiązaniu do wykonywania pracy na rzecz pracodawcy i pod jego kierownictwem, to jednak w naturę tego zatrudnienia, ryzyko pracodawcy związane z prowadzoną działalnością, wpisane są określone przerwy w pracy - okresy, kiedy pracownik, $\mathrm{z}$ różnych przyczyn, tej pracy nie świadczy. Tym samym, mimo że analizowana reguła nie odpowiada takiemu bezpośredniemu przełożeniu pracy (w sensie wysiłku z nią związanego) na odpoczynek, to jednak na pewno nie pozostaje w sprzeczności z omawianym prawem,

on z mocy odpowiednich przepisów do okresu zatrudnienia. Por. J. Iwulski, [w:] Kodeks pracy. Komentarz, Warszawa 2000, s. 445. Dotyczy to też okresu pobierania zasitku dla bezrobotnych itp. Konsekwentnie należy też przyjąć, że do stażu urlopowego nie powinien być wliczany okres między zawarciem umowy o pracę a momentem nawiązania stosunku pracy, czyli dniem określonym w umowie jako dzień rozpoczęcia pracy, co wpisuje się również w funkcję omawianej instytucji.

74 Por. tak A. Kosut, [w:] Kodeks pracy. Komentarz, red. K.W. Baran, Warszawa 2012, s. 854. Poza urlopem bezpłatnym, autorka wskazuje również na urlop wychowawczy oraz okres korzystania przez nauczyciela z tzw. stanu nieczynnego. Por. też ciekawy wyrok SN z 7 grudnia 2006 r., I PK 169/06, OSNPUS 2008, nr 3-4, poz. 26, w którym uznano, że jedynemu pracownikowi spółki handlowej, który jako prezes jednoosobowego zarządu podjął decyzję o zawieszeniu jej działalności, nie przysługuje urlop wypoczynkowy za taki okres nieświadczenia pracy i niepozostawania w gotowości do jej wykonywania.

75 Por. A. Świątkowski, Kodeks pracy. Komentarz, Warszawa 2006, s. 649. Bardziej rygorystyczne pod tym względem jest prawo francuskie, które, co do zasady, wymaga jednak pracy efektywnej. Por. G. Auzero, E. Dockès, Droit du travail, Paris 2014, s. 869 i n.

76 Por. A. Uklejska, Aktualne kierunki..., s. 24.

77 We Francji, na przykład, absencja spowodowana chorobą inną niż zawodowa powoduje, że pracownik za ten czas urlopu nie nabywa. Por. tamże, G. Auzero, E. Dockès, Droit du..., s. 869.

78 Wśród tego rodzaju przerw, poza okresem niezdolności do pracy wywołanej chorobą, wymienia się też m.in.: okresy niewykonywania pracy z przyczyn leżących po stronie pracodawcy - w tym przestoje, okresy pobierania zasiłku macierzyńskiego, świadczenia rehabilitacyjnego, korzystania z urlopu wypoczynkowego, szkoleniowego i innych zwolnień od pracy - por. M. Nałęcz, [w:] Kodeks pracy..., 2007, s. 712. 
w sensie nie jest rozwiązaniem, które ten odpoczynek by dezorganizowało czy utrudniało jego osiągnięcie, a wręcz przeciwnie.

Taka wykładnia (pewna nawet filozofia, które legła u jej podstaw) w pełni odpowiada zresztą wymogom wynikającym z prawa unijnego. W orzecznictwie Trybunału Sprawiedliwości UE wielokrotnie podkreślano bowiem, co było już we wcześniejszych rozważaniach sygnalizowane, że realizując wymogi dyrektywy dotyczącej czasu pracy chodzi też o to, aby pracownik w zakresie urlopu wypoczynkowego mógł zrealizować swoje prawo do odpoczynku nawet wówczas, gdy w danym okresie z pewnych przyczyn, usprawiedliwiających jego nieobecność, pracy nie świadczył, ale też w tym czasie nie odpoczywał (przebywając np. na zwolnieniu lekarskim i mobilizując siły organizmu do walki z chorobą).

Można mieć natomiast uzasadnione wątpliwości co tego, czy tak uregulowany i powszechnie akceptowany staż urlopowy powinien obejmować przypadki nieusprawiedliwionej nieobecności pracownika w pracy ${ }^{79}$, a w szczególności okoliczność faktycznego „porzucenia pracy”. O ile bowiem tego rodzaju nieobecność pracownika może powodować redukcję wymiaru urlopu kolejnego, o tyle brak jest przepisu, który określałby skutki takich zachowań po stronie pracownika w obszarze nabycia prawa do urlopu (czy choćby właśnie jego wymiaru) w roku kalendarzowym podjęcia pierwszej pracy.

Oczywiście opisany stan nie stanowi zagrożenia dla urzeczywistnienia funkcji wypoczynkowej urlopu, wręcz przeciwnie, zdaje się realizować ideę odpoczynku ponad wszystko, ale ze względu na ochronę słusznych interesów pracodawcy oraz zachowanie reguł równości i sprawiedliwości w kształtowaniu uprawnień pracowniczych może budzić uzasadnione wątpliwości. Stąd w doktrynie prawa pracy bywa wyrażane przekonanie, że czas występowania takiej nieobecności nie może być uznawany za okres pracy w kontekście przepisów o urlopach wypoczynkowych $^{80}$.

Kwestia ta wiąże się też z kolejnym istotnym elementem zasady braku utraty raz nabytego prawa do urlopu wypoczynkowego, a zarazem warunków ustalania stażu urlopowego, a mianowicie regułą, zgodnie z którą dla nabycia tego prawa oraz jego utrzymania, w tym zaliczenia okresów poprzedniego zatrudnia, nie ma znaczenia sposób ustania poprzedniego zatrudnienia, nawet jeśli był on wynikiem nagannego zachowania ze strony pracownika.

Zasadniczo jest to rozwiązanie słuszne. Urlop nie może być bowiem postrzegany jako nagroda, ma on do zrealizowania ściśle określony cel, jakim jest bezpośrednio ochrona pracowników przed przemęczeniem i innymi zagrożeniami związanymi z długotrwałym wykonywaniem pracy, wcześniej szerzej rozpatrywanymi.

79 W przeszłości pogląd taki sformułowała T. Liszcz. Por. taż, Prawo pracy, Gdańsk 1996, s. 343, za: A. Dubowik, Zasady udzielania urlopów wypoczynkowych według nowych przepisów, PiZS 1997, nr 4, s. 18.

80 Taki pogląd przy okazji omawiania innego problemu wyraziła w latach 90. ubiegłego wieku A. Dubowik. Por. taż, Zasady udzielania..., 
Wykorzystywanie zatem tej instytucji jako środka dyscyplinującego zdaje się wskazanym funkcjom urlopu zaprzeczać, a przynajmniej znacznie je osłabiać. Jednostkowe, czy nawet częstsze, choćby naganne zachowanie pracownika uzasadnia sięgnięcie przez pracodawcę po określone środki w tym celu przewidziane, nie dezaktualizuje natomiast samo w sobie potrzeby odpoczynku, nie czyni tego prawa bezprzedmiotowym.

$\mathrm{O}$ ile powyższe uwagi odnieść można $\mathrm{w}$ całej rozciągłości $\mathrm{w}$ szczególności do rozwiązania niezwłocznego stosunku pracy (bez względu na to, z jakiego powodu i która ze stron to czyni), o tyle więcej wątpliwości wywołuje kwestia wcześniej zasygnalizowana, tzw. porzucenia pracy. Instytucja ta w latach 90. ubiegłego stulecia została usunięta z przepisów k.p., niemniej przestała ona funkcjonować w sensie prawnym, a nie faktycznym. Nadal bowiem występują w praktyce przypadki, w których pracownik ,jednostronnie, samowolnie i niezgodnie z prawem «odstępuje» od umowy o pracę"81, bez złożenia wyraźnego oświadczenia woli w tej sprawie (niekiedy wręcz milcząco). W istocie jest to sposób zakończenia stosunku pracy przez prawo nieprzewidziany, który można uznać za niezgodne z prawem rozwiązanie niezwłoczne, któremu nie towarzyszy wyraźne oświadczenie woli w przedmiocie rozwiązania zawartej umowy. Pracodawca w związku z tym jakiś czas oczekuje na powrót pracownika do pracy lub przynajmniej na zgłoszenie przyczyny jego nieobecności w pracy, a dopiero potem podejmuje określone czynności. Wydaje się, że możliwe jest w tym przypadku albo przyjęcie, że doszło do wadliwego rozwiązania niezwłocznego umowy przez pracownika, co pracodawca potwierdzi w świadectwie pracy, albo może się on zdecydować na rozwiązanie niezwłoczne stosunku pracy z winy pracownika (co niewątpliwie jest dla pracodawcy wyborem mniej korzystnym $z$ uwagi na choćby procedurę dotyczącą takiego rozwiązania, $\mathrm{w}$ tym konsultację związkową czy potencjalny problem $\mathrm{z}$ doręczeniem oświadczenia woli ${ }^{82}$ ). W związku $\mathrm{z}$ tym, o ile nawet przy rozwiązaniu niezwłocznym pracownik świadczył, do momentu rozwiązania umowy, pracę, faktycznie pozostawał w stosunku pracy, o tyle w razie "porzucenia pracy” taka sytuacja nie zachodzi. Nastąpiło bowiem nieformalne zerwanie więzi prawnej łączącej strony, z której wynikało omawiane prawo. Wydaje się zatem, że czas od momentu niestawienia się pracownika do pracy aż do podjęcia w tej sprawie formalnych działań przez pracodawcę, prowadzących ostatecznie w istocie jedynie do potwierdzenia zakończenia nawiązanego stosunku prawnego, nie powinien być włączony do stażu urlopowego warunkującego pierwszy urlop u tego pracodawcy. Obowiązek pracodawcy dotyczący urlopu, również pierwszego, obejmuje tylko okres rzeczywistego, a nie jedynie „formalnego" pozostawania w stosunku pracy, co, moim zdaniem, daje się pośrednio wyinterpretować $\mathrm{z}$ obowiązującego prawa. Skoro prawo do urlopu łączy się bowiem z faktem pozostawania w stosunku pracy,

81 Por. tak A. Sobczyk, „Porzucenie” pracy a urlop proporcjonalny, „Przegląd Sądowy” 1998, nr 11-12, s. 168 i $n$.

82 Por. na ten temat tamże s. 169. 
a nie nabywa tego prawa pracownik w okresie jego zawieszenia, np. urlopu bezpłatnego, to tym bardziej prawo to nie przysługuje za czas, w którym stosunek pracy de facto przestał istnieć.

W praktyce jest to jednak problem bardzo złożony z uwagi na trudność, jaka pojawia się w zakresie ustalenia momentu przekształcenia nieobecności nieusprawiedliwionej właśnie w zachowanie kwalifikowane jako „porzucenie pracy”. Być może należałoby rozważyć wprowadzenie w tym zakresie pewnego domniemania połączonego $\mathrm{z}$ upływem przewidzianego przez prawo czasu na usprawiedliwienie nieobecności w pracy ${ }^{83}$, jeżeli z okoliczności sprawy nic innego nie wynika (w szczególności pracodawca pośrednio nie uzyskał informacji o powodach niestawienia się pracownika w pracy innych niż zamiar trwałego zaprzestania jej wykonywania).

Trzeba jednak wyraźnie podkreślić, że wskazana wyżej konsekwencja faktycznego porzucenia pracy powinna być zarazem w zakresie prawa urlopowego jedyną; sposób ustania stosunku pracy, zgodnie z przyjętym przez ustawodawcę, moim zdaniem słusznie, rozwiązaniem nie może bowiem sam w sobie wpływać na uprawnienia urlopowe pracownika w kolejnym zatrudnieniu, w szczególności pociągać za sobą, jak bywało na gruncie wcześniejszych przepisów, wymogu „ponownego" nabycia prawa do urlopu czy czasowego obniżenia jego wymiaru.

W kontekście okresów, za jakie pracownik nabywa prawo do urlopu wypoczynkowego wiele wątpliwości wywołuje również kwestia zakończenia trwania stosunku pracy, wskutek bezprawnych działań pracodawcy, w związku z którymi na rzecz pracownika zasądzono określone świadczenia - wynagrodzenie za czas pozostawania bez pracy lub odszkodowanie - czy też skrócenia okresu wypowiedzenia z zachowaniem prawa do odszkodowania za pozostałą jego część. We wszystkich tych przypadkach pracownik od pewnego momentu pracy nie świadczył, niemniej uzyskał za ten czas pewne świadczenia (np. wynagrodzenie) i w tym zakresie okres ten należy wliczyć pracownikowi do okresu zatrudnienia. Zarówno w doktrynie prawa pracy, jak i orzecznictwie sądowym wskazuje się jednak, że takie wliczenie omawianych okresów do stażu pracy może nastąpić dopiero w momencie nawiązania kolejnego stosunku pracy. Z chwilą zakończenia dotychczasowego nie można bowiem już uzyskać prawa do urlopu wypoczynkowego, gdyż wymienione okresy nie powodują przedłużenia trwania danego zatrudnienia ${ }^{84}$. Jest to następstwem

83 W tej chwili kwestie terminu i sposobu usprawiedliwiania nieobecności reguluje rozporządzenia Ministra Pracy i Polityki Socjalnej z dnia 15 maja 1996 r. w sprawie sposobu usprawiedliwiana nieobecności w pracy oraz udzielania pracownikom zwolnień od pracy (por. w szczególności § 2 rozporządzenia). Pozwala ono jednak wyłącznie rozróżnić nieobecność usprawiedliwioną od nieusprawiedliwionej.

84 Por. J. Iwulski, [w:] Kodeks pracy..., s. 445; M. Nałęcz, [w:] Kodeks pracy..., 2007, s. 713; E. Chmielek-Łubińska, Pierwszy urlop wypoczynkowy, „Studia z zakresu prawa pracy i polityki społecznej”, red. A. Świątkowski, Kraków 2001/2002, s. 379. Zob. też uchwała SN z 28 września 1990 r., III PZP 15/90, OSNCP 1991, nr 4, poz. 45 (dotyczący okresu, za który przyznano odszkodowanie) oraz wyrok SN z 14 marca 2006 r., I PK 144/05, OSNP 2007, nr 5-6, poz. 68 (w zakresie przywrócenia do pracy). 
braku przyjęcia przez ustawodawcę fikcji, że okres ten jest traktowany jako równorzędny z okresem pozostawania w stosunku pracy, na co wskazuje formuła zastosowana w przepisach normujących wymienione wyżej sytuacje ${ }^{85}$.

Z punktu widzenia funkcji urlopu wypoczynkowego powyższy sposób ujęcia przez ustawodawcę tego zagadnienia może budzić pewne zastrzeżenie. Choć z jednej strony pracownik w tym okresie pracy nie świadczył, co może usprawiedliwiać brak odpowiadającego mu prawa do odpoczynku, to jednak nastąpiło to z przyczyn od niego niezależnych, często $\mathrm{w}$ związku z naruszeniem przez pracodawcę przepisów prawa lub przynajmniej, jak przy skróceniu okresu wypowiedzenia, w jego interesie. Czas, w którym pracownik pracy nie świadczy, nie może być też zrównany z okresem bezczynności, skoro podejmuje on określone wysiłki na rzecz dochodzenia swych praw w postępowaniu sądowym. Wydaje się zatem, że powyższe przypadki, stanowiące efekt określonych działań pracodawcy, nie powinny negatywnie wpływać na prawo pracownika do odpoczynku.

Omówione warunki nabycia prawa do urlopu wypoczynkowego dotyczą zasadniczo wszystkich pracowników, bez względu na podstawę nawiązania stosunku pracy, a także zatrudnienie w pełnym lub niepełnym wymiarze czasu pracy lub nietypową jej organizację, np. telepracowników. Jest to przejaw realizacji wymienianych wśród ogólnych zasad prawa urlopowego - powszechności i równości uprawnień urlopowych pracowników ${ }^{86}$. W jakiejś mierze wpisują się one w ideę prawa do odpoczynku jako prawa każdego człowieka, które powinno być, w miarę możliwości, nabywane na jednakowych warunkach (przy założeniu większej dyferencjacji w obszarze jego wymiaru, o czym dalej).

W tym kontekście trzeba jednak ocenić, mające charakter wyjątku od powszechnych zasad, częściowo odmienne reguły nabycia prawa do urlopu wybranych grup pracowników, tj. młodocianych, nauczycieli, nauczycieli akademickich oraz pracowników tymczasowych.

Inne od ogólnych warunki uzyskiwania prawa do urlopu przez pracowników młodocianych są w założeniu uzasadnione przede wszystkim potrzebą szczególnej ochrony życia i zdrowia tej grupy pracowników oraz specyficznym celem i charakterem tego zatrudnienia.

Zgodnie z przepisami k.p. młodociany uzyskuje z upływem 6 miesięcy od rozpoczęcia pierwszej pracy prawo do urlopu wypoczynkowego w wymiarze $12 \mathrm{dni}$ roboczych, a z upływem roku pracy - prawo do urlopu w wymiarze 26 dni (a zatem $w$ pierwszym roku łącznie $38 \mathrm{dni}$ ). $Z$ uwagi na to, że $w$ sprawach nieuregulowanych $\mathrm{w}$ analizowanym art. 205 k.p. do młodocianych stosuje się ogólne przepisy prawa urlopowego w literaturze przedmiotu powszechnie przyjmuje się, że prawo do kolejnego urlopu młodociany uzyskuje w każdym następnym roku kalendarzowym ${ }^{87}$.

85 Por. tak: Z. Góral, [w:] Kodeks pracy. Komentarz, red. K.W. Baran, Warszawa 2012, s. 268, 353.

86 Por. T. Zieliński, Zarys..., cz. Il, s. 281.

87 Por. tak m.in.: E. Szemplińska, Zatrudnienie młodocianych, PiZS 2003, nr 6, s. 29; J. Wratny, Kodeks pracy. Komentarz, Warszawa 2013, s. 525; A. Martuszewicz, K. Piecyk, Urlopy pracownicze..., s. 38. 
Tego rodzaju zasady nabycia prawa do urlopu niewątpliwie w przeszłości uprzywilejowywały młodocianego pracownika w omawianym zakresie. Nabywał on bowiem urlop wcześniej niż pozostali pracownicy, w stosunku do których przez długi czas wymagano rocznego okresu wyczekiwania na urlop (a nawet wprowadzony urlop po sześciu miesiącach był jedynie urlopem udzielanym zaliczkowo na poczet pierwszego urlopu po roku pracy) i uzyskiwał go w wyższym wymiarze.

Przy obecnym stanie prawnym kwestia oceny warunków uzyskania prawa do urlopu przez młodocianego, abstrahując od jego wymiaru, nie jest już tak jednoznaczna. Z jednej strony bowiem pracownicy ci dłużej oczekują na swój pierwszy urlop, a z drugiej nie dochodzi do jego nadmiernego rozdrobnienia, przez co urlop ten lepiej realizuje swoje podstawowe funkcje. W przypadku pracownika młodocianego ma to z pewnością pierwszorzędne znaczenie.

Dodatkową gwarancją zabezpieczającą prawo młodocianych do odpoczynku jest również wprost wskazana w przepisie możliwość udzielenia młodocianemu, który nie nabył jeszcze prawa do urlopu, a uczęszcza do szkoły, na jego wniosek, urlopu wypoczynkowego zaliczkowo w okresie ferii szkolnych. Unormowanie to z pewnością doskonale wpisałoby się w konstrukcję odpoczynku rocznego tej grupy zatrudnionych, niwelując ostatecznie obawy związane $z$ dłuższym w stosunku do powszechnego okresem wyczekiwania na urlop przez pracownika młodocianego, niemniej ostateczną decyzję w tej sprawie, jak wynika z art. $205 \$ 3$ k.p., pozostawiono pracodawcy, w przeciwieństwie do sytuacji młodocianego, który ma już prawo do urlopu i w stosunku do którego przepis obliguje pracodawcę do udzielania urlopu w tym terminie. Tym samym w związku z kilkumiesięcznym okresem pracy wymaganym do nabycia uprawnień urlopowych, powodującym ich uzyskanie zawsze po zakończeniu ferii zimowych lub letnich, nie ma pewności, czy młodociany, który jednocześnie uczy się i pracuje, będzie mógł w okresie owych ferii szkolnych z tego urlopu faktycznie skorzystać, a zarazem w pełni efektywnie zrealizować prawo do odpoczynku. Nie podlega bowiem dyskusji, że odpowiednie skorelowanie okresów odpoczynku od nauki i pracy w przypadku pracowników młodocianych staje się podstawowym warunkiem urzeczywistnienia omawianego prawa. Słusznie zwrócił uwagę M. Włodarczyk, że główny cel urlopu wypoczynkowego nie może zostać osiągnięty, jeśli młodociany musiałby w okresie ferii wykonywać pracę lub w czasie takiego urlopu uczestniczyć jednocześnie $\mathrm{w}$ zajęciach szkolnych ${ }^{88}$. Ponadto taka sytuacja mogłaby w znacznym stopniu zakłócać prawidłowy przebieg procesu przygotowania zawodowego, stanowiącego wiodący powód zatrudniania młodocianych ${ }^{89}$.

Problem ten był podnoszony pośrednio, choć w nieco innym od rozpatrywanego kontekście, przy okazji wykładni przepisów Europejskiej Karty Społecznej

88 Por. M. Włodarczyk, [w:] Kodeks pracy. Komentarz, red. K.W. Baran, Warszawa 2012, s. 1038.

89 Jak bowiem wskazuje M. Włodarczyk, w ramach takiego przygotowania zawodowego każdy jego dzień dzielony jest najczęściej w określonej proporcji między czas pracy i czas nauki. Tamże, s. 1039. 
Rady Europy - konkretnie jej art. 7 ust. $3^{90}$. Komitet Praw Społecznych odnosząc się do kwestii odpoczynku wakacyjnego, krytycznie ocenił dopuszczalność wykonywania pracy ( 8 godzin na dobę i 40 godzin tygodniowo) przez cały okres jego trwania, zwracając uwagę na zagrożenia płynące również dla zdolności poznawczych osoby zatrudnionej, a wynikające z niedostatecznego czasu na wypoczynek po rocznej nauce. W rezultacie zaleca się, aby odpoczynek ten obejmował nie mniej niż połowę okresu wakacyjnego ${ }^{91}$.

Z punktu widzenia prawa do odpoczynku, a zarazem podstawowej funkcji urlopu wypoczynkowego, pewne wątpliwości może budzić również kwestia zasad nabycia prawa do urlopu kolejnego. Jeśli uznać bowiem stanowisko wyrażane w doktrynie prawa pracy, że urlop ten uzyskuje młodociany na zasadach analogicznych jak pracownik dorosły, tj. w każdym następnym roku kalendarzowym, jeżeli tylko pozostaje $w$ zatrudnieniu pracowniczym, to pojawia się wcześniej już opisywany problem możliwości wystąpienia pewnych okresów pracy młodocianego, którym nie będą odpowiadać uprawnienia urlopowe. Chodzi bowiem o to, że w zakresie urlopu "pierwszego" ustawodawca odnosi go do roku pracy, a nie roku kalendarzowego podjęcia pracy $\mathrm{w}$ ramach stosunku pracy, stąd, jeśli młodociany nawiąże umowę w jakiejś części danego roku kalendarzowego, a zwykle tak się dzieje, to urlop po roku pracy w wymiarze 26 dni też nabędzie w części następnego roku kalendarzowego, a prawo do urlopu kolejnego w jeszcze następnym roku kalendarzowym. Tym samym między momentem nabycia prawa do urlopu „pierwszego" a momentem nabycia prawa do urlopu kolejnego może powstać nawet kilkumiesięczna przerwa, której nie odpowiada prawo do choćby jakiejś części wypoczynku rocznego, co jest sprzeczne $\mathrm{z}$ wcześniej formułowaną zasadą prawa urlopowego oraz jego ratio legis.

Trudno jednak, nawet przyjmując odmienne metody interpretacji analizowanych przepisów, dojść w tym zakresie do zadowalających wniosków. Z pewnością nie gwarantuje tego uznanie, że art. 205 k.p. reguluje w pełni nabycie prawa do urlopu wypoczynkowego pracowników młodocianych, bez potrzeby sięgania w tym zakresie do art. $153 \$ 2$ k.p. dotyczącego urlopu kolejnego. Wówczas należałoby bowiem uznać, że w roku podjęcia pierwszej pracy, do której wprost odwołuje się ustawodawca w art. $205 \$ 1$ k.p., młodociany nabywa urlop wypoczynkowy po 6 miesiącach pracy w wymiarze 12 dni roboczych, a $\mathrm{z}$ upływem roku pracy, o którym stanowi $\$ 2$ art. 205 k.p., urlop w wymiarze 26 dni. $Z$ uwagi na brak odmiennych regulacji i w związku z tym, że w powołanym wyżej $₫ 1$ art. 205 k.p. wyraźnie stanowi się jedynie o urlopie „z upływem 6 miesięcy od rozpoczęcia pierwszej pracy" trzeba byłoby przyjąć, że sytuację prawną pracownika pod względem

90 Przepis ten stanowi, że osoby podlegające obowiązkowemu nauczaniu nie mogą być zatrudniane przy pracach, które uniemożliwiałyby im pełne korzystanie z tego nauczania.

91 Por. M. Włodarczyk, Prawo dzieci i młodocianych do ochrony, „Europejska Karta Społeczna. Biuletyn Ośrodka Informacji i Dokumentacji Rady Europy Uniwersytetu Warszawskiego" 1997, nr 1-2, s. 58. 
urlopu wypoczynkowego w kolejnych latach reguluje w całości $₫ 2$ omawianego przepisu, a zatem że każdy następny urlop pracownik uzyskiwałby po kolejnym roku pracy. Tak długi okres wyczekiwania na kolejny urlop czyniłby jednak tę regulację ewidentnie sprzeczną z podstawową zasadą prawa pracy - prawa pracownika do wypoczynku i wypaczał sens odmiennego uregulowania sytuacji prawnej pracownika młodocianego ze względu na konieczność wzmożonej ochrony jego życia i zdrowia.

Trudno również racjonalnie uzasadnić koncepcję, według której pierwszym urlopem młodocianego jest wyłącznie urlop po 6 miesiącach pracy liczonych od podjęcia zatrudnienia $\mathrm{w}$ ramach stosunku pracy, skoro ustawodawca $\mathrm{w} \S 2$ wskazuje też wyraźnie na prawo do urlopu, jakie powstaje „z upływem roku pracy”.

Wydaje się zatem, że w zakresie kodeksowej regulacji nabycia prawa do urlopu wypoczynkowego przez pracowników ustawodawcy zabrakło trochę konsekwencji, usuwając bowiem wiele wątpliwości, zgłaszanych przez przedstawicieli prawa pracy, w zakresie powszechnych reguł warunkujących powstanie prawa do urlo$\mathrm{pu}, \mathrm{w}$ zasadzie zupełnie pominięto $\mathrm{w}$ tym aspekcie młodocianych, pozostawiając $\mathrm{w}$ całości dotychczasowe brzmienie przepisów wraz z wynikającymi z nich problemami.

Pewną formą rekompensaty może być jedynie dłuższy wymiar urlopu w pierwszym roku pracy młodocianego wynoszący 38 dni (12 dni po 6 miesiącach pracy i 26 po roku).

\subsection{Nabycie prawa do urlopu wypoczynkowego w świetle wybranych ustaw szczególnych}

$\mathrm{Na}$ innych warunkach prawo do urlopu wypoczynkowego nabywają nauczyciele, $\mathrm{w}$ tym także akademiccy. Przede wszystkim obejmują ich zwykle dłuższe okresy wyczekiwania na pierwszy urlop, w ich przypadku nie znajdują bowiem zastosowania kodeksowe regulacje dotyczące opisanego wcześniej urlopu cząstkowego ( $\mathrm{z}$ wyjątkiem nauczycieli zatrudnionych w szkołach, w których nie ma ferii). W rezultacie pracownicy ci, szczególnie nauczyciele akademiccy, uzyskują prawo do pierwszego urlopu wypoczynkowego na mniej korzystnych zasadach niż większość pozostałych osób świadczących pracę w ramach stosunku pracy ${ }^{92}$, co $\mathrm{w}$ jakiejś mierze jest rekompensowane $\mathrm{z}$ kolei dłuższym jego wymiarem.

W świetle art. 65 ustawy - Karta Nauczyciela ${ }^{93}$ nauczyciel zatrudniony w szkole, w której przewidziano ferie szkolne, a zatem w zdecydowanej większości przypadków, nabywa prawo do pierwszego urlopu w ostatnim dniu poprzedzającym ferie szkolne, a prawo do drugiego i dalszych urlopów w następnym roku kalendarzowym.

92 Por. m.in. P. Nowik, [w:] Prawo o szkolnictwie wyższym. Komentarz, pod red. M. Pyter, Warszawa 2012, s. 742.

93 Ustawa z 26 stycznia 1982 r. - Karta Nauczyciela, tekst jednolity Dz. U. 2018, poz. 967. 
Jest to przepis, który ze względu na swą formułę budzi pewne wątpliwości, rzutujące na ocenę stopnia urzeczywistnienia prawa do odpoczynku w odniesieniu do tej grupy zawodowej. Przede wszystkim zwraca uwagę fakt, że łączy on bezpośrednio prawo do pierwszego urlopu takiego nauczyciela $\mathrm{z}$ ostatnim dniem poprzedzającym ferie szkolne, ale bez konkretyzacji, o które ferie chodzi.

Z przepisów wykonawczych dotyczących organizacji roku szkolnego wynika, że w szkołach występują dwa rodzaje ferii:

- zimowe, trwające 2 tygodnie w okresie od połowy stycznia do końca lutego; dokładny termin rozpoczęcia i zakończenia tych ferii na obszarze poszczególnych województw ogłasza $\mathrm{z}$ odpowiednim wyprzedzeniem minister właściwy do spraw oświaty i wychowania, co będzie miało decydujące znaczenie dla ustalenia momentu nabycia prawa do pierwszego urlopu przez nauczyciela, który podjął zatrudnienie przed nadejściem tego okresu;

- letnie, które rozpoczynają się w najbliższą sobotę po zakończeniu rocznych zajęć dydaktyczno-wychowawczych i kończą się z dniem 31 sierpnia ${ }^{94}$.

Odwołanie się przez ustawodawcę w powołanym artykule do „drugiego" urlopu może rodzić wątpliwości, o który w istocie urlop chodzi. Z literalnego brzmienia przepisów można wywnioskować, że nauczyciel, który rozpoczął pierwszą pracę z początkiem września, prawo do urlopu wypoczynkowego uzyska $\mathrm{w}$ dniu poprzedzającym ferie zimowe. Problem polega jednak na tym, co $\mathrm{z}$ dalszym okresem jego zatrudnienia $\mathrm{w}$ danym roku, skoro, zgodnie $\mathrm{z}$ art. 65 analizowanej ustawy, „drugi" urlop wypoczynkowy (i kolejne) nauczyciel ten nabywa dopiero w następnym roku kalendarzowym. Skoro zatem pierwszym urlopem był dla nauczyciela urlop nabyty bezpośrednio przed wystąpieniem ferii zimowych, a przepis wskazuje tylko na jeden pierwszy urlop (a nie urlopy), to drugim powinien być urlop poprzedzający termin ferii letnich. Tymczasem z przepisów wynika, że nabywa się go dopiero z początkiem kolejnego roku kalendarzowego. Wówczas należałoby uznać, że za okres pracy przypadający po zakończeniu ferii zimowych aż do końca roku kalendarzowego nauczycielowi nie przysługują żadne uprawnienia urlopowe, co ewidentnie godziłoby w zasadę prawa pracowników do wypoczynku oraz regułę równego ich traktowania, także w omawianym aspekcie.

Można również rozważać, czy konstrukcja pierwszego urlopu nauczyciela nie została oparta na możliwości dwukrotnego nabycia do niego prawa i odniesiona do roku szkolnego podjęcia pracy w takim charakterze, co jednak z przepisów ustawy bezpośrednio nie wynika. Nauczyciel nabywałby wówczas prawo do urlopu wypoczynkowego w dzień poprzedzający ferie szkolne (zarówno zimowe, jak i letnie), zaś prawo do następnych urlopów będzie on już uzyskiwać „z góry”, z początkiem każdego kolejnego roku kalendarzowego.

W literaturze dominuje jednak wykładnia, według której nauczyciel zatrudniony w „szkole feryjnej” nabywa prawo do pierwszego urlopu wypoczynkowego

94 Por. § 3 rozporządzenia Ministra Edukacji Narodowej i Sportu z dnia 18 kwietnia 2002 r. w sprawie organizacji roku szkolnego, Dz. U. 2002, Nr 46, poz. 432, ze zm. 
w ostatnim dniu poprzedzającym ferie zimowe i że urlop ten trwa wówczas przez dwa tygodnie ferii zimowych i następnie przez okres ferii letnich ${ }^{95}$.

Istnieje zatem jeden pierwszy urlop, którego realizacja przebiega niejako w dwóch etapach, ze względu na to, że wykorzystywanie urlopu wypoczynkowego przez nauczyciela jest ex lege powiązane z okresem feryjnym (art. 64 ustawy).

Nie ma natomiast zwykle wówczas odpowiedzi na pytanie, kiedy następuje nabycie prawa do urlopu wypoczynkowego przez nauczyciela zatrudnionego już po okresie ferii zimowych (np. w celu zastępstwa). Wydaje się, że treść art. 65 analizowanej ustawy pozwala również wówczas uznać, że do nabycia tego prawa dochodzi ostatniego dnia poprzedzającego rozpoczęcie ferii letnich. Przepis nie wiąże przecież prawa do pierwszego urlopu wypoczynkowego nauczyciela wyłącznie z dniem występującym bezpośrednio przed feriami zimowymi.

$\mathrm{O}$ ile więc generalnie należy zgodzić się z takim kierunkiem interpretacji przepisów analizowanej ustawy, o tyle nie można łączyć prawa do pierwszego urlopu nauczyciela wyłącznie z okresem przerwy zimowej. Pierwszy urlop nauczyciel uzyskuje z dniem poprzedzającym najbliższe ferie, jeżeli w tym dniu takie zatrudnienie jeszcze trwa, i urlop ten przysługuje zasadniczo, zgodnie z art. 64 Karty Nauczyciela, w wymiarze odpowiadającym okresowi ferii i w czasie ich trwania. Z każdym następnym rokiem kalendarzowym (a nie szkolnym) nauczyciel nabywa prawo do urlopu kolejnego.

Trzeba jednocześnie zauważyć, że nabycie przez nauczyciela urlopu kolejnego „Z góry” ma mniejsze znaczenie praktyczne w porównaniu z innymi pracownikami, ustawodawca ograniczył bowiem dość wyraźnie swobodę stron stosunku pracy w zakresie terminu, w jakim prawo to może zostać zrealizowane, co było wyżej sygnalizowane i o czym będzie jeszcze szerzej mowa. Następuje tu zatem zagwarantowanie większej regularności tego odpoczynku kosztem właśnie owej swobody.

Przyjęcie powyższego sposobu interpretacji przepisów Karty Nauczyciela w zakresie urlopów wypoczynkowych nie eliminuje jednak i tak wszystkich problemów z nią związanych. Przede wszystkim obowiązująca regulacja generuje bowiem problem występowania okresów pracy, którym nie odpowiada ekwiwalenty okres odpoczynku.

Tego rodzaju wątpliwości powstają w przypadku rozwiązania stosunku pracy przed upływem dnia nabycia prawa do pierwszego urlopu. Nawet jeśli nauczyciel przepracował dłuższy okres (kilka miesięcy), to, zgodnie z przyjętym w literaturze i orzecznictwie poglądem, w razie rozwiązania stosunku pracy w czasie trwania semestru zimowego, nie nabędzie on prawa do urlopu wypoczynkowego ${ }^{96}$, choćby w zmniejszonym wymiarze.

95 Por. M. Szymańska, [w:] A. Barański, M.H. Szymańska, J. Rozwadowska-Skrzeczyńska, Karta Nauczyciela. Komentarz, Warszawa 2014, s. 383.

96 Por. tamże, s. 360. Zob. też wyrok sądu rejonowego w Ostrołęce z 27 lutego 2014 r., IV P 454/13, www.orzeczenia.ms.gov.pl. 
Podobna sytuacja wystąpi w razie zatrudnienia nauczyciela w okresie przypadającym między feriami, np. od kwietnia do maja, na podstawie umowy terminowej (np. w celu zastępstwa) $)^{97}$. Wówczas ten pracownik nie uzyska również za przepracowany czas prawa do pierwszego urlopu wypoczynkowego, co pośrednio stawia te osoby pod względem prawa do wypoczynku w gorszym położeniu niż pozostałych pracowników, w tym zatrudnionych także na podstawie umowy terminowej, ale nie w charakterze nauczyciela.

Ponadto kwestią, która może wywoływać pewne kontrowersje, jest ustalenie sposobu interpretacji pojęcia pierwszego urlopu, do którego odwołano się w Karcie Nauczyciela. Skoro ustawodawca nie posługuje się bowiem w przepisie pojęciem pierwszej pracy, może to sugerować, że chodzi o pierwszy urlop w charakterze nauczyciela, nawet jeśli pracownik już wielokrotnie z tego urlopu wcześniej korzystał na podstawie przepisów k.p., a nie pierwszy urlop w życiu zawodowym danego pracownika, zbiegający się z podjęciem pracy w szkole.

Trzeba przyznać, że ustawowa regulacja nie daje w tym zakresie jednoznacznej odpowiedzi, co dotyczy również nauczycieli akademickich i będzie w związku z tym dalej szerzej rozważane.

Podsumowując, przyjęcie pewnego okresu wyczekiwania na pierwszy urlop generalnie, o czym była mowa wcześniej, jest uzasadnione i dopuszczalne, zwłaszcza jeśli, tak jak w omawianym przypadku, nie przekracza okresu sześciu miesięcy $\mathrm{i}$ jest powiązane $\mathrm{z}$ organizacją roku szkolnego. Niemniej takie konstrukcje nie są szczególnie koherentne z zasadą prawa pracownika do wypoczynku, gdyż niosą za sobą zwykle ryzyko występowania pewnych okresów wydatkowania sił, którym nie będą odpowiadać żadne uprawnienia urlopowe, co staje się szczególnie widoczne $\mathrm{w}$ odniesieniu do zatrudnienia terminowego. Kilka umów na zastępstwo, obejmujących okresy przypadające $\mathrm{w}$ odpowiednim czasie przed feriami, w tej samej lub różnych szkołach, będzie bowiem legalnie pozbawiać daną osobę prawa do wypoczynku rocznego, mimo liczonego łącznie kilkumiesięcznego nawet zatrudnienia. $\mathrm{W}$ tym kontekście trzeba przypomnieć, że regułą przyjętą przez MOP jest nabywanie uprawnień urlopowych proporcjonalnie do okresu przepracowanego w danym roku, a niewystarczającego do uzyskania pełnego urlopu wypoczynkowego (por. fragment dotyczący prawa międzynarodowego), co $\mathrm{w}$ analizowanej ustawie nie znalazło w pełni swego zastosowania.

$\mathrm{Na}$ zdecydowaną krytykę zasługuje natomiast mało precyzyjny, nawet nieco chaotyczny, sposób ujęcia przez ustawodawcę omawianych zagadnień, który stwarza pole do różnorodnych interpretacji. Pomijając sygnalizowane wyżej wątpliwości, nie do końca jasne jest przy tym w ogóle, w jakim zakresie Karta Nauczyciela reguluje problem urlopów wypoczynkowych nauczycieli wyczerpująco, a w jakim mogą znaleźć swe odpowiednie zastosowanie przepisy k.p. Stąd w praktyce kwe-

97 Art. 10 ust. 7 Karty Nauczyciela przewiduje możliwość zawarcia z nauczycielem umowy terminowej, także w trakcie roku szkolnego, ze względu na zaistnienie potrzeby wynikającej z organizacji nauczania lub zastępstwa nieobecnego nauczyciela. 
stie te stają się często przedmiotem sporów sądowych, zwłaszcza w zakresie ustalenia prawa do ekwiwalentu pieniężnego za niewykorzystany urlop wypoczynkowy, będący pochodną samego prawa do urlopu, co niewątpliwie ostatecznie nie przyczynia się do spokojnej i prawidłowej realizacji omawianego prawa.

Swoiste zasady nabycia prawa do urlopu wypoczynkowego, uwzględniające także okres dłuższego wyczekiwania na urlop, zostały przewidziane również w stosunku do nauczycieli akademickich.

Zgodnie z ustawą o szkolnictwie wyższym nauczyciel akademicki nabywa prawo do pierwszego urlopu wypoczynkowego w ostatnim dniu poprzedzającym letnią przerwę w zajęciach dydaktycznych. Prawo do drugiego i kolejnych urlopów wypoczynkowych uzyskuje on natomiast, analogicznie jak inni pracownicy, z początkiem każdego następnego roku kalendarzowego ${ }^{98}$.

Wskazane wyżej reguły nabycia prawa do urlopu wypoczynkowego dotyczą wszystkich nauczycieli akademickich, - niezależnie od podstawy nawiązania stosunku pracy, charakteru wykonywanej pracy (naukowej, dydaktycznej, naukowo-dydaktycznej, dyplomowanych bibliotekarzy itd.), prowadzenia bądź nie zajęć dydaktycznych oraz rodzaju uczelni (publiczna, niepubliczna, medyczna, wojskowa itp. $)^{99}$.

Osoby te będą zatem uzyskiwały prawo do pierwszego urlopu wypoczynkowego po upływie różnych okresów pracy, w zależności od momentu podjęcia zatrudnienia na stanowisku nauczyciela akademickiego oraz przyjętej na danej uczelni organizacji roku akademickiego. Zatrudnienie od 1 października będzie wiązało się z około ośmiomiesięcznym okresem wyczekiwania na urlop, zaś następstwem zatrudnienia na początku semestru letniego jest powstanie prawa do urlopu po mniej więcej czterech miesiącach pracy (co znajdzie jednak swoje odzwierciedlenie w wymiarze należnego urlopu ze względu na proporcjonalne jego obniżenie, o czym dalej).

Mało klarowny sposób sformułowania przepisów rodzi w praktyce wiele trudności interpretacyjnych, także w zakresie problematyki nabycia prawa do urlopu wypoczynkowego.

Przede wszystkim na gruncie omawianej ustawy, podobnie jak w Karcie $\mathrm{Na}$ uczyciela, posłużono się pojęciem pierwszego urlopu, bez wskazania, czy chodzi tu o pierwsze zatrudnienie w życiu zawodowym pracownika ${ }^{100} \mathrm{czy}$ też o pierwsze zatrudnienie konkretnie w charakterze nauczyciela akademickiego ${ }^{101}$. Ustalenie tej kwestii ma pewne znaczenie zarówno z punktu widzenia nabycia prawa do urlopu

98 Por. art. 133 ustawy z dnia 27 lipca 2005 r. - Prawo o szkolnictwie wyższym, tekst jednolity: Dz. U. 2016, poz. 1842, ze zm.

99 Por. W. Sanetra, [w:] Prawo o szkolnictwie wyższym. Komentarz, red. W. Sanetra, M. Wierzbowski, Warszawa 2013, s. 302.

100 Za takim stanowiskiem opowiedział się m.in. T. Nycz. Por. tenże: Prawo do urlopu wypoczynkowego nauczyciela akademickiego, www.prawo-pracy.pl [dostęp 8.12.2010].

101 Do tego rodzaju zapatrywania zdaje się przekonywać P. Nowik. Por. tenże, [w:] Prawo o szkolnictwie wyższym. Komentarz, red. M. Pyter, Warszawa 2012, s. 742. 
wypoczynkowego przez wymienione grupy zawodowe, jak i określenia wymiaru tego urlopu ${ }^{102}$. Niestety, trudno na podstawie obowiązujących przepisów dokonać tego w sposób jednoznaczny.

Konsekwencją przyjęcia pierwszego stanowiska jest konstatacja, że termin nabycia prawa do pierwszego w życiu urlopu pracownika podejmującego pracę w charakterze nauczyciela jest wyznaczany w sposób szczególny w stosunku do regulacji kodeksowej.

Jednocześnie akceptacja powyższego poglądu pozwala uznać, że skoro omawiane zasady odnoszą się tylko do nauczyciela, dla którego podejmowane zatrudnienie jest pierwszym w życiu zawodowym, to nie będą one miały zastosowania do osoby, która już wcześniej wykonywała pracę w ramach stosunku pracy na innym stanowisku, a następnie zostaje ona zatrudniona jako nauczyciel akademicki (czy nauczyciel w rozumieniu Karty Nauczyciela). Wówczas, zdaniem m.in. T. Nycza, z momentem zatrudnienia jej na stanowisku nauczyciela akademickiego ma ona już prawo do urlopu kolejnego z pierwszym dniem takiego zatrudnienia ${ }^{103}$.

Za takim stanowiskiem może $\mathrm{w}$ jakiejś mierze przemawiać art. 136 analizowanej ustawy, który w sprawach w niej nieunormowanych odsyła do przepisów k.p. Jedną $\mathrm{z}$ takich kwestii jest liczenie stażu warunkującego prawo do urlopu wypoczynkowego. Ustawodawca nie podejmuje bowiem (również w Karcie Nauczyciela) tego wątku w żadnym aspekcie. Regulacja kodeksowa zakłada z kolei konieczność uwzględnienia ogólnego stażu pracy, a więc wszystkich okresów pracy, bez względu m.in. na rodzaj wykonywanej pracy, przerwy w zatrudnieniu czy sposób jego ustania. W takim ujęciu pracownik, który nabył już prawo do urlopu wypoczynkowego u kolejnego pracodawcy, zachowuje je od pierwszego dnia zatrudnienia.

Różny może być również wówczas rozmiar nabywanego uprawnienia. Jeśli nauczyciel akademicki będzie zatrudniony od początku roku akademickiego, nabędzie to prawo w pełnym wymiarze, tj. 36 dni roboczych. Jeżeli natomiast podjął on zatrudnienie $w$ roku kalendarzowym, $w$ którym nabył on prawo do pierwszego urlopu, wówczas, zgodnie $\mathrm{z}$ art. 133 ust. 3 pkt 1 ustawy, wymiar jego urlopu zostanie proporcjonalnie obniżony ${ }^{104}$.

Przyjęcie koncepcji drugiej, a więc, że chodzi o pierwszy urlop akademicki, a nie wyłącznie pierwszy urlop w życiu zawodowym pracownika, powoduje, jak zauważył Z. Góral, że staje się on w istocie urlopem kolejnym w sensie kodeksowym, tyle że nabywanym w pierwszym roku takiego zatrudnienia w szczególny sposób, bowiem $\mathrm{w}$ dniu poprzedzającym letnią przerwę $\mathrm{w}$ zajęciach dydaktycznych ${ }^{105}$. W konsekwencji należałoby zatem uznać, że dla wyznaczenia terminu nabycia prawa do "pierwszego urlopu akademickiego" nie mają znaczenia wcze-

$102 \mathrm{Na}$ ostatnią kwestię wskazuje szerzej Z. Góral, [w:] Akademickie prawo pracy, red. K.W. Baran, Warszawa 2015, s. 239.

103 Por. T. Nycz, Prawo do urlopu wypoczynkowego...

104 Por. Z. Góral, [w:] Akademickie prawo..., s. 239.

105 Tamże. 
śniejsze okresy zatrudnienia w ramach stosunku pracy w innym charakterze niż nauczyciel akademicki.

Niewątpliwie pierwszy pogląd jest bardziej korzystny dla pracownika, znacznie bardziej przyczynia się do urzeczywistnienia prawa pracownika do wypoczynku, przyspieszając nabycie prawa do urlopu w wielu przypadkach, jest bardziej spójny z przepisami kodeksowymi. Niemniej analiza omawianych norm ustawy prowadzi poszczególnych autorów do odmiennych wniosków, co z pewnością nie świadczy dobrze o legislatorze, ale może przyczyniać się również do stosowania tych norm w zróżnicowany sposób w praktyce, a przez to osłabiać funkcję gwarancyjną omawianego prawa.

Powyższy sposób unormowania warunków nabycia prawa do urlopu pierwszego budzi też uzasadnione wątpliwości z punktu widzenia omawianych wcześniej ogólnych zasad warunkujących optymalny odpoczynek.

Przede wszystkim nie jest do końca zrozumiałe, dlaczego ustawodawca nie powiązał prawa do urlopu wypoczynkowego, podobnie jak uczyniono to na gruncie Karty Nauczyciela, również z zimową przerwą międzysemestralną, co niewątpliwie skróciłoby dość długi, zwłaszcza w kontekście standardów MOP, okres pracy wymagany do tego, by w ogóle prawo do tego urlopu nabyć. Nie znajduje to bowiem uzasadnienia ani w samych regułach udzielania tego urlopu, gdzie następuje pewne ograniczenie swobody w zakresie terminu jego wykorzystania, ani w samym charakterze tej pracy. Wydaje się, że wręcz przeciwnie, należy uznać, że jest to praca szczególnie wyczerpująca, powiązana z licznymi obowiązkami zarówno o charakterze dydaktycznym, jak i naukowym. Tym samym prawo do odpoczynku rocznego staje się podstawowym instrumentem realizacji prawa takiego pracownika do odpoczynku. Okres wyczekiwania na to prawo, jeśli w ogóle taki się przyjmuje, odchodząc od zasad kodeksowych, powinien być zatem skrócony do maksymalnie półrocznego okresu zatrudnienia i przypadać ewentualnie na początek zimowej przerwy międzysemestralnej.

Warto też zauważyć, że uzależniając pierwszy urlop nauczyciela akademickiego od nastania dnia poprzedzającego letnią przerwę w zajęciach dydaktycznych, abstrahuje się od faktu, że pojęcie nauczyciela akademickiego, jak była mowa o tym wcześniej, jest wewnętrznie zróżnicowane, obejmuje różne grupy podmiotów, wykonujące na uczelni różne funkcje, nie zawsze powiązane z prowadzeniem zajęć dydaktycznych. Nie jest zatem jasne powiązanie ich prawa do urlopu wypoczynkowego z tak ustalonym terminem.

Być może u podstaw tej regulacji legło założenie, że w okresie wolnym od zajęć dydaktycznych maleje stopień intensywności funkcjonowania całej uczelni, co jednak, jak słusznie zauważono w doktrynie prawa pracy, jest tezą mocno ryzykowną, w szczególności w stosunku do pracowników naukowych ${ }^{106}$.

Wydaje się w związku z tym, że zadecydowały względy czysto techniczne, a nie merytoryczne - większe formalne ujednolicenie reguł nabycia prawa do urlopu przez wszystkie osoby kwalifikowane jako nauczyciele akademiccy.

106 Tamże, s. 237. 
Podobne zastrzeżenia można odnieść do związania okresu realizacji tego prawa z czasem wolnym od zajęć dydaktycznych ${ }^{107}$, gdzie też nie wprowadzono wprost wyłączenia omawianej reguły w odniesieniu do osób, które nie prowadzą zajęć dydaktycznych (np. pracowników naukowych czy dyplomowanych bibliotekarzy). W tym zakresie jednak większość przedstawicieli doktryny prawa pracy jest raczej zgodna co do tego, że mogą oni korzystać z prawa do urlopu wypoczynkowego w każdym czasie ${ }^{108}$.

Samo ograniczenie swobody realizacji prawa do urlopu wypoczynkowego, dość kategoryczne na gruncie ustawy - Karta Nauczyciela ${ }^{109}$, łagodniejsze w świetle analizowanej aktualnie ustawy dotyczącej nauczycieli akademickich ${ }^{110}$, też, moim zdaniem, nie jest do końca przekonujące. Jest oczywiste, że ze względów organizacyjnych taki okres realizacji tego prawa jest z pewnością pożądany, niemniej nie powinno się w tym zakresie wprowadzać jednoznacznych, kategorycznych nakazów, zwłaszcza że o terminie udzielenia urlopu, przy zastosowaniu ogólnych zasad kodeksowych, w większości przypadków decyduje ostatecznie pracodawca.

Ustawowe sprowadzenie urlopu wypoczynkowego do okresu wolnego od zajęć dydaktycznych wydaje się też nie do końca przystawać, szczególnie w niektórych przypadkach, do istoty tej instytucji. Urlop jest bowiem zwolnieniem pracownika z obowiązku świadczenia pracy. Trudno natomiast mówić, że dochodzi w sensie faktycznym i prawnym do takiego zwolnienia w sytuacji pracownika, którego praca polega wyłącznie na prowadzeniu zajęć dydaktycznych, a które w omawianym czasie w ogóle nie występują.

Z powyższych względów należy jednak dążyć do tego, by pozostawić stronom stosunkowo szeroki margines swobody w zakresie czasu, w jakim będzie następować realizacja omawianego prawa, w celu osiągnięcia jak najpełniejszego urzeczywistnienia jego podstawowej funkcji. W przeciwnym razie nie osiągnie się ani optymalnych rezultatów w zakresie dydaktyki (jeśli zajęcia są prowadzone przez przemęczoną osobę), ani też w zakresie odpoczynku (jeśli urlop ma być wykorzystywany nie wtedy, kiedy jest potrzebny lub w czasie, w którym nie zostanie de facto spożytkowany na odpoczynek w związku z nałożonymi na pracownika zadaniami naukowymi). Wydaje się, że uwzględniając ów aspekt organizacyjny, a także względy prawidłowego przebiegu procesu dydaktycznego, należy albo

107 Zgodnie z art. 133 ust. 1 ustawy - Prawo o szkolnictwie wyższym urlop wypoczynkowy powinien być wykorzystywany w okresie wolnym od zajęć dydaktycznych.

108 Tak m.in.: W. Sanetra, [w:] Prawo..., s. 302; Z. Góral, [w:] Akademickie prawo..., s. 237; T. Nycz, Prawo do urlopu wypoczynkowego...

109 Zgodnie z art. 64 Karty Nauczyciela, urlop „przysługuje” w czasie trwania ferii.

110 Większość komentujących przepisy ustawy przyjmuje, że należy w tym zakresie raczej mówić o pewnym postulacie niż prawnym nakazie. Ustawodawca wskazuje bowiem, że urlop ten „powinien” być wykorzystany w okresie wolnym od zajęć dydaktycznych, a nie „musi” czy „jest” wówczas wykorzystywany. Por. H. Izdebski, J.M. Zieliński, Prawo o szkolnictwie wyższym. Komentarz, Warszawa 2011, s. 344. Por. też tak Z. Góral, [w:] Akademickie prawo..., s. 237. 
przyjąć, jak uczyniono na gruncie przywołanej ustawy, że zaleca się jedynie, a nie z mocy prawa zobowiązuje do wykorzystania urlopu w okresie przerwy międzysemestralnej, albo też przy już wprowadzonym obowiązku, jaki wynika, według mnie, z przepisów Karty Nauczyciela, uwzględnić jednak możliwość odstąpienia od analizowanego wymogu, chociaż w sytuacjach, w których udzielenie urlopu $\mathrm{w}$ innym terminie nie będzie kolidować z prowadzeniem zajęć.

Na swoistych warunkach prawo do urlopu wypoczynkowego nabywają również pracownicy tymczasowi.

Jest to w dużej mierze podyktowane specyfiką tej nietypowej formy zatrudnienia, której cechą szczególną jest nie tylko wyjątkowa konstrukcja podmiotowa, ale m.in. także jego tymczasowość. Ta ostatnia właściwość omawianej pracy, jak się wydaje, w dużej mierze zadecydowała o zbliżeniu zasad nabycia prawa do urlopu przez pracowników tymczasowych do reguł stosowanych w przeszłości w odniesieniu do pracowników sezonowych (por. wcześniejsze rozważania).

Zgodnie bowiem $\mathrm{z}$ art. 17 ustawy o zatrudnianiu pracowników tymczasowych $^{111}$, pracownik ten nabywa urlop wypoczynkowy w wymiarze dwóch dni za każdy miesiąc pozostawania w dyspozycji jednego pracodawcy użytkownika lub więcej niż jednego pracodawcy użytkownika. Urlop ten nie przysługuje jednak za okres, za który pracownik wykorzystał u poprzedniego pracodawcy urlop wypoczynkowy należny na podstawie odrębnych przepisów.

$\mathrm{Z}$ powyższego unormowania wynika, że w całym okresie pozostawania w zatrudnieniu tymczasowym pracownik będzie nabywać prawo do urlopu wypoczynkowego wielokrotnie, $\mathrm{z}$ każdym miesięcznym okresem pozostawania w dyspozycji pracodawcy użytkownika, w wymiarze dwóch dni.

Pojęcie miesiąca nie zostało przez ustawodawcę zdefiniowane, niemniej z braku odmiennych unormowań w przedmiotowej ustawie w literaturze powszechnie przyjmuje się, że będą tu miały zastosowanie reguły liczenia terminów wcześniej opisane i wynikające z orzecznictwa Sądu Najwyższego, w szczególności, że za miesiąc, jeśli nie jest on liczony w sposób ciągły, należy uznać $30 \mathrm{dni}^{112}$.

W ustawie o pracy tymczasowej nie wyjaśniono również pojęcia „pozostawania w dyspozycji” pracodawcy użytkownika jako warunku nabycia prawa do urlopu wypoczynkowego, co może rodzić liczne wątpliwości interpretacyjne, a w konsekwencji wpływać na ocenę stopnia zaspokojenia prawa do odpoczynku pracownika tymczasowego. Zwrot ten, stanowiąc przesłankę prawa do urlopu wypoczynkowego, nie powinien być interpretowany rozszerzająco. Z kolei jego bardzo restrykcyjna wykładnia ograniczy możliwość nabycia prawa do urlopu przez omawianą grupę zatrudnionych, co wydaje się pozostawać w pewnej sprzeczności m.in.

111 Ustawa z 9 lipca 2003 r. o zatrudnianiu pracowników tymczasowych, tekst jednolity: Dz. U. 2016, poz. 360, ze zm.

112 Por. tak m.in.: A. Sobczyk, Ustawa o zatrudnianiu pracowników tymczasowych. Komentarz, Kraków 2005, s. 84 i n.; J. Wiśniewski, Urlop na żądanie pracownika tymczasowego, PizS 2011, nr 6, s. 31. 
z omawianymi wcześniej wymogami prawa UE w zakresie urlopów wypoczynkowych, ale też zasadą równego traktowania pracowników tymczasowych w zakresie warunków zatrudnienia ( $w$ tym urlopów) wynikającą z dyrektywy z 2008 r. dotyczącej pracy tymczasowej ${ }^{113}$.

W świetle przepisów o czasie pracy termin „pozostawanie w dyspozycji” łączony jest nie tylko z okresem faktycznie wykonywanej pracy, ale również okresem gotowości do jej wykonywania. Jeżeli zatem nie może budzić zastrzeżeń, że posługując się tym pojęciem, ustawodawca nie ogranicza owego miesięcznego okresu wyłącznie do postaci czynnego wykonywania pracy na rzecz pracodawcy użytkownika, to jednak powstaje uzasadniona wątpliwość, czy w tej formule mieszczą się również takie stany, w których pracownik ani pracy nie świadczy w sensie dosłownym, ani też nie pozostaje w gotowości do jej wykonywania, w tym zwłaszcza okresy niezdolności do pracy wywołane chorobą.

Wydaje się, że uzależniając prawo do urlopu wypoczynkowego od wymaganego czasu pozostawania $\mathrm{w}$ dyspozycji pracodawcy użytkownika, ustawodawca chciał jedynie podkreślić związek prawa do urlopu wypoczynkowego z okresem, w jakim pracownik zostaje „oddany” do dyspozycji tego pracodawcy, wykonuje na jego rzecz pracę, a nie zawęzić zakres nabycia prawa do urlopu wypoczynkowego przez pracownika tymczasowego jedynie do przypadków zachowania co najmniej stanu gotowości do realizacji swych obowiązków na rzecz owego pracodawcy użytkownika. Byłby to znaczący wyłom w formułowanej na gruncie przepisów k.p. regule uwzględniania przy nabyciu prawa do urlopu, co do zasady, okresów pozostawania w stosunku pracy, bez względu na faktyczną realizację swych obowiązków przez pracownika w tym okresie, a zarazem daleko idące ograniczenie prawa do urlopu pracownika tymczasowego. Nie to, jak można domniemywać, było celem ustawodawcy. Chodziło raczej o odróżnienie w omawianym aspekcie okresu pozostawania w dyspozycji pracodawcy użytkownika od czasu trwania umowy z agencją pracy tymczasowej. Jak wskazuje się bowiem w literaturze przedmiotu, okresy te nie zawsze się pokrywają. Różnice te mogą być powodowane niedostosowaniem czasu trwania umowy do zapotrzebowania pracodawcy użytkownika na pracę, w tym zwłaszcza rezygnacją z pracy pracownika tymczasowego przez tego pracodawcę w trybie art. 18 ust. 2 analizowanej ustawy bądź faktycznym zaprzestaniem wykonywania pracy przez pracownika tymczasowego, o którym mowa w art. 18 ust. 3 ustawy o zatrudnianiu pracowników tymczasowych ${ }^{114}$. W takim ujęciu doszłoby

113 Por. dyrektywa Parlamentu Europejskiego i Rady z 19 listopada 2008 r. w sprawie pracy tymczasowej, Dz. Urz. UE L 327/9. Istotny jest szczególnie jej art. 5 ust. 1, zgodnie z którym podstawowe warunki pracy i zatrudnienia pracowników tymczasowych w okresie skierowania do pracy w przedsiębiorstwie użytkownika odpowiadają co najmniej warunkom, jakie miałyby zastosowanie, gdyby zostali oni bezpośrednio zatrudnieni przez to przedsiębiorstwo na tym samym stanowisku (tekst dyrektywy zob. też www.eur-lex.europa.eu).

114 Na potrzebę rozróżnienia tych okresów wskazuje w szczególności A. Sobczyk. Jednocześnie autor opowiada się za wyłączeniem ze stażu urlopowego pracownika tymczasowego okresów niepozostawania w dyspozycji pracodawcy użytkownika z powodów prawnych (utrata 
do wyłączenia z miesięcznego okresu warunkującego urlop pracowników tymczasowych pewnych stanów nieświadczenia pracy, ale nielicznych i ograniczonych do przypadków wskazanych w ustawie (powołany art. 18), a zarazem zbliżonych do regulacji kodeksowej, kiedy pracownik de facto zaprzestaje świadczenia pracy na rzecz pracodawcy użytkownika ${ }^{115}$.

Taka wykładnia tego terminu nie tylko realizuje wynikający wprost z orzecznictwa Trybunału Sprawiedliwości UE zakaz uzależniania prawa do urlopu wypoczynkowego od okresów rzeczywistego świadczenia pracy, a tym samym wyłączenia możliwości jego nabycia w okresie niezdolności do pracy spowodowanej chorobą $^{116}$ (por. rozważania zawarte w pierwszej części opracowania), ale też wpisuje się w sformułowaną w powołanej wyżej dyrektywie poświęconej pracy tymczasowej zasadę zagwarantowania tej grupie pracowników w zakresie podstawowych warunków pracy co najmniej takich praw, z jakich korzystaliby, będąc bezpośrednio zatrudnionymi przez to przedsiębiorstwo.

$\mathrm{Na}$ ostatnią kwestię zwrócono uwagę w judykaturze, przyjmując ostatecznie prounijną i maksymalnie szeroką interpretacją analizowanego przepisu i uznając, że okres pozostawania w dyspozycji pracodawcy użytkownika jest to czas, na jaki pracownik tymczasowy został skierowany do niego przez agencję pracy tymczasowej. Wynika on z umowy zawartej między agencją a pracownikiem tymczasowym i w kontekście prawa do urlopu wypoczynkowego obejmuje wszystkie dni kalendarzowe mieszczące się w zakresie trwania tej umowy, a nie tylko te, w których praca była faktycznie świadczona ${ }^{117}$. Sąd opowiedział się zatem za wliczaniem do miesięcznego okresu warunkującego powstanie prawa do urlopu wypoczynkowego w zatrudnieniu tymczasowym wszystkich okresów pozostawania w dyspozycji pracodawcy użytkownika, zarówno wtedy, gdy pracownik tymczasowy wykonuje pracę na jego rzecz, jaki i wtedy, gdy tej pracy nie wykonuje, np. z powodu zwolnienia lekarskiego ${ }^{118}$.

Podobne wyjaśnienie pojęcia pozostawania w dyspozycji pracodawcy użytkownika przedstawiło w swoim czasie Ministerstwo Pracy i Polityki Społecznej. W opinii tej zwrócono uwagę, że odwołanie się do omawianego terminu na etapie tworzenia ustawy miało za zadanie wyraźne wyeksponowanie powiązania uprawnień

uprawnień) oraz faktycznych (np. choroba czy inna usprawiedliwiona nieobecność). Por. tenże, Ustawa ..., s. 86. Por. też A. Daszczyńska, Prawo pracownika tymczasowego do odpoczynku, [w:] Z problematyki zatrudnienia tymczasowego, red. A. Sobczyk, Warszawa 2011, s. 204.

115 Por. wcześniejsze rozważania, również na gruncie k.p. nie wszystkie okresy nieświadczenia pracy pozostają bez wpływu na nabycie prawa i wymiar urlopu wypoczynkowego. W szczególności pracownik nie nabywa prawa do urlopu w okresie zawieszenia stosunku pracy lub jego faktycznego zakończenia (por. uwagi dotyczące porzucenia pracy), a nieusprawiedliwiona nieobecność obniża wymiar urlopu kolejnego.

116 Por. wyrok TSUE z 24 stycznia 2012 r. w sprawie Dominguez, C-282/10.

117 Wyrok Sądu Rejonowego dla miasta stołecznego w Warszawie z 29 czerwca 2015 r., VII P 1591/14, LEX nr 2135253.

118 Tamże. 
urlopowych pracownika tymczasowego z okresem skierowania go do pracodawcy użytkownika, celem wykonywania umówionej pracy na jego rzecz (który jest zarazem okresem pozostawania pracownika tymczasowego w jego dyspozycji), a nie łączenie nabycia prawa do urlopu z okresem faktycznego wykonywania takiej pracy. $\mathrm{W}$ związku z tym analizowany art. 17 ust. 1 ustawy powinien być rozumiany w ten sposób, że pracownik tymczasowy uzyskuje urlop wypoczynkowy w wymiarze dwóch dni za każdy miesiąc pozostawania w stosunku pracy (stosunkach pracy) nawiązanym w celu wykonywania pracy na rzecz pracodawcy użytkownika (pracodawców użytkowników). W ocenie Ministerstwa „nie ma przy tym znaczenia, czy w trakcie pozostawania w stosunku pracy pracownik chorował lub korzystał $\mathrm{z}$ innej usprawiedliwionej (bądź nieusprawiedliwionej) nieobecności w pracy"119.

Za szerszym rozumieniem omawianego terminu opowiadają się też niektórzy przedstawiciele doktryny prawa pracy, podkreślając konieczność dokonania prounijnej, tj. niedyskryminującej wykładni kontrowersyjnego unormowania. Prowadzi ona do wniosku, że pracownik tymczasowy nabywa prawo do urlopu wypoczynkowego z uwzględnieniem wszystkich tych okresów, w których zgodnie z przepisami kodeksowymi uzyskałby on uprawnienia urlopowe, przypadających między skierowaniem pracownika do pracy u danego pracodawcy użytkownika a zakończeniem umowy lub rezygnacją z jego pracy przez pracodawcę użytkownika ${ }^{120}$. W propozycji tej zakłada się zatem m.in. możliwość wyłączenia pewnych okresów nieświadczenia pracy, o których stanowi art. 155 (2) k.p., ze stażu warunkującego nabycie prawa do urlopu wypoczynkowego pracownika tymczasowego ${ }^{121}$, w tym np., nieco inaczej niż wynikało z oceny Ministerstwa, nieobecności nieusprawiedliwionej.

Przyjęcie odmiennego poglądu, negującego możliwość uwzględnienia w miesięcznym okresie wymaganym do nabycia prawa do urlopu wypoczynkowego pracownika tymczasowego okresów niewykonywania pracy z przyczyn faktycznych (np. choroba) i prawnych (utrata uprawnień koniecznych do wykonywania pracy), jak wcześniej sygnalizowano, stawia pod znakiem zapytania zgodność prawa polskiego ze standardami unijnymi w kwestii prawa do odpoczynku pracowników tymczasowych $^{122}$. Niemniej w literaturze bywa on również dość często formułowany ${ }^{123}$.

119 Por. stanowisko Ministerstwa Pracy i Polityki Społecznej z 25 listopada 2010 r. Zob. I. Struczyńska, Agencja zatrudnienia oraz praca tymczasowa w świetle wybranych stanowisk Ministerstwa Pracy i Polityki Społecznej, Gdańsk 2014, s. 12.

120 Por. tak M. Raczkowski, Ustawa o zatrudnianiu pracowników tymczasowych. Komentarz, Warszawa 2012.

121 Tamże.

122 Bywają w tym zakresie formułowane też inne opinie, a mianowicie, że podstawowym celem dyrektywy dotyczącej pracy tymczasowej jest zagwarantowanie elastyczności w zatrudnianiu i konstrukcja prawa do urlopu wypoczynkowego, którego pracownik nie nabywa w okresie niezdolności do pracy z powodu choroby, sprzyja jego realizacji poprzez zmniejszenie ryzyka socjalnego pracodawcy. Por. tak E. Defańska, Urlop wypoczynkowy dla zatrudnionych przez agencję pracy tymczasowej, www.rp.pl [dostęp 4.11.2011].

123 Por. m.in. A. Sobczyk, Ustawa..., s. 86. Zob. też: A. Daszczyńska, Prawo pracownika..., s. 204, E. Defańska, Urlop wypoczynkowy... 
Biorąc pod uwagę treść przepisów ustawy o zatrudnianiu pracowników tymczasowych wydaje się, że żadne z zaproponowanych rozwiązań nie jest w pełni satysfakcjonujące. Powyższe unormowanie, dające pole do tak rozbieżnych interpretacji, stwarza jednocześnie zagrożenie nadużyć, do jakich na tym tle może dochodzić w praktyce. W odniesieniu do poszczególnych pracowników tymczasowych, w zależności od przyjętej wykładni, te same przepisy mogą być bowiem różnie stosowane, ograniczając niekiedy ich prawo do odpoczynku rocznego. Dziwić może zatem, że ustawodawca, dokonując w 2017 r. zmian w przepisach o urlopach wypoczynkowych pracowników tymczasowych ${ }^{124}$, nie zdecydował się ostatecznie wyjaśnić omawianej kwestii.

Kontrowersje wywołuje też sposób liczenia stażu warunkującego powstanie omawianego prawa.

Przede wszystkim z punktu widzenia prowadzonych rozważań dość istotne jest, czy ów miesięczny okres należy odnosić do zatrudnienia w ramach jednej agencji czy też podlega on wliczeniu do stażu urlopowego w innych agencjach pracy tymczasowej, zwłaszcza jeśli pracownik zatrudniany jest kolejno przez różne agencje, lecz w żadnej z nich okres tego zatrudnienia nie jest dłuższy niż jeden miesiąc.

Rozstrzygnięcie tej kwestii ma bardzo duże znaczenie zarówno teoretyczne, jak i praktyczne. Przyjęcie bowiem stanowiska, że chodzi o sumę okresów pozostawania w dyspozycji pracodawców użytkowników (bez względu na ewentualne przerwy w pracy), ale w obrębie jednej tylko agencji, jak czyni to wielu przedstawicieli doktryny prawa pracy ${ }^{125}$, ogranicza w znacznym stopniu możliwość uzyskania prawa do odpoczynku rocznego przez takiego pracownika. W opisanym wcześniej przypadku, mimo stosunkowo długiego łącznego okresu pozostawania $\mathrm{w}$ zatrudnieniu tymczasowym $\mathrm{w}$ ramach różnych agencji, w zasadzie pracownik prawa do urlopu wypoczynkowego nie nabywa.

Niewątpliwie z perspektywy prawa pracownika do odpoczynku zaprezentowana wykładnia jest trudna do przyjęcia, zwłaszcza że, jak słusznie zauważa D. Makowski, powołana ustawa nie uzależnia wprost prawa pracownika do urlopu wypoczynkowego od jego zatrudnienia w obrębie danej agencji ${ }^{126}$. Wydaje się zatem, że ustawodawcy chodziło raczej o wprowadzenie odmiennych od powszechnych reguł nabycia prawa do urlopu w zatrudnieniu o charakterze tymczasowym, przejściowym, podejmowanym dorywczo, niezależnie od tego, czy jest ono realizowane na podstawie umowy (czy umów) zawartych z jedną agencją czy też z kilkoma. Tym bardziej, że w ustawie nie wprowadzono możliwości zaokrąglenia niepełnego miesiąca pracy w górę i udzielenia urlopu za tak ustalony okres pracy. W konsekwencji

124 Por. ustawa z 7 kwietnia 2017 r. o zmianie ustawy o zatrudnianiu pracowników tymczasowych oraz niektórych innych ustaw, Dz. U. 2017, poz. 962.

125 Por. tak m.in.: A. Sobczyk, Ustawa..., s. 84; J. Wiśniewski, Urlop na żądanie..., s. 30; A. Daszczyńska, Prawo pracownika..., s. 205; M. Frączek, M. Łajeczko, Praca tymczasowa, pytania i odpowiedzi, „Służba Pracownicza” 2004, nr 5, s. 4.

126 Por. D. Makowski, Praca tymczasowa jako nietypowa forma zatrudnienia, Warszawa 2006, S. 117. 
należałoby uznać, jak proponuje też D. Makowski, że stosując w sprawach nieunormowanych w ustawie rozwiązania kodeksowe, podstawą nabycia prawa i wymiaru urlopu pracownika tymczasowego jest okres jego łącznego stażu pracy w takim charakterze ${ }^{127}$. A zatem, w razie zakończenia współpracy z jedną agencją pracy tymczasowej przed upływem jednego miesiąca wynikający z niej okres pozostawania w dyspozycji pracodawcy użytkownika powinna uwzględnić inna agencja zatrudniająca pracownika w tym samym roku kalendarzowym, co będzie stanowić gwarancję urzeczywistnienia prawa tego pracownika do odpoczynku w omawianym zatrudnieniu, w stopniu adekwatnym do okresu jego trwania.

Zgodzić się trzeba natomiast, że ze względu na odmienność reguł warunkujących prawo do urlopu, wynikających z analizowanej ustawy, oraz specyfikę omawianej postaci nietypowego zatrudnienia do stażu warunkującego prawo i wymiar urlopu w zatrudnieniu tymczasowym nie podlega wliczeniu dotychczasowy staż urlopowy w ramach pracy nietymczasowej, nabyty na zasadach kodeksowych ${ }^{128}$. Ustawodawca wyraźnie w tym przypadku łączy bowiem prawo do urlopu wypoczynkowego takiego pracownika $\mathrm{z}$ upływem wymaganego czasu pozostawania w dyspozycji pracodawcy użytkownika lub kilku takich pracodawców. Nie chodzi tu zatem o prawo do pierwszego urlopu w życiu zawodowym danego pracownika (co oczywiście nie oznacza, że w praktyce owym pierwszym urlopem nie może być ten uzyskany w zatrudnieniu tymczasowym), ale ogólnie o urlop wypoczynkowy w tym konkretnym zatrudnieniu, uzyskiwany na odmiennych warunkach niż $\mathrm{w}$ przypadku osób niebędących pracownikami tymczasowymi. W związku z tym pracownik, który w „normalnym” zatrudnieniu korzystał już wielokrotnie $\mathrm{z}$ prawa do urlopu wypoczynkowego, $\mathrm{w}$ zatrudnieniu tymczasowym, niezależnie od ogólnego stażu pracy czy posiadanego wykształcenia, będzie uzyskiwać urlop na warunkach wcześniej omówionych.

Jednocześnie okres zatrudnienia tymczasowego musi zostać wzięty pod uwagę, zgodnie z przepisami k.p., w razie podjęcia pracy nietymczasowej w ramach stosunku pracy, jak była bowiem o tym wcześniej mowa, do stażu warunkującego nabycie prawa do urlopu wypoczynkowego wlicza się okresy poprzedniego zatrudnienia pracowniczego (bez względu na jego charakter), niezależnie od ewentualnych przerw w zatrudnieniu czy sposobu jego ustania. Z perspektywy prawa urlopowego okres pracy tymczasowej nie będzie zatem powodować żadnych negatywnych dla pracownika konsekwencji w przyszłości, w sytuacji podjęcia stałego zatrudnienia na podstawie stosunku pracy, co jest w pełni słusznym rozwiązaniem.

Podsumowując, należy zauważyć, że przyjęta powszechnie w polskim prawie konstrukcja nabycia prawa do urlopu wypoczynkowego w założeniu, pomijając wskazane wcześniej drobniejsze problemy szczegółowe, gwarantuje pracownikowi niezbędny roczny wypoczynek. Szczególne znaczenie w tym kontekście ma wynikająca z prawa urlopowego zasada pozwalająca pracownikowi zachować raz

127 Tamże.

128 Por. A. Sobczyk, Ustawa..., s. 84. 
nabyte prawo do urlopu wypoczynkowego, bez względu na przerwy w zatrudnieniu i sposób ustania stosunku pracy. Generalnie wyeliminowano też przypadki, w których dłuższym okresom pracy nie odpowiadały ekwiwalentne uprawnienia urlopowe.

Na tym tle gorzej natomiast wypada ocena rozwiązań zastosowanych w analizowanym obszarze w stosunku do szczególnych grup zawodowych, w tym przede wszystkim nauczycieli akademickich czy pracowników tymczasowych. Jak się wydaje, nie w każdym przypadku wprowadzone w ramach odpowiednich przepisów zasady nabycia prawa do urlopu, często mniej korzystne od warunków kodeksowych, dają się uzasadnić charakterem wykonywanych zadań. Nie zawsze też uwzględnia się wymogi prawa międzynarodowego i europejskiego, co było wcześniej w kilku miejscach wyraźnie sygnalizowane, a ponadto przyjęta regulacja jest bardzo niejasna, w wielu wypadkach daleka od wymogów poprawności legislacyjnej. Stanowi to pewne zagrożenie dla urzeczywistnienia prawa pracowników do wypoczynku, zwłaszcza w kontekście zasady równego ich traktowania. Choć można zgodzić się bowiem, że wypoczynek roczny niektórych pracowników, ze względu na szczególny rodzaj pracy czy jej nietypowy charakter, może być poddany określonym modyfikacjom, to jednak powinny być one wyraźnie, precyzyjnie określone, aby nie dawać podstaw do odmiennego stosowania przepisów, ale też nie mogą odbiegać nadmiernie od ogólnych standardów prawnych przyjętych w rozważanym zakresie.

\section{Wymiar urlopu wypoczynkowego}

Wymiar urlopu wypoczynkowego generalnie także wpisuje się w podstawowe funkcje tego świadczenia.

Warto zaznaczyć, że jego optymalne określenie jest równie ważne dla realizacji zasady prawa pracownika do odpoczynku, jak warunki, który muszą być spełnione, aby prawo do urlopu wypoczynkowego w ogóle powstało. Decyduje on bowiem wprost o ilości czasu, jaki w obrębie omawianej instytucji pracownik może spożytkować de facto na odpoczynek. Nie może zatem dziwić, że jego wzrastanie postrzegano w literaturze jako najbardziej czytelny przejaw rozwoju prawa urlopowego w Polsce i na świecie ${ }^{129}$.

Minimalny wymiar urlopu, należny każdemu pracownikowi, bez względu na rodzaj wykonywanej pracy, jej charakter, specyfikę, zajmowane stanowisko wynosi, zgodnie ze standardami unijnymi, cztery tygodnie. W związku z tym w Polsce pod wpływem właśnie unormowań zawartych w prezentowanej wcześniej dyrektywie dotyczącej niektórych aspektów organizacji czasu pracy, w tym

129 Por. m.in. A. Uklejska, Aktualne kierunki..., s. 24. 
traktującej o omawianych urlopach, pozostawiono dwie powszechnie stosowane długości urlopu wypoczynkowego, tj. urlop w wymiarze 20 i 26 dni. W powiązaniu z zasadą pięciodniowego tygodnia pracy i udzielania urlopu wyłącznie na dni, które są dla danej osoby dniami pracy, generalnie przyjęta w przepisach k.p. minimalna długość tego urlopu odpowiada wymogom zawartym w dyrektywie.

Określony na wskazanym poziomie najniższy wymiar urlopu wypoczynkowego nie doznaje $\mathrm{w}$ zasadzie ograniczeń na gruncie odrębnych regulacji ustawowych odnoszących się do wybranych grup pracowniczych; przeciwnie zwykle ulega on zwiększeniu, co będzie jeszcze szerzej analizowane. Warto zauważyć, że również na podstawie ustawy regulującej status pracowników tymczasowych, przyznającej to uprawnienie na szczególnych warunkach, wymiar ten jest w ujęciu rocznym wyższy od minimum kodeksowego, wynosi on bowiem zawsze łącznie 24 dni (dwa dni za każdy miesiąc pozostawania w dyspozycji pracodawcy użytkownika). Jest to jednocześnie wymiar stały, nie ulega on zwiększeniu wraz ze wzrostem np. stażu pracy, choćby w zakresie pracy tymczasowej.

Wyjątkiem pod tym względem, który musi być krytycznie oceniany, jest urlop przyznany osobom skazanym, wykonującym pracę na podstawie umowy o pracę, które, zgodnie z art. $124 \$ 2$ Kodeksu karnego wykonawczego ${ }^{130}$, uzyskują prawo do urlopu wypoczynkowego jedynie w wymiarze 18 dni roboczych. Regulacja ta nie realizuje w odpowiedni sposób prawa pracownika do wypoczynku nie tylko w kontekście standardów europejskich, jeśli chodzi o minimalną jego długość, ale też z punktu widzenia kryteriów stanowiących podstawę dyferencjacji jego wymiaru, która w tym przypadku (chodzi o status osoby skazanej) nie pozostaje w bezpośrednim związku z funkcją urlopu i, jak słusznie zauważono w literaturze przedmiotu, jest nieuzasadniona ${ }^{131}$.

Wymiar urlopu minimalnego ma być okresem zwolnienia od obowiązku wykonywania pracy należnym każdemu pracownikowi, bez względu na potencjalny wysiłek z nią związany i wszelkie inne czynniki. Jest to zarazem taka ilość dni wolnych, która może już, z fizjologicznego punktu widzenia, umożliwić realizację podstawowego celu omawianej instytucji.

Poza urlopem w wymiarze minimalnym zwykle liczba przysługujących pracownikowi dni urlopowych wzrasta wraz z wystąpieniem pewnych dodatkowych kryteriów. Prawnie ustalone determinanty długości urlopu wypoczynkowego wskazują bezpośrednio na funkcje, jakie ustawodawca przypisuje temu świadczeniu; mogą one zatem bardziej lub mniej przyczyniać się do realizacji jego głównego celu, jakim jest odpoczynek i związana z nim regeneracja sił. Zwiększenie wymiaru urlopu wypoczynkowego zgodnie z jego przeznaczeniem powinno być niewątpliwie dokonywane na podstawie okoliczności, które wpływają na nasilenie zmęczenia pracownika; do takich w literaturze przedmiotu zaliczono np. rodzaj i warunki wykonywanej pracy, wiek pracownika, stan jego zdrowia, ogólny staż pracy, a na-

130 Ustawa z 6 czerwca 1997 r. - Kodeks karny wykonawczy, tekst jednolity: Dz. U. 2017, poz. 665, ze zm.

131 Tak por. A. Kosut, [w:] Kodeks pracy..., s. 864. 
wet sytuację rodzinną ${ }^{132}$. W przeszłości bywało jednak, że wymiar ten uzależniano od przesłanek, które nie znajdowały bezpośredniego przełożenia na prawidłową realizację funkcji głównej urlopu, choćby, jak to miało miejsce w polskim prawie, od sposobu zakończenia poprzedniego stosunku pracy czy zachowania pewnej ciągłości pracy. Wówczas urlop, niejako obok swego zasadniczego celu, realizował również inne, przyjęte przez ustawodawcę założenia (dyscyplinowanie pracownika czy utrzymanie stałego zatrudnienia), niepowiązane w żaden sposób z wypoczynkiem, a czasami wręcz, jak w przypadkach przykładowo wymienionych, z podstawowym przeznaczeniem urlopu pozostające w pewnej kolizji. Jak słusznie bowiem zauważono $\mathrm{w}$ piśmiennictwie $\mathrm{z}$ omawianego zakresu, obniżanie wymiaru urlopu w związku np. ze zmianą miejsca pracy powoduje, że nie uwzględnia się dotychczasowego stażu pracy pracownika, a zatem również rozmiaru jego zmęczenia $^{133}$.

Najczęściej stosowanym kryterium determinującym wymiar urlopu pracownika jest kryterium stażu pracy, wykorzystane też jako podstawowe na gruncie przepisów kodeksowych. Trzeba przy tym zaznaczyć, że staż ten jest ustalany analogicznie jak w przypadku nabycia prawa do urlopu, w związku z tym wszystkie wcześniejsze uwagi znajdują tutaj swoje zastosowanie. Chodzi zatem o wszystkie okresy poprzedniego zatrudnienia, bez względu na przerwy w zatrudnieniu czy sposób ustania stosunku pracy, a ponadto o długości tego stażu decyduje, co do zasady, sam fakt pozostawania w stosunku pracy, a nie faktycznego świadczenia pracy na jego podstawie. Okres wykorzystywania zwolnienia lekarskiego z powodu niezdolności do pracy wywołanej chorobą czy np. sprawowania opieki nad chorym dzieckiem nie będzie wpływać na zmniejszenie ilości należnego pracownikowi urlopu (choć wymiar ten w niektórych okolicznościach prawnie określonych może ulec pewnej redukcji, o czym w dalszej części opracowania). Taka konstrukcja, przy jednoczesnym obowiązku zaliczenia pewnych okresów szczególnych, o których dalej będzie mowa, znacznie ułatwia uzyskanie stażu urlopowego, a zarazem nabycie prawa do urlopu w wyższym wymiarze ${ }^{134}$.

Również podjęcie po pewnym czasie dodatkowego zatrudnienia nie powoduje, w świetle obowiązujących przepisów, różnic w wymiarze należnego pracownikowi u drugiego pracodawcy urlopu. Zgodnie bowiem z przyjętą przez ustawodawcę regułą, wcześniej już wspomnianą, w przypadku jednoczesnego pozostawania w dwóch lub więcej stosunkach pracy do okresu pracy, od którego zależy wymiar

132 Por. A. Uklejska, Aktualne kierunki..., s. 28. Były one wymieniane również w dokumentach MOP. Por. L. Florek, Staż..., s. 160. Współcześnie do podobnych kryteriów odwołuje się m.in. A. Sobczyk. Por. tenże, Prawo pracy..., s. 206 i n. Ostatnie z wymienionych kryteriów jest w jakimś stopniu brane pod uwagę we Francji, gdzie każda kobieta korzysta z dwóch dni dodatkowego urlopu na dziecko do 15 roku życia, które pozostaje pod jej opieką. Jeśli matka ma mniej niż 21 lat, to zwiększenie urlopu może prowadzić do przekroczenia 30 dni urlopu. Por. G. Auzero, E. Dockès, Droit..., s. 870.

133 A. Uklejska, Aktualne kierunki..., s. 30.

134 Por. L. Florek, Staż..., s. 161. 
urlopu, wliczyć należy także okres niezakończonego zatrudnienia w części przypadającej przed nawiązaniem drugiego lub kolejnego stosunku pracy. Jest to bardzo istotna zmiana $\mathrm{w}$ stosunku do wcześniejszego stanu prawnego $\mathrm{w}$ omawianym zakresie, przyczyniająca się do zagwarantowania prawidłowego przebiegu podstawowej funkcji urlopu wypoczynkowego. Pracownik w zatrudnieniu dodatkowym uzyskuje bowiem generalnie urlop w takim samym wymiarze, jaki przysługuje $\mathrm{mu} \mathrm{w}$ zatrudnieniu podstawowym (zredukowany ewentualnie $\mathrm{w}$ roku nawiązania kolejnego stosunku pracy proporcjonalnie do okresu zatrudnienia, zgodnie $\mathrm{z}$ art. $155^{1}$ k.p.). Umożliwia to pełną realizację prawa do odpoczynku od pracy wykonywanej równolegle u dwóch lub większej liczby pracodawców.

Uwzględnienie ogólnego stażu pracy jako czynnika decydującego o wymiarze urlopu wypoczynkowego pracownika zawiera $\mathrm{w}$ sobie również pośrednio kryterium jego wieku; w typowym układzie rośnie on bowiem wraz $\mathrm{z}$ nim. Z punktu widzenia wypoczynkowej funkcji omawianej instytucji znajduje to swoje uzasadnienie i służy niewątpliwie jej wzmocnieniu. U osób starszych i ogólnie dłużej pracujących może bowiem wzrastać potrzeba dłuższego wypoczynku i większej ilości czasu niezbędnego do regeneracji sił utraconych $\mathrm{w}$ związku z pracą, szczególnie wieloletnią.

$\mathrm{Z}$ drugiej jednak strony, bardzo młody wiek, kiedy organizm jest jeszcze w określonej fazie rozwoju stanowi równie ważną przesłankę determinującą dłuższy wypoczynek, co poniekąd wyjaśnia wyższy wymiar urlopu wypoczynkowego w pierwszym roku pracy pracowników młodocianych, mają oni bowiem prawo łącznie do 38 dni urlopu.

Dodatkowo jednak na wymiar urlopu istotny wpływ mają również okresy nauki, a także inne okresy, tzw. zaliczane, traktowane na równi z okresami pracy $\mathrm{w}$ ramach stosunku pracy.

Wliczanie okresów nauki do stażu urlopowego odbywa się na warunkach określonych $\mathrm{w}$ art. 155 k.p. Z przepisu tego wynika, że muszą być to okresy nauki ukończonej, a zatem poświadczonej świadectwem lub dyplomem ${ }^{135}$. Liczba lat, jaką uwzględnia się z tego tytułu w stażu urlopowym jest różna, w zależności od rodzaju ukończonej szkoły i związanego z nią planowego okresu trwania nauki (chociaż ustawodawca w niektórych wypadkach wskazuje na maksymalną liczbę lat, jaka podlega wliczeniu ${ }^{136}$ ), przy tym zawsze chodzi o ten okres nauki, który jest bardziej korzystny dla pracownika (okresy nauki w poszczególnych szkołach

135 W przypadku szkoły średniej wystarczy samo jej ukończenie potwierdzone świadectwem (nie ma tu konieczności zdania matury). Inaczej sytuacja wygląda w odniesieniu do studiów wyższych, w ramach których dyplom ich ukończenia uzyskuje się dopiero po zdaniu stosownego egzaminu kończącego (magisterskiego, licencjackiego itd.), nie wystarczy więc samo uzyskanie absolutorium, co znalazło ostatecznie swoje potwierdzenie w wyroku Wojewódzkiego Sądu Administracyjnego w Warszawie z 14 kwietnia 2008 r., II SA/Wa 100/08, LEX nr 506463.

136 Dotyczy to zasadniczej lub równorzędnej szkoły zawodowej - wlicza się przewidziany programem nauczania czas trwania nauki, ale nie więcej niż trzy lata i średniej szkoły zawodowej - nie więcej niż pięć lat. 
nie sumują się). Nie ma też znaczenia z omawianego punktu widzenia, czy dana osoba ukończyła szkołę publiczną czy prywatną oraz w jakim systemie nauka była pobierana - stacjonarnym, wieczorowym czy zaocznym ${ }^{137}$.

Wprowadzenie tego rodzaju czynnika przyczyniającego się do zwiększenia wymiaru urlopu pracowniczego służy z pewnością z jednej strony promowaniu zdobywania wykształcenia, o czym wspomina się w literaturze przedmiotu ${ }^{138}$, ale z drugiej strony, również, jak się wydaje, ma zrekompensować zmęczenie związane z nauką i czas na to poświęcony, będący zarazem szeroko rozumianym przygotowaniem do przyszłej pracy zawodowej (stąd okres ten bierze się pod uwagę tylko przy ustalaniu wymiaru urlopu wypoczynkowego a nie nabycia do niego prawa i w pewnym uproszczeniu - uwzględnia on jej długość). W tym ostatnim sensie można zatem znaleźć jego powiązanie z wypoczynkową funkcją urlopu, stanowiącego przedmiot rozważań.

Jeśli jednak wliczenie omawianych okresów do stażu decydującego o wymiarze urlopu wypoczynkowego ma oddawać w jakiś sposób wysiłek związany z uzyskaniem danego poziomu, rodzaju wykształcenia to wątpliwości może budzić kwestia dotycząca studiów wyższych. Zgodnie z regulacją kodeksową pracownikowi, który ukończył szkołę wyższą wlicza się do okresu pracy, od którego zależy wymiar urlopu, osiem lat. Studiami wyższymi są obecnie, na mocy odrębnych przepisów, zarówno studia pierwszego stopnia, studia drugiego stopnia, jak i jednolite studia magisterskie. Te pierwsze trwają zaledwie trzy lata (licencjat), a ostatnie pięć czy nawet sześć lat (medycyna). Zarówno jedna, jak i druga osoba, nawiązując stosunek pracy po ich ukończeniu, będzie miała jednak ośmioletni okres podlegający zaliczeniu przy ustalaniu wymiaru urlopu wypoczynkowego. Tym samym, o ile we wszystkich wcześniej wymienionych w art. 155 k.p. typach szkół okres uwzględniany w stażu urlopowym jest powiązany z liczbą lat trwania nauki w danej szkole, o tyle w tym ostatnim przypadku dochodzi do pewnego dysonansu w zakresie czasu niezbędnego do uzyskania danego tytułu i ukończenia określonego typu studiów a wskazanym wyżej okresem zaliczanym (bardziej adekwatną byłaby tu liczba siedmiu lat).

Należy też zwrócić uwagę, że wspominany wyżej okres ośmiu lat jest maksymalnym, jaki podlega wliczeniu do stażu decydującego o wymiarze urlopu wypoczynkowego w związku z ukończeniem nauki na mocy przepisów k.p. Niemniej dalsze jej trwanie ze względu na podjęcie studiów doktoranckich może także wpłynąć pozytywnie na szybsze zwiększenie tego wymiaru. Zgodnie z art. 198 ust. 3 ustawy o szkolnictwie wyższym doktorantowi, po uzyskaniu stopnia doktora, okres odbywania studiów doktoranckich, nie dłuższy niż cztery lata, wlicza się bowiem do okresu pracy, od którego zależą uprawnienia pracownicze, w tym także ilość dni należnego pracownikowi urlopu wypoczynkowego. Zasada ta, jak należy przyjąć,

137 Por. szerzej: E. Staszewska, [w:] M. Kuba, M. Nowak, E. Staszewska, Urlopy pracownicze..., s. 49.

138 Tak por. A. Sobczyk, Prawo pracy..., s. 206. Podobnie: P. Walorska, Staż..., s. 173. 
znajduje zastosowanie $\mathrm{w}$ każdym stosunku pracy, tj. również tym nawiązanym poza uczelnią wyższą. Rozwiązanie to wydaje się w pełni zrozumiałe, zwłaszcza że często są to studia powiązane $\mathrm{z}$ wykonywaniem określonych czynności zawodowych, np. prowadzeniem zajęć dydaktycznych ${ }^{139}$. Sposób sformułowania tego przepisu skłania do przyjęcia wniosku, że w tym konkretnym przypadku okres ten będzie nie tylko determinował wymiar urlopu wypoczynkowego, ale również samo nabycie prawa do niego (z mocy ustawy chodzi bowiem o wliczenie tego czasu do stażu warunkującego wszystkie uprawnienia pracownicze od niego zależne, a nie tylko te dotyczące wymiaru urlopu wypoczynkowego).

Poza okresami nauki do stażu wpływającego na wymiar urlopu wypoczynkowego wlicza się również wiele okresów szczególnych, których lista jest znacznie dłuższa niż w przypadku okresów warunkujących nabycie prawa do urlopu. Przesłanki uzasadniające ich uwzględnienie w stażu urlopowym decydującym o wymiarze urlopu wypoczynkowego są bardzo różnorodne (tak jak różnorodne są same okresy) i często trudno wskazać na ich jednoznaczne powiązanie z podstawową funkcją omawianej instytucji.

Dokonując próby pogrupowania tych okresów, można wyróżnić:

- okresy związane ze skróceniem okresu wypowiedzenia umowy o pracę przez pracodawcę lub bezprawnym rozwiązaniem przez niego stosunku pracy ${ }^{140}$. Ta regulacja wpisuje się w jakimś sensie w konstrukcję stażu warunkującego wymiar urlopu wypoczynkowego przyjętą na gruncie kodeksu pracy, w której urlop przysługuje, co do zasady, nie tylko w okresach aktywnej pracy, ale ogólnie w czasie trwania stosunku pracy. Stąd jeśli ten stosunek zakończono wcześniej w sposób niezgodny z prawem czy skrócono okres wypowiedzenia z przyczyn leżących po stronie pracodawcy - negatywne konsekwencje w zakresie urlopu nie mogą obciążać pracownika.

Niemniej, zarówno w doktrynie prawa pracy, jak też w orzecznictwie sądowym przyjmuje się jednocześnie, że skoro w okresie tym pracownik nie pozostaje faktycznie w stosunku pracy - to nie nabywa za ten czas prawa do urlopu wypoczynkowego, bo to prawo można uzyskać tylko w czasie trwania zatrudnienia ${ }^{141}$.

139 Zgodnie z art. 197 ust. 3 i 4 ustawy o szkolnictwie wyższym uczestnicy studiów doktoranckich mają obowiązek odbywania praktyk zawodowych w formie prowadzenia zajęć dydaktycznych lub uczestniczenia w ich prowadzeniu w wymiarze maksymalnie 90 godzin rocznie, pod groźbą skreślenia z listy uczestników takich studiów.

140 Chodzi o okres, za który przyznano odszkodowanie w związku ze skróceniem okresu wypowiedzenia umowy o pracę zawartej na czas nieokreślony lub na czas określony z powodu ogłoszenia upadłości lub likwidacji pracodawcy albo z innych przyczyn niedotyczących pracowników (art. $36^{1}$ k.p.), okres pozostawania bez pracy, za który pracownikowi przywróconemu do pracy w związku z niezgodnym z prawem lub nieuzasadnionym wypowiedzeniem przyznano wynagrodzenie oraz okres, za który przyznano pracownikowi z tego tytułu odszkodowanie, okres niewykonywania pracy, za który pracownikowi przywróconemu do pracy z powodu niezgodnego z prawem rozwiązania niezwłocznego przyznano wynagrodzenie za pracę, a także okres, za który z tego tytułu uzyskał odszkodowanie.

141 Por. Z. Góral, [w:] Kodeks pracy..., s. 268 i n. 
Uwagi powyższe należy również odnieść do okresu, o którym mowa w art. 177 $\$ 4$ k.p., tj. okresu pobierania przez kobietę w ciąży lub pracownika (matkę lub ojca dziecka) w okresie urlopu macierzyńskiego świadczeń z ubezpieczenia społecznego $\mathrm{w}$ związku z rozwiązaniem przez pracodawcę umowy o pracę za wypowiedzeniem z powodu jego likwidacji lub ogłoszenia upadłości i braku możliwości zapewnienia w tym okresie innego zatrudnienia.

- okresy powiązane z jakąś formą aktywności zawodowej realizowaną poza stosunkiem pracy - w szczególności wymienić tu można zaliczane na zasadach wskazanych w odrębnych przepisach, przy okazji omawiania problematyki nabycia prawa do urlopu już częściowo powoływane, okresy pełnienia czynnej służby wojskowej, zawodowej służby wojskowej, okresy służby w Policji, ABW, CBA, Agencji Wywiadu, SKW i innych wcześniej wymienianych służbach mundurowych, ale też okres wykonywania pracy nakładczej ${ }^{142}$, okres prowadzenia indywidualnego gospodarstwa rolnego w przypadkach wskazanych w odrębnej ustawie z 20 lipca 1990 r. $^{143}$, udokumentowane okresy zatrudnienia, przebyte za granicą u pracodawcy zagranicznego ${ }^{144}$, okresy wykonywania przez skazanego odpłatnego zatrudnienia - z wyłączeniem tego realizowanego na podstawie umów cywilnoprawnych ${ }^{145}$, czy nawet okresy pobierania stypendiów sportowych ${ }^{146}$. Połączenie tej grupy przypadków i ich wpływu na długość urlopu (a niekiedy również na nabycie do niego prawa) z prawem do odpoczynku wydaje się najsilniejsze. Jest to bowiem czas, w którym dana osoba nie pozostawała co prawda w stosunku pracy, ale wydatkowała siły w związku z wykonywaną pracą, działalnością w stopniu nie mniejszym niż odbywa się to w zatrudnieniu pracowniczym. Stąd nie ma powodu, by cały ten okres, zwł. biorąc pod uwagę podstawową funkcję urlopu, traktować po zawarciu umowy o pracę jak by go w ogóle nie było. Zasadniczo bowiem każda forma pracy, w szczególności wykonywanej w celach zarobkowych, zawodowo powinna być powiązana z odpoczynkiem, bez względu na podstawę prawną, na jakiej się to odbywa. Jeśli podstawą ustalania wymiaru urlopu jest ogólny staż pracy, to ustawodawca chciał w ten sposób wzmocnić funkcję wypoczynkową omawianej instytucji, a nie sprowadzić ją do pewnej formy odpłaty za czas poświęcony na pracę u konkretnego pracodawcy. A zatem powyższa regulacja wymienionych okresów zakładająca ich wliczenie do omawianego stażu w jakiejś mierze się w tę filozofię wpisuje - długoletnia praca przyczynia się zawsze do większego wyczerpania

142 Dotyczy to nakładcy, który uzyskiwał wynagrodzenie w wysokości co najmniej 50\% minimalnego wynagrodzenia w tym okresie - por. § 32 ust. 2 rozporządzenia z 31 grudnia 1975 r. w sprawie uprawnień pracowniczych osób wykonujących pracę nakładczą, Dz. U. 1976, Nr 3, poz. 19, ze zm.

143 Ustawa z 20 lipca 1990 r. o wliczaniu okresów pracy w indywidualnym gospodarstwie rolnym do pracowniczego stażu pracy, Dz. U. Nr 54, poz. 310.

144 Art. 86 ustawy o promocji zatrudnienia i instytucjach rynku pracy, tekst jednolity: Dz. U. 2016, poz. 645.

145 Art. 128 ustawy z 6 czerwca 1997 r. - Kodeks karny wykonawczy, tamże.

146 Por. art. 33 ustawy o sporcie z 25 czerwca 2010 r., tekst jednolity: Dz. U. 2016, poz. 176. 
organizmu ludzkiego, co uzasadnia z kolei potrzebę dłuższego wypoczynku. Można się natomiast zastanawiać, czy zgodnie z powyższą ideą - zakres owego włączenia pracy świadczonej w innych reżimach niż pracowniczy nie powinien być szerszy. W tej chwili bowiem do stażu, od którego zależy wymiar urlopu wypoczynku nie podlegają wliczeniu okresy pracy na podstawie umów prawa cywilnego (poza wymienioną pracą nakładczą), bez względu na warunki, w jakich się ona odbywa. Skoro jednak długość odpoczynku rocznego oderwana jest od pracy na rzecz jednego tylko podmiotu, rozważać można również uwzględnienie w nim okresów prowadzenia działalności na własny rachunek, choćby w jakimś ograniczonym rozmiarze.

- okresy, w których pracownik korzysta z określonych, bezpłatnych zwolnień od pracy w związku z wykonywaniem pracy u innego podmiotu, realizacją obowiązków innych niż zawodowe czy dopełnieniem prawa do odpoczynku - chodzi tu m.in. o okres urlopu bezpłatnego udzielonego młodocianemu będącemu uczniem szkoły dla pracujących w okresie ferii szkolnych, okres urlopu bezpłatnego udzielonego pracownikowi w celu wykonywania pracy u innego pracodawcy, na podstawie porozumienia między pracodawcami i za zgodą pracownika, okres szczególnego urlopu bezpłatnego - urlopu wychowawczego, wliczany do stażu pracowniczego w dniu jego zakończenia.

W każdym z wymienionych przypadków można wskazać na potrzebę wpływu wskazanych okresów na rozmiar należnego wypoczynku, choć będzie on w odniesieniu do konkretnych okoliczności podyktowany innymi względami. W przypadku pracownika młodocianego chodzi przede wszystkim o szczególną ochronę jego życia i zdrowia i związaną z nią koniczność stworzenia warunków do dłuższego wypoczynku. Zastosowane instrumenty nie mogą się z kolei negatywnie odbijać na uprawnieniach przysługujących następnie pracownikowi w zakresie tego odpoczynku.

Również druga sytuacja wydaje się oczywista. Pracownik „przekazywany” przez jeden podmiot drugiemu na podstawie zawartego między nimi porozumienia nadal świadczy pracę, stąd udzielony mu urlop bezpłatny celowy nie może być wyłączony ze stażu pracowniczego.

Mniej bezpośrednie powiązanie z podstawową funkcją urlopu wypoczynkowego występuje być może w odniesieniu do urlopu wychowawczego. Jest to bowiem czas, kiedy stosunek pracy ulega swego rodzaju zawieszeniu, pracownik pracy nie świadczy, niemniej z pewnością też w sensie ogólnym nie odpoczywa, zajmuje się bowiem wypełnianiem, istotnych ze społecznego punktu widzenia, zadań rodzicielskich powodujących także pewne zmęczenie. Sytuacja rodzinna zaś, jak wcześniej wspominano, stanowi powszechnie uzasadnione kryterium dyferencjacji uprawnień urlopowych pracownika.

- okresy pobierania pewnych świadczeń wynikających z ustawy o promocji zatrudnienia i instytucjach rynku pracy, np. zasiłków dla bezrobotnych i stypendiów związanych ze szkoleniem, stażem dla bezrobotnych oraz przygotowaniem zawodowym dorosłych, świadczeń socjalnych przysługujących na urlopie górniczym, 
górniczych zasiłków socjalnych itp. I w tych przypadkach trudno wskazać na jakąś ścisłą zależność wymienionych okresów z potrzebą odpoczynku oraz jeden podstawowy motyw ich uwzględnienia w stażu determinującym przede wszystkim jego długośćc ${ }^{147}$. Generalnie uzasadnieniem dla zaliczenia wyszczególnionych okresów do stażu pracy w sytuacji nieświadczenia pracy, ale pobierania określonych świadczeń z Funduszu Pracy jest, zdaniem Z. Górala, upatrywanie w tych świadczeniach swego rodzaju substytutu wynagrodzenia za pracę, które nie może być osiągane z powodów niezależnych od poszukującego zatrudnienia ${ }^{148}$. W kontekście urlopu wypoczynkowego być może czas ten należy jednak postrzegać bardziej jako rekompensatę za wysiłek włożony przez pracownika w proces poszukiwania nowego zatrudnienia, a w szczególności działania podjęte w celu jak najszybszego jego uzyskania, takie jak odbycie stażu, szkolenia czy przygotowania zawodowego, które w istocie stanowią jakąś formę aktywności zawodowej. To właśnie w tych ostatnich wymienionych przypadkach, z oczywistych względów, powiązanie ich ze stażem urlopowym staje się bardziej czytelne. Bywa nawet prezentowane stanowisko, że bezrobotny pobierający z tego tytułu określone świadczenia jest w istocie „pracownikiem, którego zajęcie na pełnym etacie polega na szukaniu pracy” ${ }^{149}$.

Na podstawie powyższego można uznać, że przyjęte powszechnie kryteria ustalania wymiaru urlopu wypoczynkowego generalnie również wpisują się w podstawowe funkcje tego świadczenia.

Jest on bowiem przede wszystkim zróżnicowany w zależności od, co do zasady, okresu pozostawania w stosunku pracy, a w pewnym zakresie też rodzaju ukończonej szkoły (uwzględnia się zatem wysiłek związany z procesem nauki ${ }^{150}$ ). Ujmując to w pewnym uproszczeniu, można stwierdzić, że ustawodawca przyjął założenie, że im dłuższy staż pracy, narastające zmęczenie (również pośrednio związane z wiekiem), tym dłuższy okres przysługującego pracownikowi odpoczynku.

W związku z powyższym należy jednak zastanowić się, czy progi te nie powinny być bardziej zróżnicowane i czy rzeczywiście tylko okres pozostawania w stosunku pracy powinien warunkować wymiar tego świadczenia. Generalnie ustawodawca w zakresie prawa urlopowego pomija bowiem kwestię szkodliwości i uciążliwości pracy, która może przecież powodować, że zużycie sił osoby wykonującej taką pracę będzie szczególnie trudne do wyrównania. Nie ma ona jednak zasadniczo,

147 Zarówno okresu pobierania zasiłków dla bezrobotnych, jak i stypendiów, o których wyżej mowa czy świadczeń górniczych nie uwzględnia się bowiem przy ustalaniu prawa do urlopu wypoczynkowego. Por. art. 79 ust. 2 pkt 2 ustawy o promocji zatrudnienia i instytucjach rynku pracy.

148 Por. Z. Góral, [w:] Ustawa o promocji zatrudnienia i instytucjach rynku pracy. Praktyczny komentarz, red. Z. Góral, Warszawa 2011, s. 495.

149 Por. na ten temat A. Supiot, Les inegalites entre sans-emploi, [w:] Les sans-emploi et la loi, Nantes 1987, s. 198.

150 Nie do końca zgadzam się w związku z tym z oceną sformułowaną przez A. Sobczyka, który uznał, że uwzględnianie okresu studiów przy ustalaniu wymiaru urlopu jest wyłącznie elementem promocji podnoszenia wykształcania, co w dobie jego powszechności czyni omawianą regulację co najmniej wątpliwą. Por. A. Sobczyk, Prawo pracy..., s. 206. 
na gruncie prawa powszechnego, bezpośredniego przełożenia na wymiar przysługującego pracownikowi urlopu ${ }^{151}$, co trzeba ocenić, z punktu widzenia jego głównej funkcji, jako pewien mankament obowiązującej regulacji. Mogą tu ewentualnie wchodzić w grę jedynie swoiste źródła prawa pracy czy umowa o pracę, w których nie ma przeszkód, aby korzystniej ukształtować poziom uprawnień urlopowych pracownika, w tym przyznać osobom zatrudnionym na stanowiskach, na których wykonywana praca jest szkodliwa czy uciążliwa dla zdrowia, związana ze szczególnym ryzykiem, odpowiedzialnością, wysiłkiem, określonymi dolegliwościami (np. porą jej świadczenia) wyższy wymiar urlopu wypoczynkowego. Znalazło to zresztą potwierdzenie w orzecznictwie sądowym, m.in. w wyroku Sądu Apelacyjnego w Katowicach z 2 grudnia 2008 r., w którym przyjęto, że regulacja zawarta w art. $154 \S 1$ k.p. określa jedynie minimalny wymiar urlopu wypoczynkowego pracownika, który może być odmiennie, tzn. korzystniej ukształtowany w układzie zbiorowym pracy czy w treści umowy, biorąc pod uwagę specyficzne warunki panujące na danym stanowisku pracy lub właściwe dla danego zawodu, jednocześnie, co słusznie podkreślił sąd, nie pozbawiając tego dodatkowego urlopu cech urlopu wypoczynkowego, którego celem jest przede wszystkim wypoczynek oraz regeneracja sił konkretnego pracownika ${ }^{152}$.

W literaturze przedmiotu wymienia się również inne jeszcze kryteria, które wpływając na spotęgowanie zmęczenia pracownika, wiążą się ściśle z podstawowym celem analizowanej instytucji i, zdaniem niektórych, powinny znaleźć w pierwszej kolejności odzwierciedlenie jako czynniki determinujące zróżnicowanie wymiaru urlopu także w polskim prawie ${ }^{153}$. Zaliczyć można do nich m.in. okoliczności o charakterze podmiotowym, takie jak wiek pracownika, stan jego zdrowia czy sytuację rodzinną ${ }^{154}$. Zarówno wiek (zwłaszcza zaawansowany), jak i stan zdrowia pracownika mogą z jednej strony uzasadniać potrzebę dłuższego wypoczynku z racji potencjalnie wolniej przebiegającego procesu regeneracji sił. $\mathrm{Z}$ drugiej jednak strony, moim zdaniem, nie można zupełnie abstrahować od wymienionego wcześniej kryterium stażu pracy, które, w porównaniu z wiekiem, wydaje się jednak bardziej zobiektywizowane w kontekście długości należnego pracownikom wypoczynku ${ }^{155}$. Proces starzenia się organizmu przebiega w sposób zróżnicowany u poszczególnych osób, ale przede wszystkim trzeba mieć na uwadze, że różny może być moment podjęcia pracy w ramach stosunku pracy przez osoby w określonym wieku. Trudno byłoby, w mojej ocenie, uznać za w pełni usprawiedliwiony dłuższy urlop dla osoby bardziej wiekowo zaawansowanej, która

151 Wcześniej zwrócił na to uwagę A. Sobczyk, które uznaje uciążliwość pracy za jeden z istotniejszych parametrów, od którego powinna być zależna długość urlopu. Por. tenże, Prawo pracy..., s. 206 in.

152 Por. wyrok SA w Katowicach z 2 grudnia 2008 r., III AUa 449/08, www.sip.lex.pl.

153 Por. A. Sobczyk, Prawo pracy..., s. 206 i n. Autor wprost postuluje zmianę kryteriów ustalania wymiaru urlopu wypoczynkowego, wskazując m.in. bezpośrednio na wiek, uciążliwość pracy oraz sytuację rodzinną pracownika jako właściwe determinanty długości tego urlopu.

154 Por. m.in. A. Uklejska, Aktualne kierunki..., s. 28.

155 Odmiennie A. Sobczyk, Prawo pracy..., s. 206. 
dopiero podejmuje zatrudnienie, niż wieloletniego pracownika, choćby młodszego wiekiem. Za właściwszą uznaję zatem propozycję pewnej korelacji tych czynników (np. po osiągnięciu określonego, maksymalnego wymiaru urlopu na podstawie stażu pracy, pracownik, który ukończył określoną liczbę lat nabywałby urlop w wyższym jeszcze wymiarze).

Bywa jednak, że urlop jest określony w przepisach odrębnych w jednolitym, stałym wymiarze, ale zwykle wyższym od kodeksowego ${ }^{156}$. Znajduje to swoje uzasadnienie w odniesieniu do nauczycieli czy nauczycieli akademickich, w przypadku których urlop ten jest bezpośrednio powiązany $z$ okresem przerwy w zajęciach dydaktycznych, ale jego zwiększenie, jak podkreślano już w przeszłości w doktrynie prawa pracy, wynika też w dużej mierze ze szczególnego rodzaju zmęczenia, powodującego dłuższą regenerację sił zużytych w tej pracy ${ }^{157}$.

Większe wątpliwości dotyczą natomiast pracowników tymczasowych, których wymiar urlopu jest stały, zarówno w ujęciu miesięcznym jak i rocznym, a zatem nie powiązany ani z okresem aktywności zawodowej ani wykształceniem czy innymi możliwymi miernikami. W jakimś sensie można jednak taką regulację tłumaczyć; mamy tu bowiem w istocie do czynienia z zatrudnieniem w założeniu czasowym, przejściowym, w którym, jak się wydaje, nie zakłada się potrzeby gromadzenia stażu w zakresie uprawnień urlopowych.

Na gruncie powszechnego prawa pracy zwiększanie wymiaru urlopu wypoczynkowego określonym grupom pracowniczym dokonywane jest również poprzez przyznanie prawa do urlopu dodatkowego, co jednak sprawia niekiedy wrażenie dość przypadkowego. Warto zauważyć, że jedynie wybranym, do tego nielicznym, kategoriom pracowników gwarantuje się na poziomie ustawowym tego rodzaju urlopy dodatkowe. Często, zwłaszcza z punktu widzenia istoty urlopu wypoczynkowego czy wskazanych wyżej obiektywnych kryteriów determinujących ilość należnego pracownikowi wypoczynku, nie jest do końca jasne ich przeznaczenie. O ile nie może bowiem budzić wątpliwości, że urlop taki, biorąc pod uwagę ogólne funkcje urlopu wypoczynkowego, jest w pełni uzasadniony w przypadku pracowników niepełnosprawnych podlegających wzmożonej ochronie w zatrudnieniu ${ }^{158}$

156 Nauczyciel akademicki ma prawo do urlopu wypoczynkowego w wymiarze 36 dni roboczych, bez względu na jego staż pracy w uczelni, podstawę zatrudnienia i zajmowane stanowisko. Podobnie nauczyciel, który zgodnie z ustawą - Karta Nauczyciela, jest zatrudniony w szkole, w której organizacji przewidziano ferie, ma prawo do urlopu w wymiarze odpowiadającym okresowi ferii, bez względu na podstawę zatrudnienia, a także jego wymiar oraz liczbę lat przepracowanych w szkole (z możliwością jego skrócenia o siedem dni, o czym mowa dalej). Jeśli w danej placówce nie przewidziano ferii, nauczyciel uzyskuje urlop w wymiarze 35 dni roboczych, też bez względu na podstawę zatrudnienia oraz liczbę lat przepracowanych w szkole, ale w tym przypadku stosownie do wymiaru czasu pracy.

157 A. Uklejska, Aktualne kierunki..., s. 28. Podobne zwiększenie wymiaru urlopu dotyczy pracowników naukowych i badawczo-technicznych zatrudnionych w Polskiej Akademii Nauk oraz jednostkach badawczych, o których mowa w ustawie z 30 kwietnia 2010 r. o instytucjach badawczych, tekst jednolity: Dz. U. 2015, poz. 1059, ze zm.

158 Art. 19 ustawy z 27 sierpnia 1997 r. o rehabilitacji zawodowej i społecznej oraz zatrudnianiu osób niepełnosprawnych. 
i inwalidów wojennych ${ }^{159}$, gdzie dłuższy odpoczynek determinuje stan zdrowia, czy pracowników socjalnych ${ }^{160}$, których praca jest związana ze specyficznymi obciążeniami, w szczególności psychicznymi, a w pewnym zakresie też kombatantów ${ }^{161}$, o tyle już przyznanie takich urlopów urzędnikom służby cywilnej ${ }^{162}$ czy niektórym pracownikom Najwyższej Izby Kontroli ${ }^{163}$, a brak analogicznego uprawnienia po stronie choćby osób zatrudnionych w warunkach szczególnie uciążliwych lub szkodliwych dla zdrowia ${ }^{164}$, wydaje się mocno wątpliwe i zdaje się ten urlop sprowadzać bardziej do roli przywilejów przyznanych danej grupie pracowniczej, co ostatecznie, moim zdaniem, pozostaje $\mathrm{w}$ pewnej kolizji $\mathrm{z}$ jego podstawową funkcją. Rodzaj wykonywanej pracy, warunki w jakich jest ona świadczona, mogą być bowiem w pełni uzasadnionymi kryteriami określonej dyferencjacji uprawnień w zakresie wypoczynku, trzeba jednak tu brać pod uwagę obiektywne czynniki z nią związane, takie jak szkodliwy wpływ wykonywanych zajęć na organizm ludzki, szczególny wysiłek fizyczny lub psychiczny jej towarzyszący czy szczególny typ zmęczenia skutkującego spowolnioną regeneracją organizmu ${ }^{165}$, oraz stosować je jednolicie, a nie wybiórczo, wobec wszystkich zatrudnionych.

Jak z powyższego wynika, formalną, przyjętą przez ustawodawcę przesłanką wydłużenia urlopu wypoczynkowego w opisanych przypadkach, obok wskazanego kryterium rodzaju pracy czy zawodu, jest też, znajdująca generalnie oparcie w podstawowej funkcji omawianej instytucji, forma zatrudnienia lub stan zdrowia zatrudnionej osoby. Problem leży zatem bardziej w sposobie, w jaki kryteria te

159 Art. 19 ustawy z 29 maja 1974 r. o zaopatrzeniu inwalidów wojennych i wojskowych oraz ich rodzin, Dz. U. 2015, poz. 840, ze zm.

160 Art. 121 ust. 3 ustawy z 12 marca 2004 r. o pomocy społecznej, Dz. U. 2015, poz. 163, ze zm.

161 Art. 10 ustawy z dnia 24 stycznia 1991 r. o kombatantach oraz niektórych osobach będących ofiarami represji wojennych i okresu powojennego, Dz. U. 2014, poz. 1206, ze zm. Wydaje się, że w tym przypadku funkcja wypoczynkowa urlopu nie ma charakteru wiodącego, wydłużenie tego urlopu jest dokonywane jednak bardziej na podstawie szczególnych zasług czy uznania potrzeby kompensowania określonych krzywd.

162 Na podstawie art. 105 ustawy z dnia 21 listopada 2008 r. o służbie cywilnej (Dz. U. 2014, poz. 1111, ze zm.) urzędnikowi służby cywilnej przysługuje corocznie dodatkowy urlop wypoczynkowy w wymiarze wynoszącym maksymalnie 12 dni (w zależności od okresu zatrudnienia).

163 Zgodnie z art. 79 ustawy z dnia 23 grudnia 1994 r. o Najwyższej Izbie Kontroli (tekst jednolity Dz. U. 2017, poz. 524) wybranym kategoriom pracowników przysługuje dodatkowy urlop wypoczynkowy w wymiarze sześciu dni roboczych, a po 20 latach pracy - w wymiarze 12 dni roboczych.

164 Art. $145 \S 1$ k.p. dotyczy jedynie skrócenia ich czasu pracy. Kryterium to jest wyjątkowo wprost brane pod uwagę przy ustalaniu wymiaru urlopu wypoczynkowego członka służby zagranicznej wykonującego obowiązki służbowe w placówce zagranicznej w miejscu o klimacie szczególnie szkodliwym dla zdrowia, któremu, w okresie służby w tej placówce, przysługuje urlop dodatkowy w wymiarze pięciu dni roboczych rocznie. Por. J. Stelina, Prawo urzędnicze, Warszawa 2009, s. 244. Członkowie personelu dyplomatyczno-konsularnego mają też zagwarantowany urlop dodatkowy po osiągnięciu określonego stażu pracy w służbie zagranicznej (po 10 latach - sześć dni, po 20 latach - 12 dni).

165 Por. na ten temat A. Uklejska, Aktualne kierunki..., s. 28. 
zostały zastosowane, w tym zwłaszcza w zakresie tego zastosowania. Bywa jednak, że są brane pod uwagę również czynniki niepowiązane bezpośrednio ze zmęczeniem generowanym przez daną pracę czy właściwości organizmu, jak w przypadku kombatantów, gdzie, jak się wydaje, poprzez wymiar urlopu wypoczynkowego realizuje się także funkcje dodatkowe związane z rekompensatą określonych krzywd oraz szczególnych zasług.

Dyferencjacja wymiaru urlopu wypoczynkowego, mająca miejsce w stosunku do przeważającej grupy pracowników na podstawie przepisów k.p., powoduje możliwość zwiększenia należnej danej osobie liczby dni urlopu w trakcie roku kalendarzowego, za który ten urlop przysługuje. Jest to najczęściej następstwem osiągnięcia odpowiedniego stażu pracy lub ukończenia określonej szkoły. Pracownik uzyskuje prawo do urlopu w wyższym wymiarze w dniu wystąpienia okoliczności powodującej taki skutek ${ }^{166}$. W związku z tym pracodawca albo dokonuje odpowiedniej korekty w zakresie ilości należnego pracownikowi urlopu i udziela go w odpowiednio zwiększonym wymiarze, albo, jeśli pracownik urlop za dany rok kalendarzowy już wykorzystał, udziela urlopu uzupełniającego, zgodnie z art. 158 k.p., który powinien być zrealizowany na ogólnych zasadach dotyczących urlopu wypoczynkowego. Co istotne zatem, z punktu widzenia podjętego tematu, pracownik ma roszczenie o udzielenie mu urlopu uzupełniającego w roku kalendarzowym jego nabycia, jeśli nie zaistniały okoliczności uzasadniające potrzebę jego przesunięcia. Może on, co do zasady, jeszcze w tym samym roku urlop ten spożytkować na wypoczynek.

Wymiar urlopu wypoczynkowego w danym roku kalendarzowym bywa również w pewnych przypadkach redukowany, co jednak w gruncie rzeczy daje się pogodzić z podstawowym celem omawianego świadczenia. Ustawodawca, ze zrozumiałych względów, uzależnia liczbę dni urlopowych od wymiaru czasu pracy danej osoby oraz okresu zatrudnienia w danym roku (urlop proporcjonalny) ${ }^{167}$. Niewątpliwie praca na pełen etat, przez wszystkie miesiące w roku wiąże się z większym wydatkowaniem sił niż praca jedynie na część etatu czy podjęta w części tego roku kalendarzowego. Okres odpoczynku musi być zatem dostosowany do zmęczenia, jakie przynajmniej potencjalnie generuje większa ilość pracy.

Warto też pamiętać, że podany w przepisach k.p. ogólny wymiar urlopu odnosi się do rocznego okresu pracy, co też uzasadnia jego skrócenie, gdy okres ten był odpowiednio krótszy.

Zdaniem Z. Salwy, przepisy dotyczące proporcjonalnego ustalania jego wymiaru realizują konsekwentnie wynikające z prawa urlopowego założenie, że urlop ten służy do regeneracji sił pracownika, a tym samym jego ilość powinna być

166 Por. M. Nałęcz, [w:] Kodeks pracy. Komentarz, red. W. Muszalski, Warszawa 2013, s. 518.

167 Tego rodzaju rozwiązania są stosowane również w innych państwach, np. w Anglii. Por. A.M. Przytuła-Pieniążek, The Right to Annual Leave - basic English and Polish statutory instruments compared, „Gdańsko-Łódzkie Roczniki Prawa Pracy i Prawa Socjalnego” 2016, nr 6, s. 151. 
adekwatna do czasu, w jakim pracownik te siły zużywa ${ }^{168}$. Taka konstrukcja czyni jednak wówczas ten urlop po trosze też swego rodzaju odpłatą za wykonywaną pracę ${ }^{169}$.

Ograniczenie wymiaru urlopu wypoczynkowego, jak z powyższego wynika, dotyczy w pierwszej kolejności pracowników zatrudnionych w niepełnym wymiarze czasu pracy. Ustala się go bowiem proporcjonalnie do rozmiarów tego zatrudnienia, biorąc za podstawę ogólny, roczny wymiar urlopu takiego pracownika, jaki by mu przysługiwał, gdyby był zatrudniony na cały etat.

Niepełny dzień urlopu, zgodnie z art. $154 \$ 2$ k.p., należy zaokrąglić w górę do pełnego dnia, nie ma tu zatem zasadniczo problemu, o którym była mowa przy prawie do urlopu cząstkowego nabywanego pierwszy raz w życiu zawodowym, ze zjawiskiem konieczności przeliczania urlopu na minuty i udzielania na część dnia roboczego. Jednocześnie taka regulacja jest korzystna dla pracownika również dlatego, że może de facto wpłynąć w konkretnym przypadku na zwiększenie rocznego wymiaru urlopu uzyskanego przez taką osobę, w sytuacji zmiany zatrudnienia $w$ trakcie tego roku ${ }^{170}$. Łączny wymiar urlopu nie może jednak, zgodnie $\mathrm{z}$ art. $154 \$ 3$ k.p., przekroczyć pełnego wymiaru ustawowo określonego, tj. 20 lub 26 dni.

W rezultacie zastosowania do pracowników niepełnoetatowych przepisów o przeliczaniu urlopu na godziny - według proporcji jeden dzień urlopu to osiem godzin pracy - oraz o udzielaniu go tylko na dni będące dla takiej osoby dniami pracy, w zasadzie, mimo proporcjonalnego zmniejszenia wymiaru ich urlopu, w praktyce korzystają oni z tego uprawnienia na poziomie analogicznym do pracy w pełnym wymiarze czasu pracy, a czasami nawet de facto wyższym (co będzie dalej szerzej analizowane).

Ustawodawca nie odniósł się bezpośrednio do sytuacji zmiany wymiaru czasu pracy w trakcie danego zatrudnienia. Należy jednak wówczas przyjąć, że urlop ten, biorąc pod uwagę m.in. jego cel, zachowanie prawa do adekwatnego okresu odpo-

168 Por. Z. Salwa, Urlop proporcjonalny, PiZS 1997, nr 10, s. 28 i n. Podobnie E. Chmielek-Łubińska, Urlop proporcjonalny, „Studia z zakresu prawa pracy i polityki społecznej”, red. A. Świątkowski, Kraków 1997/1998, s. 261.

169 W teorii tej urlop jest świadczeniem, którego pracodawca udziela pracownikowi w zamian za pracę wykonaną w oznaczonym czasie. Por. K. Rączka, [w:] M. Gersdorf, K. Rączka, M. Raczkowski, Kodeks pracy. Komentarz, Warszawa 2010, s. 717. Z tej perspektywy można mówić o pewnej niekonsekwencji ustawodawcy, wziąwszy pod uwagę jednoczesne zachowanie ogólnego stażu pracy.

170 Jeśli bowiem osoba z prawem do urlopu w wymiarze 26 dni podejmie zatrudnienie na 3/5 etatu i będzie pracowała w danym roku na rzecz jednego tylko pracodawcy, uzyska urlop po zaokrągleniu w wymiarze $16 \mathrm{dni}$. Jeśli natomiast będzie zmieniać pracę np. trzy razy i u każdego pracodawcy przepracuje w tym samym wymiarze po cztery miesiące, uzyska wówczas urlop łącznie za dany rok w wymiarze 18 dni (sześć dni u każdego z pracodawców). Każdy pracodawca będzie musiał bowiem przyjąć ów wymiar 16 dni (a więc po zaokrągleniu) jako podstawę ustalenia tzw. urlopu proporcjonalnego w związku z ustaniem zatrudnienia w części roku kalendarzowego. 
czynku, powinien być liczony odrębnie dla okresu wykonywania pracy na cały etat i czasu, w jakim pracownik rozpoczął w danym roku kalendarzowym pracę tylko na jego część. Kwestia ta była przedmiotem rozważań m.in. w orzecznictwie TSUE, który wyraźnie opowiedział się za taką wykładnią przepisów. W naszych warunkach, w zakresie dokonywania odpowiednich wyliczeń, zastosowanie mogłyby znaleźć przepisy o urlopie proporcjonalnym (art. $155^{1} \mathrm{k} . \mathrm{p}$ ), zwłaszcza gdy chodzi o zaokraglanie niepełnych dni urlopu czy miesięcy pracy w pełnym lub niepełnym wymiarze $^{171}$. Ustawodawca powinien jednak do tych przepisów wyraźnie odesłać. Trzeba również założyć, że jeśli przed zmianą wymiaru czasu pracy pracownik wykorzystał już urlop wypoczynkowy za dany rok w pełnym wymiarze, to proporcjonalne obniżenie wymiaru urlopu będzie dokonywane dopiero w następnym roku kalendarzowym, w odniesieniu do kolejnego urlopu wypoczynkowego, jeżeli nadal będzie on zatrudniony jedynie na część etatu.

Reguła proporcjonalności znajduje również swoje zastosowanie w przypadkach określonych w art. $155^{1}$ i $155^{2}$ k.p., tj. w razie ustania i nawiązania stosunku pracy w części roku kalendarzowego oraz wystąpienia w nim enumeratywnie wymienionych okresów nieobecności w pracy trwających dłużej niż jeden miesiąc (tzw. urlop proporcjonalny).

Wprowadzenie do Kodeksu pracy powyższych przesłanek obniżenia wymiaru urlopu wypoczynkowego nastąpiło w latach 90 . XX w. ${ }^{172} \mathrm{w}$ celu bardziej równomiernego rozłożenia obciążeń urlopowych pomiędzy pracodawców zatrudniających pracownika w danym roku kalendarzowym (wcześniej w razie rozwiązania stosunku pracy całego urlopu udzielał pracodawca, który zatrudniał pracownika w dniu nabycia prawa do tego urlopu) oraz lepszego dostosowania wymiaru urlopu należnego pracownikowi do liczby miesięcy, w jakich pozostawał on w faktycznie (a nie tylko formalnie) w danym stosunku pracy, a nawet, jak się niekiedy w pewnym uproszczeniu przyjmuje, rzeczywiście świadczył pracę ${ }^{173}$.

Przepisy te obejmują wyłącznie pracowników, którzy nabyli prawo do urlopu kolejnego, $\mathrm{z}$ racji tego, że jest to urlop przysługujący z góry ${ }^{174}$. Nie mają zatem one zastosowania w roku kalendarzowym podjęcia pierwszej w życiu pracy, kiedy to urlop wypoczynkowy nabywa się na swoistych zasadach, również opartych na jakiejś formie proporcjonalnego jego uzyskiwania, zarówno pod względem powstania prawa, jak i jego wymiaru.

171 Por. tak A. Kosut, [w:] Kodeks pracy..., s. 868.

172 Wcześniej, tj. przed 1 stycznia 1997 r., urlop proporcjonalny był regulowany w polskim prawie, ale w drodze aktów wykonawczych i w znacznie węższym zakresie. Dotyczył on sytuacji powrotu do pracy po urlopie bezpłatnym, wychowawczym, a także po odbyciu zasadniczej służby wojskowej lub jej form zastępczych. Przysługiwał też pracownikom wykonującym pracę za granicą na budowie eksportowej. Por. M. Łajeczko, Urlop..., s. 15.

173 Por. tak E. Staszewska, [w:] Urlopy..., s. 68. Zob. też E. Chmielek-Łubińska, [w:] Kodeks pracy..., Warszawa 2009, s. 884.

174 Jeśli zatrudnienie ma ustać w części roku, a pracownik ma prawo wystąpić o urlop w dniu jego nabycia, tj. np. pierwszego stycznia, pracodawca musi mieć możliwość ustalenia w jakim wymiarze, adekwatnym do okresu pozostawania w stosunku pracy, tego urlopu udzielić. 
Pierwsza grupa sytuacji, kiedy wymiar kolejnego urlopu wypoczynkowego będzie proporcjonalnie zmniejszany, w zasadzie nie budzi większych wątpliwości. Jeśli stosunek pracy ustaje w części roku kalendarzowego, pracownikowi przysługuje urlop $\mathrm{w}$ wymiarze proporcjonalnym do okresu trwania tego zatrudnienia $\mathrm{w}$ danym roku, a w razie nawiązania kolejnego stosunku pracy w części tego samego lub innego roku kalendarzowego - w wymiarze proporcjonalnym do końca roku (jeśli stosunek pracy obejmuje ten koniec) lub proporcjonalnym do okresu, na jaki ten stosunek pracy nawiązano, w razie zatrudnienia na czas krótszy niż do końca roku.

Mimo zróżnicowanej terminologii użytej w tym przepisie - raz ustawodawca wskazuje na okres „przepracowany”, za chwilę zaś na okres zatrudnienia, jako punkt odniesienia dla odpowiedniego obniżenia wymiaru urlopu - należy przyjąć, że znajdują tu zastosowanie ogólne zasady liczenia stażu pracy, o których wcześniej była mowa. Chodzi zatem o okres faktycznego trwania stosunku pracy, a nie czynnego wykonywania swoich obowiązków przez pracownika, choć w przeszłości były w tym zakresie zgłaszane pewne wątpliwości ${ }^{175}$. Trudno jednak byłoby znaleźć racjonalne uzasadnienia dla zróżnicowania w omawianym obszarze sytuacji dotychczasowego pracodawcy, który miałby, ustalając okres, za jaki udzieli urlopu, brać pod uwagę tylko czas dosłownie „przepracowany” na jego rzecz oraz pracodawcy kolejnego, który zgodnie z literalnym brzmieniem art. $155^{1} \$ 1$ k.p., miałby udzielać urlopu w wymiarze proporcjonalnym do okresu zatrudnienia w danym roku. Ponadto sam ustawodawca obecnie zobowiązuje pracodawcę do zaokrąglania niepełnych miesięcy pracy w górę, o czym będzie jeszcze dalej mowa, co ewidentnie świadczy o wątpliwej możliwości przypisania mu zamiaru łączenia urlopu proporcjonalnego z szeroko nawet rozumianymi, ale tylko okresami przepracowanymi. Tym bardziej, że okresy nieświadczenia pracy przypadające w czasie trwania stosunku pracy, które mają obniżać wymiar urlopu, zostały wyszczególnione w katalogu zamkniętym w kolejnym przepisie k.p.

Urlop proporcjonalny przysługuje pracownikowi niezależnie od trybu rozwiązania stosunku pracy, strony, która tego dokonuje czy wreszcie powodu jego ustania, a także ewentualnego zamiaru podjęcia kolejnej pracy ${ }^{176}$. Powodem wprowadzenia analizowanej regulacji kodeksowej nie jest w związku z tym jedynie chęć rozdzielenia obowiązków urlopowych pomiędzy wszystkich pracodawców zatrudniających pracownika w danym roku, która uzasadniałaby ograniczenie działania tego przepisu wówczas, gdy pracownik nie będzie nawiązywał kolejnego stosunku pracy, np. w związku z przejściem na emeryturę. Wydaje się, że równie ważna była tu kwestia związana ściśle z funkcją tego świadczenia, a konkretnie aspektem odzyskiwania zdolności psychofizycznej do pracy, której utrata następuje w procesie

175 Por. A. Sobczyk, „Porzucenie” pracy..., s. 171 oraz E. Chmielek-Łubińska, Urlopy wypoczynkowe po nowelizacji Kodeksu pracy, „Służba Pracownicza” 1997, nr 1, s. 3. Autorka sugerowata, że może chodzić w tym przypadku o dni faktyczne przepracowane oraz takie, które nie zostały przepracowane, ale z przyczyn usprawiedliwionych.

176 Por. uchwała SN z 20 sierpnia 1997 r., III ZP 26/97, OSNP 1998, nr 5, poz. 145. 
jej świadczenia; im jest on krótszy, tym, w założeniu, mniejsze generuje straty. Stąd przerwy w zatrudnieniu czy szybsze jego zakończenie w danym roku musi znaleźć swoje przełożenie na wymiar należnego za ten rok wypoczynku.

Zasady, na jakich dokonuje się obliczenia wielkości urlopu pracownika w opisanym wyżej wypadku są generalnie dla niego korzystne. Ich podstawą jest bowiem kalendarzowy miesiąc pracy odpowiadający 1/12 wymiaru urlopu wypoczynkowego przysługującego danej osobie, który zaokrągla się w górę do pełnego miesiąca, jeżeli stosunek pracy zostaje nawiązany lub ustaje w jakiejś jego części ${ }^{177}$. Zaokrągleniu podlega również niepełny dzień urlopu będący wynikiem dokonanych przez pracodawcę wyliczeń. W żadnym jednak razie, ilość należnego pracownikowi urlopu nie może przekroczyć ogólnego wymiaru ustawowo określonego, stąd ostatni pracodawca zatrudniający pracownika w danym roku kalendarzowym powinien $\mathrm{w}$ razie potrzeby dokonać $\mathrm{w}$ tym zakresie stosownych modyfikacji ${ }^{178}$. Jest to szczególne istotne w sytuacji, gdy pracownik wykorzystał wcześniej cały przysługujący mu urlop, a więc jednorazowo zrealizował swoje prawo do odpoczynku rocznego, w związku choćby z brakiem wiedzy stron co do ustania zatrudnienia w trakcie tego roku kalendarzowego. Wówczas, co istotne, dotychczasowy pracodawca nie ma wobec pracownika żadnych roszczeń, mimo że udzielił urlopu w wymiarze wyższym niż wynika z reguły proporcjonalności, niemniej fakt ten powinien uwzględnić kolejny podmiot nawiązujący stosunek pracy $z$ tym pracownikiem $\mathrm{w}$ tym samym roku kalendarzowym. Zmiana zatrudnienia nie może bowiem powodować zwiększenia uprawnień urlopowych takiej osoby w stosunku do pracowników wykonujących pracę przez cały rok na rzecz tego samego pracodawcy.

Obowiązek zaokrąglenia niepełnych dni urlopu i miesięcy pracy został, moim zdaniem, słusznie przyjęty, choć trzeba przyznać, że poprzez zastosowanie takiego mechanizmu liczba dni urlopu, jaką pracodawca musi zagwarantować pracownikowi, nie zawsze oddaje rzeczywisty nakład jego pracy, np. praca w okresie 31 stycznia - 6 lutego (tygodniowa) gwarantuje urlop w takim samym wymiarze jak zatrudnienie trwające od początku stycznia i zakończone na koniec lutego (dwumiesięczne). Stąd w przeszłości w doktrynie prawa pracy były wyrażane opinie, że być może bardziej sprawiedliwym rozwiązaniem (również z perspektywy funkcji urlopu wypoczynkowego) byłoby liczenie pełnych miesięcy kalendarzowych jako odpowiadających 1/12 wymiaru urlopu, a miesięcy niepełnych jako określonej liczby przepracowanych $\mathrm{dni}^{179}$.

Urlop w wymiarze proporcjonalnym jest udzielany przez pracodawcę równiez w związku z wystąpieniem co najmniej miesięcznych, wyraźnie przez prawo wymienionych przerw w zatrudnieniu. Przede wszystkim chodzi o okres pewnego

177 Jeśli stosunek pracy ustaje i nawiązuje się kolejny w tym samym miesiącu, zaokrąglenia do pełnego miesiąca dokonuje wyłącznie dotychczasowy pracodawca.

178 Por. m.in.: A. Kosut, [w:] Kodeks pracy..., s. 971 oraz E. Chmielek-Łubińska, [w:] Kodeks pracy..., Warszawa 2009, s. 895.

179 E. Chmielek-Łubińska, Urlopy wypoczynkowe. Nowe uregulowania od stycznia 1997 r., Warszawa 1997, s. 45. 
„Zawieszenia” stosunku pracy, wzajemnych podstawowych praw i obowiązków stron tego stosunku, w którym nie nabywa się praw pracowniczych powiązanych ze stażem pracy, w tym prawa do urlopu wypoczynkowego. Stąd ową redukcję wymiaru urlopu wypoczynkowego powodują urlop bezpłatny, okres służby wojskowej - zasadniczej i jej form zastępczych, okresowej, ale też tej mającej postać przeszkolenia lub ćwiczeń wojskowych, okres tymczasowego aresztu i odbywania kary pozbawienia wolności, a w pewnym zakresie także, po dokonanych w ostatnich latach zmianach ${ }^{180}$, urlop wychowawczy.

W tym ostatnim przypadku zmniejszenie wymiaru urlopu następuje wyłącznie wtedy, gdy pracownik powraca do pracy po trwającym co najmniej jeden miesiąc urlopie wychowawczym w roku kalendarzowym, w którym nie nabył on jeszcze prawa do urlopu wypoczynkowego (np. korzystał z urlopu wychowawczego na przełomie lat). Nie ma natomiast możliwości obniżenia tego wymiaru, jeśli pracownik będzie pozostawał na urlopie wychowawczym już po nabyciu prawa do urlopu wypoczynkowego za dany rok. Dokonana w przepisach kodeksowych zmiana jest wyrazem dostosowania naszego prawa do omawianych wcześniej przepisów unijnych, wspartych orzecznictwem TSUE, z których wynika konieczność przyjęcia regulacji gwarantującej pracownikom korzystającym z takiego urlopu, że nie będą tracili nabytego przed nim prawa do urlopu wypoczynkowego ${ }^{181}$. Po zakończeniu urlopu wychowawczego pracownik powinien pozostawać w zakresie praw nabytych przed jego rozpoczęciem w sytuacji identycznej do tej, w jakiej znajdował się przed tym urlopem.

Rozpatrując powyższe okresy z punktu widzenia prawa do odpoczynku w zasadzie trudno przyjąć, aby regulacje te kolidowały z podstawową funkcją urlopu wypoczynkowego. Skoro pracownik okresowo pozostaje właściwie jedynie formalnie w stosunku pracy, strony nie realizują swych podstawowych obowiązków, pracownik nie wydatkuje sił w związku z pracą zawodową, to może być odpowiednio zmniejszony okres należnego mu odpoczynku.

Akceptując generalnie przyjęte kryterium stanowiące podstawę wyodrębnienia wymienionych przesłanek obniżenia wymiaru urlopu, można jednak zastanawiać się, czy w tym zakresie ustawodawca nie powinien wprowadzić odstępstw od reguły proporcjonalności w odniesieniu do urlopu wychowawczego oraz okresu służby wojskowej, zwłaszcza jeśli trwają one krócej niż rok. W obu przypadkach przemawiają za tym względy społeczne powiązane z szeroko rozumianą potrzebą wypoczynku. Obie instytucje służą bowiem wypełnianiu istotnych zadań o charakterze ogólnospołecznym, jakim jest wychowywanie dzieci oraz budowanie poczucia bezpieczeństwa obywateli, przy dość znacznym nakładzie sił. Przerwa w wykonywaniu pracy, spowodowana wymienionymi przyczynami, nie zawsze zresztą jest zależna od samego zatrudnionego, jak choćby w przypadku powoła-

180 Por. ustawa z 26 lipca 2013 r. o zmianie ustawy - Kodeks pracy, Dz. U. 2013, poz. 1028.

181 Por. orzeczenie TSUE z 22 kwietnia 2010 r. w sprawie Zentralbetriebsrat der Landeskrankenhäuser Tirols, pkt 50 i n. 
nia na ćwiczenia czy przeszkolenie wojskowe, niemniej leży, jak można założyć, w interesie państwa. Stąd okresy te być może nie powinny wpływać ograniczająco na wymiar urlopu wypoczynkowego.

Dodatkowo w przypadku urlopu wychowawczego przemawia za tym również generalna zasada przyjęta w orzecznictwie unijnym, że jeden urlop gwarantowany przez przepisy prawa wspólnotowego nie powinien mieć negatywnych skutków dla skorzystania $z$ innego urlopu gwarantowanego przez to prawo, zwłaszcza wtedy, gdy ich cele nie są ze sobą zbieżne. Zasada ta jest realizowana w polskim prawie niemal w odniesieniu do wszystkich urlopów związanych z rodzicielstwem, z wyjątkiem urlopu wychowawczego, gdzie po dokonanych w 2013 r. zmianach w przepisach k.p. znajduje już swoje odzwierciedlenie, ale nadal w ograniczonym stopniu. Budzi to pewne wątpliwości, jakby ustawodawca zatrzymał się w pół drogi; o tym, czy urlop pracownika zostanie zredukowany, decyduje bowiem nie samo wystąpienie okresu zwolnienia z obowiązku wykonywania pracy z omawianego powodu, nie bezpośrednio jego długość, ale moment, w jakim pracownik będzie z tego urlopu korzystać. W rezultacie pracownicy, którym udzielono tak samo długiego urlopu wychowawczego (np. półrocznego), będą mieli różny wymiar urlopu wypoczynkowego w zależności od tego, w której części roku na tym urlopie pozostawali. Nie wydaje się to dostatecznie przekonującym kryterium zróżnicowania sytuacji prawnej osób w omawianym zakresie.

Ponadto trzeba mieć na uwadze, że wykorzystywanie urlopu wychowawczego może zostać zamienione na obniżenie wymiaru czasu pracy pracownika do tego urlopu uprawnionego, maksymalnie do połowy, a więc łączenie obowiązków zawodowych $\mathrm{z}$ wychowywaniem dzieci, co generuje z pewnością większe zmęczenie. Wówczas, moim zdaniem, omawiany przepis tym bardziej nie powinien znaleźć swojego zastosowania. Tezy tej można bronić już na gruncie obecnego stanu prawnego, skoro bowiem nie jest to okres nieobecności w pracy, to trudno przyjąć, by chodziło tu o pracownika „powracającego do pracy u dotychczasowego pracodawcy”, o którym stanowią analizowane przepisy. Ich ratio legis jest oparte na przekonaniu, że w okresach wymienionych w tym przepisie, w związku z nieobecnością pracownika i związanym z nią zaprzestaniem wykonywania przez strony stosunku pracy swych podstawowych obowiązków, następuje osłabienie więzi prawnej istniejącej między nimi, czego w omawianym przypadku nie sposób dostrzec. Ponadto trzeba przyjąć, że praca w mniejszym wymiarze godzinowym, o której mowa, nie stanowi urlopu wychowawczego sensu stricto, ale uprawnienie w stosunku do niego alternatywne, choć wykorzystywane w ramach ogólnych regulacji dotyczących bezpośrednio tej instytucji.

W grę może jednak wchodzić proporcjonalne zredukowanie ilości przysługującego pracownikowi urlopu wypoczynkowego z tytułu zmniejszonego wymiaru czasu pracy, wynikające z powołanego wcześniej art. $154 \$ 2$ k.p., chociaż i w tym przypadku, z uwagi na to, że jest to forma realizowana zamiast urlopu wychowawczego, można mieć co do tego uzasadnione wątpliwości, zwłaszcza w kontekście wspomnianego wcześniej prawa UE, w którym wymaga się, aby pracownik 
korzystający z takiego urlopu zachował co najmniej prawa przed nim nabyte (w tym przypadku urlop wypoczynkowy w pełnym wymiarze, jeśli prawo do niego powstało przed rozpoczęciem wykorzystania uprawnień w omawianej postaci). Ponadto sytuacja osoby, która korzysta $\mathrm{z}$ formy alternatywnej wobec urlopu wychowawczego, pracuje, choć mniej, nie może być gorsza od sytuacji prawnej pracownika, który w okresie takiego urlopu w ogóle nie świadczy pracy (a zachowuje czasami, przy spełnieniu powyższych warunków, urlop wypoczynkowy w pełnym wymiarze). Takie rozróżnienie nie znajduje bowiem racjonalnego uzasadnienia, szczególnie w aspekcie prawa do odpoczynku i podstawowej funkcji urlopów wypoczynkowych. Trudno zatem przypisywać ustawodawcy takie intencje. Kwestia ta powinna jednak zostać wyraźnie uregulowana w przepisach k.p.

Ostatnią okolicznością wymienioną w art. $155^{2}$ k.p. wpływającą na obniżenie wymiaru urlopu wypoczynkowego jest nieusprawiedliwiona nieobecność w pracy. Jej oddziaływanie na rozmiar wypoczynku w roku kalendarzowym, w którym wystąpiła, jest w pełni zrozumiałe. Jak wynika bowiem z wcześniejszych rozważań, trudno przyjąć, aby czas jej trwania traktować na równi z okresem pracy zarówno w kontekście urlopu kolejnego, co wynika już z samego przepisu, jak i nabycia prawa do urlopu pierwszego. Brak tego rodzaju przesłanki obniżenia wymiaru urlopu prowadziłby, jak słusznie zauważono w literaturze przedmiotu, do zupełnie niezrozumiałego, również w zakresie prawa do odpoczynku, uprzywilejowania pracownika, który ciężko naruszając swoje podstawowe obowiązki, przez miesiąc w ogóle nie stawiał się w pracy w stosunku do tego pracownika, który był nieobecny $\mathrm{w}$ pracy $\mathrm{z}$ powodu udzielonego mu na miesiąc np. urlopu bezpłatnego. Ten pierwszy, przy pominięciu omawianego okresu $\mathrm{w}$ katalogu zawartym $\mathrm{w}$ art. $155^{2}$ k.p., musiałby być bowiem w zakresie urlopu wypoczynkowego traktowany tak, jak pracownik, który w czasie istnienia stosunku pracy nie miał żadnych przerw w wykonywaniu pracy ${ }^{182}$, co nie znajduje swojego uzasadnienia tak ogólnie w funkcji ochronnej prawa pracy, jak i podstawowej funkcji urlopu wypoczynkowego.

Niemniej objęcie okresów nieusprawiedliwionej nieobecności treścią analizowanego art. $155^{2}$ k.p., ale na równi $z$ innymi przerwami w świadczeniu pracy $\mathrm{w}$ przepisie tym wyszczególnionymi, których przyczyna jest pracodawcy znana (a niekiedy nawet on sam takiego zwolnienia udzielił), budzi pewne zastrzeżenia ${ }^{183}$. Trzeba bowiem zauważyć, że nieobecność taka, stanowiąca przejaw nagannego zachowania pracownika, nie w każdej sytuacji daje pracodawcy możliwość proporcjonalnego zmniejszenia wymiaru należnego pracownikowi urlopu. Warunkiem takiego działania jest bowiem upływ co najmniej jednego miesiąca trwania tej nieobecności, co oznacza, że jednorazowa taka nieobecność przez 2/3 tego miesiąca nie uprawnia do takiej redukcji i pracownik nabędzie urlop za ten czas. Ustawodawca nie zróżnicował bowiem w tym zakresie okresów nieobecności usprawiedliwionej i nieusprawiedliwionej. Nawet jeśli pracodawca wcześniej

182 Zob. A. Dubowik, Zasady udzielania..., s. 18.

183 Por. na ten temat w szczególności A. Sobczyk, „Porzucenie” pracy..., s. 171 i n. 
zdecydował o rozwiązaniu stosunku pracy z takim pracownikiem, choćby w trybie niezwłocznym, to i tak nabędzie on prawo do urlopu za miesiąc, w którym taka nieobecność wystąpiła w związku z zasadą zaokrąglania niepełnych miesięcy pracy do pełnego miesiąca, którą należy w tym przypadku, z braku odmiennych uregulowań, konsekwentnie stosować. Bywa to oceniane jako niesprawiedliwie dla pracodawców oraz pracowników rzetelnie wykonujących swoje obowiązki, a nawet dyskryminujące osoby nieobecne w pracy z innych przyczyn (usprawiedliwionych) wskazanych w omawianym przepisie ${ }^{184}$.

W jakimś sensie można zrozumieć ustawodawcę, który przyjmując za wiodący cel przepisów urlopowych zagwarantowanie pracownikowi wypoczynku w związku z pracą w ramach stosunku pracy, nie tyle brał pod uwage przyczynę jej nieświadczenia, co czas jej trwania, uzasadniający odjęcie z dwunastu części wypoczynku rocznego okresów mniej więcej adekwatnych do czasu faktycznego niewykonywania pracy, a nawet swoistego zawieszenia stosunku pracy. W tym ujęciu krótkotrwałe przerwy w pracy, nawet w okolicznościach, o jakich wyżej była mowa, nie powinny wpływać na ogólny wymiar wypoczynku pracownika w skali całego roku.

Nie wydaje się więc z drugiej strony możliwe, mając na względzie przeznaczenie omawianego urlopu, przyjęcie reguły, że jakakolwiek nieobecność nieusprawiedliwiona, nawet jednodniowa, spowoduje obniżenie wymiaru urlopu o $1 / 12$; byłoby to bowiem nieproporcjonalne zmniejszenie tego wymiaru w stosunku do rzeczywistego czasu wykonywania pracy w danym roku, a zatem i wysiłku z nią związanego, i jako takie sprzeczne $\mathrm{z}$ wiodącą funkcją tytułowej instytucji. Uprawnienia urlopowe nie mogą bowiem pełnić roli swego rodzaju sankcji za określone, nawet naganne, zachowania pracowników.

W tym kontekście zasadnie zwrócono w przeszłości w piśmiennictwie uwagę na problem porzucenia pracy, wcześniej już sygnalizowany. Na gruncie obowiązującego prawa, w którym instytucja ta nie jest już bezpośrednio regulowana, żadna z możliwych koncepcji dotyczących prawa do urlopu wypoczynkowego w związku z faktycznym wystąpieniem takiej okoliczności nie daje bowiem zadowalających rezultatów.

Porzucenie pracy, które w swej istocie jest czymś zdecydowanie dalej idącym niż nieusprawiedliwiona nieobecność, powinno być w kontekście prawa urlopowego odmiennie od tamtej traktowane. Chodzi bowiem de facto o sytuację, w której pracownik zrywa więź prawną łączącą go z pracodawcą i czyni to w sposób sprzeczny z przepisami prawa pracy.

Tymczasem, jeśli uznamy, biorąc pod uwagę charakter opisanego zdarzenia, że doszło tu do rozwiązania stosunku pracy przez pracownika, to po pierwsze, pojawia się problem, wcześniej już zgłaszany, ustalenia momentu, w jakim nieobecność pracownika przestaje być nieobecnością nieusprawiedliwioną i przekształca się w porzucenie pracy oraz ustalenia chwili skutecznego dojścia do pracodawcy

184 Tamże, s. 170 i n. 
takiego oświadczenia, zgodnie z art. 61 k.c. Jest to bardzo istotne z punktu widzenia podjętych rozważań - decyduje bowiem o zakresie zastosowania art. $155^{2}$ k.p. (a wówczas dopiero upływ miesiąca powoduje obniżenie wymiaru urlopu) oraz art. $155^{1}$ k.p.

Po drugie, nawet przyjmując, że doszło do rozwiązania stosunku pracy już pierwszego czy kolejnego dnia takiej nieobecności - zgodnie z art. $155^{1}$ k.p. należy zastosować wobec pracownika wszystkie wynikającego z niego „przywileje”, a zatem zaokrąglić niepełny miesiąc pracy w górę do pełnego miesiąca i analogicznie postąpić $\mathrm{z}$ niepełnym dniem urlopu. W efekcie, mimo że taka osoba faktycznie nie pozostawała już $\mathrm{w}$ stosunku pracy, $\mathrm{z}$ braku odmiennych unormowań, może ona nabyć prawo do $1 / 12$ wymiaru urlopu za ten czas, tj. nawet trzy dni urlopu, jeśli „porzuci pracę" np. drugiego czy kolejnego dnia danego miesiąca.

Analogiczny do powyższego skutek wystąpi, jeśli pracodawca zdecyduje się rozwiązać niezwłocznie umowę o pracę z pracownikiem nieobecnym w pracy z przyczyn pracodawcy nieznanych. Będzie mógł bowiem zredukować wymiar urlopu pracownika $z$ tej przyczyny tylko wówczas, gdy nieobecność ta wyniosła co najmniej miesiąc. Jeśli zaś powołując się na nieusprawiedliwioną nieobecność, rozwiąże stosunek pracy wcześniej, również mogą wystąpić konsekwencje, o których wyżej mowa, a więc wynikające $\mathrm{z}$ art. $155^{1}$ k.p.

Trzeba mieć też świadomość, jak podkreślano w doktrynie prawa pracy, że procedura takiego rozwiązania może być rozciągnięta w czasie. Pracodawca zwykle podejmuje bowiem decyzję o rozwiązaniu umowy nie w pierwszym dniu takiej nieobecności. Ponadto musi on zasięgnąć w tej sprawie co najmniej opinii związku zawodowego (w przypadku niektórych pracowników szczególnie chronionych uzyskać zgodę), a także skutecznie doręczyć pracownikowi złożone w tej sprawie oświadczenie woli ${ }^{185}$. Przez ten czas pracownik formalnie pozostaje $\mathrm{w}$ zatrudnieniu, niemniej, moim zdaniem, jeśli stan taki wynosi co najmniej jeden miesiąc, będzie to podstawą do obniżenia wymiaru urlopu pracownika na podstawie art. $155^{2}$ k.p., niezależnie od późniejszego rozwiązania stosunku pracy z tego powodu i zastosowania określonych w art. $155^{1}$ k.p. reguł proporcjonalności.

Generalnie jednak opisany stan prawny w zakresie przypadków faktycznego porzucenia pracy nadmiernie chroni interes pracownika, co nie znajduje, w mojej ocenie, swego uzasadnienia również w funkcji wypoczynkowej urlopu.

Zmniejszenie wymiaru urlopu wypoczynkowego pracownika powracającego do pracy po trwającym co najmniej jeden miesiąc okresie nieobecności, o którym mowa w analizowanym art. $155^{2}$ k.p., jest dokonywane na dwa sposoby ${ }^{186}$.

1) Jeśli okres tej nieobecności wystąpił przed nabyciem prawa do urlopu wypoczynkowego za dany rok (np. na przełomie dwóch lat kalendarzowych), wówczas, zgodnie z $\$ 1$ powołanego przepisu, należy pracownikowi udzielić urlopu

185 Tamże, s. 169.

186 Choć w literaturze z zakresu prawa pracy były w tej kwestii wyrażane różne stanowiska. Zob. A. Dubowik, Zasady udzielania..., s. 17 i powołana tam literatura. 
$\mathrm{w}$ wymiarze proporcjonalnym do końca roku (jeśli stosunek pracy obejmuje ten czas) lub proporcjonalnym do okresu trwania stosunku pracy, w razie zatrudnienia na czas krótszy niż do końca roku, przy zachowaniu zasady zaokrąglania niepełnych miesięcy pracy i dni urlopu w górę. Uwzględnieniu przy obliczaniu urlopu proporcjonalnego będą zatem podlegać tu tylko pełne miesiące takiej nieobecności, co poniekąd, jak się wydaje, wynika z faktu, że wystąpienie nieobecności przed nabyciem prawa do urlopu $\mathrm{w}$ danym roku nie może mieć w tym samym roku powtarzalnego charakteru, bez zachowania ciągłości tej nieobecności.

2) W sytuacji, gdy okresy nieobecności z wymienionych wyżej przyczyn wystąpią po nabyciu przez pracownika prawa do urlopu wypoczynkowego w danym roku, wymiar urlopu pracownika ulega proporcjonalnemu obniżeniu, o ile pracownik wcześniej nie wykorzystał urlopu. W tym przypadku jednak, zgodnie z treścią $\$ 2$ rozporządzenia urlopowego, jeśli okresy owej nieobecności obejmują części miesięcy kalendarzowych, za miesiąc uważa się upływ łącznie 30 dni. Oznacza to, że nawet krótsze niż miesięczne nieobecności pracownika z powodów wymienionych w przepisach kodeksowych, ale występujące $\mathrm{z}$ większą częstotliwością, mogą po ich zsumowaniu doprowadzić do obniżenia wymiaru urlopu wypoczynkowego należnego pracownikowi za ten rok. W kontekście wypoczynku chodzi bowiem o ustalenie faktycznego okresu wydatkowania sił w danym roku odpowiadającego poszczególnym jednostkom urlopu wypoczynkowego, tj. okresom miesięcznym.

Z ostatnią kwestią wiąże się częściowo problem jak traktować omawiane okresy nieobecności - łącznie czy każdy z nich rozpatrywać osobno. Ustawodawca nie rozstrzygnął bowiem tego wprost w przepisach dotyczących urlopu proporcjonalnego. W sprawie tej za dominujący należy uznać pogląd, według którego trzeba sumować wszystkie okresy nieobecności wymienione w przepisie, niezależnie od ich rodzaju ${ }^{187}$, co znajduje też swoje uzasadnienie w sformułowanym wyżej założeniu. Z perspektywy prawa do odpoczynku decydujący jest czas, w którym stosunek pracy de facto nie był realizowany, a dopiero $\mathrm{w}$ drugiej kolejności przyczyna takiego stanu, która może lub nie uzasadniać pewne uszczuplenie należnego pracownikowi wypoczynku. Jak wcześniej wspomniano, krótkotrwała przerwa w pracy, bez względu na okoliczności, nie powinna wpływać na ogólny wymiar wypoczynku pracownika w skali całego roku.

W kontekście tytułowej materii podkreślenia wymaga także, że dla obniżenia wymiaru urlopu wypoczynkowego istotny jest okres, w jakim można zastosować regułę proporcjonalności. Dotyczy to bowiem okresu rozliczeniowego charakterystycznego dla urlopu wypoczynkowego, tj. roku kalendarzowego. W konsekwencji pracodawca nie ma możliwości zredukowania wymiaru urlopu pracownika za rok kolejny z tytułu okresu nieobecności upoważniającej do takiego obniżenia, ale występującej w roku poprzednim. W każdym rocznym okresie, w jakim rozliczany jest urlop wypoczynkowy, pracownik nabywa bowiem do niego ponownie prawo i - w pewnym uproszczeniu - na ten odpoczynek pracuje. Dlatego też

187 Por. tak m.in. E. Chmielek-Łubińska, [w:] Kodeks pracy..., Warszawa 2009, s. 892. 
ustawodawca słusznie przyjmuje, że proporcjonalne zmniejszenie urlopu staje się bezprzedmiotowe w sytuacji, gdy pracownik już wcześniej, w roku wystąpienia danej nieobecności czy ustania zatrudnienia, ten urlop wykorzystał w przysługującym mu lub w wyższym wymiarze niż wynika z zastosowania omawianych reguł.

Na gruncie przepisów kodeksowych proporcjonalna redukcja wymiaru urlopu na podstawie art. $155^{2}$ k.p. nie zawsze będzie zatem możliwa. Przede wszystkim pracownik mógł bowiem wykorzystać urlop wcześniej - przed wystąpieniem przesłanki uzasadniającej jego proporcjonalne obniżenie, nawet jeśli pracodawca miał świadomość, że w przyszłości jeden z okresów nieobecności wymienionych w tym przepisie rozpocznie się. Wynika to, moim zdaniem, z konstrukcji urlopu proporcjonalnego przyjętej w obowiązującym prawie, w ramach której odpowiednie zmniejszenie wymiaru urlopu może nastąpić wobec pracownika „powracającego do pracy", a więc po okresie takiej nieobecności, a nie już przed momentem jej wystąpienia, niejako awansem. W chwili wcześniejszego wnioskowania o urlop wypoczynkowy nie jest pewne, czy taka nieobecność rzeczywiście będzie miała miejsce i jak długo ostatecznie będzie trwała (np. w związku ze skróceniem pierwotnie na dłużej udzielonego urlopu bezpłatnego). Stąd, formalnie, pracodawca nie może odrzucić wniosku pracownika o udzielenie mu urlopu w pełnym wymiarze, powołując się na wskazane wyżej okoliczności. Stanowi to formę zabezpieczenia interesów pracownika w zakresie prawa do odpoczynku, kosztem niekiedy naruszenia zasady adekwatności okresu odpoczynku do okresu pracy w danym roku, stanowiącej podstawę urlopu proporcjonalnego. Nie bez znaczenia jest tu jednak fakt, że generalnie o terminie udzielenia urlopu wypoczynkowego decyduje pracodawca, co może mu pozwolić w pewnych przypadkach na zminimalizowanie niekorzystnych dla niego skutków wynikających z takiego, a nie innego ukształtowania przepisów.

Proporcjonalne zmniejszanie rocznego wymiaru przysługującego pracownikowi wypoczynku nie jest instytucją właściwą wyłącznie dla regulacji kodeksowej. Bywa ona bowiem modyfikowana na gruncie innych ustaw z zakresu prawa pracy dotyczących określonych grup pracowników ${ }^{188}$, ze względu na specyficzne warunki ich zatrudnienia. W każdym jednak wypadku przepisy te zdają się wyrażać tę samą filozofię leżącą u podstaw wprowadzenia do Kodeksu pracy urlopu proporcjonalnego, a mianowicie, że urlop w pełnym wymiarze powinien nabywać pracownik zatrudniony u danego pracodawcy przez cały rok kalendarzowy. Jeśli natomiast ten czas jest krótszy, odpowiedniemu ograniczeniu należy poddać również liczbę dni urlopu udzielanego przez tego pracodawcę. Idea ta jest różnie jednak realizowana na gruncie wymienionych niżej pragmatyk pracowniczych.

Wśród regulacji odbiegających, przynajmniej częściowo, w analizowanym zakresie od unormowań kodeksowych należy wymienić przede wszystkim Kartę $\mathrm{Na}$ uczyciela oraz ustawę o szkolnictwie wyższym.

188 Czasami jednak do pracowników, których urlopy wypoczynkowe są częściowo regulowane przez inne niż Kodeks pracy akty prawne. 
Zgodnie z tą pierwszą, nauczyciel pracujący w szkole, w której organizacji przewidziano ferie, będzie uzyskiwać urlop wypoczynkowy w wymiarze proporcjonalnym do określonego $\mathrm{w}$ umowie okresu prowadzenia zajęć, $\mathrm{w}$ przypadku, jeśli był zatrudniony na czas krótszy niż 10 miesięcy, nieobejmujący całego okresu trwania zajęć w danym roku szkolnym, np. na jeden semestr (art. 65 ust. 5 Karty Nauczyciela). Wydaje się zatem, że przepis ten będzie miał zastosowanie wyłącznie do zatrudnienia terminowego ${ }^{189}$. Wówczas nauczyciel taki uzyskuje prawo do urlopu wypoczynkowego w wymiarze odpowiednim do określonego w umowie okresu prowadzenia zajęć. Ustawodawcy chodziło zatem, jak się można domyślać, by powiązać $\mathrm{w}$ omawianym aspekcie urlop wypoczynkowy nie tyle $\mathrm{z}$ okresem zatrudnienia $\mathrm{w}$ szkole, co procesem rzeczywistego wydatkowania sił w związku z prowadzonymi zajęciami. W takim ujęciu zasadniczo unormowanie to współgrałoby dość wyraźnie z podstawową funkcją urlopu wypoczynkowego, ale chyba nie zachowano w tym zakresie pełnej konsekwencji. Przede wszystkim wskazuje się w nim na okres zatrudnienia, a nie na czas przepracowany, ponadto nie uwzględnia się wyraźnie sytuacji ustania stosunku pracy $\mathrm{z}$ takim nauczycielem $\mathrm{w}$ czasie trwania roku szkolnego ${ }^{190}$ ( $\mathrm{z}$ wyjątkiem nauczycieli szkół, w których nie ma ferii). Z powyższego unormowania można bowiem wyprowadzić wniosek, że nawet jeśli nauczyciel nie przepracuje faktycznie 10 miesięcy, ale jego umowa obejmowała cały cykl zajęciowy w roku szkolnym, to nie ma podstaw do zmniejszenia należnego nauczycielowi wypoczynku, choćby do realizacji przez niego tych zajęć w istocie nie doszło w związku z wcześniejszym ustaniem jego zatrudnienia.

Zakres zastosowania omawianego przepisu, a zarazem również uregulowań kodeksowych dotyczących urlopu proporcjonalnego, wywołuje wiele kontrowersji w praktyce. W szczególności w uchwale Sądu Najwyższego z 10 maja 2006 r. przyjęto, że nauczyciel, także ten zatrudniony w szkole, w której są przewidziane ferie, nabywa prawo do ekwiwalentu za niewykorzystany urlop wypoczynkowy $\mathrm{w}$ wymiarze proporcjonalnym do okresu pracy w roku kalendarzowym, w którym ustał stosunek pracy ${ }^{191}$. Sąd przyjął bowiem, że brak w omawianej ustawie przepisu odsyłającego do norm kodeksowych w zakresie urlopu proporcjonalnego, jak w przypadku nauczycieli zatrudnionych w placówkach, w których nie ma ferii, nie oznacza automatycznie, że ustawodawca chciał sytuację tej drugiej grupy nauczycieli ukształtować korzystniej, przyznając jej prawo do urlopu w pełnym

189 Kwestia ta nie jest jednoznaczna, pierwsza jego część stanowi bowiem, że nauczyciel zatrudniony przez cały okres trwania zajęć w danym roku szkolnym w szkole, w której organizacji pracy przewidziano ferie szkolne, ma prawo do urlopu wypoczynkowego w wymiarze i na zasadach określonych w ust. 1, a więc w pełnym wymiarze odpowiadającym okresowi ferii. Ustawodawca nie zastrzega, że chodzi wyłącznie o umowę terminową, co może być odnoszone do wszystkich nauczycieli, bez względu na podstawę nawiązania stosunku pracy, choć ta koncepcja nie spotkała się z aprobatą w orzecznictwie sądowym. Por. m.in. wyrok Sądu Okręgowego w Ostrołęce z 3 lipca 2014 r., III Pa 14/14, LEX nr 1885398.

190 Na przykład w związku z jego wygaśnięciem, o którym stanowi art. 26 Karty Nauczyciela.

191 Por. uchwała SN z 10 maja 2006 r., III PZP 3/06, LEX nr 180655. 
wymiarze, niezależnie od okresu przepracowanego przez nauczyciela w danym roku szkolnym. Zdaniem Sądu Najwyższego, nie ma żadnych racjonalnych podstaw, przesłanek natury aksjologicznej, aby szczególnie uprzywilejowywać nauczycieli zatrudnionych na czas nieokreślony w szkołach tzw. feryjnych. Kwestia ta jako wyraźnie nieunormowana w Karcie Nauczyciela musi być rozstrzygnięta na podstawie odpowiednich przepisów Kodeksu pracy, tj. art. $155^{1}$ k.p. w związku $\mathrm{z}$ art. $91 \mathrm{c}$ ust. 1 Karty Nauczyciela ${ }^{192}$. Oznacza to, że ustanie stosunku pracy nauczyciela zatrudnionego na czas nieokreślony w szkole, w której organizacji przewidziano ferie szkolne, musi powodować proporcjonalne zmniejszenie wymiaru urlopu wypoczynkowego stosownie do okresu przepracowanego w danym roku kalendarzowym.

W świetle obowiązujących przepisów Karty Nauczyciela, wyżej powołanych, możliwa jest jednak i taka interpretacja, zgodnie z którą ustawodawca świadomie nie odesłał w odniesieniu do nauczycieli szkół feryjnych zatrudnionych bezterminowo do odpowiednich przepisów kodeksowych poświęconych proporcjonalnemu zmniejszeniu urlopu w związku z ustaniem stosunku w części roku kalendarzowego (co uczynił wyraźnie wobec nauczycieli placówek nieferyjnych), stawiając ich w znacznie korzystniejszym położeniu w obszarze uprawnień urlopowych niż pozostałych nauczycieli (tj. zatrudnionych w szkołach, gdzie nie ma ferii lub są, ale nauczyciel ma umowę terminową). Wówczas nabywaliby oni bowiem prawo do urlopu w pełnym wymiarze, niezależnie od okresu przepracowanego w danym roku, co trzeba przyznać, również z punktu widzenia funkcji tego świadczenia, nie znajduje dostatecznego uzasadnienia. Niemniej trudno racjonalnie wyjaśnić, dlaczego ustawodawca odesłał wyraźnie do urlopu proporcjonalnego wynikającego z przepisów k.p. w odniesieniu do nauczycieli szkół, w których nie ma ferii, a nie wspomina w tym zakresie o drugiej grupie nauczycieli, zakładając, że omawiany wyżej przepis Karty Nauczyciela, co też nie jest pewne, dotyczy wyłącznie tych nauczycieli z tej grupy, których podstawą nawiązania stosunku pracy jest umowa terminowa.

Jednocześnie taka konstrukcja urlopu proporcjonalnego nauczycieli, w której pracownicy tego samego typu szkół (w których organizacji przewidziano ferie) mają $\mathrm{w}$ określonych przypadkach różny wymiar urlopu, mimo prowadzenia takiej samej ilości zajęć w analogicznym okresie, tylko na podstawie kryterium zatrudnienia terminowego lub nie, jawi się nie tylko jako wysoce niesprawiedliwa, ale wręcz dyskryminująca osoby wykonujące pracę na podstawie umowy terminowej, która, jak wiadomo, sama w sobie nie może stanowić przesłanki dyferencjacji uprawnień pracowniczych.

Można wyobrazić sobie i taką wykładnię art. 64 ust. 5 analizowanej ustawy, ze względu na niejednoznaczne jego brzmienie, zgodnie z którą przepis ten dotyczy wszystkich nauczycieli szkół feryjnych, a nie tylko tych zatrudnionych na czas określony, zaś do pozostałych nauczycieli znajdzie zastosowanie urlop propor- 
cjonalny określony w Kodeksie pracy, zgodnie z art. 64 ust. 5a Karty Nauczyciela. Ze względów, o których mowa była wcześniej, ona również nie przynosi zadowalających rezultatów.

Biorąc pod uwagę kontrowersje, jakie wywołuje omawiana regulacja, należy postulować zdecydowanie jej doprecyzowanie.

Urlop proporcjonalny został też odrębnie unormowany w odniesieniu do nauczycieli akademickich, choć, jak słusznie podkreśla się w literaturze przedmiotu, prawo o szkolnictwie wyższym jest w tym zakresie mało precyzyjne ${ }^{193}$.

Zgodnie z art. 133 ust. 3 ustawy, nauczyciel akademicki ma prawo do urlopu wypoczynkowego w wymiarze proporcjonalnym do okresu zatrudnienia w następujących przypadkach:

- zatrudnienia w ciągu roku kalendarzowego,

- ustania stosunku pracy w trakcie tego roku,

- podjęcia pracy po powrocie z urlopu bezpłatnego, wychowawczego oraz urlopu dla poratowania zdrowia.

Jest to zatem regulacja znacznie szersza w porównaniu z Karta Nauczyciela, ale jednocześnie w stosunku do odpowiednich przepisów kodeksowych stanowi w gruncie rzeczy ich „zubożoną wersję"194.

Ponadto, analogicznie jak na gruncie Kodeksu pracy, nauczycielowi akademickiemu zatrudnionemu w niepełnym wymiarze czasu pracy przysługuje urlop w wymiarze proporcjonalnym do okresu zatrudnienia.

Pomijając szczegółową analizę powołanej części artykułu, w związku z jego znacznym podobieństwem do urlopu proporcjonalnego wynikającego z Kodeksu pracy, przy założeniu, że pewna część wcześniejszych wniosków i tu może znaleźć swoje odniesienie, warto zwrócić uwagę na dwie kwestie, które z punktu widzenia realizacji prawa do odpoczynku nauczyciela akademickiego mogą mieć istotne znaczenie.

Przede wszystkim trzeba podkreślić nadmierną lakoniczność zawartych w ustawie unormowań dotyczących zastosowania reguły proporcjonalności w wyszczególnionych sytuacjach, powodującą problem z ustaleniem wymiaru należnego pracownikowi urlopu w praktyce. Chodzi tu m.in. nie tylko o brak przepisów dotyczących ewentualnego zaokrąglania niepełnych miesięcy pracy czy dni urlopu, ale też o ocenę wpływu innych niż wymienione w ustawie okresów nieobecności, o których stanowi art. $155^{2}$ k.p., na ostateczny rozmiar urlopu należny nauczycielowi akademickiemu. Nie jest bowiem do końca jasne, w jakim zakresie, uzupełniająco, można stosować do nich w tym obszarze odpowiednie regulacje kodeksowe. W konsekwencji budzi to w praktyce wiele kontrowersji ${ }^{195}$, a formułowane

193 Por. Z. Góral, [w:] Akademickie prawo..., s. 240.

194 Tamże.

195 Zdaniem Z. Górala we wszystkich wymienionych sytuacjach, ale i tych niewymienionych wyżej, a nieuregulowanych w ustawie, powinny znaleźć zastosowanie odpowiednie przepisy kodeksowe. W szczególności, w ocenie autora, wobec nieuzasadnionej selektywności i nadmiernie lakonicznej regulacji dotyczącej okresów nieobecności obniżających wymiar 
opinie w różny sposób wpływają na ostateczny zakres uprawnień wypoczynkowych pracownika, co w założeniu nie sprzyja prawidłowej realizacji głównej funkcji tytułowej instytucji.

Druga sprawa dotyczy też okresów nieobecności w pracy skutkujących zastosowaniem reguły proporcjonalności, ale w kontekście ich rodzaju oraz sposobu, w jaki wpływają na wymiar urlopu w porównaniu do analogicznych okresów kodeksowych. Pomijając już sygnalizowany wyżej problem trudnego do wytłumaczenia wybiórczego ich ujęcia, w porównaniu z treścią art. $155^{2}$ k.p., a tym samym zróżnicowania ich oddziaływania na wymiar urlopu wypoczynkowego poszczególnych grup pracowniczych, wątpliwości budzi kompatybilność przyjmowanych rozwiązań z prawem wspólnotowym.

Trzeba bowiem odnotować, że w odniesieniu do urlopu wychowawczego we wspomnianej ustawie nie znalazły zastosowania zmiany analogiczne do tych przeprowadzonych w Kodeksie pracy, uwzględniających wymogi unijne, mające na celu ograniczenie wpływu urlopu wychowawczego na długość wypoczynku pracownika. W świetle ustawy nie ma znaczenia, w jakim momencie nauczyciel akademicki korzysta z urlopu wypoczynkowego (przed nabyciem prawa do urlopu czy po tym dniu), jego urlop w każdym przypadku będzie podlegać proporcjonalnemu zmniejszeniu. Adresatem normy jest ogólnie nauczyciel „podejmujący pracę po powrocie" z urlopu wychowawczego.

Krytycznie należy również, moim zdaniem, ocenić wyróżnienie w tym katalogu urlopu zdrowotnego (zwłaszcza przy braku okresu nieusprawiedliwionej nieobecności). Przede wszystkim jest to bowiem okres rodzajowy odmienny od wcześniej omawianych, w którym nie dochodzi do swoistego zawieszenia stosunku pracy, a pracownik korzysta $\mathrm{z}$ jednego z przysługujących mu dodatkowych zwolnień od pracy. Nie powinno być ono zatem realizowane kosztem urlopu wypoczynkowego, szczególnie biorąc pod uwagę odmienne funkcje obu tych instytucji, na co zwracano już uwagę we wcześniejszych rozważaniach i co było przedmiotem analizy Trybunału Sprawiedliwości UE.

$\mathrm{W}$ odniesieniu do pozostałych grup pracowniczych poddanych zasadniczo odrębnym regulacjom, $\mathrm{z}$ braku unormowań szczególnych w zakresie urlopu proporcjonalnego, będą znajdowały odpowiednie zastosowanie omówione przepisy kodeksowe. Taką interpretację przyjęto w stosunku do nauczycieli szkół tzw. „nieferyjnych”, do których należy stosować art. $155^{1}$ k.p. w związku z nawiązaniem lub ustaniem stosunku pracy w części roku kalendarzowego ${ }^{196}$, co wynika już obecnie bezpośrednio z samej ustawy (por. art. 64 ust. 5a Karty Nauczyciela).

urlopu należy odwołać się też do art. $155^{2}$ k.p. i okresów tam wyszczególnionych. Por. tenże, [w:] Akademickie prawo..., s. 240. Odmienne stanowisko w tej kwestii zaprezentował W. Witoszko. Por. tenże, Zasady udzielania urlopu wypoczynkowego nauczycielowi akademickiemu, [w:] Zatrudnienie nauczycieli akademickich, red. W. Sanetra, Warszawa 2015, s. 465.

196 Opinia Ministerstwa Edukacji Narodowej i Sportu w sprawie wymiaru urlopu wypoczynkowego dla nauczycieli zatrudnionych w placówkach nieferyjnych w niepełnym wymiarze czasu pracy, „Przegląd Oświatowy” 2004, nr 11, s. 10. 
Nie dotyczy to jednak, jak się wydaje, pracowników tymczasowych ${ }^{197}$, ze względu na konstrukcję nabycia prawa do urlopu wypoczynkowego, wcześniej omawianą, opartą na miesięcznym okresie pozostawania w dyspozycji pracodawcy użytkowania jako przesłance warunkującej uzyskanie dwóch dni takiego urlopu. Jest to zatem urlop przysługujący z dołu, analogicznie jak urlop w pierwszym roku zatrudnienia w ramach stosunku pracy, do którego zasady urlopu proporcjonalnego również nie znajdują zastosowania.

Niemniej niektórzy autorzy za pewne nawiązanie do przepisów k.p. dotyczących urlopu proporcjonalnego uznają art. 17 ust. 1 in fine ustawy o zatrudnianiu tymczasowym, w którym stanowi się, że urlopu nie uzyskuje się za okres, za który pracownik wykorzystał u poprzedniego pracodawcy urlop wypoczynkowy przysługujący na podstawie odrębnych przepisów ${ }^{198}$. Oznacza to, że jeśli pracownik tymczasowy pozostawał wcześniej w danym roku kalendarzowym w zatrudnieniu nietymczasowym i z tego tytułu wykorzystał urlop w wyższym wymiarze niż to wynikało $\mathrm{z}$ art. $155^{1} \mathrm{k}$.p., wówczas musi to być odpowiednio uwzględnione przez obecnego pracodawcę, tj. agencję. Za okres, jakiego nadwyżka ta dotyczyła, nie będzie on uzyskiwać urlopu w zatrudnieniu tymczasowym ${ }^{199}$. Zgodnie z zasadą, że zmiana zatrudnienia w roku kalendarzowym nie powinna powodować zwiększenia należnego pracownikowi za ten rok wypoczynku.

Dość istotna z punktu widzenia zachowania należytej realizacji prawa pracownika tymczasowego do odpoczynku jest jednak wykładnia tego przepisu zaproponowana przez A. Sobczyka, który uznał, że agencja pracy tymczasowej na podstawie powołanej normy nie udziela urlopu jedynie za okresy, za które pracownik ten uzyskał wcześniej urlop w naturze. Wskazana możliwość nie dotyczy więc okresów, za które wypłacono pracownikowi w poprzednim zatrudnieniu ekwiwalent pieniężny ${ }^{200}$. Autor słusznie zauważa, że prawidłowo stosowane przepisy o urlopie proporcjonalnym nie powinny prowadzić w praktyce do sytuacji, że pracodawca wypłaca pracownikowi ekwiwalent za większą część urlopu niż wynika z czasu trwania jego zatrudnienia u tego pracodawcy. Jednocześnie odwołanie się przez ustawodawcę do „urlopu wykorzystanego” w wymiarze wyższym niż wynikający $\mathrm{z}$ regulacji kodeksowych przeciwdziała $\mathrm{w}$ istocie pozbawieniu pracownika szans na odpoczynek w danym roku, jeśli poprzedni pracodawca zatrudniający tego pracownika na podstawie „typowego” stosunku pracy, z jakichś przyczyn jednak wysokość tego ekwiwalentu znacząco zawyżył.

197 Wątpliwości dotyczą możliwości odpowiedniego zastosowania art. $155^{2}$ k.p., co było już sygnalizowane przy omawianiu pojęcia pozostawania w dyspozycji pracodawcy użytkownika warunkującego nabycie prawa do urlopu w zatrudnieniu tymczasowym. W tym miejscu wystarczy zatem przypomnieć, że za ewentualnym uwzględnieniem tego przepisu zdaje się opowiadać M. Raczkowski, Ustawa...

198 Por. tak M. Raczkowski, Ustawa..., za: A. Sobczyk, Zatrudnienie tymczasowe, s. 90.

199 Por. A. Sobczyk, Ustawa..., s. 87.

200 Tamże. 
Z kolei art. $155^{2}$ k.p. może znaleźć zastosowanie do pracowników tymczasowych, jeżeli uznamy ewentualnie, że w okresach w przepisie tym wymienionych pracownik tymczasowy nie pozostaje „w dyspozycji pracodawcy użytkownika”, a zatem nie nabywa za ten czas urlopu wypoczynkowego ${ }^{201}$, co też rodzi pewne wątpliwości ze względu na duży stopień autonomii omawianej regulacji. Przede wszystkim jednak, $\mathrm{z}$ uwagi na bezpośrednie powiązanie w ustawie nabycia prawa do urlopu $\mathrm{z}$ jego wymiarem, jako urlopu nabywanego $\mathrm{z}$ dołu, należałoby chyba wówczas przyjąć, że chodzi o każdy okres takiej nieobecności, a nie tylko okres co najmniej miesięczny, który odsuwając w czasie moment nabycia prawa do urlopu przez pracownika tymczasowego, redukowałby w pewnych sytuacjach jego wymiar, ale w skali rocznej, w ujęciu maksymalnym.

Faktyczny wymiar urlopu wypoczynkowego pracownika, jego przełożenie na zakres potencjalnego odpoczynku, jest niewątpliwie związany z ustalonymi przez ustawodawcę zasadami jego udzielania. Mogą one bowiem wpłynąć na większe lub mniejsze ograniczenie czasu przeznaczonego na pracę w danym dniu czy tygodniu, szczególnie w systemach o zróżnicowanym dobowym wymiarze czasu pracy obowiązującym pracownika.

W świetle aktualnych przepisów jeden dzień urlopu odpowiada, co do zasady, ośmiu godzinom pracy. Wyjątek dotyczy osób, których dobowa norma czasu pracy, na podstawie odrębnych przepisów jest krótsza niż osiem godzin, wówczas jeden dzień urlopu odpowiada owej niższej normie dobowej (por. art. $1542 \S 3$ k.p.).

Związana $\mathrm{z}$ wymiarem urlopu wypoczynkowego zasada przeliczania urlopu na godziny nie wpływa znacząco na funkcję wypoczynkową omawianego prawa, chociaż pozwala bardziej równomiernie rozłożyć odpoczynek pracownika $\mathrm{w}$ stosunku do natężenia jego pracy $\mathrm{w}$ danym okresie (urlop udzielany $\mathrm{w}$ dniach w systemie równoważnym nie uwzględniał rzeczywistego wymiaru czasu pracy w danym dniu, w związku z tym albo obniżał ilość rzeczywistego wypoczynku, jeśli przypadał np. na okres pracy czterogodzinnej, albo go podwyższał, jeśli był udzielony na dni z wymiarem czasu pracy 12 godzin) i sprzyja idei równości. Niewątpliwie upraszcza to też zasady udzielania urlopu wypoczynkowego, pozwala bowiem rozstrzygnąć wiele wcześniejszych wątpliwości (por. rozważania zawarte w części pierwszej niniejszego opracowania).

Dla rzeczywistej długości okresu odpoczynku rocznego pracownika istotne znaczenie ma również sposób oznaczenia dni, na jakie urlop jest udzielany.

Warto przypomnieć choćby okres międzywojenny w Polsce, w którym nastąpiło ograniczenie faktycznego wymiaru urlopu wypoczynkowego pracownika poprzez uznanie za dni urlopu wszystkich, następujących po sobie dni kalendarzowych przypadających na czas jego udzielenia, z uwzględnieniem niedziel i świąt (por. też wcześniejsze rozważania).

Określenie wymiaru urlopu $\mathrm{w}$ dniach roboczych, przez wiele lat powszechnie stosowane $\mathrm{w}$ polskim prawie, również powodowało de facto liczne problemy

201 M. Raczkowski, Ustawa... 
z udzielaniem tego urlopu osobom wykonującym pracę także w niedziele i święta, o czym była wcześniej mowa.

Niewątpliwie bardziej czytelna jest formuła przyjęta ostatecznie przez ustawodawcę, według której urlopu udziela się w dni, które są dla pracownika dniami pracy, zgodnie z obowiązującym go rozkładem czasu pracy, w wymiarze godzinowym odpowiadającym dobowemu wymiarowi czasu pracy pracownika w danym dniu (art. $1542 \$ 1$ k.p.).

W połączeniu z zasadą wcześniej wskazaną, według której jeden dzień urlopu odpowiada ośmiu godzinom pracy, powoduje ona jednak pewne wątpliwości interpretacyjne w odniesieniu do osób zatrudnionych w niepełnym wymiarze czasu pracy, mogąc w wyjątkowych sytuacjach nadmiernie okres wykorzystywania wypoczynku wydłużać, zwłaszcza biorąc pod uwagę wymiar czasu pracy tych osób i generowane w związku $\mathrm{z}$ nim zmęczenie. Jak wskazano bowiem w literaturze przedmiotu, łączna długość odpoczynku osób wykonujących pracę na część etatu, mimo proporcjonalnego obniżenia wymiaru urlopu, o którym wcześniej była mowa, może być de facto dłuższa niż maksymalny wymiar urlopu wynoszący 26 dni. Jeśli pracownik z prawem do 26 dni urlopu zostanie zatrudniony na $1 / 8$ etatu, wówczas wymiar jego urlopu zostanie zredukowany do czterech dni, a zatem 32 godzin. Jeśli pracownik ten, zgodnie z rozkładem czasu pracy, pracował od poniedziałku do piątku po jednej godzinie, wówczas korzystając z całego przysługującego mu w tym stosunku pracy urlopu, tj. 32 godzin, będzie nieobecny przez 32 dni będące dla niego dniami pracy ${ }^{202}$. Zgadzam się jednak, że nie ma w tym przypadku podstaw do ograniczania tego wymiaru na podstawie art. $154 \$ 3$ k.p., a więc przepisu, zgodnie z którym wymiar urlopu nie może przekroczyć wymiaru ustawowo określonego, w tym przypadku taka sytuacja nie zachodzi, wymiar urlopu obejmuje bowiem cztery dni ${ }^{203}$.

Można mówić tu o pewnej dysproporcji w długości odpoczynku osoby wykonującej pracę na część etatu w stosunku do osób zatrudnionych w pełnym wymiarze, choć i te ostatnie w wyjątkowych przypadkach mogą mieć de facto dłuższy okres odpoczynku niż wynika to z wymiaru urlopu. Taka sytuacja może powstać w odniesieniu do osób zatrudnionych w systemie równoważnych norm czasu pracy, którzy mają np. w jednym tygodniu zaplanowaną pracę na cztery godziny każdego dnia od poniedziałku do piątku, a w drugim tygodniu pracę po osiem godzin. Wówczas pracownik z prawem do $20 \mathrm{dni}$ urlopu, chcąc w tych tygodniach wykorzystać jego połowę, tj. 10 dni (80 godzin), też będzie miał de facto więcej dni wolnych niż wynika $z$ tego wymiaru. W tym przypadku udzielenie urlopu na owe 10 dni pracy powoduje wykorzystanie dopiero 60 godzin tego urlopu, co oznacza, że w zależności od wymiaru czasu pracy w początkowych dniach kolejnego tygodnia może on mieć jeszcze np. dwa dni „robocze” wolne od pracy (przy pracy zaplanowanej na 12 godzin i 8).

202 Por. A. Malinowski, Urlopy pracownicze..., s. 63.

203 Por. A. Kosut, [w:] Kodeks pracy..., s. 868. 
Oczywiście sytuacja tych ostatnich pracowników jest trochę inna w stosunku do wcześniej omawianego przypadku osób zatrudnionych na część etatu, bowiem tutaj faktycznie dłuższy odpoczynek jest zawsze wynikiem wzmożonego wysiłku w innych dniach czy tygodniach, w związku z przypadającym na nie wydłużonym dobowym wymiarem czasu pracy (często do 12 godzin).

Zasada udzielania urlopu na dni zaplanowane dla danej osoby jako dni pracy nie jest konsekwentnie stosowana wobec wszystkich pracowników. Zwraca uwagę, że w odniesieniu do niektórych grup zatrudnionych, np. młodocianych, pozostawiono zasadę udzielania urlopu wypoczynkowego w „dniach roboczych” bez wyjaśnienia znaczenia użytego terminu. Pojęcie to było stosowane na gruncie wcześniejszego stanu prawnego (tj. do końca 2003 r.) w stosunku do ogółu pracowników podlegających regulacji kodeksowej i definiowane jako wszystkie dni, $\mathrm{z}$ wyjątkiem niedziel i świąt określonych w odrębnych przepisach ${ }^{204}$. Jednocześnie jednak ustawodawca wówczas w odrębnym przepisie wyraźnie wyłączył z urlopu wypoczynkowego dni dodatkowo wolne od pracy ${ }^{205}$.

Odwołanie się do tej definicji oznaczałoby, że wymiar urlopu młodocianego będzie rozkładać się na wszystkie dni przypadające w danym okresie, który ma być objęty urlopem, z wyjątkiem niedziel oraz świąt. Pominięcie tych ostatnich, szczególnych dni przy udzielaniu urlopu wypoczynkowego nie rodzi większych problemów w tym przypadku, bowiem $\mathrm{z}$ uwagi na prawo młodocianego do czterdziestoośmiogodzinnego nieprzerwanego odpoczynku obejmującego z zasady niedzielę, i tak osoby młodociane pracy w te dni zwykle nie świadczą. Jeśli natomiast okaże się, że w tygodniu występują dni będące dla młodocianego dniami pracy i te od tej pracy wolne, inne niż niedziele i święta (tu głównie soboty), wówczas niewątpliwie pozostawienie takiej metody wyznaczania dni urlopowych de facto skraca łączną ilość należnego młodocianemu wypoczynku ${ }^{206}$, co z punktu widzenia głównej funkcji urlopu wypoczynkowego, zwłaszcza w odniesieniu do omawianej grupy wiekowej, staje się trudne do racjonalnego wyjaśnienia.

Można również rozważać zawężającą interpretację pojęcia „dni roboczych”, jako że w Kodeksie pracy nie ma już definicji legalnej tych dni, w ramach której dniami roboczymi byłyby wszystkie dni oznaczone dla danego pracownika jako dni pracy, z wyłączeniem niedziel i świąt, które ustawowo są wolne od pracy. W efekcie doszłoby do większego zrównania w istocie zasad udzielania urlopu wypoczynkowego w omawianym zakresie w odniesieniu do wszystkich kategorii pracowników, ze względu na możliwość nieudzielania urlopu wymierzanego w dniach roboczych na dni dodatkowo wolne od pracy.

204 Por. dawny art. 154 § 2 k.p.

205 Por. dawny art. 154 § 3 k.p., zgodnie z którym dodatkowych dni wolnych od pracy, o których mowa w art. $129^{1} \S 1$ i $129^{2}$, nie wlicza się do urlopu.

206 Osoba petnoletnia z prawem do 26 dni urlopu, pracując od poniedziałku do piątku po osiem godzin, uzyska, wykorzystując cały urlop, ponad pięć tygodni wolnych od pracy. Tymczasem młodociany z prawem do 26 dni urlopu, wykonując pracę od poniedziałku do piątku, uzyska tylko nieco ponad cztery tygodnie urlopu. 
W literaturze przedmiotu zaprezentowano także stanowisko, według którego chodzi o dni robocze w wymiarze indywidualnym, a więc zrównujące w pełni pojęcie dni, które są dla danego pracownika dniami pracy (przy uwzględnieniu niedziel i świąt) $\mathrm{z}$ omawianym terminem ${ }^{207}$. Takie ujęcie pozwala $\mathrm{w}$ najpełniejszy sposób zrealizować przyznany poszczególnym pracownikom większy wymiar odpoczynku rocznego, choć budzi pewne wątpliwości w kontekście przepisów ustawowych, w których, po pierwsze, ustawodawca nie odwołuje się do dni roboczych danego pracownika, a ponadto, według których niedziele i święta są dniami wolnymi od pracy, a tym samym niemieszczącymi się w pojęciu dni roboczych. Ustawodawca powinien niewątpliwie jednoznacznie tę kwestię rozstrzygnąć.

Tego rodzaju interpretacja analizowanego zwrotu jest przyjmowana zwłaszcza w odniesieniu do nauczycieli akademickich, których wymiar urlopu również został określony w dniach roboczych. Niemniej w tym przypadku ustawodawca w ust. 6 art. 133 ustawy - Prawo o szkolnictwie wyższym wyraźnie wskazuje, że nie wlicza się do tego urlopu dni wolnych od pracy wynikających z rozkładu czasu pracy w pięciodniowym tygodniu pracy. Zdaniem Z. Górala, oznacza to, że zwrot „dni robocze” jest w zasadzie równoznaczny z formułą kodeksową - dni, które są dla danego pracownika dniami pracy, co w praktyce oznacza, że urlop wypoczynkowy takiego nauczyciela dotyczy tylko dni od poniedziałku do piątku, z wyłączeniem niedziel i świąt oraz sobót ${ }^{208}$.

W powyższym ujęciu nie uwzględnia się jednak faktu, że nauczyciel akademicki świadczy często pracę w soboty i niedziele, co oznaczałoby, przy bezpośrednim zrównaniu omawianego pojęcia z regulacją zawartą w Kodeksie pracy, konieczność objęcia również tych dni urlopem.

Udzielanie urlopu wypoczynkowego tej grupie zawodowej na dni od poniedziałku do piątku uznaje za zasadne również W. Sanetra, choć autor ten utożsamia, jak sam wskazuje, analizowany termin z dniami kalendarzowymi, z wyłączeniem jednak niedziel, świąt oraz sobót. Podstawą przyjęcia takiej metody ustalania dni, na które udziela się urlopu nauczycielowi akademickiemu, jest czas pracy nauczyciela akademickiego będący formą zadaniowego czasu pracy oraz okoliczność, że urlop ten powinien być wykorzystany w okresie wolnym od zajęć dydaktycznych, a ponieważ $\mathrm{w}$ tym okresie nauczyciel zajęć nie prowadzi, to inna interpretacja prowadziłaby do wniosku, że dni przypadające na ten okres nie są w ogóle dniami roboczymi ${ }^{209}$.

Warto w nawiązaniu do powyższego przypomnieć, że kwestia możliwości wykorzystania przez nauczyciela akademickiego urlopu wypoczynkowego wyłącznie w okresie wolnym od zajęć dydaktycznych jest w doktrynie prawa pracy sporna, co było już wcześniej sygnalizowane.

207 Por. A. Kosut, [w:] Kodeks pracy..., s. 864. Podobnie T. Nycz, Prawo do urlopu wypoczynkowego... 208 Por. Z. Góral, [w:] Akademickie prawo..., s. 236 i n.

209 Por. W. Sanetra, [w:] Prawo..., s. 303. 
Ponadto rodzi się też taka refleksja, że powiązanie urlopu wypoczynkowego nauczyciela akademickiego zatrudnionego na stanowisku naukowo-dydaktycznym wyłącznie z okresem prowadzenia zajęć dydaktycznych powoduje, że w zasadzie ten pierwszy aspekt jego zatrudnienia nie znajduje w tych uprawnieniach swego odzwierciedlenia.

Analogiczny problem, choć bardziej jeszcze złożony, występuje także na gruncie ustawy - Karta Nauczyciela, która również przewiduje udzielanie urlopu wypoczynkowego $\mathrm{w}$ dniach roboczych $\mathrm{w}$ odniesieniu do nauczycieli zatrudnionych w szkołach, w których organizacji nie przewidziano ferii szkolnych (pozostałym udziela się urlopu po prostu na czas trwania tych ferii, a zatem w dniach kalendarzowych), jednocześnie nie wyjaśniając tego terminu ${ }^{210}$. I tutaj zatem ustawodawca z jednej strony, zwiększając nominalny wymiar tego urlopu do 35 dni, jednocześnie, poprzez zasady jego udzielania, może $\mathrm{w}$ istocie, $\mathrm{w}$ zależności od przyjętego sposobu liczenia tego urlopu, długość wypoczynku takiego pracownika w pewnych przypadkach ograniczać. Nauczyciele również objęci są bowiem zasadą maksymalnie pięciodniowego tygodnia pracy, co oznacza, przy założeniu, że niedziele są wolne od pracy, występowanie przynajmniej jednego dnia dodatkowo wolnego od zajęć w tygodniu (niekiedy mogą wystąpić nawet dwa takie dni) - por. art. 42c ust. 1 Karty Nauczyciela. Ponadto mogą być oni zatrudnieni na część etatu i świadczyć pracę tylko w pojedyncze, wybrane dni tygodnia. Rodzi to problem, na jakie dni wówczas należy takiemu nauczycielowi udzielić urlopu. W praktyce sugeruje się przyjmowanie korzystniejszej dla tej grupy nauczycieli wykładni, o której była mowa wyżej, odpowiadającej regulacji kodeksowej, a zatem udzielania urlopu na dni, które są dla danego nauczyciela dniami pracy według arkusza organizacji pracy placówki (np. przedszkola czy poradni psychologiczno-pedagogicznej) $)^{211}$.

Nie rozwiązuje to jednak wszystkich problemów, zważywszy na fakt występowania placówek nieferyjnych, w ramach których praca jest wykonywana też w niedziele i święta (np. schroniska młodzieżowe), które to dni w świetle obowiązującego prawa, $z$ braku odmiennych postanowień w samej ustawie, nie powinny być raczej utożsamiane $\mathrm{z}$ „dniami roboczymi”, choć zaprezentowano w tej kwestii odmienną opinię, o czym była wyżej mowa.

Kwestią budzącą pewne wątpliwości, z braku wyraźnego przepisu w Karcie Nauczyciela, jest również przeliczanie urlopu omawianej grupy nauczycieli na godziny, zgodnie $\mathrm{z}$ regułami kodeksowymi, które generalnie $\mathrm{w}$ większym stopniu znajdują do nich swoje zastosowanie. W praktyce jest to powszechnie przyjmowane, niemniej i w tym zakresie powstają komplikacje dotyczące zwłaszcza określenia liczby godzin wykorzystanego przez nauczyciela urlopu związane z brakiem określenia dobowej normy czasu pracy nauczyciela i zaliczaniem do tego czasu nie tylko godzin prowadzonych zajęć dydaktycznych (pensum), ale i innych czynności (np. związanych z samodoskonaleniem zawodowym, dokształcaniem, realizacją zadań opiekuńczo-wychowawczych).

210 Por. art. 64 ust. 1 i ust. 3 wskazanej ustawy.

211 Por. tak [w:] 22 wskazówki jak udzielać urlopów nauczycielom i je rozliczać. Urlopy i ekwiwalent w placówkach feryjnych i nieferyjnych, www.portaloswiatowy.pl, s. 14. 
Mało precyzyjny sposób regulacji ustawowej próbuje się m.in. w analizowanym obszarze wypełnić w praktyce konkretnymi wskazówkami interpretacyjnymi212, lecz nie zawsze odpowiadają one w pełni literalnemu brzmieniu ustawy oraz gwarantują zadowalające i spójne rezultaty, co samo w sobie stanowi pewne zagrożenie dla prawidłowego przebiegu funkcji wypoczynkowej urlopu nauczycieli szkół nieferyjnych, w tym zwłaszcza pod względem równego ich traktowania ${ }^{213}$. Tego rodzaju niejasności powinny zostać niewątpliwie wyraźnie rozstrzygnięte przez ustawodawcę.

W nieco innej formie zasada wyrażona w Kodeksie pracy, zgodnie z którą urlopu udziela się pracownikowi na dni będące dla niego dniami pracy, znalazła natomiast swój wyraz w ustawie o pracownikach tymczasowych, w której stanowi się o udzieleniu takiemu pracownikowi urlopu wypoczynkowego w te dni, które byłyby dla niego dniami pracy, gdyby nie korzystał z tego urlopu. Dni urlopowe nie mogą zatem obejmować tych dni, w których pracownik tymczasowy pracy w ogóle nie świadczył.

W odniesieniu do tej grupy nie przelicza się jednak urlopu na godziny ${ }^{214}$.

\section{Zasady prawa urlopowego}

\subsection{Niezbywalność prawa do urlopu wypoczynkowego}

Jednym z podstawowych osiągnięć w zakresie prawa urlopowego jest uznanie niezbywalności tego prawa. Jeszcze w okresie Polskiej Rzeczypospolitej Ludowej dość długo funkcjonowało przeświadczenie, że pracownik ma podmiotowe prawo do urlopu, z którego może, ale nie musi skorzystać ${ }^{215}$. Z czasem ustawodawca zdecydowanie odstąpił od takiego zapatrywania i zgodnie z obowiązującym

212 Departament Strategii Ministerstwa Edukacji Narodowej w piśmie z dnia 31 grudnia 2009 r. (DS.-WPZN-WE-421-4/09) przyjąt, że do celów rozliczania urlopu wypoczynkowego nauczycieli szkół nieferyjnych należy uwzględnić nie tylko godziny dydaktyczne, tj. pensum, ale łączny wymiar czasu pracy nauczyciela. Wymiar ten tygodniowo wynosi do 40 godzin, stąd uznano, że ustalając uprawnienia urlopowe takiego nauczyciela należy założyć, że średnio na dobę pracuje on osiem godzin. W rezultacie nauczyciel zatrudniony na cały etat ma prawo do urlopu w wymiarze 280 godzin. Udzielając 4 dni urlopu, należy zatem odliczyć z tej puli 32 godziny.

213 Zgodnie m.in. z pismem Generalnego Inspektora Pracy z 14 stycznia 2010 r. (GPP-118-456092/09/PE/RP), nie jest chociażby możliwe przyjęcie innego niż wyjaśnione w powyższym przypisie sposobu rozliczania urlopu wypoczynkowego nauczyciela placówki nieferyjnej, gdyż powodowałoby to nieuzasadnione różnice w uprawnieniach urlopowych nauczycieli z uwagi na ich zróżnicowane pensum.

214 Por. tak: A. Sobczyk, Ustawa..., s. 87.

215 Por. szerzej: J. Loga, Urlopy wypoczynkowe..., s. 112. 
art. $152 \$ 2$ k.p. pracownik nie może zrzec się prawa do urlopu. Nie może on ponadto również zrzec się roszczenia już wymagalnego, gdyż art. 161 i 168 k.p. nakładają na pracodawcę wyraźny obowiązek udzielenia pracownikowi urlopu w terminach przewidzianych prawem. Oznacza to, że wszelkie jednostronne oświadczenia pracownika, bez względu na to, czy złożone w pełni dobrowolnie czy też nie, oraz porozumienia zawierane $\mathrm{z}$ pracodawcą, $\mathrm{w}$ których zwalniałby on pracodawcę z obowiązku udzielenia urlopu w całości lub choćby w części, należy uznać za nieważne z mocy prawa.

Zasada powyższa, mająca charakter bezwzględny, stanowi niewątpliwie podstawowy gwarant skutecznej realizacji prawa pracownika do wypoczynku (nie tylko $w$ Polsce $\left.{ }^{216}\right)$. Z jednej strony chroni bowiem pracownika przed wszelkimi formami presji ze strony pracodawcy w kwestii rezygnacji z przysługującego mu wypoczynku, wbrew jego woli, ale ma również, z drugiej strony, przeciwdziałać praktykom swego rodzaju sprzedaży tego prawa, polegającym na zrzeczeniu się urlopu w związku z określoną gratyfikacją finansową. Dłuższa przerwa od wykonywanej $\mathrm{w}$ celach zarobkowych pracy u danego pracodawcy ma pierwszorzędne znaczenia dla ochrony życia i zdrowia pracownika, ale też innych osób z nim współpracujących, czy nawet istotny walor społeczny, o czym była mowa w pierwszej części opracowania. Stąd prawo to nie może być poddane swoistym targom, czy w zakresie jego realizacji narażone na wykorzystywanie przez pracodawcę trudnej sytuacji materialnej zatrudnionego.

Pracodawca, który nie wywiąże się ze swego obowiązku udzielenia urlopu wypoczynkowego, popełnia wykroczenie przeciwko prawom pracownika. Zagadnienie to, choć dziś wydaje się, że jednoznacznie rozstrzygnięte normami Kodeksu pracy, nadal wywołuje wiele kontrowersji w praktyce. Osoby stosujące przepisy prawa urlopowego często zgłaszają bowiem, że pracownicy niekiedy nie chcą wykorzystać przysługującego im urlopu. W tym kontekście trzeba jeszcze raz podkreślić, że pisemne oświadczenie pracownika, zwalniające pracodawcę z obowiązku udzielenia urlopu w ogóle lub w maksymalnym ustawowym terminie (do końca września roku następnego) nie ma żadnego znaczenia prawnego. Pracodawca, chcąc uniknąć negatywnych konsekwencji związanych z nieudzieleniem urlopu w odpowiednim czasie, powinien odmówić dopuszczenia pracownika do pracy $\mathrm{w}$ terminie ustalonym $\mathrm{w}$ planie (czy indywidualnie $\mathrm{z}$ pracownikiem $\mathrm{w}$ razie braku planu urlopów) jako moment rozpoczęcia urlopu lub też w sytuacji przesunięcia urlopu i braku doprecyzowania terminu jego wykorzystania - w ostatnich dniach września roku następnego odpowiednio do wymiaru tego urlopu ${ }^{217}$. W szczegól-

216 Zakaz taki sformułowano m.in. w hiszpańskim prawie urlopowym. Pracownik nie może się zrzec prawa do urlopu za podwójną płacę. Por. M.A. Olea, F. Rodriguez-Sanudo, Labour Law in Spain, Alphen aan den Rijn 2010, s. 72.

217 Taka możliwość jest również uznawana w judykaturze. Por. uzasadnienie wyroku SN z 7 maja 2008 r., II PK 313/07, OSNP 2009, nr 17-18, poz. 229. Por też: wyrok SN z 2 września 2003 r., I PK 403/02, OSNP 2004, nr 18, poz. 310. Na ten temat ogólnie też E. Chmielek-Łubińska, Urlopy wypoczynkowe..., s. 54. 
ności nie można tu, w moim przekonaniu, z uwagi właśnie na podstawową zasadę prawa pracownika do wypoczynku i określone przepisy kodeksowe kształtujące reguły udzielania urlopu wypoczynkowego, powoływać się na normy prawa cywilnego i wypływające z nich skutki dotyczące braku współdziałania dłużnika z wierzycielem w celu wykonania zobowiązania ${ }^{218}$.

W sytuacji przeciwnej, kiedy to pracodawca nie dopełnia obowiązku związanego z udzieleniem urlopu wypoczynkowego, dominuje pogląd, że pracownik nie ma prawa do podjęcia urlopu bez zgody pracodawcy, a służy mu jedynie prawo dochodzenia tego świadczenia na drodze sądowej ${ }^{219}$, ewentualnie, w szczególnych przypadkach, prawo do rozwiązania niezwłocznego stosunku pracy z powodu ciężkiego naruszenia podstawowych obowiązków przez pracodawcę, czy możliwość wystąpienia o odszkodowanie i zadośćuczynienie na podstawie przepisów prawa cywilnego. Ustawodawca decyzję w przedmiocie udzielenia urlopu pozostawia bowiem we wszystkich przypadkach (nawet urlopu na żądanie) pracodawcy. Zapatrywanie to zdaje się ponadto w pełni podzielać dziś Sąd Najwyższy, który w licznych swych orzeczeniach przyjmuje zasadę, że pracownikowi bez wyraźnej akceptacji pracodawcy (nawet gdy pracodawca narusza obowiązujące prawo) rozpocząć urlopu nie wolno ${ }^{220}$.

$\mathrm{Z}$ perspektywy istoty i znaczenia prawa do odpoczynku taki stan nie jest być może idealny, ale, jak się wydaje, dostatecznie zabezpieczający podstawową funkcję omawianego prawa. Sankcja finansowa wynikająca z popełnionego wykroczenia oraz możliwość dochodzenia udzielenia urlopu na drodze sądowej, nawet w naturze, o czym będzie dalej mowa, są środkami sprzyjającymi jego urzeczywistnianiu. Być może należałoby też rozważyć możliwość wyposażenia inspekcji pracy w dodatkowe instrumenty, zwłaszcza w sytuacji rażących naruszeń po stronie pracodawcy, w związku z tym, że nie zawsze pracownicy są skorzy do sądowego sporu, szczególnie w okresie trwającego zatrudnienia, a więc wtedy, gdy prawo do odpoczynku ma największe znaczenie i może zostać najskuteczniej zrealizowane.

218 Na taki obowiązek wskazuje się czasami w literaturze. Por. np. I. Boruta, Urlopy wypoczynkowe..., s. 49.

219 Por. J. Loga, Urlopy wypoczynkowe..., s. 143 i n.

220 Por. m.in. orzeczenie SN z 10 listopada 1998 r., I PKN 364/98, OSNP 1999, nr 24, poz. 788; orzeczenie SN z 13 maja 1998 r., I PKN 99/98, OSNP 1999, nr 10, poz. 331. O urlopie „udzielanym” pracownikowi, a nie przez niego „branym” por też A. Sobczyk, Państwo zakładów pracy, Warszawa 2017, s. 255. Jak wskazuje autor, pracownik posiada prawo do urlopu, ale nie może z niego samodzielnie skorzystać. Podobną zasadę formułuje się również na gruncie prawa niemieckiego. Por. M. Henssler, H.J. Willemsen, H.-J. Kalb (Hrsg.), Arbeitsrecht..., s. 1903 i n. 


\subsection{Nieprzerwany charakter urlopu wypoczynkowego}

Z art. $152 \$ 1$ k.p. wynika bezpośrednio, że urlop wypoczynkowy powinien mieć charakter nieprzerwany.

W szerokim ujęciu będzie to oznaczać, że pracodawca ma zasadniczo obowiązek udzielenia pracownikowi w wyraźnie określonym czasie urlopu, w pełnym przysługującym mu wymiarze (zakaz dzielenia urlopu na części), a pracownik powinien ten urlop bez przeszkód w tym okresie wykorzystać zgodnie z jego przeznaczeniem $^{221}$.

Zasada ta rozumiana węziej sprowadza się natomiast do uznania za podstawową regułę prawa pracownika do zrealizowania w sposób nieprzerwany udzielonej mu części (czy też całości) należnego urlopu wypoczynkowego. Tym samym jeśli pracownik już urlop rozpoczął, to w sposób niezakłócony, zwłaszcza przez pracodawcę, powinien do końca umówionego czasu z niego korzystać, wypoczywać. Jak tłumaczył J. Loga, „nieprzerwany czas wolny od pracy oznacza, że przez ustaloną liczbę dni następujących po sobie, pracodawca nie ma prawa żądania świadczenia pracy przez urlopowanego pracownika"222.

Reguła powyższa zarówno w ujęciu wąskim, jak i szerokim, przyjętym ostatecznie na potrzeby niniejszych rozważań, odgrywa bardzo ważną rolę w procesie urzeczywistniania podstawowej funkcji urlopu, co dostrzegł wyraźnie ustawodawca (nie tylko polski ${ }^{223}$ ), eksponując ją jako jedną z głównych cech omawianej instytucji. Jej konsekwencją jest bowiem wiele istotnych ograniczeń, które zarówno z osobna, jak i łącznie gwarantują, że urlop zostanie wykorzystany zgodnie z jego przeznaczeniem. Wśród nich należy zwrócić uwagę przede wszystkim na:

221 Tak pojmował tę zasadę m.in. J. Loga, Wymiar urlopu wypoczynkowego, PiZS 1981, nr 5-6, s. 140. Czasami jednak wyodrębnia się w związku z tym obok zasady urlopu nieprzerwanego, rozumianej wąsko, zasadę urlopu w całości, która oznacza zakaz dzielenia urlopu na części. Por. m.in. M. Kuba, M. Nowak, E. Staszewska, Urlopy pracownicze, s. 115 i n.

222 J. Loga, Wymiar urlopu..., s. 138. Niemniej, jak już wyżej sygnalizowano, dalsze wywody autora świadczą, że rozumiał on tę cechę urlopu wypoczynkowego szeroko, również jako ograniczenie swobody podziału urlopu na części.

223 Zasada urlopu nieprzerwanego (ciągłego) jest formułowana m.in. w prawie włoskim. W praktyce jednak czas trwania tego urlopu jest negocjowany przez pracodawcę z reprezentacją pracowniczą; zwykle gwarantuje się minimum trzytygodniowy ciągły urlop. Por. T. Treu, Labour Law in Italy, Alphen aan den Rijn 2011, s. 85. W Hiszpanii regułą jest minimum trzydziestodniowy urlop wypoczynkowy, który wyjątkowo może być podzielony na części, po warunkiem, że jedna część tego urlopu nie będzie krótsza niż dwa tygodnie. Por. M.A. Olea, F. Rodriguez-Sanudo, Labour Law in Spain, s. 72. Określone gwarancje w tym zakresie przyjęto również w prawie francuskim. Z drugiej strony urlop wypoczynkowy nie może tam być udzielony jednorazowo w wymiarze wyższym niż 24 dni robocze. Por. G. Auzero, E. Dockès, Droit ..., s. 872. Także w Niemczech urlop powinien być udzielony w całości, a wyjątkowo, jeśli pilne potrzeby pracownika i pracodawcy za tym przemawiają, może być podzielony na części, z zastrzeżeniem, że jedna jego część będzie obejmować nie mniej niż 12 dni roboczych następujących po sobie. Por. M. Henssler, H.J. Willemsen, H.-J. Kalb (Hrsg.), Arbeitsrecht..., s. 1881 i n. 
- ograniczenie możliwości dzielenia urlopu na części z woli stron;

- niedopuszczalność zobowiązywania pracownika do pozostawania w dyspozycji pracodawcy w tym czasie, a w szczególności realizowania obowiązku wykonywania pracy i związanego z tym przerywania okresu odpoczynku; chodzi zatem o to, aby w całym okresie udzielonego pracownikowi zwolnienia od pracy, wyraźnie określonym ${ }^{224}$, nie musiał się on liczyć $\mathrm{z}$ wezwaniem go przez pracodawcę do świadczenia pracy (w konsekwencji często pojęciem urlopu obejmuje się również dni bezpośrednio do niego przylegające, ale nie będące urlopem sensu stricto);

- wyłączenie możliwości korzystania z urlopu w okresach pokrywających się z przerwami w pracy, których cel jest inny niż wypoczynek ${ }^{225}$.

Ostatnie dwie kwestie wiążą się ściśle z zasadą spokoju urlopowego, o której będzie dalej mowa.

Ważne znaczenie z punktu widzenia urlopu jako instytucji realizującej prawo pracownika do wypoczynku ma niewątpliwie powinność wykorzystania przez pracownika urlopu wypoczynkowego w całości, tj. jednorazowo, w pełnym przysługującym mu wymiarze. Urlop wypoczynkowy ma bowiem służyć przede wszystkim do regeneracji psychicznej i fizycznej pracownika, stąd jego nadmierne rozdrobnienie mogłoby realizacji tej podstawowej funkcji urlopu istotnie zagrażać, a niekiedy wręcz ją przekreślać. Odpoczynek, aby spełnił swe podstawowe funkcje, powinien trwać dłuższy czas. Z badań wynika, że organizm ludzki przez pierwszy tydzień przystosowuje się do nowej sytuacji wynikającej z zaprzestania wykonywania pracy zawodowej, zmiany otoczenia, warunków klimatycznych itp., a dopiero w kolejnym tygodniu rozpoczyna się pełny proces jego psychofizycznej regeneracji. Stąd dość ważne jest ograniczenie możliwości podziału urlopu wypoczynkowego na części.

Ustawodawca formalnie dostrzegł wagę omawianego zagadnienia, zabezpieczając tym samym wypoczynkową funkcję urlopu w minimalnym zakresie i wprowadzając w art. 162 k.p. wymóg, aby w razie podziału urlopu na wniosek pracownika, jedna jego część, bez znaczenia która, obejmowała nie mniej niż 14 kolejnych dni kalendarzowych.

Odwołanie się w powołanej normie do dni kalendarzowych, a nie do dni urlopu, powoduje, że ustalając, czy ów warunek prawidłowego podziału wypoczynku został spełniony, należy uwzględnić poza dniami stricte urlopowymi wszystkie przystające do nich niedziele, święta i dni dodatkowo wolne od pracy. W praktyce oznacza to, że jeśli ktoś pracuje tradycyjnie od poniedziałku do piątku w podstawowym systemie czasu pracy (osiem godzin na dobę), to wystarczy w jakimś okresie udzielić mu 10 dni urlopu, żeby opisany wymóg kodeksowy został spełniony.

224 Por. w tym zakresie wyrok SN z 19 stycznia 2017 r., I PK 40/16, LEX nr 2209124, w którego uzasadnieniu SN bardzo słusznie podkreślit, że pracodawca udzielając urlopu, musi precyzyjnie wskazać datę jego rozpoczęcia i zakończenia, tak aby pracownik wiedział, w jakim okresie może swoim czasem swobodnie dysponować.

225 Tak por. m.in.: J. Loga, Urlopy wypoczynkowe..., s. 114. 
Nie tyle istotne jest tu bowiem, ile dni urlopu pracownikowi udzielono, co ile czasu może on de facto z tego tytułu odpoczywać.

Jednocześnie jest to jedyne ograniczenie swobody stron $\mathrm{w}$ zakresie dzielenia urlopu na części, w szczególności ustawodawca nie zdecydował się, co wydaje się ważne ze względu na przedmiot rozważań, określić maksymalnej liczby dopuszczalnych ostatecznie podziałów dokonywanych z inicjatywy pracownika (np. że urlop może być podzielony maksymalnie na x części, z których jedna powinna obejmować nie mniej...). Z jednej strony, jak się wydaje, może być to uwarunkowane treścią innych unormowań z zakresu prawa urlopowego, które $\mathrm{w}$ istocie do takiego podziału prowadzą, np. urlop na żądanie (choć można w tym zakresie dokonać stosownego wyłączenia). Ponadto pewna swoboda pracownika co do określenia sposobu realizacji jego prawa do odpoczynku powinna być jednak zachowana. W wielu wypadkach bowiem to od rodzaju pracy, preferowanej formy wypoczynku, właściwości organizmu zależy to, jak korzystając z urlopu (jednorazowo czy w określonych odcinkach czasowych) pracownik spożytkuje ten odpoczynek najefektywniej ${ }^{226}$.

$\mathrm{Z}$ drugiej jednak strony, brak takiego limitu powoduje możliwość rozdrobnienia pozostałej części urlopu (połowy i więcej) na pojedyncze dni, co nie do końca przystaje do charakteru i celów omawianej instytucji i może być poczytywane jako poważny mankament przyjętych w tym obszarze rozwiązań. Powstaje bowiem realna groźba, że urlop ten będzie wykorzystywany przez pracownika na załatwienie ważnych spraw, a nie na odpoczynek.

Z powyższego wynika, że ustawowa możliwość podziału urlopu na części, na etapie zarówno jego planowania, jak i realizacji, może być dokonana tylko na wniosek pracownika. Generalnie wyłączono zatem dopuszczalność udzielenia urlopu w ograniczonym wymiarze $\mathrm{z}$ inicjatywy podmiotu zatrudniającego. Pracownik, który chce wykorzystać urlop w określonych fragmentach, powinien więc wystąpić w tej sprawie do pracodawcy ze stosownym wnioskiem, najlepiej mającym formę pisemną i zawierającym dokładne wskazanie, kiedy i ile dni urlopu ma być temu pracownikowi udzielone $e^{227}$.

Niemniej wniosek pracownika w omawianej sprawie nie ma dla pracodawcy charakteru wiążącego, tzn. pracodawca może uznać np., że dla sprawnej organi-

226 Bardzo ciekawe, z tego punktu widzenia, rozwiązanie funkcjonuje we Francji, gdzie pracownik jeden tydzień niewykorzystanego urlopu (piąty) może odłożyć na swoje konto oszczędnościowe czasu pracy. Por. G. Auzero, E. Dockès, Droit..., s. 871 i n.

$227 \mathrm{~W}$ piśmiennictwie bywa formułowany pogląd, że wniosek taki powinien być dodatkowo uzasadniony ważnymi przyczynami, jeśli pracownik swą wolę w zakresie podziału urlopu ujawnia już po jego zaplanowaniu czy uzgodnieniu terminu jego wykorzystania z pracodawcą. Wówczas dochodzi bowiem do przesunięcia terminu urlopu i zastosowanie powinien znaleźć art. 164 k.p. Por. tak E. Chmielek-Łubińska, [w:] Kodeks pracy..., s. 902; A. Kosut, [w:] Kodeks pracy..., s. 898 i n.; J. Iwulski, [w:] J. Iwulski, W. Sanetra, Kodeks pracy..., s. 459. Odmiennie K. Rączka, [w:] Kodeks pracy..., 2003, s. 528. Zmiana dotyczy, zdaniem autora, terminu końcowego urlopu, a nie, jak przy jego przesunięciu, daty początkowej. 
zacji procesu pracy, a także efektywności wypoczynku pracownika, będzie lepiej, jeśli pracownik wykorzysta ten urlop w określonym czasie w całości i w związku z tym wniosek pracownika odrzucić.

De facto konstrukcja podziału urlopu na części została oparta na swoistym porozumieniu, do jakiego musi w tym zakresie dojść między stronami stosunku pracy, z ograniczeniem inicjatywy jego zawarcia do osoby pracownika. Ten ostatni powinien zdecydować, czy preferuje odpoczynek jednorazowy, ale dłuższy, czy też woli odpoczynek jednorazowo nieco krótszy, ale z możliwością wykorzystania pozostałej części urlopu w innym terminie. Ostateczną decyzję w tej sprawie podejmie jednak pracodawca, który poza względami czysto organizacyjnymi powinien dokonać również oceny poziomu zmęczenia danego pracownika.

Biorąc pod uwagę możliwą i często występującą praktykę łączenia dni urlopu z dniami ustawowo wolnymi od pracy, zwłaszcza świętami, wydaje się, że główna funkcja urlopu wypoczynkowego przy tak sformułowanym wyjątku została, mimo wszystko, zachowana.

Warunkiem prawidłowego przebiegu wypoczynkowej funkcji urlopu przy wprowadzeniu omawianego przepisu jest jednak właściwe jego stosowanie. Dziwić więc może, że nie określono sankcji za niedopełnienie wynikających z niego obowiązków, co w praktyce powoduje, że jest on często naruszany, zwłaszcza jeśli chodzi o podmiot inicjujący podział urlopu na części. Rozważać oczywiście można w tym zakresie roszczenie pracownika o odszkodowanie na ogólnych zasadach prawa cywilnego ${ }^{228}$, którego dochodzenie, w związku z koniecznością wykazania szkody, może się okazać stosunkowo trudne. Wskazuje się jednak w tym obszarze też na zadośćuczynienie w związku z naruszeniem dóbr osobistych pracownika, do których, według omawianego w pierwszej części orzecznictwa, należy również odpoczynek jako wartość prawnie chroniona. Tym samym, zgodnie z wyrażonym w doktrynie prawa pracy poglądem, samo prawo do czternastodniowego odpoczynku oraz związana z nim przyjemność odczuwana przez zatrudnionego mogą stanowić swego rodzaju dobro osobiste ${ }^{229}$. Słusznie też podnosi się w literaturze, że mając na uwadze cel urlopu, tego rodzaju naruszenia prawa pracownika do nieprzerwanego odpoczynku nie pozwalają na pełną regenerację jego sił, a tym samym stanowią zagrożenie dla zdrowia pracownika, które w świetle art. 23 k.c. także podlega ochronie ${ }^{230}$. W rezultacie pracownik, któremu nie udzielono urlopu przy zachowaniu omawianej reguły, może dochodzić od pracodawcy odpowiedniego zadośćuczynienia, a ten, któremu pracodawca odmawia odpoczynku, w określonym przez prawo minimalnym wymiarze, będzie mógł wystąpić z roszczeniem o zaniechanie naruszeń ${ }^{231}$.

$228 \mathrm{Na}$ temat zgłaszanych w tym zakresie w doktrynie opinii por. A. Wypych-Żywicka, [w:] Kodeks pracy z komentarzem, red. U. Jackowiak, Warszawa 2004.

229 Por. S. Koczur, Faktyczne możliwości realizacji pracowniczego prawa do nieprzerwanego odpoczynku, M.P.P. 2015, nr 9, s. 465.

230 Tamże.

231 Tamże. 
Warto zauważyć, że sam kształt obecnych regulacji z zakresu prawa urlopowego, pomijając opisany wyżej wyjątek bezpośrednio odnoszący się do tej kwestii, czyni w niektórych przypadkach regułę udzielania urlop w całości w istocie mało skuteczną, a czasami wręcz iluzoryczną. Takie instytucje, jak odwołanie pracownika z urlopu czy jego obligatoryjne przerwanie w określonych przez prawo przypadkach, również będą powodować, że nie zawsze urlop ten może zostać przez pracownika w odpowiednim wymiarze i bez przeszkód wykorzystany, o czym szerzej w ostatniej części opracowania.

Ze swoistym rozdrobnieniem prawa do urlopu wypoczynkowego łączy się też urlop w pierwszym roku zatrudnienia, o czym była mowa wcześniej, oraz urlop pracowników tymczasowych. Mamy tu jednak do czynienia ze specyficzną konstrukcją, nie dochodzi tu bowiem do podziału już przysługującego pracownikowi pełnego wymiaru urlopu, ale do nabycia prawa do urlopu w cząstkowym jego wymiarze. $\mathrm{Z}$ uwagi na to urlop ten, mimo że bardzo krótki, jest w jakimś sensie zrealizowany w całości.

Zasada nieprzerwanego urlopu wypoczynkowego opiera się również na założeniu, że w udzielonym pracownikowi czasie wolnym od pracy powinien on w sposób ciągły odpoczywać, zgodnie z samą istotą omawianej instytucji.

Pierwszą konsekwencją takiego jej ujęcia jest konieczność uznania, że pracownik nie może być w okresie urlopu zobowiązany nie tylko do świadczenia pracy, ale też pozostawania w gotowości do jej wykonywania czy oczekiwania na wezwanie podmiotu zatrudniającego, np. poprzez sformułowanie obowiązku utrzymywania stałego kontaktu telefonicznego z pracodawcą.

W dobie telefonii komórkowej jest to bardzo poważne zagrożenie dla zachowania zasady urlopu nieprzerwanego oraz spokoju urlopowego, o którym będzie szerzej mowa w dalszej części rozważań, a ostatecznie dla samej funkcji, jaką urlop wypoczynkowy powinien spełniać. $\mathrm{W}$ tym przypadku zwolnienie od obowiązku świadczenia pracy w celu wypoczynku, dodatkowo o charakterze nieprzerwanym, stanowiące jego cechę pojęciową, musi być rozumiane szeroko. Żeby urlop spełnił swoje zadanie, pozwolił na psychofizyczną regenerację organizmu, powinien to być okres wolny także od samego myślenia o obowiązkach zawodowych. Stąd naruszeniem wskazanych wyżej zasad, jest nie tylko kontaktowanie się w czasie urlopu z pracownikiem $\mathrm{w}$ celu wyjaśnienia określonych spraw związanych z pracą przez pracodawcę lub inne osoby działające w jego imieniu, ale też za niedopuszczalne, moim zdaniem, należy uznać wszelkie formy zobowiązywania pracownika do odbierania tego rodzaju telefonów lub do korzystania z innych środków komunikowania się na odległość (np. odbierania służbowych e-maili). Byłoby to wówczas znaczące ograniczenie prawa pracownika do wypoczynku, a w niektórych przypadkach wręcz wypaczenie jego zasadniczej idei. Jak wynika z wcześniejszej analizy, urlop jest zwolnieniem pracownika $\mathrm{z}$ obowiązku wykonywania pracy w określonym czasie przeznaczonym na wypoczynek. Stan oczekiwania na potencjalne wezwanie do pracy pozostaje więc w sprzeczności zarówno z samym charakterem omawianej instytucji, jak i potrzebą urzeczywistnienia jej podstawowej 
funkcji, która w opisanych warunkach nie może być w pełni zachowana. Stan ten można bowiem uznać, zwłaszcza w niektórych przypadkach, za swoistą postać dyżuru „pod telefonem”232.

Powyższy sposób interpretacji obowiązujących przepisów poświęconych urlopom wypoczynkowym znalazł swoje odzwierciedlenie także w orzecznictwie sądowym. W szczególności za trafny należy uznać wyrok Sądu Najwyższego z 3 lutego 2011 r., z którego pośrednio wynika, że pracodawca nie może skutecznie polecić pracownikowi pełnienia dyżuru w czasie urlopu, nawet jeśli pracownik wyraził na to zgodę $e^{233}$.

Takie zachowanie nie tylko kłóci się z celem urlopu i omawianą wyżej zasadą, ale też z zakazem zrzeczenia się prawa do urlopu na etapie jego realizacji, o którym wcześniej była mowa.

Odbywanie z pracownikiem rozmów służbowych w czasie jego urlopu wypoczynkowego, jeśli nie ma to charakteru sporadycznego i krótkotrwałego, może być, w mojej ocenie, kwalifikowane jako bezprawne przerwanie omawianego urlopu, chyba że zaistniały przesłanki uzasadniające odwołanie pracownika z urlopu i pracodawca zdecydował się skorzystać ze swego uprawnienia w tej formie (mniej dotkliwej dla pracownika) ${ }^{234}$. Wówczas powinien jednak wprost poinformować pracownika o swej decyzji (zob. szerzej przy omawianiu instytucji odwołania z urlopu). Jeśli natomiast taka ewentualność w danym przypadku nie zachodzi, to mimo że ustawodawca nie określił w tym zakresie bezpośrednio żadnych roszczeń po stronie pracownika, możliwe wydaje się przyjęcie, że w związku z tym pracownik ma roszczenie o wynagrodzenie i udzielenie mu takiego dnia (czy dni) urlopu w innym terminie. Według mnie, właściwe byłoby tu zagwarantowanie w przepisach takiego dnia (czy dni), na wniosek pracownika, bezpośrednio po terminie zakończenia urlopu. Ponadto możliwe są również sankcje o charakterze majątkowym, na zasadach określonych w prawie cywilnym, związane z naruszeniem prawa pracownika do odpoczynku, stanowiącego, m.in. w ocenie Sądu Najwyższego, jedno z dóbr osobistych pracownika (por. w tym zakresie wcześniejsze rozważania dotyczące odpoczynku dobowego i tygodniowego). Z tych względów pracownik może domagać się od pracodawcy w opisanych przypadkach stosownego zadośćuczynienia. Słusznie też podnosi się w literaturze, choć w nieco innym kontekście, że mając na uwadze cel urlopu, tego rodzaju naruszenia prawa pracownika

232 W jednym z orzeczeń SN uznał, że pozostawanie pracownika pod służbowym telefonem komórkowym stanowi dyżur pozazakładowy, który choć nie kwalifikuje się do czasu pracy, to nie może być utożsamiany również z odpoczynkiem. Por. wyrok SN z 9 grudnia 2011 r., II PK 115/11, www.sn.pl. Miejsce zaś takiego dyżuru, jak przyjęto w judykaturze, może być wyznaczone w różny sposób, np. jako punkt czy obszar geograficzny. Por. wyrok SN z 13 maja 2009 r., III PK 9/09, www.sn.pl. Podobnie K. Płaczek, Prawo pracownika do niezakłóconego wypoczynku, M.P.P. 2017, nr 7, s. 357 i n.

233 Wyrok SN z 3 lutego 2011 r., III PK 32/10, LEX nr 1375430.

234 Odmienny pogląd, według którego odwołanie z urlopu wymaga powrotu pracownika do pracy por. K. Płaczek, Prawo pracownika..., s. 359. 
do nieprzerwanego odpoczynku nie pozwalają na pełną regenerację jego sił, generują stres, a tym samym stanowią zagrożenie również dla zdrowia pracownika, które także jest dobrem prawnie chronionym na podstawie art. 23 k.c. ${ }^{235}$

Wydaje się jednak, że biorąc pod uwagę rozwój różnorodnych form komunikowania się na odległość we współczesnym świecie i związane z tym zagrożenia, m.in. w obszarze korzystania z urlopu wypoczynkowego czy w ogóle prawa do odpoczynku, ustawodawca powinien kwestie te uczynić przedmiotem bezpośredniej regulacji.

Problem ten został już dostrzeżony w kilku krajach europejskich, w tym m.in. we Francji. Zdecydowano się tam, mimo i tak stosunkowo krótkiej tygodniowej normy czasu pracy i dłuższych urlopów, podjąć określone kroki legislacyjne w celu sformułowania wyraźnego prawa, a nawet pewnego zobowiązania pracownika do nieodpowiadania poza godzinami pracy, zwłaszcza w godzinach wieczornych i w weekendy, na służbowe e-maile i telefony (tzw. prawo do odłączenia ${ }^{236}$. Służy to nie tylko skutecznemu urzeczywistnianiu prawa pracownika do wypoczynku, ochronie jego zdrowia ${ }^{237}$, ale ma również sprzyjać uzyskaniu odpowiedniej harmonii i równowagi między życiem zawodowym a prywatnym, a w rezultacie przeciwdziałać nasilającemu się zjawisku wypalenia zawodowego ${ }^{238}$.

Ostatecznie tego rodzaju regulacją objęto na razie we Francji tylko pracodawców zatrudniających co najmniej 50 osób i dotyczy ona konieczności zawarcia $\mathrm{w}$ tej sprawie $\mathrm{z}$ pracownikiem stosownego porozumienia, ewentualnie wydania swego rodzaju regulaminu „dobrego postępowania” dotyczącego warunków kontaktowania się z pracownikiem po godzinach pracy (szczególnie określającego czas, kiedy pracownik nie powinien odbierać służbowej poczty i korzystać w celach zawodowych z telefonu).

Podobne inicjatywy podjęli również Niemcy ${ }^{239}$. Nie ma tam jeszcze podobnych unormowań prawnych jak we Francji, ale część firm przestrzega zalecenia, aby po godzinach pracy w określonym przedziale czasowym (między 18.15 a 7 rano) nie kontaktować się drogą elektroniczną z pracownikami.

Sami pracodawcy, dostrzegając zagrożenia związane $\mathrm{z}$ brakiem odpoczynku, podejmują też $\mathrm{w}$ tym zakresie stosowane inicjatywy, np. zawieszając $\mathrm{w}$ okresie urlopowym (na dwa, trzy tygodnie w roku) swoją działalnośćc ${ }^{240}$.

235 Por. S. Koczur, Faktyczne możliwości realizacji..., s. 465.

236 Por. Francja wprowadza zakaz korzystania z poczty służbowej po pracy. Czy słusznie?, „Polityka", 18.02.2016, www.polityka.pl. Na ten temat zob. też independent.co.uk.

237 Badania przeprowadzone w Niemczech wykazały, że pozostawanie po godzinach pracy w stałym kontakcie z pracodawcą (telefon, Internet) generuje dodatkowy stres i związane z nim choroby, zwłaszcza natury psychicznej, obniża też znacznie efektywność pracy pracownika.

238 Francja wprowadza zakaz..., www.polityka.pl.

239 A. Żelazińska, Służbowe maile i telefony - tylko w godzinach pracy, „Polityka”, 3.10.2014, www.polityka.pl.

240 Takie rozwiązanie jest bardzo często stosowane w okresie letnim np. we Francji. Jeśli zamknięcie przedsiębiorstwa przedłuża się ponad ustawowy okres urlopu wypoczynkowego, pracow- 
Drugim aspektem nieprzerwanego charakteru odpoczynku jest przypisanie tej cechy tylko takim okresom, które zasadniczo nie pokrywają się z innymi przerwami w wykonywaniu pracy spełniającymi odmienne funkcje. Jeśli w okresie urlopu pracownik musiałby bowiem realizować inne cele i zadania uzasadnione przyczyną usprawiedliwiającą nieobecność pracownika w pracy lub udzielonym zwolnieniem z obowiązku jej wykonywania, wówczas następuje swego rodzaju przerwa w odpoczynku, z którego pracownik w związku z urlopem korzysta. W rezultacie tego rodzaju okoliczności powodujące nieświadczenie pracy nie powinny pozostawać w zbiegu z urlopem wypoczynkowym, a jeśli z przyczyn niezależnych od stron wystąpią one już w okresie korzystania z niego, wówczas urlop ten nie może być w sposób nieprzerwany dalej realizowany ${ }^{241}$.

W tym ujęciu okoliczności, z którymi przepisy prawa wiążą obowiązek przerwania urlopu, wymienione w art. 166 k.p., z jednej strony stanowią wyjątek od powołanej reguły, ale $\mathrm{z}$ drugiej wpisują się w omawiany aspekt tytułowej zasady i znajdują $\mathrm{w}$ niej swoje uzasadnienie. Przerwanie tego urlopu w sensie prawnym jest bowiem tu tylko następstwem faktycznego przerwania wypoczynku na skutek wystąpienia określonych zdarzeń powodujących brak możliwości wykorzystania przez pracownika urlopu wypoczynkowego w sposób zgodny z jego przeznaczeniem.

Do przesłanek tych ustawodawca zaliczył:

- czasową niezdolność do pracy wskutek choroby (choćby obejmowała ona jeden dzień) ${ }^{242}$;

- odosobnienie w związku z chorobą zakaźną;

- odbywanie ćwiczeń wojskowych albo przeszkolenia wojskowego przez okres do trzech miesięcy;

- urlop macierzyński, ale również dodatkowy urlop macierzyński, urlop ojcowski, urlop na warunkach urlopu macierzyńskiego, dodatkowy urlop na warunkach urlopu macierzyńskiego (art. $166 \mathrm{w}$ związku z art. $182^{1} \$ 7$, art. $182^{3} \$ 3$ i art. 183 $\$ 1$ i 4 k.p.).

nicy nabywają prawo do odszkodowania w wysokości co najmniej równej wynagrodzeniu urlopowemu. Jeśli zamknięcie przedsiębiorstwa nie przekracza tego okresu, to pracownicy nabywający prawo w niższym wymiarze niż okres zamknięcia mają prawo do odszkodowania z tytułu bezrobocia częściowego. Por. szerzej G. Auzero, E. Dockès, Droit..., s. 873.

241 Warto odnotować, że w przeszłości kwestia była jednak różnie postrzegana, szczególnie jeśli chodzi o wptyw okresu choroby na wymiar omawianego urlopu. W literaturze z zakresu prawa urlopowego znaleźć można również opinie, że urlop w pełnym wymiarze powinien być powiązany z obowiązkiem zachowania pewnego stosunku między okresem faktycznie świadczonej w danym roku pracy a prawem do niego. Korzystanie z urlopu, mimo niedługiego okresu czynnie wykonywanych obowiązków, stanowi nadużycie analizowanego prawa. Por. tak A. Hueck, [w:] A. Hueck, C.H. Nipperdey, Lehrbuch des Arbeitsrecht, t. 1, Berlin 1955, s. 401 i n.

242 Niezdolność do pracy z powodu choroby jest szczególnie eksponowaną w prawie europejskim oraz w przepisach krajowych poszczególnych państw okolicznością, której wystąpienie uznaje się za uniemożliwiające jednoczesną realizację prawa do urlopu wypoczynkowego. Tak przyjęto m.in. w prawie niemieckim. Por. M. Henssler, H.J. Willemsen, H.-J. Kalb (Hrsg.), Arbeitsrecht..., s. 1903 i n. 
Chodzi więc generalnie o sytuacje trudne do przewidzenia w chwili udzielania urlopu wypoczynkowego, których jednak zaistnienie w jego trakcie skutkuje niemożnością kontynuowania tego urlopu w sposób zgodny z jego podstawową funkcją.

Urlop wypoczynkowy, także udzielony na żądanie pracownika, ulega wówczas przerwaniu na czas trwania danej przyczyny ${ }^{243}$.

Katalog ten ma charakter zamknięty, co oznacza, że wystąpienie w czasie urlopu wypoczynkowego jakichkolwiek innych zdarzeń, które zdaniem pracownika zakłócają ciągłość tego urlopu, np. choroba współmałżonka, nie powodują przerwania urlopu z mocy komentowanego przepisu, czyli niezależnie od woli stron. Ewentualnie pracownik może wówczas zwrócić się do pracodawcy o wyrażenie zgody na skrócenie urlopu wypoczynkowego i udzielenie niewykorzystanej części tego urlopu w dalszym terminie, ale pracodawca nie musi takiego wniosku uwzględnić. Tylko w wymienionych wyżej czterech sytuacjach ani pracodawca ani pracownik nie mogą bowiem skutecznie sprzeciwić się przerwaniu urlopu wypoczynkowego bądź zawrzeć porozumienia wyłączającego taki skutek. Wynika to bezpośrednio $\mathrm{z}$ przepisu, ale zostało dodatkowo potwierdzone w orzecznictwie sądowym ${ }^{244}$.

Można zastanawiać się w związku z tym, czy ów katalog nie powinien jednak zostać poszerzony, zwłaszcza o przypadki koniecznego, okresowego sprawowania przez pracownika opieki nad chorym członkiem rodziny, przypadające w czasie urlopu.

Części urlopu wypoczynkowego niewykorzystanej z powodów opisanych w art. 166 k.p. należy udzielić, zgodnie z wolą ustawodawcy, w terminie późniejszym. Może to nastąpić albo bezpośrednio po planowanej dacie zakończenia urlopu wypoczynkowego czy ustaniu przyczyny nieobecności powodującej jego przerwanie bądź w dalszym terminie, zasadniczo nie później niż do końca września roku następnego. Trzeba mieć jednak na uwadze, że jeśli chodzi o pracowników pozostających na urlopie macierzyńskim, mogą oni wystąpić o urlop wypoczynkowy po zakończeniu urlopu macierzyńskiego, a wniosek taki wiąże pracodawcę.

Poza tym, jak słusznie podnosi się w literaturze przedmiotu, należy uznać, że nie ma podstaw prawnych do udzielenia urlopu wypoczynkowego $\mathrm{w}$ okresie urlopu wychowawczego, np. w sytuacji, gdy z powodu choroby pracownica nie mogła wykorzystać udzielonego jej po urlopie macierzyńskim urlopu wypoczynkowego, a następnie rozpoczęła urlop wychowawczy ${ }^{245}$. Urlop wychowawczy po-

243 Pewne wątpliwości powstały w związku z niezdolnością do pracy z powodu choroby, która zgodnie z art. 92 k.p. obejmuje zarówno dni pracy, jak i dni wolne od pracy. W literaturze z dziedziny prawa pracy przyjęto, że przy obliczaniu dni urlopu niewykorzystanych z powodu choroby należy uwzględniać wyłącznie dni, które w tym okresie byłyby dla danego pracownika dniami pracy, tj. dni stricte urlopowe. Urlop będzie więc ulegał przesunięciu tylko o liczbę dni urlopu, jakie przypadały w okresie choroby. Por. E. Chmielek-Łubińska, Kodeks pracy..., 2011, s. 843 i n.

244 Por. m.in. wyrok SN z 10 listopada 1999 r., I PKN 350/99, OSNP 2001, nr 6, poz. 198.

245 Por. A. Świątkowski, Kodeks pracy..., s. 685 i n. 
woduje bowiem swego rodzaju zawieszenie podstawowych praw i obowiązków wynikających ze stosunku pracy, stąd urlop wypoczynkowy może być wykorzystany dopiero po jego zakończeniu ${ }^{246}$. Trzeba również mieć na uwadze odmienne przeznaczenie obu wskazanych wyżej zwolnień od pracy.

Na podobnych do powyższych przesłankach oparto także obowiązek przesunięcia terminu urlop wynikający z art. 165 k.p., choć szerzej zakreślono przyczyny jego powstania. Konieczność podjęcia przez pracodawcę stosownych działań związanych ze zmianą terminu urlopu danego pracownika powstaje na gruncie powołanego przepisu zawsze, ilekroć pracownik nie może rozpocząć urlopu wypoczynkowego z przyczyn usprawiedliwiających jego nieobecność pracy, w tym również w wymienionych wcześniej okolicznościach.

W związku $\mathrm{z}$ tym przepis ten ma przeciwdziałać sytuacjom zbiegu prawa do urlopu wypoczynkowego z innymi okresami nieświadczenia pracy o różnym od urlopu wypoczynkowego przeznaczeniu.

W konsekwencji jakiekolwiek porozumienie pracownika i pracodawcy w tej sprawie, wyłączające lub modyfikujące zastosowanie omawianego przepisu, jest prawnie nieskuteczne.

Potwierdza to wyrok SN z 10.11.1999 r., zgodnie z którym pracodawca nie może skutecznie udzielić urlopu wypoczynkowego pracownikowi niezdolnemu do pracy, nawet wówczas, gdy pracownik wyraził na to zgodę ${ }^{247}$.

Odnosi się to odpowiednio również do urlopu na żądanie. Sąd Najwyższy słusznie uznał bowiem, że obowiązek pracodawcy, o którym mowa w art. $167^{2}$ k.p., musi być rozumiany jako konieczność uwzględnienia wniosku pracownika co do terminu, w którym ma być wykorzystana określona w nim część urlopu, ale pod warunkiem, że udzielenie w tym czasie urlopu wypoczynkowego jest prawnie dopuszczalne $e^{248}$.

Urlop na żądanie jest urlopem wypoczynkowym, z zastrzeżeniem jedynie ograniczenia swobody pracodawcy w zakresie terminu jego udzielenia, stąd musi być, w stopniu, w jakim jest to możliwe, poddany ogólnym zasadom urlopowym tak,

246 Tamże.

247 Wyrok SN z 10 listopada 1999 r., I PKN 350/99, OSNAPiUS z 2001 r., nr 6, poz. 198. Podobne stanowisko zostało wyrażone w wyroku SN z 28 października 2009 r., II PK 123/09, LEX nr 551056 - niezdolność do pracy wyłącza możliwość korzystania z urlopu zgodnie z jego przeznaczeniem, w związku z czym udzielenie urlopu w okresie niezdolności do pracy jest prawnie niedopuszczalne, także wówczas, gdy pracownik wyraził na to zgodę.

248 Wyrok SN z 18 maja 2006 r., III PK 26/06, LEX nr 551013, teza nr 4. Komentowany przepis wyklucza udzielenie urlopu na żądanie w okresie np. niezdolności do pracy z powodu choroby. Por. tak też: E. Chmielek-Łubińska, Urlop na żądanie pracownika, PiZS 2003, nr 3, s. 31 oraz A. Marek, Urlop na żądanie, „Służba Pracownicza” 2003, nr 8, s. 9. Krytyczny pogląd odnośnie do takiego stanowiska SN wyrazit M. Zieleniecki. Zob. tenże, [w:] Kodeks pracy. Komentarz, red. A. Sobczyk, Warszawa 2014, s. 653. Autor uznaje, że zarówno komentowany art. 165, jak i 166 k.p., o którym była mowa wcześniej, dotyczą wyłącznie urlopów, które zostały zaplanowane, tj. objęte planem urlopów lub których termin został ustalony w trybie indywidualnych uzgodnień z pracownikiem i nie może zostać dotrzymany. Tym samym nie można przepisów tych zastosować do urlopu na żądanie, który planowaniu nie podlega. 
aby jego podstawowa funkcja jako urlopu wypoczynkowego została zrealizowana. W szczególności z tej perspektywy trudno byłoby racjonalnie wytłumaczyć ewentualne wyłączenie niemożności korzystania $\mathrm{z}$ tego urlopu w okresie m.in. niezdolności do pracy z powodu choroby, z uwagi na to, że urlop ten nie podlega planowaniu ${ }^{249}$, skoro reguła ta jest pochodną istoty urlopu wypoczynkowego oraz zasady nieprzerwanego odpoczynku, a nie zasady planowego jego udzielania.

Ponadto w art. 165 k.p. ustawodawca wskazuje jedynie na brak możliwości rozpoczęcia urlopu „w ustalonym terminie”, nie precyzując, kto tego dokonuje. Można zatem uznać, że w przypadku urlopu na żądanie chodzi o termin ustalony przez pracownika.

Dość kontrowersyjna, także z punktu widzenia prowadzonych rozważań, jest natomiast przyjęta $\mathrm{w}$ orzecznictwie sądowym teza, że nie jest sprzeczna z przepisami prawa pracy i nie stanowi podstawy obligatoryjnego przesunięcia terminu urlopu sytuacja, w której rozpoczęcie urlopu wypoczynkowego pracownika, w dacie wskazanej w planie urlopów, przypada bezpośrednio po ustaniu niezdolności do pracy tego pracownika z powodu choroby, nawet jeśli niezdolność ta trwała dłużej niż $30 \mathrm{dni}^{250}$.

W literaturze przedmiotu słusznie zwrócono uwagę, że nie ma wówczas pewności, czy pracownik taki odzyskał faktycznie zdolność do pracy czy też powinien nadal pozostawać na zwolnieniu lekarskim ${ }^{251}$. W drugim przypadku wyklucza to automatycznie możliwość wykorzystania udzielonego mu urlopu zgodnie z jego przeznaczeniem. Stąd pracodawca powinien w pierwszej kolejności skierować pracownika na badania kontrolne, zgodnie z art. $229 \$ 2$ k.p., potwierdzające fakt odzyskania zdolności do wykonywania pracy, a dopiero potem ewentualnie kierować pracownika na urlop.

Jednocześnie należy przyjąć, jak uczynił to Sąd Najwyższy w wyroku z 7 lutego 2001 r., że nie ma potrzeby, aby pracownik występował do pracodawcy ze specjalnym wnioskiem w sprawie przesunięcia terminu urlopu wypoczynkowego, jeśli pracodawca ma świadomość istnienia przyczyny usprawiedliwiającej nieobecność danego pracownika w pracy i powodującej niemożność rozpoczęcia zaplanowanego urlopu wypoczynkowego ${ }^{252}$.

Analogicznie jak w przypadku przesunięcia urlopu z woli stron, nowy termin wykorzystania urlopu wypoczynkowego przez pracownika powinien zostać z nim uzgodniony. Należy jednak mieć na uwadze, że pracownikowi należy udzielić urlopu najpóźniej do końca września kolejnego roku.

$\mathrm{Z}$ pojęciem urlopu nieprzerwanego wiąże się również w jakimś stopniu kwestia sposobu pojmowania okresu urlopu wypoczynkowego. Zgodnie $\mathrm{z}$ art. $154^{2} \$ 1$ k.p.,

249 Tak M. Zieleniecki, [w:] Kodeks pracy...., s. 653.

250 Wyrok SN z 20 marca 2008 r., II PK 214/07, OSNP 2009, nr 15-16, poz. 194.

251 A. Kosut, [w:] Kodeks pracy. Komentarz [dostęp: 11.08.2014]. Zwraca się uwagę, że nie ma pewności, czy kierowany na urlop pracownik odzyskał faktycznie zdolność do pracy czy też powinien nadal pozostawać na zwolnieniu lekarskim.

252 Wyrok SN z 7 lutego 2001 r., I PKN 240/00, OSNAPiUS 2002, nr 21, poz. 518. 
urlopu udziela się na dni, które są dla pracownika dniami pracy, zgodnie z obowiązującym go rozkładem czasu pracy. Niemniej zarówno w literaturze z zakresu prawa pracy, jak i orzecznictwie sądowym niemal zgodnie przyjmuje się, że za czas realizacji urlopu należy uznać nie tylko dni stricte urlopowe w rozumieniu powołanego przepisu, ale również łączące się z nimi bezpośrednio niedziele, święta i dni dodatkowo wolne od pracy. Stąd również zasada urlopu nieprzerwanego powinna obejmować cały tak szeroko rozumiany okres urlopowy. Nie należy więc zakłócać pracownikowi tzw. spokoju urlopowego, o którym będzie dalej mowa, nie tylko w tych dniach, na które bezpośrednio udzielono urlopu, ale również w dniach, które są wolne od pracy z innego tytułu, ale ściśle do tego urlopu przylegają. Ma to szczególne znaczenie w zakresie np. możliwości wezwania pracownika do pracy w dzień dodatkowo wolny od pracy, ale przypadający na czas urlopu, czy szczególnej ochrony trwałości zatrudnienia, co zostanie przy omawianiu kolejnej zasady poddane szerszej analizie.

Na gruncie doktryny prawa pracy wiele wątpliwości wywołuje jednak samo pojęcie „dzień urlopu”, którym posłużył się ustawodawca m.in. w art. $154 \$ 1$ k.p. Warto odnotować bowiem, że zrezygnowano z wcześniej stosowanego w odniesieniu do urlopów wypoczynkowych terminu „dni robocze” (były nimi wszystkie dni, z wyjątkiem niedziel i świąt określonych w odrębnych przepisach, co samo w sobie sugerowało, jak zauważył A. Sobczyk ${ }^{253}$, że chodzi o „dzień” w znaczeniu astronomicznym), a wprowadzono natomiast w przepisach dotyczących czasu pracy pojęcie „doba pracownicza”. W związku z tym pojawił się problem, jak na gruncie obowiązującego prawa interpretować pojęcie dnia urlopu, czy chodzi nadal o dzień kalendarzowy czy też raczej należy odnieść je do doby pracowniczej i uznać, że dzień urlopu, to okres 24 godzin, licząc od godziny rozpoczęcia pracy przez danego pracownika.

Problem ten nabiera szczególnego znaczenia praktycznego w odniesieniu do osób pracujących na przełomie dób kalendarzowych (na nocną zmianę), zwłaszcza w kontekście ochrony trwałości ich zatrudnienia (art. 41 k.p.), ale też omawianej w tym punkcie zasady. Udzielenie odpowiedzi na pytanie, czy pracownik, który poprosił, aby udzielono mu na czwartek urlopu, a zakończył pracę w ten czwartek o godz. 4 rano i został ponownie wezwany do pracy tego dnia o godz. 6.00 pozostawał już na urlopie wypoczynkowym czy nie, pozwoli ocenić również ewentualne odstąpienie przez pracodawcę od reguły urlopu nieprzerwanego bądź jego brak.

W kwestii tej w literaturze przedmiotu zarysowały się różne poglądy.

Część przedstawicieli doktryny prawa pracy stoi na stanowisku, że dzień urlopu należy wiązać z dobą pracowniczą, co znalazło swoją wyraźną akceptację również w jednym z orzeczeń Sądu Najwyższego. W wyroku z 4 listopada 2010 r. Sąd Najwyższy zdecydował, że o początku urlopu wypoczynkowego decyduje rozkład

$253 \mathrm{Na}$ ten temat bardzo szeroko i ciekawie por. A. Sobczyk, Urlop na żądanie, PizS 2004, nr 7, s. $12 \mathrm{i} \mathrm{n}$. 
czasu pracy pracownika. W konsekwencji znaczenie ma początek kolejnej doby pracowniczej, a nie ta sama doba kalendarzowa ${ }^{254}$.

Przenosząc tę tezę na grunt prowadzonych w tym punkcie rozważań, należałoby przyjąć, że pracodawca ma możliwość wezwania pracownika w tym dniu kalendarzowym do pracy do godziny rozpoczęcia kolejnej zmiany (w podanym stanie faktycznym - do godz. 20), bez naruszania zasady urlopu nieprzerwanego.

Powiązanie urlopu wypoczynkowego $\mathrm{z}$ dobą pracowniczą ma na pewno swoje uzasadnienie. Urlop jest bowiem zwolnieniem z obowiązku wykonywania pracy, a zatem musi być $\mathrm{z}$ tym obowiązkiem wprost skorelowany.

Niemniej z punktu widzenia prawa do odpoczynku budzi to określone obawy, zwłaszcza gdy urlop ten obejmuje pojedyncze dni. Wówczas mogą wystąpić bowiem sytuacje, w których realizacja funkcji wypoczynkowej urlopu może być bardzo utrudniona w związku z tym, że pracownik, jak w omawianym przypadku, de facto nie uzyska do swojej dyspozycji pełnego dnia kalendarzowego. Dodatkowo pora dzienna, na którą urlop w analizowanej sytuacji przypada, poprzedza godziny rozpoczęcia pracy w kolejnej dobie pracowniczej. Stanowi to istotne ograniczenie w zakresie choćby możliwości urzeczywistnienia planów wyjazdowych. Być może należałoby zatem postulować objęcie okresem urlopowym również godzin bezpośrednio przed nim występujących, a zatem godzin przypadających po zakończeniu pracy, w tych wypadkach, w których godziny pracy pracownika obejmują przełom dób kalendarzowych.

Częściowo odmienne od wyżej omówionego zdanie w tej kwestii zaprezentował A. Sobczyk, który uważa, że wykładnia pojęcia „dnia urlopowego” powinna być zrelatywizowana do rozkładu czasu pracy danego pracownika ${ }^{255}$. Oznacza to, że jeśli pracownik wykonuje pracę w obrębie doby astronomicznej, urlopu należy udzielić na dzień kalendarzowy, jeśli zaś określona osoba świadczy pracę w sposób obejmujący dwa dni kalendarzowe, to wówczas pojęcie dnia urlopu należy zrównać z pojęciem doby pracowniczej ${ }^{256}$.

Zasada urlopu nieprzerwanego, ze względu na swą szczególną wagę, została wyeksponowana również w niektórych pragmatykach pracowniczych. Jej konstrukcja opiera się jednak na podobnych do kodeksowych założeniach.

W szczególności nauczyciele mają ustawowo zagwarantowane prawo do nieprzerwanego co najmniej czterotygodniowego urlopu wypoczynkowego. Regulacja ta ma istotne znaczenie w kontekście wynikającego z art. 64 ust. 2 Karty Nauczyciela uprawnienia dyrektora szkoły, w której organizacji przewidziano ferie, do zobowiązania nauczyciela pracującego w takiej szkole do wykonywania w ich trakcie określonych w ustawie czynności (m.in. przeprowadzenia egzaminów czy podjęcia prac związanych z zakończeniem roku szkolnego i przygotowaniem nowego roku szkolnego) w wymiarze maksymalnie siedmiu dni.

254 Wyrok SN z 4 listopada 2010 r., II PK 116/10, M.P.P. 2011, nr 3, s. 145.

255 Por. A. Sobczyk, Urlop na żqqdanie, s. 13.

256 Tamże. 
Powołana norma jest zarazem podstawą skrócenia wymiaru urlopu omawianej grupy nauczycieli, których urlop obejmuje z zasady cały okres ferii (art. 64 ust. 1 ustawy) oraz podziału urlopu nauczyciela na części i jego przerwania, z zastrzeżeniem warunku wyżej wymienionego mającego zagwarantować nauczycielowi odpoczynek w minimalnym, niezbędnym wymiarze.

Ważne znaczenie dla realizacji prawa do odpoczynku omawianej grupy zawodowej ma również art. 66 Karty Nauczyciela, który stanowi, że jeśli nauczyciel, w okolicznościach określonych w tym przypisie ${ }^{257}$, niemal identycznych do tych wymienionych w Kodeksie pracy, nie wykorzystał w okresie ferii całości lub części należnego mu urlopu wypoczynkowego, wówczas przysługuje mu urlop w ciągu roku szkolnego w wymiarze uzupełniającym do ośmiu tygodni.

Uzupełniający charakter tego urlopu, wynikający z powyższego unormowania, nie zmienia jego prawnej natury; jest to nadal urlop wypoczynkowy, na co wyraźnie zwrócono uwagę w orzecznictwie Sądu Najwyższego ${ }^{258}$.

Przepis ten obejmuje przypadki, w których urlop wypoczynkowy zbiegał się ze wskazanym przez ustawodawcę okresem usprawiedliwionej nieobecności w pracy, której przyczyna nie pozwala w założeniu na prawidłowy przebieg głównej funkcji omawianej instytucji, co ostatecznie powoduje obowiązek przerwania tego urlopu lub brak możliwości jego rozpoczęcia. Dlatego też wyjątkowo nauczyciel uzyskał wówczas możliwość wykorzystania tego urlopu w innym niż zwykle terminie.

Zarówno w literaturze przedmiotu, jak i w orzecznictwie sądowym przyjmuje się jednak, że nauczyciel ma prawo do takiego urlopu, jeśli w czasie trwania ferii letnich i zimowych nie wykorzystał łącznie ośmiu tygodni urlopu ${ }^{259}$. Nie zawsze będzie to zatem urlop w pełni rekompensujący wakacyjny wypoczynek. Jeśli nauczyciel wykorzystał bowiem dwa tygodnie urlopu w okresie ferii zimowych i sześć tygodni w okresie ferii letnich, a następnie zachorował, wówczas, zgodnie z przyjętą wykładnią, nie nabędzie prawa do urlopu za pozostałą do końca wakacji część niezrealizowanego odpoczynku.

Wynika z tego pośrednio, że stricte wypoczynkową funkcję, w ocenie ustawodawcy, pełni w przypadku nauczyciela urlop w wymiarze ośmiu tygodni. Pozostała część wymiaru jego urlopu wypoczynkowego wydaje się jedynie pochodną okresu przerwy w zajęciach szkolnych.

Tego rodzaju „zastępczy” urlop w okresie roku szkolnego przysługuje również dyrektorowi i wicedyrektorowi szkoły, którzy na polecenie lub za zgodą organu

257 Do przyczyn powodujących niemożność wykorzystania urlopu wypoczynkowego przez nauczyciela należą niezdolność do pracy wywołana chorobą lub odosobnieniem ze względu na chorobę zakaźną, urlop macierzyński, dodatkowy urlop macierzyński, urlop na warunkach urlopu macierzyńskiego i dodatkowy urlop na warunkach urlopu macierzyńskiego, urlop ojcowski oraz rodzicielski, odbywanie ćwiczeń wojskowych lub krótkotrwałego przeszkolenia wojskowego.

258 Por. wyrok SN z 6 października 2005 r., II PK 72/2005, OSNP 2006, nr 15-16, poz. 242.

259 Por. M. Szymańska, [w:] Karta Nauczyciela..., s. 384. Por. też wyrok SN z 2 września 1998 r., I PKN 298/98, OSNP 1999, nr 18, poz. 584. 
prowadzącego szkołę nie wykorzystali urlopu w okresie ferii szkolnych z powodu wykonywania zadań zleconych przez ten organ lub prowadzenia w szkole inwestycji albo kapitalnych remontów. W tym przypadku chodzi jednak w istocie nie o przerwanie urlopu, ale o zmianę terminu, $\mathrm{w}$ jakim zostanie on wykorzystany.

W stosunku do nauczycieli zatrudnionych w placówkach, w których organizacji nie przewidziano ferii, będą miały zastosowanie omawiane wcześniej przepisy kodeksowe.

Ważny dla skutecznego wykorzystania prawa do urlopu wypoczynkowego przez nauczyciela wydaje się też art. 67c powoływanej ustawy, który przewiduje, że w przypadku, gdy nauczycielowi zostanie udzielony urlop wychowawczy przed wykorzystaniem nabytego urlopu wypoczynkowego, wówczas termin zakończenia tego pierwszego powinien nastąpić z końcem zajęć szkolnych, a więc w czerwcu, tak aby nauczyciel w okresie wakacyjnym mógł wykorzystać urlop wypoczynkowy bez przeszkód $\mathrm{d}^{260}$.

Według przyjętej w literaturze wykładni, nauczyciel, który korzystał z urlopu wychowawczego, nabędzie prawo do urlopu wypoczynkowego pierwszego dnia ferii szkolnych przypadających po jego powrocie do pracy w szkole. W sytuacji, gdy nauczyciel rozpocznie urlop wychowawczy przed wykorzystaniem przysługującego mu urlopu wypoczynkowego (np. w marcu), termin zakończenia tego pierwszego powinien nastąpić z końcem zajęć szkolnych, czyli w czerwcu, tak aby nauczyciel ten $\mathrm{w}$ okresie ferii letnich mógł wykorzystać przysługujący mu urlop wypoczynkowy ${ }^{261}$.

\subsection{Spokój urlopowy}

Niezwykle ważną zasadą służącą wykorzystywaniu urlopu wypoczynkowego zgodnie z jego przeznaczeniem jest zasada spokoju urlopowego. W jej ramach należy przyjąć, że po udzieleniu urlopu wypoczynkowego pracownikowi powinien on bez przeszkód i w warunkach pełnego odpoczynku od pracy zarobkowej ten urlop realizować. W tym czasie pracownik nie może zatem pozostawać w jakiejkolwiek, choćby bardzo ograniczonej, dyspozycji pracodawcy ${ }^{262}$, wyłączone powinny być przypadki każdej ingerencji pracodawcy w spędzany przez pracownika czas wolny - szczególnie podejmowania przez niego czynności zakłócających ten odpoczynek. Zasada ta obejmuje konieczność stworzenia urlopowanemu pracownikowi warunków nie tylko do odpoczynku fizycznego, ale także psychicznego.

Mimo że nie została ona bezpośrednio wyrażona w przepisach prawa pracy, służy jej ostatecznie kilka rozwiązań w prawie tym przyjętych. Przede wszystkim w dużej mierze pokrywa się ona z zasadą urlopu nieprzerwanego, wcześniej omawianą, stanowi też jej uzasadnienie, ale ma od niej jednocześnie nieco szerszy za-

260 Por. też A. Szymańska, [w:] Karta Nauczyciela..., s. 391 i n.

261 Tamże.

262 Por. w tym zakresie wyrok SN z 19 stycznia 2017 r., I PK 40/16. 
kres. Poza samym zakazem przerywania w sensie dosłownym udzielonego pracownikowi urlopu, w związku np. z jego wezwaniem do pracy, ma ona zapewniać pracownikowi odpowiedni komfort tego wypoczynku. Stąd w jej ramach mieści się również kwestia ograniczenia dokonywania przez pracodawcę czynności niezwiązanych bezpośrednio z samym urlopem, ale mogących zaważyć ostatecznie na jego jakości, tj. wypowiadania w tym okresie umowy o pracę ${ }^{263}$. Wypowiedzenie umowy samo w sobie stanowi poważne naruszenie spokoju urlopowego pracownika, a dodatkowo pracownik ten w czasie urlopu pozostawałby w okresie wypowiedzenia, co jest sprzeczne $z$ ideą wypoczynku będącego głównym celem analizowanej instytucji.

Zakaz złożenia przez pracodawcę oświadczenia woli o wypowiedzeniu w okresie urlopu wypoczynkowego pracownika (ale też innej usprawiedliwionej nieobecności) wynika wprost z art. 41 k.p. i służy do zagwarantowania realizacji podstawowej funkcji tego urlopu w znaczeniu wyżej wskazanym. W związku z tym dotyczy on każdego okresu urlopowego, bez względu na to, czy jest to urlop podstawowy, dodatkowy, uzupełniający, zaległy, udzielony w normalnym trybie czy też na żądanie $^{264}$ i co do zasady, niezależnie od tego, czy pracownik korzysta z urlopu wypoczynkowego w pełnym wymiarze czy też pojedynczego dnia. Ochrona trwa zatem generalnie przez cały czas przebywania pracownika na urlopie wypoczynkowym, z pewnym ograniczeniem wynikającym z ustawy dotyczącej rozwiązywania stosunków pracy z przyczyn niedotyczących pracowników, w której wyłącza się tę ochronę w razie urlopu trwającego co najmniej trzy miesiące ${ }^{265}$. Tak długi okres w przypadku urlopu wypoczynkowego jest jednak w praktyce rzadkością (chyba że pracodawca udziela urlopu bieżącego łącznie z urlopami zaległymi), co powoduje zwykle objęcie całego urlopu wypoczynkowego omawianym zakazem, mimo zwolnień dokonywanych na podstawie przepisów tej ustawy. Ponadto, nawet jeśli ustawodawca decyduje się w powyższej sytuacji uchylić ochronę, to jednak czyni to po odpowiednio długim okresie odpoczynku pracownika, więc główny cel tego urlopu zostaje wówczas zachowany. Należy bowiem przyjąć, choć kwestia ta jest w doktrynie prawa pracy sporna, że w świetle przepisów powołanej ustawy nie chodzi jedynie o udzielenie pracownikowi urlopu na okres trzech miesięcy, ale jego wykorzystanie przez pracownika w tym wymiarze, po którym to okresie będzie można dokonać dopiero wypowiedzenia umowy o pracę ${ }^{266}$. Art. 5 ust. 3

$263 \mathrm{Na}$ zasadę spokoju urlopowego jako uzasadnienie omawianego zakazu wskazywał Z. Góral, [w:] Kodeks pracy..., s. 289.

264 Tamże.

265 Ustawa z 13 marca 2003 r. o szczególnych zasadach rozwiązywania z pracownikami stosunków pracy z przyczyn niedotyczących pracowników, tekst jednolity: Dz. U. 2015, poz. 192, ze zm.

266 Por. tak M. Latos-Miłkowska, Ł. Pisarczyk, Zwolnienie z przyczyn niedotyczacych pracownika, Warszawa 2005, s. 112. Tak też L. Krysińska-Wnuk, Regulacja zwolnień grupowych pracowników, Warszawa 2009, s. 131 i n. Odmiennie w tej kwestii K. Jaśkowski, [w:] K. Jaśkowski, E. Maniewska, J. Stelina, Grupowe zwolnienia. Komentarz, Kraków 2004, s. 80. 
ustawy odwołuje się bowiem do pojęcia „urlopu trwającego co najmniej 3 miesiące", a nie urlopu udzielonego na ten czas oraz upływu okresu ochronnego w przypadku innych niż urlop okresów nieobecności pracownika w pracy. Można zatem przypuszczać, że celem ustawodawcy było wyłączenie tej ochrony dopiero po upływie pewnego czasu, a nie już z pierwszym dniem trwania urlopu udzielonego na wskazaną liczbę miesięcy, co znajduje też swoje uzasadnienie w omawianej zasadzie spokoju urlopowego.

Całkowite uchylenie zakazu wypowiadania umowy o pracę podczas urlopu wypoczynkowego ma charakter wyjątkowy i jest ograniczone do sytuacji szczególnych, takich zwłaszcza jak upadłość czy likwidacja pracodawcy.

Istotne jest również, że pracodawca, który złoży wypowiedzenie w omawianym okresie ochronnym będzie ponosił, $\mathrm{w}$ razie odwołania się przez pracownika do sądu, określone prawem konsekwencje związane z wadliwym wypowiedzeniem umowy o pracę.

Z drugiej strony trzeba mieć na uwadze, że konstrukcja tego zakazu jest oparta na wyłączeniu możliwości wypowiadania przez pracodawcę umowy o pracę od dnia rozpoczęcia urlopu do ostatniego dnia jego trwania, co oznacza, że zgodne z prawem będzie wypowiedzenie złożone przed pierwszym dniem urlopu, nawet jeśli okres takiego wypowiedzenia upłynie już w jego trakcie. Wówczas też w dniu ustania stosunku pracy urlop, jeśli jeszcze trwał, ulegnie przerwaniu, a za pozostałą jego część pracodawca będzie zobowiązany wypłacić pracownikowi ekwiwalent pieniężny. Tym samym ochrona pracownika i zabezpieczenie funkcji wypoczynkowej urlopu jest tu w jakimś sensie ograniczone. Ów spokój urlopowy obowiązuje bowiem $\mathrm{z}$ chwilą rozpoczęcia korzystania $\mathrm{z}$ tego zwolnienia i do tego momentu jest odnoszone wyłączenie swobody pracodawcy w zakresie podejmowania określonych czynności związanych z wypowiedzeniem.

Ochrona wynikająca $z$ art. 41 k.p. nie obejmuje więc również rozwiązania niezwłocznego umowy o pracę, które może być dokonane przez pracodawcę w czasie urlopu wypoczynkowego pracownika, także w związku z pewnymi działaniami pracownika podjętymi w jego trakcie ${ }^{267}$, jak i rozwiązania umowy w drodze porozumienia stron ${ }^{268}$, co wydaje się w pełni zrozumiałe.

W celu ustalenia rzeczywistego czasu trwania ochrony przed wypowiedzeniem i związanej z nią realizacji tytułowego spokoju urlopowego istotne znaczenie ma przyjęty sposób interpretacji pojęcia dnia urlopu oraz okresu jego trwania.

Jak już wcześniej wskazywano, zarówno w doktrynie prawa pracy, jak i w orzecznictwem sądowym pojęcie dnia urlopu zwykle jest odnoszone obecnie do zde-

267 Por. wyrok SN z 16 grudnia 2004 r., II PK 109/04, LEX nr 138361. Wskazano w nim, że pewnych obowiązków pracownika (np. zakazu prowadzenia działalności konkurencyjnej, dbałości o dobro pracodawcy) nie można ograniczyć tylko do czasu pracy. W związku z tym również w czasie urlopu wypoczynkowego pracownik może dopuścić się ciężkiego naruszenia podstawowych obowiązków, uzasadniającego rozwiązanie umowy bez wypowiedzenia z winy pracownika.

268 Por. m.in. wyrok SN z 12 listopada 2003 r., I PK 593/02, „Monitor Prawniczy” 2004, nr 14, poz. 662. Zob. też: Z. Góral, [w:] Kodeks pracy..., s. 251. 
finiowanej w Kodeksie pracy doby pracowniczej. Zdaniem Sądu Najwyższego, wyrażonym w jednym z orzeczeń, dla ustalenia momentu rozpoczęcia urlopu wypoczynkowego decydujące znaczenie ma więc rozkład czasu pracy pracownika ${ }^{269}$.

W stanie faktycznym, którego dotyczyło powołane orzeczenie pracownicy, która zakończyła nocną zmianę o godz. 5 rano, bezpośrednio po zakończeniu pracy wręczono wypowiedzenie umowy o pracę i jednocześnie, przychylając się do wcześniejszego wniosku pracownicy, udzielono na ten dzień urlopu wypoczynkowego. Sąd uznał, że ponieważ zatrudniona rozpoczynała kolejną zmianę o godz. 22 w tym dniu, z tą też godziną rozpoczyna się jej urlop wypoczynkowy. Ostatecznie oceniono więc, że wręczone wypowiedzenie nie narusza art. 41 k.p. ${ }^{270}$.

Powyższe stanowisko Sądu Najwyższego budzi pewne wątpliwości. Przychylam się tu do poglądu niektórych autorów, że w przypadku osób, które wykonują pracę na nocną zmianę zakresem zastosowania art. 41 k.p. należałoby objąć zarówno dzień kalendarzowy, w którym ta zmiana się rozpoczyna, jak i ten, w którym następuje jej zakończenie ${ }^{271}$.

Jest to, moim zdaniem, konsekwencją powszechnie przyjmowanej wykładni, według której okres urlopowy stanowią nie tylko dni stricte urlopowe w rozumieniu kodeksowym, ale również łączące się z nimi bezpośrednio niedziele, święta i dni dodatkowo wolne od pracy. Nie należy więc zakłócać pracownikowi tzw. spokoju urlopowego nie tylko w tych dniach, na które bezpośrednio udzielono mu urlopu, ale również w dniach, które są wolne od pracy z innego tytułu, ale ściśle do tego urlopu przylegają. Analogicznie można uznać, że w przypadku nawet pojedynczych dni urlopu, zwłaszcza jeśli pracownik wykonuje pracę na przełomie dób kalendarzowych, zasada spokoju urlopowego powinna być rozciągnięta na czas po zakończeniu pracy czy przed jej rozpoczęciem w kolejnej dobie, jako ściśle przylegający do dnia urlopu w ujęciu dosłownym. Jest oczywiste, że pracownik po zakończeniu pracy w ostatnim dniu przed urlopem de facto już ten urlop wówczas rozpoczyna.

Przyjęcie wykładni zrównującej dni urlopu z dniami wolnymi od pracy z innego tytułu, ale bezpośrednio do tego urlopu przystającymi ma też samo w sobie bardzo istotne znaczenie $\mathrm{z}$ punktu widzenia ochrony trwałości zatrudnienia w okresie urlopu wypoczynkowego. Art. 41 k.p. statuujący tę ochronę i zakazujący pracodawcy dokonywania wypowiedzenia umowy o pracę w czasie m.in. urlopu pracownika, będzie miał bowiem swoje zastosowanie do całego tak pojmowanego okresu urlopowego. Jeśli pracownik w danym tygodniu miał zaplanowaną pracę na cztery dni po osiem godzin, wówczas mimo że wykorzystuje tylko cztery dni urlopu wypoczynkowego, pracodawca w całym tym tygodniu nie będzie mógł w sposób zgodny z prawem złożyć pracownikowi oświadczenia woli o wypowiedzeniu umowy o pracę.

269 Wyrok SN z 4 listopada 2010 r., II PK 116/10.

270 Tamże.

271 Por. T. Nycz, Nowe zasady urlopowe, M.P.P. 2004, nr 3, s. 70. 
Jest to interpretacja $\mathrm{w}$ pełni przekonująca, uzasadniona $\mathrm{w}$ dużej mierze omawianą zasadą oraz charakterem urlopu wypoczynkowego, który z natury powinien mieć nieprzerwany charakter. Jeżeli urlopu udziela się na dni pracy, to w założeniu pozostałe dni występujące w pewnym ciągu muszą być od tej pracy wolne. Pozwala to w pełnym zakresie realizować funkcję wypoczynkową omawianego świadczenia.

\subsection{Coroczność prawa do urlopu wypoczynkowego}

Dla osiągnięcia podstawowego celu urlopu wypoczynkowego nie jest bez znaczenia termin, w jakim zasadniczo powinien on być udzielony. Generalnie chodzi bowiem o to, by do jego wykorzystania doszło w okresie, za który urlop ten przysługuje, tak aby nie generować zbyt długich okresów wykonywania pracy bez możliwości odpoczynku i jednocześnie nie doprowadzać do kumulacji tego ostatniego w późniejszym czasie. Tak jak u pracownika następuje sukcesywne wydatkowanie sił, tak też adekwatna do tego okresu powinna być ich regeneracja. Zbyt długie w czasie obciążenie pracą stanowi zagrożenie dla zdrowia pracownika, którego nie da się wyeliminować $\mathrm{w}$ danym momencie perspektywą dłuższego wypoczynku, ani też zniwelować do końca jego skutków, a przynajmniej nie zawsze, udzieleniem w kolejnych latach pracownikowi zaległych urlopów wypoczynkowych, choćby łącznie z bieżącym.

Z powyższych względów za w pełni uzasadnioną należy uznać przyjętą przez ustawodawcę regułę, zgodnie z którą pracodawca powinien udzielić pracownikowi urlopu wypoczynkowego w tym roku kalendarzowym, w którym ten ostatni uzyskał do niego prawo (art. 161 k.p. w związku z art. $152 \$ 1$ k.p.).

Okresem rozliczeniowym w przypadku urlopu wypoczynkowego jest okres roku kalendarzowego i w tym czasie uprawnienie to powinno zostać zrealizowa$n e^{272}$. Obliguje to pracodawcę do takiego planowania pracy i odpoczynku, aby nie dochodziło do zbiegu omawianych uprawnień urlopowych w kolejnych latach w odniesieniu do poszczególnych pracowników. Coroczność urlopu gwarantuje zatem, w założeniu, dłuższą przerwę od pracy w każdym roku kalendarzowym, w którym dana osoba pozostaje w stosunku pracy, a także spełnia bardzo ważną rolę $\mathrm{w}$ procesie przeciwdziałania nawarstwianiu się zmęczenia związanego $\mathrm{z}$ wykonywanymi obowiązkami. Dlatego też m.in. postuluje się w literaturze, by omawiana zasada była bezwzględnie realizowana przynajmniej wobec pracowników młodocianych ${ }^{273}$.

272 Tego rodzaju reguła jest przyjmowana nie tylko w Polsce. Jak wskazuje się w literaturze, $\mathrm{np}$. w Anglii również generalną zasadą jest wykorzystanie urlopu wypoczynkowego przez uprawnionego do końca roku. Por. A.M. Przytuła-Pieniążek, The Right to Annual Leave..., s. 151.

273 Por. M. Włodarczyk, [w:] Kodeks pracy..., s. 1039. 
Przekonanie to znalazło też swój wyraz w orzecznictwie Sądu Najwyższego, w którym przyjęto, że w zakresie określonych przez prawo terminów wykorzystania urlopu wypoczynkowego ustawodawca stwarza normatywną gwarancję urlopu wypoczynkowego, który, żeby spełnił właściwą mu rolę, musi być udzielony $\mathrm{w}$ czasie sprzężonym relewantnie $\mathrm{z}$ procesem pracy $^{274}$.

Jednocześnie w tym kontekście wyrażono w literaturze pogląd, że w obrębie analizowanej zasady mieści się również zakaz udzielania przez pracodawcę urlopu „zaliczkowo”, tj. udzielenia w danym roku kalendarzowym urlopu wypoczynkowego na poczet urlopu, do którego prawo zostanie nabyte w roku kolejnym (czy w latach kolejnych) ${ }^{275}$. Taka wykładnia powołanego wyżej przepisu wydaje się przekonująca i zgodna z podstawową funkcją urlopu, z uwagi na wskazaną wcześniej pożądaną periodyczność omawianego świadczenia. W przeciwnym razie pracownik mógłby korzystać w jednym roku kalendarzowym z dwóch urlopów, a w kolejnym roku w ogóle, co jest sprzeczne z samą definicją urlopu, o której wcześniej była mowa, a także jego charakterem.

Szczególny wyjątek w tym zakresie wynika z prawa urzędniczego. Członkom służby zagranicznej, jeśli przemawia za tym interes tej służby, może być udzielony urlop wypoczynkowy łącznie za dwa lata kalendarzowe, zamiast dwóch corocznych urlopów wypoczynkowych ${ }^{276}$.

Coroczność urlopu wypoczynkowego, stanowiąca jedną z jego podstawowych właściwości, nie ma też bezwzględnego charakteru w zakresie terminu realizacji nabytego uprawnienia. Na skutek bowiem różnych okoliczności powodujących niemożność wykorzystania urlopu wypoczynkowego w danym roku, tj. uzasadniających przesunięcie terminu urlopu, jego przerwanie (o czym była mowa), dopuszcza się możliwość, a jednocześnie zobowiązuje się pracodawcę do udzielenia pracownikowi tego urlopu najpóźniej do dnia 30 września następnego roku kalendarzowego.

Urlop niewykorzystany w roku jego nabycia staje się tzw. urlopem zaległym.

Podany termin wrześniowy jest ostateczny w tym sensie, że niedopełnienie przez pracodawcę powinności udzielenia urlopu wypoczynkowego do tej daty, w zależności od sytuacji występującej w konkretnym przypadku, może zostać zakwalifikowane, zgodnie z art. $282 \$ 1$ pkt 2 k.p., jako wykroczenie przeciwko prawom pracownika zagrożone karą grzywny czy też w skrajnych wypadkach może uzasadniać rozwiązanie umowy o pracę bez wypowiedzenia przez pracownika (art. $55 \$ 1^{1}$ k.p.).

Natomiast, według powszechnej opinii, naruszenie przez pracodawcę powyższego obowiązku nie daje pracownikowi prawa do rozpoczęcia zaległego urlopu

274 Por. uzasadnienie wyroku SN z 24 stycznia 2006 r., I PK 124/05, OSNP 2006, nr 23-24, poz. 354. 275 Por. tak A.M. Świątkowski, Kodeks pracy..., s. 674. Autor uznaje, że tego rodzaju porozumienie zawarte między stronami stosunku należy uznać za nieważne, w związku z tym, nawet jeśli pracownik w danym roku kalendarzowym wykorzystał urlop, do którego prawo powstanie w roku kolejnym, to może mimo wszystko domagać się udzielenia tego urlopu w roku jego nabycia. Podobnie E. Chmielek-Łubińska, Urlopy wypoczynkowe..., s. 49.

276 Por. J. Stelina, Prawo urzędnicze, s. 244. 
wypoczynkowego po wskazanym w art. 168 k.p. terminie bez zgody pracodawcy. Teza ta znalazła bezpośrednio swój wyraz m.in. w orzeczeniu Sądu Najwyższego z 5 grudnia $2000 \mathrm{r}^{277}$. Udzielenie urlopu wypoczynkowego, jak trafnie zauważył Sąd Najwyższy, jest bowiem czynnością jednostronną pracodawcy zwalniającą pracownika $\mathrm{z}$ obowiązku świadczenia pracy. Przepisy prawa nie dają możliwości zastąpienia jej żadnym oświadczeniem pracownika. Tym samym pracownik nie może sam sobie skutecznie udzielić urlopu, a samo „zawiadomienie” pracodawcy o jego rozpoczęciu nie stanowi podstawy do usprawiedliwienia jego nieobecności w pracy. Samowolne rozpoczęcie urlopu przez pracownika będzie prowadziło zatem do naruszenia jego podstawowych obowiązków ${ }^{278}$.

Stanowisko to jest zasadniczo zgodne $\mathrm{z}$ istotą urlopu wypoczynkowego, chodzi bowiem o zwolnienie pracownika z obowiązku wykonywania pracy, którego w założeniu może dokonać jedynie podmiot zatrudniający lub osoba działająca w jego imieniu. Biorąc jednak pod uwagę funkcję i znaczenie omawianej instytucji, należy rozważyć możliwość wprowadzenia bardziej skutecznych instrumentów egzekwowania prawa do urlopu wypoczynkowego, szczególnie w przypadkach rażącego jego naruszenia, o czym była już mowa wcześniej (por. zasada niezbywalności prawa do urlopu wypoczynkowego).

Podzielić należy również w związku z powyższym ocenę Sądu Najwyższego wyrażoną w wyroku z 12 sierpnia 2004 r., w którym uznano, że samowolne rozpoczęcie urlopu przez pracownika nie zawsze może być kwalifikowane jako ciężkie naruszenie jego podstawowych obowiązków. Ważna jest bowiem w tym zakresie także postawa pracodawcy i przyczyna, dla której odmawia on udzielenia tego urlopu w terminie wskazanym przez pracownika ${ }^{279}$.

Dość istotna w kontekście funkcji urlopu wypoczynkowego jest kwestia wyznaczonego przez ustawodawcę ostatecznego terminu udzielenia urlopu zaległego. W przeszłości owo przesunięcie urlopu na rok następny mogło mieć miejsce, ale w stosunkowo nieznacznym zakresie - urlopu trzeba było udzielić pracownikowi najpóźniej do końca pierwszego kwartału roku następnego, co miało w jakiś sposób godzić omawiany obowiązek uzasadniony celem urlopu z występującą wyjątkowo potrzebą jego przesunięcia, pozostającą niekiedy w interesie samego zatrudnionego. Obecnie ustawodawca znacznie wydłużył ten okres, zgodnie z art. 168 k.p. urlopu niewykorzystanego w roku jego nabycia należy pracownikowi udzielić najpóźniej do dnia 30 września następnego roku kalendarzowego. Zmiana ta może być postrzegana jako zagrażająca prawidłowej realizacji funkcji wypoczynkowej urlopu, co zostanie szerzej omówione w kolejnych częściach pracy.

W praktyce zdarza się, że pracownicy, z różnych względów, odmawiają wykorzystania zaległego urlopu wypoczynkowego w podanym terminie (niekiedy podpisując stosowne oświadczenie). Należy, według mnie, uznać, że absolutnie nie

277 Wyrok SN z 5 grudnia 2000 r., I PKN 121/00, OSNP 2002, nr 15, poz. 353.

278 Tamże. Podobnie w wyroku SN z 15 marca 2001 r., I PKN 306/00, OSNP 2002, nr 24, poz. 591. 279 III PK 32/04, M.P.P. 2004, nr 9, s. 230. 
zwalnia to pracodawcy z wykonania omawianego obowiązku udzielenia urlopu wypoczynkowego do końca września. Powstaje natomiast pytanie, czy wówczas można pracownika po prostu na taki urlop skierować, np. niedopuszczając go do pracy w odpowiednim okresie.

W mojej ocenie odpowiedź na to pytanie powinna być twierdząca. Kodeks pracy nie przewiduje bowiem żadnych wyjątków w zakresie ostatecznego terminu udzielenia urlopu wypoczynkowego wynikającego z art. 168 k.p. Ponadto trzeba wziąć pod uwagę, że naruszenie tego obowiązku pociąga za sobą odpowiedzialność pracodawcy $\mathrm{z}$ tytułu popełnionego wykroczenia, musi więc on mieć do dyspozycji środki umożliwiające, wobec sprzeciwu pracownika, doprowadzenie do stanu zgodnego z prawem.

Nie do końca jednoznaczne jest w tej kwestii stanowisko Sądu Najwyższego.

W tezie 3. wyroku z 2 września 2003 r. Sąd Najwyższy zdecydowanie uznał, że udzielenie na podstawie art. 168 k.p. urlopu wypoczynkowego za poprzednie lata w terminie wskazanym w tym przepisie (wówczas jeszcze chodziło o pierwszy kwartał następnego roku) nie wymaga zgody pracownika ${ }^{280}$. Sąd podkreślił wręcz, że pracodawca w zakresie urlopu zaległego nie musi uzgadniać z pracownikiem terminu wykorzystania tego urlopu, lecz ma on obowiązek udzielenia urlopu w okresie wskazanym w powołanym przepisie.

W nieco późniejszym orzeczeniu Sąd Najwyższy przyjął jednak, że „nie ma jednej i prostej odpowiedzi na pytanie, czy pracodawca może jednostronnie skierować pracownika na zaległy urlop wypoczynkowy”, gdyż zależy to od okoliczności faktycznych, a te, zdaniem Sądu Najwyższego, „mogą być rozmaite”281.

Co istotne, według niemal powszechnej wśród przedstawicieli prawa pracy wykładni, jeśli pracodawca nie wywiąże się ze swego obowiązku i nie udzieli pracownikowi urlopu wypoczynkowego w terminie określonym w art. 168 k.p. nie powoduje to po stronie pracownika utraty prawa do tego urlopu ${ }^{282}$ (inne stanowisko zajął A. Sobczyk, o czym dalej). Niemniej roszczenie o udzielenie zaległego urlopu wypoczynkowego (ewentualnie zapłatę ekwiwalentu pieniężnego za ten niewykorzystany urlop w razie ustania stosunku pracy) przedawnia się z upływem trzech lat, licząc od dnia, w którym roszczenie to stało się wymagalne. Bieg okresu przedawnienia roszczenia o urlop wypoczynkowy nie rozpoczyna się jednak, a rozpoczęty ulega zawieszeniu na czas korzystania z urlopu wychowawczego.

Jeśli chodzi o ostatnią kwestię, a więc rozpoczęcie biegu okresu przedawnienia roszczenia urlopowego, to Sąd Najwyższy uznał w uchwale z 20 lutego 1980 r., że bieg przedawnienia tego roszczenia rozpoczyna się ostatniego dnia roku kalendarzowego, w którym pracownik uzyskał prawo do urlopu, chyba że szczególne przepisy Kodeksu pracy lub innych aktów normatywnych przewidują obowiązek

280 Wyrok SN z 2 września 2003 r., I PK 403/02.

281 Wyrok SN z 25 sierpnia 2004 r., I PZP 4/04, „Wspólnota” 2004, nr 19, poz. 5.

282 Por. m.in.: F. Małysz, Pracownicze urlopy wypoczynkowe, s. 68; E. Chmielek-Łubińska, Urlopy wypoczynkowe..., s. 54. 
udzielenia urlopu w innych terminach ${ }^{283}$. Tym samym należy przyjąć, że jeśli wyjątkowo nie było możliwości wykorzystania urlopu w roku jego nabycia i strony ustaliły termin jego wykorzystania zgodnie $\mathrm{z}$ art. 168 k.p., to dzień wskazany jako pierwszy dzień tego urlopu będzie rozpoczynał bieg trzyletniego okresu przedawnienia roszczenia o ten urlop, a jeśli dojdzie do jego przesunięcia na kolejny rok kalendarzowy bez wskazania konkretnej daty, ostatecznie dzień 30 września (lub jak chcą niektórzy autorzy, 1 października ${ }^{284}$ ) stanie się początkiem biegu omawianego okresu. Zdaje się to potwierdzać znacznie późniejszy od wspomnianej uchwały wyrok Sądu Najwyższego z 11 kwietnia 2001 r., w którym stwierdzono, że roszczenie o udzielenie urlopu wypoczynkowego przedawnia się z upływem trzech lat od dnia, w którym stało się wymagalne, przy czym rozpoczęcie biegu tego terminu następuje bądź z końcem roku kalendarzowego, za który urlop przysługuje, bądź najpóźniej z końcem pierwszego kwartału roku następnego (dotyczy starej wersji art. 168 k.p., obecnie z końcem września), jeżeli urlop został przesunięty na ten rok z przyczyn leżących po stronie pracownika lub pracodawcy ${ }^{285}$.

Warto też odnotować pogląd Naczelnego Sądu Administracyjnego w Warszawie, wyrażony w wyroku z 1 kwietnia 2003 r., że pracodawca nie jest obowiązany do udzielenia pracownikowi, z własnej inicjatywy, w pierwszej kolejności zaległego urlopu wypoczynkowego ${ }^{286}$. Jak się wydaje, sąd uznał, że to pracownik powinien wystąpić do pracodawcy ze stosownym wnioskiem w tej sprawie, co może mieć szczególne znaczenie w sytuacji, gdy bliski jest moment upływu terminu przedawnienia roszczenia o zaległy urlop wypoczynkowy danego pracownika.

W wyroku tym zerwano zatem z przyjętą w praktyce regułą, niewyrażoną bezpośrednio $\mathrm{w}$ ustawie, że udzielając pracownikowi w określonym czasie zwolnienia urlopowego, należy zaliczyć na jego poczet w pierwszej kolejności niewykorzystany urlop z lat poprzednich. Niemniej stanowisko Naczelnego Sądu Administracyjnego jest, w mojej ocenie, przekonujące. Należy bowiem dążyć przede wszystkim do tego, aby urlop bieżący został udzielony jeszcze w tym roku kalendarzowym, w którym pracownik nabył do niego prawo. Wówczas najpełniej realizuje on bowiem swoje przeznaczenie, a jego wykorzystywanie daje potencjalnie najlepsze efekty. Niewątpliwie wartością jest więc taka wykładnia obowiązującego prawa urlopowego, która będzie przeciwdziałać narastaniu zaległości urlopowych, np. w wyniku przesuwania urlopów bieżących na kolejny rok w związku z realizacją w pierwszej kolejności urlopu zaległego, który powinien być wyjątkiem, a nie regułą. Pracodawca musi mieć jednak na uwadze ostateczny termin dotyczący udzielenia urlopu zaległego, stąd jeśli przed upływem tego terminu pracownik nie wykorzystał w pełni urlopu bieżącego za dany rok, a może to zrobić po wykorzystaniu urlopu zaległego, wówczas ten ostatni powinien być przez pracodaw-

283 Uchwała siedmiu sędziów SN z 20 lutego 1980 r., V PZP 6/79, OSNC 1980, nr 7-8, poz. 131.

284 Tak por. M. Zieleniecki, [w:] Kodeks pracy. Komentarz, red. A. Sobczyk, s. 648.

285 Wyrok SN z 11 kwietnia 2001 r., I PKN 367/00, OSNP 2003, nr 2, poz. 38.

286 Wyrok NSA w Warszawie z 1 kwietnia 2003 r., II SA 2162/02, „Prawo Pracy” 2003, nr 6, poz. 43. 
cę udzielony w pierwszej kolejności, tak aby były respektowane przepisy Kodeksu pracy w zakresie omawianej zasady. Urlop zaległy, którego podstawowa funkcja i tak już jest zagrożona, może z upływem czasu tracić na znaczeniu, a nawet może dojść do zupełnej jego utraty w związku z okresem przedawnienia, czemu powinno się w praktyce stosowania prawa zdecydowanie przeciwdziałać.

Należy uznać jednocześnie, że konstrukcja przedawnienia prawa do urlopu wypoczynkowego nie pozostaje w sprzeczności z wypoczynkową funkcją urlopu. W jakiejś mierze się nawet w tę funkcję wkomponowuje. Odpoczynek, aby spełnił swoje zasadnicze cele, musi być bowiem udzielany w miarę systematycznie, tj. we właściwych mu czasookresach (doby, tygodnia, czy tak jak w omawianym przypadku, roku). Znaczny odstęp czasowy pomiędzy momentem nabycia prawa do odpoczynku a dniem jego realizacji przekreśla możliwość osiągnięcia leżących u jego podstaw efektów.

$\mathrm{Z}$ powyższych względów odmienną od powszechnie przyjętej interpretację w zakresie urlopu zaległego zaprezentował w ostatnim czasie A. Sobczyk ${ }^{287}$. Autor przede wszystkim zwraca uwagę, że literalne brzmienie art. 168 k.p. skłania do wniosku, że z urlopem zaległym sensu stricto, a więc podlegającym udzieleniu do końca września roku następnego, mamy do czynienia tylko wówczas, gdy urlop został „udzielony”, zgodnie z art. 163 k.p., jak należy rozumieć, wyznaczono termin jego wykorzystania, ale wskutek okoliczności przewidzianych prawem (związanych np. z odwołaniem z urlopu czy jego przesunięciem) do realizacji tego prawa nie doszło. W konsekwencji omawiany art. 168 k.p. nie będzie miał zastosowania do tych przypadków, w których urlop należny za dany rok nie został w ogóle udzielony. Prawo do tego rodzaju urlopu, określonego przez A. Sobczyka jako „nieprawidłowy urlop zaległy”, zdaniem autora, wygasa wraz z końcem roku jego nabycia, podobnie jak nieudzielony do końca września roku następnego „prawidłowy urlop zaległy”288. Wówczas jednak po stronie pracownika powstaje prawo do odszkodowania $\mathrm{z}$ powodu bezprawnie nieudzielonego urlopu w naturze (uwzględniającego ewentualne dodatkowe wynagrodzenie w związku z większą ilością pracy i regułą równego traktowania) oraz zadośćuczynienia $\mathrm{z}$ tytułu naruszenia dóbr osobistych. Pracodawca poniesie dodatkowo sankcje o charakterze karnym (z tytułu popełnionego wykroczenia, za jakie należy uznać nieustalenie terminu urlopu bieżącego

287 A. Sobczyk, Nieprawidłowe wypoczynkowe urlopy zaległe, M.P.P. 2017, nr 5, s. 251.

288 Według możliwej do przyjęcia, zdaniem A. Sobczyka, innej interpretacji, prawo do urlopu nie wygasa, ale pracodawca nie może go już udzielić jednostronnie. Oznacza to, że realizacja prawa pracownika do takiego urlopu wymaga uzgodnienia przez obie strony stosunku pracy (a więc zgody pracownika na jego udzielenie, który w ten sposób traci prawo przynajmniej do dochodzenia wyżej wymienionego odszkodowania), a w razie braku takiego uzgodnienia, zaczyna on podlegać przedawnieniu. Autor proponuje również trzecią wykładnię - „mieszaną”, zgodnie z którą prawo do urlopu, w opisanych wcześniej sytuacjach, wygasa, ale dopuszczalne będzie udzielenie pracownikowi urlopu na podstawie zawartej między stronami umowy, co zwalania pracodawcę z obowiązku wypłaty odszkodowania. Wówczas jednak urlop ten traci swój kodeksowy charakter ze wszystkimi tego konsekwencjami i staje się urlopem „umownym”. Por. tenże, Nieprawidłowe wypoczynkowe urlopy..., s. 253 i n. 
w tym roku kalendarzowym, w którym pracownik nabył do niego prawo ${ }^{289}$, a nawet $\mathrm{z}$ tytułu przestępstwa, o którym mowa w art. 218 k.k., jeżeli taka praktyka ma charakter trwały lub masowy).

W powyższym ujęciu przedawniają się zatem wymienione roszczenia związane $\mathrm{z}$ nieudzielonym urlopem, ale nie on sam, gdyż prawo do urlopu wygasa $\mathrm{z}$ ostatnim dniem roku ${ }^{290}$.

Zdaniem A. Sobczyka, taka wykładnia analizowanych przepisów jest uzasadniona nie tylko ich literalnym brzmieniem, ale też pozostaje zgodna $\mathrm{z}$ istotą tej instytucji. Pracownik nabywa prawo do urlopu na dany rok, a nie na lata kolejne, kiedy to ma już prawo do urlopu bieżącego, a ponadto urlop zaległy, tracąc związek ze zmęczeniem powodowanym pracą, przestaje mieć rację bytu. Dlatego też ściśle wykładany art. 168 k.p. jednoznacznie wskazuje, że zjawisko urlopów zaległych powinno mieć charakter sporadyczny. Osiągnięciu takiego stanu lepiej sprzyja, zdaniem autora, wskazana koncepcja, w tym zwłaszcza związane z nią roszczenia, które powinny działać zniechęcająco na pracodawcę w kwestii nierespektowania zasady urlopu corocznego.

Zaproponowane nowe spojrzenie na problem urlopów zaległych z pewnością zasługuje na uwagę. Zbyt często bowiem, także za przyzwoleniem pracowników, wyjątek od reguły urlopu corocznego staje się trwałą praktyką w procesie udzielania urlopów wypoczynkowych przez pracodawcę. Uznanie, że niezrealizowane $\mathrm{w}$ terminie prawo do urlopu co do zasady wygasa, wywierałoby niewątpliwie presję na samych zatrudnionych w kierunku domagania się od pracodawcy udzielenia urlopu we właściwym czasie.

Pogląd ten wpisuje się również w jakieś mierze w założenie, które legło u podstaw zasady urlopu corocznego, że odpoczynek, aby spełnił w stopniu optymalnym swą funkcję, musi być wykorzystywany w okresie, z jakim prawo łączy obowiązek jego realizacji.

Zaprezentowana powyżej koncepcja wywołuje jednak też pewne wątpliwości.

Przede wszystkim trzeba zwrócić uwagę, że dominująca obecnie wykładnia, wobec braku przepisu jednoznacznie przesądzającego, co dzieje się z nieudzielonym w terminie urlopem wypoczynkowym, stanowi dość istotne zabezpieczenie prawa pracownika do urlopu w naturze, które z kolei najpełniej realizuje jego prawo do odpoczynku. Żadna inna forma rekompensaty, zwłaszcza pieniężna, nie zapewni nigdy osiągnięcia celów, dla których prawo to zostało ustanowione i podniesione do rangi podstawowej zasady prawa pracy.

Trudno także w pełni i bez żadnych zastrzeżeń zaaprobować stanowisko, według którego urlop udzielony pracownikowi w kolejnym roku kalendarzowym traci zupełnie swój walor wypoczynkowy. Nie podlega dyskusji, że im później następuje udzielenie urlopu wypoczynkowego w stosunku do roku jego naby-

289 Nieudzielenie urlopu, o którym stanowi art. $281 \S 1$ k.p., autor utożsamia z nieustaleniem terminu urlopu zgodnie $z$ art. 161 k.p. Tamże, s. 252.

290 Tamże. 
cia przez pracownika, tym większe występuje poluźnienie związku między pracą i powiązanym z nią wysiłkiem a mającym to zbilansować odpoczynkiem. Stąd ustawodawca przyjmuje, że zasadą ma być korzystanie z urlopu w tym roku kalendarzowym, w którym pracownik nabył do niego prawo, a jedynie wyjątkowo może dojść do realizacji tego urlopu w roku kolejnym. Wydłużenie ostatecznego terminu, w jakim pracodawca powinien tego urlopu udzielić, oceniam bardzo krytycznie, o czym będzie mowa w kolejnej części opracowania, niemniej traktowanie owych sytuacji jako sporadycznych, a takie wynika z regulacji kodeksowych, każe uznać, że w jakieś mierze odpoczynek, choćby udzielony z pewnym opóźnieniem, ma z punktu widzenia jego celów większą wartość dla pracownika niż przyznana mu, nawet wysoka, rekompensata pieniężna ${ }^{291}$. Oczywiście kwestią do dyskusji jest, czy prawo do urlopu wykraczającego poza wskazany w ustawie termin powinno być poddane ogólnym przepisom dotyczącym przedawnienia roszczeń, z których wynika stosunkowo długi czas jego możliwej realizacji, być może zbyt długi z punktu widzenia jego podstawowej funkcji oraz omawianej zasady. Niemniej wygaśnięcia prawa pracownika o tak podstawowym znaczeniu, mającego swe konstytucyjne umocowanie, nie powinno się pośrednio wyinterpretowywać z przepisów, ale raczej postulować ich zmianę, zwłaszcza że we wcześniejszym prawie urlopowym sytuacje, w których następuje utrata prawa do urlopu każdorazowo były wyraźnie normowane (por. pierwsza część rozważań). Jest to szczególnie istotne w kontekście tzw. nieprawidłowego urlopu zaległego, w przypadku którego, jak się wydaje, mając na względzie wyżej prezentowaną wykładnię, pracownik w sytuacji, gdy pracodawca działa nielegalnie, narusza jego prawo do wypoczynku, znajduje się w gorszym położeniu niż ten, któremu co prawda przesunięto urlop na kolejny rok, ale w okolicznościach wskazanych w przepisach. Pierwszy z nich, w kolejnym roku (jeśli uznamy, że prawo do urlopu z końcem roku wygasło) nie będzie miał możliwości uzyskania czasu wolnego od pracy (być może otrzyma w zamian świadczenia pieniężne, jeśli w ogóle zdecyduje się odwołać do sądu pozostając w stosunku pracy, co jednak samo w sobie nie sprzyja ochronie zdrowia), drugi natomiast będzie miał ograniczoną czasowo możliwość skorzystania z dłuższego wypoczynku po okresie dłuższej pracy.

$\mathrm{Z}$ tej perspektywy klarowniejsze wydają się rozwiązania przyjęte w prawie niemieckim, w którym urlop powinien być zasadniczo wykorzystany w roku jego nabycia ${ }^{292}$. Wyjątkowo, ze szczególnie ważnych powodów leżących po stronie pracownika lub pracodawcy, może on być udzielony w roku kolejnym, do końca pierw-

291 Warto przy tym zauważyć, że nawet w przypadku odpoczynków dotyczących bardzo krótkich odcinków czasowych, dobowych i tygodniowych, w których istotę wpisane są duża regularność i szybkość ich udzielania, dopuszcza się, zarówno w samej ustawie, jak i orzecznictwie SN, pewne odstępstwo czasowe (por. wcześniejsze rozważania).

292 Podkreśla się tam wyraźnie, że roszczenie o urlop wypoczynkowy przysługuje „w roku kalendarzowym”, a nie „na rok kalendarzowy”. Por. M. Henssler, H.J. Willemsen, H.-J. Kalb (Hrsg.), Arbeitsrecht..., s. 1891. 
szego kwartału ${ }^{293}$. Po tym terminie pracownik zwykle traci prawo do urlopu wypoczynkowego za poprzedni rok, chyba że umowa w tym zakresie stanowi inaczej ${ }^{294}$.

W związku z orzecznictwem Trybunału Sprawiedliwości UE uznano w ostatnim czasie, że powyższy skutek nie dotyczy urlopu w wymiarze minimalnym (a więc z pominięciem urlopu dodatkowego), który nie mógł być wykorzystany $\mathrm{w}$ podanych terminach $\mathrm{z}$ powodu choroby pracownik $\mathrm{a}^{295}$.

Co istotne jednak w kontekście analizowanego zagadnienia, w prawie niemieckim konsekwencji utraty przez pracownika roszczenia o urlop po upływie wskazanego terminu towarzyszy, jak zdaje się wynikać z przyjętego prawa i ukształtowanej praktyki, większy wpływ zatrudnionego na okres, w jakim urlop będzie przez niego wykorzystywany. Nieco inaczej rozłożono tam bowiem akcenty w zakresie procedury jego udzielania; pracodawca jest zobowiązany do udzielenia urlopu, jeśli pracownik wystąpi z odpowiednim podaniem, a jedynie wyjątkowo może odmówić udzielenia urlopu w terminie wskazanym przez pracownika, jeśli wymaga tego ważny interes zakładu lub innych pracowników (w tym zwłaszcza uprzywilejowanych, np. mających dzieci).

Przeciwdziałając istniejącej w Polsce praktyce odchodzenia od zasady urlopu corocznego można też zastanawiać się nad ewentualnym wzmocnieniem gwarancji jej realizacji, co niewątpliwie pozwoliłoby na pełniejsze urzeczywistnienie prawa pracownika do odpoczynku. Działania w tym zakresie mogłyby polegać na przyznaniu pracownikowi uprawnienia do wskazania terminu urlopu, jeśli doszło do przesunięcia tego pierwotnie ustalonego z przyczyn leżących po stronie pracodawcy czy w sytuacji, gdy nie został on w ogóle wyznaczony. Można również rozważyć wprowadzenie zasady udzielania urlopu zaległego w wymiarze wyższym (np. dwukrotnie) od pozostałej do wykorzystania części urlopu z roku ubiegłego. Ostatnie rozwiązanie $\mathrm{w}$ jakiś sposób wpisuje się $\mathrm{w}$ istotę prawa do odpoczynku - powinien on być dłuższy, skoro pracownik wcześniej nie mógł z niego skorzystać, bardziej intensywna i rozciągnięta $\mathrm{w}$ czasie praca usprawiedliwia bowiem dłuższy czas na regenerację organizmu. Ponadto pracodawca wyraźnie zaczyna mieć interes w terminowym udzielaniu pracownikom urlopów, zwłaszcza że ma on też instrumenty prawne, o czym była mowa, by wyegzekwować wykorzystanie omawianego zwolnienia od pracy przez pracownika w przewidzianym prawem terminie.

293 Por. $\S 7$ niemieckiej ustawy urlopowej Mindesturlaubsgesetz fur Arbeitnehmer (Bundesurlaubsgesetz) z 1963 r., www.gesetze-im-internet.de.

294 Por. wyrok Federalnego Sądu Pracy z 9 sierpnia 2011 r., 9 AZR 425/10. Por. też M. Lipa, H. von Zanthier, Prawo pracy w Niemczech, Berlin 2012, s. 31.

295 Por. tamże, s. 32. Zob. też: wyrok Federalnego Sądu Pracy z 22 maja 2012 r., 9 AZR 575/10. Niemniej, jak wskazuje się w niemieckiej literaturze, jeśli urlop nie mógł być wykorzystany w roku jego nabycia z powodu stwierdzonej przez lekarza niezdolności do pracy wywołanej chorobą, powinien być on zrealizowany do końca marca roku następnego, a jeśli choroba (ta sama lub inna) uniemożliwia udzielenie urlopu w tym terminie, do końca roku. W żadnym razie jednak okres ten nie może być dłuższy niż 15 miesięcy (po tym czasie roszczenie wygasa). Por. M. Henssler, H.J. Willemsen, H.-J. Kalb (Hrsg.), Arbeitsrecht..., s. 1904. 


\subsection{Udzielanie urlopu w naturze}

W kontekście realizacji podstawowej funkcji urlopu wypoczynkowego niezwykle ważna jest zasada urlopu w naturze, która stanowi zapewnienie, że pracownik uzyska ten urlop w postaci dla niego właściwej, tj. czasu wolnego od pracy przeznaczonego na regenerację sił. Wynika z niej zakaz zastępowania zwolnienia od obowiązku świadczenia pracy z tytułu należnego urlopu inną formą świadczeń, w szczególności wypłatą pieniężną. Ustawodawca (nie tylko polski ${ }^{296}$ ) chroni pracownika w ten sposób zarówno przed pokusą większego zarobku kosztem odpoczynku, ale też potencjalnymi naciskami ze strony pracodawców w kierunku zamiany urlopu na finansową postać rekompensaty.

Waga tego zagadnienia dla zachowania istoty urlopu wypoczynkowego została dostrzeżona również $\mathrm{w}$ orzecznictwie sądowym. W jednym ze swych wyroków Sąd Najwyższy stwierdził wyraźnie, że pracownik w czasie trwania zatrudnienia może dochodzić przed sądem pracy nakazania pracodawcy udzielenia mu urlopu w naturze ${ }^{297}$.

Potwierdzenie roszczenia pracownika o udzielenie urlopu w postaci dni wolnych od pracy jest niezwykle istotne dla urzeczywistnienia jego prawa do odpoczynku, może bowiem w praktyce m.in. skutecznie przeciwdziałać próbom obchodzenia omawianej zasady, choćby poprzez świadome przesuwanie terminu urlopu wypoczynkowego przez pracodawcę aż do końca zawartej umowy terminowej, w celu zastąpienia tego urlopu ekwiwalentem. Stanowi też o możliwości skutecznego reagowania przez pracownika na wszelkie inne zaniechania pracodawcy i naruszenia przepisów urlopowych dotyczących terminowego udzielania tego urlopu, które niekiedy mogą przybrać nawet postać szykany.

Ekwiwalent pieniężny za niewykorzystany urlop wypoczynkowy może być zatem wypłacony jedynie wyjątkowo i w ściśle przez prawo określonych przypadkach. Podstawową normą w tym zakresie jest art. $171 \$ 1$ k.p., który dopuszcza, zgodnie z wymogami prawa europejskiego, możliwość wypłaty ekwiwalentu za urlop w sytuacji, gdy de facto świadczenie to nie może być już zrealizowane w jego właściwej formie, tj. w razie ustania stosunku pracy (jego rozwiązania lub wygaśnięcia).

296 Tego rodzaju regulacja obowiązuje również m.in. w Szwecji; zasadą jest brak możliwości zamiany urlopu na ekwiwalent pieniężny. Por. A. Adlercreutz, B. Nyström, Labour Law in Sweden, Alphen aan den Rijn 2010, s. 93. Podobnie jest we Włoszech; tylko sytuacja przerwania stosunku pracy pozwala na zastąpienie urlopu w naturze ekwiwalentem pieniężnym. Por. T. Treu, Labour Law in Italy, s. 85. Także we Francji urlop nie może być przez pracownika zamieniony na inne korzyści, zwłaszcza dodatkowe wynagrodzenie. Por. G. Auzero, E. Dockès, Droit..., s. 871.

297 Postanowienie SN z 10 kwietnia 1997 r., I PKN 112/97, OSNAPiUS 1998, nr 4, poz. 116. Po ustaniu stosunku pracy, jak przyjął SN, pracownik nie ma już jednak interesu prawnego w ustaleniu, że nie wykorzystał urlopu wypoczynkowego w naturze. Może dochodzić bowiem na podstawie art. 171 k.p. ekwiwalentu za niewykorzystany urlop. Zob. postanowienie SN z 14 maja 1998 r., I PKN 111/98, OSNAP 1999, nr 9, poz. 310. 
W doktrynie prawa pracy dominuje w pełni uzasadnione, według mnie, przekonanie, że art. 171 k.p. należy uznać za przepis o charakterze bezwzględnie obowiązującym. Oznacza to, że katalog przesłanek warunkujących wypłatę ekwiwalentu nie może być ani w swoistych źródłach prawa pracy (układ zbiorowy pracy, regulamin itp.), ani też w umowie o pracę ukształtowany odmiennie niż to uczynił ustawodawca ${ }^{298}$. W konsekwencji same strony stosunku pracy, ale też partnerzy społeczni nie mogą swą wolą wyłączyć omawianej zasady czy ograniczyć zakresu jej zastosowania.

Stanowisko to znalazło również swoje potwierdzenie w judykaturze.

Między innymi z powyższego powodu za nieważne uznano np. zastrzeżenie poczynione $\mathrm{w}$ umowie przy jej zawieraniu, że wynagrodzenie pracownika będzie obejmować także ekwiwalent za urlop. Zdaniem sądu, założenie takie prowadziłoby do sytuacji, w której pracownik już zawierając umowę o pracę, zrzekałby się urlopu i godził na wypłatę ekwiwalentu ${ }^{299}$.

Do podobnych wniosków doszedł też Trybunał Sprawiedliwości UE, w ocenie którego wszelkie tego rodzaju praktyki są sprzeczne z postanowieniami dyrektywy dotyczącej niektórych aspektów organizacji czasu pracy i jako takie niedopuszczalne ${ }^{300}$.

Należy zatem podkreślić, że ewentualne porozumienie stron co do wypłaty ekwiwalentu pieniężnego $\mathrm{w}$ innych okolicznościach niż te wymienione w przepisach prawa musi być zasadniczo objęte sankcją nieważności ${ }^{301}$.

298 Por. A. Dubowik, Zasada udzielania urlopu wypoczynkowego w naturze i plan urlopów, PiZS 2003, nr 5, s. 31.

299 Wyrok SA w Katowicach z 15 grudnia 2006 r., III APa 176/05, LEX nr 310405.

300 W świetle tego orzeczenia, niezgodne z dyrektywą jest, aby część wynagrodzenia wypłaconego pracownikowi za wykonaną pracę stanowiło wynagrodzenie za coroczny urlop, jeśli pracownik nie otrzymuje z tytułu tego urlopu wynagrodzenia wypłacanego dodatkowo obok wynagrodzenia za wykonaną pracę. Odstępstwa od tego prawa w drodze postanowień umownych są niedopuszczalne. Por. wyrok TSUE z 16 marca 2016 r. w sprawach połączonych C.D. Robinson Steele oraz Michael Jason Clarke, C-131/04 i C-257/04, ZOTSiS 2006/3A/I2531, pkt 1 sentencji wyroku.

301 Warto jednak przypomnieć, że w przeszłości odmienne stanowisko w tej sprawie zostało wyrażone w jednym z orzeczeń SN, dość krytycznie ocenionym w literaturze przedmiotu. W uzasadnieniu do uchwały z 8 lipca 1999 r. (III ZP 10/99, OSNAPiUS 2000, nr 6, poz. 233) sąd uznał, że w praktyce mogą wystąpić jeszcze inne sytuacje niż opisane w art. 171 k.p., które będą uniemożliwiać pracownikowi wykorzystanie urlopu w naturze i uzasadniać wypłatę ekwiwalentu pieniężnego. Strony stosunku pracy mogły więc w takim przypadku umówić się na wypłatę owego ekwiwalentu za urlop. Za: A. Dubowik, Zasada udzielania urlopu wypoczynkowego..., s. 31. Jak słusznie podkreśla się w doktrynie prawa pracy, teza ta, nawet jeśli w określonych okolicznościach korzystna dla pracownika (ponieważ upływa termin przedawnienia roszczenia o urlop, a z powodów obiektywnych nie może on wykorzystać urlopu w naturze), jest sprzeczna z przepisami prawa urlopowego oraz zakazem dokonywania rozszerzającej interpretacji wyjątków od ogólnych regut. Por. M. Nałęcz, [w:] Kodeks pracy..., s. 779 oraz A. Kosut, [w:] Kodeks pracy..., s. 943. Należy również dodać, że taka wykładnia omawianego unormowania jest też nie do zaakceptowania w świetle prawa europejskiego i rozstrzygnięć dokonywanych w tym obszarze przez Trybunał Sprawiedliwości UE. 
Również w wyroku Naczelnego Sądu Administracyjnego w Białymstoku przyjęto, że Rada Gminy nie jest uprawniona do podjęcia uchwały przyznającej wójtowi-pracownikowi ekwiwalent za niewykorzystany urlop wypoczynkowy, poza przypadkami określonymi w art. 171 k.p. ${ }^{302}$

W sytuacji zakończenia stosunku pracy roszczenie pracownika o ekwiwalent pieniężny za niewykorzystany urlop wypoczynkowy, zarówno bieżący, jak i zaległy, staje się wymagalne w dacie ustania stosunku pracy ${ }^{303}$.

Niemniej, jak ocenił Sąd Najwyższy, przyznając swego rodzaju priorytet zasadzie urlopu w naturze w związku z główną funkcją tego urlopu, zastąpienie urlopu wypoczynkowego ekwiwalentem pieniężnym jest możliwe wyjątkowo tylko wówczas, gdy dochodzi do definitywnego rozwiązania lub wygaśnięcia stosunku pracy przed wykorzystaniem przysługującego pracownikowi urlopu. Nie dotyczy to zatem sytuacji, w której nastąpiła restytucja stosunku pracy w wyniku przywrócenia pracownika do pracy i jej podjęcia ${ }^{304}$. Wtedy pracownik może jeszcze wykorzystać ten urlop w sposób zgodny z jego przeznaczeniem.

Zajęte przez Sąd Najwyższy stanowisko w jakimś sensie wpisuje się w filozofię leżącą u podstaw rozwiązania przyjętego przez ustawodawcę w ostatnich latach, gwarantującego możliwość odstąpienia od obowiązku wypłaty ekwiwalentu i wykorzystania przez pracownika urlopu w naturze, mimo nawet ustania zatrudnienia. Jest to dopuszczalne, jeśli strony stosunku pracy postanowią o wykorzystaniu tego urlopu w czasie pozostawania pracownika w stosunku pracy na podstawie kolejnej umowy o pracę zawartej z tym samym pracodawcą, pod warunkiem jednak, że będzie ona zawarta bezpośrednio po rozwiązaniu lub wygaśnięciu poprzedniej umowy o pracę z tym pracodawcą (art. $171 \$ 3$ k.p.). Chodzi zatem o pewną ciągłość zatrudnienia, która powoduje, że pracownik ma jeszcze możliwość wykorzystania urlopu na odpoczynek, a więc w postaci, w jakiej z definicji ten urlop powinien być udzielony.

Pewne wątpliwości na gruncie przytoczonej regulacji wywołuje pojęcie, a zarazem warunek skutecznego zawarcia odpowiedniego porozumienia stron w omawianej sprawie, bezpośredniego następowania kolejnej umowy o pracę w stosunku do ustania poprzedniej umowy o pracę z tym samym pracodawcą.

W literaturze są wypowiadane na ten temat różne opinie.

Zdaniem K. Rączki, mając na uwadze podstawowy cel analizowanego unormowania, jakim jest wykorzystanie urlopu w naturze, należy odejść od dosłownego rozumienia użytego w komentowanym przepisie terminu „bezpośrednio”. Autor uważa, że ze względu na art. 161 k.p. bezpośrednie zawarcie nowej umowy o pracę, o którym mowa w $171 \$ 3$ k.p., oznacza jej zawarcie w tym samym roku kalendarzowym, w którym nastąpiło ustanie poprzedniego zatrudnienia pomiędzy tymi

302 Por. wyrok NSA w Białymstoku z 25 kwietnia 1996 r., SA/Bk 538/95, „Prawo Pracy” 1996, nr 12, s. 45.

303 Postanowienie SN z 5 grudnia 1996 r., I PKN 34/96, OSNAPiUS 1997, nr 13, poz. 237.

304 Zob. pkt 4 wyroku SN z 12 kwietnia 2007 r., I PK 261/06, LEX nr 509048. 
samymi podmiotami ${ }^{305}$. Rok kalendarzowy jest bowiem okresem rozliczeniowym $\mathrm{w}$ przypadku urlopu wypoczynkowego. $\mathrm{W}$ tym czasie pracownik może zatem terminowo i zgodnie $\mathrm{z}$ analizowanymi zasadami wykorzystać ten urlop.

Taka wykładnia niewątpliwie rozszerza zakres możliwego stosowania zasady urlopu $\mathrm{w}$ naturze, przez co formalnie sprzyja też skuteczniejszej realizacji celu omawianego urlopu.

Powstaje jednak problem, czy zwrot „bezpośrednio”, jakim posłużył się ustawodawca w powołanym przepisie, może być tak szeroko interpretowany, a także jak ustalić w chwili ustania jednego stosunku pracy, jeśli nawiązanie kolejnego nie następuje krótko po tym, czy w danym roku kalendarzowym do podpisania kolejnej umowy z tym samym pracodawcą $\mathrm{w}$ istocie dojdzie. Występuje tu bowiem realne zagrożenie, że przy tak liberalnym podejściu pracodawcy mogą odraczać moment wypłaty ekwiwalentu do końca danego roku kalendarzowego, powołując się na okoliczność możliwego nawiązania kolejnego stosunku z danym pracownikiem w tym samym roku, a więc niejako kredytować się na koszt pracownika, co wypaczałoby sens przyjętego rozwiązania. Wówczas należałoby chyba konsekwentnie uznać, że prawo do takiego ekwiwalentu powstaje nie $\mathrm{z}$ dniem ustania stosunku pracy, skoro ustawodawca $w \$ 3$ art. 171 k.p. uchyla obowiązek jego wypłaty, ale $\mathrm{z}$ dniem, w którym pracownik traci możliwość wykorzystania urlopu wypoczynkowego w tym samym roku kalendarzowym u danego pracodawcy.

Odsunięcie momentu ewentualnej wypłaty ekwiwalentu, jeśli jednak w danym roku pracodawca nie zatrudnił ponownie pracownika, od ustania stosunku pracy rodzi również pewne ryzyko skutecznego egzekwowania tych należności.

Wydaje się, że mimo wszystko, przy obecnej konstrukcji przepisu, zaproponowana wyżej wykładnia jest zbyt daleko idąca. Przepis ten stanowi wyjątek, a zatem zwroty w nim użyte muszą być interpretowane ściśle. Bezpośredniość kolejnego zatrudnienia, o której stanowi komentowany przepis, należałoby raczej tłumaczyć jako zawieranie umów o pracę między tymi samymi podmiotami w sposób następujący po sobie, czyli bez przerw (chyba że umowy przedzielają dni ustawowo wolne od pracy). Należy założyć, że gdyby ustawodawcy chodziło o proponowane szerokie ujęcie opisanej możliwości, zostałoby to w przepisie wprost wyrażone (np. poprzez odniesienie się do roku kalendarzowego).

$\mathrm{Z}$ tych względów bardziej przekonujący wydaje się wyrażony w literaturze pogląd, według którego owo pojęcie należy tłumaczyć w sposób zbliżony do jego dosłownego rozumienia, co ograniczy zakres zastosowania komentowanego przepisu do tych sytuacji, w których „kolejna umowa będzie zawierana pierwszego dnia roboczego po rozwiązaniu dotychczasowej umowy o pracę lub w krótkim czasie po tej dacie"s06.

305 Por. K. Rączka, Urlopy wypoczynkowe po zmianach, PiZS 2002, nr 10, s. 26.

306 Tak A. Dubowik, Zasada udzielania urlopu wypoczynkowego..., s. 33. Bywają wyrażane jednak również bardziej zdecydowane poglądy, według których omawiany warunek jest spełniony wyłącznie w przypadku takiej umowy, która została zawarta „najpóźniej następnego 
Pomocne przy interpretacji użytego w art. $171 \S 3$ k.p. terminu „bezpośrednio” jest orzecznictwo Sądu Najwyższego, który dokonując jego wykładni w kontekście innych przepisów, przyjął właśnie takie jego rozumienie ${ }^{307}$. Wynika z niego, że zastosowany przez ustawodawcę zwrot należy łączyć z możliwie najkrótszym następstwem czasowym pomiędzy zawieranymi między tymi samymi podmiotami umowami, ale nie musi zachodzić bezpośredniość w sensie dosłownym, czyli z dnia na dzień.

Analogiczne do powyższego unormowanie zostało ostatnio wprowadzone w ustawie o zatrudnianiu pracowników tymczasowych ${ }^{308}$, zwiększając teoretycznie szanse również tej grupy zatrudnionych na wykorzystanie urlopu w sposób zgodny z jego przeznaczeniem. Biorąc jednak pod uwagę niezmienioną treść art. 10 ustawy, wątpliwe wydaje się, by było to głównym motywem dokonanej nowelizacji.

Zasada urlopu w naturze, ze względu na swoje fundamentalne znaczenie dla urzeczywistnienia prawa pracownika do odpoczynku, powinna być konsekwentnie gwarantowana wszystkim pracownikom, bez względu na rodzaj wykonywanej pracy, podstawę nawiązania stosunku czy charakter zatrudnienia. Brzmienie powołanego wyżej art. 10 ustawy zdaje się natomiast sugerować, że została ona w znacznym stopniu ograniczona właśnie w zatrudnieniu tymczasowym, co będzie przedmiotem szerszej analizy w kolejnej części niniejszego opracowania.

Zdarzają się jednak w odrębnych ustawach i takie unormowania, które wspomnianą zasadę wyraźnie wzmacniają, jak np. art. 75a ustawy kształtującej status prawny sędziów ${ }^{309}$, w którym wskazano, że w razie przeniesienia sędziego na inne miejsce służbowe nie przysługuje mu ekwiwalent pieniężny za niewykorzystane dni urlopu wypoczynkowego, ale sędzia zachowuje prawo do wykorzystania tego urlopu w czasie pełnienia służby w miejscu, do którego przeniesienie nastąpiło. Dotyczy to też awansu sędziego na wyższe stanowisko sędziowskie.

dnia po ustaniu poprzedniej umowy o pracę", nawet gdy wskazany w niej termin nawiązania stosunku pracy przypada na okres późniejszy. Por. M. Zieleniecki, [w:] Kodeks pracy. Komentarz, s. 655.

307 A. Dubowik, Zasada udzielania urlopu wypoczynkowego..., s. 33.

308 Art. 17 ust. 3a ustawy stanowi, że agencja pracy tymczasowej jest zwolniona z obowiązku wypłaty ekwiwalentu za niewykorzystany urlop wypoczynkowy w przypadku, gdy strony postanowią o wykorzystaniu urlopu wypoczynkowego w czasie pozostawania pracownika tymczasowego w stosunku pracy na podstawie kolejnej umowy o pracę zawartej z tą samą agencją pracy tymczasowej, w celu powierzenia wykonywania pracy tymczasowej u tego samego pracodawcy użytkownika, u którego była wykonywana taka praca, bezpośrednio przed rozwiązaniem lub wygaśnięciem poprzedniej umowy o pracę z tą agencją.

309 Ustawa z 27 lipca 2001 r. - Prawo o ustroju sq̨dów powszechnych, tekst jednolity: Dz. U. 2016, poz. 2062, ze zm. 


\subsection{Odpłatność urlopu}

Istotą urlopu wypoczynkowego, jak wynika z wcześniejszych rozważań, jest, poza zwolnieniem z obowiązku wykonywania pracy, również wypłata wynagrodzenia za ten czas. Odpłatność urlopu będąca bezwzględną zasadą prawa urlopowego determinuje bezpośrednio możliwość rzeczywistego wypoczynku w trakcie tego zwolnienia, a tym samym stanowi gwarancję wykorzystania urlopu w sposób zgodny z jego przeznaczeniem. Chodzi bowiem o to, że pracownik, ujmując to nieco kolokwialnie, może sobie na ten urlop pozwolić, ponieważ w okresie pozostawania na urlopie nie traci środków utrzymania, a poza tym ma też szanse odpoczynek, stosownie do swych zarobków, sfinansować. Ponadto wynagrodzenie, które uzyskuje, mimo przerwy w pracy, zachęca niewątpliwie pracownika do korzystania z tego urlopu.

W związku z powyższym w literaturze wskazuje się, że z samego charakteru urlopu wypoczynkowego wynika, że wynagrodzenie urlopowe pracownika nie może być niższe od zwykle przez niego uzyskiwanego ${ }^{310}$. Niewątpliwie w pełni usprawiedliwione wypoczynkową funkcją urlopu byłoby jednak świadczenie wyższe, uwzględniające wydatki ponoszone przez pracownika w czasie wypoczynku. W praktyce przybierać ono może różną postać, np. we Francji funkcjonowała w przeszłości instytucja zwana premią urlopową, zaś w Belgii gwarantowano po prostu wynagrodzenie za czas urlopu w podwójnej wysokości ${ }^{311}$.

W naszych warunkach wynagrodzenie urlopowe wspierane jest ewentualnie przez świadczenia socjalne wynikające $z$ ustawy o zakładowym funduszu świadczeń socjalnych, które nie mają jednak charakteru powszechnego ${ }^{312}$.

Ustawodawca polski w art. 172 k.p. wprowadza ów obowiązek minimum, a więc zasadę, zgodnie z którą za czas urlopu wypoczynkowego pracownik powinien uzyskać takie wynagrodzenie, jakie by otrzymał, gdyby w tym czasie normalnie pracował $^{313}$.

310 Por. A. Uklejska, Aktualne kierunki..., s. 31.

311 Tamże. Obecnie jednak we Francji, by zagwarantować lepszy wypoczynek osobom o najniższych wynagrodzeniach, wprowadza się tzw. czeki wakacyjne. System ten, przyjmowany w poszczególnych przedsiębiorstwach, jest finansowany z okresowych wpłat pracowników oraz składek pracodawców. Por. G. Auzero, E. Dockès, Droit..., s. 877. Mogą być one wykorzystane na zapłatę należności za transport publiczny, kwaterę, positki itp.

$312 \mathrm{Na}$ gruncie obecnego stanu prawnego nie można mówić o generalnym obowiązku pracodawcy dofinansowywania odpoczynku pracownika w ramach jego uprawnień urlopowych. Zgodnie z ustawą z 4 marca 1994 r. o zakładowym funduszu świadczeń socjalnych (tekst jednolity: Dz. U. 2016, poz. 800, ze zm.) taka możliwość jednak istnieje albo za pośrednictwem funduszu, albo w formie świadczenia urlopowego. Por. szerzej: A. Bigaj, Prawo do urlopu..., S. 258 i n. Zob. też: J. Stefaniak, Dofinansowywanie wypoczynku pracowniczego, „Służba Pracownicza" 2005, nr 5, s. 21 i n. oraz taż, Udział pracodawców w finansowaniu wypoczynku urlopowego pracowników, cz. I-II, „Służba Pracownicza” 2003, nr 6, s. 17 i n. oraz nr 7, s. 29 i n.

313 Analogiczną zasadę sformułowano np. również w ustawie o szkolnictwie wyższym, jeśli chodzi o wynagrodzenie urlopowe nauczyciela akademickiego. Por. art. 153 ustawy. 
Nie chodzi jednak o faktyczną sytuację pracownika w danym okresie, w jakim pozostaje na urlopie, m.in. nie ma większego znaczenia, czy podczas takiego urlopu zakład prowadzi bez przeszkód swoją działalność czy też wystąpiły jakieś przerwy w pracy, np. przestój ${ }^{314}$. To sformułowanie odnosi się bowiem do pewnej metody wyliczania wysokości wynagrodzenia za czas urlopu. Tym samym okres wykorzystywania urlopu wypoczynkowego należy traktować na równi z okresem faktycznej pracy, nawet jeśli akurat $\mathrm{w}$ trakcie urlopu pracownika wystąpiły czasowe przerwy w pracy wywołane innymi przyczynami, uniemożliwiającymi jej wykonywanie, jak np. wskazany wyżej przestój ${ }^{315}$. Jest to więc obowiązek o charakterze niemal bezwzględnym, niezależny od okoliczności związanych z organizacją pracy u danego pracodawcy i jego sytuacją finansową. Tylko wyjątkowo, jak wynika z Kodeksu pracy, pracodawca może odstąpić od wypłaty wynagrodzenia urlopowego - wówczas, gdy na podstawie odrębnych przepisów jest on zobowiązany objąć pracownika ubezpieczeniem gwarantującym mu otrzymanie świadczenia pieniężnego za czas urlopu. Świadczenie to nie może być jednak mniejsze niż wynagrodzenie ustalone na podstawie art. 172 k.p., w przeciwnym razie pracodawca musi wypłacić pracownikowi kwotę stanowiącą różnicę między tymi należnościami.

W rezultacie każdy pracownik w okresie urlopu zachowuje jako minimum prawo do świadczenia pieniężnego w wysokości ustalonej na podstawie art. 172 k.p., niezależnie od źródła, z jakiego to świadczenie pochodzi.

Reguła wynikająca z Kodeksu pracy, gwarantująca pracownikowi wynagrodzenie urlopowe w wysokości nie niższej od tego, jakie by uzyskał, wykonując pracę w tym czasie, co oczywiste, nie pozwala sama w sobie na precyzyjne wyliczenie wysokości wynagrodzenia pracownika korzystającego w danym miesiącu z urlopu wypoczynkowego, niemniej stanowi bardzo ważną wskazówkę interpretacyjną w procesie wykładni prawa, była też niewątpliwie podstawową wytyczną na etapie tworzenia odpowiednich przepisów wykonawczych w tym zakresie.

Szczegółowe warunki obliczania wynagrodzenia za czas urlopu wypoczynkowego zostały określone w rozporządzeniu Ministra Pracy i Polityki Socjalnej z 8 stycznia 1997 r. w sprawie szczegółowych zasad udzielania urlopu wypoczynkowego, ustalania i wypłacania wynagrodzenia za czas urlopu oraz ekwiwalentu pieniężnego za urlop (zwanym w skrócie rozporządzeniem urlopowym) ${ }^{316}$ i generalnie odpowiadają one sformułowanej przez ustawodawcę zasadzie.

$\mathrm{Z}$ rozporządzenia wynika bowiem, że jeśli pracownik uzyskuje składniki wynagrodzenia określone w stawce miesięcznej w stałej wysokości, uwzględnia się je w wynagrodzeniu urlopowym w wysokości należnej pracownikowi w miesiącu wykorzystywania urlopu. Oznacza to w praktyce, że niezależnie od długości urlopu wypoczynkowego, pracownik uzyska za miesiąc, w którym korzystał z tego

314 Por. K. Rączka, Kodeks pracy..., 2003, s. 542. Tak też E. Wichrowska-Janikowska, Nowe zasady obliczania wynagrodzenia i ekwiwalentu za urlop wypoczynkowy, PizS 1997, nr 5, s. 28.

315 Por. T. Zieliński, Zarys..., cz. II, s. 292.

316 Dz. U. 1997, Nr 2, poz. 14, ze zm. 
urlopu, wszystkie przysługujące mu składniki wynagrodzenia określone w stałej stawce miesięcznej, w ustalonej np. w umowie wysokości ${ }^{317}$.

Również składniki przysługujące za okresy dłuższe niż jeden miesiąc (np. premie kwartalne) wypłaca się w przyjętych terminach ich wypłaty, przy czym okres urlopu jest tu traktowany na równi z okresem wykonywania pracy.

Dotyczy to również deputatów, które w świetle $\$ 12$ pkt 2 rozporządzenia przysługują pracownikowi wykorzystującemu urlop wypoczynkowy w takiej samej wysokości, w jakiej pracownik ten by je uzyskał, gdyby nie korzystał z urlopu.

Nieco bardziej złożona jest natomiast metoda obliczania wynagrodzenia pracownika za czas urlopu wypoczynkowego, gdy pracownik jest wynagradzany według zmiennych składników wynagrodzenia (tj. takich, których wysokości nie można z góry określić), przysługujących za okresy nie dłuższe niż jeden miesiąc (np. przy wynagrodzeniu akordowym, prowizyjnym, składnikach określonych w stawkach godzinowych, „dniówkach”, premiach, dodatkach za godziny nadliczbowe $^{318}$ ). Wówczas, zgodnie $\mathrm{z}$ rozporządzeniem, są one uwzględniane $\mathrm{w}$ wynagrodzeniu urlopowym, ale przy wykorzystaniu tzw. podstawy wymiaru wynagrodzenia urlopowego, która jest oparta na średnim wynagrodzeniu pracownika z określonego czasu, zwykle z trzech miesięcy poprzedzających miesiąc rozpoczęcia urlopu; możliwe jest również wyliczenie, przy znacznym wahaniu się ich wysokości, z dłuższego przedziału czasowego wynoszącego maksymalnie 12 miesięcy. Służy to większemu zbliżeniu wysokości wynagrodzenia za czas urlopu do rzeczywistego poziomu przeciętnego miesięcznego wynagrodzenia danego pracownika.

Z tych względów zmienne składniki wynagrodzenia, będące podstawą ustalania wynagradzania za czas urlopu nauczyciela akademickiego w związku z nierównomiernym obciążeniem ich pracą, wylicza się, zgodnie $\mathrm{z}$ ustawą o szkolnictwie wyższym, z zasady z okresu 12 miesięcy ${ }^{319}$.

Mając podstawę wymiaru wynagrodzenia urlopowego, można przejść do określenia jego wysokości. Dzieli się uzyskaną podstawę wymiaru przez liczbę godzin, w czasie których pracownik wykonywał pracę w okresie, z którego została ustalona

317 A. Martuszewicz, K. Piecyk, Urlopy pracownicze..., s. 119.

318 W przypadku dodatku za godziny nadliczbowe słusznie, w mojej ocenie, zwraca się w literaturze przedmiotu uwagę, że dodatek $z$ tytułu przekroczenia przeciętnej normy tygodniowej (ponieważ ustala się go na koniec okresu rozliczeniowego), może być uwzględniony w wynagrodzeniu urlopowym tylko wówczas, gdy pracownika obowiązuje nie dłuższy niż miesięczny okres rozliczeniowy. Tylko wówczas spełniony zostaje warunek wystąpienia zmiennego składnika wynagrodzenia przysługującego za okres nie dłuższy niż jeden miesiąc. Niektórym pracownikom będzie więc pracodawca wliczał te dodatki (mającym okres rozliczeniowy miesięczny), a innym nie. Zob. E. Wronikowska, Akty wykonawcze do Kodeksu pracy. Komentarz, Warszawa 2009, s. 169 i n.

319 Por. szerzej K. Walczak, Wynagrodzenie i inne świadczenia dla pracowników uczelni, [w:] Akademickie prawo pracy, red. K.W. Baran, Warszawa 2015, s. 331 i n. Szczegółowe warunki wyliczania tego wynagrodzenia, trochę odmienne od kodeksowych, określa rozporządzenie Ministra Nauki i Szkolnictwa Wyższego z 2 listopada 2006 r. w sprawie sposobu ustalania wynagrodzenia za urlop wypoczynkowy oraz ekwiwalentu pieniężnego za okres niewykorzystanego urlopu wypoczynkowego nauczycieli akademickich, Dz. U. 2006, Nr 203, poz. 1499, ze zm. 
ta podstawa (chodzi o godziny faktycznie przepracowane $e^{320}$ ), a następnie mnoży tak ustalone wynagrodzenie za jedną godzinę pracy przez liczbę godzin, jakie pracownik przepracowałby w czasie urlopu w ramach normalnego czasu pracy, zgodnie z obowiązującym go rozkładem czasu pracy, gdyby w tym czasie nie korzystał z urlopu ( $\$ 9$ rozporządzenia) $)^{321}$.

W celu osiągnięcia wysokości wynagrodzenia urlopowego odpowiadającej wynagrodzeniu, jakie pracownik by otrzymał, gdyby w tym czasie świadczył pracę, z omawianego rozporządzenia wynika też, że w przypadku zmiany w omawianych składnikach wynagrodzenia lub zmiany wysokości tych składników w okresie, z którego ustala się podstawę wymiaru wynagrodzenia urlopowego (np. zwiększeniu lub zmniejszeniu ulega stawka godzinowa wynagrodzenia za pracę), wprowadzonej przed rozpoczęciem przez pracownika urlopu wypoczynkowego lub w miesiącu jego wykorzystywania, podstawę wymiaru, o której wyżej mowa, należy ustalić ponownie z uwzględnieniem wprowadzonych zmian.

Ponadto, zgodnie $\mathrm{z} \$ 11$ pkt 1 rozporządzenia, jeśli przez cały okres przyjęty do ustalania podstawy wymiaru, poprzedzający miesiąc wykorzystania urlopu wypoczynkowego, lub przez okres krótszy, lecz obejmujący pełny miesiąc lub pełne miesiące kalendarzowe, pracownikowi nie przysługiwało omawiane wynagrodzenie, przy ustalaniu podstawy wymiaru uwzględnia się najbliższe miesiące, za które pracownikowi takie wynagrodzenie przysługiwało.

Pewną konsekwencją odniesienia się przez ustawodawcę w art. 172 k.p. do pojęcia wynagrodzenia jest jednak zawężenie rodzajów należności ze stosunku pracy, które w wynagrodzeniu urlopowym mogą być uwzględnione. Poza świadczeniami wprost wyłączonymi w rozporządzeniu ${ }^{322}$, ze względu na ich zwykle jednorazowy charakter i brak bezpośredniego powiązania $\mathrm{z}$ wykonywaną przez pracownika pracą oraz możliwość zaniżenia wysokości wynagrodzenia urlopowego (jak wynagrodzenie za czas przestoju czy choroby $\left.{ }^{323}\right)$, Sąd Najwyższy, wbrew literalnemu brzmieniu $₫ 6$ rozporządzenia odwołującemu się do wynagrodzenia i innych

320 Należy więc także uwzględnić godziny przepracowane w niedziele i święta oraz w dni dodatkowo wolne od pracy. Natomiast nie bierze się pod uwagę tych dni, w których pracownik nie świadczył pracy, mimo że zachował prawo do wynagrodzenia, np. niezdolność do pracy z powodu choroby, przestój. Por. A. Martuszewicz, K. Piecyk, Urlopy pracownicze..., s. 120.

321 Nieco inaczej, zgodnie z powołanym wcześniej rozporządzeniem, wylicza się wynagrodzenie za czas urlopu nauczycieli akademickich. Różnice te wynikają z faktu, że w przypadku urlopu wypoczynkowego nauczycieli akademickich urlopu zawsze udziela się w dniach, a nie w wymiarze godzinowym. Por. szerzej K. Walczak, Wynagrodzenie..., s. 332.

322 Por. szerzej M. Nowak, [w:] M. Kuba, M. Nowak, E. Staszewska, Urlopy pracownicze..., s. 136 i n.

323 Zasadą jest, że pracownik za czas urlopu powinien otrzymać takie wynagrodzenie, jakie by uzyskał, gdyby w tym czasie normalnie pracował. Dlatego też niezawinione przez pracownika przerwy w wykonywaniu pracy w okresie, z którego wylicza się wynagrodzenie urlopowe nie powinny wpływać na obniżenie tego wynagrodzenia. Zgodnie więc z rozporządzeniem, z wynagrodzenia za czas urlopu wyłącza się wiele wypłat gwarancyjnych, takich jak wynagrodzenie za czas choroby czy wynagrodzenie za czas gotowości do pracy, w tym za czas przestoju. Zastosowanie znajdzie tu wówczas powołany wyżej § 11 rozporządzenia. 
świadczeń ze stosunku pracy, przyjął, że przy ustalaniu wynagrodzenia za urlop mogą być brane pod uwagę tylko świadczenia o obowiązkowym charakterze. Zdaniem sądu, za taką tezą przemawia zarówno art. 172 k.p., który stanowi wyłącznie o „wynagrodzeniu” (a nie innych świadczeniach ze stosunku pracy) i wyznacza zakres swobody kształtowania zasad obliczania wynagrodzenia urlopowego przez odpowiedniego ministra oraz determinuje kierunek wykładni przepisów wydanych na jego podstawie, jak i wymienione kolejno w $\$ 6$ rozporządzenia wyjątki, które sprowadzają się do obowiązkowych należności ze stosunku pracy, a więc tych, które stanowią przedmiot zobowiązania pracodawcy. Tylko takie świadczenia należy uwzględniać przy obliczaniu wynagrodzenia za czas urlopu wypoczynkowego. Z tego też względu Sąd Najwyższy stwierdził, że tzw. premia uznaniowa będąca w istocie nagrodą (a więc pozbawiona roszczeniowego charakteru, zależna od swobodnej oceny podmiotu zatrudniającego) nie mieści się w pojęciu wynagrodzenia urlopowego ${ }^{324}$.

Charakter omawianego świadczenia wywołuje jednak wiele wątpliwości w doktrynie prawa pracy. Ustawodawca posługuje się bowiem pojęciem wynagrodzenia za czas urlopu. Tyle że, jak wskazują niektórzy autorzy, wynagrodzenie jest $\mathrm{z}$ definicji świadczeniem wzajemnym pracodawcy za wykonywaną przez pracownika pracę, tymczasem $\mathrm{w}$ okresie urlopu pracownik pracy de facto nie świadczy, stąd należy tu mówić raczej o kategorii tzw. wypłat kompensacyjnych czy gwarancyjnych, a nie o wynagrodzeniu sensu stricto ${ }^{325}$.

Bywa jednak prezentowany często także pogląd odmienny, oparty na szerszym ujęciu pojęcia „wynagrodzenia”326, w ramach którego tego rodzaju należności też wchodzą $\mathrm{w}$ jego skład, zgodnie z literalnym brzmieniem przepisów. W tym kontekście zwraca się uwagę m.in. na zasadę ryzyka podmiotu zatrudniającego, zwłaszcza socjalnego, które powoduje, że pracownik zachowuje prawo do wynagrodzenia również $\mathrm{w}$ okresach pewnych przerw w świadczeniu pracy, takich jak np. urlop wypoczynkowy 327 .

Kwestia ta wiąże się więc $\mathrm{w}$ jakieś mierze także $\mathrm{z}$ oceną charakteru prawnego urlopu wypoczynkowego, zwłaszcza jako świadczenia socjalnego czy rodzaju odpłaty.

W ramach teorii odpłaty można bowiem uznać z kolei, że należność ta spełnia jednak cechy wynagrodzenia za pracę, gdyż urlop, podobnie jak wynagrodzenie, też jest formą świadczenia wzajemnego pracodawcy. M. Święcicki wyjaśniał,

324 Wyrok SN z 20 lipca 2000 r., I PKN 17/00, OSNAPiUS 2002, nr 3, poz. 77. Por. też w tym zakresie W. Sanetra, Ustalenie wynagrodzenia urlopowego i ekwiwalentu za urlop w świetle kilku orzeczeń Sądu Najwyższego, PiZS 2001, nr 2, s. 29 i n.

325 Por. m.in. A. Walas, Prawo do wypoczynku..., s. 500 i n. Tak też Z. Salwa, Prawo pracy i ubezpieczeń społecznych, Warszawa 2004, s. 190 i n.

326 Por. M. Seweryński, Wynagrodzenie za pracę. Pojęcie, regulacja i ustalenie, Łódź 1976, s. 105 i n. Por. też W. Szubert, Zarys..., s. 237 i n.

327 Por. tak B. Wagner, Wynagrodzenie za pracę i jego zwiqzzek z praca, [w:] Człowiek, obywatel, pracownik. Studia z zakresu prawa, red. J. Stelina, A. Wypych-Żywicka, „Gdańskie Studia Prawnicze" 2007, t. XVII, s. 308. 
że w jej ramach chodzi o następującą z upływem czasu akumulację wynagrodzenia urlopowego w rękach podmiotu zatrudniającego, którego wypłata nastąpi w określonym momencie ${ }^{328}$.

Odmienną koncepcją, zrywającą w jakimś sensie z dotychczasowymi próbami tłumaczenia prawnej natury wynagrodzenia urlopowego, zaprezentował w ostatnim czasie A. Sobczyk, który uznał, że w świetle obowiązującej Konstytucji odpłatność za urlop nie jest formą płacy odroczonej czy zatrzymanej, ale jest świadczeniem samoistnym i niepowiązanym w ogóle $\mathrm{z}$ wynagrodzeniem za pracę. Nie można go zatem rozważać w relacji pewnej wzajemności do określonego świadczenia pracownika. Jest to, zdaniem autora, należność o charakterze socjalnym, społecznym, wykazująca nawet, w związku ze swym konstytucyjnym umocowaniem, pewne cechy publicznoprawne ${ }^{329}$. Tym samym roszczenie o wynagrodzenie za urlop też jest obciążeniem o publicznoprawnym charakterze mającym źródło $\mathrm{w}$ ustawie, a nie w umowie i służy zapewnieniu efektywności korzystania z konstytucyjnego prawa do odpoczynku $\mathrm{u}^{330}$.

Z punktu widzenia podstawowej funkcji urlopu wypoczynkowego przytoczona wyżej różnica zdań ma znaczenie o tyle, że może w jakimś stopniu determinować poziom ochrony, jakiej udziela się analizowanej należności, wpływać na pewność uzyskania tego świadczenia i jego ostateczną wysokość, a tym samym pośrednio oddziaływać na stopień urzeczywistnienia prawa do odpoczynku. W szczególności, jeśli uznać, że wynagrodzenie za czas urlopu mieści się w zakresie wynagrodzenia za pracę, wówczas przepisy ochronne dotyczącego tego świadczenia będą miały również do niego swoje zastosowanie ${ }^{331}$. Powoduje to niemożność zrzeczenia się tego świadczenia, którą akurat daje się wyprowadzić też z samej istoty urlopu, ale również ochronę przed jego nadmiernym i bezpodstawnym uszczupleniem czy określone gwarancje w zakresie terminu i form jego wypłaty.

W dotychczasowym orzecznictwie Sądu Najwyższego wynagrodzenie za czas urlopu było ową ochroną obejmowane, choć raczej wskazuje się, że tego rodzaju świadczenia jak wynagrodzenie za urlop czy ekwiwalent za niewykorzystany urlop wypoczynkowy stanowią część wypłat gwarancyjnych, nie są więc wynagrodzeniem sensu stricto. Niemniej z woli ustawodawcy pełnią one podobne jak wynagrodzenie funkcje, stąd muszą być tak jak ono chronione ${ }^{332}$.

Gwarantuje się w ten sposób m.in., że pracownik za czas urlopu uzyska wynagrodzenie poddane tym samym regułom w zakresie możliwości dokonywania z niego potrąceń czy formy jego wypłaty jak wynagrodzenie, które by uzyskał, gdyby w tym czasie normalnie pracował, co wpisuje się w pełni w omawianą wcześniej ogólną zasadę.

328 Por. M. Święcicki, Prawo pracy, s. 445 i n.

329 Por. szerzej A. Sobczyk, Prawo pracy..., s. 203 i n.

330 Tamże.

331 Tak m.in. T. Zieliński, Zarys..., cz. II, s. 292.

332 Tak m.in. w uzasadnieniu uchwały SN z 17 stycznia 2013 r., II PZP 4/12, www.sn.pl. Por. też analogicznie: wyrok SN z 11 czerwca 1980 r., I PR 43/80, LEX nr 179272 oraz z 29 stycznia 2007 r., II PK 181/06, www.sn.pl. 
Zabezpiecza to również $\mathrm{w}$ jakimś stopniu realizację głównej funkcji urlopu poprzez znaczne ograniczenie dopuszczalności zajęcia uzyskiwanego za ten czas świadczenia, a jeśli to tylko w ściśle określonych granicach, na rzecz wierzycieli ( $w$ tym pracodawcy), a tym samym przeciwdziała sytuacjom pozbawienia pracownika środków finansowych niezbędnych dla właściwego przebiegu tego wypoczynku.

Z tej perspektywy istotne są prawne konsekwencje naruszenia przez pracodawcę obowiązku wypłaty wynagrodzenia za czas urlopu, które są w zasadzie analogiczne do tych dotyczących wynagrodzenia w ogóle.

Przede wszystkim trzeba podkreślić, że brak wypłaty wynagrodzenia urlopowego w ustalonym terminie, co wynika $\mathrm{z}$ art. $282 \S 1$ pkt 1 k.p., czy bezpodstawne zaniżanie jego wysokości, stanowi wykroczenie przeciwko prawom pracownika zagrożone karą grzywny.

Pracownik może dochodzić wypłaty wynagrodzenia za czas urlopu wypoczynkowego w postępowaniu sądowym, ale możliwy jest tutaj również nakaz zapłaty należnego wynagrodzenia za pracę oraz innego świadczenia przysługującego pracownikowi, wystawiony przez Inspekcję Pracy, który, zgodnie z art. 11 ust. 7 ustawy o Państwowej Inspekcji Pracy ${ }^{333}$, podlega natychmiastowemu wykonaniu. Może to zatem znacznie przyspieszyć uzyskanie przez pracownika stosownej należności, co z punktu widzenia prawa do odpoczynku jest dość istotne. Niemniej warunkiem zastosowania owego nakazu jest bezsporny charakter danego świadczenia oraz jego wymagalność w chwili dokonywania kontroli. Wynagrodzenie urlopowe, jako wynikające wprost z przepisów prawa, w zasadzie takich wątpliwości zwykle nie budzi.

Jeśli pracodawca nie wykonuje $\mathrm{w}$ terminie obowiązku wypłaty wynagrodzenia za czas urlopu, w grę wchodzi prawo do odsetek z tytułu zaistniałego opóźnienia, a także możliwość dochodzenia przez pracownika odszkodowania na zasadach określonych w prawie cywilnym, jeśli wskutek tego pracownik dodatkowo poniósł szkodęę3. Szkoda taka może polegać np. na konieczności zaciągnięcia pożyczki i poniesienia $\mathrm{w}$ związku $\mathrm{z}$ tym dodatkowych wydatków $\mathrm{z}$ powodu braku środków na pokrycie kosztów zorganizowanego wypoczynku (np. zakwaterowania).

Terminem wypłaty wynagrodzenia za czas urlopu wypoczynkowego, z braku odmiennych unormowań, jest dzień ustalony u danego pracodawcy jako termin wypłaty wynagrodzenia. Z punktu widzenia optymalizacji funkcji wypoczynkowej omawianego urlopu być może lepszym rozwiązaniem była przyjęta w przeszłości reguła, według której na wniosek pracownika wynagrodzenie urlopowe było wypłacane przez pracodawcę przed rozpoczęciem urlopu ${ }^{335}$, co w jakiejś mierze mo-

333 Ustawa z 13 kwietnia 2007 r. o Państwowej Inspekcji Pracy, tekst jednolity: Dz. U. 2017, poz. 786 , ze zm.

334 Szerzej na temat roszczeń związanych z naruszeniem obowiązku wypłaty wynagrodzenia por. M. Nowak, Wynagrodzenie za pracę, Warszawa 2014, s. 179 i n.

335 Tak w § 13 rozporządzenia Ministra Pracy i Polityki Socjalnej z 8 stycznia 1997 r. w sprawie szczegółowych zasad udzielania urlopu wypoczynkowego, ustalania i wypłacania wynagro- 
gło ułatwiać pracownikowi organizację wypoczynku w czasie objętym tym urlopem. W literaturze przedmiotu wskazywano nawet, że właśnie cel urlopu, ale też jednolity charakter roszczenia o urlop przemawiają za tym, by wynagrodzenie to było wymagalne jednocześnie z czasem wolnym od pracy, jaki pracownik z tego tytułu uzyskuje $\mathrm{e}^{336}$.

Wynagrodzenie za czas urlopu wypoczynkowego, podobnie jak ekwiwalent za niewykorzystany urlop, podlegają też wypłacie z Funduszu Gwarantowanych Świadczeń Pracowniczych w razie niewypłacalności pracodawcy ${ }^{337}$, co dodatkowo wzmacnia ich ochronę i gwarantuje ich otrzymanie, mimo zaprzestania realizowania swych zobowiązań finansowych przez pracodawcę w sytuacjach określonych w odrębnej ustawie ${ }^{338}$.

Trzeba też wyraźnie podkreślić, że prawo do wynagrodzenia za czas urlopu nie podlega ograniczeniom związanym ze sposobem wykorzystywania urlopu przez pracownika, nawet gdy ten podejmuje w czasie urlopu pracę gdzie indziej ${ }^{339}$. Jest to konsekwencją zmiany sposobu postrzegania prawa do odpoczynku jako pewnej wolności, z której zainteresowany może generalnie korzystać według swojego uznania (por. wcześniejsze rozważania).

Szczególne zasady ustalania wynagrodzenia za czas urlopu wypoczynkowego obowiązują w odniesieniu do pracowników tymczasowych. W ostatnim czasie dokonano jednak w tym zakresie wyraźnych zmian mających z jednej strony zbliżyć odpowiednią regulację zawartą w ustawie o pracy tymczasowej do reguł określania wysokości tego świadczenia wynikających z Kodeksu pracy, a tym samym zniwelować nieuzasadnione, nadmierne różnice, jakie powstawały pod tym względem między pracownikami tymczasowymi a pozostałymi pracownikami podlegającymi unormowaniom powszechnym, a z drugiej strony, doprecyzować przepisy tej ustawy w kilku kwestiach związanych z odpłatnością za urlop.

Chodziło przede wszystkim o wyraźnie wskazanie, że wynagrodzenie za urlop dotyczy okresu pracy u danego pracodawcy użytkownika, co nie wynikało bezpośrednio z wcześniejszych przepisów ${ }^{340}$. Jak zauważono, pracownik w okresie trzech miesięcy może zmieniać pracodawcę użytkownika i otrzymywać w tym czasie u każdego z nich różne wynagrodzenia, a pracodawca użytkownik udzielający urlopu nie powinien pokrywać kosztów innego pracodawcy użytkownika.

dzenia za czas urlopu oraz ekwiwalentu pieniężnego za urlop (Dz. U. 1997, Nr 2, poz. 14, ze zm.). Zasada taka obowiązuje w Hiszpanii - wynagrodzenie urlopowe jest wypłacane pracownikowi na początku urlopu. Por. M.A. Olea, F. Rodriguez-Sanudo, Labour Law in Spain, s. 72.

336 Zob. J. Loga, Urlopy wypoczynkowe..., s. 141.

337 Tamże, s. 212 i n.

338 Por. ustawa z 13 lipca 2006 r. o ochronie roszczeń pracowniczych w razie niewypłacalności pracodawcy, tekst jednolity: Dz. U. 2016, poz. 1256.

339 Por. W. Szubert, Zarys..., s. 231.

340 Zgodnie z art. 17 ust. 4 ustawy w jego poprzednim brzmieniu, wynagrodzenie za jeden dzień urlopu wypoczynkowego (lub ekwiwalent pieniężny) ustala się, dzieląc wynagrodzenie uzyskane przez pracownika tymczasowego w okresie wykonywania pracy tymczasowej przez liczbę dni pracy, za które to wynagrodzenie przysługiwało. 
Stąd w obecnym brzmieniu art. $17 \mathrm{w}$ ust. 4 ustawy stanowi, że wynagrodzenie za urlop wypoczynkowy pracownika tymczasowego ustala się, dzieląc wynagrodzenie uzyskiwane przez pracownika tymczasowego z okresu trzech miesięcy wykonywania pracy na rzecz tego samego pracodawcy użytkownika, na podstawie jednej lub kilku umów z daną agencją pracy tymczasowej, poprzedzających miesiąc kalendarzowy, w którym udzielono pracownikowi w ramach urlopu czasu wolnego od pracy, przez liczbę godzin pracy, w czasie których wykonywał on pracę $\mathrm{w}$ okresie tych trzech miesięcy, a następnie mnożąc tak otrzymane wynagrodzenie za jedną godzinę wykonywania pracy przez liczbę godzin przypadających w czasie wolnym od pracy w dniach, w których pracownik ten wykonywałby pracę, gdyby nie korzystał z urlopu.

$\mathrm{W}$ ten sposób uwzględnia się też przy obliczeniu wynagrodzenia urlopowego okoliczność zatrudnienia pracownika tymczasowego na część etatu oraz w systemie równoważnych norm czasu pracy. 


\section{Część III}

\section{Dysfunkcjonalne elementy regulacji prawa urlopowego z punktu widzenia realizacji prawa do odpoczynku}

\section{Uwagi wprowadzające}

Prawna konstrukcja urlopu wypoczynkowego jest niewątpliwie w dużej mierze uzasadniona przeznaczeniem tego zwolnienia. Niemniej w prawie urlopowym znajdują się również takie rozwiązania, które nie do końca przystają do podstawowej funkcji omawianego urlopu bądź wręcz pozostają z nią w sprzeczności. Trzeba przy tym wyraźnie zaznaczyć, że przyczyny tego stanu rzeczy mogą być bardzo różne. Nie zawsze bowiem tytułowa dysfunkcja wiąże się z wadliwością regulacji prawnej powodującą konieczność wprowadzenia w tym obszarze określonych zmian ustawodawczych. Niektóre z przyjmowanych odstępstw od ogólnych zasad zabezpieczających cel urlopu będą bowiem podyktowane dążeniem ustawodawcy do większej elastyczności obowiązujących przepisów, próbą pogodzenia niekiedy sprzecznych interesów stron stosunku pracy czy, ogólnie rzecz ujmując, kwestią wyboru określonych priorytetów.

Kwalifikując zatem pewne unormowania dotyczące urlopów jako dysfunkcjonalne, bierzemy przede wszystkim pod uwagę ich negatywny wpływ na główną funkcję urlopu wypoczynkowego, jej osłabienie czy też nawet pewną kolizję, jaka się w tym zakresie zarysowuje lub przynajmniej ich umotywowanie innymi niż prawo do odpoczynku względami. Tym samym opisywane w niniejszym rozdziale instytucje nie mogą być automatycznie oceniane jako bezzasadne czy wręcz szkodliwe. Część z nich, co zostanie wykazane w kolejnych fragmentach opracowania, nie przyczynia się po prostu do optymalizacji zasadniczych celów, dla których urlop wypoczynkowy został wprowadzony, a niekiedy nie gwarantuje w ogóle ich realizacji. 


\section{Pracodawca jako podmiot decydujący o planowanym terminie urlopu wypoczynkowego}

Dla optymalnego wykorzystania urlopu wypoczynkowego w sposób zgodny $\mathrm{z}$ jego przeznaczeniem ważną sprawą jest na pewno termin, $\mathrm{w}$ jakim ostatecznie zostanie on udzielony pracownikowi. Czas ten determinuje bowiem możliwy sposób jego realizacji, wpływając w jakiejś mierze na stopień zniwelowania zmęczenia pracownika, zwłaszcza jeśli urlop ten nie pokrywa się z miesiącami powszechnie uznanymi za najbardziej sprzyjające wypoczynkowi, tj. miesiącami letnimi. Ponadto urlop wypoczynkowy, który w założeniu służy regeneracji psychofizycznej organizmu, powinien być bez wątpienia udzielany wówczas, gdy ta regeneracja staje się konieczna, co w dużej mierze jest oparte na odczuciach indywidualnego pracownika. Należałoby zatem przyjąć, że ten ostatni powinien mieć istotny wpływ na kwestię ostatecznego wyznaczenia terminu tego urlopu.

Jak wskazywał w przeszłości M. Święcicki, urlop ma być dogodny, tj. udzielony w terminie dogodnym dla pracownika, pozwalającym mu najlepiej zrealizować cel urlopu ${ }^{1}$. Tymczasem, jak się wydaje, polskie prawo nie do końca ten postulat realizuje. Ustawodawca z jednej strony stanowi o potrzebie planowania urlopów, co samo w sobie jest $\mathrm{z}$ pewnością regułą pożądaną. Plan urlopów, stanowiący podstawowy dokument w tym zakresie, m.in. pozwala osobom wykonującym pracę $\mathrm{w}$ ramach stosunku pracy na odpowiednie przygotowanie i zagospodarowanie okresu wolnego od pracy. Służy też urzeczywistnieniu zasady urlopu corocznego, zgodnie z którą pracownik powinien wykorzystać urlop w tym roku kalendarzowym, w którym nabył do niego prawo². Niemniej trzeba zauważyć, że plan ten jest jednak w dużej mierze traktowany jako dokument pracodawcy, mający zagwarantować przede wszystkim sprawną organizację procesu pracy, przynajmniej na etapie jego przygotowywania.

Plan urlopów sporządza pracodawca. Sformułowane w art. 163 k.p. zobowiązanie podmiotu zatrudniającego nie ma jednak bezwzględnego charakteru. Wyjątkowo, jak wynika $\mathrm{z}$ dalszej części przepisu, pracodawca jest zwolniony bowiem z obowiązku wydania takiego planu, jeśli albo nie działa u niego zakładowa organizacja związkowa, albo też, jeśli taka organizacja działa, ale wyraziła zgodę na to, aby planu urlopów nie tworzyć. Zgodnie z ustawą o związkach zawodowych ${ }^{3}$ odstąpić od ustalania planu urlopów może również pracodawca, u którego działa kilka organizacji związkowych i nie przedstawią one (lub przynajmniej wszystkie organizacje reprezentatywne $\mathrm{w}$ rozumieniu art. $241^{25 a}$ k.p.) we właściwym terminie (30 dni)

1 Por. M. Święcicki, Prawo pracy, Warszawa 1968, s. 463.

2 Por. A. Kosut, [w:] Kodeks pracy. Komentarz, red. K.W. Baran, Warszawa 2012, s. 900.

3 Ustawa z dnia 23 maja 1991 r. o związkach zawodowych, tekst jednolity: Dz. U. 2015, poz. 1881 - art. 30 ust. 5 . 
wspólnie uzgodnionego stanowiska w tej sprawie 4 . Decyzję podejmuje wówczas pracodawca, po rozpatrzeniu odrębnych stanowisk organizacji związkowych.

Warto też zauważyć, że w powszechnym przekonaniu przedstawicieli doktryny prawa pracy zgoda organizacji związkowych odnosi się wyłącznie do kwestii ewentualnego odstąpienia od wydawania planu urlopów, a nie do samego procesu kształtowania tego planu ${ }^{5}$. Ustalanie jego treści, a więc wyznaczenie terminów urlopów poszczególnych pracowników zostało pozostawione bezpośrednio pracodawcy, bez możliwości ingerencji w te sprawy ze strony reprezentacji pracowniczej.

Jak wynika z powyższego, sytuacja, w której w danym zakładzie pracy omawianego dokumentu nie będzie w ogóle, może występować w praktyce stosunkowo często, zwłaszcza u tzw. małych i średnich pracodawców. Konieczne było zatem wprowadzenie alternatywnej w stosunku do omawianego planu formy ustalania terminu udzielenia urlopu wypoczynkowego przez pracodawcę. W rezultacie pracodawca, który nie ma obowiązku wydania planu urlopów i w konsekwencji tego nie czyni, jest obowiązany ustalić termin urlopu „po porozumieniu” indywidualnie z każdym pracownikiem (art. $163 \$ 1^{1}$ k.p.).

Zarówno jednak sporządzając plan urlopów, jak i określając czas wykorzystania urlopu „po porozumieniu z pracownikiem”, ustawodawca zobowiązuje pracodawcę do wzięcia pod uwagę z jednej strony wniosków pracowników, ale z drugiej strony konieczności zapewnienia normalnego toku pracy. Powoduje to, że zarówno w literaturze $z$ zakresu prawa pracy, jak i orzecznictwie sądowym ${ }^{6}$ powszechnie przyjmuje się, że co do zasady wniosek pracownika nie wiąże pracodawcy. Tym samym powołany wcześniej termin „po porozumieniu z pracownikiem”, którym posłużono się w art. $163 \$ 1^{1}$ k.p., według dominującej w doktrynie prawa pracy interpretacji, nie oznacza porozumienia w pełnym tego słowa znaczeniu (tj. zgody obu stron co do terminu wykorzystania urlopu wypoczynkowego), ale raczej powinność pracodawcy zapoznania się z preferencjami poszczególnych pracowników w tej kwestii ${ }^{7}$. Ostatecznie o dacie wykorzystania urlopu wypoczynkowego

4 To znaczy w sprawie wydania lub niewydania przez pracodawcę takiego planu urlopowego.

5 Zob. m.in. A. Kosut, [w:] Kodeks pracy..., s. 901. Tak też A. Dubowik, Zasada udzielania urlopu wypoczynkowego w naturze i plan urlopów, PiZS 2003, nr 5, s. 35; M. Zieleniecki, [w:] Kodeks pracy. Komentarz, red. A. Sobczyk, Warszawa 2014, s. 648.

6 Por. m.in. wyrok SN z 20 sierpnia 2001 r., I PKN 590/00, OSNP 2003, nr 14, poz. 336. Sąd jednoznacznie w tym orzeczeniu uznat, że pracodawca nie jest związany wnioskiem pracownika zawierającym propozycję terminu udzielenia mu urlopu wypoczynkowego. Podobna teza została sformułowana w uzasadnieniu do wyroku SN z 5 grudnia 2000 r., I PKN 121/00, w którym wyraźnie stwierdzono, że generalnie „wniosek urlopowy pracownika jest brany przez pracodawcę pod uwagę, ale nie jest dla niego wiążący”. Realizacja prawa pracowniczego do odpoczynku jest, zdaniem sądu, „korygowana potrzebami pracodawcy, koniecznością obecności pracownika w zakładzie".

$7 \quad$ Zdaniem B. Cudowskiego zwrot ten należy interpretować w ten sposób, że pracodawca powinien podjąć jedynie próbę wspólnego uzgodnienia terminu urlopu, nie jest tu natomiast konieczna zgoda pracownika; por. tenże, Urlop wypoczynkowy i bezpłatny a dodatkowe zatrudnienie, [w:] Człowiek, obywatel, pracownik. Studia z zakresu prawa. Księga Jubileuszo- 
decyduje więc z reguły pracodawca, który zawsze może powołać się na to, iż udzielenie urlopu w terminie wskazanym przez pracownika koliduje $\mathrm{z}$ jego interesem, zagraża sprawnej organizacji procesu pracy.

Do nielicznych należą orzeczenia sądowe, w których, wobec braku bardziej stanowczych unormowań w omawianym obszarze, próbuje się jednak eksponować większy wpływ pracownika na termin udzielanego mu urlopu wypoczynkowego. Istotny z tego punktu widzenia jest wyrok SN z 12 sierpnia 2004 r., w którym SN zaznaczył, że ponieważ stosunek pracy jest oparty na zasadzie równości stron, pracodawca nie może bez naprawdę ważnej przyczyny odmawiać pracownikom udzielenia urlopu wypoczynkowego w terminach przewidzianych w Kodeksie pracy $^{8}$. Odrzucając wniosek pracownika, należy w związku z tym kierować się względami obiektywnymi, faktycznymi, poważnymi trudnościami i zagrożeniami dla prawidłowego funkcjonowania zakładu pracy, jakie nieobecność pracownika może spowodować, a nie osobistymi odczuciami. W szczególności odmowa udzielenia urlopu we wskazanym terminie nie może być formą wywierania nacisku na pracownika w określonym celu czy formą szykany, co byłoby w sposób oczywisty sprzeczne $\mathrm{z}$ funkcją omawianego świadczenia.

Niezależnie od powyższego, trzeba jednak zdecydowanie podkreślić, co czynił wielokrotnie SN, że urlopu wypoczynkowego udziela zawsze pracodawca. Bez względu na okoliczności pracownik sam sobie urlopu udzielić nie może. Samo złożenie przez pracownika wniosku urlopowego nie usprawiedliwia zatem jego nieobecności w pracy, nie stanowi podstawy do rozpoczęcia tego urlopu' ${ }^{9}$, chyba że brak wymogu wyraźnej akceptacji takiego wniosku jest zwyczajowo przyjęty w danym zakładzie pracy (tzn. praktyka jest taka, że pracownik może rozpocząć urlop w terminie podanym we wniosku, jeśli pracodawca się temu wprost nie sprzeciwił).

Z powyższego wynika niemal jednoznacznie, że poza pojedynczymi przypadkami, ściśle przez prawo określonymi ${ }^{10}$, na etapie planowania terminu wykorzystania przez

wa poświęcona Profesor U. Jackowiak, red. J. Stelina, A. Wypych-Żywicka, „Gdańskie Studia Prawnicze” 2007, t. XVII, s. 49. Tak też M. Zieleniecki, [w:] Kodeks pracy. Komentarz, s. 648. Podobnie T. Liszcz, Prawo pracy, Warszawa 2004, s. 370. Odmienne zdanie zaprezentowała w tej sprawie A. Dubowik; por. taż, Zasada udzielania urlopu..., s. 35 i n.

8 Wyrok SN z 12 sierpnia 2004 r., III PK 32/04. Podobnie w uzasadnieniu do orzeczenia SN z 5 grudnia 2000 r., I PKN 121/00, w którym stwierdzono, że pracodawca powinien wniosek urlopowy pracownika uwzględnić, jeśli zwolnienie urlopowe we wnioskowanym czasie nie koliduje z koniecznością zapewnienia normalnego toku pracy zakładu.

9 Por. wyrok SN z 13 maja 1998 r., I PKN 99/98.

10 Pracodawca jest obowiązany uwzględnić taki wniosek w sytuacji, gdy występuje z nim pracownica, która chce wykorzystać urlop wypoczynkowy bezpośrednio po urlopie macierzyńskim (także urlopie na warunkach urlopu macierzyńskiego). Dotyczy to też pracownika - ojca wychowującego dziecko, który korzysta z urlopu macierzyńskiego i urlopu ojcowskiego (art. $182^{3} \S 3$ k.p. w związku z art. 163 § 3 k.p.) oraz pracowników przebywających na urlopie rodzicielskim (art. $182^{1 \mathrm{a}} \S 6$ k.p. w związku z art. $163 \S 3$ k.p.). Wniosek o urlop staje się ponadto wiążący dla pracodawcy, gdy składa go pracownik młodociany, będący uczniem szkoły dla pracujących, któremu pracodawca musi udzielić urlopu w okresie ferii szkolnych (art. $205 \S 4$ k.p.). 
pracownika urlopu wypoczynkowego, ostateczna decyzja w tej kwestii należy zasadniczo do pracodawcy. Planowany termin urlopu wypoczynkowego nie jest więc w sensie prawnym, jakby można było oczekiwać, wziąwszy pod uwagę cel urlopu wypoczynkowego, nawet wyrazem pewnego kompromisu między stronami, skoro pracownik może co prawda wypowiedzieć się w tej sprawie, a pracodawca powinien to „wziąć po uwagę", ale ostatecznie samodzielnie będzie o tym terminie przesądzał. Prawo nie wiąże bowiem z procedurą planowania okresu, w jakim urlop będzie wykorzystywany, obowiązku jego uzgodnienia przez strony stosunku pracy. W skrajnych przypadkach termin ten może być zatem w istocie narzucony przez pracodawcę, czemu nie przeciwdziała w dostatecznym stopniu orzecznictwo sądowe, w którym często przyjmuje się, że odrzucenie propozycji pracownika nie wymaga szczególnego uzasadnienia ${ }^{11}$. Prawo do wypoczynku jawi się tu trochę jako prawo pracownika o podstawowym znaczeniu, ale realizowane w terminie dogodnym przede wszystkim dla pracodawcy ${ }^{12}$.

Konstatacja ta dotyczy zresztą nie tylko etapu planowania bieżącego urlopu wypoczynkowego, lecz także tych sytuacji, w których urlopu danego pracownika nie zaplanowano czy zaplanowany przesunięto i pracownik ten występuje do pracodawcy z określonym wnioskiem urlopowym. W szczególności brak związania pracodawcy terminem w nim wskazanym dotyczy także urlopu zaległego i to nawet wówczas, gdy pracodawca nie udziela tego urlopu w maksymalnym terminie przewidzianym w Kodeksie pracy (czyli do końca września roku następnego) ${ }^{13}$. Przepisy nie przewidują bowiem, aby analogicznie jak np. przy urlopie na żądanie, wniosek złożony przez pracownika w takim przypadku był dla pracodawcy wiążący. Biorąc pod uwagę funkcje urlopu wypoczynkowego, przyznanie pracownikowi prawa wystąpienia $\mathrm{z}$ tego rodzaju żądaniem, po upływie wskazanego w prawie ostatecznego terminu, byłoby w pełni usprawiedliwione. Urlop, aby spełnił swe zasadnicze funkcje, musi być udzielony w stosunkowo krótkim odstępie czasowym od okresu, za jaki przysługuje, co było wielokrotnie podkreślane w orzecznictwie europejskim. Taki instrument dawałby pracownikowi szansę szybszego wyegzekwowania należnego mu prawa, a zatem jego wykorzystanie $\mathrm{z}$ zachowaniem właściwego mu przeznaczenia, oraz zmniejszałby ryzyko jego utraty w związku z upływem okresu przedawnienia. Żądanie to pracodawca ewentualnie mógłby odrzucić wyłącznie w sytuacjach nadzwyczajnych ${ }^{14}$.

11 Por. tak m.in. w wyroku SN z 13 maja 1998 r., I PKN 99/98.

12 Na przykład we Francji zobowiązuje się do udzielania zasadniczej części urlopu w okresie od maja do października. Ponadto, przy braku ustaleń układowych, pracodawca decydując o kolejności urlopów, powinien wziąć pod uwagę sytuację rodzinną uprawnionego (zwłaszcza termin urlopu współmałżonka), okres stażu pracy pracownika, a nawet, co istotne przy pracy niepełnoetatowej, jego aktywność u innych pracodawców. Gwarantuje się też prawo do urlopu w tym samym czasie małżonkom lub osobom pozostającym w związkach partnerskich, zatrudnionym w tym samym przedsiębiorstwie. Por. G. Auzero, E. Dockès, Droit du travail, Paris 2014, s. 871 i n.

13 Por. wyrok SN z 5 grudnia 2000 r., I PKN 121/00. Zob. też uzasadnienie do wyroku SN z 16 grudnia 2008 r., I PK 88/08, OSNP 2010, nr 11-12, poz. 137.

14 Podobnie $w$ orzecznictwie przyjęto $w$ stosunku do urlopu na żądanie, o którym stanowi art. $167^{2}$ k.p. Zob. uzasadnienie wyroku SN z 28 października 2009 r., II PK 123/09. 
Trzeba mieć jednak przy tym na uwadze, że każdy urlop, m.in. też zaległy czy na żądanie, w świetle obowiązujących przepisów wymaga zgody pracodawcy. W orzecznictwie SN często podkreśla się, że pracownik nie może rozpocząć urlopu bez wyraźnej akceptacji pracodawcy, nawet jeśli po stronie pracodawcy występują pewne uchybienia, np. pracownik nie został objęty planem urlopów ${ }^{15}$, przekroczono ustawowy termin, w jakim urlop powinien być udzielony lub, co może już budzić pewne zastrzeżenia, nie ma przez pewien czas w zakładzie pracy osób uprawnionych do udzielania pracownikowi urlopu wypoczynkowego ${ }^{16}$.

W szczególności jeśli chodzi o ostatnie stanowisko wydaje się, że brak tu pewnej symetrii. Zgadzając się zasadniczo z tezą, że urlopu udziela ostatecznie pracodawca i polskie prawo właściwie nie dopuszcza odstępstw w omawianym zakresie, należy wymagać, aby zawsze zostały wyznaczone osoby, które w tym przedmiocie będą uprawnione do podejmowania stosownych decyzji. Prawo pracownika do odpoczynku nie może być bowiem uzależnione od obecności w danym zakładzie pracy osoby upoważnionej formalnie do udzielenia tego urlopu. Nieprawidłowości dotyczące organizacji pracy zakładu nie powinny bowiem obciążać pracownika, zwłaszcza w zakresie możliwości skorzystania z jego podstawowych uprawnień.

Poza tym kwestią szczególnie wątpliwą $\mathrm{w}$ analizowanym kontekście jest brak regulacji zobowiązującej pracodawcę, jako głównego decydenta w sprawie wyznaczenia terminu urlopu wypoczynkowego, do zawiadomienia pracownika o swej decyzji w jakimś minimalnym okresie przed rozpoczęciem przez tego ostatniego wykorzystywania omawianego zwolnienia, $\mathrm{w}$ razie nieuwzględnienia preferowanego przez pracownika terminu urlopu. Tym samym można sobie wyobrazić sytuację, w której pracownik w zasadzie niemal z dnia na dzień zostanie powiadomiony o tym, że ten urlop rozpoczyna, co może być uzasadniane przez pracodawcę koniecznością zachowania odpowiedniej organizacji pracy. Z punktu widzenia prawa do odpoczynku jest to jednak sytuacja niewłaściwa i mogąca istotnie wpłynąć na jakość udzielonego urlopu, którego pracownik nie zdążył sobie zorganizować, a tym samym na jakość samego odpoczynku.

$\mathrm{W}$ orzecznictwie SN z lat 80. ubiegłego wieku sformułowano zasadę prawną, że nie jest konieczne oddzielne zawiadomienie pracownika o terminie urlopu wypoczynkowego, jeśli plan urlopu został podany do wiadomości pracownika w sposób przyjęty w zakładzie pracy co najmniej na miesiąc przed rozpoczęciem urlopu $^{17}$. Wyrok ten był jednak wydany na podstawie nieobowiązującej już dziś regulacji kodeksowej, która wprost stanowiła, że pracownik powinien być zawiadomiony o terminie urlopu nie później niż na miesiąc przed jego rozpoczęciem ${ }^{18}$, co,

15 Wyrok SN z 10 listopada 1998 r., I PKN 364/98.

16 Wyrok SN z 16 grudnia 2008 r., I PK 88/08. Zgodnie z tezą 2. tego wyroku, czasowa nieobecność osób uprawnionych do udzielenia pracownikowi urlopu wypoczynkowego nie usprawiedliwia jego rozpoczęcia bez zgody pracodawcy.

17 Uchwała 7 sędziów SN z 6 marca 1980 r., V PZP 7/79, OSNC 1980, nr 7-8, poz. 132.

18 Dawny art. 163 k.p. Por. też T. Zieliński, Zarys wykładu prawa pracy, cz. II, Katowice 1984, S. 289. 
moim zdaniem, stanowiło swego rodzaju zabezpieczenie należytego urzeczywistnienia prawa pracownika do odpoczynku, choć powinno być odnoszone przede wszystkim do sytuacji, gdy termin urlopu wskazany przez pracodawcę znacząco różni się od tego, który określił pracownik.

Istotą planowego udzielania urlopów wypoczynkowych jest też konieczność podania przez pracownika swoich preferencji z bardzo dużym wyprzedzeniem. Plan ten, jak wskazuje się zgodnie w literaturze przedmiotu, mimo braku ustawowo określonego terminu, powinien bowiem powstać, biorąc pod uwagę jego funkcje i charakter, możliwie najwcześniej, tj. pod koniec roku bieżącego pracodawca winien zająć się konstruowaniem takiego planu na rok następny. J. Iwulski postuluje wręcz, aby plan urlopów, ze względu na to, iż zatrudniony ma możliwość skorzystania z kolejnego urlopu już od 1 stycznia następnego roku kalendarzowego, był gotowy pod koniec roku poprzedzającego rok, którego ten plan dotyczy ${ }^{19}$. Nie zawsze pracownik ma jednak już wówczas dostatecznie wykrystalizowane plany urlopowe, nie uwzględnia to też w jakimś sensie potrzeby odpoczynku, która może pojawić się w części roku kalendarzowego, zwłaszcza jeśli przyjąć brak obowiązku pracodawcy przesunięcia urlopu na wniosek pracownika, niezależnie od przyczyn podanych we wniosku, co będzie przedmiotem szerszej analizy w kolejnym punkcie. Stąd w pełni uzasadnione wydają się te stanowiska formułowane w literaturze, według których nie ma przeszkód, aby pracodawca podzielił ten plan na części ${ }^{20}$, przynajmniej dwie. Niewątpliwie może to zmniejszyć ryzyko wystąpienia po stronie pracownika czy pracodawcy nieprzewidzianych okoliczności uniemożliwiających rozpoczęcie urlopu w terminie wskazanym w planie, a tym samym prawdopodobieństwo konieczności korygowania tego planu. W tym ujęciu metodą bardziej sprzyjającą realizacji funkcji wypoczynkowej urlopu wydają się jednak indywidualne uzgodnienia poczynione $\mathrm{w}$ omawianym zakresie $\mathrm{z}$ pracownikami, mające, mimo wszystko, charakter mniej sformalizowany.

Zgodzić się też należy, że ostatnia forma wyznaczania terminu urlopu jest wskazana zwłaszcza w odniesieniu do pierwszego urlopu w życiu zawodowym pracownika z uwagi na szczególną konstrukcję tego urlopu i pewną trudność objęcia go planem rocznym ${ }^{21}$.

Kwestią dyskusyjną jest również charakter prawny sporządzonego planu, precyzującego konkretne terminy rozpoczęcia urlopu przez poszczególnych pracowników. Z uwagi na to, że problem ten nie jest jednoznacznie rozstrzygnięty przez ustawodawcę, w literaturze przedmiotu formułowano w tej sprawie zróżnicowane oceny.

19 J. Iwulski, [w:] J. Iwulski, W. Sanetra, Kodeks pracy. Komentarz, Warszawa 2000, s. 460.

20 Tak m.in. E. Wichrowska-Janikowska, Plan urlopów, PiZS 1999, nr 1, s. 31; A. Bigaj, Prawo do urlopu wypoczynkowego, Warszawa 2015, s. 216; F. Małysz, Pracownicze urlopy wypoczynkowe, Warszawa 1987, s. 70.

21 Por. A. Kosut, [w:] Kodeks pracy. Komentarz, s. 902. 
Według części autorów, określenie $\mathrm{w}$ takim planie terminu wykorzystania urlopu wypoczynkowego przez konkretnego pracownika nie jest równoznaczne $\mathrm{z}$ udzieleniem mu tego urlopu ${ }^{22}$. Oznacza to, że pracownik będzie musiał ponadto przed rozpoczęciem urlopu wypoczynkowego w ustalonym w planie czasie każdorazowo uzyskać zgodę pracodawcy na jego rozpoczęcie, zgodnie ze zwyczajem panującym w danym zakładzie pracy. Może do tego służyć często występująca w praktyce tzw. karta urlopowa czy zwykłe podanie o urlop akceptowane przez pracodawcę lub osobę upoważnioną $w$ tym zakresie do działania $w$ jego imieniu. Wiele zależy zatem od wprowadzonych w konkretnym zakładzie reguł postępowania, przyjętych form wyrażania takiej zgody. Niemniej bez akceptacji pracodawcy pracownik nie może rozpocząć urlopu. Zgodnie z taką wykładnią, plan urlopów wiąże strony stosunku pracy, ale tylko co do terminu wykorzystania urlopu wypoczynkowego. Oznacza to, że pracownik ma roszczenie o udzielenie mu urlopu w okresie wskazanym w planie (o ile nie wystąpią okoliczności przewidziane prawem, uzasadniające przesunięcie urlopu wypoczynkowego na inny termin), którego może dochodzić przed sądem pracy, ale też pracodawca wobec bezprawnego sprzeciwu pracownika $\mathrm{w}$ kwestii rozpoczęcia urlopu w zaplanowanym terminie może go w tym czasie nie dopuścić do pracy, powołując się na omawiany dokument i wskazaną $\mathrm{w}$ nim datę.

Pogląd ten znajduje częściowo poparcie we wcześniejszym orzecznictwie SN dotyczącym omawianej problematyki. W sposób najbardziej zdecydowany ocena ta została wyrażona w jednym ze starszych wyroków SN, w którym uznano, że plan urlopów nie daje pracownikowi uprawnienia do rozpoczęcia urlopu w zaplanowanym terminie. Konieczne jest ponadto, zdaniem sądu, „oświadczenie przez zakład pracy wobec pracownika woli (wyrażenie zgody), by pracownik w konkretnym okresie [...] (z reguły jest to okres przewidziany w planie) urlop wykorzystał. Praktycznie zakład pracy wyraża swoją wolę w tym przedmiocie - najczęściej - wydając pracownikowi tzw. kartę urlopową" ${ }^{33}$. W późniejszych orzeczeniach SN kwestia ta nie była już tak jednoznacznie stawiana.

Według mnie za taką interpretacją, niewątpliwie w jakiejś mierze kolidującą z niezakłóconym przebiegiem funkcji urlopu, może przemawiać sam sposób sformułowania przepisu, w którym wskazano, że urlopy „powinny być udzielane zgodnie z planem urlopów". Na tej podstawie można wnioskować, że ów plan staje się, co do zasady, podstawą zobowiązania pracodawcy, ale do udzielenia w przyszłości tego urlopu w okresie, który został wcześniej ustalony. Pracodawca, jak wynika z powyższego, powinien udzielić urlopu, mając na uwadze to, co zostało w przeszłości zaplanowane, chyba że wystąpią przesłanki uzasadniające odstąpienie od postanowień zawartych w planie urlopowym lub dojdzie do zawarcia przez strony stosunku pracy stosownego porozumienia w tej sprawie. Obowiązek ten nie ma bowiem charakteru bezwzględnego.

22 Tak m.in. L. Florek, T. Zieliński, Prawo pracy, Warszawa 2004, s. 181; M. Zieleniecki, [w:] Kodeks pracy. Komentarz, s. 649.

23 Wyrok SN z 5 września 1979 r., I PRN 82/79 (niepublikowany). 
Na taką okoliczność powołano się m.in. w uzasadnieniu wyroku jednego z warszawskich sądów pracy, który uznał, że „samo ustalenie planu urlopów nie jest równoznaczne z udzieleniem urlopów, gdyż przepis art. 163 k.p. rozróżnia plan urlopów oraz udzielenie zgody na urlop zgodnie z tymże planem" ${ }^{24}$.

Argumentem wzmacniającym taką ocenę charakteru prawnego planu urlopów może być również fakt znacznego zliberalizowania procedury jego tworzenia oraz braku sankcji za naruszenie obowiązku jego wydania i respektowania postanowień w nim zawartych. W przepisach Kodeksu pracy ustawodawca nie określa bowiem w żaden sposób konsekwencji, jakie grożą pracodawcy, który wbrew swym zobowiązaniom nie wydaje omawianego dokumentu czy też udzielając urlopów poszczególnym pracownikom, zwyczajnie go ignoruje (pomijając, w drugim przypadku, wspominaną wcześniej możliwość wystąpienia przez pracownika do sądu pracy z określonymi roszczeniami). Art. $282 \$ 1$ pkt 2 k.p. stanowi bowiem, że wykroczenie przeciwko prawom pracownika popełnia ten, kto nie udziela w ogóle przysługującego pracownikowi urlopu wypoczynkowego lub bezpodstawnie obniża jego wymiar. Tym samym brak planu urlopów w zakładzie pracy lub udzielanie urlopów w sposób z nim niezgodny takiego wykroczenia nie stanowią. Również regulujący omawianą materię art. 163 k.p. w ogóle nie odnosi się do tej kwestii. Niewątpliwie może to obniżać rangę planu urlopów i zawartych w nim ustaleń, co ostatecznie wprowadza dość znaczną niepewność w sytuacji pracownika w zakresie ostatecznego terminu realizacji jego prawa do odpoczynku. O ile pracodawca może bowiem niejako wymusić na pracowniku, aby w ustalonym wcześniej terminie ten urlop wykorzystał, o tyle środki, którymi dysponuje pracownik są z pewnością znacznie słabsze. Jeśli pracodawca bezpośrednio przed dniem rozpoczęcia urlopu, mimo swego zobowiązania, odmawia udzielenia urlopu w zaplanowanym czasie, wystąpienie pracownika do sądu pracy nie gwarantuje mu natychmiastowego rezultatu, co zapewne spowoduje faktyczne przesunięcie terminu tego urlo$\mathrm{pu}$, niweczące niekiedy sens podejmowania przez pracownika takiego działania.

Znaczna część przedstawicieli doktryny prawa pracy wyraża w związku z tym odrębne opinie, tj. że w przypadku, gdy w zakładzie pracy został przyjęty plan urlopów (lub określono termin wykorzystania urlopu wypoczynkowego „po porozumieniu" z pracownikiem) pracownik może rozpocząć urlop w ustalonym terminie bez dodatkowych oświadczeń (zgody) pracodawcy w tym zakresie ${ }^{25}$. Tego rodzaju obowiązek, jak podkreślają niektórzy autorzy, należy uznać za bezzasadny, a $\mathrm{w}$ razie zaistnienia wyjątkowych okoliczności uzasadniających przesunięcie terminu urlopu, to pracodawca powinien wykazać odpowiednią „aktywność”26.

24 Por. wyrok sądu okręgowego w Warszawie z 25 listopada 2016 r., XXI Pa 578/16, www.orzeczenia. warszawa.so.gov.pl.

25 Por. tak K. Jaśkowski, E. Maniewska, Kodeks pracy. Komentarz, LEX/el. 2011 [dostęp: 6.04.2011]; A. Świątkowski; por. tenże, Kodeks pracy. Komentarz, Warszawa 2006, s. 676; T. Liszcz, Prawo pracy, 2004, s. 369. Podobnie: E. Wichrowska-Janikowska, Plan urlopów, s. 31 oraz E. Chmielek-Łubińska, Urlopy wypoczynkowe. Nowe uregulowania od stycznia 1997 r., Warszawa 1997, s. 53.

26 Tak zob. A. Bigaj, Prawo do urlopu..., s. 221. 
Konkludując należy stwierdzić, że reguły, na jakich ustawodawca oparł wymóg planowania urlopu wypoczynkowego, w tym wyznaczania terminu tego urlopu, nie odpowiadają w dużej mierze prowypoczynkowej funkcji tej instytucji. Nie kwestionując tego, że pracodawca musi wyrazić zgodę na wykorzystywanie urlopu w określonym czasie, jako że jest to jednak jego świadczenie, a ponadto na nim spoczywa obowiązek i zarazem odpowiedzialność za prawidłową organizację pracy oraz pogodzenie wzajemnych interesów wszystkich zatrudnionych w zakresie ich prawa do odpoczynku, to nie można nie dostrzegać, że urlop, jak podkreślano w piśmiennictwie, dotyczy pracownika, który ma czynny udział w jego realizacji, stąd przy ustalaniu omawianych kwestii jego zgoda nie może być pominięta ${ }^{27}$. W konsekwencji cel urlopu wypoczynkowego może być w pełni osiągnięty wówczas, gdy termin jego rozpoczęcia będzie ustalany w drodze porozumienia stron, $\mathrm{w}$ dosłownym tego słowa znaczeniu.

O ile, niezależnie od wskazanych wyżej zastrzeżeń, na gruncie przepisów kodeksowych pozostawia się stronom szeroką swobodę w zakresie ustalania terminu, $\mathrm{w}$ jakim urlop wypoczynkowy w danym roku kalendarzowym będzie wykorzystywany, o tyle warto przypomnieć, że niektóre ustawy szczególne wiążą zasadniczo możliwość realizacji tego prawa z konkretnym okresem.

Dotyczy to generalnie nauczycieli, $w$ tym również akademickich, i jest związane z charakterem oraz organizacją ich pracy, które w założeniu powodują, że intensywność tej pracy w okresie wolnym od zajęć dydaktycznych maleje lub niemal zupełnie ustaje, co jednak, jak słusznie zauważono w doktrynie prawa pracy, jest tezą mocno ryzykowną w stosunku do pracowników naukowych uczelni wyż$\operatorname{szych}^{28}$. Niemniej zarówno w Karcie Nauczyciela, która stanowi, że urlop przysługuje w czasie trwania ferii, jak i w ustawie o szkolnictwie wyższym, która w sposób mniej kategoryczny wskazuje na powinność jego wykorzystania w okresie wolnym od zajęć dydaktycznych, łączy się zasadniczo prawo do wykorzystania urlopu wypoczynkowego $\mathrm{z}$ okresem, w którym trwa przerwa w omawianych zajęciach.

Nawet jeśli przyjąć, jak czyni się często na gruncie przepisów dotyczących nauczycieli akademickich, że należy w tym zakresie mówić raczej o pewnym postulacie niż prawnym nakazie ${ }^{29}$, czego nie można odnieść do nauczycieli podlegających Karcie Nauczyciela, to samo ograniczenie (lub jego próba) swobody realizacji prawa do urlopu wypoczynkowego, z którym w istocie ma się tu do czynienia, budzi w kontekście głównej funkcji urlopu pewne wątpliwości, co było już wcześniej wyraźnie sygnalizowane.

Urlop, jak wyżej przekonywano, ze swej natury zakłada udział pracownika $\mathrm{w}$ ustalaniu jego terminu, który powinien być najbardziej dla niego, z różnych

27 Por. tak M. Święcicki, Prawo pracy, s. 461.

28 Por. Z. Góral, [w:] Akademickie prawo pracy, red. K.W. Baran, Warszawa 2015, s. 237.

29 Ustawodawca wskazuje bowiem, że urlop ten „powinien” być wykorzystany w okresie wolnym od zajęć dydaktycznych, a nie „musi” czy „jest” wówczas wykorzystywany. Por. H. Izdebski, J.M. Zieliński, Prawo o szkolnictwie wyższym. Komentarz, Warszawa 2011, s. 344. Zob. też Z. Góral, [w:] Akademickie prawo..., s. 237. 
względów, dogodny, tj. pozwalający na optymalne urzeczywistnienie zasadniczego celu omawianej instytucji. Jest oczywiste, że z jednej strony, ze względów organizacyjnych taki okres realizacji tego prawa jest z pewnością w przypadku nauczycieli pożądany. Nie powinno się w tym zakresie jednak wprowadzać jednoznacznych, kategorycznych nakazów, szczególnie obejmujących całość urlopu wypoczynkowego, biorąc pod uwagę, o czym była wyżej mowa, że o terminie udzielenia urlopu, przy zastosowaniu ogólnych zasad kodeksowych, w większości przypadków decyduje ostatecznie pracodawca. I to on lub osoby działające w jego imieniu, kierując się wymogami dotyczącymi niezakłóconej pracy zakładu, szkoły czy obciążeniami dydaktycznymi nauczyciela w danym czasie, mogą podjąć decyzję o możliwości lub braku możliwości udzielenia nauczycielowi takiego urlopu. Dlatego należy pozostawiać stronom stosunku pracy stosunkowo szeroki margines swobody odnośnie do określenia czasu, w jakim pracownik może korzystać z urlopu, w celu osiągnięcia jak najpełniejszego urzeczywistnienia jego podstawowej funkcji. W przeciwnym razie, na co zwracano uwage już we wcześniejszych rozważaniach, nie osiągnie się ani optymalnych rezultatów w zakresie dydaktyki (jeśli zajęcia są prowadzone przez przemęczoną osobę), ani też w zakresie odpoczynku (jeśli ma on być wykorzystywany nie wtedy, kiedy jest potrzebny lub w czasie, w którym nie zostanie de facto spożytkowany na odpoczynek w związku z nałożonymi na pracownika zadaniami naukowymi). Optymalnym rozwiązaniem byłoby, moim zdaniem, sformułowanie jedynie zalecenia wykorzystania urlopu w okresie przerwy w zajęciach dydaktycznych, albo też przy wprowadzonym jednak obowiązku, jaki wynika aktualnie, według mnie, z Karty Nauczyciela, ograniczyć ów wymóg do części urlopu czy też uwzględnić możliwość odstąpienia od analizowanego obowiązku chociaż w tych sytuacjach, w których udzielenie urlopu w innym terminie nie będzie kolidować z prowadzeniem zajęć.

Trzeba ponadto zwrócić uwagę, że ograniczenie terminu wykorzystania urlopu, jeśli już wprowadzone, musi być w zakresie podmiotów nim objętych sprowadzone do minimum i zawsze obiektywnie usprawiedliwione. Tymczasem na gruncie unormowań obejmujących szkolnictwo wyższe ustawodawca nie uwzględnia faktu, że pojęcie nauczyciela akademickiego jest złożone, obejmuje różne grupy podmiotów, również te, które zajęć nie prowadzą (np. dyplomowanych bibliotekarzy). Wprowadzanie w ich przypadku ograniczeń w zakresie terminu realizacji prawa do urlopu wypoczynkowego wydaje się bezzasadne i jako takie naruszające ich prawo do wypoczynku w dogodnym czasie. Stąd w doktrynie prawa pracy panuje zgodne przekonanie co do tego, że mogą one korzystać z prawa do urlopu wypoczynkowego w każdej części roku, na ogólnych warunkach określonych w Kodeksie pracy $^{30}$.

30 Tak m.in. W. Sanetra, [w:] Prawo o szkolnictwie wyższym. Komentarz, red. W. Sanetra, M. Wierzbowski, Warszawa 2013, s. 302; Z. Góral, [w:] Akademickie prawo..., s. 237; T. Nycz, Prawo do urlopu wypoczynkowego nauczyciela akademickiego, 8.12.2010, www.prawo-pracy.pl. 


\section{Przesuwanie terminu urlopu ze względu na szczególne potrzeby pracodawcy}

W związku z podjętą wyżej tematyką dotyczącą wykorzystywania urlopu wypoczynkowego $\mathrm{w}$ terminie wcześniej wyznaczonym pozostaje zagadnienie dopuszczalności jego przesunięcia na inny okres. Z uwagi na to, że wypoczynkowa funkcja omawianego urlopu wymaga, by urlop był świadczeniem dogodnym dla pracownika, w znaczeniu w poprzednim punkcie wyjaśnionym, oraz pewnym, tj. pozwalającym pracownikowi przygotować się na jego wykorzystanie ${ }^{31}$, należy uznać, że zasadniczo będą kolidować z głównym celem urlopu wszelkie przepisy dopuszczające zmianę momentu rozpoczęcia zaplanowanego wcześniej urlopu, dokonywane $\mathrm{z}$ woli pracodawcy. $\mathrm{U}$ podstaw tego rodzaju wyjątków z natury leżą bowiem nie dążenia do zagwarantowania pracownikowi optymalnych warunków do wypoczynku, lecz względy organizacyjne, szczególne potrzeby pracodawcy, zmniejszenie kosztów pracy, które korygują uprawnienia pracownicze w omawianym obszarze, niekiedy istotnie krzyżując plany urlopowe pracownika. Stąd każda regulacja pozwalająca na ingerencję pracodawcy w ustalony termin wykorzystania urlopu wypoczynkowego przez pracownika powinna być ograniczona do niezbędnych przypadków i dobrze przemyślana.

Instytucję przesunięcia terminu urlopu z przyczyn leżących po stronie pracodawcy (ale też na wniosek pracownika) reguluje w tytułowym zakresie art. 164 k.p., który stanowi, że przesunięcie terminu urlopu może nastąpić na wniosek pracownika umotywowany ważnymi przyczynami, ale także ze względu na szczególne potrzeby pracodawcy, jeżeli nieobecność pracownika spowodowałaby poważne zakłócenia toku pracy.

Przepis ten, w części dotyczącej zmiany terminu urlopu z powodów dotyczących pracodawcy, jak była o tym wyżej mowa, ze swej istoty służący nie do urzeczywistniania prawa pracownika do odpoczynku, ale do zgoła odmiennych celów, budzi również wiele wątpliwości interpretacyjnych, których rozstrzygnięcie może wpłynąć na ustalenie zakresu możliwego stosowania omawianego wyjątku, a tym samym stopień potencjalnego zagrożenia naruszeniem głównej funkcji urlopu wypoczynkowego, w tym zwłaszcza jego efektywności.

Przede wszystkim trzeba zwrócić uwagę, że ustawodawca posłużył się w nim klauzulami generalnymi, takimi jak „szczególne potrzeby” czy „poważne zakłócenia toku pracy", które dają podmiotom stosującym prawo (pracodawcy) pewną swobodę oceny i możliwość wskazania różnorodnych okoliczności mieszczących się w obszarze działania tej normy prawnej.

Mimo nieostrych pojęć użytych w tym przepisie, należy jednak, moim zdaniem, mieć na względzie ustawowy wymóg powołania potrzeb o „szczególnym” charakterze jako powodu odstąpienia przez pracodawcę od przyjętego wcześniej

31 Por. M. Święcicki, Prawo pracy, s. 464. 
terminu udzielenia urlopu, aby m.in. zminimalizować zakres zakłócenia przebiegu jego podstawowej funkcji. W konsekwencji tego rodzaju przesunięcia powinny występować wyjątkowo, sporadycznie, przede wszystkim w sytuacjach trudnych do przewidzenia i wówczas, gdy nieobecność pracownika grozi poważnymi utrudnieniami w funkcjonowaniu zakładu pracy (czy wręcz je uniemożliwia), naraża pracodawcę na poważne szkody. W literaturze sformułowano nawet pogląd, że chodzi tu o okoliczności nieznane pracodawcy w chwili planowania urlopu ${ }^{32}$, co jednak z przepisu bezpośrednio nie wynika.

$\mathrm{Z}$ pewnością, biorąc pod uwagę m.in. sposób sformułowania powyższej przesłanki przesunięcia terminu urlopu wypoczynkowego z inicjatywy pracodawcy, za okoliczność uzasadniającą takie przesunięcie nie może być uznany przestój. Warunkiem zmiany daty rozpoczęcia urlopu w omawianym przypadku jest wystąpienie sytuacji, w której obecność pracownika w zakładzie pracy jest konieczna, natomiast przy przestoju z założenia jest dokładnie odwrotnie, następuje czasowe wstrzymanie toku pracy. Pracodawca, w moim przekonaniu, nie może udzielić urlopu wypoczynkowego w okresie przestoju nie tylko wówczas, gdy urlop został zaplanowany, a termin jego rozpoczęcia nie pokrywa się z czasem trwania przestoju, ale też wtedy, gdy strony nie ustaliły w ogóle terminu wykorzystania tego urlopu. Urlop wypoczynkowy i przestój stanowią dwie odrębne instytucje prawne spełniające odmienne funkcje. Udzielenie urlopu wypoczynkowego w opisanych okolicznościach stanowiłoby niedopuszczalne obejście przepisów prawa dotyczących przestoju oraz przerzucenie części ryzyka techniczno-organizacyjnego na pracownika.

Zasadniczo należy zgodzić się również z oceną formułowaną przez niektórych przedstawicieli doktryny prawa pracy, że przesunięcie przez pracodawcę terminu urlopu na podstawie analizowanego przepisu nie może dotyczyć urlopu na żądanie, z uwagi na szczególny tryb jego udzielania ${ }^{33}$.

Drugą kwestią wywołującą poważne kontrowersje jest niejasny charakter prawny omawianej normy. Chodzi zwłaszcza o ustalenie, czy pracodawca ma tutaj pełną swobodę działania, w tym swobodę oceny przesłanek warunkujących takie przesunięcie, czy też nie. Problem ten nie jest bowiem zarówno w doktrynie, jak i orzecznictwie jednoznacznie rozstrzygany.

Treść art. 164 k.p., w tym zwłaszcza jego początek - „przesunięcie terminu urlopu może nastąpić" - powoduje, że bardzo trudno ostatecznie ocenić, czy w tym wypadku o przesunięciu terminu urlopu decyduje tylko pracodawca i to wyłącznie

32 Zob. A. Kosut, [w:] Kodeks pracy. Komentarz, s. 909.

33 Dopuszczalne będzie natomiast jego przesunięcie na wniosek pracownika; por. A. Kosut, [w:] Kodeks pracy. Komentarz, s. 931. Podobnie M. Zieleniecki, [w:] Kodeks pracy. Komentarz, s. 653. Autor uznaje, że zarówno komentowany aktualnie art. 164 § 2 k.p., jak i art. 165 i 166 k.p., o których będzie mowa dalej, dotyczą wyłącznie urlopów, które zostały zaplanowane, tj. objęte planem urlopów lub których termin został ustalony w trybie indywidualnych uzgodnień z pracownikiem i nie może zostać dotrzymany. Tym samym nie można przepisów tych zastosować do urlopu na żądanie, który planowaniu nie podlega. 
jego woli pozostawiono ocenę przesłanek i ostateczną decyzję w tej sprawie (tym bardziej, że dość często mówi się w tym kontekście o przesunięciu „fakultatywnym"), czy też decyzję taką podejmuje pracodawca, ale podlega ona kontroli sądu.

$\mathrm{Za}$ ostatnim rozwiązaniem opowiedział się zdecydowanie J. Iwulski. Autor trafnie zauważa, że za porozumieniem stron termin urlopu może być przesunięty zawsze i nie ma wówczas znaczenia, która ze stron występuje $\mathrm{z}$ odpowiednią inicjatywą. Dlatego, jak można domniemywać, sens art. 164 k.p. sprowadza się do możliwości „żądania przesunięcia terminu urlopu”, mimo braku zgody drugiej strony, czemu muszą jednak towarzyszyć określone roszczenia, zasadniczo po stronie pracownika ${ }^{34}$.

Oznaczałoby to w praktyce, że pracownik, któremu przesunięto urlop ze względu na potrzeby pracodawcy, które zdaniem pracownika nie miały szczególnego charakteru, mógłby wystąpić do sądu pracy i żądać, w zależności od sytuacji, odpowiednio dopuszczenia go do pracy (łącznie z wynagrodzeniem za czas gotowości do niej), udzielenia urlopu w terminie wcześniej ustalonym (wskazanym np. w planie urlopów) $)^{35}$ czy nawet, jak wskazują niektórzy przedstawiciele doktryny, wystąpić z żądaniem naprawienia szkody wyrządzonej w wyniku niewykonania lub nienależytego wykonania zobowiązania przez pracodawcę (art. 471 k.c. w związku z art. 300 k.p. $)^{36}$.

Sądzę, że należy zdecydowanie postulować przyjęcie koncepcji drugiej. Pozostawienie wszak pracodawcy pewnej swobody oceny w opisanym zakresie nie może oznaczać jego dowolności, skoro ustawodawca w przepisie sformułował jednak określone przesłanki dające prawo do przesunięcia terminu urlopu wypoczynkowego $\mathrm{z}$ inicjatywy stron, ograniczając $\mathrm{w}$ ten sposób negatywne $\mathrm{z}$ punktu widzenia celu omawianej instytucji jego konsekwencje. Tak też, moim zdaniem, trzeba rozumieć zwrot „przesunięcie [...] może nastąpić”, nie jako pełną swobodę podmiotu zatrudniającego, ale prawo odstąpienia od zasady planowego udzielania urlopów wypoczynkowych, które powstaje po spełnieniu opisanych warunków. Orzecznictwo SN nie dostarcza jednak na ten temat jednoznacznej odpowiedzi ${ }^{37}$.

Niejasna jest również sytuacja prawna pracownika po dokonaniu omawianego przesunięcia terminu urlopu przez pracodawcę w sposób legalny. Istotne zastrzeżenia budzi przede wszystkim brak w analizowanym przepisie regulacji przyznającej pracownikowi prawo do rekompensaty kosztów przez niego poniesionych $\mathrm{w}$ związku z przesunięciem terminu urlopu z przyczyn leżących po stronie pra-

34 Zob. J. Iwulski, W. Sanetra, Kodeks pracy..., s. 462.

35 Tamże. Natomiast pracownik, co należy przypomnieć, nie może sam, bez zgody pracodawcy, rozpocząć urlopu w terminie wskazanym we wniosku, nawet jeśli, w jego ocenie, przemawiają za tym ważne przyczyny.

36 Tak M. Zieleniecki, [w:] Kodeks pracy. Komentarz, s. 649.

37 Można wskazać natomiast na wyrok Sądu Okręgowego w Legnicy z 8 maja 2014 r., V Pa 45/14, LEX nr 1886911, w uzasadnieniu którego oceniono powody przesunięcia terminu urlopu przez pracodawcę, uznając, że miały one charakter szczególny, ale bez szerszego odniesienia się do omawianego problemu. 
codawcy, szczególnie jeśli następuje to w krótkim czasie przed ustalonym rozpoczęciem tego urlopu. Trzeba bowiem zauważyć, że ustawodawca nie wprowadza tu żadnego „okresu ochronnego”, maksymalnego terminu w stosunku do zaplanowanej daty urlopu na skorzystanie przez pracodawcę ze swego uprawnienia ${ }^{38}$, co już samo w sobie może być postrzegane jako poważne zagrożenie z punktu widzenia realizacji celu urlopu. Może się zatem okazać, że pracownik zostanie powiadomiony o konieczności przesunięcia urlopu wypoczynkowego na dzień przed jego planowanym rozpoczęciem. Wówczas najczęściej taki pracownik poniósł już określone wydatki na zorganizowanie swojego wypoczynku, np. wykupił wczasy, zapłacił za kwaterę itp. i trudno byłoby przyjąć, że będą go one jeszcze dodatkowo obciążać.

W literaturze przedmiotu słusznie uznaje się, że mamy w tym zakresie do czynienia z brakiem właściwej regulacji, który należy wypełnić, stosując w drodze analogii art. $167 \$ 2$ k.p., czyli przepis ustanawiający obowiązek pracodawcy pokrycia kosztów poniesionych przez pracownika w bezpośrednim związku z odwołaniem go z urlopu ${ }^{39}$. Oznacza to, że pracodawca będzie również zobligowany do pokrycia wspomnianych kosztów w przypadku, gdy przesuwa termin rozpoczęcia urlopu przez pracownika ze względu na swe szczególne potrzeby. Nie ma bowiem większej różnicy w sytuacji pracownika odwoływanego np. po dwóch dniach z urlopu wypoczynkowego i tego, który krótko przed przystąpieniem do jego wykorzystywania został powiadomiony przez zatrudniającego o koniecznej zmianie terminu tego urlop. Zarówno jeden, jak i drugi pracownik, jeśli ponieśli koszty bezpośrednio związane $\mathrm{z}$ takim odwołaniem czy przesunięciem, mają prawo domagać się od pracodawcy stosownej rekompensaty.

Powstaje też pytanie o sposób wyznaczenia innego terminu urlopu wypoczynkowego w związku ze zmianą daty pierwotnie przyjętej, szczególnie, jeśli następuje to $z$ przyczyn leżących po stronie pracodawcy.

Zgodnie z $\$ 5$ rozporządzenia Ministra Pracy i Polityki Socjalnej z 8 stycznia 1997 r. w sprawie szczegółowych zasad udzielania urlopu wypoczynkowego, ustalania i wypłacania wynagrodzenia za czas urlopu oraz ekwiwalentu pieniężnego za urlop - w okolicznościach uzasadniających przesunięcie urlopu na inny termin niż określony w planie urlopów (lub ustalony indywidualnie z pracownikiem) pracodawca udziela pracownikowi niewykorzystanego urlopu w terminie $\mathrm{z}$ nim uzgodnionym.

38 We Francji, na przykład, zmiana terminu urlopu, poza sytuacjami nadzwyczajnymi, nie może być dokonana w okresie miesiąca przed przewidywaną datą rozpoczęcia urlopu; por. G. Auzero, E. Dockès, Droit..., s. 872.

39 Tak m.in. K. Rączka, [w:] Kodeks pracy. Komentarz, red. Z. Salwa, Warszawa 2003, s. 533; K. Jaśkowski, E. Maniewska, Komentarz aktualizowany do Kodeksu pracy, LEX/el. 2017; F. Małysz, Pracownicze urlopy wypoczynkowe, s. 74. W przeszłości odmienny pogląd w tej kwestii wyraził I. Wolberg, który uznał, że w tej sytuacji zastosowanie powinny znaleźć przepisy prawa cywilnego; por. tenże, Planowanie i przesuwanie urlopów wypoczynkowych, PizS 1969, nr 12, s. 44. 
Zwraca uwagę, że przepis ten wskazuje na obowiązek „uzgodnienia” z pracownikiem nowego terminu urlopu, co wyraźnie sugeruje, że pracownik i pracodawca muszą w tej kwestii osiągnąć porozumienie. Wydaje się jednak, że w praktyce zwrotowi temu nie przypisuje się tak daleko idącego znaczenia i ustalenie nowego terminu urlopu poddaje się ogólnej, kodeksowej procedurze jego wyznaczania, tj. po zasięgnięciu „opinii” pracownika.

Również w doktrynie prawa pracy norma ta bywa różnie interpretowana, chociaż poszczególni autorzy są raczej zgodni co do tego, że z powołanego paragrafu nie wynika, by pracodawca był związany wnioskiem pracownika $\mathrm{w}$ tej sprawie ${ }^{40}$.

Niemniej dość często podkreśla się w komentarzach do analizowanego przepisu, że uzgodnienie, o którym mowa w rozporządzeniu, ma w założeniu gwarantować pracownikowi większy wpływ na podejmowanie decyzji przez pracodawcę w przedmiocie terminu udzielenia urlopu niż „zwykły” wniosek urlopowy. Pracodawca powinien bowiem udzielić przesuniętego urlopu w terminie dogodnym i akceptowalnym przez obie strony ${ }^{41}$, co jest $\mathrm{w}$ pełni usprawiedliwione okolicznościami powodującymi takie przesunięcie i wypoczynkową funkcją omawianego świadczenia.

Powyższe zapatrywanie znalazło także swój wyraz w uzasadnieniu jednego z orzeczeń SN, w którym sąd wypowiadając się zasadniczo w innej sprawie, zwrócił przy tej okazji uwagę, że wynikające z $\$ 5$ omawianego rozporządzenia „uzgodnienie terminu" jest równoznaczne $\mathrm{z}$ obowiązkiem wspólnego jego określenia. Oznacza to, że nie może go ani jednostronnie wyznaczyć pracodawca, wbrew woli pracownika, ani też pracownik bez akceptacji pracodawcy ${ }^{42}$. Dla nadania tej regule większego znaczenia w praktyce powinna być ona jednak wyraźnie sformułowana w ustawie.

Maksymalny termin, w jakim należy udzielić pracownikowi urlopu niewykorzystanego wcześniej z powodu jego przesunięcia, wynika z art. 168 k.p. Wyjątkowo zatem urlop ten może być udzielony dopiero w kolejnym roku kalendarzowym. Warto przy tym wyraźnie zauważyć, że w przeszłości owo przesunięcie urlopu mogło mieć miejsce, ale w stosunkowo nieznacznym zakresie, trzeba było urlopu udzielić pracownikowi najpóźniej do końca pierwszego kwartału roku następnego. Obecnie ustawodawca znacznie wydłużył ten okres, zgodnie z art. 168 k.p. urlopu niewykorzystanego w roku jego nabycia należy pracownikowi udzielić bowiem najpóźniej do 30 września następnego roku kalendarzowego. Biorąc pod uwagę uprawnioną, moim zdaniem, wykładnię, zgodnie z którą przepis nie obliguje do wykorzystania urlopu w tym terminie, ale do udzielenia go do tej daty przez pracodawcę (pracownik może więc rozpocząć urlop 30 września) ${ }^{43}$, pracow-

40 W ocenie A. Kosut, owo „uzgodnienie” oznacza konieczność zaakceptowania przez obie strony nowego terminu urlopu, a nie zobowiązanie pracodawcy do udzielenia urlopu zgodnie z wnioskiem pracownika; por. taż, [w:] Kodeks pracy. Komentarz, s. 909 i n.

41 Por. m.in. tamże. Podobnie A. Świątkowski, Kodeks pracy. Komentarz, s. 681.

42 Por. uzasadnienie do wyroku SN z 28 października 2009 r., II PK 123/09.

43 Por. m.in. K. Rączka, [w:] Kodeks pracy..., 2003, s. 539. Por. też M. Kuba, M. Nowak, E. Staszewska, Urlopy pracownicze, red. Z. Góral, Warszawa 2016, s. 90 i n. 
nik będzie w niektórych przypadkach świadczyć pracę nieprzerwanie przez okres niemal dwóch lat (bez trzech miesięcy). Mając świadomość przyczyn, które legły u podstaw modyfikacji przepisu, i często zadowolenia samych zatrudnionych z takiej regulacji, trzeba jednoznacznie podkreślić, że zmiana ta jest w istocie sprzeczna $\mathrm{z}$ podstawowym celem omawianego świadczenia, które dla swej optymalnej realizacji powinno być wykorzystane w roku nabycia do niego prawa.

Problem ten potęguje jeszcze ostatnia część art. 168 k.p., w której ustawodawca wskazał, że przepis ten nie dotyczy urlopu na żądanie, co część przedstawicieli doktryny prawa pracy ${ }^{44}$ oraz inspekcji pracy ${ }^{45}$ interpretują jako regulację wyłączającą w ogóle urlop na żądanie spod zakresu działania tego przepisu ${ }^{46}$. W konsekwencji prowadzi to do konstatacji, że termin wykorzystania tych dni urlopowych, które w kolejnym roku stają się „zwykłym urlopem wypoczynkowym”, może przypadać także po dacie określonej w art. 168 k.p., tj. po 30 września następnego roku kalendarzowego.

Z perspektywy prawa pracownika do odpoczynku inaczej należy ocenić dopuszczalność przesunięcia urlopu wypoczynkowego z inicjatywy pracownika, o której stanowi również powoływany wcześniej art. 164 k.p. w $\$ 1$. W tym przypadku konieczność przesunięcia urlopu może być bowiem właśnie (i zasadniczo powinna) wywołana brakiem możliwości wykorzystania tego zwolnienia od pracy w sposób w pełni zgodny z jego przeznaczeniem, a zatem niekolidujący z jego podstawową funkcją.

Zmiana terminu urlopu, jak wynika wprost z przepisów Kodeksu pracy, może nastąpić na wniosek pracownika umotywowany „ważnymi przyczynami”. Ustawodawca tu również zastosował klauzulą generalną, która służy możliwości zindywidualizowania oceny dokonywanej przez pracodawcę ${ }^{47}$, niemniej ocena ta powinna być przeprowadzana przede wszystkim z uwzględnieniem głównego celu urlopu.

Podzielam w związku z tym pogląd A. Kosut, że za ważne przyczyny, obiektywnie uzasadniające udzielenie urlopu w innym terminie, należy uznać takie zdarzenia w życiu pracownika, których wystąpienie pociąga za sobą niemożność osiągnięcia tego celu ${ }^{48}$. Wówczas dochodzi bowiem do wystąpienia „szczególnych”,

44 A. Marek, Urlop na żądanie, „Służba Pracownicza” 2003, nr 8, s. 8. Zdaniem przywołanego autora, urlop może być udzielony wówczas do końca następnego roku kalendarzowego. Bywają jednak formułowane również opinie, że skoro według przyjętej interpretacji przepisy prawa pracy nie obligują do udzielenia tego urlopu w terminie określonym $w$ komentowanym art. 168 k.p., to pracownik może z niego skorzystać w ciągu kolejnych trzech lat, tj. do upływu okresu przedawnienia; tak por. A. Podgórska, Urlop na żądanie, „Służba Pracownicza" 2010, nr 11, s. 20.

45 Por. pismo Departamentu Prawnego Głównego Inspektoratu Pracy z 7 kwietnia 2008 r., GIP GPP-110-4560-170/08/PE, „Rzeczpospolita”, 9.04.2008.

46 Odmienny pogląd zob. szerzej M. Nowak, [w:] M. Kuba, M. Nowak, E. Staszewska, Urlopy pracownicze, s. 93 i n. oraz podana tam literatura.

47 Por. E. Chmielek-Łubińska, [w:] Kodeks pracy. Komentarz, red. L. Florek, Warszawa 2009, S. 908.

48 Por. A. Kosut, [w:] Kodeks pracy. Komentarz, s. 908. 
z punktu widzenia prawa urlopowego, okoliczności. Wymienić tu można np. chorobę najbliższych członków rodziny pracownika, podyktowaną różnymi względami konieczność sprawowania nad nimi opieki, brak możliwości uzyskania urlopu przez współmałżonka w tym samym czasie, katastrofy (powódź, pożar), ale też wszelkie inne tego rodzaju zdarzenia.

Teza ta znalazła swój wyraz także w orzecznictwie SN, który w wyroku z 27 listopada 1997 r. uznał, że chęć uczestniczenia pracownika w strajku (proteście) głodowym nie obliguje pracodawcy do przesunięcia zaplanowanego terminu urlopu wypoczynkowego ${ }^{49}$. Sąd ocenił więc przesłanki będące podstawą odmownej decyzji pracodawcy i uznał, iż chęć wzięcia udziału w takim proteście nie stanowi na tyle szczególnej przyczyny na gruncie przepisów o urlopach wypoczynkowych, aby uzasadniała ona przesunięcie terminu tego urlopu. W uzasadnieniu do przytoczonego wyroku wyraźnie przy tym wskazano, że „pracodawca nie jest obowiązany do udzielenia urlopu poza terminem wynikającym z planu urlopów, a jedynie może to uczynić na wniosek pracownika umotywowany ważnymi przyczynami, podlegającymi ocenie m.in. z punktu widzenia funkcji urlopu”. „Zarzutu nadużycia prawa”, zdaniem sądu, „nie można więc stawiać pracodawcy odmawiającemu przesunięcia terminu urlopu ze względu na cele sprzeczne z jego wypoczynkową funkcją, chyba że przemawiałby za tym szczególny interes osobisty lub rodzinny pracownika”.

Dążenie do optymalizacji wypoczynkowej funkcji urlopu, której pracownik $\mathrm{w}$ danym terminie, wbrew wcześniejszym przewidywaniom, nie może zrealizować z określonych, obiektywnych przyczyn, o których była mowa wyżej, nakazywałoby wprowadzić w przepisach prawa wyraźne zobowiązanie pracodawcy do przesunięcia na wniosek pracownika urlopu wypoczynkowego na inny okres. Wskazane wcześniej wątpliwości dotyczące charakteru analizowanego art. 164 k.p. powodują, że trudno jednoznacznie ocenić, czy teza taka jest realizowana na gruncie obecnego stanu prawnego. Literalne jego brzmienie sugeruje raczej, że pracodawca może urlop przesunąć lub nie, dysponując swobodą w zakresie oceny przesłanek wskazanych przez pracownika. Niemniej bardziej przekonująca, moim zdaniem, jest koncepcja, według której pracownik po spełnieniu warunków określonych w tym przepisie może domagać się przesunięcia terminu urlopu przez pracodawcę, również na drodze sądowej (por. wcześniejsze rozważania). W rezultacie pracownik, którego wniosek o przesunięcie urlopu, mimo podania, w jego odczuciu, ważnych przyczyn, został przez pracodawcę odrzucony, mógłby wystąpić do sądu pracy i dochodzić udzielenia urlopu w terminie wnioskowanym.

W orzecznictwie SN brak jednak w tym zakresie konkretnego stanowiska. Między innymi z przywoływanej wcześniej treści uzasadnienia wyroku SN z 27 listopada 1997 r. zdaje się wynikać, że sąd uznaje możliwość dochodzenia swych roszczeń przez pracownika w opisanych okolicznościach, ale przede wszystkim w oparciu o konstrukcję nadużycia prawa (art. 8 k.p.), a nie bezpośrednio art. 164 k.p.

49 Wyrok SN z 27 listopada 1997 r., I PKN 393/97, OSNP 1998, nr 17, poz. 511. 
Z powyższych względów, jeśli okazuje się, że powstały obiektywne przeszkody w wykorzystaniu urlopu zgodnie z jego przeznaczeniem, dopuszczalna powinna być także możliwość przerwania urlopu przez zatrudnionego. De lege lata kwestia ta budzi wątpliwości, bowiem ustawodawca w przeciwieństwie do odpowiedniego uprawnienia pracodawcy w tym zakresie (odwołanie $\mathrm{z}$ urlopu) takiego prawa po stronie pracownika wprost w przepisach nie wprowadził. W literaturze wyrażono zapatrywanie, że taka możliwość istnieje, pod warunkiem uzyskania zgody pracodawcy oraz przy zachowaniu przesłanek wynikających z art. 164 k.p., a także z poszanowaniem zasady, że jedna część wypoczynku pracownika nie powinna być krótsza niż 14 kolejnych dni kalendarzowych ${ }^{50}$. Wniosek pracownika o przerwanie urlopu może być bowiem w świetle obowiązującego prawa potraktowany jako wystąpienie o jego przesunięcie, do którego w istocie, jak wcześniej wskazywano, wówczas dochodzi (podobnie jak do jego podziału na części z inicjatywy pracownika). Objęcie zaś odrębnym przepisem instytucji odwołania z urlopu, jako swego rodzaju odpowiednika omawianego uprawnienia pracownika, można tłumaczyć ewentualnie jego inaczej ukształtowanym zakresem przedmiotowym w stosunku do warunków uzasadniających przesunięcie urlopu przez pracodawcę ze względu na ochronę jego interesów ${ }^{51}$, co będzie dalej szerzej analizowane.

Wydaje się, że wobec tak wielu niejasności oraz licznie podejmowanych prób ustalenia charakteru omawianego unormowania, które jednak nie dają jednoznacznych odpowiedzi, przepis ten powinien zostać doprecyzowany przez ustawodawcę, jako że ma istotne znaczenie dla zabezpieczenia podstawowej funkcji tytułowego urlopu, choćby w sensie wyznaczenia granic ochrony interesów pracodawcy.

\section{Skierowanie pracownika na urlop wypoczynkowy w okresie wypowiedzenia}

O dopuszczalności szczególnego rodzaju przesunięciu terminu urlopu pracownika w wyniku jednostronnej decyzji pracodawcy można też mówić w kontekście przepisu dotyczącego udzielania urlopu wypoczynkowego w okresie wypowiedzenia.

Zgodnie $\mathrm{z}$ art. $167^{1}$ k.p., w okresie wypowiedzenia umowy o pracę pracownik jest obowiązany wykorzystać bowiem przysługujący mu urlop, jeżeli w tym okresie pracodawca mu go udzieli.

50 Por. E. Chmielek-Łubińska, Urlopy wypoczynkowe..., s. 70.

51 W przypadku odwołania musi chodzić o przyczyny nieznane pracodawcy w chwili kierowania pracownika na urlop, a ponadto w przepisie tym nie wspomina się o okolicznościach wpływających na konieczność zachowania normalnego toku pracy, jak w regulacji o przesunięciu urlopu z inicjatywy pracodawcy, co wskazuje, że mogą tu decydować również inne względy, np. konieczność reprezentowania pracodawcy na rozprawie sądowej. 
Z powyższego wynika, że pracodawca ma prawo skierować pracownika na urlop wypoczynkowy w okresie wypowiedzenia zarówno wówczas, gdy pracownik miał akurat zaplanowany w tym czasie urlop, jak i wówczas, gdy tego urlopu z jakichś przyczyn w ogóle nie zaplanowano lub jego planowany termin nie pokrywa się $\mathrm{z}$ okresem wypowiedzenia.

Brak możliwości sprzeciwienia się przez pracownika woli pracodawcy potwierdza też jednoznacznie $\mathrm{SN}^{52}$, który dodatkowo wyraźnie podkreślił, że na zasadach określonych $\mathrm{w}$ art. $167^{1} \mathrm{k}$.p. w okresie wypowiedzenia pracownik jest obowiązany wykorzystać zarówno bieżący, jak i zaległy urlop wypoczynkowy ${ }^{53}$.

Przyjęcie tego rodzaju konstrukcji w prawie urlopowym niewątpliwie budzi pewne kontrowersje, o czym świadczą m.in. wielokrotne zmiany przepisów dokonywane w tym zakresie ${ }^{54}$. Na jej tle ścierają się bowiem ze sobą dwie wartości, niezwykle ważne dla prawidłowej realizacji podstawowej funkcji urlopu wypoczynkowego.

Z jednej strony wskazuje się omawiany przepis jako gwarancję realizacji urlopu w naturze, a więc w postaci, która jako jedyna umożliwia wykorzystanie tego uprawnienia w sposób w pełni zgodny z jego przeznaczeniem. Alternatywą dla sytuacji nieudzielenia urlopu w okresie wypowiedzenia będzie bardzo często wypłata ekwiwalentu za urlop, która sama w sobie celu, dla którego urlop został ustanowiony nie urzeczywistnia (o czym będzie jeszcze mowa w kolejnych punktach pracy) i tym samym powinna znaleźć zastosowanie w sytuacjach absolutnie wyjątkowych, gdy w związku z ustaniem zatrudnienia nie było z przyczyn obiektywnych szans na udzielenie tego urlopu we właściwej mu formie, tj. dni wolnych od pracy. Wprowadzając omawiany przepis pozwalający pracodawcy na odstąpienie od planu urlopowego czy indywidualnie z pracownikiem ustalonego terminu, ustawodawca, jak może się wydawać, rozszerza w rezultacie zakres zastosowania zasady urlopu w naturze. Jeśli jednak to stanowiło podstawowy motyw przyjęcia omawianego rozwiązania, co wydaje się mocno wątpliwe $e^{55}$, to dziwić może brak analogicznego uprawnienia po stronie pracownika, a więc możliwości wystąpienia do pra-

52 Por. wyrok SN z 26 kwietnia 2011 r., II PK 302/10, www.sn.pl. W punkcie pierwszym tego orzeczenia SN jednoznacznie stwierdza - udzielenie pracownikowi urlopu wypoczynkowego w okresie wypowiedzenia zależne jest jedynie od woli pracodawcy, której pracownik nie może się sprzeciwić. Kwestia ta nie budzi też wątpliwości w doktrynie prawa pracy - por. m.in.: L. Mitrus, Sytuacja pracownika w okresie wypowiedzenia umowy o pracę, cz. II, PizS 2010, $\mathrm{nr} 8$, s. 4.

53 Wyrok SN z 2 września 2003 r., I PK 403/02, tamże.

54 Tego rodzaju regulacja została wprowadzona po raz pierwszy w ustawie urlopowej z 1969 r., ale była ona ograniczona do wypowiedzenia dokonywanego przez pracodawcę. Wcześniej w orzecznictwie SN konsekwentnie przyjmowano, że urlopu wypoczynkowego nie należy udzielać w okresie wypowiedzenia. Obowiązek (a nie prawo) pracodawcy dotyczący omawianej kwestii rozszerzono w uchwalonym Kodeksie pracy - w art. 170 tego aktu. Przepis ten uchylono w latach 90., a następnie w nieco zmienionej formie wprowadzono go w wyniku nowelizacji Kodeksu pracy z 2002 r. (por. rozważania zawarte w części I opracowania).

55 Raczej głównym celem było tu ograniczenie kosztów związanych z obowiązkiem wypłaty ekwiwalentu za niewykorzystany urlop wypoczynkowy. 
codawcy z żądaniem udzielenia urlopu w tym okresie, które pracodawca musiałby zasadniczo zrealizować, chyba że istotnie zagrażałoby to normalnemu funkcjonowaniu zakładu ${ }^{56}$. Zasada urlopu w naturze leży wszak w interesie pracownika, zatem to on powinien mieć w pierwszej kolejności sposobność do skutecznego jej wyegzekwowania. Decydując więc o utrzymaniu analizowanego przepisu, jako faktycznej gwarancji udzielania urlopu wypoczynkowego w naturze, należałoby przynajmniej zmodyfikować jego treść.

Z drugiej jednak strony cel urlopu wypoczynkowego oraz okresu wypowiedzenia jest zgoła odmienny. Ten pierwszy powinien być przeznaczony na odpoczynek, zarówno fizyczny, jak i psychiczny, regenerację organizmu. Istotą zaś okresu wypowiedzenia jest umożliwienie stronom stosunku pracy przystosowania się do nowej sytuacji, w tym, w razie gdy wypowiedzenia dokonuje pracodawca, pozostawienie pracownikowi czasu na znalezienie nowego zatrudnienia przy zachowaniu gwarancji wynagrodzenia. Stąd powstaje uzasadniona obawa, czy w okresie wypowiedzenia, szczególnie, jeśli termin urlopu jest jednostronnie wskazywany przez pracodawcę, główna funkcja urlopu może być faktycznie prawidłowo zrealizowana. Jak podkreślał bowiem w przeszłości J. Loga, okres wypowiedzenia i prawo do urlopu stanowią dwie odrębne instytucje prawne. Celem okresu wypowiedzenia jest umożliwienie pracownikowi znalezienia nowego zatrudnienia, urlop nie powinien więc tego okresu skracać ${ }^{57}$. Celem urlopu jest wypoczynek, trudno zaś, by pracownik, który ma w perspektywie rychłą utratę pracy, przeznaczył udzielony mu w okresie wypowiedzenia urlop w pełni na wypoczynek czy też miał zagwarantowany tzw. spokój urlopowy. Należy przyjąć, zdaniem Logi, zasadę, że tak jak wypowiedzenie umowy o pracę nie jest możliwe w okresie urlopu, tak też należny urlop nie powinien przypadać w okresie wypowiedzenia ${ }^{58}$.

Podzielając zasadniczo powyższe przekonanie, należałoby jednak poczynić pewne zastrzeżenia w zakresie strony dokonującej wypowiedzenia. Poważne zagrożenie wypoczynkowej funkcji urlopu powstaje bowiem, moim zdaniem, przede wszystkim wtedy, gdy wypowiedzenie zostaje złożone przez pracodawcę. Wówczas pracownik poszukujący nowego miejsca pracy, obciążony świadomością utraty zatrudnienia, nie jest w stanie najczęściej przeznaczyć udzielonego mu przez pracodawcę, bez jego zgody, urlopu na wypoczynek, zgodnie z istotą tej instytucji. Tym samym wydaje się, że w takim przypadku realizuje się co prawda ideę urlopu w naturze, ale wyłącznie w ujęciu formalnym, a nie faktycznym, co w gruncie rzeczy nie stanowi istotnej wartości, nie urzeczywistnia ostatecznie celu, który jest tej zasadzie przypisywany. Urlop udzielany w czasie, w którym nie może być on przeznaczony na wypoczynek zatraca swój charakter i de facto urlopem wypoczynkowym i tak w istocie nie jest.

56 Obecnie pracownik w okresie wypowiedzenia może wnioskować jedynie o przesunięcie urlopu wypoczynkowego na ogólnych zasadach opisanych we wcześniejszym punkcie, ewentualnie zrealizować swe uprawnienia do czterech dni urlopu na żądanie.

57 Por. J. Loga, Urlopy wypoczynkowe, Łódź 1963, s. 147 i n.

58 Tamże, s. 147. 
Nieco inaczej natomiast w tym kontekście należy ocenić sytuację, gdy umowę o pracę rozwiązuje $\mathrm{w}$ omawianym trybie pracownik. Wówczas nadanie zasadzie urlopu w naturze charakteru priorytetowego ma swoje uzasadnienie również $\mathrm{w}$ wypoczynkowej funkcji tytułowej instytucji. Można $\mathrm{z}$ wysokim prawdopodobieństwem założyć bowiem, że osoba, która sama dokonuje wypowiedzenia umowy o pracę ma już zapewnione inne zatrudnienie i może wykorzystać urlop wypoczynkowy zgodnie z jego celem.

Wniosek powyższy nie znalazł jednak odzwierciedlenia w obowiązującym prawie, jako że, zgodnie z treścią art. $167^{1}$ k.p., pracodawca może odstąpić od planu urlopów lub wcześniejszych indywidualnych uzgodnień jego terminu w stosunku do pracownika znajdującego się w okresie wypowiedzenia, niezależnie od tego, kto tego wypowiedzenia dokonał (pracownik czy pracodawca) i jak długi jest to okres.

Ostatni element dla ogólnej oceny wpływu omawianej regulacji na prawidłowość przebiegu funkcji urlopowej też może mieć pewne znaczenie. Wydaje się bowiem, że szanse na realizację celu urlopu wypoczynkowego, przy założeniu że wypowiedzenia dokonuje pracodawca, potencjalnie rosną wraz z długością okresu wypowiedzenia. Szczególnie przy trzymiesięcznym okresie wypowiedzenia (tak jak przyjęto w ustawie urlopowej z 1969 r.) można ewentualnie założyć, że jakaś część tego czasu może być teoretycznie przeznaczona na wypoczynek, co jednak również w gruncie rzeczy jest bardzo wątpliwe.

Aspekt ten, jak wyżej sygnalizowano, nie został przez ustawodawcę dostrzeżony. W świetle powołanego art. $167^{1}$ k.p. pracodawca może zobowiązać pracownika do wykorzystania bieżącego i zaległego urlopu wypoczynkowego w okresie wypowiedzenia, niezależnie od długości tego ostatniego, choć urlopu można udzielić jedynie w wymiarze nie wyższym od przysługującego pracownikowi u danego pracodawcy. Tym samym urlop w niektórych przypadkach będzie mógł objąć cały okres wypowiedzenia, nawet jeśli ten jest stosunkowo krótki i wynosi np. dwa tygodnie. Tego rodzaju rozwiązania, w moim odczuciu, nie sposób pogodzić z koniecznością odpowiedniego zabezpieczenia funkcji wypoczynkowej analizowanego urlopu, mając na względzie odmienność celów obu tych instytucji.

Powyższa kwestia wiąże się też bezpośrednio z prawem pracownika do określonych zwolnień od pracy, innych niż urlop wypoczynkowy, o które może on, po spełnieniu odpowiednich przesłanek dotyczących danego zwolnienia, wnioskować w okresie wypowiedzenia. Należy przyjąć, że będą one ograniczać swobodę pracodawcy w zakresie długości urlopu, jakiego ostatecznie może on pracownikowi udzielić w rozważanym okresie. Chodzi przede wszystkim o dni wolne na poszukiwanie pracy (art. 37 k.p.), ale można również wymienić tu choćby dni wolne przeznaczone na opiekę nad dzieckiem w wieku do 14 lat (art. 188 k.p. $)^{59}$.

Nie ulega wątpliwości, że zwolnienia te pełnią odmienne od urlopu wypoczynkowego funkcje, stąd nie mogą być z nim łączone. Celem omawianego urlopu jest

59 Por. m.in. A. Martuszewicz, K. Piecyk, Urlopy pracownicze i inne zwolnienia od pracy, Warszawa 2007, s. 105. 
odpoczynek, tymczasem przeznaczeniem np. zwolnienia na poszukiwanie pracy jest, jak sama nazwa wskazuje, umożliwienie poszukiwania nowego zatrudnienia. Dlatego też nie można uznać, że udzielenie urlopu wypoczynkowego w okresie wypowiedzenia zwalnia pracodawcę z obowiązku zagwarantowania pracownikowi dni wolnych na poszukiwanie pracy, do których nabył on prawo ${ }^{60}$. Jak trafnie zwrócono uwagę $\mathrm{w}$ doktrynie prawa pracy, udzielenie dni wolnych na poszukiwanie pracy w okresie trwającego urlopu wypoczynkowego stanowiłoby zwolnienie „od wypoczynku”, a nie zwolnienie „od pracy”"61, naruszałoby zatem podstawową funkcję omawianego urlopu i było sprzeczne $\mathrm{z}$ istotą zarówno jednego, jak i drugiego zwolnienia. W związku z tym urlop pracownika uprawnionego jednocześnie do innych zwolnień od pracy, szczególnie tych, które mogą być realizowane tylko w okresie wypowiedzenia (jak wskazane wyżej dni na poszukiwanie pracy), musi być odpowiednio skorygowany, jeśli pracownik wystapi ze stosownym wnioskiem, o wymiar takiego zwolnienia, a zatem nie może on wówczas objąć całego okresu wypowiedzenia danego pracownika. Pracodawca nie może bowiem wykonywać swych uprawnień (np. do skierowania pracownika na urlop w okresie wypowiedzenia) kosztem praw pracowniczych.

Zakres dopuszczalnej ingerencji pracodawcy w zmianę terminu urlopu pracownika na podstawie omawianego przepisu zależy też w dużym stopniu od przyjęcia określonej wykładni dotyczącej rozpoczęcia biegu okresu wypowiedzenia.

Zdaniem części autorów, okres wypowiedzenia musi być liczony tak, aby jego zakończenie nastąpiło zgodnie z przepisami o terminach, które determinują też, według tego ujęcia, samo rozpoczęcie biegu okresu wypowiedzenia.

Z przepisów tych wynika, że okres wypowiedzenia, obejmujący tydzień lub miesiąc albo ich wielokrotność, kończy się odpowiednio w sobotę albo w ostatnim dniu miesiąca (art. 30 k.p.). Upływ zaś 3-dniowego okresu wypowiedzenia ustala się zgodnie z przepisami Kodeksu cywilnego ${ }^{62}$ o terminach; okres ten kończy się ostatniego dnia, ale określając ten termin nie uwzględnia się dnia, w którym wypowiedzenie zostało złożone.

Zwolennicy tego stanowiska uznają więc, że wypowiedzenie rozpoczyna swój bieg albo pierwszego dnia tygodnia przypadającego po tygodniu, w którym wypowiedzenie zostało złożone (przy okresach liczonych w tygodniach), albo pierwszego dnia miesiąca (przy okresach liczonych w miesiącach) przypadającego po miesiącu złożenia wypowiedzenia. Tym samym jeśli w przypadku miesięcznego okresu wypowiedzenia pracodawca złoży oświadczenie o wypowiedzeniu umowy o pracę pracownikowi np. 15 czerwca, wówczas ów miesięczny okres wypowiedzenia, zgodnie $z$ art. $30 \$ 2^{1}$ k.p., zakończy swój bieg ostatniego dnia lipca; w związku

60 Por. też A. Piszczek, K. Stefański, Dni wolne na poszukiwanie pracy - wybrane problemy, „Gdańsko-Łódzkie Roczniki Prawa Pracy i Prawa Socjalnego" 2012, nr 2, s. 39.

61 Por. I. Więckiewicz-Szabłowska, Konkurencja uprawnień pracodawcy i pracownika w okresie wypowiedzenia w świetle przepisów art. 37 oraz art. $167^{1}$ KP, M.P.P. 2010, nr 1, s. 18.

62 Ustawa z 23 kwietnia 1964 r. - Kodeks cywilny, Dz. U. 1964, Nr 16, poz. 93. 
z tym wypowiedzenie musi rozpocząć swój bieg pierwszego lipca, w przeciwnym razie doszłoby do przekroczenia miesięcznego okresu wypowiedzenia ${ }^{63}$.

W konsekwencji, odnosząc powyższe stanowisko do art. $167^{1}$ k.p., pracodawca będzie mógł skierować pracownika na urlop wypoczynkowy dopiero w momencie rozpoczęcia biegu okresu wypowiedzenia, a nie z datą złożenia tego oświadczenia.

Moim zdaniem należy, mimo wszystko, przyjąć odmienny pogląd i uznać, tak jak czyni to duża część przedstawicieli doktryny prawa pracy, że okres wypowiedzenia rozpoczyna swój bieg z chwilą złożenia oświadczenia woli o wypowiedzeniu przez jedną ze stron stosunku pracy. Z braku odpowiedniej regulacji w Kodeksie pracy znajdują tu zastosowanie przepisy Kodeksu cywilnego, z których wynika, że oświadczenie woli ( $w$ tym przypadku o wypowiedzeniu umowy o pracę) uznaje się za złożone z chwilą, gdy dotarło do drugiej strony w taki sposób, że mogła ona zapoznać się z jego treścią. Koniec zaś owego okresu wypowiedzenia będą wyznaczać powoływane wcześniej przepisy Kodeksu pracy dotyczące terminów (art. $30 \$ 2^{1}$ k.p.). Ich zastosowanie może spowodować w określonych przypadkach faktyczne wydłużenie okresu wypowiedzenia danego pracownika, np. wypowiedzenie złożone 15 lipca (przy obowiązującym pracownika miesięcznym okresie wypowiedzenia) rozpocznie bieg okresu wypowiedzenia, który zakończy się, zgodnie $\mathrm{z}$ art. $30 \$ 2^{1}$ k.p., 31 sierpnia. Przechodząc na grunt rozważań poświęconych art. $167^{1}$ k.p., musi to oznaczać, że pracodawca w całym tym czasie (od złożenia wypowiedzenia przez jedną ze stron do dnia ustania stosunku pracy) będzie mógł skierować pracownika na bieżący i zaległy urlop wypoczynkowy.

Za taką koncepcją stanowczo opowiedział się również SN w wyroku z 26 kwietnia 2011 r., formułując w punkcie trzecim tezę, zgodnie $\mathrm{z}$ którą „okres wypowiedzenia, o którym mowa $\mathrm{w}$ art. $167^{1}$ k.p., należy liczyć od złożenia oświadczenia woli o wypowiedzeniu do rozwiązania umowy o pracę, choćby faktycznie był on dłuższy niż okres wypowiedzenia określony w art. $36 \$ 1$ k.p."64.

Taka wykładnia może mieć swoje negatywne konsekwencje w obszarze prawa urlopowego, w zależności od ogólnej oceny dopuszczalności skierowania pracownika na urlop w okresie wypowiedzenia, gdyż pozwala w gruncie rzeczy na czasowe rozszerzenie zakresu działania omawianego, kontrowersyjnego unormowania. W związku z przepisami o terminach, wyżej przywoływanymi, i faktycznym wydłużeniem okresu wypowiedzenia, pracodawca będzie w stanie w tych przypadkach udzielić całego urlopu wypoczynkowego należnego danemu pracownikowi $\mathrm{z}$ tytułu trwającego jeszcze zatrudnienia we wskazanym, szczególnym okresie, z zachowaniem jednocześnie ewentualnej możliwości wykorzystania przez pracownika dni wolnych na poszukiwanie pracy, jeśli takie mu przysługują.

W okresie wypowiedzenia umowy o pracę pracodawcy niekiedy zależy na tym, aby pracownik nie świadczył pracy lub wykonywał ją możliwie krótko. Decydują

63 Por. w ostatnim czasie M. Rylski, o powszechnym rozumieniu okresów wypowiedzenia i sposobach ich obliczania - krytycznie, cz. I, M.P.P. 2015, nr 6, s. 297 i n.

64 Wyrok SN z 26 kwietnia 2011 r., II PK 302/10. 
o tym różne względy, np. likwidacja jego stanowiska pracy, niecelowość dalszego wykonywania określonych zadań przez zatrudnionego, obawy związane z ogólnie rzecz ujmując brakiem lojalności osoby zwalnianej wobec pracodawcy, w tym m.in. ograniczenie dostępu do określonych informacji ${ }^{65}$.

W tym celu, a więc w zasadzie w sposób sprzeczny z przyjętymi założeniami i jego przeznaczeniem, był wykorzystywany właśnie m.in. analizowany art. 167 k.p. ${ }^{66}$ Niekiedy dodatkowo jednak pracodawca zwalniał pracownika z obowiązku świadczenia pracy w okresie wypowiedzenia, z zachowaniem prawa do wynagrodzenia, za jego zgodą, tj. na podstawie zawartego między stronami porozumienia lub nawet bez takiej zgody, jeśli przepis zawarty w określonej pragmatyce pracowniczej taką możliwość przewidywał" ${ }^{67}$.

Oczekiwaniom pracodawców w tym zakresie wyszedł ostatecznie naprzeciw sam ustawodawca, który w wyniku nowelizacji Kodeksu pracy z 2015 r. wprowadził art. $36^{2}$ k.p. pozwalający zwolnić pracownika z obowiązku świadczenia pracy do upływu okresu wypowiedzenia, $\mathrm{z}$ gwarancją wypłaty wynagrodzenia za ten czas.

$\mathrm{W}$ związku z regulacją zawartą $\mathrm{w}$ art. $167^{1} \mathrm{k}$.p., ale też innymi podstawami zwolnienia pracownika $\mathrm{z}$ obowiązku wykonywania pracy w okresie wypowiedzenia, w tym art. $36^{2}$ k.p., należy z pewnością ustalić relację między wymienionymi przepisami, a w szczególności, czy z obu uprawnień pracodawca może skorzystać w jednym czasie, jako że kwestia ta nie została bezpośrednio rozstrzygnięta przez ustawodawcę.

Wydaje się, że w okresie wypowiedzenia generalnie możliwe jest zastosowanie przez pracodawcę obydwu instytucji (np. pracodawca kieruje pracownika na urlop, a po urlopie zwalnia go z obowiązku wykonywania pracy). Wynikają one bowiem $\mathrm{z}$ różnych podstaw, mają odmienne cele (w przypadku urlopu wypoczynkowego chodzi w założeniu o wykorzystanie go przez pracownika w naturze i uniknięcie wypłaty ekwiwalentu przez pracodawcę), choć niekiedy prowadzą do osiągnięcia tych samych rezultatów, tj. nieświadczenia przez pracownika pracy w danym okresie. Również w normach statuujących uprawnienia pracodawcy w tym zakresie brak jest wyłączenia możliwości skorzystania z nich w ramach tego samego okresu wypowiedzenia.

Ponadto w literaturze wyrażono też przekonanie, że zarówno jeden, jak i drugi przepis stanowią przejaw organizatorskiej funkcji prawa pracy, a zatem na gruncie „ogólnoteoretycznym” nie ma przeszkód do ich łączenia w okresie wypowiedzenia ${ }^{68}$.

65 W literaturze zaproponowano podział tych przyczyn na takie, które powodują, że dany pracownik staje się dla pracodawcy nieprzydatny, i takie, w wyniku których pracownik staje się niechciany; por. M. Gersdorf, Zwolnienie pracownika z obowiq̨zku świadczenia pracy, PiZS 2005, nr 3, s. 31.

66 W piśmiennictwie wyrażono nawet wprost pogląd, według którego przepis ten może „pełnić funkcję prewencyjną" w związku z negatywnymi emocjami towarzyszącymi wypowiedzeniu umowy o pracę, zwłaszcza przez pracodawcę. Por. A. Bigaj, Prawo do urlopu..., s. 234.

67 Zob. m.in. J. Stelina, Prawo urzędnicze, Warszawa 2009, s. 209, 260.

68 Por. J. Witkowski, Relacja między art. $36^{2}$ a art. $167^{1}$ KP, M.P.P. 2016, nr 12, s. 632 i n. 
Znacznie trudniej jednak udzielić jednoznacznej odpowiedzi na pytanie, czy z wymienionych uprawnień pracodawcy dotyczących okresu wypowiedzenia może on zrobić użytek jednocześnie, a zatem czy pracodawca, który zwolnił już pracownika $\mathrm{z}$ obowiązku wykonywania pracy, może skierować go w trakcie tego zwolnienia na urlop wypoczynkowy.

Trudność w zajęciu kategorycznego stanowiska w tej sprawie wiąże się m.in. z dość ogólnym ujęciem omawianego zwolnienia $\mathrm{z}$ obowiązku wykonywania pracy w samym art. $36^{2}$ k.p. i związaną z tym różną interpretacją jego dopuszczalnego zakresu, ale też niejednolitą kategorią, jaką w gruncie rzeczy jest takie zwolnienie. W szczególności należy brać pod uwagę treść ewentualnego porozumienia, do którego zawarcia może dojść między stronami w omawianym obszarze. Pracodawca zyskał bowiem obecnie prawo do jednostronnego zwolnienia pracownika $\mathrm{z}$ obowiązku wykonywania pracy, ale do takiego zwolnienia może przecież dojść (co już wcześniej powszechnie akceptowano) również na mocy porozumienia stron. Zwolnienie takie może następować także z mocy samego prawa, jak ma to miejsce w przypadku pracowników zatrudnionych na podstawie powołania (art. $70 \$ 2 \mathrm{w}$ związku $\mathrm{z}$ art. 71 k.p.).

$\mathrm{W}$ doktrynie prawa pracy w kontekście wskazanego problemu zarysowały się dwa odmienne stanowiska.

Zgodnie z pierwszym z nich, nie ma przeszkód, aby pracodawca, który zwalnia pracownika $z$ obowiązku świadczenia pracy na podstawie art. $36^{2}$ k.p., nawet $\mathrm{w}$ trakcie tego zwolnienia udzielił pracownikowi urlopu wypoczynkowego w myśl art. $167^{1}$ k.p. Zwolnienie, o którym mowa w art. $36^{2}$ k.p., według autorów, nie obejmuje wszystkich obowiązków pracownika, a jedynie ten związany ze świadczeniem pracy. Pracownik musi zatem wykonywać polecenia pracodawcy, choćby dotyczące wykorzystania udzielonego mu urlopu, nawet jeśli zbiega się to $\mathrm{z}$ omawianym zwolnieniem od pracy. Podkreśla się różną sytuację prawną pracownika w tych okresach, w tym zwłaszcza okoliczność, że pracownika zwolnionego z obowiązku wykonywania pracy można wezwać zawsze i w każdym czasie, a pracownika, który pozostaje na urlopie wypoczynkowym, tylko wyjątkowo ${ }^{69}$.

Wydaje się jednak, że powyższa argumentacja nie oddaje w pełni istoty omawianych instytucji. Obowiązek zaś wykonywania poleceń pracodawcy, abstrahując od faktu, że skierowanie na urlop pozostaje w pewnym związku ze świadczeniem pracy, ogranicza się do poleceń zgodnych z prawem. Trzeba zatem w pierwszej kolejności ustalić relacje między analizowanymi przepisami i związany z tym zakres uprawnień pracodawcy.

Część autorów zdecydowanie opowiada się przeciwko możliwości skierowania pracownika na urlop wypoczynkowy w okresie wypowiedzenia w czasie, w którym pracownik ten został zwolniony przez pracodawcę z obowiązku wykonywania pracy ${ }^{70}$.

69 Por. K. Jaśkowski, E. Maniewska, Komentarz aktualizowany do Kodeksu pracy, LEX/el. 2017.

70 Por. A. Kosut, [w:] Kodeks pracy. Komentarz, s. 923; J. Witkowski, Relacja..., s. 634; tenże, Jednostronne zwolnienie pracownika z obowiqzzu świadczenia pracy w świetle art. $36^{2} \mathrm{KP}$, M.P.P. 2016, nr 6, s. 298. Podobnie P. Prusinowski, Zwolnienie z obowiqzzu świadczenia pracy - czynność jednostronna czy porozumienie stron, M.P.P. 2012, nr 4, s. 177 oraz L. Mitrus, Sytu- 
Zasadniczo należy ten pogląd podzielić i przyjąć, że zatrudniający nie może równocześnie zastosować obu tych rozwiązań, tzn. pracownik nie może w okresie, w którym zwolniono go z obowiązku świadczenia pracy, zostać też skierowany przez pracodawcę na urlop wypoczynkowy. Urlop jest bowiem również formą zwolnienia od pracy, choć o szczególnym przeznaczeniu, jeśli więc ktoś już nie ma obowiązku wykonywania pracy, niezależnie czy na mocy zawartego w tej sprawie z pracodawcą porozumienia czy przepisu prawa, to każde inne zwolnienie staje się w tej sytuacji bezprzedmiotowe. Pracodawca powinien w związku z tym wyraźnie określić granice czasowe urlopu udzielonego na podstawie art. $167^{1}$ k.p. oraz ewentualnie okresu zwolnienia od obowiązku wykonywania pracy z zachowaniem prawa do wynagrodzenia, jakie ma mieć miejsce na podstawie art. $36^{2}$ k.p. Nie ma przy tym większego znaczenia, czy omawiane zwolnienie poprzedzi urlop czy też wystąpi po nim, a nawet, jak uzasadniają niektórzy autorzy, okres urlopowy może przedzielać ów czas nieświadczenia pracy w związku z art. $36^{2}$ k.p., ale nie odwrotnie $^{71}$. Oznaczałoby to bowiem podział urlopu na części, który może nastąpić, jak była o tym mowa we wcześniejszych rozważaniach, tylko na wniosek pracownika, a ponadto koliduje on zasadniczo z wypoczynkową funkcją tej instytucji. Jeśli zatem zwolnieniem $\mathrm{z}$ obowiązku świadczenia pracy objęto cały okres wypowiedzenia, udzielenie dodatkowo urlopu wypoczynkowego w tym okresie byłoby sprzeczne z jego istotą.

Nie sposób jednak nie dostrzec, że sytuacja nieco się komplikuje wówczas, gdy zwolnienie, o którym mowa w art. $36^{2}$ k.p., obejmie jedynie część obowiązków pracownika. W literaturze przedmiotu trafnie podnosi się bowiem, że skoro pracodawca może zwolnić pracownika z obowiązku wykonywania wszystkich czynności związanych z jego stanowiskiem pracy, co wynika bezpośrednio z powołanego artykułu kodeksowego, to tym bardziej może to zrobić w stosunku tylko do konkretnej części tych zadań czy nawet pojedynczych obowiązków ${ }^{72}$. Wtedy nie dochodzi do przyjętego w powyższej argumentacji generalnego zwolnienia z obowiązku wykonywania pracy, ale de facto jedynie ograniczenia wymiaru zadań danego pracownika.

Być może powinno to znaleźć wówczas swoje odzwierciedlenie w wymiarze urlopu, jaki pracodawca mógłby udzielić w okresie wypowiedzenia, przy założeniu, że w takim przypadku zwolnienia z obowiązku świadczenia pracy skierowanie na urlop wynikające $z$ art. $167^{1}$ k.p. może być w ogóle zastosowane. Należałoby uznać, że pracodawca mógłby takim skierowaniem objąć część urlopu proporcjonalną do pozostałych obowiązków pracownika, które musi on realizować w ramach

acja pracownika..., s. 5 i E. Szemplińska, Konsultacje i wyjaśnienia, PiZS 2005, nr 8, s. 39. Zob. też J. Czerniak-Swędzioł, S. Koczur, Granice możliwości zwolnienia pracownika z obowiq̨zku świadczenia pracy, „Studia z zakresu prawa pracy i polityki społecznej”, Kraków 2013, s. 283.

71 Por. J. Witkowski, Relacja..., s. 635 i n.

72 Por. K. Jaśkowski, Zwolnienie pracownika z obowiq̨zku świadczenia pracy, PiZS 2016, nr 3, s. 25. 
istniejącego jeszcze stosunku pracy. Wymagałoby to jednak wyraźnej interwencji ustawodawcy, a ponadto w praktyce mogłoby wywołać istotne trudności z ustaleniem procentowej części obowiązków, jaka pozostała danemu pracownikowi do wykonania. Rozwiązanie to nie wydaje się zatem najlepsze.

Warto również odnieść się do charakteru omawianego zwolnienia, nawet jeśli obejmuje ono ogół czynności wynikających z rodzaju pracy danego pracownika, gdyż przyjęte w tym zakresie ustalenia mogą także determinować w jakiś sposób rozstrzygnięcie omawianego problemu.

Znaczące będą zwłaszcza te wypowiedzi, w których wskazuje się, że zwolnienie wynikające $\mathrm{z}$ art. $167^{1} \mathrm{k}$.p. nie wymaga oświadczenia woli, ponieważ należy do sfery uprawnień kierowniczych pracodawcy, a zatem dokonuje się poprzez jego polecenie ${ }^{73}$. Ich konsekwencją jest bowiem przede wszystkim konieczność uznania, że może ono zostać w każdej chwili przez pracodawcę odwołane, co po stronie pracownika rodzi $z$ kolei obowiązek ponownego podjęcia pracy „bez zbędnej zwłoki" "'4 . Wspomina się ponadto, że pracownik może zostać zobowiązany w tym okresie, $\mathrm{w}$ związku $\mathrm{z}$ jego powinnością dbałości o dobro pracodawcy, do wykonania określonych zadań na rzecz podmiotu zatrudniającego, związanych z zaprzestaniem wykonywania pracy (np. potrzebą wdrożenia nowego pracownika $)^{75}$. Zwolnienie to nie może być zatem, w żadnym wypadku, utożsamiane z okresem odpoczynku, jak uczynił to w swoisty sposób w jednym ze swych orzeczeń $\mathrm{SN}^{76}$. Po pierwsze, inne są cele porównywanych instytucji, o czym była mowa wcześniej, a po drugie, upowszechnienie się powyższego zapatrywania, że chodzi w tym przypadku o polecenie pracodawcy, a nie jego oświadczenie woli, powoduje, że pracownik $\mathrm{w}$ tym okresie nie pozostaje $\mathrm{w}$ dyspozycji pracodawcy w pełnym tego słowa znaczeniu, ale musi zachowywać swoistą gotowość do pracy. Tym samym $\mathrm{w}$ żadnym razie okres zwolnienia $\mathrm{z}$ obowiązku wykonywania pracy nie „konsumuje” sam w sobie okresu urlopu wypoczynkowego. Niemniej inną sprawą jest, że skoro pracownik w tym okresie pozostaje jednak w jakiejś formie gotowości do pracy, a nawet mogą na nim spoczywać określone obowiąz$\mathrm{ki}$, to tym samym zasadne byłoby udzielenie urlopu w celu odpoczynku i wyłączenia możliwości ingerencji pracodawcy w ten czas w związku z zasadą spokoju urlopowego.

73 Tak por. K. Jaśkowski, Zwolnienie pracownika..., s. 24.

74 Tamże, s. 25. Analogiczne stanowisko zajął SN, dokonując wykładni art. 95 ustawy z 23 grudnia 1994 r. o Najwyższej Izbie Kontroli (tekst jednolity: Dz. U. 2017, poz. 524), podobnego w swej treści do analizowanego przepisu kodeksowego, i uznając, że pracownik, który został zwolniony z obowiązku wykonywania pracy, ma obowiązek wykonać polecenie powrotu do niej. Por. wyrok SN z 13 marca 2014 r., I PK 204/13, LEX nr 1464689.

75 Por. K. Jaśkowski, Zwolnienie pracownika..., s. 25.

76 Wyrok SN z 29 marca 1983 r., I PRN 41/83, LEX nr 182842. W wyroku tym SN przyjąt, że zwolnienie z obowiązku wykonywania pracy w okresie wypowiedzenia jest równoznaczne $z$ faktem rzeczywistego wykorzystania urlopu wypoczynkowego w roku kalendarzowym, w którym dochodzi do rozwiązania stosunku pracy, co w rezultacie czyni niezgodnym z zasadami współżycia społecznego żądanie wypłaty ekwiwalentu za niewykorzystany urlop. 
Trzeba też mieć na uwadze, że pewne kwestie, jak np. pozostawanie przez pracownika w stałym kontakcie z pracodawcą czy podejmowanie na jego rzecz określonych czynności, mogą wynikać z zawartego dodatkowo porozumienia między stronami. Wówczas udzielenie urlopu w okresie omawianego zwolnienia wydaje się już bardziej zasadne. Urlop wypoczynkowy jest bowiem z definicji zwolnieniem nie z konkretnych obowiązków głównych pracownika, ale z wszelkich form aktywności na rzecz pracodawcy. Trudno zatem uznać, by te zwolnienia w takiej sytuacji rzeczywiście się w pełni pokrywały.

Wydaje się, że sformułowany na wstępie pogląd o niemożności udzielenia urlopu wypoczynkowego w okresie zwolnienia pracownika z obowiązku wykonywania pracy budzi mniej wątpliwości w sytuacji, jeśli do takiego zwolnienia dochodzi $\mathrm{w}$ drodze porozumienia stron. O ile $\mathrm{z}$ treści porozumienia nic innego nie wynika, sytuacja pracownika w omawianym okresie jest zdecydowanie korzystniejsza i trudno mówić o jego obowiązku pozostawania w gotowości do wykonywania pracy. Zgodnie z ugruntowanym zarówno w doktrynie, jak i orzecznictwie przekonaniem, ponowne podjęcie pracy przez pracownika, a zatem przerwanie owego zwolnienia, będzie wymagać jego zgody. Zostało to wprost wyrażone choćby w wyroku Sądu Apelacyjnego w Warszawie z 21 czerwca 2005 r., w którym skonstatowano, że okres zwolnienia pracownika z obowiązku świadczenia pracy nie jest równoznaczny (jakościowo i pojęciowo) z okresem wykorzystywania urlopu wypoczynkowego. Jeżeli pracodawca podjął decyzję o zwolnieniu pracownika z obowiązku świadczenia pracy, to nie może bez jego zgody nakazać, by w tym samym okresie wykorzystał on urlop wypoczynkowy ${ }^{77}$.

Ostatecznie treść porozumienia będzie miała zatem w tym przypadku decydujące znaczenie, co potwierdził SN w orzeczeniu z 26 kwietnia 2011 r. (teza 2.), w którym uznał, że jeżeli zwolnienie pracownika z obowiązku świadczenia pracy w okresie wypowiedzenia umowy o pracę jest wynikiem zawartego między stronami porozumienia, to pracodawca nie może zobowiązać pracownika do wykorzystania urlopu wypoczynkowego w tym okresie, chyba że z zawartego porozumienia wynika taki obowiązek zatrudnionego ${ }^{78}$.

Innymi słowy, strony mogą w treści porozumienia określić, w jakim zakresie pracownik nie będzie świadczyć pracy w wyniku ogólnego zwolnienia go z tego obowiązku, a w jakim z tytułu wykorzystywanego urlopu wypoczynkowego.

I tu jednak powstaje sygnalizowany wcześniej problem zwolnienia pracownika, za jego zgodą, tylko z części obowiązków pracowniczych i wpływu tej okoliczności na dopuszczalność udzielenia w tym samym czasie urlopu wypoczynkowego.

Warto jednak przypomnieć, że odmienny od wyżej zaprezentowanego pogląd w tej kwestii wyraził Trybunał Sprawiedliwości UE, który w jednej ze spraw zdecydował, że pracownik, który na mocy porozumienia zawartego z pracodawcą został zwolniony z obowiązku świadczenia pracy w określonym czasie poprzedzającym

77 Wyrok SA w Warszawie z 21 czerwca 2005 r., III APa 48/0, Apel.-W-wa 2006, nr 1, poz. 1.

78 Wyrok SN z 26 kwietnia 2011 r., II PK 302/10. 
rozwiązanie umowy, z zachowaniem prawa do wynagrodzenia, nie nabywa ekwiwalentu za niewykorzystany w tym okresie urlop, chyba że nie mógł tego urlopu wykorzystać $\mathrm{z}$ powodu choroby ${ }^{79}$. Tym samym, w ocenie Trybunału, samo zwolnienie pracownika z obowiązku świadczenia pracy nie wyklucza możliwości realizacji prawa do urlopu wypoczynkowego w naturze. Niemniej trudno jednoznacznie stwierdzić na ile to stanowisko Trybunału przekłada się na ocenę relacji między omawianymi instytucjami na gruncie prawa polskiego. W stanie faktycznym, którego dotyczył wspomniany wyrok, okres zwolnienia z obowiązku świadczenia pracy był bardzo długi (wynosił 1,5 roku), a przede wszystkim zwolnienie nie przypadało $\mathrm{w}$ okresie wypowiedzenia.

Znacznie bardziej zdecydowanie można odnieść się natomiast do zwolnienia $\mathrm{z}$ obowiązku wykonywania pracy dokonywanego z mocy prawa, jak w przypadku pracowników odwoływanych ze stanowiska. Wówczas pracodawca nie może bowiem powierzyć temu pracownikowi innej pracy bez jego zgody (art. 71 k.p.), a czasami nie ma nawet fizycznie takiej możliwości. W takim wypadku udzielenie urlopu wypoczynkowego w tym czasie stanowiłoby istotnie „zwolnienie od zwolnienia”, a zatem było sprzeczne $z$ istotą omawianego świadczenia. Inaczej wygląda sytuacja $\mathrm{w}$ razie podjęcia przez pracownika odwołanego zaproponowanej przez pracodawcę pracy $\mathrm{w}$ analizowanym okresie, wówczas, $\mathrm{w}$ moim przekonaniu, realizacja prawa do urlopu wypoczynkowego będzie zasadna.

Kwestia ta była jednak w judykaturze inaczej rozstrzygana. W tej sprawie wypowiedział się SN m.in. w wyroku z 7 lutego 2001 r., w którym przyjął, że brak obowiązku wykonywania pracy przez odwołanego pracownika w okresie wypowiedzenia nie jest przeszkodą do udzielenia mu w tym czasie urlopu wypoczynkowego ${ }^{80}$.

W stanie faktycznym, którego dotyczyło powyższe orzeczenie SN, miało miejsce, jak podkreśla sąd, ustawowe zwolnienie pracownika zatrudnionego na podstawie powołania z obowiązku świadczenia pracy. Argumentowano, że brak obowiązku świadczenia pracy $\mathrm{w}$ okresie wypowiedzenia nie jest równoznaczny z zerwaniem więzów łączących pracodawcę $\mathrm{z}$ pracownikiem, stąd pracodawca może żądać od niego w tym czasie wypełniania konkretnych powinności. Zdaniem SN, „ustawowe zwolnienie pracownika od obowiązku świadczenia pracy nie oznacza absolutnej swobody pracownika i nie może być utożsamiane z okresem wypoczynku lub też z czasem wolnym od pracy w rozumieniu np. art. 14 k.p., w który ingerencja pracodawcy nie jest, co do zasady, dopuszczalna. Zatem korzystanie przez pracownika ze zwolnienia od świadczenia pracy nie sprzeciwia się udzieleniu mu w tym czasie urlopu wypoczynkowego, gdyż czas ten nie został przeznaczony na jakiś określony cel, z którym sprzeczne byłoby korzystanie z urlopu wypoczynkowego"s1.

79 Wyrok TSUE z 20 lipca 2016 r. w sprawie Hansa Mascheka, C-341/15, pkt 35-37.

80 Wyrok SN z 7 lutego 2001 r., I PKN 240/00. Analogicznie w wyroku SN z 13 kwietnia 1999 r., I PKN 1/99, OSNAPiUS 2000, nr 12, poz. 458.

81 Tamże. 
Bezdyskusyjnym pozostaje fakt, że omawiany okres dotyczy trwającego stosunku pracy i nie może być traktowany na równi z prawem pracownika do wypoczynku, ale pojęcie czasu wolnego jest pojęciem szerszym, jak wynika z poczynionych na wstępie niniejszego opracowania ustaleń. Obejmuje zatem zarówno czas przeznaczony przez ustawodawcę na odpoczynek, jak i inne okresy nieświadczenia pracy, np. związane z określonymi normami czasu pracy czy zwolnieniami udzielanymi w celach innych niż odpoczynek. Z uwagi na to, że powyższy okres nie jest też z pewnością czasem pracy (pracodawca nie ma tu swobody w zakresie dysponowania osobą pracownika (zwolnienie ustawowe), ten nie pozostaje w jego dyspozycji, pracodawca nie może bowiem wymagać włączenia się w każdym momencie do procesu wykonywania umówionej pracy, nie ma uprawnień do wyznaczenia miejsca oczekiwania przez pracownika na ewentualne wezwanie), musi być zatem kwalifikowany jako czas wolny. Ustawodawca w tym przypadku nie uzależnia bowiem wypłaty wynagrodzenia za ten czas od zachowania przez pracownika stanu gotowości do pracy, skoro sam go od tego obowiązku zwolnił.

Stanowisko to zostało jednak podtrzymane również w późniejszym orzecznictwie SN. Na przykład wystarczy powołać wyrok SN z 26 kwietnia 2011 r. (teza 4.), w którym sąd potwierdza, że pracodawca może zobowiązać pracownika zatrudnionego na podstawie powołania, którego odwołał ze stanowiska, do wykorzystania w okresie wypowiedzenia zaległego i proporcjonalnie także bieżącego urlopu wypoczynkowego, mimo że w okresie wypowiedzenia pracownik, zachowując prawo do wynagrodzenia, nie ma obowiązku świadczenia pracy ${ }^{82}$.

Powyższa analiza zdaje się wskazywać na złożoność problemu, jakim jest dopuszczalność skierowania pracownika na urlop w okresie zwolnienia z obowiązku wykonywania pracy, na tle konkretnego stanu faktycznego pewne znaczenie może mieć bowiem zarówno zakres takiego zwolnienia, dodatkowe ustalenia stron stosunku pracy, jak i ugruntowujące się stopniowo przekonanie co do jego charakteru. Zasadniczo jednak, jeśli pracownik nie ma obowiązku wykonywania pracy w konkretnym czasie, to nie powinno się dodatkowo obejmować go urlopem wypoczynkowym.

Podsumowując wywody zamieszczone powyżej, wprowadzane odstępstwo od zasady planowego udzielania urlopów wypoczynkowych, pozwalające na udzielenie pracownikowi urlopu wypoczynkowego w okresie wypowiedzenia, trudno jednoznacznie ocenić w kontekście prawa pracownika do wypoczynku. Choć bowiem samo kierowanie pracownika na urlop, niejako wbrew jego w woli, w tym szczególnym okresie, w którym zwykle pracownik poszukuje intensywnie nowego zatrudnienia, zwłaszcza gdy to nie on rozwiązuje umowę o pracę, jest bardzo wątpliwe i zagraża prawidłowej realizacji głównej funkcji tego urlopu, to jednak alternatywą dla pracownika, który znajduje się już w okresie wypowiedzenia, jest wypłata ekwiwalentu za niewykorzystany urlop, która ze swej natury również nie pozwala osiągnąć celu, w jakim omawiane prawo zostało wprowadzone. Można

82 Wyrok SN z 26 kwietnia 2011 r., II PK 302/10. 
co najwyżej wskazywać, że pewnym „dobrodziejstwem” uzyskanego świadczenia pieniężnego będzie potencjalna poprawa jakości wypoczynku w przyszłości, jeśli pracownik zdecyduje się na przeznaczenie tej kwoty na jego organizację w związku z urlopem w kolejnym stosunku pracy.

Ewentualnie w celu usunięcia omawianej kolizji można rozważyć prawne zobowiązanie pracodawcy do udzielenia urlopu przed wypowiedzeniem umowy o pracę, co jednak byłoby, moim zdaniem, rozwiązaniem sztucznym, a ponadto też nie gwarantowało samo w sobie zgodnego z planem i spokojnego wykorzystania urlopu, jeśli ustalony wcześniej termin urlopu danej osoby przypadałby na znacznie późniejszy okres, a pracownikowi towarzyszyłaby obawa przed możliwym przyszłym zwolnieniem. Nie wspominając o kolejnej komplikacji w złożonej procedurze wypowiadania umowy o pracę. Wprowadzenie tego rodzaju unormowania mogłoby bowiem uniemożliwić pracodawcy, przynajmniej przez pewien czas, złożenie oświadczenia woli o wypowiedzeniu umowy pracownikowi, dla którego nieoczekiwane kierowanie go na urlop byłoby czytelnym sygnałem dotyczącym zamiarów pracodawcy i mogło skutkować przedłożeniem zaświadczenia o niezdolności do pracy z powodu choroby jeszcze w czasie urlopu wypoczynkowego lub bezpośrednio po nim.

Tym samym, jak się wydaje, w sytuacji, gdy dochodzi już do wypowiedzenia umowy o pracę, trudno zagwarantować pracownikowi za pomocą instrumentów prawnych efektywność nabytego prawa do urlopu wypoczynkowego i związanego z nim odpoczynku.

\section{Odwotanie z urlopu}

Wśród rozwiązań kwalifikowanych jako dysfunkcjonalne z punktu widzenia odpoczynku, jaki ma gwarantować omawiany urlop, nie sposób nie wymienić instytucji odwołania pracownika $\mathrm{z}$ urlopu wypoczynkowego, wynikającej z art. 167 k.p. W sensie zarówno faktycznym, jak i prawnym sprowadza się ona do możliwości przerwania rozpoczętego przez pracownika $z$ tego tytułu odpoczynku z przyczyn leżących po stronie pracodawcy. Już w swym założeniu została ona więc ustanowiona w celu ochrony interesów pracodawcy, a jej istotą jest dopuszczalność zakłócenia przebiegu podstawowej funkcji tego urlopu. O efektywnym odpoczynku można bowiem mówić wówczas, gdy jest on realizowany bez przeszkód i przez ustalony przez strony, najlepiej dłuższy, czas. I choć nie budzi większych wątpliwości zasadność wprowadzenia tego rodzaju unormowania, zwłaszcza wziąwszy pod uwagę przesłanki jego zastosowania, które będą dalej omawiane, to jednak nie zmienia to faktu, że czyni ono poważny wyłom w wielu zasadach prawa urlopowego, nakierowanych na zapewnienie właściwej realizacji prawa pracownika do odpoczynku, jak np. w szeroko rozumianej zasadzie urlopu nieprzerwanego, spokoju 
urlopowego, a w jakimś zakresie też planowego jego udzielania czy niekiedy nawet zasadzie urlopu corocznego (jeśli w związku z przerwaniem urlopu pracodawca udziela go w roku kolejnym). Oceny wymaga zatem sposób regulacji omawianej instytucji i stopień zabezpieczenia uprawnień pracownika w związku z jej zastosowaniem przez pracodawcę.

Zgodnie z powołanym wyżej przepisem, pracodawca ma prawo odwołać pracownika z urlopu wypoczynkowego, ale tylko i wyłącznie wówczas, gdy jego obecności w zakładzie wymagają okoliczności nieprzewidziane w chwili rozpoczynania przez niego urlopu.

Biorąc pod uwagę, że regulacja ta ma charakter wyjątkowy i stanowi poważne zagrożenie dla skutecznego wypoczynku, jaki urlop z definicji powinien umożliwiać, trzeba uznać, że prawidłowe wezwanie do pracy pracownika pozostającego na urlopie jest uzależnione od spełnienia dwóch warunków.

Po pierwsze, obecność tego pracownika w zakładzie pracy jest niezbędna, np. z punktu widzenia możliwości dalszego funkcjonowania całości czy części zakładu pracy, ryzyka wystąpienia po stronie pracodawcy wysokich strat materialnych, wizerunkowych itp. Mowa tu zwłaszcza o przypadkach, w których wskutek określonych zdarzeń okazuje się, że nie ma już możliwości zastąpienia tego pracownika w danym czasie innymi osobami zatrudnionymi przez pracodawcę, ze względu na jego kwalifikacje, umiejętności, przygotowanie do danej pracy, posiadane uprawnienia itd. Oczywiście pracodawca musi zapewnić właściwą obsadę stanowisk również na wypadek takich okresów jak urlop czy choroba pracownika, niemniej w określonych okolicznościach, o których niżej, mimo potencjalnego zabezpieczenia obsługi każdego miejsca pracy w danym zakładzie, odwołanie pracownika z urlopu może okazać się konieczne.

Jednocześnie uważam, choć może być to przedmiotem kontrowersji, że odwołanie z urlopu nie musi zawsze polegać na wezwaniu pracownika do zakładu pracy $^{83}$. Trzeba bowiem zauważyć, że w analizowanym przepisie ustawodawca odnosi się do „okoliczności” wymagających obecności pracownika w zakładzie. Nie można zatem wykluczać, że w pewnych sytuacjach ten warunek zostanie spełniony i wystąpi wskazana konieczność, ale ze względu na charakter zadania czy szczególne warunki, w jakich świadczona jest praca (np. w przypadku telepracownika), pracodawca będzie miał możliwość zobowiązania pracownika do stawienia się w miejscu pracy, by tam pracę wykonał lub wskazania mu innego miejsca świadczenia pracy - w tym, za zgodą pracownika, aktualnego miejsca pobytu. Drugie rozwiązanie nie zmienia charakteru samej przesłanki, w tym w szczególności jej nie rozszerza, a jest z pewnością mniej dotkliwe dla osoby, której urlop w sensie faktycznym i prawnym zostaje przerwany - ze wszystkimi tego konsekwencjami (również w zakresie zwrotu kosztów). Jeśli pracodawca może wezwać pracownika do miejsca pracy (nakazać powrót z urlopu), to chyba tym bardziej może polecić mu wykonanie określonych pilnych zadań na miejscu, jeśli tylko obiektywne

83 Odmienny pogląd w tej sprawie por. K. Płaczek, Prawo pracownika do niezakłóconego wypoczynku, M.P.P. 2017, nr 7, s. 359. 
warunki na to pozwalają, zrównując to pod względem prawnym z obowiązkiem stawienia się w zakładzie pracy. W przeciwnym razie dochodziłoby do paradoksu, w którym pracodawca mogąc zlecić pracownikowi wykonanie określonych czynności w dogodnym dla niego miejscu byłby zmuszony wezwać go do zakładu pracy, by formalnie dokonać omawianego odwołania.

Po drugie, przyczyną wezwanie pracownika do pracy są okoliczności, które nie były znane pracodawcy w momencie rozpoczynania urlopu przez pracownika, ich wystąpienia nie dało się przewidzieć. Klasycznym przykładem jest choroba innego pracownika zatrudnionego na analogicznym stanowisku i niemożność powierzenia tej pracy innej osobie, poważna awaria, nagłe przyspieszenie przez drugą stronę działań prowadzących do zawarcia z pracodawcą dużego kontraktu, powódź, pożar i inne tego typu wydarzenia. Ich wspólną cechą jest to, że mają one zwykle charakter bardzo dynamiczny, wręcz nagły, często niecodzienny, niespodziewany. Podstawą jest tu jednak zawsze brak wiedzy pracodawcy, w momencie kierowania pracownika na urlop wypoczynkowy, o okoliczności uzasadniającej następnie takie odwołanie. Jeśli pracodawca miał wcześniej informację na ten temat, urlop może zostać najwyżej przesunięty (pod warunkiem, że się jeszcze nie rozpoczął), ale w żadnym razie nie można go wówczas przerywać.

Omawiając przesłanki warunkujące zgodne z prawem odwołanie pracownika $\mathrm{z}$ urlopu wypoczynkowego, trzeba zaznaczyć, że $\mathrm{w}$ doktrynie prawa pracy dominuje przekonanie, że pracodawca nie musi informować odwoływanego o powodach swojej decyzji, a pracownik powinien w każdym przypadku stawić się na wezwanie pracodawcy, niezależnie od tego, jak on sam ocenia okoliczności tego odwołania, o ile zostały mu one jednak przedstawione ${ }^{84}$. Odmowa wykonania polecenia pracodawcy może być wszak przyczyną pociągnięcia pracownika do odpowiedzialności porządkowej, wypowiedzenia mu umowy o pracę przez pracodawcę, a w cięższych przypadkach nawet podstawą do niezwłocznego rozwiązania umowy o pracę z tym pracownikiem (art. $52 \$ 1$ pkt 1 k.p.).

Niemniej pracodawca odwołujący pracownika $\mathrm{z}$ urlopu w sposób niezgodny z komentowanym artykułem może ponieść konsekwencje odszkodowawcze, znacznie wykraczające poza gwarancje wynikające z Kodeksu pracy. Przyjmuje się bowiem, że w razie bezprawnego odwołania zatrudnionego $\mathrm{z}$ urlopu wypoczynkowego, ten może wystąpić na drogę sądową, dochodząc na podstawie przepisów prawa cywilnego pełnej rekompensaty poniesionej z tego tytułu szkody (obejmującej zarówno rzeczywiste straty, jak i utracone korzyści, np. wynagrodzenie związane z podjęciem w okresie urlopu innej pracy zarobkowej) $)^{85}$.

84 W opinii A. Świątkowskiego, oceny sytuacji dokonuje pracodawca i nie musi on nawet informować pracownika o przyczynach takiego odwołania; por. A. Świątkowski, Kodeks pracy..., s. 686. Podobnie A. Kosut, [w:] Kodeks pracy. Komentarz, s. 916. Zob. też A. Bigaj, Prawo do urlopu..., s. 280. Częściowo odmiennie, jak się wydaje, M. Nałęcz, który wspomina o konieczności podania przez pracodawcę do wiadomości pracownika przyczyn odwołania; por. tenże, [w:] Kodeks pracy. Komentarz, red. W. Muszalski, Warszawa 2007, s. 767.

85 Tak K. Jaśkowski, E. Maniewska, Komentarz aktualizowany..., LEX/el. 2017. Por. też A. Marek, Odwołanie pracownika z urlopu, „Służba Pracownicza” 2010, nr 10, s. 11 i n. 
Trzeba jednak podkreślić, że odszkodowanie uzyskane przez pracownika w związku z bezprawnym odwołaniem, choćby w wyższej kwocie, nie zastąpi nigdy pełnego wypoczynku, jakiego pracownik nie mógł w omawianych okolicznościach zrealizować.

Uważam zatem, że skoro pracodawca, powołując się na przesłanki z art. 167 k.p., ingeruje w czas wolny pracownika, a nawet więcej, w okres jego odpoczynku, powinien swoją decyzję uzasadnić. Trzeba bowiem pamiętać, że obowiązek pracownika wykonywania poleceń pracodawcy dotyczy tych zakazów i nakazów, które są zgodne z prawem. Pracownik musi mieć możliwość oceny w tych kategoriach przyczyn, które zadecydowały o jego odwołaniu z urlopu. W sytuacjach oczywiście sprzecznych z powołanym przepisem, pracownik ten powinien, moim zdaniem, zachować prawo odmowy wykonania takiego polecenia, ze świadomością, że przejmuje na siebie wówczas ryzyko związane z niewłaściwą oceną zaistniałych okoliczności. Nawet bowiem, choć bywa to przedmiotem kontrowersji, przyjęcie, że podstawą obowiązku pracownika stawienia się na wezwanie pracodawcy jest w tym przypadku dodatkowo szczególna dbałość o dobro pracodawcy, do której został on zobowiązany na mocy art. 100 k.p. ${ }^{86}$, nie upoważnia jednak do twierdzenia, że pracownik, odmawiając przerwania urlopu, ten obowiązek narusza, jeśli dobro pracodawcy nie było obiektywnie zagrożone, szczególnie że dotyczy to ingerencji w tak podstawową wartość jak prawo do odpoczynku. We współczesnym ujęciu stanowi ono jedno z dóbr osobistych pracownika, o czym była mowa w pierwszej części niniejszych rozważań, których ochrona musi ograniczać zakres uprawnień kierowniczych pracodawcy. Sam obowiązek dbałości o dobro pracodawcy, jak zauważa się $\mathrm{w}$ piśmiennictwie $\mathrm{z}$ tego zakresu, również nie może być interpretowany jako „wszechobowiązek czynienia wszystkiego, co służy dobru pracodawcy”"

Ponadto brak obowiązku podania pracownikowi uzasadnienia takiego odwołania, za jakim opowiada się część przedstawicieli doktryny, może także utrudniać mu podjęcie decyzji o wystąpieniu na drogę postępowania sądowego i dochodzeniu z tego tytułu odszkodowania. Nie sposób bowiem zakładać, że w każdym przypadku pracownik będzie w stanie to wywnioskować z okoliczności i sytuacji, jaką zastał na miejscu. Uważam zatem, że pracownik zdecydowanie ma prawo do takiej informacji, której powinien udzielić mu pracodawca lub inna osoba działająca $\mathrm{w}$ tym zakresie w jego imieniu.

Z punktu widzenia stopnia ograniczenia prawa pracownika do wypoczynku, jakie następuje $\mathrm{w}$ związku z instytucją odwołania z urlopu, ważne jest również

86 Tak m.in. E. Chmielek-Łubińska, [w:] Kodeks pracy..., Warszawa 2009, s. 917. Odmienny pogląd zob. A. Bigaj, Prawo do urlopu..., s. 279. Autor wskazuje, że obowiązek stawienia się na polecenie pracodawcy, dotyczące przerwania urlopu, wynika wprost z art. 167 k.p. Nie ma zatem potrzeby powoływania się na zwrot niedookreślony, którym ustawodawca posłużył się w art. 100 § 2 pkt 4 k.p.

87 Por. M. Skąpski, Wpływ pracowniczego obowiqzzku dbałości o dobro zakładu pracy na zakres kompetencji pracodawcy do kontrolowania pracownika, [w:] Kontrola pracownika. Możliwości techniczne i dylematy prawne, red. Z. Góral, Warszawa 2010, s. 74. 
ustalenie, jak często pracodawca w danym roku kalendarzowym może przerywać na podstawie art. 167 k.p. urlop wypoczynkowy pracownika. Trzeba bowiem podkreślić, że ustawodawca jednoznacznie w przepisie tego nie rozstrzygnął.

W ocenie części autorów, jeżeli tylko zostaną spełnione przesłanki sformułowane w powołanym artykule, pracodawca może odwoływać pracownika z urlopu tyle razy, ile uzna za konieczne, choć zaznacza się przy tym, że powinno mieć to miejsce w naprawdę wyjątkowych przypadkach ${ }^{88}$.

Odmienne stanowisko w tej kwestii zaprezentował A. Świątkowski, który zwrócił uwagę na występujący w analizowanym przepisie zwrot „w chwili rozpoczynania" urlopu. Zdaniem autora, każdy pracownik rozpoczyna swój urlop tylko raz w roku, w dniu, w którym zaczyna wykorzystywać nabyte prawo do urlopu. Stąd pracodawca, który odwołał już raz pracownika z urlopu wypoczynkowego, nie może tego zrobić ponownie wobec tego samego pracownika, uprawnienie to zostało bowiem przyznane pracodawcy na zasadzie wyjątku i odnosi się do nieprzewidzianych okoliczności występujących w chwili „rozpoczynania urlopu”, a nie okresu późniejszego, w którym pracownik już „tylko” kontynuuje korzystanie $\mathrm{z}$ nabytego urlopu, zgodnie z planem ${ }^{89}$.

Powyższa próba wykładni omawianego przepisu, zawężająca w istocie uprawnienia pracodawcy w rozważanym obszarze, a tym samym ograniczająca dysfunkcjonalne jego oddziaływanie na podstawowy cel urlopu, niestety nie znajduje, jak się wydaje, dostatecznego uzasadnienia w treści analizowanego przepisu.

Termin, jakim posłużył się ustawodawca, dotyczący „rozpoczęcia urlopu” łączy się bowiem nie tyle $\mathrm{z}$ momentem skorzystania $\mathrm{z}$ tego prawa, co wystąpienia okoliczności uzasadniających odwołanie $\mathrm{z}$ urlopu. Wskazuje na to wprost $₫ 1$ art. 167 k.p., który stanowi o okolicznościach nieprzewidzianych w chwili rozpoczynania urlopu. Tym samym jeśli ograniczać możliwości pracodawcy powoływania się na ten przepis, to ewentualnie w kontekście okoliczności, które muszą być pracodawcy nieznane nie w chwili rozpoczęcia danej części urlopu, ale w dniu poprzedzającym pierwszy w danym roku kalendarzowym dzień urlopu pracownika.

I ta interpretacja nie wydaje się jednak przekonująca, gdyż trudno znaleźć jej racjonalne uzasadnienie. Celem tego unormowania jest zagwarantowanie sprawnego funkcjonowania zakładu, dla którego obecność pracownika przebywającego na urlopie jest konieczna. Przyczyna, dla której tak się dzieje, ma w założeniu, jak była o tym mowa wcześniej, charakter nagły, szczególny, obiektywnie trudny do przewidzenia, stąd nie może być odnoszona do stanów występujących w przeszłości, niekiedy stosunkowo odległej, kiedy to pracownik skorzystał po raz pierwszy w danym roku z pierwszego dnia tego urlopu. Chcąc ograniczyć działanie tego przepisu, ustawodawca zapewne zrobiłby to wyraźnie.

88 Por. M. Nałęcz, [w:] Kodeks pracy. Komentarz, red. W. Muszalski, Warszawa 2013, s. 667. Zob. też A. Wypych-Żywicka, [w:] Kodeks pracy z komentarzem, LEX 2004 oraz E. Chmielek-Łubińska, Urlopy wypoczynkowe..., s. 69.

Por. A.M. Świątkowski, [w:] Kodeks pracy..., s. 687. 
Jednocześnie może dziwić, że tego nie uczynił. Przyjęcie wykładni odmiennej od zaproponowanej przez A. Świątkowskiego prowadzi bowiem do trudnych do zaakceptowania wniosków z perspektywy zabezpieczenia przez ustawodawcę skutecznej realizacji konstytucyjnego prawa do urlopu i związanego z nim odpoczynku. Wielokrotne przerywanie urlopu wypoczynkowego w związku z odwołaniem, którego niedopuszczalność, jak była mowa wyżej, nie wynika wprost z przepisów prawa, nie tylko może zakłócić ten odpoczynek w stopniu, w którym trudno uznać, że w ogóle miał on miejsce i osiągnięte zostały zawierające się w jego istocie cele, ale może powodować też faktyczne rozczłonowanie tego urlopu. Nie ma tu bowiem, co też należy ocenić krytycznie, odpowiedniego odesłania do art. 162 k.p., z którego wynika, że jedna część urlopu, w razie jego podziału, powinna obejmować nie mniej niż 14 kolejnych dni kalendarzowych. W rezultacie, jeśli pracodawca skorzysta ze swojego prawa w danym roku kilka razy, może okazać się, że pracownik będzie wykorzystywać de facto cały urlop w krótkich odcinkach czasowych, niegwarantujących możliwości odpoczynku, a zatem w sposób całkowicie sprzeczny z podstawową funkcją tej instytucji.

Warto jednak przy tej okazji podkreślić, że brak wskazanego odniesienia do art. 162 k.p. stwarza zagrożenie dla faktycznej realizacji zasady urlopu w całości, mającej istotne znaczenie dla efektywności osiąganego w związku z nim odpoczynku, nawet przy jednorazowym przerwaniu urlopu wypoczynkowego przez pracodawcę. Może się bowiem okazać, że owa 14-dniowa część urlopu pracownika jest ostatnią i jej przerwanie, np. po czterech dniach, wskutek wezwania pracownika do pracy przez pracodawcę (ustawodawca nie zastrzegł bowiem braku możliwości odwołania $\mathrm{z}$ urlopu z naruszeniem art. 162 k.p.), nie pozwala na skorzystanie $\mathrm{z}$ tego świadczenia $\mathrm{z}$ zachowaniem omawianej reguły, nie daje też podstaw do dochodzenia od pracodawcy udzielenia mu ponownie pełnej 14-dniowej części wypoczynku; oznaczałoby to wszak zwiększenie rocznego wymiaru tego urlopu, a nie ma w Kodeksie pracy normy, która nakazywałaby to uczynić w opisanym przypadku.

Może to skłaniać do smutnej w sumie refleksji, że na etapie tworzenia gwarancji odpoczynku realizowanego $\mathrm{w}$ ramach urlopu bardziej chodziło o zaplanowanie urlopu w sposób zgodny z art. 162 k.p. niż zabezpieczenie jego faktycznego wykorzystania $\mathrm{w}$ co najmniej podanym $\mathrm{w}$ tym przepisie rozmiarze.

Z powyższych względów $\mathrm{w}$ doktrynie prawa pracy uznaje się, że przywoływany przepis nie powinien być stosowany do pracowników młodocianych, mimo zawartego w art. $205 \$ 5$ k.p. ogólnego odesłania w sprawach nieunormowanych do działu siódmego Kodeksu pracy, jako że zakłócając bardzo mocno przebieg głównej funkcji urlopu, generuje istotne zagrożenie dla zdrowia młodocianego, które powinno być poddane wzmożonej ochronie ${ }^{90}$.

90 Por. tak M. Piankowski, [w:] Kodeks pracy z komentarzem, red. U. Jackowiak, Gdańsk 1996, s. 468 oraz M. Włodarczyk, [w:] Kodeks pracy. Komentarz, red. K.W. Baran, Warszawa 2012, s. 1039. 
W literaturze z obszaru prawa pracy wątpliwości powstają również wokół odwołania pracownika z urlopu na żądanie. Część autorów dopuszcza taką możliwość na ogólnych zasadach ${ }^{91}$, ale wydaje się, że więcej zwolenników zyskuje pogląd, według którego odwołanie pracownika $\mathrm{z}$ urlopu na żądanie jest możliwe jedynie w okolicznościach nadzwyczajnych, kwalifikowanych w stosunku do przesłanek przerwania „Zwykłego" urlopu wypoczynkowego ${ }^{92}$.

Dość kontrowersyjną kwestią dotyczącą realizacji prawa do odwołania pracownika z urlopu, wymagającą rozważenia w kontekście charakteru urlopu wypoczynkowego i jego celu, jest dopuszczalność zobowiązania pracownika do pozostawania w czasie urlopu w stałym kontakcie z pracodawcą.

$\mathrm{W}$ mojej ocenie, zasadniczo jest to niezgodne $\mathrm{z}$ istotą urlopu wypoczynkowego, który, jak już wcześniej wielokrotnie wskazywano, jest okresem zwolnienia pracownika z obowiązku wykonywania pracy w celu wypoczynku, a więc czasem, który w swym założeniu powinien być wolny od wszelkiej ingerencji pracodawcy. Jak uznał w jednym ze swych wyroków SN, pracownik korzystający z urlopu wypoczynkowego "pozostaje czasowo poza sferą pracowniczego podporządkowania”" Podmiot zatrudniający nie może wymagać od pracownika pozostawania w stanie swoistej gotowości do pracy w tym czasie, tj. pewnego oczekiwania na potencjalne wezwanie go do pracy, ponieważ wpływa to znacząco na efektywność i jakość tego odpoczynku, a niekiedy może go wręcz czynić nieskutecznym (np. w sytuacji zobowiązania pracownika do utrzymywania permanentnego kontaktu telefonicznego lub e-mailowego). Prawo do odpoczynku, którego jednym z podstawowych instrumentów jest urlop wypoczynkowy, musi być postrzegane szeroko, jako prawo do spokoju, relaksu, poczucia komfortu, a zatem również pewnej przyjemności tego wypoczynku.

$\mathrm{W}$ jakimś zakresie teza ta znajduje też swoje potwierdzenie w orzecznictwie, w którym przyjęto m.in., że pracownik przebywający na urlopie wypoczynkowym nie ma obowiązku kontrolowania poczty elektronicznej ${ }^{94}$.

91 Por. m.in. M. Podgórska, Urlop na żądanie, s. 19. Autorka przyjmuje, w ślad za orzecznictwem SN, że skoro urlop na żądanie jest częścią urlopu wypoczynkowego, to stosuje się do niego, poza wyraźnie określonymi wyjątkami, kodeksowe regulacje urlopowe. Ponadto, jeżeli w orzecznictwie sądowym dopuszcza się możliwość odmowy udzielenia urlopu na żądanie ze względu na szczególne okoliczności, które powodują, że zasługujący na ochronę interes pracodawcy wymaga obecności pracownika w zakładzie pracy, to z tych samych powodów można pracownika z urlopu na żądanie odwołać.

92 E. Chmielek-Łubińska, Urlop na żądanie pracownika, PiZS 2003, nr 3, s. 31. Podobnie Ł. Pisarczyk, [w:] Kodeks pracy. Komentarz, red. L. Florek, LEX 2011 oraz A. Marek, Odwołanie pracownika..., s. 9. Niektórzy autorzy wskazują ponadto, że odwołanie takie może mieć miejsce pod warunkiem urlopu dłuższego niż jeden dzień; por. M. Mędrala, Instytucja urlopu na żądanie z punktu widzenia interesów obu stron stosunku pracy, „Studia z zakresu prawa pracy i polityki społecznej", red. A. Świątkowski, Kraków 2008, s. 272. Choć wyrażano również początkowo pogląd, że przepis o odwołaniu pracownika z urlopu w ogóle nie może znaleźć zastosowania do urlopu na żądanie ze względu na jego szczególny charakter; tak A. Marek, Urlop..., s. 9. Por. wyrok SN z 8 marca 2017 r., II PK 26/16, LEX nr 2270901. Tamże. 
Pracownik ma również, moim zdaniem, prawo do nieujawniania informacji o miejscu swego wypoczynku ${ }^{95}$. Jest to z jednej strony pochodną zasady spokoju urlopowego, o której była wcześniej mowa, a z drugiej jego prawa do prywatności. Naruszenie tego ostatniego powinno być dopuszczalne wyłącznie na podstawie wyraźnego przepisu prawa, interpretowanego ściśle, i ograniczone do niezbędnego minimum ${ }^{96}$. W omawianym przypadku nie ma normy, która wprost ustanawiałaby taki obowiązek zatrudnionego.

Niemniej, zdaniem niektórych autorów, co w moim przekonaniu jest dyskusyjne, zobowiązanie pracownika do pozostawania w okresie urlopu w kontakcie z pracodawcą, np. telefonicznym, może wynikać z zawartej umowy o pracę bądź obowiązującego u danego pracodawcy regulaminu pracy. Rodzi to jednak pytanie, czy tego rodzaju postanowienie umowne lub regulaminowe nie pogarsza sytuacji pracownika w stosunku do gwarancji ustawowych i nie pozostaje w sprzeczności z podstawową zasadą prawa pracy - prawa pracownika do odpoczynku (art. 14 k.p.) i jako takie nie powinno zostać uznane za nieważne.

W tym zakresie bardziej przychylam się do poglądu, że tego rodzaju zobowiązanie pracownika jest dopuszczalne na podstawie art. $100 \$ 2$ pkt 4 k.p. (obowiązek pracownika dbałości o dobro pracodawcy), ale wyłącznie w sytuacjach nadzwyczajnych $^{97}$, a zatem wyjątkowo i to przede wszystkim w odniesieniu do pracowników zatrudnionych na stanowiskach kluczowych z punktu widzenia funkcjonowania danego zakładu pracy ${ }^{98}$.

Jak zauważa A. Kosut, taka interpretacja zdaje się najlepiej wypośrodkowywać interesy obu stron stosunku pracy, tj. z jednej strony chroni w podstawowym zakresie prawo pracownika do niezakłóconego urlopu wypoczynkowego, a z drugiej ułatwia pracodawcy korzystanie z omawianego uprawnienia w szczególnych przypadkach $^{99}$.

W konsekwencji realizacja prawa do odwołania pracownika z urlopu wypoczynkowego przez pracodawcę może okazać się w wielu wypadkach niełatwa. Wydanie pracownikowi polecenia powrotu do pracy może być w tym okresie wyraźnie utrudnione lub wręcz niemożliwe (jeśli np. pracownik ma wyłączony telefon, zostawił go w domu, pracodawca nie dysponuje informacją o miejscu jego pobytu).

Jednocześnie należy w każdej sytuacji wymagać także, by decyzja pracodawcy o odwołaniu pracownika z urlopu została przekazana bezpośrednio pracownikowi i w taki sposób, który nie budzi wątpliwości co do intencji pracodawcy. Zwrócono

95 Odmiennie por. m.in. J. Wratny, Kodeks pracy. Komentarz, Warszawa 2013, s. 425. Na ten temat nieco inaczej też K. Płaczek, Prawo pracownika..., s. 359. Autorka wskazuje, że zobowiązanie pracownika do umożliwienia pracodawcy kontaktu z nim „nie powinno być uznane za niedopuszczalne co do zasady".

96 Por. M. Wujczyk, Prawo pracownika do ochrony prywatności, Warszawa 2012, s. 285.

97 Tak K. Jaśkowski, E. Maniewska, Komentarz aktualizowany..., LEX/el. 2017.

98 Tak też m.in. A. Kosut, Kodeks pracy. Komentarz, s. 917 i n. Podobnie: E. Chmielek-Łubińska, [w:] Kodeks pracy..., Warszawa 2009, s. 917 oraz A. Marek, Odwołanie..., s. 9.

99 Por. A. Kosut, Kodeks pracy. Komentarz, s. 917. 
na to uwagę w wyroku SN z 8 marca 2017 r. ${ }^{100}$, w którym SN podkreślił, że skoro odwołanie $\mathrm{z}$ urlopu stanowi ograniczenie konstytucyjnego prawa pracownika do wypoczynku, pracodawca korzystający z tej możliwości powinien to uczynić w jednoznacznym oświadczeniu woli, które wywołuje skutek z chwilą złożenia go pracownikowi w taki sposób, aby mógł zapoznać się z jego treścią. Nie można wymagać od pracownika, aby „odczytywał intencję pracodawcy odwołania $z$ urlopu z faktów konkludentnych".

Elementem analizowanego uprawnienia pracodawcy, który ma przeciwdziałać jego nadmiernemu wykorzystywaniu w praktyce, $\mathrm{z}$ pewną szkodą dla pracowniczego prawa do odpoczynku, jest zobowiązanie pracodawcy do pokrycia kosztów bezpośrednio związanych z takim odwołaniem. Stanowi to niewątpliwie dość skuteczny instrument ochronny, powodując powstanie po stronie pracodawcy stosunkowo wysokich wydatków dotyczących takiego odwołania. Mimo że ustawodawca ogranicza bowiem obowiązek pracodawcy do kosztów, które powstały bezpośrednio wskutek odwołania, a więc takich, których pracownik nie poniósłby, gdyby go z urlopu do pracy nie wezwano ${ }^{101}$, to jednak niemal powszechnie przyjmuje się, że należy do nich niewątpliwie koszt wykupionych wczasów, uiszczone z góry opłaty za pobyt w hotelu lub na prywatnej kwaterze pracownika i jego rodziny, w zakresie w jakim pracownik z tego nie skorzystał i nie uzyskał zwrotu wpłaconych kwot, dodatkowe koszty powrotu pracownika wraz z najbliższymi do miejsca zamieszkania ${ }^{102}$, a nawet, zdaniem części komentatorów, koszty imprez kulturalnych, turystycznych i rozrywkowych, w których odwoływany zamierzał uczestniczyćc ${ }^{103}$. Muszą być to przy tym koszty rzeczywiście przez zatrudnionego poniesione oraz, jak chcą niektórzy autorzy, odpowiednio udokumentowane ${ }^{104}$.

Poza zakresem działania analizowanego przepisu pozostają natomiast wszelkie koszty o charakterze pośrednim, jak np. zakupiony specjalnie w związku z wyjazdem sprzęt czy utracony zarobek (jeśli pracownik zdecydował się wykonywać w tym czasie inną pracę, którą musiał przerwać w związku z odwołaniem). Dotyczy to jednak sytuacji zgodnego z prawem odwołania pracownika z urlopu. Jak

100 Por. wyrok SN z 8 marca 2017 r., II PK 26/16.

101 Por. tak: Ł. Pisarczyk, [w:] Kodeks pracy..., LEX 2011. Jak się wydaje, szersze rozumienie pojęcia „kosztów bezpośrednich” zaproponował A. Malinowski, zdaniem którego chodzi o obowiązek pracodawcy pokrycia kosztów poniesionych przez pracownika w celu „wykupienia, zaplanowania lub wyposażenia całego zamierzenia urlopowego". A zatem będą to nie tylko koszty, których pracownik by nie ponióst, gdyby go pracodawca nie odwołat, ale także koszty, które by nie powstały, gdyby pracownik „nie przebywał na urlopie”; por. tenże, Urlopy pracownicze. Komentarz, Warszawa 2010, s. 139.

102 Powiązane choćby z koniecznością nabycia nowych biletów, przy braku możliwości zwrotu wcześniej zakupionych, lub dodatkową opłatą z tego tytułu. Słusznie jednak wskazuje się, że pracownik nie uzyska zwrotu kosztów poniesionych w związku z podróżą własnym samochodem, które są zasadniczo niezmienne niezależnie od daty powrotu; por. Ł. Pisarczyk, [w:] Kodeks pracy..., LEX 2011.

103 Tak A. Świątkowski, Kodeks pracy..., s. 687.

104 Tak m.in. A. Wypych-Żywicka, [w:] Kodeks pracy z komentarzem, LEX 2004. Zob. też B. Lenart, Przerwanie urlopu wypoczynkowego, „Służba Pracownicza” 2003, nr 6, s. 22. 
wcześniej sygnalizowano, w razie wezwania pracownika $\mathrm{z}$ urlopu do pracy z naruszeniem art. $167 \$ 1$ k.p., pracownik może dochodzić wówczas na podstawie przepisów prawa cywilnego (art. 361 i 471 k.c. w związku z art. 300 k.p.) pokrycia pełnej poniesionej przez niego $\mathrm{z}$ tego powodu szkody ${ }^{105}$.

Biorąc pod uwagę wybitnie dysfunkcjonalny charakter omawianego unormowania z punktu widzenia urzeczywistnienia prawa pracownika do odpoczynku, dziwić może natomiast, że ustawodawca nie zdecydował się zakwalifikować zachowania pracodawcy polegającego na niezgodnym z prawem odwołaniu z urlopu do kategorii wykroczeń przeciwko prawom pracownika ${ }^{106}$.

Konsekwencją zastosowania omawianej w tym punkcie instytucji, poza obowiązkiem pokrycia kosztów poniesionych przez pracownika w bezpośrednim związku z odwołaniem go z urlopu, jest konieczność udzielenia pracownikowi niewykorzystanej przez niego z tego powodu części urlopu wypoczynkowego.

W przepisach prawa pracy nie zostało wyraźnie sprecyzowane, kiedy i w jakim trybie do udzielenia takiego urlopu powinno dojść. Przyjmując, że odwołanie z urlopu stanowi przerwanie odpoczynku pracownika przez pracodawcę, trudno, według mnie, mówić na gruncie art. 167 k.p. o zobowiązaniu tego ostatniego do ewentualnego kontynuowania urlopu do ustalonej pierwotnie daty, po ustaniu przyczyny uzasadniającej wezwanie pracownika do pracy. Raczej należy chyba wówczas przyjąć, że jego ewentualne dalsze wykorzystywanie w zaplanowanych wcześniej ramach czasowych będzie możliwe wyłącznie, jeśli wolę taką wyrazi pracownik, w zależności od konkretnych okoliczności towarzyszących danemu odwołaniu (w tym zwłaszcza od okresu objętego wezwaniem, długości urlopu i kolejnych planów urlopowych tego pracownika). Urlop przerwany okresem wykonywania pracy traci bowiem zasadniczo swe podstawowe właściwości, a w wielu wypadkach „powrót” do jego wykorzystywania staje się po prostu bezcelowy, co trzeba w istocie wiązać z jego zakończeniem.

Kwestia ta może być postrzegana też inaczej, tj. że skoro pracodawca „jedynie” przerywa urlop, to po okresie przerwy pracownik dalej swoje prawo realizuje ${ }^{107}$, co trudno jednak, w moim odczuciu, zaaprobować, mając na względzie istotę i przeznaczenie tytułowej instytucji.

Niezależnie od powyższego powstaje jednak pytanie, w jakim terminie pracownik będzie mógł uzyskać tę część urlopu wypoczynkowego, której nie wykorzystał w związku z odwołaniem ${ }^{108}$. Zwraca uwagę, że cytowany już wcześniej $₫ 5$ tzw.

105 Por. m.in. na ten temat: A. Marek, Odwołanie..., s. 11.

106 Zob. też A. Bigaj, Prawo do urlopu..., s. 284.

107 Między innymi Ł. Pisarczyk wyraził opinię, że literalne brzmienie przepisów wskazuje, że po ustaniu przyczyny odwołania pracownik powinien kontynuować urlop, co jednak, jak zauważa równocześnie autor, budzi pewne wątpliwości; por. tenże, [w:] Kodeks pracy..., LEX 2011.

108 Bez względu na to, czy przyjmie się zaprezentowany wyżej sposób rozumienia przepisu, tj. że po odwołaniu z urlopu dalsza jego część powinna być udzielona w innym terminie, czy też, że pracownik powinien kontynuować urlop po okresie wykonywania pracy w związku z odwołaniem, jeżeli planowo ten urlop jeszcze trwa, zawsze powstaje jakaś część urlopu wypoczynkowego, która wskutek wezwania do pracy nie została zrealizowana. 
rozporządzenia urlopowego, w którym sformułowano wymóg udzielenia pracownikowi niewykorzystanego urlopu $\mathrm{w}$ terminie $\mathrm{z}$ nim uzgodnionym, dotyczy bezpośrednio jedynie okoliczności uzasadniających przesunięcie urlopu na termin inny niż określony w planie urlopów (lub ustalony indywidualnie z pracownikiem), a nie tych powodujących jego przerwanie. Nie jest więc do końca jasne, czy wspomniana reguła odnosi się również do odwołania pracownika z urlopu.

Biorąc pod uwagę literalne brzmienie tego unormowania, można uznać, że obejmuje ono swym zakresem jedynie przesunięcie urlopu, o którym wprost w tych kategoriach stanowi Kodeks pracy (art. 164 i 165 k.p.), co oznacza w konsekwencji, że pracownik, którego urlop został przerwany przez pracodawcę, będzie w nieco gorszej sytuacji niż gdyby jego urlop został przesunięty, ma on bowiem prawo do niewykorzystanej części urlopu, ale, z braku odmiennych uregulowań, w terminie, o którym ostatecznie zadecyduje przede wszystkim pracodawca (korekta planu lub indywidualne ustalenia).

Wydaje się, że można jednak bronić również tezy, że odwołanie z urlopu, które ze swej natury uniemożliwia realizację prawa pracownika do odpoczynku, także w jakimś sensie powoduje konieczność udzielenia tego urlopu (w zależności od przyjętej wykładni - dni, w których wezwany świadczył pracę, lub całej pozostałej części urlopu niewykorzystanej w związku z takim odwołaniem) w czasie innym niż wcześniej planowano, a zatem oznacza w rezultacie jego przesunięcie na inny termin, uzgodniony, jak wynika $\mathrm{z} \$ 5$ tzw. rozporządzenia urlopowego, z pracownikiem. Wówczas też, pracownik, co było podnoszone we wcześniejszych rozważaniach dotyczących tego przepisu, zyskuje znaczący wpływ na wyznaczenie kolejnego terminu tego urlopu. Trudno wszak przyjąć, że pracodawca, który spowodował, że pracownik nie mógł wykorzystać urlopu zgodnie z pierwotnymi ustaleniami, będzie następnie narzucać ten termin pracownikowi ${ }^{109}$.

Podobną interpretację zaproponował Ł. Pisarczyk, który uznał z kolei, że przerwanie urlopu będące skutkiem odwołania należy w zasadzie traktować jako ważną przyczynę uzasadniającą przesunięcie terminu urlopu na wniosek pracownika, którego odrzucenie byłoby dopuszczalne jedynie w razie niemożności jego pogodzenia z koniecznością zachowania prawidłowej organizacji procesu pracy ${ }^{110}$.

Uzgadniając nowy termin urlopu, strony muszą mieć na uwadze, że zasadniczo powinien on przypadać w tym samym roku kalendarzowym.

Moim zdaniem, aby odpowiednio zabezpieczyć prowypoczynkową funkcję omawianego urlopu, należy poważnie rozważyć zmianę obowiązującej regulacji prawnej w kierunku wyraźnego zagwarantowania pracownikowi, którego moment rozpoczęcia urlopu pracodawca przesuwa z przyczyn leżących po jego stronie,

109 Por. A. Dubowik, Zasady udzielania urlopów wypoczynkowych według nowych przepisów, PiZS 1997, nr 4, s. 20. O odwołaniu jako szczególnej formie przesunięcia urlopu por. też I. Wolberg, Planowanie i przesuwanie..., s. 43. Na zastosowanie powołanego przepisu rozporządzenia również przy odwołaniu z urlopu wskazuje M. Nałęcz; por. tenże, Kodeks pracy..., 2007, s. 768.

110 Por. Ł. Pisarczyk, [w:] Kodeks pracy..., LEX 2011. 
o czym była mowa wcześniej, lub którego urlop w związku z odwołaniem zostaje przerwany, prawa do wskazania innego, wiążącego pracodawcę terminu jego wykorzystania, bezpośrednio po ustaniu przyczyn uzasadniających takie przesunięcie czy odwołanie. Tego rodzaju zobowiązanie pracodawcy odnośnie do terminu udzielenia pracownikowi urlopu w istocie będzie minimalizować ryzyko występowania sytuacji, w których „odkłada się”, nie zawsze w sposób w pełni zgodny $\mathrm{z}$ prawem, udzielenie niewykorzystanego z przyczyn leżących po stronie pracodawcy w zaplanowanym terminie urlopu na bliżej nieokreślony czas, w praktyce najczęściej na kolejny rok kalendarzowy, co w istotnym stopniu zagraża prawidłowej realizacji podstawowej funkcji tego świadczenia.

Konkludując, trzeba przyjąć, że choć instytucja odwołania pracownika z urlopu wypoczynkowego jest generalnie usprawiedliwiona ochroną słusznego interesu pracodawcy, którego dobra kondycja przekłada się też pośrednio na sytuację samego zatrudnionego, to jednak nie może być nadużywana. Wprowadza ona wyraźny wyłom w prawie pracownika do odpoczynku, zakłóca prawidłowy przebieg głównej funkcji urlopu, stąd przepisy ją statuujące powinna cechować większa precyzja, zwłaszcza w zakresie zasad jej realizacji i konsekwencji skorzystania przez pracodawcę $\mathrm{z}$ omawianego uprawnienia, a ponadto muszą one podlegać ścisłej wykładni. Jednocześnie ustawodawca winien mieć na uwadze konieczność minimalizowania skutków negatywnego oddziaływania analizowanych przepisów na podstawowe, konstytucyjne prawo pracownika do odpoczynku, co wymaga przyznania również temu ostatniemu pewnych uprawień związanych z odwołaniem, do których poza zwrotem kosztów poniesionych na organizację urlopu należałoby zaliczyć w szczególności także prawo wskazania terminu, w którym niewykorzystana część urlopu miałaby być przez pracodawcę udzielona.

\section{Urlop na żądanie}

Instytucja urlopu na żądanie została wprowadzono do Kodeksu pracy nowelą z lipca 2002 r. ${ }^{111}$ i generalnie cieszy się dużą akceptacją ze strony pracowników. Niemniej jej pogłębiona analiza z perspektywy funkcji wypoczynkowej urlopu wskazuje na kilka co najmniej kontrowersyjnych kwestii, jakie wiążą się z tym urlopem. Trudno tu o jednoznacznie negatywną ocenę, nie można bowiem wykluczyć, że urlop ten zostanie wykorzystany na odpoczynek, w szczególności w połączeniu z dniami ustawowo wolnymi od pracy. Trzeba jednak przyznać, że jego konstrukcja, oparta dodatkowo na lakonicznie sformułowanych przepisach, w dużej mierze temu przeczy.

111 Por. ustawa z dnia 26 lipca 2002 r. o zmianie ustawy - Kodeks pracy oraz o zmianie niektórych innych ustaw, Dz. U. 2002, Nr 135, poz. 1146. 
Zgodnie z podstawowym w tym zakresie art. $167^{2}$ k.p., pracodawca jest zobowiązany udzielić na żądanie pracownika i w terminie przez niego wskazanym nie więcej niż cztery dni urlopu w każdym roku kalendarzowym. Pracownik zgłasza żądanie udzielenia urlopu najpóźniej w dniu jego rozpoczęcia.

Przede wszystkim kwestią zasadniczą z punktu widzenia prowadzonych rozważań jest niejasne przeznaczenie omawianego urlopu. Z jednej strony należy bowiem przyjąć, jak czyni większość przedstawicieli doktryny prawa pracy, że ów maksymalnie 4-dniowy urlop w danym roku kalendarzowym stanowi część urlopu wypoczynkowego pracownika i mieści się w jego wymiarze ${ }^{112}$. Wskazuje na to bezpośrednio zarówno usytuowanie powołanego wyżej przepisu w dziale siódmym Kodeksu pracy poświęconym właśnie tej kategorii urlopów, jak i treść art. 168 k.p., z której wynika, że wyjątek od zasady urlopu corocznego (dotyczącej wprost urlopów wypoczynkowych) musi być zmodyfikowany w odniesieniu do urlopu na żądanie czy art. 163 k.p. stanowiącego o nieobejmowaniu urlopu na żądanie planem urlopowym. Ponadto przyjęcie odmiennego zapatrywania, jak trafnie zauważyła E. Chmielek-Łubińska, prowadziłoby do zmiany charakteru prawnego tego urlopu ( $w$ płatne zwolnienie udzielane $\mathrm{w}$ innych celach niż odpoczynek), a w rezultacie do uszczuplenia rocznego wymiaru urlopu wypoczynkowego pracownika ${ }^{113}$. Będzie to zatem determinować główny cel tego urlopu, jakim jest odpoczynek, co wynika nie tylko $\mathrm{z}$ istoty urlopu wypoczynkowego, ale też podstawowej zasady prawa pracy wyrażonej w art. 14 k.p. ${ }^{114}$

Powyższe zapatrywanie znalazło swój wyraz także w orzecznictwie SN. Przede wszystkim w wyroku z 16 września 2008 r. SN uznał, że urlop na żądanie stanowi część urlopu wypoczynkowego i ma identyczny do urlopu wypoczynkowego charakter prawny ${ }^{115}$. O jego odmienności decyduje zatem jedynie szczególny tryb, w jakim ta część urlopu wypoczynkowego jest udzielana, w ramach którego to pracownik zasadniczo wyznacza jego termin.

Tymczasem już w samym uzasadnieniu projektu ustawy wprowadzającej omawiany urlop zakładano, że będzie on służyć możliwości załatwienia przez pracownika ważnych spraw osobistych lub stanie się alternatywą dla kilkudniowych zwolnień lekarskich w związku z krótkotrwałą chorobą ${ }^{116}$.

112 Por. tak m.in. E. Chmielek-Łubińska, Urlop na żq̨danie pracownika, M.P.P. 2005, nr 10, s. 213 oraz A. Sobczyk, Urlop na żądanie, PiZS 2004, nr 7, s. 12; A. Kosut, Przemiany regulacji prawnej urlopów wypoczynkowych w Kodeksie pracy, [w:] Przemiany prawa pracy..., s. 189 i n.; Ł. Pisarczyk, [w:] Kodeks pracy..., LEX 2011.

113 Por. E. Chmielek-Łubińska, Urlop na żądanie..., s. 273.

114 W ostatnim czasie chyba odmiennie A. Sobczyk, Prawo pracy w świetle Konstytucji RP, t. 1: Teoria publicznego i prywatnego indywidualnego prawa pracy, Warszawa 2013, s. 204 i n., a także M. Mędrala, która uznała, że urlop ten w założeniu powinien służyć „nagłym, bliżej niesprecyzowanym potrzebom lub sytuacjom losowym pracownika"; por. taż, Instytucja urlopu..., s. 267.

115 Por. wyrok SN z 16 września 2008 r., II PK 26/08, OSNP 2010, nr 3-4, poz. 36.

116 Por. A. Kosut, Urlop na żądanie, [w:] Studia z prawa pracy. Księga pamiątkowa ku czci Docenta Jerzego Logi, Łódź 2007, s. 155. 
Powyższe sugeruje, że zamiarem ustawodawcy było więc nie tyle zagwarantowanie pracownikowi możliwości krótkotrwałego odpoczynku, o którego terminie mógłby sam zadecydować, ale przeznaczenie części urlopu wypoczynkowego na załatwienie przez pracownika określonych spraw, co już w samym założeniu kłóci się ewidentnie z wypoczynkową funkcją tego urlopu.

Początkowo, w ślad za projektodawcami, urlop ten bywał tak postrzegany również w judykaturze. W uzasadnieniu do wyroku z 26 stycznia 2005 r. SN przyjął, że celem omawianego unormowania jest umożliwienie pracownikowi załatwienia spraw osobistych w terminie dla niego dogodnym bez konieczności informowania o nich pracodawcy ${ }^{117}$.

Niemniej i obecnie, choć już niemal powszechnie uznaje się ten urlop za część urlopu wypoczynkowego, zdarzają się orzeczenia, w których wskazuje się jednocześnie, że jego specyficzny charakter polega na przyznaniu pracownikowi szczególnego przywileju, by w sytuacjach nagłych i niedających się przewidzieć, „Związanych z zaistnieniem różnorakich sytuacji życiowych, mógł nie stawić się do pracy"118.

Trudno zatem, jak można przypuszczać, w praktyce orzeczniczej zniwelować pewien dysonans między zakwalifikowaniem tego urlopu jako wypoczynkowego a jego mało prowypoczynkową konstrukcją.

Trzeba też zauważyć, że urlop na żądanie bardzo często jest w ten sam sposób traktowany przez samych uprawnionych i wykorzystywany w zupełnie innych celach niż wypoczynek, w tym zwłaszcza na załatwienie pilnych spraw czy leczenie. Co więcej, wielokrotnie instytucja ta służyła do wywierania określonej presji na pracodawców, jako forma pracowniczego protestu, a więc w celach zasadniczo odmiennych od jej prawnego przeznaczenia ${ }^{119}$. Legalność tego rodzaju działań została zresztą w doktrynie prawa pracy dość szybko podważona ${ }^{120}$.

Pomijając powyższe przypadki ewidentnego wykorzystywania urlopu w sposób sprzeczny z jego przeznaczeniem, słusznie podnosi się, że w rzeczywistości od pracownika w gruncie rzeczy zależy, na jaki cel ten urlop zostanie ostatecznie przeznaczy. W Kodeksie pracy nie określono bowiem szczególnych okoliczności, które uzasadniałyby udzielenie pracownikowi takiego urlopu, pracownik nie musi

117 Por. wyrok SN z 26 stycznia 2005 r., II PK 197/04, www.sn.pl

118 Por. wyrok Sądu Apelacyjnego w Warszawie z 23 listopada 2016 r., III APa 61/15, LEX nr 2256929.

119 Por. szerzej K. Serafin, Urlop na żądanie a pracownicze formy protestu, [w:] Z zagadnień wspótczesnego prawa pracy. Księga jubileuszowa Profesora Henryka Lewandowskiego, red. Z. Góral, Warszawa 2009, s. 210 i n.; T. Wrocławska, Kontrowersje wokół prawa do urlopu na żądanie (ze szczególnym uwzględnieniem statusu prawnego lekarzy), [w:] Z zagadnień współczesnego prawa pracy..., s. 365 i n. Zob. też na ten temat G. Orłowski, Urlop na żadanie jako pozastrajkowa forma protestu, M.P.P. 2007, nr 9, s. 452.

120 K. Serafin zdecydowanie uznaje za nielegalną taką formę pracowniczego prostu, m.in. z uwagi na wykorzystywanie przez pracownika swojego uprawnienia urlopowego w sposób sprzeczny z jego przeznaczeniem; por. taż, Urlop na żądanie..., s. 216 i n. Podobnie T. Wrocławska, Kontrowersje wokót prawa..., s. 374 i n. 
zatem swojego wniosku uzasadniać, ale też jego decyzja w tej kwestii zasadniczo nie podlega kontroli ${ }^{121}$.

Wypoczynkowej funkcji, jaką urlop ten powinien ze swej istoty realizować, nie sprzyja także jego nagłość i nieznaczny wymiar. Pracownik ma bowiem prawo do czterech dni urlopu na żądanie w roku kalendarzowym, które może zrealizować jednorazowo lub w częściach, w tym też rozłożyć na pojedyncze dni ${ }^{122}$. Stanowi to poważny wyłom w zasadzie urlopu w całości, której idea opiera się na przekonaniu, że urlop, aby spełnił swą podstawową funkcję, powinien być wykorzystany w pełnym, przysługującym pracownikowi wymiarze, a przynajmniej w jego istotnej części, tak, by biorąc pod uwagę choćby aspekt fizjologiczny, mogło dojść do faktycznej regeneracji psychofizycznej organizmu w związku z wykonywaną pracą.

W tym kontekście warto też zwrócić uwagę, że urlop ten może spowodować w pewnych sytuacjach, że podział urlopu wypoczynkowego na części dokona się $\mathrm{z}$ naruszeniem wprowadzonego wymogu, by jedna $\mathrm{z}$ tych części obejmowała nie mniej niż 14 kolejnych dni kalendarzowych, którego znaczenie dla urzeczywistnienia wypoczynkowej funkcji tej instytucji było wcześniej szerzej omawiane. Chodzi o urlop proporcjonalny, który nawet jeśli przysługiwałby w wymiarze gwarantującym możliwość zachowania wspomnianej reguły, w związku z wystąpieniem przez pracownika z omawianym żądaniem może zmniejszyć się na tyle, że pozostała jego część nie pozwoli na jej realizację. Jeżeli jednak, mimo czterech dni urlopu na żądanie, ogólny wymiar urlopu pracownika umożliwia zachowanie powyższej zasady, wówczas po wykorzystaniu urlopu na żądanie jego dalszy podział musi dokonywać się z jej uwzględnieniem ${ }^{123}$.

Liczba dni, jaką pracownik może na żądanie wykorzystać, jest niezależna od przysługującego mu ogólnego wymiaru urlopu, a także, co wzbudziło wiele wątpliwości w literaturze i praktyce, szczególnie w związku z brakiem wyjaśnienia pojęcia dnia urlopu na żądanie, wymiaru czasu pracy tego pracownika. Zatrudnienie na część etatu, jak wskazywano wcześniej, wpływa na ogólny wymiar urlopu wypoczynkowego pracownika, nie ma jednak podstaw, by ową regułę proporcjonalnego ustalania tego wymiaru odnosić do liczby dni urlopu na żądanie. Wywołuje to liczne problemy, zwłaszcza że ustawodawca nie wyłączył wprost w stosunku do urlopu na żądanie stosowania reguły, że jeden dzień urlopu odpowiada ośmiu godzinom pracy. Prowadzi to w przypadku osób zatrudnionych na część etatu, wykonujących pracę od poniedziałku do piątku, ale w niskim wymiarze godzinowym (np. po jednej czy dwie godziny) do nieco absurdalnych wniosków, że niemal cały swój urlop lub znaczną jego część mogą na żądanie wykorzystać $(4 \times 8=32$ godziny urlopu), co nie było z pewnością intencją ustawodawcy. Odwrotny problem

121 Por. K. Serafin, Urlop na żądanie..., s. 208 i n. Zob. też E. Chmielek-Łubińska, Urlop na żądanie pracownika, PiZS 2003, nr 3, s. 26.

122 Por. M. Nałęcz, [w:] Kodeks pracy..., 2013, s. 534; E. Staszewska, [w:] M. Kuba, M. Nowak, E. Staszewska, Urlopy pracownicze, s. 80 i n.

123 Por. E. Chmielek-Łubińska, Urlop na żądanie pracownika, PiZS 2003, s. 27. 
dotyczy osób zatrudnionych w systemie równoważnym, których dobowy wymiar czasu pracy może być wyższy niż osiem godzin.

$\mathrm{W}$ piśmiennictwie z zakresu prawa pracy sformułowano różne propozycje rozwiązania powyższego problemu ${ }^{124}$. Kierując się literalnym brzmieniem przepisów oraz funkcją urlopu wypoczynkowego, którego urlop na żądanie jest częścią, należałoby przyjąć, że urlop ten na ogólnych zasadach kodeksowych powinien być przeliczany na godziny (ustawodawca stanowi wyraźnie o „dniach urlopu” na żądanie). Dominuje chyba ostatecznie przekonanie, że urlop ów musi być liczony w dniach, niezależnie od dobowego wymiaru czasu pracy w dniu, w którym pracownik z tego urlopu korzysta ${ }^{125}$. Taka interpretacja, zdaniem niektórych autorów, bardziej odpowiada jednak założeniu, że przeznaczeniem tego urlopu jest załatwienie spraw osobistych, wówczas wartością jest bowiem wolny dzień, niezależnie od przypadającej na niego ilości godzin pracy ${ }^{126}$.

Trzeba jednak wyraźnie stwierdzić, że żadna z możliwych interpretacji dokonywanych na gruncie analizowanych przepisów nie jest pozbawiona wad, stąd kwestia ta powinna zostać wyraźnie rozstrzygnięta przez ustawodawcę.

Wniosek o udzielenie takiego urlopu należy, zgodnie z literalnym brzmieniem przepisu, złożyć najpóźniej w dniu jego rozpoczęcia, co samo w sobie sugeruje, że na decyzję pracownika $w$ tym przedmiocie wpływ mogą mieć jakieś nieprzewidziane zdarzenia, zupełnie niepowiązane $\mathrm{z}$ wypoczynkiem. Zwrot ten wzbudził wiele kontrowersji zarówno w doktrynie, jak i orzecznictwie ${ }^{127}$, niemniej zgodnie z ugruntowaną już, jak się wydaje, wykładnią, pracownik powinien z nim wystąpić najpóźniej w dniu, w którym zamierza skorzystać z urlopu, ale przed godziną rozpoczęcia pracy wynikającą z obowiązującego go rozkładu czasu pracy ${ }^{128}$.

Co więcej, nadzwyczajny charakter tego urlopu eksponuje się również czasami w orzecznictwie, szczególnie gdy chodzi o sądy niższej instancji. W jednej ze spraw przyjęto np., że złożenie przez pracownika wniosku o urlop na żądanie z tygodniowym wyprzedzeniem uzasadnia odmowę jego udzielenia, jako że „wynikający z art. $167^{2}$ k.p. obowiązek pracodawcy udzielenia takiego urlopu ma na celu uwzględnienie nadzwyczajnych sytuacji, które powodują, że pracownik w danym terminie nie może świadczyć pracy" ${ }^{129}$. Stąd, jak ocenił sąd, wystąpienie o urlop na żądanie ze znacznym wyprzedzeniem wypacza jego sens.

Trudno zgodzić się $\mathrm{z}$ wykładnią zaproponowaną $\mathrm{w}$ powołanym orzeczeniu, chyba że przyjmuje się, że jest to urlop na załatwienie spraw pilnych, nagłych, a nie

124 Zob. A. Sobczyk, Urlop na żądanie, s. 16; E. Chmielek-Łubińska, Urlop na żądanie pracownika, M.P.P. 2005, s. 274; T. Nycz, Nowe zasady urlopowe, M.P.P. 2004, nr 3, s. 69 i n.

125 Por. M. Chakowski, P. Ciszek, Kontrowersje wokół tzw. urlopu na żadanie a orzecznictwo SN, M.P.P. 2010, nr 3, s. 131.

126 Por. A. Sobczyk, Urlop na żądanie, s. 16.

127 Por. na ten temat: tamże, s. 13 i n.

128 Por. wyrok SN z 15 listopada 2006 r., I PK 128/06, OSNP 2007, nr 23-24, poz. 346.

129 Por. wyrok Sądu Rejonowego w Ostrołęce z 24 lipca 2008 r.; por. uzasadnienie do wyroku SN z 28 października 2009 r., II PK 123/09. 
na odpoczynek. Jeśli jest to bowiem urlop wypoczynkowy, to z punktu widzenia jego funkcji, a także zabezpieczenia interesów pracodawcy, korzystne jest, jeśli pracownik zgłasza ów wniosek wcześniej. Daje to bowiem pracownikowi możliwość przygotowania owego wypoczynku, a pracodawcy podjęcia działań w celu zachowania właściwej organizacji pracy w zakładzie. Sam przepis, co trzeba wyraźnie podkreślić, zawiera wskazanie jedynie najpóźniejszego terminu złożenia takiego wniosku, a nie obowiązek, by żądanie w przedmiotowej sprawie zostało sformułowane w dniu, który ma być objęty urlopem.

Generalnie trzeba jednak przyznać, że zarówno wymiar owego urlopu, jak i prawo pracownika do wystąpienia o taki urlop w dniu jego rozpoczęcia zdecydowanie lepiej wpisują się w konstrukcję zwolnienia od pracy, o charakterze okolicznościowym, w tym przypadku na załatwienie ważnych spraw osobistych pracownika. Wypoczynek, jak była o tym wcześniej mowa, dla osiągnięcia swej pełnej efektywności powinien trwać dłuższy czas, a nie jeden czy dwa dni, a jego realizacja wymaga pewnej organizacji.

Kwestia ta bywa też podnoszona w judykaturze. W jednym $\mathrm{z}$ wyroków uznano urlop na żądanie za część urlopu wypoczynkowego, zauważając jednocześnie, że możliwość zgłoszenia żądania w dniu jego rozpoczęcia wskazuje, że zasadniczo „nie zmierza on do zaspokojenie potrzeb regneracyjno-rekreacyjnych"130.

Konsekwencją możliwości wystąpienia przez pracownika o urlop na żądanie $\mathrm{w}$ wybranym przez niego terminie, nawet $\mathrm{w}$ dniu, w którym chce korzystać $\mathrm{z}$ urlopu, jest wyłączenie tych dni z procedury planowania urlopu wypoczynkowego, wynikającej z art. 163 k.p.

Warto nadmienić, że w praktyce nie zawsze jest to sprawą prostą, zwłaszcza $\mathrm{z}$ uwagi na problemy powstające na tle pojęcia dnia urlopu na żądanie, o których wspomniano już wcześniej ${ }^{131}$.

Dyskusyjne jest również, czy ustalając terminy urlopów pracowników, należy te dni zupełnie z planu wyłączyć, jak zdaje się sugerować treść przepisu, ryzykując, że nie zostanie on w danym roku wykorzystany, czy też nie. Powszechnie przyjmuje się, że pracodawca nie obejmuje planem tego urlopu, co oznacza, że dni te pozostają poza nim, do dyspozycji pracownika.

Do rozważenia jest również inna, mogąca budzić jednak kontrowersje, interpretacja kodeksowego sformułowania, zgodnie z którym planem urlopu nie obejmuje się części urlopu zwanego urlopem na żądanie. Skoro ten urlop jest udzielany $\mathrm{w}$ terminie wskazanym przez pracownika $\mathrm{w}$ wymiarze nieprzekraczającym czterech dni urlopu w roku kalendarzowym, niezwiększającym puli urlopu przysługującego pracownikowi $\mathrm{w}$ danym roku, to jest oczywiste, że takiego urlopu nie można $\mathrm{z}$ góry uwzględnić $\mathrm{w}$ przyjętym planie urlopowym. W planie tym należałoby w związku z tym uwzględnić cały przysługujący pracownikowi urlop, a w razie skorzystania przez pracownika z urlopu na żądanie przed terminem objętym

130 Por. wyrok Sądu Apelacyjnego w Warszawie z 23 listopada 2016 r.

131 Por. też szerzej M. Nowak, Kilka uwag na temat planu urlopów wypoczynkowych, „Gdańsko-Łódzkie Roczniki Prawa Pracy i Prawa Socjalnego" 2015, nr 5, s. 53 i n. 
planem urlopowym, przyjęty plan powinien być skorygowany. Jeśli pracownik wykorzystał cały zaplanowany urlop wypoczynkowy, bezprzedmiotowe w danym roku staje się prawo do urlopu na żądanie. Mamy tu zatem do czynienia z inną sytuacją niż w przypadku planowania urlopu w wymiarze pomniejszonym o urlop na żądanie, z którego pracownik może do końca roku (ale nie musi) skorzystać, co może prowadzić do przekształcenia niewykorzystanego urlopu na żądanie w urlop zaległy, podlegający wykorzystaniu w zwykłym trybie.

Sygnalizowana w tym miejscu interpretacja kodeksowego przepisu o planowaniu urlopu wypoczynkowego, choć zdaje się wpisywać dobrze w zasady prawa urlopowego, nie jest jednak pozbawiona wad. Nawet przyjęcie tego rodzaju reguły może bowiem w praktyce rodzić określone problemy techniczne, np. w razie podziału urlopu na kilka części. Ktoś (najlepiej obie strony w drodze porozumienia) musiałby decydować, którą z zaplanowanych części, przy zachowaniu warunku z art. 162 k.p. ${ }^{132}$, uszczuplić o wykorzystane dni urlopu na żądanie i czy w wyniku tego działania przesunięciu ma ulec moment rozpoczęcia tej części urlopu czy też jej zakończenia. W sytuacji, gdy pracownik korzysta z urlopu na żądanie w różnym czasie (np. po jednym dniu), plan urlopów wypoczynkowych musiałby być wielokrotnie modyfikowany. Ponadto pojawiają się wątpliwości, czy przyjęcie omawianej koncepcji daje się pogodzić z treścią art. $163 \$ 1$ k.p., który stanowi, że planem urlopów nie obejmuje się części urlopu udzielanego pracownikowi na żądanie. Nawet jeśli uznać, że przemawia za tym wykładnia funkcjonalna i systemowa, to wydaje się, że potrzebna byłaby tutaj, mimo wszystko, pewna interwencja ustawodawcy, choćby w zakresie rozstrzygnięcia przykładowo wskazanych wyżej kwestii szczegółowych.

Obecnie, moim zdaniem, można rozważać zaplanowanie całego urlopu wypoczynkowego należnego danemu pracownikowi przede wszystkim wówczas, gdy sam pracownik $\mathrm{z}$ takim wnioskiem wystąpił, np. wskazując preferowany przez niego termin wykorzystania urlopu wypoczynkowego obejmujący pełny wymiar tego urlopu. Chociaż i tu pojawiają się obawy, czy nie stanowi to swego rodzaju zrzeczenia się urlopu na żądanie, szczególnie jeśli aprobuje się tezę, że pracownik chcąc cofnąć swoje oświadczenie woli w tej sprawie, będzie musiał uzyskać na to zgodę pracodawcy.

Zdaniem E. Chmielek-Łubińskiej, urlop na żądanie należy z planu wyłączyć, ale w sytuacji, gdy dochodzi do udzielenia urlopu w ustalonym terminie, to od pracownika zależy, czy pozostawi je do wykorzystania w terminie późniejszym czy też włączy je do urlopu, by zrealizować go w pełnym wymiarze ${ }^{133}$.

Pojawia się jednak wówczas obawa, czy pracownik, ze względu na przyjętą wykładnię, zgodnie z którą żądanie pracownika nie jest dla pracodawcy bezwzględnie wiążące, o czym niżej, będzie mógł skutecznie wyegzekwować urlop w tym terminie. Zdaje się za tym przemawiać, ważna z punktu widzenia wypoczynkowej

132 W przepisie tym ustawodawca wymaga, by jedna część wypoczynku obejmowała nie mniej niż 14 kolejnych dni kalendarzowych.

133 Por. E. Chmielek-Łubińska, Urlop na żądanie..., 2003, s. 29. 
funkcji urlopu, zasada urlopu w całości, która wyłącza swobodę pracodawcy w zakresie możliwości dokonywania podziału urlopu pracownika na części.

Z punktu widzenia zachowania możliwości optymalnej realizacji głównego celu urlopu, pewne znaczenie ma również skutek niewykorzystania przez pracownika tego urlopu w danym roku kalendarzowym. W tym zakresie nie ma chyba wątpliwości co do tego, że urlop na żądanie nie podlega kumulacji, stąd nie może być przenoszony przy zachowaniu szczególnego trybu jego udzielania na kolejny rok kalendarzowy. Nowy rok kalendarzowy to nowy urlop na żądanie wynikający $\mathrm{z}$ prawa do bieżącego urlopu, a niewykorzystane dni urlopu z roku poprzedniego tracą z końcem tego roku swój specyficzny charakter.

Kontrowersje powstają jednak na tle bardzo nieprecyzyjnie sformułowanego art. 168 k.p., w którym stanowi się, że urlopu niewykorzystanego w terminie pierwotnie ustalonym należy pracownikowi udzielić najpóźniej do końca trzeciego kwartału następnego roku kalendarzowego, ale „nie dotyczy to części urlopu udzielonego zgodnie $\mathrm{z}$ art. 1672”, a zatem urlopu na żądanie. W piśmiennictwie zarysowały się w tej kwestii dwa odmienne stanowiska.

Część autorów, moim zdaniem słusznie uznaje, że przepis ten powoduje jedynie, że urlop na żądanie w kolejnym roku kalendarzowym traci swój szczególny charakter, a zatem okres jego wykorzystania podlega uzgodnieniu między stronami, i że stając się „zwykłym” urlopem wypoczynkowym musi być udzielony w terminie podanym w komentowanym przepisie ${ }^{134}$. Trudno znaleźć bowiem racjonalne uzasadnienie dla takiego wyłączenia.

Równie często jednak znawcy przedmiotu (w tym inspektorzy pracy ${ }^{135}$ ) interpretują tę regulację jako wyłączającą w ogóle urlop na żądanie spod zakresu jej działania, co w konsekwencji prowadzi do konstatacji, że termin wykorzystania tych dni urlopowych, które w kolejnym roku stają się „zwykłym urlopem wypoczynkowym", może przypadać także po dacie określonej w art. 168 k.p., tj. po 30 września następnego roku kalendarzowego ${ }^{136}$.

Ostatni pogląd niewątpliwie nie uwzględnia podstawowego celu omawianego urlopu, jakim jest wypoczynek, którego realizacja jest tym efektywniejsza, im znajduje większe powiązanie, także czasowe, $\mathrm{z}$ wykonywaną pracą. Urlop powinien być więc z zasady wykorzystywany w roku jego nabycia, a wyjątkowo jedynie w kolej-

134 Tak m.in. K. Jaśkowski (red.), E. Maniewska, Kodeks pracy, t. 1: Komentarz. Ustawy towarzyszące z orzecznictwem. Europejskie prawo pracy z orzecznictwem, wyd. IX, LEX 2014 [dostęp 20.08.2014]; T. Liszcz, Prawo pracy, 2004, s. 373; E. Chmielek-Łubińska, Urlop na żądanie..., 2003, s. 28.

135 Por. pismo Departamentu Prawnego Głównego Inspektoratu Pracy z 7 kwietnia 2008 r., GIP GPP-110-4560-170/08/PE, „Rzeczpospolita”, 9.04.2008.

136 A. Marek, Urlop na żq̨danie, s. 8. Zdaniem przywołanego autora, urlop może być udzielony wówczas do końca następnego roku kalendarzowego. Bywają formułowane również opinie, że skoro, według przyjętej interpretacji, przepisy prawa pracy nie obligują do udzielenia tego urlopu w terminie określonym w komentowanym art. 168 k.p., to pracownik może z niego skorzystać w ciągu kolejnych trzech lat, tj. do upływu okresu przedawnienia; tak por. A. Podgórska, Urlop na żq̨danie, s. 20. 
nym roku kalendarzowym. Trudno natomiast wytłumaczyć dopuszczenie przez ustawodawcę tak sprzecznego z podstawową funkcją urlopu wypoczynkowego wyjątku w odniesieniu do niewykorzystanego urlopu na żądanie, w odniesieniu do których to dni możliwe byłoby swobodne odsuwanie w czasie momentu udzielenia przez pracodawcę (nawet o kilka lat) stosownego zwolnienia. Jest on częścią urlopu wypoczynkowego, a nie odrębnym bytem, w kolejnym roku staje się zatem „Zwykłym” urlopem zaległym, który musi być udzielony pracownikowi zgodnie z ogólnymi regułami prawa urlopowego, w tym również dotyczącymi maksymalnego terminu jego wykorzystania.

Z ideą urlopu na żądanie jako krótkotrwałego zwolnienia od pracy w celu regeneracji sił (urlop wypoczynkowy) w terminie wskazanym przez pracownika wiąże się także ocena skuteczności przyjętych ostatecznie w tym zakresie rozwiązań prawnych.

Od stanowiącego istotę urlopu na żądanie obowiązku pracodawcy udzielenia określonej przez pracownika liczby dni urlopu (maksymalnie czterech) w wyznaczonym przez niego terminie w Kodeksie pracy nie wprowadzono bezpośrednio żadnych wyjątków. Zarówno sposób sformułowania przepisu, jak i fakt, że urlop ten stanowi część urlopu wypoczynkowego, powodują jednak, że obowiązek ten ma w gruncie rzeczy dość względny charakter. Będą generalnie do tego urlopu stosowane bowiem ogólne przepisy prawa urlopowego, z wyjątkiem tych unormowań, które zostały wprost wyłączone przez samego ustawodawcę oraz tych, które nie dają się pogodzić ze specyfiką omawianego urlopu ${ }^{137}$.

Przede wszystkim zatem wymaga zwrócenia uwagi, że urlop na żądanie, zgodnie z treścią art. $167^{2}$ k.p., jest „udzielany” przez pracodawcę. Zarówno w doktrynie prawa pracy, jak i ostatecznie w orzecznictwie przyjmuje się, że zwrot ten ma takie samo znaczenie normatywne, jakie uzyskuje w innych przepisach dotyczących reguł wykorzystywania urlopu wypoczynkowego, którego urlop na żądanie jest przecież częścią. Trudno bowiem przyjąć, że racjonalny ustawodawca posługiwałby się terminem, mającym ustalone znaczenie prawne, bez wyraźnego celu. Na tej podstawie przyjmuje się, że do wykorzystania tego urlopu nie wystarczy samo zgłoszenie jego żądania przez pracownika, ale konieczne jest również wyrażenie przez pracodawcę zgody na jego realizację (a zatem, jak przyjmuje SN, jego udzielenie $)^{138}$. Rozpoczęcie tego urlopu przed udzieleniem go przez pracodawcę może być zatem, co potwierdzono w orzecznictwie, uznane za nieusprawiedliwioną nieobecność w pracy, będącą ciężkim naruszeniem podstawowych obowiązków pracowniczych w rozumieniu art. $52 \$ 1$ pkt 1 k.p. ${ }^{139}$

137 Por. tak wyrok SN z 16 września 2008 r., II PK 26/08. W literaturze wymienia się w tym zakresie m.in. zasadę proporcjonalności czy zasadę przesunięcia terminu urlopu z inicjatywy pracodawcy; por. E. Chmielek-Łubińska, Urlop na żądanie, 2003, s. 30 i n. Kwestią kontrowersyjną jest, o czym była mowa wcześniej, dopuszczalność odwołania pracownika z urlopu na żądanie.

138 Postanowienie SN z 11 listopada 2012 r., III PK 17/12, LEX nr 2041816. Tak też w wyroku SN z 16 września 2008 r., II PK 26/08. Tak też por. m.in. A. Kosut, Urlop na żądanie..., s. 163; A. Sobczyk, Urlop na żądanie, s. 15.

139 Por. wyrok SN z 16 września 2008 r., II PK 26/08. 
Istotną implikacją praktyczną powyższego stanowiska jest jednak konieczność uznania, że jeśli pracodawca, nawet bez uzasadnionych powodów, odmówi żądaniu pracownika, naraża się wprawdzie na konsekwencje karne, ale pracownik ten nie może rozpocząć urlopu ${ }^{140}$, co, moim zdaniem, nie do końca przystaje do pierwotnych zamierzeń projektodawców.

Sam obowiązek pracodawcy udzielenia urlopu na żądanie pracownika, według, jak się wydaje, ugruntowanej już wykładni, nie ma jednak charakteru bezwzględnego. Skoro ustawodawca wprowadził wymóg udzielenia urlopu przez pracodawcę, to byłby on de facto zbędny, gdyby przyjąć, że w każdym przypadku czynność pracodawcy powinna sprowadzać się do akceptacji wniosku pracownika. Pracodawca może więc odrzucić taki wniosek ze względu na szczególne okoliczności, które powodują, że jego zasługujący na ochronę wyjątkowy interes wymaga obecności pracownika w pracy $^{141}$. Stanowisko SN w tej kwestii uwzględnia w ogólnym ujęciu postulaty zgłaszane wcześniej w tym zakresie przez przedstawicieli doktryny prawa pracy ${ }^{142}$.

Jak z powyższego wynika, urlop na żądanie nie jest urlopem, który w każdym przypadku może zostać wykorzystany przez pracownika na krótki odpoczynek w terminie przez niego wyznaczonym.

Wydaje się też, że nie każdy pracownik może swobodnie z owego prawa korzystać. Jego zakres podmiotowy również budzi pewne wątpliwości. Są grupy pracowników, w odniesieniu do których, czy to ze względu na charakter ich pracy (np. lekarze ${ }^{143}$ ), czy szczególne warunki korzystania z prawa do urlopu (nauczyciele, w tym także akademiccy ${ }^{144}$ ) bądź specyficzną formę zatrudnienia (praca tymczasowa ${ }^{145}$ ), odpowiednie stosowanie tych unormowań jest postrzegane często jako dyskusyjne.

140 Por. A. Sobczyk, Urlop na żadanie, s. 15.

141 Por. wyrok SN z 28 października 2009 r., II PK 123/09.

142 Por. m.in. E. Chmielek-Łubińska, Urlop na żądanie..., 2003, s. 27; A. Sobczyk, Urlop na żądanie, s. 15; A. Marek, Urlop na żądanie, s. 9. Jak podkreśla jednak M. Mędrala, sytuacje takie powinny być absolutnie wyjątkowe; taż, Instytucja urlopu..., s. 271.

143 Pewne wątpliwości, jeśli chodzi o stosowanie urlopu na żądnie przez tę grupę zawodową, sformułowała T. Wrocławska; por. taż, Kontrowersje wokół prawa..., s. 370 i n.

144 W odniesieniu do możliwości stosowania urlopu na żądanie przez nauczycieli akademickich wątpliwości wyraził m.in. W. Sanetra; por. tenże, Prawo o szkolnictwie..., s. 304. Odmienne zapatrywanie na tę kwestię zaprezentował Z. Góral; por. tenże, Akademickie prawo..., s. 238. Ostatni przywołany autor zauważa, że nie wydaje się, by de lege lata istniały argumenty prawne zdecydowanie wykluczające prawo do urlopu na żądanie tej grupy zawodowej (zwłaszcza w stosunku do nauczycieli akademickich, którzy nie prowadzą zajęć dydaktycznych).

$145 \mathrm{~W}$ literaturze przedmiotu, zgodnie z treścią art. 17 ust. 2 ustawy, wskazuje się, że prawo do urlopu na żądanie ma tylko ten pracownik tymczasowy, którego okres wykonywania pracy na rzecz danego pracodawcy użytkownika wynosi sześć miesięcy i więcej. Jeżeli okres ten jest krótszy, pracownik tymczasowy nie ma prawa do takiego urlopu; por. A. Sobczyk, Ustawa o zatrudnianiu pracowników tymczasowych. Komentarz, Kraków 2005, s. 88; J. Wiśniewski, Urlop na żadanie pracownika tymczasowego, PiZS 2011, nr 6, s. 30; A. Chobot, K. Pachciarek, Prawa i obowiqzki agencji pracy tymczasowej i pracodawcy użytkownika wobec pracownika tymczasowego, PiZS 2005, nr 1, s. 26 i n. 
Podsumowując, należy zauważyć, że urlop na żądanie, biorąc pod uwagę jego konstrukcję, sposób regulacji i ujawnione zamierzenia projektodawców zmian w tym zakresie, jest pomyślany bardziej jako zwolnienie na załatwienie ważnych spraw, a zatem powinien być instytucją odrębną od urlopu wypoczynkowego. Jak wynika bowiem z przeprowadzonej analizy, nie służy on bezpośrednio wypoczynkowi, a w niektórych aspektach wręcz utrudnia jego realizację. Jednocześnie trzeba przyznać, że można wskazać na kilka argumentów uzasadniających wprowadzenie tego rodzaju zwolnienia do polskiego prawa. Zdarzają się bowiem sytuacje, kiedy pracownik, czy to ze względów zdrowotnych (nieuzasadniających zwolnienia lekarskiego w ogóle bądź ewentualnie zwolnienie krótkotrwałe wymagające jednak pewnego zachodu), czy z powodów osobistych, bądź konieczności załatwienia jakiś spraw urzędowych, nie może (nie powinien) świadczyć pracy w danym dniu. W obecnym stanie prawnym jedyną alternatywą dla zwolnienia lekarskiego jest urlop wypoczynkowy (na żądanie lub w trybie normalnych ustaleń z pracodawcą), a zatem realizacja często ważnych i pilnych obowiązków związanych z życiem prywatnym pracownika odbywa się kosztem jego czasu przeznaczonego na odpoczynek. Pozostaje jeszcze ewentualnie urlop bezpłatny, który jednak musi być zwykle wcześniej z pracodawcą uzgodniony, a poza tym korzystanie z tego rodzaju zwolnienia pociąga za sobą wiele negatywnych dla pracownika konsekwencji (choćby w zakresie zaliczenia tego urlopu do okresu warunkującego uprawnienia pracownicze).

Tego rodzaju zwolnienia, w różnych wariantach, występują w prawodawstwie innych państw europejskich. Przykładem może być tu ustawa norweska, w której wprowadzono instytucję polegającą na możliwości zwolnienia pracownika od obowiązku świadczenia pracy w związku z krótkotrwałą niedyspozycją zdrowotną pracownika (egenmelding). Chodzi o niezdolność do pracy, w subiektywnym odczuciu pracownika, trwającą nie dłużej niż trzy dni kalendarzowe, o której zatrudniony powiadamia jedynie pracodawcę $\mathrm{w}$ trybie przyjętym $\mathrm{w}$ danym zakładzie $\operatorname{pracy}^{146}$.

Sam urlop na żądanie jako urlop wypoczynkowy też nie może być oceniany jednoznacznie negatywnie. Może on bowiem w sytuacjach pewnego przesilenia organizmu, szczególnie po okresie wytężonej pracy, dawać pracownikowi szanse, zwłaszcza w połączeniu $\mathrm{z}$ weekendem, na ograniczone, ale jednak zniwelowanie objawów narastającego zmęczenia. Tego rodzaju regulacja mogłaby się okazać zbędna po wprowadzeniu do polskiego prawa wskazanego wyżej „zwolnienia okolicznościowego”, przy jednoczesnym zwiększeniu wpływu pracownika na termin, w jakim pracodawca udzieli mu ostatecznie urlopu wypoczynkowego.

146 Może z niej skorzystać zasadniczo pracownik legitymujący się co najmniej 2-miesięcznym stażem pracy u danego pracodawcy. Instytucja ta może być wykorzystywana nawet kilkakrotnie, po upływie 16 dni od wystąpienia tego zwolnienia pracownik może ponownie zgłosić tego rodzaju niedyspozycję; por. szerzej J. Damhaug, T. Wrocławska, Konsekwencje pracowniczej niezdolności do pracy z powodu choroby w świetle przepisów ustawodawstwa norweskiego, „Studia Prawno-Ekonomiczne” 2012, t. LXXXV, s. 46 i n. 


\section{Ekwiwalent za urlop}

Ekwiwalent pieniężny, choć pozostaje w ścisłym związku z prawem do urlopu wypoczynkowego, a zasadność jego wprowadzenia trudno kwestionować, nie przyczynia się bezpośrednio do realizacji funkcji wypoczynkowej urlopu. Istotą prawa do odpoczynku, które może być realizowane dzięki urlopom wypoczynkowym, jest bowiem czas wolny od pracy zarobkowej, przeznaczony przede wszystkim na regenerację psychofizyczną organizmu, ale też umożliwiający wzmacnianie więzi rodzinnych czy samorealizację. Tymczasem ekwiwalent za niewykorzystany urlop, którego charakter prawny był w literaturze przedmiotem dyskusji ${ }^{147}$, jest świadczeniem pieniężnym stanowiącym raczej swoistą finansową rekompensatę związaną z brakiem owego odpoczynku, jak wskazywał T. Zieliński, świadczeniem zbliżonym do odszkodowania, przyznanym pracownikowi, który w okolicznościach wskazanych w ustawie nie mógł zrealizować swego prawa urlopowego ${ }^{148}$. Jeśli można go rozważać w kontekście odpoczynku, to tylko w tym sensie, że może on działać zniechęcająco na pracodawców, jeśli chodzi o nieudzielanie urlopów wypoczynkowych, skoro $\mathrm{w}$ ten sposób pracodawca nie uniknie dodatkowych kosztów związanych z tym urlopem.

Ze względu na to, że ekwiwalent dotyczy urlopu niewykorzystanego, a zatem nie pozwala na zrealizowanie jego zasadniczych celów, dopuszczalność jego wypłaty jest ściśle reglamentowana przez prawo.

Ustawodawca, jak była o tym mowa przy omawianiu zasady urlopu w naturze, pozwala bowiem na jego wypłatę w tych okolicznościach, w których nie ma już faktycznych możliwości wykorzystania urlopu wypoczynkowego we właściwej mu formie, a zatem w postaci dni wolnych od pracy. Zgodnie $\mathrm{z}$ art. 171 k.p. pracodawca ma obowiązek (a zarazem możliwość) wypłacenia takiego świadczenia wówczas, gdy pracownik nie wykorzystał przysługującego mu urlopu wypoczynkowego (bieżącego lub zaległego) w całości lub w części z powodu rozwiązania lub wygaśnięcia stosunku pracy. Nie ma przy tym znaczenia ani sposób, w jaki dochodzi do tego rozwiązania (np. niezwłocznie z winy pracownika czy za porozumieniem stron), ani też przyczyna powodująca wygaśnięcie stosunku pracy, ani powód niewykorzystania wcześniej w naturze urlopu wypoczynkowego.

147 W szczególny sposób ekwiwalent postrzegał M. Święcicki. Uznawał on, że ekwiwalent jest również wynagrodzeniem urlopowym, tyle że wypłacanym przez podmiot zatrudniający, mimo że zwolnienie z obowiązku wykonywania pracy nie miało miejsca; por. tenże, Prawo pracy, s. 462. Wydaje się, że podobnie W. Szubert, Zarys..., s. 234. Z kolei odszkodowawczy charakter przypisywał temu świadczeniu J. Loga; por. tenże, Urlopy wypoczynkowe..., s. 157 i n. Zob. też tenże, Pracownicze urlopy wypoczynkowe, „Nowe Prawo” 1975, nr 3, s. 371 i n. W sposób zbliżony do ostatniego przywołanego autora traktował ekwiwalent T. Zieliński; tenże, Prawo pracy. Zarys systemu, cz. II, Warszawa 1986, s. 293.

148 Tak por. T. Zieliński, Prawo pracy. Zarys..., s. 258. O ekwiwalencie jako prawnym obowiązku zapłaty za urlop niewykorzystany wspomina A. Sobczyk; por. tenże, Prawo pracy..., s. 203. 
Ponadto, zarówno w doktrynie prawa pracy, jak i orzecznictwie sądowym, przyjmuje się, że przepis ten ma charakter bezwzględnie obowiązujący, jeśli chodzi o możliwość wypłaty ekwiwalentu, co oznacza wyłączenie swobody strony w zakresie umownego modyfikowania przesłanek nabycia analizowanego świadczenia (por. rozważania dotyczące zasady urlopu w naturze).

W Kodeksie pracy nie określono wyraźnie zasad ustalania wysokości omawianego ekwiwalentu. W szczególności nie sformułowano w nim wprost reguły, że jego wysokość powinna odpowiadać wynagrodzeniu, jakie by pracownikowi wypłacono, gdyby korzystał z urlopu wypoczynkowego, a więc pośrednio wynagrodzeniu, który by uzyskał, świadcząc w tym czasie pracę. W doktrynie prawa pracy słusznie, według mnie, wskazuje się jednak, podobnie jak w powołanym wcześniej orzecznictwie Trybunału Sprawiedliwości UE, że skoro ekwiwalent jest swego rodzaju surogatem urlopu wypoczynkowego, to wysokość świadczenia, jakie pracownik w zamian otrzymuje, musi odpowiadać temu, które by mu przysługiwało w okresie objętym tym urlopem (a więc wynagrodzeniu urlopowemu) ${ }^{149}$. Ekwiwalent ów powinien bowiem zrekompensować pracownikowi brak urlopu wypoczynkowego, a zatem również wynagrodzenia za ten czas, które stanowi nieodłączny element świadczenia urlopowego ${ }^{150}$. W tym sensie trudno uznać, żeby minister pracy i polityki socjalnej, upoważniony w świetle art. 173 k.p. do uregulowania szczegółowych warunków obliczenia ekwiwalentu za urlop, był w tym procesie nieograniczony żadnymi wymogami. Niemniej, zdaniem niektórych autorów, z różnych względów rozporządzenie to budzi wątpliwości natury konstytucyjnej ${ }^{151}$.

Ostatecznie ekwiwalent za niewykorzystany urlop wypoczynkowy, zgodnie z powoływanym już wielokrotnie tzw. rozporządzeniem urlopowym, ustala się, stosując w znacznej części zasady obowiązujące przy wyliczaniu wynagrodzenia za czas urlopu, a pewne odmienności wynikają przede wszystkim z jednorazowego charakteru omawianego świadczenia. W rezultacie wysokość tego ekwiwalentu generalnie odpowiada wynagrodzeniu urlopowemu pracownika, jakie by otrzymał, gdyby mu udzielono urlopu wypoczynkowego w naturze ${ }^{152}$.

Do reguły, że ekwiwalent za niewykorzystany urlop wypoczynkowy powinien być ukształtowany na zasadach analogicznych jak wynagrodzenie urlopowe, które z kolei powinno odpowiadać wynagrodzeniu pracownika, jakie by uzyskał, gdyby

149 Por. tak E. Wichrowska-Janikowska, Nowe zasady obliczania wynagrodzenia i ekwiwalentu za urlop wypoczynkowy, PizS 1997, nr 5, s. 34. Podobnie A. Kosut, [w:] Kodeks pracy. Komentarz, s. 954 i n. Odmienny pogląd wyraził J. Wratny, którego zdaniem powoływana zasada, wobec braku możliwości wykorzystania urlopu, staje się bezprzedmiotowa; por. tenże, Nowe rozporzadzenie urlopowe, PiZS 1997, nr 3, s. 36.

150 Por. M. Święcicki, Prawo pracy, s. 462.

151 Por. szerzej A. Bigaj, Prawo do urlopu..., s. 255 i n.

152 Por. E. Wichrowska-Janikowska, Nowe zasady..., s. 34. W kwestii szczegółowych problemów związanych z obliczaniem wynagrodzenia za czas urlopu i ekwiwalentu za niewykorzystany urlop, w szczególności dotyczących konkretnych składników uwzględnianych w tych świadczeniach, por. W. Sanetra, Ustalenie wynagrodzenia urlopowego i ekwiwalentu za urlop w świetle kilku orzeczeń Sądu Najwyższego, PiZS 2001, nr 2, s. 29 i n. 
w tym czasie świadczył pracę, odwołano się natomiast wprost w art. 153 ust. 2 ustawy o szkolnictwie wyższym. Z powyższych względów TK uznał za niezgodny z Konstytucją przepis rozporządzenia wykonawczego normującego tę materię $e^{153}$, który nakazywał przy ustalaniu ekwiwalentu pieniężnego za niewykorzystany urlop, w stosunku do składników wynagrodzenia określonych w stawkach miesięcznych w stałej wysokości, obliczanie tego ekwiwalentu, przyjmując za podstawę dni kalendarzowe ${ }^{154}$. Tego rodzaju regulacja, zdaniem Trybunału, nie gwarantuje w każdym przypadku wypłaty ekwiwalentu w wysokości wynagrodzenia urlopowego, a przez to także wynagrodzenia w wysokości, jakie uzyskałby nauczyciel akademicki, gdyby w tym czasie pracował. Nie uwzględnia zatem wytycznych wynikających z powołanej ustawy ${ }^{155}$.

Wydaje się, że ustawowe zagwarantowanie pracownikowi konieczności respektowania tej zasady w zakresie obliczania ekwiwalentu jest jednak kwestią pożądaną.

Ekwiwalent pieniężny, jak była o tym mowa wcześniej, choć stanowi dla pracownika niewątpliwą wartość, nie przyczynia się bezpośrednio do efektywnego wykorzystania jego prawa do odpoczynku. Dlatego też zasada urlopu w naturze, która ma fundamentalne $\mathrm{w}$ tym aspekcie znaczenie, powinna być $\mathrm{w}$ miarę możliwości konsekwentnie zapewniana wszystkim pracownikom, bez względu na rodzaj wykonywanej pracy, podstawę nawiązania stosunku czy charakter zatrudnienia. Niektóre jednak z odrębnych ustaw normujących status prawny określonych grup zatrudnionych nie w pełni tę ideę realizują, zawężając tym samym ich prawo do wypoczynku i możliwość jego skutecznej realizacji. Pod tym względem najwięcej wątpliwości budzi ustawa o zatrudnianiu pracowników tymczasowych.

Podmiotem zobowiązanym do udzielenia urlopu wypoczynkowego pracownikowi tymczasowemu jest agencja pracy tymczasowej jako pracodawca (zgodnie $\mathrm{z}$ art. 1 ustawy). Niemniej, skoro urlop ma być zwolnieniem pracownika $\mathrm{z}$ obowiązku wykonywania pracy, pracodawca użytkownik powinien umożliwić pracownikowi jego wykorzystanie, co niestety nie wynika jednoznacznie z przepisów ustawy. W jej art. 10 ust. 1 przyjęto bowiem, że agencja pracy tymczasowej i pracodawca użytkownik mogą, a nie muszą, uzgodnić wykorzystanie przez pracownika tymczasowego urlopu wypoczynkowego, w całości lub w części, w okresie wykonywania pracy tymczasowej na rzecz tego pracodawcy użytkownika, ustalając zarazem tryb udzielenia tego urlopu. O tego rodzaju ustaleniach agencja ma obowiązek powiadomić osobę, która będzie wykonywać pracę tymczasową przed zawarciem umowy (art. 11 ustawy). Natomiast obowiązek pracodawcy użytkownika umożliwienia pracownikowi tymczasowemu wykorzystania w tym okresie urlopu w postaci czasu wolnego od pracy, zgodnie z ust. 2 analizowanego prze-

153 Rozporządzenie Ministra Nauki i Szkolnictwa Wyższego z dnia 2 listopada 2006 r. w sprawie sposobu ustalania wynagrodzenia za urlop.

154 Wyrok TK z 16 lipca 2013 r., P 53/11, OTK-A 2013, nr 6, poz. 78. Zwraca na to uwagę również K. Walczak; tenże, Wynagrodzenia i inne świadczenia dla pracowników uczelni, [w:] Akademickie prawo pracy, red. K.W. Baran, Warszawa 2015, s. 333.

155 Zob. Zasady obliczania ekwiwalentu pieniężnego za niewykorzystany urlop, P 53/11, www. trybunał.gov.pl [dostęp: 1.07.2017]. 
pisu, powstaje dopiero wówczas, gdy okres wykonywania pracy na rzecz danego pracodawcy użytkownika obejmuje co najmniej sześć miesięcy.

W związku z tym w piśmiennictwie interpretuje się bardzo często powyższy przepis jako gwarantujący pracownikowi tymczasowemu urlop wypoczynkowy w naturze wyłącznie w dwóch przypadkach:

- jeśli okres wykonywania pracy na rzecz tego pracodawcy użytkownika wynosi co najmniej sześć miesięcy; wówczas obowiązek taki powstaje bezpośrednio na podstawie art. 10 ust. 2 ustawy i nie może być wyłączony w drodze zawarcia jakiegokolwiek porozumienia;

- jeżeli okres pracy na rzecz pracodawcy użytkownika jest krótszy niż sześć miesięcy, ale pomiędzy agencją pracy tymczasowej a pracodawcą użytkownikiem zostało zawarte stosowne porozumienie w tej sprawie ${ }^{156}$.

W sytuacji natomiast, gdy takiego porozumienia nie było, bo ustawa nie obliguje do jego zawarcia, a pracownik tymczasowy ma świadczyć pracę na rzecz pracodawcy użytkownika krócej niż sześć miesięcy, wówczas obowiązek udzielenia urlopu w naturze zdaje się nie powstawać ${ }^{157}$.

W takim ujęciu trudno mówić w ogóle o regule udzielania urlopu wypoczynkowego w postaci dni wolnych od pracy, skoro odwrotnie niż w przypadku regulacji kodeksowej wymienia się w istocie okoliczności, w których ekwiwalent nie może zastąpić urlopu w naturze. Potwierdzeniem tego jest art. 17 ust. 3 ustawy, w którym ustawodawca ogólnie stanowi o obowiązku agencji pracy tymczasowej wypłaty ekwiwalentu pieniężnego w razie niewykorzystania przez pracownika urlopu wypoczynkowego w okresie wykonywania pracy tymczasowej.

W związku z tym bywa wyrażany też pogląd, że w razie, gdy okres wykonywania pracy na rzecz pracodawcy użytkownika trwa krócej niż sześć miesięcy i nie zawarto wspomnianego porozumienia, a pracownik tymczasowy nabył prawo do urlopu, powinna tego urlopu udzielić agencja pracy tymczasowej w okresie, w którym praca nie jest już wykonywana u pracodawcy użytkownika, a obowiązuje jeszcze umowa zawarta między agencją a pracownikiem tymczasowym ${ }^{158}$.

Wykładnia ta nie poprawia jednak znacząco sytuacji pracownika tymczasowego w zakresie jego prawa do odpoczynku, ponieważ, jak zauważają sami pomysłodawcy, w praktyce zwykle okres wykonywania pracy tymczasowej pokrywa się z okresem trwania umowy, co prowadzi w opisanych wyżej przypadkach do wypłaty ekwiwalentu za urlop ${ }^{159}$.

156 Por. A. Daszczyńska, Prawo pracownika tymczasowego do odpoczynku, [w:] Z problematyki zatrudnienia tymczasowego, red. A. Sobczyk, Warszawa 2011, s. 201 i n.

157 Por. tak m.in. A. Sobczyk, Ustawa o zatrudnianiu..., s. 56. Por. też A. Chobot, K. Pachciarek, Prawa i obowiq̨zki..., s. 27; A. Daszczyńska, Prawo pracownika tymczasowego..., s. 202; M. Raczkowski, Ustawa o zatrudnianiu pracowników tymczasowych. Komentarz, Warszawa 2012. Por. też uzasadnienie do wyroku Sądu Rejonowego dla Wrocławia - Śródmieścia we Wrocławiu z 19 maja 2014 r., X P 959/13, LEX nr 1911075.

158 Zob. A. Sobczyk, Zatrudnianie pracowników tymczasowych, PiZS 2004, nr 4, s. 38. Por. też A. Chobot, K. Pachciarek, Prawa i obowiq̨zki..., s. 26 i n.

159 Tamże. 
Ponadto nie do końca przystaje ona do charakteru urlopu wypoczynkowego, który ze swej natury ma być zwolnieniem z obowiązku wykonywania pracy, a nie przypadać na okres, kiedy na pracowniku już taki obowiązek nie ciąży.

Kwestią sporną w literaturze jest też sposób liczenia owego 6-miesięcznego okresu uprawniającego do uzyskania urlopu w naturze. Zdaniem A. Sobczyka, pojęcie wykonywania pracy na rzecz pracodawcy użytkownika należy utożsamiać w zasadzie z terminem „pozostawania w jego dyspozycji”, do którego odwołuje się analizowany we wcześniejszych rozważaniach art. 17 ustawy, a więc nie chodzi tu o kryterium czasu trwania umowy ${ }^{160}$. W konsekwencji, w braku odpowiednich uzgodnień między agencją pracy tymczasowej a pracodawcą użytkownikiem, pracownik mógłby wykorzystać urlop dopiero po sześciu miesiącach wykonywania pracy u pracodawcy użytkownika.

Odmienną interpretację proponuje w związku z tym M. Raczkowski, zdaniem którego użyty przez ustawodawcę zwrot „okres wykonywania pracy na rzecz pracodawcy użytkownika obejmuje..." może być odnoszony do okresu pracy wskazanego $\mathrm{w}$ umowie, co oznacza, że w razie zawarcia umowy na czas dłuższy niż sześć miesięcy pracownikowi takiemu przysługuje roszczenie o udzielenie urlopu w naturze także przed upływem tego czasu ${ }^{161}$.

Sześciomiesięczny okres, o którym mowa w cytowanym przepisie, powinien być przy tym, zdaniem M. Raczkowskiego, liczony łącznie, a więc ustalany na podstawie zawieranych $\mathrm{z}$ danym pracownikiem kolejnych umów na czas określony, co obecnie znajduje pośrednio swe potwierdzenie w powoływanym wyżej, dodanym $\mathrm{w}$ art. 17 ustawy ustępie 3a.

Trzeba podzielić tu opinię przywołanego powyżej autora, że taka wykładnia jest dodatkowo uzasadniona konstytucyjną i kodeksową regułą prawa pracownika do urlopu w naturze, która wymaga, by wszelkie wyjątki od niej były interpretowane ściśle, tj. przede wszystkim w kierunku optymalizacji, a nie zawieszenia prawa do odpoczynku ${ }^{162}$.

Brak możliwości skorzystania z tego uprawnienia w przypadkach krócej trwającego zatrudnienia, mimo nabycia prawa do urlopu, sam w sobie wydaje się nie do końca zrozumiały i zgodny z istotą urlopu wypoczynkowego. Urlop w założeniu jest bowiem coroczną przerwą w pracy, z której pracownik może skorzystać, po spełnieniu warunków do niej uprawniających, w celu przynajmniej psychofizycznej regeneracji organizmu. Na gruncie omawianych unormowań, notabene bardzo niejasnych i budzących wiele wątpliwości interpretacyjnych, jakaś część pracowników nie może w istocie tego urlopu spożytkować na odpoczynek, a więc wykorzystać nabytego prawa w sposób odpowiadający jego przeznaczeniu. Nie sposób bowiem uznać, by ekwiwalent pieniężny za urlop ten cel mógł zastępczo realizować, a jeśli nawet, to tylko pośrednio (jako kwota, która może służyć bardziej komfortowemu wypoczynkowi później) i w minimalnym stopniu.

160 Por. A. Sobczyk, Ustawa o zatrudnianiu..., s. 56.

161 Por. M. Raczkowski, Ustawa o zatrudnianiu...

162 Tamże. 
Słusznie zatem zauważono w literaturze przedmiotu, że ustawa dotycząca pracowników tymczasowych, w omawianym obszarze, nie zawiera wystarczających gwarancji w zakresie realizacji prawa pracownika do odpoczynku, a wręcz jego urzeczywistnieniu zagraża i powinna być zmieniona. Może zdarzyć się bowiem, że pracownik tymczasowy $\mathrm{w}$ danym roku kalendarzowym, mimo w miarę regularnego wykonywania pracy, ale na rzecz różnych pracodawców użytkowników, nie będzie w ogóle korzystać z urlopu wypoczynkowego w jego właściwej formie, tj. w postaci dni wolnych od pracy ${ }^{163}$, czego nie można w żadnym razie usprawiedliwiać nawet charakterem tego zatrudnienia i potrzebą zachowania w nim większej elastyczności. Zasadnie postuluje się zatem zagwarantowanie pracownikowi tymczasowemu, by przynajmniej w ograniczonym wymiarze ten urlop był wykorzystywany w naturze ${ }^{164}$.

Sama instytucja ekwiwalentu za urlop, o czym była mowa wcześniej, nie jest rozwiązaniem w pełni kompatybilnym z prawem do odpoczynku w jego szerokim nawet rozumieniu. Niemniej zawężenie dopuszczalności jego wypłaty do obiektywnie istniejącego braku możliwości wykorzystania urlopu, jak uczyniono to w Kodeksie pracy, nie stanowi dla podstawowego prawa pracowniczego - prawa do odpoczynku poważniejszego zagrożenia.

$\mathrm{Z}$ tego punktu widzenia krytycznie należy odnieść się również do innej ustawy z zakresu prawa pracy, która choć zachowuje zasadę prawa do urlopu w naturze, to rozszerza katalog przesłanek pozwalających na jego wypłatę.

Chodzi tu o wielokrotnie już powoływaną Kartę Nauczyciela i zawarty w niej art. 66 ust. 2 ustawy. Przepis ten stanowi, że w razie niewykorzystania przez nauczyciela przysługującego mu urlopu wypoczynkowego z powodu nie tylko rozwiązania lub wygaśnięcia stosunku pracy, ale też powołania do zasadniczej służby wojskowej albo do odbywania zastępczo obowiązku tej służby, do okresowej służby wojskowej lub do odbywania długotrwałego przeszkolenia wojskowego, nabywa on prawo do ekwiwalentu pieniężnego za ten okres, nie więcej jednak niż za osiem tygodni w stosunku do nauczycieli zatrudnionych w tzw. placówkach feryjnych i nie więcej niż za 35 dni roboczych w odniesieniu do nauczycieli zatrudnionych w szkołach, w których nie są przewidziane ferie szkolne.

Powyższa regulacja, zbliżona do tej istniejącej w przeszłości w Kodeksie pracy, zwiększa w porównaniu z przepisami powszechnymi liczbę dopuszczalnych odstępstw od zasady urlopu w naturze, co nie znajduje do końca swego racjonalnego uzasadniania i budzi poważne wątpliwości w kontekście zgodności z dyrektywą dotyczącą niektórych aspektów organizacji czasu pracy. Dyrektywa ta była już wcześniej szerzej omawiana, stąd $\mathrm{w}$ tym miejscu wystarczy przypomnieć, że zgodnie z jej przepisami, a także orzecznictwem TSUE, zasada urlopu w naturze ma fundamentalne znaczenie dla efektywnego wypoczynku pracownika, bezpieczeństwa i ochrony jego zdrowia, stąd może być wyłączona tylko w jedynym

163 Por. A. Daszczyńska, Prawo pracownika tymczasowego..., s. 203.

164 Tamże. 
przypadku wyraźnie określonym w samej dyrektywie, a więc w sytuacji, gdy dochodzi do ustania stosunku pracy ${ }^{165}$. Z tego głównie powodu dokonano zmian w Kodeksie pracy, eliminując występujące wcześniej wśród przesłanek wypłaty ekwiwalentu, powołanie do służby wojskowej (zasadniczej, okresowej, zawodowej) czy do odbycia przeszkolenia wojskowego trwającego dłużej niż trzy miesiące oraz skierowanie do pracy za granicą ${ }^{166}$. We wskazanych okolicznościach, zdaniem ustawodawcy, powinno się bowiem mimo wszystko dążyć do udzielenia urlopu wypoczynkowego $\mathrm{w}$ postaci czasu wolnego od pracy, zapewniającego niezbędny odpoczynek, co obiektywnie jest możliwe do zrealizowania, albo przed ich wystąpieniem albo już po, jak np. w związku z odbywaniem służby wojskowej czy przeszkolenia wojskowego, o których mowa w Karcie Nauczyciela. Nie do końca jest zatem zrozumiałe, dlaczego polski ustawodawca, nowelizując w rozważanym zakresie Kodeks pracy, nie dokonał stosownych zmian również w powołanej ustawie. Trudno bowiem przyjąć, że dostatecznym uzasadnieniem jest tu termin urlopu nauczyciela, który powinien zbiegać się z okresem ferii letnich i zimowych, skoro po pierwsze, $\mathrm{w}$ ustawie do tego warunku w omawianym kontekście nie ma żadnego odniesienia, a kilkumiesięczne przeszkolenie wojskowe może przypadać między wskazanymi feriami (np. od października do grudnia), po drugie, wyjątkowo dopuszcza się możliwość wykorzystania przez nauczyciela urlopu w innym terminie, jak w przypadku np. choroby występującej w czasie urlopu, co i w tej sytuacji mogłoby znaleźć swoje zastosowanie, a po trzecie, regulacja ta obejmuje również nauczycieli zatrudnionych w placówkach nieferyjnych, którzy korzystają $\mathrm{z}$ urlopu wypoczynkowego $\mathrm{w}$ terminie ustalonym $\mathrm{w}$ planie.

O braku, a zarazem konieczności swego rodzaju odświeżenia omawianego przepisu świadczyć może także fakt, że w obowiązującym prawie nie dokonuje się już rozróżnienia między krótkotrwałym a długotrwałym przeszkoleniem wojsko${ }^{w y m}{ }^{167}$. Nie jest zatem do końca jasne, jak kwalifikować przeszkolenie wojskowe absolwentów szkół wyższych, o którym stanowi obecnie ustawa o powszechnym obowiązku obrony RP, trwające do trzech miesięcy, w kontekście przepisów analizowanej ustawy, czy jako przeszkolenie długotrwałe uprawniające nauczyciela do ekwiwalentu za urlop, czy też krótkotrwałe, o którym ustawodawca wspomina w powoływanym wcześniej art. 66 ust. 1 Karty Nauczyciela, generujące pra-

165 Por. m.in. wyrok TSUE z 6 kwietnia 2006 r. w sprawie Federatie Nederlandse Vakbeweging, C-124/05, pkt 32 i n.

166 Nowe brzmienie art. 171 k.p. zostało nadane mu ustawą nowelizującą Kodeks pracy z 14 listopada 2003 r., Dz. U. 2003, Nr 213, poz. 2081.

167 Długotrwałe przeszkolenie wojskowe było zdefiniowane w nieobowiązującym już rozporządzeniu Ministra Obrony Narodowej z 22 czerwca 1992 r. w sprawie zasadniczej służby wojskowej i nadterminowej zasadniczej służby wojskowej oraz przeszkolenia wojskowego, Dz. U. 1992, Nr 56, poz. 227. W art. 101 ustawy z dnia 21 listopada 1967 r. o powszechnym obowiązku obrony Rzeczypospolitej Polskiej stanowi się obecnie o długotrwałych ćwiczeniach wojskowych trwających nieprzerwanie do 90 dni. Natomiast przeszkolenie wojskowe, bez podziału na długotrwałe i krótkotrwałe, odbywają, według art. 92 tej ustawy, absolwenci szkół wyższych w wymiarze do trzech miesięcy. 
wo do urlopu uzupełniającego. Biorąc pod uwagę podstawowe prawo pracownika do urlopu wypoczynkowego w naturze, wszelkie wyjątki od tej zasady należy interpretować ściśle, w sposób, który będzie gwarantować jak najpełniejszą możliwość realizacji omawianego prawa w sposób zgodny z jego przeznaczeniem. Stąd należy w tym przypadku uznać, że powołanie nauczyciela na przeszkolenie wojskowe uprawnia go w obecnym stanie prawnym do urlopu uzupełniającego ${ }^{168}$.

Warto również zauważyć, że w odniesieniu do nauczycieli zatrudnionych w szkołach, w których organizacji przewidziano ferie, ekwiwalent, o którym wyżej była mowa, nie pokrywa pełnego okresu urlopowego. Zgodnie z art. 66 ust. 1 Karty Nauczyciela, przysługuje on bowiem za okres niewykorzystanego urlopu, nie więcej jednak niż za osiem tygodni. W konsekwencji, jak przyjęto w piśmiennictwie z tego zakresu oraz orzecznictwie sądowym, nauczyciel, który przed wystąpieniem wymienionych przesłanek wypłaty ekwiwalentu wykorzystał urlop w wymiarze ośmiu tygodni, nie nabywa już prawa do tego ekwiwalentu ${ }^{169}$.

Podobnie zatem jak w wypadku urlopu uzupełniającego, ustawodawca realnymi gwarancjami obejmuje nie cały okres urlopu nauczyciela (przypadający na okres ferii letnich i zimowych), ale urlop w wymiarze ośmiu tygodni.

Prawo do ekwiwalentu pieniężnego w ściśle określonych przez prawo przypadkach, choć nie służy wprost wypoczynkowi, to jednak nie może być uznane za rozwiązanie wadliwe (pomijając wskazane wyżej regulacje szczególne) czy zbyteczne. Trzeba bowiem zauważyć, że w sytuacji, w której powstaje prawo do ekwiwalentu, a zatem w razie ustania stosunku pracy, do którego dochodzi niekiedy w sposób nagły czy stosunkowo szybki, urlop w naturze nie może zostać już przez pracownika zrealizowany. Dlatego też przyznano mu świadczenie, które w założeniu ma zrekompensować $\mathrm{w}$ jakimś stopniu niemożność skorzystania $\mathrm{z}$ tego uprawnienia, które być może zostanie spożytkowane na faktyczny wypoczynek w terminie późniejszym lub pozwoli na jego organizację w okresie poprzedzającym podjęcie kolejnego zatrudnienia (niejako zastąpi wówczas brak wynagrodzenia urlopowego). Wyraźnie sformułowany obowiązek pracodawcy jego wypłaty i ustalenie zasad jego wyliczania powoduje też stosunkową łatwość w jego egzekwowaniu.

168 Podobnie M. Szymańska, [w:] A. Barański, M.H. Szymańska, J. Rozwadowska-Skrzeczyńska, Karta Nauczyciela. Komentarz, Warszawa 2014, s. 388.

169 Por. tamże, s. 386. 



\section{Zakończenie}

Prawo pracownika do odpoczynku jest współcześnie uznawane powszechnie za jedno z podstawowych praw pracowniczych. Jego źródeł należy upatrywać w niekwestionowanej obecnie ogólnej wartości, a zarazem kategorii prawnej, jaką jest ludzka godność. Wymaga ona bowiem, aby człowiek nigdy nie był traktowany przez nikogo wyłącznie jako środek, ale zawsze też jako cel ${ }^{1}$. Pociąga to za sobą konieczność zapewnienia wszystkim osobom m.in. odpowiednich warunków życia i pracy. Wydaje się oczywiste, że środkiem przyczyniającym się do osiągnięcia tego celu są odpowiednie gwarancje w zakresie odpoczynku związanego $\mathrm{z}$ wykonywaną pracą. Prawo do odpowiedniego odpoczynku z jednej strony znajduje bowiem $\mathrm{w}$ owej godności swoje uzasadnienie, ale $\mathrm{z}$ drugiej staje się ważnym gwarantem jej realizacji. Przekłada się ono także na możliwość faktycznego urzeczywistnienia innych fundamentalnych praw przypisanych każdej jednostce ludzkiej, takich jak prawo do życia, bezpieczeństwa, wolności, ochrony zdrowia i rozwoju. Rolą ustawodawcy jest zatem takie kształtowanie rozwiązań prawnych w tym zakresie, aby prawo to mogło być w optymalnym stopniu realizowane.

Z pewnością krytycznej refleksji wymaga wyznaczenie zakresu przedmiotowego rozważanego prawa. W sferze prawnej powinno się reagować na różne rodzaje zmęczenia pracownika. Tymczasem, jak wynika z zaprezentowanych wywodów, zarówno na poziomie międzynarodowym, europejskim, jak i krajowym podejmuje się określone kroki na rzecz zniwelowania zmęczenia wywołanego długą pracą w ciągu dnia (odpoczynek dobowy) czy tygodnia (odpoczynek tygodniowy, dni dodatkowo wolne od pracy), zmęczenia pracą całoroczną (urlop wypoczynkowy), ale jednocześnie brakuje odpowiedniej reakcji na narastające zmęczenie

1 Tak por. I. Kant, za: I. Boruta, Godność człowieka - kategoriq prawa pracy, PiZS 2001, nr 8, s. 3. 
spowodowane długoletnią aktywnością zawodową. W tym obszarze coraz wyraźniej widać, że obowiązujące prawo chyba nie do końca nadąża za nasilającymi się we współczesnym świecie zjawiskami (związanymi z nadmiernym tempem pracy, narastającymi oczekiwaniami wobec pracowników i bardzo wysokim poziomem stresu oraz zmęczenia), do jakich należy zaliczyć m.in. tzw. zespół wypalenia zawodowego (zwany też „chorobą nadmiernego zaangażowania”) ${ }^{2}$.

Chociaż zjawisko to pojawiło się prawdopodobnie już na przełomie XIX i XX w. jako jeden ze skutków drugiej rewolucji przemysłowej, a opisywane jest szerzej w literaturze począwszy od lat 70. ubiegłego stulecia, to jednak prowadzone ostatnio badania dowodzą, że obejmuje ono coraz większe grupy pracowników, stając się dla osób świadczących pracę jednym z największych zagrożeń XXI w. Wypalenie zawodowe jest różnie definiowane w literaturze przedmiotu ze względu na jego złożony charakter. Najczęściej określa się je ogólnie jako stan wyczerpania cielesnego, uczuciowego oraz duchowego pracownika ${ }^{3}$. Jak oceniają niektórzy autorzy, stanowi ono reakcję organizmu na „długotrwałe przeciążenie wyczerpującymi obowiązkami, ale też i monotonną pracę"", choć poszczególni badacze wskazują na wiele różnorodnych czynników będących źródłem omawianego problemu. Wiąże się ono m.in. $\mathrm{z}$ brakiem satysfakcji $\mathrm{z}$ wykonywanej pracy, ze spadkiem zaangażowania $\mathrm{w}$ pracę oraz z wyraźnym pogorszeniem kondycji organizmu - licznymi dolegliwościami psychosomatycznymi, co w konsekwencji prowadzi też do obniżenia efektywności i jakości wykonywanej pracy oraz stopniowego „wycofywania się z dotychczasowej aktywności” ${ }^{5}$, również w innych niż praca sferach życia. Dlatego coraz częściej wskazuje się, że stanowi ono jeden z poważniejszych problemów społecznych.

W Stanach Zjednoczonych ${ }^{6}$ oraz wielu państwach europejskich odpowiedzią na wyzwanie, o którym wyżej mowa, jest szczególny urlop - tzw. sabbatical. Jego ogólną funkcją jest odpoczynek od pracy zawodowej, choć w poszczególnych krajach ma on bardziej lub mniej szczegółowo określone przeznaczenie, a ponadto różny zakres podmiotowy, różne źródła (często ustawowe) oraz warunki, na jakich jest udzielany ${ }^{7}$. Istotne jest to, że zwykle jest to urlop płatny (przynajmniej

2 Por. G. Bartkowiak, Człowiek w pracy. Od stresu do sukcesu w organizacji, Warszawa 2009, s. 75.

3 Por. J.E. Karney, Psychopedagogika pracy, Warszawa 2007, s. 405 i n.

4 Por. A. Kisiel, Wypalenie zawodowe - przykładowe symptomy i przeciwdziałania, [w:] Wspótczesne wyzwania menedżerskie w przeciwdziałaniu wypaleniu zawodowemu, red. J. Koprowicz, W. Bańka, „Humanizacja Pracy” 2011, nr 6, s. 33 i n.

5 Por. A. Wajda, Rola pracy w życiu człowieka w perspektywie historycznej - jej humanizacja i wypalenie zawodowe, [w:] Wspótczesne wyzwania..., s. 28 i n.

6 W Stanach Zjednoczonych urlopy dodatkowe, tzw. sabbatical vacations, były wprowadzane w układach zbiorowych pracy już w latach 70. XX w., początkowo w przemyśle stalowym, aluminium i maszynowym (był to urlop w wymiarze 13 tygodni, po 15 latach zatrudnienia, udzielany co 5 lat). Korzystali z niego również profesorowie wyższych uczelni; por. A. Uklejska, Aktualne kierunki rozwoju prawa urlopowego, PiZS 1974, nr 6, s. 26.

$7 \quad$ Na przykład we Włoszech kładzie się nacisk na jego funkcję edukacyjną, a w Finlandii ma on służyć w dużym stopniu do redukcji bezrobocia oraz stwarzać warunki do przekwalifiko- 
częściowo) oraz urlop z gwarancją zachowania dotychczasowego miejsca pracy . $^{8}$ Ocenia się go jako bardzo skuteczne narzędzie ochrony przed wypaleniem zawodowym.

W Polsce obecnie nie ma w zasadzie instytucji prawnej o powszechnym charakterze ${ }^{9}$, która stanowiłaby bezpośrednią reakcję na omawiane zagrożenie. Pracownicy, u których pojawiły się symptomy wypalenia zawodowego, korzystają najczęściej ze zwolnień lekarskich, co jednak w konsekwencji może skutkować utratą zatrudnienia, szczególnie jeśli nieobecność w pracy jest długotrwała ${ }^{10}$. Tymczasem wypalenie zawodowe jest przecież swego rodzaju kosztem, nienaturalnym i nadmiernym, ale jednak kosztem wysokiego zaangażowania pracownika w pracę na rzecz danego podmiotu ${ }^{11}$.

Teoretycznie można rozważać również urlop bezpłatny, który jednak wiąże się z utartą dochodów, co powoduje, biorąc pod uwagę położenie materialne większości rodzin pracowniczych w naszym kraju, że nie stanowi on realnej i skutecznej alternatywy.

W świetle obowiązującego ustawodawstwa jedynie nauczyciele, również akademiccy, mają, po spełnieniu określonych przesłanek, możliwość skorzystania ze szczególnych urlopów dla poratowania zdrowia, które w swej istocie są zbliżone do instytucji sabbatical.

Być może zatem należałoby wprowadzić jakieś szczególne zwolnienie od pracy, np. właśnie w formie urlopu, które dawałoby szerszej grupie pracowników czas i szanse na zniwelowanie objawów tej choroby, odpoczynek od pracy zarobkowej i ponowny powrót do zatrudnienia. Urlop ten mógłby przybrać postać dodatkowego urlopu wypoczynkowego, jego cel pozostaje bowiem zgodny z funkcjami tego ostatniego, udzielanego na wniosek pracownika, ewentualnie stać się swego rodzaju odpowiednikiem „urlopu dla poratowania zdrowia” występującego, jak była o tym wyżej mowa, w niektórych pragmatykach pracowniczych.

Wprowadzenie tego typu urlopów pozwoliłoby chronić życie i zdrowie zatrudnionego, ponadto przyczyniłoby się niewątpliwie do zmniejszenia liczby

wania; por. szerzej na ten temat: E. Nowak-Jamróz, Urlop sabbatical jako sposób zapobiegania wypaleniu zawodowemu. Próba analizy porównawczej istniejących regulacji prawnych, [w:] Współczesne wyzwania..., s. 201 i n. Tego rodzaju urlopy funkcjonują również we Francji; por. M. Despax, J. Rojot, J. Laborde, Labour Law in France, Alphen aan den Rijn 2011, s. 140.

8 E. Nowak-Jamróz, Urlop sabbatical..., s. 206 i n.

9 Jak podaje „Dziennik Gazeta Prawna”, niektóre duże koncerny gwarantują tego rodzaju urlopy swoim pracownikom, m.in. Ernst \& Young, IBM, Pricewaterhouse czy McDonald's; http://praca.gazetaprawna.pl/ artykuly/366139,jestes-wypalony-popros-swojego-szefa-o-roczne-platne-wakacje.html [dostęp 19.12.2016].

10 Warto przypomnieć jedynie w tym kontekście regulację art. 53 k.p. oraz orzecznictwo SN, z którego wynika, że częste i długotrwałe nieobecności pracownika w pracy z powodu choroby stanowią uzasadnioną przyczynę wypowiedzenia mu umowy o pracę na czas nieokreślony.

11 W literaturze fachowej podkreśla się, że wypalenie zawodowe, jak wcześniej sygnalizowałam, dotyka najczęściej osoby bardzo zaangażowane zawodowo, dla których praca staje się sensem ich życia; por. G. Bartkowiak, Człowiek w pracy..., s. 3 i n. 
występujących zwolnień lekarskich, ale także, w ocenie części psychologów, przełożyłoby się na zwiększoną motywację i wydajność pracownika powracającego do pracy po okresowej przerwie ${ }^{12}$. Jak wynika z raportu Polska 2030. Wyzwania rozwojowe problem ten stał się kilka lat temu przedmiotem zainteresowania polskiego rządu. W dokumencie tym pojawiła się bowiem wzmianka o urlopach „na rekwalifikację, a także na podtrzymanie zdrowia” dla osób między 45. a 50. rokiem życia, które dodatkowo byłyby środkiem łagodzącym wydłużenie wieku emerytalnego ${ }^{13}$. Rozważano też możliwość wprowadzenia tego rodzaju rocznego lub 6-miesięcznego odpłatnego urlopu dla szerszej grupy pracowników (zauważono bowiem, że wypalenie zawodowe dotyka coraz częściej ludzi młodych i to niezależnie od rodzaju wykonywanej pracy ${ }^{14}$ ), z którego można byłoby skorzystać raz w karierze zawodowej, choć pewne wątpliwości budziła kwestia źródła finansowania tych urlopów ${ }^{15}$. Pomysły te nie doczekały się jednak realizacji.

Nie tylko zakres przedmiotowy prawa do odpoczynku, ale również jego zakres podmiotowy rodzą daleko idące wątpliwości. Coraz bardziej nie przekonuje, aby było ono ograniczone tylko do osób posiadających status pracowniczy. Poważne racje przemawiają za jego rozszerzeniem także na osoby świadczące pracę na innej podstawie niż stosunek pracy. Dotyczy to, co oczywiste, także instytucji urlopu wypoczynkowego.

O ile, historycznie rzecz ujmując, pracownicza natura prawa do urlopu miała swoje uzasadnienie w stosunkach społeczno-gospodarczych, które charakteryzowały się tym, że pracownicy stanowili podstawową grupę zatrudnionych ${ }^{16}$, o tyle zdecydowanie trudniej znaleźć racje przemawiające za ograniczeniem prawa do urlopu tylko do tej grupy współcześnie.

Przede wszystkim w ciągu ostatnich kilku (czy kilkunastu) lat w znacznym stopniu modyfikacji uległa sytuacja w zakresie podstaw prawnych wykonywania pracy zarobkowej. Co prawda pracownicy nadal stanowią dominującą grupę na rynku pracy, ale jednocześnie pojawił się stosunkowo duży odsetek osób wykonujących pracę poza stosunkiem pracy, w tym zwłaszcza na podstawie

12 Nowy pomyst rządu: roczny urlop dla wypalonych, „Dziennik Gazeta Prawna”, http://wiadomosci.dziennik.pl/ wydarzenia/artykuly/323515, nowy-pomysl-rzadu-roczny-urlop-dla-wypalonych.html [dostęp: 19.12.2016].

13 Por. Polska 2030. Wyzwania rozwojowe, red. M. Boni, s. 17, www.mpips.gov.pl [dostęp: 1.12.2016].

14 Opinia M. Kochan, członkini sejmowej komisji polityki społecznej i rodziny, za: L. Kostrzewski, P. Miączyński, Rok wakacji od pracy, „Gazeta Wyborcza”, www.wyborcza.pl [dostęp: 1.12.2016].

15 Por. szerzej L. Kostrzewski, P. Miączyński, Roczny urlop dla wypalonych, „Gazeta Wyborcza”, www.wyborcza.pl [dostęp: 1.12.2016].

16 Dodatkowo prawo niekiedy zabraniało wręcz zawierania umów cywilnoprawnych, stwarzając warunki do swego rodzaju „ręcznego" sterowania rynkiem zatrudnienia; por. szerzej B. Cudowski, Zmiany regulacji prawnej dodatkowego zatrudnienia, [w:] Przemiany prawa pracy. Od kodyfikacji do współczesności. Księga Jubileuszowa Prof. T. Liszcz, red. A. Kosut, W. Perdeus, „Studia luridica Lublinensia” 2015, t. XXIV, s. 132. 
umów prawa cywilnego ${ }^{17}$. Warunki wykonywania w ich ramach pracy nie odbiegają w sposób zasadniczy od zatrudnienia pracowniczego. W jednym i drugim przypadku świadczenie pracy odbywa się na podstawie względnie trwałych więzi prawnych, najczęściej z jednym podmiotem, cechujących się zależnością ekonomiczną w stosunku do powierzającego pracę ${ }^{18}$. Podporządkowanie pracownika pracodawcy, które dotąd stanowiło niezawodne kryterium pozwalające na odróżnienie stosunków pracy od umów cywilnoprawnych, również ulega zasadniczym przeobrażeniom niwelującym odrębności między zatrudnieniem pracowniczym i cywilnoprawnym ${ }^{19}$. To ostatnie staje się powszechną formą świadczenia pracy, choć nie zawsze dobrowolnie wybieraną ${ }^{20}$. Daleko idące podobieństwo wykazuje też sytuacja społeczna i ekonomiczna, w jakiej znajdują się osoby zatrudnione na podstawie umów o pracę i umów cywilnoprawnych ${ }^{21}$. Dotyczy to w coraz większym stopniu również samozatrudnionych (mówi się wręcz o „zależnym samozatrudnieniu"22).

17 Już według danych sprzed kilku lat Polska należała do czołówki państw w UE pod względem udziału osób wykonujących pracę na własny rachunek w ogólnej liczbie aktywnych zawodowo. Trudno jest jednoznacznie określić liczbę osób zatrudnionych na podstawie umów cywilnoprawnych, niemniej według bardzo ostrożnych, wstępnych szacunków GUS, w 2012 r. około 1,5 mln miało podpisaną wyłącznie umowę cywilnoprawną; por. M. Pańków, Polityka państwa wobec upowszechnienia elastycznych form zatrudnienia w Polsce, „Studia z Polityki Publicznej" 2015, nr 3 (7), s. 144 i n.

18 Por. J. Wratny, Problemy ochrony pracowników w elastycznych formach zatrudnienia, PizS 2007 , nr 7, s. 7. Por. też B. Bury, Dylematy na tle prawa do wypoczynku w zatrudnieniu niepracowniczym typu cywilnoprawnego, [w:] Przemiany prawa pracy..., s. 377 i n.

19 Warto bowiem podkreślić, że choć podporządkowanie nadal pozostaje nieodłącznym elementem definicyjnym tego stosunku, to jednak zmienia bardzo wyraźnie swoją formułę. Pracownik nie jest już, jak to było pierwotnie, jedynie wykonawcą prac o charakterze skooperowanym, powtarzalnym i odtwórczym, świadczonych pod ścisłym nadzorem pracodawcy, ale często zyskuje znaczną samodzielność pod względem sposobu realizowania swych zadań, a niekiedy także miejsca i czasu; por. L. Mitrus, Podporządkowanie pracownicze jako zmieniająca się cecha stosunku pracy, [w:] Wspótczesne problemy prawa pracy i ubezpieczeń społecznych, red. L. Florek, Ł. Pisarczyk, Warszawa 2011, s. 123 i n. Zob. też T. Duraj, Ewolucja pracowniczego podporządkowania jako cechy konstrukcyjnej stosunku pracy w świetle przepisów prawa pracy, [w:] Przemiany prawa pracy..., s. 160. Na temat możliwości występowania pewnych cech zatrudnienia pracowniczego w innych stosunkach zatrudnienia, m.in. cywilnoprawnych, oraz trudności w przeprowadzeniu jednolitego podziału stosunków prawnych, w ramach których świadczona jest praca, por. szerzej A.M. Świątkowski, Cywilnoprawne zatrudnienie niepracownicze, [w:] System prawa pracy, t. 7, red. K.W. Baran, Warszawa 2015, s. 68 i n. oraz M. Gersdorf, Prawo zatrudnienia, Warszawa 2013, s. 39 i n. Por. też wyrok SN z 11 września 2013 r., II PK 372/12, OSNP 2014, nr 6, poz. 80 oraz wyrok SN z 18 czerwca 1998 r., I PKN 191/98, www.sn.pl.

20 M. Gersdorf, Pozapracownicze stosunki zatrudnienia w najnowszym orzecznictwie Sadu Najwyższego, PiZS 2012, nr 11, s. 16 i n. Zwraca na to uwagę również J. Wratny, Problemy..., s. 7.

21 Por. Z. Kubot, Urlop wypoczynkowy w zatrudnieniu niepracowniczym typu cywilnoprawnego, PiZS 2002, nr 9, s. 29.

22 Por. H. Szewczyk, Ochrona praw i interesów osób zatrudnionych a nietypowe formy zatrudnienia w społecznej gospodarce rynkowej, „Roczniki Administracji i Prawa” 2013, t. XIII, s. 175. 
W rezultacie coraz trudniej wskazać na przekonujące argumenty natury prawnej, które uzasadniałyby pozbawienie licznej grupy osób świadczących pracę na zasadach zbliżonych do zatrudnienia pracowniczego możliwości korzystania z praw tradycyjnie pracowniczych, w tym również prawa do odpoczynku. Już dziś prawo do urlopu wypoczynkowego przysługuje chałupnikom ${ }^{23}$, zwolnienia od pracy zwane „quasi urlopami wypoczynkowymi” są przyznawane osobom pozostającym w zatrudnieniu typu penalnego ${ }^{24}$, dni wolne od pracy o celach wypoczynkowych są też uprawnieniem bezrobotnych korzystających $z$ takich instrumentów rynku pracy, jak staż czy przygotowanie zawodowe dorosłych ${ }^{25}$, wreszcie do przerw wypoczynkowych mają prawo uczestnicy studiów doktoranckich ${ }^{26}$. Zapewnienie

23 Por. rozporządzenie Rady Ministrów z 31 grudnia 1975 r. w sprawie uprawnień pracowniczych osób wykonujących pracę nakładczą. Urlop wypoczynkowy w tym zatrudnieniu typu cywilnoprawnego też ma charakter coroczny i odpłatny, a ponadto zasadniczo powinien być udzielony w całości, planowo i w sposób nieprzerwany (zastosowanie znajdują do niego bowiem art. 162-167 k.p.; por. § 16 ust. 2 rozporządzenia). Zmodyfikowano jednak zasady nabycia prawa do tego urlopu, przysługuje on bowiem wykonawcy uzyskującemu z tytułu pracy nakładczej wynagrodzenie w wysokości co najmniej 50\% najniższego wynagrodzenia, za przepracowany w całości lub części rok kalendarzowy, w wymiarze 1/12 wymiaru urlopu (ustalanego zgodnie z przepisami kodeksowymi) za każdy przepracowany miesiąc, ale udziela się go w roku następnym, w stosunku do roku nabycia prawa (a więc zawsze z dołu). Ponadto urlop ten ulega skróceniu o 1/12 za każdy miesiąc kalendarzowy, w którym wykonawca ze swej winy nie uzyskał wynagrodzenia, o którym wyżej mowa.

24 Por. A. Kosut, Zatrudnianie skazanych odbywajacych karę pozbawienia wolności - nowe uregulowania prawne, PiZS 1998, nr 10, s. 36. Zgodnie z art. 124 k.k.w. skazanemu, wykonującemu pracę na podstawie skierowania do pracy lub umowy o pracę nakładczą (a zatem na podstawie innej niż stosunek pracy), przysługuje po roku nieprzerwanej pracy, w czasie odbywania kary pozbawienia wolności, płatne zwolnienie od pracy przez okres 14 dni roboczych, chyba że praca ta była świadczona nieodpłatnie, wówczas zwolnienie bez prawa do wynagrodzenia za ten czas. Skazany, co istotne, prawa do wskazanego zwolnienia nie może się zrzec. Pozostawiono tu zatem roczny okres pracy, warunkujący prawo do zwolnienia udzielanego w celu wypoczynku, ale jednocześnie podwyższono jego wymiar w stosunku do stanu poprzedniego. Jeśli natomiast skazany wykonuje pracę w ramach umowy o pracę, uzyskuje urlop wypoczynkowy na zasadach kodeksowych, niemniej z modyfikacją dotyczącą wymiaru tego urlopu, który zgodnie z art. 124 § 2 k.k.w. wynosi w każdym przypadku 18 dni roboczych. W ocenie A. Kosut budzi to też określone kontrowersje, powstaje bowiem kwestia obiektywnych przyczyn skrócenia urlopu wypoczynkowego pracownikowi, który świadczy pracę w czasie odbywania kary pozbawienia wolności, polegającego na nieuwzględnianiu w wymiarze tego urlopu poprzednich okresów zatrudnienia oraz posiadanego wykształcenia - por. taż, Zatrudnianie skazanych..., s. 35. Warto też nadmienić, że pewnemu urealnieniu prawa do odpoczynku od pracy w tych specyficznych warunkach, w jakich znajdują się skazani, służą przepisy prawa karnego wykonawczego przyznające im w tym okresie szczególne uprawnienia, m.in. do dłuższych spacerów czy pierwszeństwa lub częstszego udziału w zajęciach kulturalno-oświatowych, z zakresu kultury fizycznej i sportu.

25 Por. E. Staszewska, [w:] M. Kuba, M. Nowak, E. Staszewska, Urlopy pracownicze, red. Z. Góral, Warszawa 2016, s. 31.

26 Przerwa ta nie może przekraczać 8 tygodni w ciągu roku i powinna być wykorzystana w okresie wolnym od zajęć dydaktycznych. Prawo do tej przerwy jest powiązane, jak się wydaje, z obowiązkiem nałożonym na doktorantów przez wymienioną ustawę, dotyczącym prowadzenia zajęć dydaktycznych lub uczestniczenia w ich prowadzeniu. 
pewnego minimalnego poziomu ochrony osób, które świadczą pracę w porównywalnej sytuacji, a więc, co do zasady, pracę zarobkową, w warunkach pewnej zależności i w sposób ciągły powinno mieć jednak szerszy zakres. Należy zatem podzielić wyrażany już dość powszechnie postulat przyznania osobom pozostającym w zatrudnieniu niepracowniczym, spełniającym wskazane cechy, ochrony, również w zakresie prawa do odpoczynku, zbliżonej do tej, z jakiej korzystają pracownicy $^{27}$. Bywa, że wprost formułuje się postulat ustawowego zagwarantowania im prawa do urlopu wypoczynkowego ${ }^{28}$, choć nie zawsze na takich samych warunkach, na jakich $\mathrm{z}$ uprawnienia tego korzystają osoby świadczące pracę w ramach stosunku pracy, np. jako zwolnienia nieodpłatnego ${ }^{29}$. Rodzi to oczywiście obawy o faktyczną skuteczność tego prawa (np. utrata dochodu przez dłuższy czas może zniechęcać do korzystania z tego rodzaju odpoczynku).

Na potrzebę rozszerzenia zakresu podmiotowego prawa do urlopu wypoczynkowego wpływa również sposób postrzegania istoty i funkcji prawa do odpoczyn$\mathrm{ku}$, w tym prawa do urlopu wypoczynkowego. O ile w przeszłości powstawały bowiem różne teoretyczne koncepcje w zakresie charakteru prawnego omawianego świadczenia (m.in. teoria darowizny, obowiązku pieczy pracodawcy czy, bardziej rozpowszechnione i konkurujące ze sobą, teoria urlopu jako świadczenia społecznego i urlopu jako odpłaty za świadczoną pracę $e^{30}$ ), to obecnie prezentowane zaczyna być także zupełnie odmienne od dotychczasowego podejście do analizowanej kwestii, w ramach którego odchodzi się od tradycyjnie wymienianych teorii na rzecz koncepcji urlopu jako „powszechnego prawa człowieka, powiązanego z pracą in abstracto" 31 . Jego konsekwencją jest właśnie m.in. postulat objęcia przedmiotem regulacji indywidualnego prawa pracy, w tym i prawem do urlopu wypoczynkowego, każdej pracy, a nie tylko tej wykonywanej w ramach stosunku $\operatorname{pracy}^{32}$.

Tym samym prawo do odpoczynku współcześnie nie powinno być postrzegane jako przywilej pracowniczy, ale jako jedno z podstawowych praw człowieka, które już z tego tytułu musi podlegać ochronie, niezależnie od formy, w jakiej praca jest wykonywana. W prawo to wpisanych jest bowiem wiele fundamentalnych, uniwersalnych wartości, takich jak prawo do życia, wolności, ochrony zdrowia, prywatności, rozwoju itp., które powinny być udziałem możliwie najszerszej grupy zatrudnionych.

O znaczeniu, randze, jaką przypisuje się prawu do urlopu wypoczynkowego, świadczy wielość aktów prawa międzynarodowego i europejskiego, wcześniej

27 Por. m.in. H. Szewczyk, Ochrona praw..., s. 184.

28 Por. A. Sobczyk, Prawo pracy w świetle Konstytucji RP, t. 1: Teoria publicznego i prywatnego indywidualnego prawa pracy, Warszawa 2013, s. 204. Por. też B. Bury, Dylematy..., s. 387 i n.

29 Por. tak J. Wratny, Problemy..., s. 8.

30 Por. J. Loga, Urlopy wypoczynkowe, tódź 1963, s. 42 i n.

31 Por. A. Bigaj, Charakter prawny urlopu wypoczynkowego, [w:] Studia z zakresu prawa pracy i polityki społecznej, red. A. Świątkowski, Kraków 2012, s. 176 i n.

32 Tak: A. Świątkowski, za: A. Bigaj, Charakter prawny urlopu..., s. 177. 
omawianych, w których prawo to znalazło bezpośrednio swój wyraz ${ }^{33}$. Poza zobowiązaniami międzynarodowymi, w doktrynie prawa pracy często wskazuje się, że argumentów do objęcia prawem do odpoczynku, w tym do urlopu wypoczynkowego, osób zatrudnionych na podstawach innych niż stosunek pracy dostarcza również Konstytucja RP. Kwestia ta, będąca przedmiotem pewnych kontrowersji, była podnoszona $\mathrm{w}$ pierwszej części rozważań, przy okazji omawiania regulacji konstytucyjnej w zakresie prawa do odpoczynku.

Jest sprawą do dyskusji nie tylko to, w jakim zakresie prawo do odpoczynku, a zwłaszcza prawo do urlopu wypoczynkowego, powinno być przyznane osobom pozostającym w zatrudnieniu niepracowniczym, ale także, w jaki formalny sposób należałoby ten cel osiągnąć. Można więc rozważać albo odpowiednie rozciągnięcie określonych przepisów kodeksowych na inne niż pracownicy grupy zatrudnionych albo też, uwzględniając swoistość pracy wykonywanej w innym charakterze niż pracowniczy, w wykonaniu obowiązku konstytucyjnego uregulować te kwestie odrębnie.

Nie sposób w tym miejscu przesądzić, które z proponowanych rozwiązań jest korzystniejsze. Być może jednak odrębna konstrukcja prawa do odpoczynku osób objętych zatrudnieniem pozapracowniczym - zwł. cywilnoprawnym, pozwalałaby w lepszym stopniu uwzględnić odmienny typ i charakter tego rodzaju zatrudnienia jako całości i poszczególnych jego odmian. Jest to jednak zadanie bardzo trudne i złożone, $\mathrm{z}$ tej perspektywy zastosowanie metody analogicznej jak wobec chałupników, a więc objęcie danej grupy osób określonymi instytucjami kodeksowymi, z odpowiednimi modyfikacjami, w drodze aktu wykonawczego, wydaje się sprzyjać szybszej realizacji wskazanych postulatów.

Idea deregulacji rynku pracy, choć doceniam jej wagę i znaczenie, nie powinna być jedynym wyznacznikiem zakresu uprawnień osób zatrudnionych. W szczególności nie może być dokonywana wbrew współczesnym kanonom praw człowieka oraz humanistycznemu aspektowi ludzkiej pracy. Jak bowiem słusznie zwrócono uwagę w doktrynie prawa pracy, praca zbyt często jest współcześnie postrzegana jedynie w kontekście wskaźników ekonomicznych, w oderwaniu od jej istotnej roli - jako elementu samorealizacji człowieka. Uwzględnienie drugiego z wymienionych aspektów oznacza zaś m.in. konieczność skoncentrowania uwagi na podmiotach wykonujących pracę oraz ich prawach - w tym przede wszystkim na zabezpieczeniu godnych warunków pracy i życia każdego pracującego oraz członków jego rodziny ${ }^{34}$. Wymaga to m.in. również przeciwdziałania wyzyskowi

33 Warto przypomnieć m.in. stanowisko Komitetu Praw Gospodarczych, Społecznych i Kulturalnych, jakie zostało sformułowane w stosunku do Polski. Komitet wyraził swoje zaniepokojenie stosunkowo wysokim poziomem umów cywilnoprawnych, na podstawie których świadczona jest praca, co ostatecznie może mieć negatywny wpływ na realizację prawa pracownika do sprawiedliwych i korzystnych warunków pracy, w tym m.in. prawa do odpoczynku. Por. Uwagi końcowe dotyczące VI Sprawozdania Okresowego Rzeczypospolitej Polskiej, 7.10.2016, E/C.12/POL/CO/6, www.rpo.gov.pl

Por. H. Szewczyk, Ochrona praw..., s. 186 i n. 
osób pozostających w niepracowniczym zatrudnieniu oraz ochrony ich dóbr osobistych - w tym zwł. zdrowia ${ }^{35}$, któremu niewątpliwie służy wypoczynek realizowany przede wszystkim poprzez instytucję urlopów wypoczynkowych.

W literaturze przedmiotu słusznie podkreśla się, że regulacje prawne, z pewnością i te dotyczące urlopu wypoczynkowego, by spełniały swe podstawowe funkcje, muszą być dostosowane do aktualnych warunków społeczno-ekonomicznych ${ }^{36}$. Wydaje się, że nie do końca udało się to uczynić we wskazanym obszarze.

Przeprowadzona w pracy analiza pozwala stwierdzić, że prawo pracownika do odpoczynku nie jest w świetle obowiązujących przepisów w optymalnym stopniu urzeczywistniane. Wniosek taki odnosi się przede wszystkim, co oczywiste $z$ uwagi na temat pracy, do urlopu wypoczynkowego, ale należy sobie zdawać sprawę, że określone niedostatki występują również w regulacji dotyczącej innych instrumentów prawnych służących realizacji konstytucyjnego prawa pracownika do odpoczynku, na co zwracano uwagę w początkowej części rozważań.

Jak wynika $\mathrm{z}$ dokonanych $\mathrm{w}$ niniejszej pracy ustaleń, urlop wypoczynkowy ze swej natury jest zwolnieniem od pracy służącym wypoczynkowi, a zatem przede wszystkim regeneracji psychofizycznej organizmu, a przez to też ochronie zdrowia, ale i ochronie życia rodzinnego, czy możliwości rozwijania własnych zainteresowań. Realizuje on zatem prawo do odpoczynku w jego współczesnym, szerszym ujęciu. Konstrukcja pracowniczego urlopu wypoczynkowego przyjęta w polskim prawie w znacznym stopniu tym założeniom odpowiada. W szczególności sformułowane w Kodeksie pracy przesłanki nabycia do niego prawa i jego wymiaru w zasadzie cel wypoczynkowy urlopu dość dobrze realizują. Rozważyć należy ewentualnie możliwość większego ustawowego powiązania wymiaru należnego pracownikowi urlopu (poprzez choćby instytucję urlopu dodatkowego) z faktycznymi warunkami wykonywania pracy, szczególnie jeśli są one wyjątkowo szkodliwe lub uciążliwe dla zdrowia.

Więcej wątpliwości budzą natomiast przesłanki uzyskania urlopu wynikające z przepisów szczególnych, które czasami wydają się trochę nie nadążać za zmianami w powszechnych przepisach dotyczących jego udzielania, które w znacznym stopniu uwzględniają już wynikające z prawa międzynarodowego i europejskiego wymogi. Niekiedy, tak jak w przypadku nauczycieli akademickich, chodzi o nadmiernie, w mojej ocenie, wydłużony okres wyczekiwania na urlop, a w niektórych przypadkach niepokojący jest brak jednoznacznie określonych warunków jego nabycia, z uwagi na zbyt dużą lakoniczność przepisów czy posłużenie się pojęciami dającymi asumpt do różnorakich interpretacji, jak na gruncie ustawy o zatrudnianiu pracowników tymczasowych.

Poza kwestią nabycia prawa do urlopu wypoczynkowego niezwykle ważną rolę w tytułowym zakresie odgrywają podstawowe reguły prawa urlopowego, które formalnie efektywność wypoczynku pracownika istotnie zabezpieczają.

35 Tamże, s. 184.

36 Por. W. Muszalski, Ogólna refleksja o rozwoju prawa pracy i jego uwarunkowaniu, [w:] Przemiany prawa pracy..., s. 59. 
Trzeba jednak zauważyć, że nie wszystkie unormowania występujące w obrębie prawa urlopowego są nakierowane na urzeczywistnienie podstawowej funkcji omawianej instytucji. Stosunek pracy stanowi pewną formę kooperacji, stąd uprawnienia jednej strony muszą być $\mathrm{w}$ jakimś stopniu, $\mathrm{z}$ uwagi na inne jeszcze chronione wartości, korygowane uprawnieniami drugiej. W tym zakresie zatem, w jakim ustawodawca nieco zakłóca przebieg podstawowej funkcji tego urlopu, mając na względzie zasługujący na szczególną ochronę interes pracodawcy, wydaje się to zrozumiałe.

Nie ulega jednakże wątpliwości, że gdy chodzi o tak podstawowe dla człowieka pracującego prawo, jak prawo do odpoczynku, ograniczenia w jego praktycznej realizacji powinny być sprowadzone do niezbędnego minimum, z poszanowaniem ogólnych reguł gwarantujących jego efektywność. Tymczasem część omawianych rozwiązań prawnych dotyczących uprawnień urlopowych pracowników, nie zawsze, jeśli chodzi o szczegóły, w pełni ten postulat realizuje. W zakresie prowadzonych rozważań występują bowiem takie unormowania, które, jak się wydaje, albo nie zostały dostatecznie przemyślane w kontekście funkcji omawianego świadczenia albo też przy ich wprowadzaniu przeważyły inne aspekty niż względy bezpieczeństwa pracowników (choćby kwestia elastyczności zatrudnienia), ewentualnie ich wadliwość wynika z braku precyzji w konstruowaniu przepisu i upowszechnionej niekorzystnej dla pracownika czy wręcz niewłaściwej jego wykładni. W kilku co najmniej przypadkach, sygnalizowanych w niniejszym opracowaniu, interwencja ustawodawcy ze względu na dużą niejednoznaczność przepisu lub wadliwą jego konstrukcję, wydaje się wręcz niezbędna.

Zastrzeżenia budzi przede wszystkim skuteczność formułowanych w ramach prawa urlopowego podstawowych zasad, gwarantujących w założeniu pełną realizację głównych funkcji urlopu wypoczynkowego. W wielu miejscach zwracano uwagę, że wynikające z nich powinności określonego zachowania się stron stosunku pracy stają się w dużej mierze postulatami, ze względu na brak dostatecznych instrumentów prawnych dla ich egzekwowania, w tym zwł. wobec przyjętej w doktrynie prawa pracy i orzecznictwie wykładni zasadniczo niedopuszczającej możliwości ingerencji pracownika w proces udzielania urlopów wypoczynkowych. Nawet naruszenie przez pracodawcę nałożonych na niego prawem obowiązków wobec pracownika, mających istotne znaczenie dla optymalnego wypoczynku, nie pozwala bowiem podjąć pracownikowi określonych „działań naprawczych”, w tym np. „samowolnego" przedłużenia okresu odpoczynku do wymaganych przez prawo $14 \mathrm{dni}$. Tego rodzaju kierunek powszechnie funkcjonującej interpretacji przepisów, spowodowany być może ich małą stanowczością, budzi pewne wątpliwości. Stosunek pracy nie jest bowiem stosunkiem jednostronnie kształtowanym, ale został oparty na przynajmniej formalnej równości obu jego stron - pracownik powinien świadczyć pracę sumienie i starannie, ale w ten sam sposób pracodawca powinien podchodzić do realizacji jego podstawowych powinności wobec pracownika, zwłaszcza w zakresie tak podstawowych praw jak prawo do odpoczynku osoby zatrudnianej. Tak jak pracodawca ma określone instrumenty, żeby wyeg- 
zekwować określone zachowania pracowników, tak również ci ostatni powinni mieć możliwość bardziej skutecznego egzekwowania swoich zasadniczych praw, szczególnie jeśli są one nagminnie przez pracodawcę naruszane. Trzeba wyraźnie bowiem zaznaczyć, że wszelkie roszczenia o charakterze majątkowym, z którymi zatrudniony może ewentualnie, jak się przyjmuje, wystąpić, nie zastąpią mu czasu wolnego, którego z powodu nielegalnych zachowań pracodawcy nie mógł wykorzystać, ze szkodą dla własnego zdrowia, osobistego rozwoju czy dobra swojej rodziny. Pomijając już aspekt braku dostatecznej wiedzy pracowników w tym zakresie i ich obawę czy wręcz niechęć do występowania na drogę postępowania sądowego, w szczególności w okresie trwającego zatrudnienia.

Drugą z zasadniczych kwestii budzących wątpliwości z perspektywy prawa pracownika do wypoczynku jest zbyt mocno, w moim odczuciu, ograniczony wpływ pracownika na czas, w jakim ostatecznie będzie z tego urlopu korzystać. Urlopu wypoczynkowego udziela pracodawca, ale nie można abstrahować od faktu, że jest to jednak uprawnienie pracownika, które ze względu na swój charakter powinno być generalnie realizowane w czasie najbardziej dla pracownika dogodnym. Tymczasem, według zawartych w Kodeksie pracy przepisów oraz powszechnie stosowanej ich wykładni, o terminie urlopu wypoczynkowego w znacznej mierze decyduje podmiot zatrudniający, który powinien jedynie wziąć pod uwage sugestie pracownika w tym zakresie. Wydaje się, że akcent musi być jednak położony na obowiązek pracodawcy udzielenia urlopu w terminie przez pracownika wskazanym, który może zostać ostatecznie skorygowany ważnymi, obiektywnymi potrzebami pracodawcy, podlegającymi, w razie wątpliwości, weryfikacji w postępowaniu sądowym. W takiej jednak sytuacji strony stosunku pracy powinny ustalać inny termin urlopu wypoczynkowego w drodze porozumienia. W Polsce jest on jednak często w dużej mierze jednostronnie kształtowany, czemu trochę sprzyja nie tylko niezbyt jednoznaczne sformułowanie przepisów w tym zakresie, ale też przyjmowana zwykle w orzecznictwie sądowym zdecydowanie propracodawcza ich interpretacja (choć, moim zdaniem, możliwa jest też inna).

Ze względu na powyższe urlop wypoczynkowy bywa też wykorzystywany jako swego rodzaju remedium na mniejsze zapotrzebowanie na pracę w danym okresie, czego konsekwencją jest jednak „wysyłanie” pracowników na urlop w okresach jesiennych czy zimowych, w których oczywiście odpoczynek jest możliwy, ale generalnie nie sprzyjają one jego optymalnemu wykorzystaniu. W niektórych krajach dość skutecznie prawo przeciwdziała tego rodzaju praktykom.

We Francji na przykład zasadnicza część urlopu wypoczynkowego powinna być wykorzystana w okresie od maja do końca października. Pracownik nigdy nie jest też zaskakiwany udzieleniem urlopu, kolejność korzystania z urlopu wypoczynkowego i datę jego rozpoczęcia pracodawca ogłasza bowiem co najmniej na miesiąc przed tym terminem ${ }^{37}$ (w wyniku liberalizacji prawa pracy dopuszczono możliwość skrócenia tego okresu w drodze umowy zbiorowej).

37 Por. G. Auzero, E. Dockès, Droit du travail, Paris 2014, s. 872. 
Polskie prawo nie przewiduje żadnego minimalnego terminu $\mathrm{w}$ stosunku do momentu rozpoczęcia urlopu przez pracownika, w jakim pracodawca powinien zawiadomić pracownika o ostatecznej dacie rozpoczęcia urlopu, co ma znaczenie szczególnie wtedy, gdy termin ten jest inny niż preferowany przez zatrudnionego.

Nie ma również określonego minimalnego okresu, w jakim pracodawca powinien powiadomić pracownika o zmianie zaplanowanej daty urlopu, w razie zaistnienia po jego stronie szczególnych potrzeb. Konieczne staje się zatem, od dawna postulowane, wprowadzenie obowiązku pracodawcy pokrycia kosztów, które pracownik poniósł w związku z przesunięciem terminu jego urlopu. W literaturze wskazuje się na możliwość odpowiedniego stosowania w takich sytuacjach przepisów o odwołaniu z urlopu, choć wydaje się, że wyraźne sformułowanie takiego obowiązku w prawie urlopowym będzie jednoznacznie tę kwestię przesądzać i być może ograniczać w praktyce wykorzystywanie przepisów o przesunięciu urlopu do rzeczywiście niezbędnych przypadków.

Zwiększenie wpływu pracowników na ustalany termin urlopu jest szczególnie uzasadnione w sytuacji, gdy dochodzi do jego zmiany z przyczyn leżących po stronie pracodawcy. $Z$ rozporządzenia urlopowego wynika wprawdzie, że strony uzgadniają nowy termin takiego urlopu, niemniej nadanie tej regulacji charakteru ustawowego niewątpliwie wzmocniłoby jej znaczenie także w praktyce.

Zmiana sposobu interpretacji obowiązującego prawa w zakresie ustalania terminu wykorzystania urlopu, o której była wyżej mowa, czy wprowadzenie bardziej rygorystycznych przepisów regulujących tę kwestię, w dużej mierze czyniłyby też zbędną instytucję urlopu na żądanie, budzącą w piśmiennictwie wiele kontrowersji, również z punktu widzenia wypoczynkowej funkcji urlopu. Należy bowiem przypomnieć, że urlop ten, według ugruntowanej już wykładni, także nie ma bezwzględnego charakteru i pracodawca może odmówić jego udzielenia. Biorąc pod uwagę jak wiele niedoskonałości wykazuje omawiana konstrukcja, zdecydowanie lepszym rozwiązaniem byłoby wprowadzenie możliwości skorzystania przez pracownika ze specjalnego zwolnienia na załatwienie pilnych spraw, w wymiarze pojedynczych dni, tak by tego rodzaju potrzeby zatrudnionego nie były realizowane kosztem wypoczynku.

Wiele kontrowersji wywołuje również stopień respektowania zasady urlopu corocznego, zwłaszcza że w ostatnim czasie ustawodawca znacznie zwiększył zakres możliwego odstępstwa czasowego od tej reguły, co musi być w kontekście wypoczynkowej funkcji urlopu oceniane negatywnie. W praktyce, niekiedy za zgodą samych zatrudnionych, dochodzi do jej częstego naruszania, szczególnie że panuje powszechne przekonanie, iż urlop, bez względu na zaistniałe okoliczności, może być udzielony do końca trzeciego kwartału roku następnego. Z przepisów wynika jednak wprost, że udzielenie urlopu w tym czasie jest dopuszczalne jedynie wyjątkowo w razie wystąpienia przesłanek powodujących konieczność zmiany wcześniej zaplanowanego terminu urlopu. Ze względu na wagę omawianej zasady dla efektywności wypoczynku pracownika z tytułu udzielonego urlopu, wydaje się, że warto rozważyć wprowadzenie swoistej „sankcji” dla pracodawcy, który jej nie 
respektuje, polegającej na obowiązku udzielenia zaległego urlopu wypoczynkowego w wymiarze wyższym w stosunku do niewykorzystanej części urlopu z roku ubiegłego. Niewątpliwie motywowałoby to pracodawców do udzielania urlopów wypoczynkowych w okresie właściwym dla jego rozliczania i zapewniało większą skuteczność takiego wypoczynku. Również przyznanie pracownikowi prawa do wskazania terminu urlopu, w sytuacji, gdy pierwotnie określona data jego rozpoczęcia uległa zmianie z przyczyn leżących po stronie pracodawcy, czy też nie została w ogóle przez pracodawcę z pracownikiem ustalona, mogłoby się w jakiejś mierze przyczynić do zwiększenia skuteczności egzekwowania tej zasady.

W nawiązaniu do powyższej zasady warto pomyśleć o ewentualnym wprowadzeniu przepisów przesądzających jednoznacznie, co dzieje się w przypadku, gdy urlop nie został wykorzystany we właściwym terminie, tj. do końca roku lub w razie okoliczności uzasadniających jego szeroko rozumiane przesunięcie - do końca września roku następnego. Do niedawna w literaturze powszechnie przyjmowano, że urlopu tego pracownik nie traci, a prawo do niego przedawnia się z upływem trzech lat. W ostatnim czasie wyrażono jednak wątpliwości co do trafności takiego zapatrywania, zwłaszcza z uwagi na wspomnianą wyżej zasadę i jej znaczenie dla realizacji funkcji urlopu, o czym była wcześniej mowa. Choć nie podzielam w całości proponowanej odmiennej wykładni, to jednak warto rozważyć, czy możliwość realizacji prawa do urlopu przez pracownika nie powinna być bardziej ograniczona w czasie, biorąc pod uwagę, że urlop ma jednak stanowić coroczny odpoczynek. Trzeba mieć świadomość, że jego udzielenie po dłuższym okresie w stosunku do roku jego nabycia, np. 2,5-letnim, zaczyna być bowiem bezcelowe. Groźba utraty tego prawa w połączeniu z proponowanym wzmocnieniem pozycji pracownika w procedurze udzielania urlopu (w tym zwłaszcza określania jego terminu) mogłoby wywierać określoną presję na samych zatrudnionych w kierunku wykorzystywania nabytego uprawnienia w przewidzianym prawem terminie. Wymagałoby to jednak, moim zdaniem, wyraźnej interwencji ustawodawcy.

Wreszcie zwrócić trzeba baczniejszą uwagę na regulacje zawarte w ustawach szczególnych. Nie sposób nie zauważyć bowiem, że niektóre wprowadzane w nich odstępstwa od ogólnych zasad prawa urlopowego nie tylko nie znajdują wystarczającego obiektywnego uzasadnienia, nie uwzględniają wymogów wspólnotowych, ale stanowią istotne zagrożenie dla skutecznego urzeczywistniania prawa pracownika do odpoczynku i powinny być zmienione. Wystarczy wspomnieć choćby zakres odstąpienia od zasady urlopu w naturze w stosunku do pracowników tymczasowych, mającej dla omawianego prawa fundamentalne wręcz znaczenie, który powoduje, że w istocie prawo do odpoczynku tej grupy zatrudnionych staje się w znacznym stopniu iluzoryczne. Pracownik taki nie zawsze będzie miał szansę wykorzystać nabyte prawo do urlopu wypoczynkowego w sposób zgodny z jego przeznaczeniem i istotą. Tymczasem należy wyraźnie podkreślić, że prawo do odpoczynku może być w pewnym zakresie korygowane, również z uwagi na charakter zatrudnienia, ale nigdy w sposób, który będzie sprzeciwiać się jego naturze czy podważać jego skuteczność. 



\section{Bibliografia}

Adlercreutz A., Nystrom B., Labour Law in Sweden, The Netherlands 2010

Arystoteles, Dzieła wszystkie, t. 6, Warszawa 2003

Au-delà de l'emploi, ed. A. Supiot, Paris 1999

Auzero G., Dockès E., Droit du travail, Paris 2014

Babeuf G., Pisma wybrane, przedmowa i komentarz G. i C. Willard, Warszawa 1951

Banaszak B., Konstytucja Rzeczypospolitej Polskiej. Komentarz, Warszawa 2009

Baran K.W., Prawo pracy, Warszawa 2005

Barnard C., EC Employment Law, Chichester 1995

Bartkowiak G., Człowiek w pracy. Od stresu do sukcesu w organizacji, Warszawa 2009

Bigaj A., Charakter prawny urlopu wypoczynkowego, [w:] Studia z zakresu prawa pracy i polityki społecznej, red. A. Świątkowski, Kraków 2012

Bigaj A., Prawo do urlopu wypoczynkowego, Warszawa 2015

Bigaj A., Wybrane aspekty prawa do wypoczynku, [w:] Aktualne zagadnienia prawa pracy i polityki socjalnej (zbiór studiów), t. 2, red. B.M. Ćwiertniak, Sosnowiec 2013

Blanpain R., Matey M., Europejskie prawo pracy w polskiej perspektywie, Warszawa 1993

Bombol M., Czas wolny jako kategoria diagnostyczna procesów rozwoju społeczno-gospodarczego, Warszawa 2008

Boruta I., Urlopy wypoczynkowe po zmianie Kodeksu pracy, Warszawa 1997

Bury B., Dylematy na tle prawa do wypoczynku w zatrudnieniu niepracowniczym typu cywilnoprawnego, [w:] Przemiany prawa pracy. Od kodyfikacji do współczesności, Księga Jubileuszowa Prof. T. Liszcz, red. A. Kosut, W. Perdeus, „Studia Iuridica Lublinensia” 2015, vol. XXIV

Chakowski M., Ciszek P., Kontrowersje wokół tzw. urlopu na żądanie a orzecznictwo SN, M.P.P. 2010, nr 3

Chmielek-Łubińska E., [w:] Kodeks pracy. Komentarz, red. B. Wagner, Gdańsk 2004

Chmielek-Łubińska E., [w:] Kodeks pracy. Komentarz, red. L. Florek, Warszawa 2009

Chmielek-Łubińska E., Pierwszy urlop wypoczynkowy, [w:] Studia z zakresu prawa pracy i polityki społecznej, red. A. Świątkowski, Kraków 2001/2002

Chmielek-Łubińska E., Pracownicze urlopy bezpłatne i zwolnienia od pracy, Warszawa 1999

Chmielek-Łubińska E., Urlop na żądanie pracownika, M.P.P. 2005, nr 10

Chmielek-Łubińska E., Urlop na żądanie pracownika, PiZS 2003, nr 3

Chmielek-Łubińska E., Urlop proporcjonalny, Studia z zakresu prawa pracy i polityki społecznej, red.

A. Świątkowski, Kraków 1997/1998 
Chmielek-Łubińska E., Urlop wypoczynkowy po nowelizacji, PiZS 2004, nr 1

Chmielek-Łubińska E., Urlopy wypoczynkowe po nowelizacji Kodeksu pracy, „Służba Pracownicza” 1997, nr 1

Chmielek-Łubińska E., Urlopy wypoczynkowe. Nowe uregulowania od stycznia 1997 r., Warszawa 1997

Chobot A., Czas pracy w znowelizowanym kodeksie pracy, Poznań 2003

Chobot A., Pracowniczy obowiązek dbałości o dobro zakładu a ograniczenia zasady wolności pracy, Poznań 1983

Chobot A., Pachciarek K., Prawa i obowiązki agencji pracy tymczasowej i pracodawcy użytkownika wobec pracownika tymczasowego, PiZS 2005, nr 1

Cicero, O powinnościach, [w:] tenże, Pisma filozoficzne, t. 2, Warszawa 1960

Cudowski B., Urlop wypoczynkowy i bezpłatny a dodatkowe zatrudnienie, [w:] „Człowiek, obywatel, pracownik. Studia z zakresu prawa". Księga Jubileuszowa poświęcona Profesor U. Jackowiak, red. J. Stelina, A. Wypych-Żywicka, „Gdańskie Studia Prawnicze” 2007, t. XVII

Cudowski B., Zmiany regulacji prawnej dodatkowego zatrudnienia, [w:] Przemiany prawa pracy. Od kodyfikacji do współczesności, Księga Jubileuszowa Prof. T. Liszcz, red. A. Kosut, W. Perdeus, „Studia Iuridica Lublinensia” 2015, t. XXIV

Ćwiertniak B.M., [w:] Prawo pracy, red. K. W. Baran, Kraków 2010

Czarnek P., Rodzaje rozrywki w polskiej radiofonii komercyjnej, Łódź 2014

Czerniak-Swędzioł J., Koczur S., Granice możliwości zwolnienia pracownika z obowiązku świadczenia pracy, [w:] Studia z zakresu prawa pracy i polityki społecznej, red. A. Świątkowski, Kraków 2013

Czas wolny w starożytnym Rzymie, www.imperiumromanum.edu.pl [dostęp: 6.02.2017]

Damhaug J., Wrocławska T., Konsekwencje pracowniczej niezdolności do pracy z powodu choroby w świetle przepisów ustawodawstwa norweskiego, „Studia Prawno-Ekonomiczne” 2012, t. LXXXV

Daszczyńska A., Prawo pracownika tymczasowego do odpoczynku, [w:] Z problematyki zatrudnienia tymczasowego, red. A. Sobczyk, LEX 2011

Deborad G., Społeczeństwo spektaklu, „Panoptikum” 2008, nr 7

Defańska E., Urlop wypoczynkowy dla zatrudnionych przez agencje pracy tymczasowej, 4.11.2011, www.rp.pl

Despax M., Rojot J., Laborde J., Labour Law in France, Alphen aan den Rijn 2011

Driczinski S., Elastyczność pojęcia czasu pracy, Szczecin 2002

Driczinski S., [w:] Kodeks pracy. Komentarz, red. K.W. Baran, Warszawa 2012

Drozdek M., Prawa społeczne w konstytucji, „Tygodnik Solidarność” 1994, nr 41

Dubowik A., Zasada udzielania urlopu wypoczynkowego w naturze i plan urlopów, PiZS 2003, nr 5

Dubowik A., Zasady udzielania urlopów wypoczynkowych według nowych przepisów, PiZS 1997, nr 4

Duniewska Z., Polisemia godności w terminologii prawnej, „Studia Prawno-Ekonomiczne” 2005, t. LXXI

Dunning E., O emocjach w sporcie i wypoczynku, [w:] Socjologia codzienności, red. P. Sztompka, M. Bogunia-Borowska, Kraków 2008

Duraj T., Ewolucja pracowniczego podporzadkowania jako cechy konstrukcyjnej stosunku pracy w świetle przepisów prawa pracy, [w:] Przemiany prawa pracy. Od kodyfikacji do wspótczesności, Księga Jubileuszowa Prof. T. Liszcz, red. A. Kosut, W. Perdeus, „Studia Iuridica Lublinensia” 2015, t. XXIV

Dyląg W., Prawo do wypoczynku jako przejaw funkcji ochronnej prawa pracy, [w:] Funkcja ochronna prawa pracy a wyzwania współczesności, red. M. Bosak, Warszawa 2014

Dyoniziak R., Społeczeństwo w procesie zmian, Kraków, Szczecin, Zielona Góra 1997

European Social Charter: European Committee of Social Rights, Konkluzje XIX-3 (Niemcy), Strasbourg 2011

Florek L., Czas pracy i urlopy wypoczynkowe w prawie europejskim, PiZS 1999, nr 2

Florek L., Europejskie prawo pracy, Warszawa 2005

Florek L., Konstytucyjne gwarancje uprawnień pracowniczych, PiP 1997, nr 12 
Florek L., Prawo pracy Unii Europejskiej, [w:] Europejskie prawo pracy i ubezpieczeń społecznych, red.

L. Florek, Warszawa 1996

Florek L., Staż pracy, Warszawa 1980

Florek L., Seweryński M., Międzynarodowe prawo pracy, Warszawa 1988

Florek L., Zieliński T., Prawo pracy, Warszawa 1997, 2004

Francja wprowadza zakaz korzystania z poczty służbowej po pracy. Czy stusznie?, „Polityka”, 18.02.2016, www.poltyka.pl

Frączek M., Łajeczko M., Praca tymczasowa, pytania i odpowiedzi, „Służba Pracownicza” 2004, nr 5 Friedmann G., Maszyna i człowiek, Warszawa 1961

Garlicki L., Prawa socjalne w orzecznictwie Trybunału Konstytucyjnego, „Przegląd Sejmowy” 1995, nr 2 Gersdorf M., Pozapracownicze stosunki zatrudnienia w najnowszym orzecznictwie Sądu Najwyższego, PiZS 2012, nr 11

Gersdorf M., Prawo zatrudnienia, Warszawa 2013

Gersdorf M., Zwolnienie pracownika z obowiązku świadczenia pracy, PiZS 2005, nr 3

Gersdorf M., Rączka K., Raczkowski M., Kodeks pracy. Komentarz, Warszawa 2014

Gładzicki Z., Humanizacja pracy ludzkiej w encyklice, [w:] „Powołany do pracy”. Komentarz, red.

J. Krucina, Wrocław 1983

Goździewicz G., Zieliński T., [w:] Kodeks pracy. Komentarz, red. L. Florek, LEX 2011

Góral Z., [w:] Akademickie prawo pracy, red. K.W. Baran, Warszawa 2015

Góral Z., [w:] Kodeks pracy. Komentarz, red. K.W. Baran, Warszawa 2012

Góral Z., [w:] Ustawa o promocji zatrudnienia i instytucjach rynku pracy. Praktyczny komentarz, Warszawa 2011

Góral Z., O kodeksowym katalogu zasad indywidualnego prawa pracy, Warszawa 2011

Góral Z., Podstawowe zasady indywidualnego prawa pracy, [w:] System prawa pracy, t. 1: Część ogólna, red. K.W. Baran, Warszawa 2017

Góral Z., Prawo do pracy. Studium prawa polskiego w świetle porównawczym, Łódź 1994

Grzebyk P., Ochrona odpoczynku niedzielnego, [w:] Czas pracy, red. L. Florek, Warszawa 2011

Henssler M., Willemsen H.J., Kalb H.-J., Arbeitsrecht Kommentar, Köln 2016

Hueck A., Nipperdey C. H., Lehrbuch des Arbeitsrecht, t. 1, Berlin 1955

Ignatowska-Jaroszewska I., [w:] K. Walczak, M. Wojewódka, Prawo pracy dla sędziów i petnomocników, Warszawa 2017

Informacje na temat Europejskiej Karty Społecznej, maj 1999, Ministerstwo Pracy i Polityki Socjalnej Iwulski J., Sanetra W., Kodeks pracy. Komentarz, Warszawa 2000

Izdebski H., Zieliński J.M., Prawo o szkolnictwie wyższym. Komentarz, Warszawa 2011

Jarosz Z., Zawadzki S., Prawo konstytucyjne, Warszawa 1980

Jaroszewska M., Urlopy wypoczynkowe, Warszawa 2009

Jaśkiewicz W., Jackowiak C., Piotrowski W., Prawo pracy w zarysie, Warszawa 1980

Jaśkowski K., Zwolnienie pracownika z obowiązku świadczenia pracy, PiZS 2016, nr 3

Jaśkowski K., Maniewska E., Kodeks pracy. Komentarz, Zakamycze 2006

Jaśkowski K., Maniewska E., Kodeks pracy. Komentarz, LEX/el. 2011

Jaśkowski K., Maniewska E., Komentarz aktualizowany do Kodeksu pracy, LEX/el. 2017

Jaśkowski K., Maniewska E., Zagadnienie ochrony dóbr osobistych w prawie pracy, PiP 1963, nr 7-8.

Jaśkowski K., Maniewska E., Stelina J., Grupowe zwolnienia. Komentarz, Kraków 2004

Jędrzejowski B., Ruch czartystów w Anglji, Warszawa 1907

Jończyk J., Zagadnienie ochrony dóbr osobistych w prawie pracy, PiP 1963, nr 7-8

Kantor R., Zabawa w dobie społeczeństwa konsumpcyjnego: Szkice o ludyzmie, ludyczności i powadze, a w istocie o jej braku, Kraków 2013

Karney J.E., Psychopedagogika pracy, Warszawa 2007

Kędzia Z., Burżuazyjna koncepcja praw człowieka, Wrocław 1980 
Kisiel A., Wypalenie zawodowe - przykładowe symptomy i przeciwdziałania, [w:] Współczesne wyzwania menedżerskie w przeciwdziałaniu wypaleniu zawodowemu, red. J. Koprowicz, W. Bańka, „Humanizacja Pracy” 2011, nr 6

Koczur S., Faktyczne możliwości realizacji pracowniczego prawa do nieprzerwanego odpoczynku, M.P.P. 2015, $\mathrm{nr} 9$

Kodeks pracy, t. 1: Komentarz. Ustawy towarzyszace $z$ orzecznictwem. Europejskie prawo pracy $z$ orzecznictwem, red. K. Jaśkowski, E. Maniewska, wyd. IX, LEX 2014 [dostęp: 20.08.2014]

Kodeks pracy. Komentarz, red. L. Florek, LEX 2011

Kodeks pracy. Komentarz, red. W. Muszalski, Warszawa 2009, 2011

Kodeks pracy. Komentarz, red. B. Wagner, Gdańsk 2004

Kolasiński K., Podstawy prawa pracy, Toruń 1979

Kolasiński K., Prawo pracy znowelizowane, Toruń 1996

Kolny B., Czas wolny w świetle zrównoważonego rozwoju, „Konsumpcja i Rozwój” 2014, nr 2

Konstytucja Albanii, wstęp A. Bosiacki, Warszawa 1997

Konstytucja Belgii z lutego 1831 r., tekst jednolity z 14 lutego 1994 r., wstęp W. Skrzydło, Warszawa 1996

Konstytucja Estonii, wstęp L. Garlicki, P. Łossowski, Warszawa 1997

Konstytucja Federacji Rosyjskiej z 12 grudnia 1993 r., wstęp A. Bosiacki, Warszawa 2000

Konstytucja Federalna Konfederacji Szwajcarskiej z 18 kwietnia 1999 r., tłum. i wstęp Z. Czeszejko-Sochacki, Warszawa 2000

Konstytucja Hiszpanii, tłum. i wstęp: T. Mołdawa, Warszawa 1993

Konstytucja Ludowej Republiki Bułgarii, wstęp E. Gdulewicz, Wrocław, Warszawa, Kraków, Gdańsk 1979 Konstytucja Republiki Chorwackiej z 22 grudnia 1990 r., wstęp: A. i L. Garliccy, Warszawa 1995

Konstytucja Republiki Czeskiej z 16 grudnia 1992 r., wstęp i tłum. M. Kruk, Warszawa 2000

Konstytucja Republiki Łotewskiej z 15 lutego 1922 r., wstęp P. Kierończyk, Warszawa 2001

Konstytucja Republiki Portugalskiej z 2 kwietnia 1976 r., tłum. A. Wojtyczek-Bonnand, Warszawa 2000

Konstytucja Republiki Słowenii z 23 grudnia 1991 r., tłum. i wstęp P. Winczorek, Warszawa 1994

Konstytucji Republiki Wegierskiej z 1990 r., tłum. i wstęp H. Donath, Warszawa 1996

Konstytucja Republiki Włoskiej, [w:] Nowe konstytucje państw europejskich, red. L. Gelberg, Warszawa 1949

Konstytucja Republiki Włoskiej z 27 grudnia 1947 r., tłum. Z. Witkowski, Warszawa 2004

Konstytucja Rumunii z 21 listopada 1991 r., wstęp: W. Brodziński, Warszawa 1996

Konstytucja Rzeczypospolitej Polskiej. Komentarz, t. 3, red. L. Garlicki, Warszawa 2003

Konstytucja Ukrainy z 28 czerwca 1996 r., wstęp i tłum. E. Toczek, Warszawa 1999

Konstytucja Węgierskiej Republiki Ludowej, red. A. Gwiżdż, Wrocław, Warszawa, Kraków, Gdańsk 1975

Konwencje i zalecenia Międzynarodowej Organizacji Pracy 1919-2012, t. 1, Warszawa 2014

Kostrzewski L., Miączyński P., Roczny urlop dla wypalonych, „Gazeta Wyborcza”, www.wyborcza.pl [dostęp: 1.12.2016]

Kostrzewski L., Miączyński P., Rok wakacji od pracy, „Gazeta Wyborcza”, www.wyborcza.pl [dostęp: 1.12.2016]

Kosut A., [w:] Kodeks pracy. Komentarz, red. K.W. Baran, Warszawa 2012

Kosut A., Przemiany regulacji prawnej urlopów wypoczynkowych w Kodeksie pracy, [w:] Przemiany prawa pracy. Od kodyfikacji do współczesności. Księga Jubileuszowa Prof. T. Liszcz, red. A. Kosut, W. Perdeus, „Studia Iuridica Lublinensia” 2015, t. XXIV

Kosut A., Urlop na żądanie, [w:] Studia z prawa pracy. Księga pamiątkowa ku czci Docenta Jerzego Logi, Łódź 2007

Kosut A., Zatrudnianie skazanych odbywających kare pozbawienia wolności - nowe uregulowania prawne, PiZS 1998, nr 10 
Krysińska-Wnuk L., Regulacja zwolnień grupowych pracowników, Warszawa 2009

Kuba M., Nowak M., Staszewska E., Urlopy pracownicze, red. Z. Góral, Warszawa 2016

Kubot Z., Kompensacyjny czas wolny - analiza pojęcia, PiZS 2008, nr 9

Kubot Z., Pojęcie dyżuru medycznego, PiZS 2000, nr 4

Kubot Z., Urlop wypoczynkowy w zatrudnieniu niepracowniczym typu cywilnoprawnego, PiZS 2002, nr 9

Kuczynski J., Die theorie der Lager der Arbeiter, Berlin 1952

Kuczynski J., Położenie robotników w Stanach Zjednoczonych. Od roku 1789 do czasów dzisiejszych, Warszawa 1950

Kulig K., Aksjologia „zakazu pracy” w niedziele i święta w kontekście nowelizacji Kodeksu pracy, M.P.P. 2014, nr 6

Kulig K., Prawo pracownika do odpoczynku dobowego, PiZS 2015, nr 2

Kwilecki K., Rozważania o czasie wolnym. Wybrane zagadnienia, Katowice 2011

Lafargue P., Prawo do lenistwa, Warszawa 2006

Landau W., Ośmiogodzinny dzień pracy, Warszawa 1927

Latos-Miłkowska M., Czas pracy. Między gospodarka a ochrona pracy, [w:] Prawo pracy. Między gospodarka a ochrona pracy. Księga jubileuszowa Profesora Ludwika Florka, red. M. Latos-Miłkowska, Ł. Pisarczyk, Warszawa 2016

Latos-Miłkowska M., Okresy rozliczeniowe czasu pracy, [w:] Czas pracy, red. L. Florek, Warszawa 2011

Latos-Miłkowska M., Pisarczyk Ł., Zwolnienie z przyczyn niedotyczących pracownika, Warszawa 2005

Lehmann G., Praktyczna fizjologia pracy, Warszawa 1960

Lenart B., Przerwanie urlopu wypoczynkowego, „Służba Pracownicza” 2003, nr 6

Leon XIII, Encyklika „Rerum novarum”, www.nonpossumus.pl [dostęp: 17.02.2016]

Lewandowski H., Dyżur medyczny - uwagi na kanwie wyroku SN z 6.6.2006 r., M.P.P. 2008, nr 1

Lewy M., Prawo przemystowe i robotnicze, Warszawa 1918

Lipa M., von Zanthier H., Prawo pracy w Niemczech, Berlin 2012

Liszcz T., Kiedy pracownik nie powinien pracować, [w:] Prawo pracy. Między gospodarka a ochrona pracy. Ksiega Jubileuszowa Profesora L. Florka, red. M. Latos-Miłkowska, Ł. Pisarczyk, Warszawa 2016

Liszcz T., Prawo pracy, Gdańsk 1996

Liszcz T., Prawo pracy, Warszawa 2004

Liszcz T., Przyszła Konstytucja Rzeczypospolitej Polskiej a prawo pracy, „Annales UMCS” 1997, t. XLIV

Locke J., Dwa traktaty o rządzie, tłum. Z. Rau, Warszawa 1992

Loga J., Poglady nauki burżuazyjnej na charakter prawny urlopu wypoczynkowego, „Zeszyty Naukowe Uniwersytetu Łódzkiego" 1958, seria I, z. 14

Loga J., Polskie prawo pracy w okresie międzywojennym, Łódź 1980

Loga J., Pracownicze urlopy wypoczynkowe, „Nowe Prawo” 1975, nr 3

Loga J., Urlopy wypoczynkowe, Łódź 1963

Loga J., Wymiar urlopu wypoczynkowego, PiZS 1981, nr 5-6

Lorens B., Czas wolny i formy jego spędzania w miastach polskich doby nowożytnej (XVI-XVIII wiek),

[w:] Czas wolny: przeszłość - teraźniejszość - przyszłość, red. J. Daszykowska, R. Pelczar, Stalowa Wola 2009

Łajeczko M., Urlop wypoczynkowy, „Prawo Pracy” 1999, nr 3

Łapiński K., Wynagrodzenie za pracę w niedzielę i święto, [w:] $Z$ aktualnych zagadnień prawa pracy i zabezpieczenia społecznego. Ksiega Jubileuszowa Profesora W. Sanetry, red. B. Cudowski, J. Iwulski, Białystok 2013

Łętowska E., Po co ludziom konstytucja, Warszawa 1994

Majka J., Katolicka nauka społeczna, Warszawa 1988

Majmurek J., Prawo do pracy, prawo do lenistwa, www.krytykapolityczna.pl [dostęp: 6.02.2017] 
Makowski D., Praca tymczasowa jako nietypowa forma zatrudnienia, Warszawa 2006

Malanowski A., Niektóre zagadnienia prawa do urlopu wypoczynkowego, „Studia Prawnicze” 1976, nr 3

Malinowski A., Urlopy pracownicze. Komentarz, Warszawa 2010

Małysz F.J., Pracownicze urlopy wypoczynkowe, Warszawa 1987

Marek A., Odwołanie pracownika z urlopu, „Służba Pracownicza” 2010, nr 10

Marek A., Urlop na żądanie, „Służba Pracownicza” 2003, nr 8

Marks K., Kapitał, t. 3, cz. 2, Warszawa 1959

Marks K., Engels F., Dzieła, t. 3, Warszawa 1967

Martuszewicz A., Piecyk K., Urlopy pracownicze i inne zwolnienia od pracy, Warszawa 2007

Masewicz W., Czas pracy, Warszawa 1994

Masewicz W., Dzwonkowski S., Czas pracy. Komentarz, Warszawa 1968

Masternak Z., [w:] Prawo pracy. Zarys wykładu, Warszawa 2005

Mazurek F.J., Jacquesa Maritaina koncepcja praw człowieka, „Kościół i Prawo” 1993, t. XI.

Mazurek F.J., Katalog praw człowieka w dokumentach społecznego nauczaniu Kościoła, „Kościół i Prawo" 1998, t. XIII

Mazurek F.J., Ochrona praw człowieka w świetle encyklik Jana XXIII, „Kościół i Prawo” 1991, t. IX

Mazurek F.J., Pojęcie godności człowieka. Historia i miejsce w projektach Konstytucji III Rzeczypospolitej, „Roczniki Nauk Prawnych” 1996, t. VII

Mędrala M., Instytucja urlopu na żądanie z punktu widzenia interesów obu stron stosunku pracy, [w:] Studia z zakresu prawa pracy i polityki społecznej, red. A. Świątkowski, Kraków 2008

Michalska A., Podstawowe prawa człowieka w prawie wewnętrznym a pakty praw człowieka, Warszawa 1976

Mielczarek M.A., Charakter prawny dni wolnych od pracy, „Gdańsko-Łódzkie Roczniki Prawa Pracy i Prawa Socjalnego" 2016, nr 4

Mielczarek M.A., Praca w niedziele i święta w ujęciu aksjologicznym (aspekt ekumeniczny i legislacyjny), [w:] 40 lat Kodeksu pracy, red. Z. Góral, M.A. Mielczarek, Warszawa 2015

Mitrus L., Karta Praw Podstawowych Unii Europejskiej. Komentarz, red. A. Wróbel, Warszawa 2012

Mitrus L., Podporządkowanie pracownicze jako zmieniająca się cecha stosunku pracy, [w:] Współczesne problemy prawa pracy i ubezpieczeń społecznych, red. L. Florek, Ł. Pisarczyk, Warszawa 2011

Mitrus L., Powstanie i ewolucja prawa pracy, [w:] System prawa pracy, t. 1: Część ogólna, red. K.W. Baran, Warszawa 2017

Mitrus L., Stosunek pracy, Kraków 2005

Mitrus L., Sytuacja pracownika w okresie wypowiedzenia umowy o prace, cz. II, PiZS 2010, nr 8

Mitrus L., Wpływ regulacji wspólnotowych na polskie prawo pracy, Kraków 2006.

Musiała A., Kim jest: „pracownik” w ujęciu przepisów Konstytucji?, M.P.P. 2017, nr 4

Muszalski W., Czas pracy i czas poza praca, [w:] Polityka społeczna, red. A. Rajkiewicz, Warszawa 1979

Muszalski W., Ogólna refleksja o rozwoju prawa pracy i jego uwarunkowaniu, [w:] Przemiany prawa pracy. Od kodyfikacji do współczesności, Księga Jubileuszowa Prof. T. Liszcz, red. A. Kosut, W. Perdeus, „Studia Iuridica Lublinensia” 2015, t. XXIV

Nadolski B., Niedziela. Historia, znaczenie, symbolika, Kraków 2010

Nałęcz M., [w:] Kodeks pracy. Komentarz, red. W. Muszalski, Warszawa 2007, 2011, 2013

Nałęcz A., Ochrona pracy, [w:] Polityka społeczna, red. A. Rajkiewicz, Warszawa 1979

Nieciuński W., Jeśli wejdziesz między wrony, czyli spór o prawa socjalne w konstytucji, „Rzeczpospolita", 5.11 .1995

Nowak M., Kilka uwag na temat charakteru prawnego i funkcji urlopu wypoczynkowego w świetle zmieniajacych się przepisów kodeksu pracy, [w:] 40 lat Kodeksu pracy, red. Z. Góral, M.A. Mielczarek, Warszawa 2015

Nowak M., Kilka uwag na temat planu urlopów wypoczynkowych, „Gdańsko-Łódzkie Roczniki Prawa Pracy i Prawa Socjalnego" 2015, nr 5 
Nowak M., Prawo do godziwego wynagrodzenia w konstytucjach państw europejskich, PiZS 2002, nr 5

Nowak M., Przesłanki i zakres konstytucjonalizacji praw pracowniczych, „Studia Prawno-Ekonomiczne" 2002, t. LXV

Nowak M., Wynagrodzenie za prace, Warszawa 2014

Nowak-Jamróz E., Urlop sabbatical jako sposób zapobiegania wypaleniu zawodowemu. Próba analizy porównawczej istniejących regulacji prawnych, [w:] Współczesne wyzwania menedżerskie w przeciwdziałaniu wypaleniu zawodowemu, red. J. Koprowicz, W. Bańka, „Humanizacja Pracy” 2011, nr 6

Nowe konstytucje, red. J. Makowski, Warszawa 1925

Nowe konstytucje państw europejskich, red. L. Gelberg, Warszawa 1949

Nowik P., Prawo o szkolnictwie wyższym. Komentarz, red. M. Pyter, Warszawa 2012

Nowy pomyst rządu: roczny urlop dla wypalonych, „Dziennik Gazeta Prawna”, http://wiadomosci. dziennik.pl/wydarzenia/artykuly/323515,nowy-pomysl-rzadu-roczny-urlop-dla-wypalonych. html

Nycz T., Nowe zasady urlopowe, M.P.P. 2004, nr 3

Nycz T., Ochronne przepisy o czasie pracy - wybrane zagadnienia, PiZS 1999, nr 3

Nycz T., Prawo do urlopu wypoczynkowego nauczyciela akademickiego, 8.12.2010, www.prawo-pracy.pl

Nycz T., Urlop $w$ dodatkowym miejscu pracy, PiZS 1999, nr 9

Olea M.A., Rodrlguez-Sanudo F., Labour Law in Spain, The Netherlands 2010

Olkuśnik M., Podróż, turystyka i wypoczynek pozamiejski w świadomości społeczeństwa Warszawy na przełomie XIX i XX w., Warszawa 2013

Oniszczuk J., Konstytucyjne źródła prawa pracy, [w:] System prawa pracy, t. 1: Część ogólna, red. K.W. Baran, Warszawa 2017

Opinia MENiS w sprawie wymiaru urlopu wypoczynkowego dla nauczycieli zatrudnionych w placówkach nieferyjnych w niepełnym wymiarze czasu pracy, „Przegląd Oświatowy” 2004, nr 11

Orłowski G., Urlop na żądanie jako pozastrajkowa forma protestu, M.P.P. 2007, nr 9

Ostaszewski W., Raczkowski M., Konstrukcja instytucji dyżuru pracowniczego i jej praktyczne wykorzystanie, PiZS 2012, nr 4

Pańków M., Polityka państwa wobec upowszechnienia elastycznych form zatrudnienia w Polsce, „Studia z Polityki Publicznej” 2015, nr 3 (7)

Penc J Dialektyka podzielonego czasu, „Ruch Prawniczy, Ekonomiczny i Socjologiczny” 1985, z. 2

Penc J., Fizjologiczne przesłanki optymalizacji czasu pracy, „Ekonomia i Organizacja Pracy” 1977, nr 12

Peretiakowicz A., Filozofia społeczna J. J. Rousseau, Poznań 1921

Piankowski M., [w:] Kodeks pracy z komentarzem, red. U. Jackowiak, Gdańsk 1996

Piątkowski M., Uprawnienia socjalne pracowników, Warszawa 1979

Piechowiak M., Filozofia praw człowieka. Prawa człowieka w świetle ich międzynarodowej ochrony, Lublin 1999

Pieniążek-Przytuła A. M., The Right to Annual Leave - basic English and Polish statutory instruments compared, „Gdańsko-Łódzkie Roczniki Prawa Pracy i Prawa Socjalnego” 2016, nr 6

Pieper J., Czas wolny jako kategoria diagnostyczna procesów rozwoju społeczno-gospodarczego, Warszawa 2008

Pisarczyk Ł., [w:] Kodeks pracy. Komentarz, red. L. Florek, LEX 2011

Piszczek A., Stefański K., Dni wolne na poszukiwanie pracy - wybrane problemy, „Gdańsko-Łódzkie Roczniki Prawa Pracy i Prawa Socjalnego" 2012, nr 2

Piwowarski W., Społeczne nauczanie ojca świętego Jana Pawła II, [w:] Jan Paweł II, „Laborem exercens". Tekst i komentarze, red. J. Gałkowski, Lublin 1986

Płaczek K., Prawo pracownika do niezakłóconego wypoczynku, M.P.P. 2017, nr 7

Podgórska A., Urlop na żądanie, „Służba Pracownicza” 2010, nr 11

Polska 2030. Wyzwania rozwojowe, red. M. Boni, www.mpips.gov.pl

Prawa podstawowe a dyrektywa o czasie pracy, European Trade Union Confederation (ETUC),www. etuc.org [dostęp: 14.02.2017] 
Prawo do odpoczynku, [w:] Zagadnienia prawne Konstytucji Polskiej Rzeczypospolitej Ludowej, t. 3, red. S. Grzybowski, Warszawa 1954

Prusinowski P., Zwolnienie z obowiązku świadczenia pracy - czynność jednostronna czy porozumienie stron, M.P.P. 2012, $\mathrm{nr} 4$

Przecławski K., Czas wolny dzieci i młodzieży, [w:] Encyklopedia pedagogiczna, red. W. Pomykało, Warszawa 1993

Przegląd Dyrektywy o Czasie Pracy - 2. etap konsultacji z partnerami społecznymi, COM (2010) 801, www.for.org.pl

Raczkowski M., Ustawa o zatrudnianiu pracowników tymczasowych. Komentarz, Lexis-Nexis 2012

Rączka K., [w:] Kodeks pracy. Komentarz, red. Z. Salwa, Warszawa 2003, 2005

Rączka K., [w:] M. Gersdorf, K. Rączka, M. Raczkowski, Kodeks pracy. Komentarz, Warszawa 2010

Rączka K., Czas pracy - nowa regulacja prawna, PiZS 2001, nr 4

Rączka K., Dni wolne od pracy, PiZS 2001, nr 8

Rączka K., Dodatkowe dni wolne od pracy, PiZS 1997, nr 12

Rączka K., Praca w dni wolne, [w:] Z zagadnień współczesnego prawa pracy. Księa jubileuszowa Prof. H. Lewandowskiego, Warszawa 2009

Rączka K., Urlopy bezpłatne i zwolnienia od pracy działaczy związkowych, PiZS 2013, nr 11

Rączka K., Urlopy wypoczynkowe po zmianach, PiZS 2002, nr 10

Romer M.T., Prawo pracy. Komentarz, Warszawa 2010

Roszkowski S., Urlopy wypoczynkowe pracowników najemnych, Warszawa 1929

Rousseau J.J., Umowa społeczna, Warszawa 1966

Ruchała S., Wspótczesne filozoficzne spory o ugruntowanie praw człowieka, Katowice 2006

Rycak M.B., Planowanie i rozliczanie czasu pracy, Warszawa 2009

Rychliński S., Czas pracy w przemyśle polskim, Warszawa 1929

Rylski M., O powszechnym rozumieniu okresów wypowiedzenia i sposobach ich obliczania - krytycznie, cz. 1, M.P.P. 2015, nr 6

Salimowa O., Walka czartystów o oświatę ludową, „Rozprawy z Dziejów Oświaty” 1960, nr 3

Salwa Z., Nabycie prawa do urlopu wypoczynkowego, [w:] Prawo pracy po zmianach, red. K. Rączka, Warszawa 1997

Salwa Z., Praca oraz prawa socjalne obywateli w przyszłej konstytucji, PiP 1990, nr 9

Salwa Z., Prawo pracy i ubezpieczeń społecznych, Warszawa 2004

Salwa Z., Urlop proporcjonalny, PiZS 1997, nr 10

Salwa Z., Założenia i kierunki nowelizacji Kodeksu pracy, [w:] Prawo pracy po zmianach, red. K. Rączka, Warszawa 1997

Samuel L., Droits sociaux fondamentaux. Jurisprudence de la Charte sociale européenne, Strasbourg 1997

Sanetra W., [w:] Prawo o szkolnictwie wyższym. Komentarz, red. W. Sanetra, M. Wierzbowski, Warszawa 2013

Sanetra W., Prawa (wolności) pracownicze w Konstytucji, PiZS 1997, nr 11

Sanetra W., Ustalenie wynagrodzenia urlopowego i ekwiwalentu za urlop w świetle kilku orzeczeń Sądu Najwyższego, PiZS 2001, nr 2

Sanetra W., Uwarunkowania instytucji czasu pracy, [w:] Czas pracy, red. L. Florek, Warszawa 2011

Schiek D., Europaisches Arbeitsrecht, Baden-Baden 1997

Schnorr von Carolsfeld L., Arbeitsrecht, Göttingen 1954

Serafin K., Urlop na żądanie a pracownicze formy protestu, [w:] Z zagadnień wspótczesnego prawa pracy. Ksiegga jubileuszowa Profesora Henryka Lewandowskiego, red. Z. Góral, Warszawa 2009

Seweryński M., Wynagrodzenie za pracę. Pojęcie, regulacja i ustalenie, Łódź 1976

Sęk H. (red.), Wypalenie zawodowe. Przyczyny i zapobieganie, Warszawa 2006

Sieg J., Problem cywilizacji czasu wolnego, „Śląskie Studia Historyczno-Teologiczne” 1970, nr 3

Siemieński E., Podstawowe prawa, wolności i obowiązki obywateli w europejskich państwach socjalistycznych, [w:] Prawa i obowiązki obywatelskie w Polsce i świecie, red. M. Szczepaniak, Warszawa 1978 
Simon G., Zagadnienie społeczne w Konstytucji polskiej, Warszawa 1928

Skąpski M., Funkcje regulacji czasu pracy wobec idei równości i sprawiedliwości, „Annales Universitatis Mariae Curie-Skłodowska", sectio G, 2015, t. LXII, 2

Skąpski M., Wpływ pracowniczego obowiązku dbałości o dobro zakładu pracy na zakres kompetencji pracodawcy do kontrolowania pracownika, [w:] Kontrola pracownika. Możliwości techniczne i dylematy prawne, red. Z. Góral, Warszawa 2010

Skoczyński J., Pojęcie czasu pracy w prawie Unii Europejskiej, [w:] Czas pracy, red. L. Florek, Warszawa 2011

Skulimowska B., Prawo do odpowiednich warunków pracy, „Europejska Karta Społeczna. Biuletyn Ośrodka Informacji i Dokumentacji Rady Europy Uniwersytetu Warszawskiego" 1997, nr 1-2

Smoliński T., Podstawowe prawa, wolności i obowiąki obywateli w pozaeuropejskich państwach socjalistycznych, [w:] Prawa i obowiązki obywatelskie w Polsce i świecie, red. M. Szczepaniak, Warszawa 1978

Sobczyk A., Nieprawidłowe wypoczynkowe urlopy zaległe, M.P.P. 2017, nr 5

Sobczyk A., Państwo zakładów pracy, Warszawa 2017

Sobczyk A., „Porzucenie” pracy a urlop proporcjonalny, „Przegląd Sądowy” 1998, nr 11-12

Sobczyk A., Praca w placówkach handlowych w święta i w niedzielę, M.P.P. 2007, nr 12

Sobczyk A., Prawo i człowiek pracujacy - między ochrona godności a równości, [w:] Aksjologiczne podstawy prawa pracy i ubezpieczeń społecznych, red. M. Skąpski, K. Ślebzak, Poznań 2014

Sobczyk A., Prawo pracy w świetle Konstytucji RP, t. 1: Teoria publicznego i prywatnego indywidualnego prawa pracy, Warszawa 2013

Sobczyk A., Urlop na żadanie, PiZS 2004, nr 7

Sobczyk A., Ustawa o zatrudnianiu pracowników tymczasowych. Komentarz, Zakamycze 2005

Sobczyk A., Zasady prawnej regulacji czasu pracy, Warszawa 2005

Sobczyk A., Zatrudnianie pracowników tymczasowych, PiZS 2004, nr 4

Sobolewski M., Prawa i wolności obywatelskie w wysoko rozwiniętych państwach kapitalistycznych, [w:] Prawa i obowiązki obywatelskie w Polsce i świecie, red. M. Szczepaniak, Warszawa 1978

Sobótka E., Propozycje zmian w Konstytucji PRL dotyczacych prawa pracy i zabezpieczenia społecznego, „Polityka Społeczna” 1988, nr 8

Soltys A., Prawa człowieka, http://bip.ms.gov.pl [dostęp: 2.02.2017]

Stanowisko Głównego Inspektoratu Pracy z 10 października 2007 r. w sprawie równoważenia odpoczynku, GNP/401/4560-461/07/PE

Stanowisko Polskiego Komitetu Europejskiej Sieci Przeciwdziałania Ubóstwu (EAPN) Polska w sprawie realizacji Międzynarodowego Paktu Praw Gospodarczych, Społecznych i Kulturalnych w Polsce, Warszawa 2016

Staszewska E., Kontrowersje wokót sposobów liczenia terminów określonych w kodeksie pracy w świetle orzecznictwa Sądu Najwyższego, [w:] 40 lat Kodeksu pracy, red. Z. Góral, M. Mielczarek, Warszawa 2015

Stefaniak J., Dofinansowywanie wypoczynku pracowniczego, „Służba Pracownicza” 2005, nr 5

Stefaniak J., Udział pracodawców w finansowaniu wypoczynku urlopowego pracowników, cz. I-II, „Służba Pracownicza” 2003, nr 6

Stefański K., [w:] Kodeks pracy. Komentarz, red. K. W. Baran, Warszawa 2016

Stefański K., Czas pracy, Warszawa 2013

Stefański K., Elastyczny czas pracy, Warszawa 2016

Stefański K., Konieczność odpracowania dni wolnych - uwagi dotyczące art. $130 \$ 2$ k.p., PiZS 2006, nr 4

Stefański K., Pojęcie miesiąca w kodeksie pracy w świetle orzecznictwa Sądu Najwyższego, PiZS 2016, nr 2

Stefański K., Problem pracy w dni świąteczne, PiZS 2007, nr 12

Stefański K., Problem świąt przypadających $w$ dni wolne od pracy - uwagi w związu $z$ wyrokiem Trybunatu Konstytucyjnego, PiZS 2013, nr 4

Stefański K., Problem świąt przypadających $w$ dni wolne od pracy wynikające z pięciodniowego tygodnia pracy, PiZS 2010, nr 12

Stelina J., Prawo urzędnicze, Warszawa 2009 
Struczyńska I., Agencja zatrudnienia oraz praca tymczasowa w świetle wybranych stanowisk Ministerstwa Pracy i Polityki Społecznej, Gdańsk 2014

Suchocka H., Zakres i sposób realizacji praw ekonomicznych, socjalnych i kulturalnych $w$ przyszłej konstytucji, [w:] Prawa, wolności i obowiązki człowieka i obywatela w nowej polskiej konstytucji, red. Z. Kędzia, Poznań 1990

Supiot A., Les inegalites entre sans-emploi, [w:] Les sans-emploi et la loi, Nantes 1987

Syryjczyk T., Granice misji ekonomicznej i socjalnej państwa w konstytucji, [w:] Konstytucja i gospodarka, red. P. Kaczanowski, Warszawa 1995

Szczypiorski A., Czartyzm ( $z$ dziejów walk robotników angielskich o prawa polityczne), Warszawa 1925

Szemplińska E., [w:] Kodeks pracy. Komentarz, red. L. Florek, Warszawa 2005

Szemplińska E., Konsultacje i wyjaśnienia, PiZS 2005, nr 8

Szemplińska E., Zatrudnienie młodocianych, PiZS 2003, nr 6

Szewczyk H., Ochrona praw i interesów osób zatrudnionych a nietypowe formy zatrudnienia w spoŁecznej gospodarce rynkowej, „Roczniki Administracji i Prawa” 2013, t. XIII

Szostek Mic A., „Communio personarum” przez prace, [w:] Jan Paweł II, „Laborem exercens”. Tekst $i$ komentarze, red. J. Gałkowski, Lublin 1986

Szymańska M., [w:] A. Barański, M.H. Szymańska, J. Rozwadowska-Skrzeczyńska, Karta Nauczyciela. Komentarz, Warszawa 2014

Świątkowski A.M., Cywilnoprawne zatrudnienie niepracownicze, [w:] System prawa pracy, t. 7, red. K.W. Baran, Warszawa 2015

Świątkowski A.M., Karta Praw Społecznych Rady Europy, Warszawa 2006

Świątkowski A.M., Kodeks pracy. Komentarz, Warszawa 2006

Świątkowski A.M., Międzynarodowe prawo pracy, t. 1, Warszawa 2008

Świątkowski A.M., Normy prawa pracy i prawa ubezpieczeń społecznych w przyszłej polskiej konstytucji, „Krakowskie Studia Prawnicze” 1990

Świątkowski A.M., Prawo pracy Unii Europejskiej, Warszawa 2015

Świątkowski A.M., Zasady prawa pracy, Warszawa 1997

Święcicki M., Instytucje polskiego prawa pracy w latach 1918-1939, Warszawa 1960

Święcicki M., Prawo pracy, Warszawa 1968

Treu T., Labour Law in Italy, The Netherlands 2011

Truszkowska-Wojtkowiak M., Fenomen czasu wolnego, Gdańsk 2012

Uklejska A., Aktualne kierunki rozwoju prawa urlopowego, PiZS 1974, nr 6

Ustawa zasadnicza Wegier z 25 kwietnia 2011 r., tłum. J. Snopek, [w:] Konstytucje państw UE, Warszawa 1996

Uziak W., Czas pracy - kilka uwag do dyskusji, [w:] Człowiek, obywatel, pracownik. Studia z zakresu prawa pracy, „Gdańskie Studia Prawnicze” 2007, t. XVII

Veblen T., Teoria klasy próżniaczej, Warszawa 1998

Wagner B., Wynagrodzenie za prace i jego zwiazek z praca, [w:] Człowiek, obywatel, pracownik. Studia z zakresu prawa, red. J. Stelina, A. Wypych-Żywicka, „Gdańskie Studia Prawnicze” 2007, t. XVII

Wajda A., Rola pracy w życiu człowieka w perspektywie historycznej - jej humanizacja i wypalenie zawodowe, [w:] Współczesne wyzwania menedżerskie w przeciwdziałaniu wypaleniu zawodowemu, red. J. Koprowicz, W. Bańka, „Humanizacja Pracy” 2011, nr 6

Walas A., Prawo do wypoczynku. Zagadnienia prawne Konstytucji PRL, t. 3, Warszawa 1954

Walczak K., Wynagrodzenie i inne świadczenia dla pracowników uczelni, [w:] Akademickie prawo pracy, red. K.W. Baran, Warszawa 2015

Walorska P., Staż pracy, Warszawa 2014

Wichrowska-Janikowska E., Nowe zasady obliczania wynagrodzenia i ekwiwalentu za urlop wypoczynkowy, PiZS 1997, nr 5

Wichrowska-Janikowska E., Plan urlopów, PiZS 1999, nr 1

Więcek A., Praca w handlu i ustugach w niedziele i święta - problem nadal aktualny, PiZS 2013, nr 10 
Więckiewicz-Szabłowska I., Konkurencja uprawnień pracodawcy i pracownika w okresie wypowiedzenia $w$ świetle przepisów art. 37 oraz art. 1671 KP, M.P.P. 2010, nr 1

Winniczuk L., Ludzie i obyczaje starożytnej Grecji i Rzymu, Warszawa 2006

Wiśniewski J., Urlop na żądanie pracownika tymczasowego, PiZS 2011, nr 6

Wiśniewski L., Podstawowe prawa, wolności i obowiąki obywateli PRL na tle nowych konstytucji socjalistycznych, PiP 1977, nr 1.

Wiśniewski L., Zakres i konstrukcja praw socjalnych w przyszłej konstytucji RP, „Ekspertyzy i Opinie Instytutu Nauk Prawnych PAN" 1995, t. I

Witkowski J., Jednostronne zwolnienie pracownika $z$ obowiązku świadczenia pracy w świetle art. 362 KP, M.P.P. 2016, nr 6

Witkowski J., Relacja między art. 362 a art. 1671 KP, M.P.P. 2016, nr 12

Witoszko W., Zasady udzielania urlopu wypoczynkowego nauczycielowi akademickiemu, [w:] Zatrudnienie nauczycieli akademickich, red. W. Sanetra, Warszawa 2015

Włodarczyk M., [w:] Kodeks pracy. Komentarz, red. K.W. Baran, Warszawa 2012

Włodarczyk M., Prawo dzieci i młodocianych do ochrony, „Europejska Karta Społeczna. Biuletyn Ośrodka Informacji i Dokumentacji Rady Europy Uniwersytetu Warszawskiego" 1997, nr 1-2

Włoszczewski S., O czasie pracy z punktu widzenia interesu narodowego, Warszawa 1922

Wnuk-Lipiński E., Budżet czasu - struktura społeczna - polityka społeczna, Wrocław 1981

Wnuk-Lipiński E., Czas wolny. Współczesność i perspektywy, Warszawa 1975

Wojciechowska A., Otium $i$ negotium $w$ starożytnym Rzymie, www.wilanów-pałac.pl [dostęp: 6.02.2017]

Wojtkowiak D., Podstawowe prawa, wolności i obowiazki obywateli w pokolonialnych państwach o orientacji socjalistycznej, [w:] Prawa i obowiąki obywatelskie w Polsce i świecie, red. M. Szczepaniak, Warszawa 1978

Wolberg I., Planowanie i przesuwanie urlopów wypoczynkowych, PiZS 1969, nr 12

Wratny J., Kodeks pracy. Komentarz, Warszawa 2013

Wratny J., Normy konstytucyjne a prawo pracy i zabezpieczenia społecznego, PiP 1990, nr 2

Wratny J., Nowe rozporzadzenie urlopowe, PiZS 1997, nr 3

Wratny J., Prawo pracy Rady Europy, [w:] Europejskie prawo pracy i ubezpieczeń społecznych, red. L. Florek, Warszawa 1996

Wratny J., Problemy ochrony pracowników w elastycznych formach zatrudnienia, PiZS 2007, nr 7

Wratny J., Sytuacja prawna pracowników sezonowych, „Studia i Materiały IPiSS” 1977, z. 2

Wrocławska T., Kontrowersje wokół prawa do urlopu na żądanie (ze szczególnym uwzględnieniem statusu prawnego lekarzy), [w:] Z zagadnień współczesnego prawa pracy. Księga jubileuszowa Profesora Henryka Lewandowskiego, red. Z. Góral, Warszawa 2009

Wronikowska E., Akty wykonawcze do Kodeksu pracy. Komentarz, Warszawa 2009

Wujczyk M., Prawo pracownika do ochrony prywatności, Warszawa 2012

Wyka T., Konstytucyjne prawo każdego do bezpiecznych i higienicznych warunków pracy a zatrudnienie na innej podstawie niż stosunek pracy oraz praca na własny rachunek - uwagi de lege ferenda, „Gdańskie Studia Prawnicze” 2007, t. XVII

Wypych-Żywicka A., [w:] Kodeks pracy z komentarzem, red. U. Jackowiak, LEX 2004

Wypych-Żywicka A., [w:] Kodeks pracy z komentarzem, red. U. Jackowiak, wyd. IV, LEX 2011 [dostęp: 6.04.2011]

Wypych-Żywicka A., Kilka uwag o urlopie wypoczynkowym $z$ art. 153 \$ 1 k.p., PiZS 2004, nr 6

Wypych-Żywicka A., Prawa podmiotowe w prawie pracy, [w:] System prawa pracy. Część ogólna, t. 1, red. K.W. Baran, Warszawa 2017

Wypych-Żywicka A., Problem praktycznego stosowania art. 155(2) \& 1 k.p., PiZS 1997, nr 2

Zamach majstrów piekarskich na spoczynek niedzielny, Dziennik „Naprzód”, 9.04.1902, nr 96

Zasady obliczania ekwiwalentu pieniężnego za niewykorzystany urlop, P 53/11, www.trybunał. gov.pl [dostęp: 1.07.2017]

Zawadzka B., Ochrona odpoczynku niedzielnego, [w:] Czas pracy, red. L. Florek, Warszawa 2011

Zawadzki S., „Państwo dobrobytu”. Doktryna i praktyka, Warszawa 1964 
Zbiór praw, instrukcyi i przepisów obowiązujących dla prywatnego przemystu górniczego w guberniach Królestwa Polskiego, Dąbrowa 1899

Zieleniecki M., [w:] Kodeks pracy. Komentarz, red. A. Sobczyk, Warszawa 2014

Zieliński A., Środki ochrony wolności i praw według nowej Konstytucji, PiP 1997, nr 12

Zieliński T., Klauzule generalne w prawie pracy, Warszawa 1988

Zieliński T., Prawo pracy. Zarys systemu, cz. II, Warszawa 1986

Zieliński T., Zarys wykładu prawa pracy, cz. I, Katowice 1979

Zieliński T., Zarys wykładu prawa pracy, cz. II, Katowice 1984

Żelazińska A., Stużbowe maile i telefony - tylko w godzinach pracy, „Polityka”, 3.10.2014

22 wskazówki jak udzielać urlopów nauczycielom i je rozliczać. Urlopy i ekwiwalent w placówkach feryjnych i nieferyjnych, www.portaloswiatowy.pl 


\section{Wykaz ważniejszych aktów prawnych}

\section{Akty prawa międzynarodowego}

Międzynarodowy Pakt Praw Gospodarczych, Społecznych i Kulturalnych ONZ z 19 grudnia 1966 r., Dz. U. 1977, Nr 38, poz. 169

Konwencja nr 1 MOP z 29 października1919 r. dotycząca ograniczenia czasu pracy do ośmiu godzin dziennie i czterdziestu ośmiu godzin tygodniowo w zakładach przemysłowych, www.mop.pl

Konwencja nr 14 MOP z 17 listopada 1921 r. o odpoczynku tygodniowym w zakładach przemysłowych, Dz. U. 1925, Nr 54, poz. 384

Konwencja nr 30 MOP z 28 czerwca 1930 r. dotycząca uregulowania czasu pracy w handlu i w biurach, www.mop.pl

Konwencja nr 47 MOP z 22 czerwca 1935 r. dotycząca skracania czasu pracy do czterdziestu godzin tygodniowo, www.mop.pl

Konwencja nr 52 MOP z 24 czerwca 1936 r. dotycząca corocznych płatnych urlopów, www.mop.pl Konwencja nr 101 MOP z 1952 r. dotycząca płatnych urlopów w rolnictwie, www.mop.pl

Konwencja nr 106 MOP z 5 czerwca 1957 r. dotycząca cotygodniowego odpoczynku w handlu i w biurach, www.mop.pl

Konwencja nr 132 MOP z 24 czerwca 1970 r. dotycząca corocznych płatnych urlopów, www.mop.pl

\section{Akty prawa europejskiego}

Europejska Karta Społeczna Rady Europy z 18 października 1961 r., Dz. U. 1999, Nr 8, poz. 67

Zrewidowana Europejska Karta Społeczna Rady Europy z 3 maja 1996 r., www.strasburgre.msz.gov.pl Karty Praw Podstawowych Unii Europejskiej z 7 grudnia 2000 r., Dz. Urz. UE C 83 z 30 marca 2010 r. Dyrektywa 2003/88/WE z 4 listopada 2003 r., dotycząca niektórych aspektów organizacji czasu pracy, Dz. Urz. UE L 299 z 18 listopada 2003 r.

Dyrektywa Parlamentu Europejskiego i Rady z 19 listopada 2008 r. w sprawie pracy tymczasowej, Dz. Urz. UE L 327/9, www.eur-lex.europa.eu 
Dyrektywa 2010/18/UE z 8 marca 2010 r. w sprawie wdrożenia zmienionego porozumienia ramowego dotyczącego urlopu rodzicielskiego zawartego przez BUSINESSEUROPE, UEAPME, CEEP i ETUC oraz uchylająca Dyrektywę 96/34/WE, Dz. Urz. UE L 68 z 18 marca 2010, s. 13

\section{Akty prawa polskiego}

Konstytucja Rzeczypospolitej Polskiej z 2 kwietnia 1997 r., Dz. U. Nr 78, poz. 483, ze zm.

Konstytucja Polskiej Rzeczypospolitej Ludowej, Dz. U. PRL 1952, Nr 33, poz. 232

Ustawa z 18 grudnia 1919 r. o czasie pracy w przemyśle i handlu, Dz. U. 1920, Nr 2, poz. 7 (nieobowiązująca)

Ustawa z 16 maja 1922 r. o urlopach dla pracowników zatrudnionych w przemyśle i handlu, Dz. U. Nr 40, poz. 334 (nieobowiązująca)

Ustawa z 18 stycznia 1951 r. o dniach wolnych od pracy, tekst jednolity: Dz. U. 2015, poz. 90

Ustawa z 23 kwietnia 1964 r. - Kodeks cywilny, Dz. U. Nr 16, poz. 93

Ustawa z 21 listopada 1967 r. o powszechnym obowiązku obrony Rzeczypospolitej Polskiej, tekst jednolity: Dz. U. 2016, poz. 1534, ze zm.

Ustawa z 29 kwietnia 1969 r. o pracowniczych urlopach wypoczynkowych, Dz. U., Nr 12, poz. 85

Ustawa z dnia 29 maja 1974 r. o zaopatrzeniu inwalidów wojennych i wojskowych oraz ich rodzin, tekst jednolity: Dz. U. 2015, poz. 840, ze zm.

Ustawa z 26 stycznia 1982 r. - Karta Nauczyciela, tekst jednolity: Dz. U. 2017, poz. 1189

Ustawa z 6 kwietnia 1990 r. o Policji, tekst jednolity: Dz. U. 2016, poz. 1782, ze zm.

Ustawa z 20 lipca 1990 r. o wliczaniu okresów pracy w indywidualnym gospodarstwie rolnym do pracowniczego stażu pracy, Dz. U., Nr 54, poz. 310

Ustawa z 12 października 1990 r. o Straży Granicznej, tekst jednolity: Dz. U. 2016, poz. 1643

Ustawa z dnia 24 stycznia 1991 r. o kombatantach oraz niektórych osobach będących ofiarami represji wojennych i okresu powojennego, tekst jednolity: Dz. U. 2014, poz. 1206, ze zm.

Ustawa z dnia 23 maja 1991 r. o związkach zawodowych, tekst jednolity: Dz. U. 2015, poz. 1881

Ustawa z 24 sierpnia 1991 r. o Państwowej Straży Pożarnej, tekst jednolity: Dz. U. 2016, poz. 603, ze zm.

Ustawa z 4 marca 1994 r. o zakładowym funduszu świadczeń socjalnych, tekst jednolity: Dz. U. 2016, poz. 800 , ze zm.

Ustawa z dnia 23 grudnia 1994 r. o Najwyższej Izbie Kontroli, tekst jednolity: Dz. U. 2017, poz. 524

Ustawa z dnia 2 lutego 1996 r. o zmianie ustawy - Kodeks pracy oraz o zmianie niektórych ustaw, Dz. U., Nr 24, poz. 110

Ustawa o wykonywaniu mandatu posła i senatora z 9 maja 1996 r., tekst jednolity: Dz. U. 2016, poz. 1510 , ze zm.

Ustawa z 6 czerwca 1997 r. - Kodeks karny wykonawczy, tekst jednolity: Dz. U. 2017, poz. 665, ze zm.

Ustawa z 27 sierpnia 1997 r. o rehabilitacji zawodowej i społecznej oraz zatrudnianiu osób niepełnosprawnych, tekst jednolity: Dz. U. 2016, poz. 2046, ze zm.

Ustawa z 29 sierpnia 1997 r. - Prawo bankowe, tekst jednolity: Dz. U. 2015, poz. 128, ze zm.

Ustawa z 1 marca 2001 r. o zmianie ustawy - Kodeks pracy, Dz. U., Nr 28, poz. 301

Ustawa z 27 lipca 2001 r. - Prawo o ustroju sądów powszechnych, tekst jednolity: Dz. U. 2016, poz. 2062, ze zm.

Ustawa z 24 maja 2002 r. o Agencji Bezpieczeństwa Wewnętrznego oraz Agencji Wywiadu, tekst jednolity: Dz. U. 2016, poz. 1897

Ustawa z 26 lipca 2002 r. o zmianie ustawy - Kodeks pracy oraz o zmianie niektórych innych ustaw, Dz. U., Nr 135, poz. 1146 
Ustawa z 13 marca 2003 r. o szczególnych zasadach rozwiązywania z pracownikami stosunków pracy z przyczyn niedotyczących pracowników, tekst jednolity: Dz. U. 2015, poz. 192, ze zm.

Ustawa z 9 lipca 2003 r. o zatrudnianiu pracowników tymczasowych, tekst jednolity: Dz. U. 2016, poz. 360 , ze zm.

Ustawa z 11 września 2003 r. o służbie wojskowej żołnierzy zawodowych, tekst jednolity: Dz. U. 2014, poz. 1414 , ze zm.

Ustawa z dnia 14 listopada 2003 r. o zmianie ustawy - Kodeks pracy oraz o zmianie niektórych innych ustaw, Dz. U., Nr 213, poz. 2081

Ustawa z dnia 12 marca 2004 r. o pomocy społecznej, tekst jednolity: Dz.U. 2015, poz. 163, ze zm.

Ustawa z 20 kwietnia 2004 r. o promocji zatrudnienia i instytucjach rynku pracy, tekst jednolity: Dz. U. 2016, poz. 645

Ustawa z 24 sierpnia 2004 r. o czasie pracy kierowców, Dz. U., Nr 123, poz. 1354, ze zm.

Ustawa z 27 lipca 2005 r. - Prawo o szkolnictwie wyższym, tekst jednolity: Dz. U. 2016, poz. 1842, ze zm.

Ustawa z 13 lipca 2006 r. o ochronie roszczeń pracowniczych w razie niewypłacalności pracodawcy, tekst jednolity: Dz. U. 2016, poz. 1256

Ustawa z 13 kwietnia 2007 r. o Państwowej Inspekcji Pracy, tekst jednolity: Dz. U. 2017, poz. 786, ze zm.

Ustawa z 24 sierpnia 2007 r. o zmianie ustawy - Kodeks pracy, Dz. U., Nr 176, poz. 1239

Ustawa z dnia 21 listopada 2008 r. o służbie cywilnej, Dz. U. 2014, poz. 1111, ze zm.

Ustawa z 30 kwietnia 2010 r. o instytucjach badawczych, tekst jednolity: Dz. U. 2015, poz. 1059, ze zm.

Ustawa o sporcie z 25 czerwca 2010 r., tekst jednolity: Dz. U. 2016, poz. 176

Ustawa z dnia 12 lipca 2013 r. o zmianie ustawy - Kodeks pracy oraz ustawy o związkach zawodowych, Dz. U. 2013, poz. 896

Ustawa z 26 lipca 2013 r. o zmianie ustawy - Kodeks pracy, Dz. U. 2013, poz. 1028

Ustawa z 24 stycznia 2014 r. o zmianie ustawy - Kodeks pracy, Dz. U. 2014, poz. 208

Ustawa z 7 kwietnia 2017 r. o zmianie ustawy o zatrudnianiu pracowników tymczasowych oraz niektórych innych ustaw, Dz. U. 2017, poz. 962

Dekret z 19 września 1946 r. o zmianie ustawy o czasie pracy w przemyśle i handlu, Dz. U., Nr 51, poz. 285

Dekret z 20 lipca 1972 r. o dodatkowych dniach wolnych od pracy, Dz. U., Nr 29, poz. 203

Rozporządzenia Ministra Pracy i Opieki Społecznej z 11 czerwca 1923 r. wydane w porozumieniu z Ministrem Przemysłu i Handlu w przedmiocie wykonania ustawy z 16 maja 1922 r. o urlopach dla pracowników, zatrudnionych w przemyśle i handlu, Dz. U. 1923, Nr 62, poz. 464

Rozporządzenie Prezydenta Rzeczypospolitej z 27 października 1933 r. - Kodeks zobowiązań, Dz. U., Nr 82, poz. 598

Rozporządzenie Rady Ministrów z 2 września 1985 r. w sprawie zasad stosowania czasu pracy w uspołecznionych zakładach pracy oraz zmian niektórych przepisów o czasie pracy, Dz. U., $\mathrm{Nr} 51$, poz. 263, ze zm.

Rozporządzenie Rady Ministrów z 23 grudnia 1988 r. w sprawie czasu pracy w uspołecznionych zakładach pracy w latach 1989-1992, Dz.U., Nr 42, poz. 329

Rozporządzenie Ministra Pracy, Płac i Spraw Socjalnych z 21 października 1974 r. w sprawie pracowniczych urlopów wypoczynkowych, Dz. U., Nr 43, poz. 259

Rozporządzenie Rady Ministrów z 31 grudnia 1975 r. w sprawie uprawnień pracowniczych osób wykonujących pracę nakładczą, Dz. U. 1976, Nr 3, poz. 19, ze zm.

Rozporządzenie Ministra Obrony Narodowej z 22 czerwca 1992 r. w sprawie zasadniczej służby wojskowej i nadterminowej zasadniczej służby wojskowej oraz przeszkolenia wojskowego, Dz. U., Nr 56, poz. 227

Rozporządzenie Ministra Pracy i Polityki Socjalnej z 15 maja 1996 r. w sprawie sposobu usprawiedliwiania nieobecności w pracy oraz udzielania pracownikom zwolnień od pracy, tekst jednolity: Dz. U. 2014, poz. 1632 
Rozporządzenie Ministra Pracy i Polityki Socjalnej z 8 stycznia 1997 r. w sprawie szczegółowych zasad udzielania urlopu wypoczynkowego, ustalania i wypłacania wynagrodzenia za czas urlopu oraz ekwiwalentu pieniężnego za urlop, Dz. U., Nr 2, poz. 14, ze zm.

Rozporządzenie Ministra Edukacji Narodowej i Sportu z 18 kwietnia 2002 r. w sprawie organizacji roku szkolnego, Dz.U., Nr 46, poz. 432, ze zm.

Rozporządzenie Ministra Nauki i Szkolnictwa Wyższego z 2 listopada 2006 r. w sprawie sposobu ustalania wynagrodzenia za urlop wypoczynkowy oraz ekwiwalentu pieniężnego za okres niewykorzystanego urlopu wypoczynkowego nauczycieli akademickich, Dz. U., Nr 203, poz. 1499, ze zm. 


\section{Wykaz orzeczeń}

\section{Orzecznictwo TSUE}

Wyrok z 12 listopada 1996 r. w sprawie Zjednoczone Królestwo Wielkiej Brytanii i Irlandii Północnej przeciwko Radzie, C-84/94, Zb. Orz. 1996, s. I-05755

Wyrok z 3 października 2000 r. w sprawie SiMAP, C-303/98, www.eur-lex.europa.eu

Wyrok z 26 czerwca 2001 r. w sprawie BECTU, C-173/99, Zb. Orz., s. I-04881

Wyrok z 9 września 2003 r. w sprawie Jaeger, C-151/02, www.eur-lex.europa.eu

Wyrok z 18 marca 2004 r. w sprawie Merino Gomez, C-342/01, www.curia.europa.eu

Wyrok z 5 października 2004 r. w sprawie Pfeifer, C-397/01 oraz C-403/01, www.eur-lex.europa.eu

Wyrok z 14 kwietnia 2005 r. w sprawie Komisja przeciwko Luksemburgowi, C-519/03, www.curia. europa.eu

Wyrok z 1 grudnia 2005 r. w sprawie Abdelkader Dellas i in. przeciwko Premier ministre i in., C-14/04, Dz.U. UE C 36/8

Wyrok z 16 marca 2006 r. w sprawach połączonych Robinson-Steele i in., C-131/04 i C-257/04, Zb. Orz., s. I-2531

Wyrok z 6 kwietnia 2006 r. w sprawie Federatie Nederlandse Vakbeweging, C-124/05, www.ec.europa.eu

Wyrok z 20 stycznia 2009 r. w sprawach połączonych Schultz-Hoff i in., C-350/06 i 520/06, Zb. Orz., s. I-179, pkt 43, 55

Wyrok z 22 kwietnia 2010 r. w sprawie Zentralbetriebsrat der Landeskrankenhäuser Tirols, C-486/08, www.curia.europa.eu

Wyrok z 1 lipca 2010 r. w sprawie Parviainen, C-471/08, Zb. Orz., s. I-6533

Wyrok z 10 września 2010 r. Vicente Pereda, C-277/08, www.curia.europa.eu

Wyrok z 22 listopada 2011 r. w sprawie KHS AG przeciwko Winfriedowi Schultemu, C-214/10, www. eur-lex.europa.eu

Wyrok z 24 stycznia 2012 r. w sprawie Dominguez, C-282/10, EU:C:2012:33

Wyrok z 3 maja 2012 r. w sprawie Neidel, C-337/10, EU:C:2012:263

Wyrok z 21 czerwca 2012 r. w sprawie ANGED, C-78/11, www.curia.europa.eu

Wyrok z 22 maja 2014 r. w sprawie Z.J.R. Locka, C-539/12, www.curia.europa.eu

Wyrok z 22 maja 2014 r. w sprawie Williams i in., C-155/10, Zb. Orz., s. I-8409 
Wyrok z 10 września 2015 w sprawie Federacion de Servicios Privados del sindicato Comisiones obreras v „Tyco”, C-266/14, Dz. U. UE C 363/16

Wyrok z 16 marca 2016 r. w sprawach połączonych C.D. Robinson Steele oraz Michael Jason Clarke, C-131/04 i C-257/04, ZOTSiS 2006/3A/I-2531

Wyrok TSUE z 30 czerwca 2016 r. w sprawie Alicja Sobczyszyn przeciwko Szkole Podstawowej w Rzeplinie, C-178/15, www.eur-lex.europa.eu

Wyrok z 20 lipca 2016 r. w sprawie Hansa Mascheka, C-341/15, www.curia.europa.eu

\section{Orzecznictwo sądów polskich}

\section{Orzecznictwo TK}

Wyrok TK z 2 października 2012 r., K 27/11, Dz. U., poz. 1110

Wyrok TK z 16 lipca 2013 r., P 53/11, OTK-A 2013, nr 6, poz. 78

Wyrok TK z 2 czerwca 2015 r., K 1/13, Dz. U. 2015, poz. 791

\section{Orzecznictwo SN}

Wyrok SN z 5 lutego 1931 r., III Rw. 1691/30, „Głos Prawa” 1931, nr 10, s. 500 i n.

Wyrok SN z 21 grudnia 1931 r., C 1929/31, OSP XI, poz. 158

Uchwała SN z 7 stycznia 1932, C 1599/ 31, „Głos Kupiectwa” 1936, nr 8, s. 12

Wyrok SN z 4 lutego 1932 r., IC 1835/31, ZO 1/32/31

Wyrok SN z 11 maja 1932 r., III Rw. 435/32, OSP XII, poz. 85

Wyrok SN z 23 maja 1953 r., I.C. 1882/52, niepubl.

Wyrok SN z 16 stycznia 1973 r., I PR 25/73, OSNC 1974, nr 1, poz. 7

Uchwała składu 7 sędziów SN z 27 stycznia 1977 r., V PZP 5/76, OSNCP 1977, nr 4, poz. 63

Uchwała SN z 12 grudnia 1978 r., I PZP 25/78, OSPiKA 1980, nr 4

Uchwała SN z 6 lutego 1979 r., V PZP 5/78, OSNCP 1979, nr 6, poz. 109

Wyrok SN z 5 września 1979 r., I PRN 82/79, niepubl.

Uchwała 7 sędziów SN z 20 lutego 1980 r., V PZP 6/79, OSNC 1980, nr 7-8, poz. 131

Uchwała 7 sędziów SN z 6 marca 1980 r., V PZP 7/79, OSNC 1980, nr 7-8, poz. 132

Wyrok SN z 11 czerwca 1980 r., I PR 43/80, LEX nr 179272

Wyrok SN z 29 marca 1983 r., I PRN 41/83, LEX nr 182842

Wyrok SN z 10 lutego 1988 r., I PR 7/88, „Służba Pracownicza” 1988, nr 5, s. 28

Uchwała SN z 28 września 1990 r., III PZP 15/90, OSNCP 1991, nr 4, poz. 45

Wyrok SN z 14 lutego 1991 r., I PRN 1/91, OSNCP 1992, nr 11, poz. 207

Uchwała SN z 4 kwietnia 1995 r., I PZP 10/95, OSNAPiUS 1995, nr 18, poz. 228

Postanowienie SN z 5 grudnia 1996 r., I PKN 34/96, OSNAPiUS 1997, nr 13, poz. 237

Wyrok SN z 19 grudnia 1996 r., I PKN 47/96, OSNP 1997, nr 17, s. 310

Postanowienie SN z 10 kwietnia 1997 r., I PKN 112/97, OSNAPiUS 1998, nr 4, poz. 116

Uchwała SN z 20 sierpnia 1997 r., III ZP 26/97, OSNP 1998, nr 5, poz. 145

Wyrok SN z 27 listopada 1997 r., I PKN 393/97, OSNP 1998, nr 17, poz. 511

Wyrok SN z 13 maja 1998 r., I PKN 99/98, OSNP 1999, nr 10, poz. 331

Postanowienie SN z 14 maja 1998 r., I PKN 111/98, OSNAP 1999, nr 9, poz. 310

Wyrok SN z 18 czerwca 1998 r., I PKN 191/98, www.sn.pl 
Wyrok SN z 2 września 1998 r., I PKN 298/98, OSNP 1999, nr 18, poz. 584

Wyrok SN z 10 listopada 1998 r., I PKN 364/98, OSNP 1999, nr 24, poz. 788

Wyrok SN z 13 kwietnia 1999 r., I PKN 1/99, OSNAPiUS 2000, nr 12, poz. 458

Uchwała SN z 8 lipca 1999 r., III ZP 10/99, OSNAPiUS 2000, nr 6, poz. 233

Wyrok SN z 10 listopada 1999 r., I PKN 350/99, OSNAPiUS 2001, nr 6, poz. 198

Wyrok SN z 20 lipca 2000 r., I PKN 17/00, OSNAPiUS 2002, nr 3, poz. 77

Wyrok SN z 5 grudnia 2000 r., I PKN 121/00, OSNP 2002, nr 15, poz. 353

Wyrok SN z 7 lutego 2001 r., I PKN 240/00, OSNAPiUS 2002, nr 21, poz. 518

Wyrok SN z 15 marca 2001 r., I PKN 306/00, OSNP 2002, nr 24, poz. 591

Wyrok SN z 11 kwietnia 2001 r., I PKN 367/00, OSNP 2003, nr 2, poz. 38

Wyrok SN z 20 sierpnia 2001 r., I PKN 590/00, OSNP 2003, nr 14, poz. 336

Uchwała składu siedmiu sędziów SN z 14 listopada 2001 r., III ZP 20/01, www.sn.pl

Wyrok SN z 2 września 2003 r., I PK 403/02, OSNP 2004, nr 18, poz. 310

Wyrok SN z 12 listopada 2003 r., I PK 593/02, „Monitor Prawniczy” 2004, nr 14, poz. 662

Wyrok SN z 12 sierpnia 2004 r., III PK 32/04, M.P.P. 2004, nr 9, s. 230

Wyrok SN z 25 sierpnia 2004 r., I PZP 4/04, „Wspólnota” 2004, nr 19, poz. 5

Wyrok SN z 17 listopada 2004 r., II PK 64/04, M.P.P 2005, nr 1, s. 342

Wyrok SN z 16 grudnia 2004 r., II PK 109/04, LEX nr 138361

Wyrok SN z 26 stycznia 2005 r., II PK 197/04, www.sn.pl

Wyrok SN z 23 czerwca 2005 r., II PK 265/04, OSNP 2006, nr 5-6, poz. 76

Wyrok SN z 6 października 2005 r., II PK 72/2005, OSNP 2006, nr 15-16, poz. 242

Wyrok SN z 24 stycznia 2006 r., I PK 124/05, OSNP 2006, nr 23-24, poz. 354

Wyrok SN z 14 marca 2006 r., I PK 144/05, OSNP 2007, nr 5-6, poz. 68

Uchwała SN z 10 maja 2006 r., III PZP 3/06, LEX nr 180655

Wyrok SN z 18 maja 2006 r., III PK 26/06, LEX nr 551013

Wyrok SN z 6 czerwca 2006 r., I PK 263/05, www.sn.pl

Wyrok SN z 15 listopada 2006 r., I PK 128/06, OSNP 2007, nr 23-24, poz. 346

Wyrok SN z 7 grudnia 2006 r., I PK 169/06, OSNAPiUS 2008, nr 3-4, poz. 26

Wyrok SN z 29 stycznia 2007 r., II PK 181/06, www.sn.pl

Wyrok SN z 12 kwietnia 2007 r., I PK 261/06, LEX nr 509048

Uchwała siedmiu sędziów SN z 13 marca 2008 r., I PZP 11/07, www.sn.pl

Wyrok SN z 20 marca 2008 r., II PK 214/07, OSNP 2009, nr 15-16, poz. 194

Wyrok SN z 7 maja 2008 r., II PK 313/07, OSNP 2009, nr 17-18, poz. 229

Uchwała SN z 3 czerwca 2008 r., I PZP 10/07, OSNP 2008, nr 23-24, poz. 342

Wyrok SN z 16 września 2008 r., II PK 26/08, OSNP 2010, nr 3-4, poz. 36

Wyrok SN z 16 grudnia 2008 r., I PK 88/08, OSNP 2010, nr 11-12, poz. 137

Wyrok SN z 13 maja 2009 r., III PK 9/09, www.sn.pl

Wyrok SN z 23 lipca 2009 r., II PK 26/09, LEX nr 533037

Wyrok SN z 11 sierpnia 2009 r., III PK 22/09, niepubl.

Wyrok SN z 11 sierpnia 2009 r., III PK 21/09, niepubl.

Wyrok SN z 3 września 2009 r., III PK 33/09, LEX nr 560865.

Wyrok SN z 8 października 2009 r., II PK 110/09, LEX nr 558295

Wyroku SN z 28 października 2009 r., II PK 123/09, LEX nr 551056

Postanowienie SN z 11 grudnia 2009 r., II PK 223/09, LEX nr 585777

Wyrok SN z 4 listopada 2010 r., II PK 116/10, M.P.Pr. z 2011 r., nr 3, poz. 145

Wyrok SN z 3 lutego 2011 r., III PK 32/10, LEX nr 1375430.

Wyrok SN z 26 kwietnia 2011 r., II PK 302/10, www.sn.pl

Wyrok SN z 21 czerwca 2011 r., III PK 96/10, www.sn.pl

Wyrok SN z 9 grudnia 2011 r., II PK 115/11, www.sn.pl

Postanowienie SN z 11 listopada 2012 r., III PK 17/12, LEX nr 2041816

Uchwała SN z 17 stycznia 2013 r., II PZP 4/12, www.sn.pl 
Wyrok SN z 11 września 2013 r., II PK 372/12, OSNP 2014, nr 6, poz. 80

Wyrok SN z 13 marca 2014 r., I PK 204/13, LEX nr 1464689

Wyrok SN z 19 stycznia 2017 r., I PK 40/16, LEX nr 2209124

Wyrok SN z 8 marca 2017 r., II PK 26/16, LEX nr 2270901

\section{Orzecznictwo NSA}

Wyrok NSA w Białymstoku z 25 kwietnia 1996 r., SA/Bk 538/95, „Prawo Pracy” 1996, nr 12, s. 45 Wyrok NSA w Warszawie z 1 kwietnia 2003 r., II SA 2162/02, „Prawo Pracy” 2003, nr 6, poz. 43 Wyrok Wojewódzkiego Sądu Administracyjnego w Warszawie z 14 kwietnia 2008 r., II SA/Wa 100/08, LEX nr 506463

\section{Orzecznictwo Sądów Rejonowych, Okręgowych i Apelacyjnych}

Wyrok Sądu Rejonowego w Ostrołęce z 27 lutego 2014 r., IV P 454/13, www.orzeczenia.ms.gov.pl Wyrok Sądu Rejonowego dla Wrocławia - Śródmieścia we Wrocławiu z 19 maja 2014 r., X P 959/13, LEX nr 1911075

Wyrok Sądu Rejonowego dla miasta stołecznego w Warszawie z 29 czerwca 2015 r., VII P 1591/14, LEX nr 2135253.

Wyrok Sądu Okręgowego w Legnicy z 8 maja 2014 r., V Pa 45/14, LEX nr 1886911

Wyrok Sądu Okręgowego w Ostrołęce z 3 lipca 2014 r., III Pa 14/14, LEX nr 1885398.

Wyrok Sądu Okręgowego w Warszawie z 25 listopada 2016 r., XXI Pa 578/16, www.orzeczenia.warszawa.so.gov.pl

Wyrok SA w Warszawie z 21.06.2005 r., III APa 48/0, Apel.-W-wa z 2006 r., nr 1, poz. 1

Wyrok SA w Katowicach z 15 grudnia 2006 r., III APa 176/05, LEX nr 310405

Wyrok SA w Katowicach z 2 grudnia 2008 r., III AUa 449/08, www.sip.lex.pl

Wyrok SA w Warszawie z 23 listopada 2016 r., III APa 61/15, LEX nr 2256929

\section{Orzecznictwo Niemieckiego Federalnego Sądu Pracy}

Wyrok Federalnego Sądu Pracy z 9 sierpnia 2011 r., 9 AZR 425/10

Wyrok Federalnego Sądu Pracy z 22 maja 2012 r., 9 AZR 575/10 


\section{Summary}

\section{Annual Leave as an Instrument of Exercising Employee's Right to Rest}

An employee's right to rest is one of the fundamental employment rights. It is primarily informed by the universal value, as well as legal category, of human dignity. Also, the right to rest must be perceived as an effective guarantor of dignity. This is so because it conditions the full exercise of other fundamental human rights attributed to every human being, e.g. the right to life, security, liberty, health, or development.

The approach to the legal issue of working time and time-off has undergone major modifications over time. While in the mid-20th century the first and foremost demand was to reduce working time, these days more attention is being given to the liberty to have it flexibly scheduled. This is largely informed by the need to seek new forms of working time management in connection with progressing globalisation and the ensuing strong competition and irregular living and working conditions. Hence, the significance of rest is on the increase. The foregoing phenomena are essentially boosting the pace of life and work, as well as ever-increasing expectations from employees, both in terms of their qualifications and availability. This is increasingly causing fatigue and stress and, what follows, a series of ailments and psychosomatic disorders, as well as the socalled job burnout which is afflicting more and more groups of employees, including the young ones. All this is also enhancing the apparent process weakening the role of the family and social relationships. Therefore, in the best interest of both society and individuals it is essential to enact or preserve the right to rest, as much as it is to usher in such legal instruments that will be conducive to its effective exercise and help alleviate the negative effects of the phenomena contemplated herein above.

One such fundamental instrument is the right to holiday. This right entitles an employee to take an annual leave from work in order to regenerate their mental 
and physical powers and, what follows, help protect their life and health. The right to holiday is the principal subject of this book. However, the book is not intended to present and analyse in full all the relevant solutions adopted by the Polish legislator, but rather to assess the structure of holiday leave and the rules of it being granted on the grounds of Polish laws and regulations in the context of the functions which such a leave should fulfil, and the extent to which abided by is one of the fundamental principles of Polish labour law - the right to rest. The author's focus is, therefore, on those elements of holiday entitlement which most strongly affect the said assessment.

Following a close examination of the subject matter, as presented in the book, it transpired that an employee's right to rest - in the light of the existing Polish legislation - is not abided by to the optimal extent - also in respect of holiday entitlement. Some of the legal solutions discussed in the book and concerning holiday entitlement of employees, above all those laid down in the Labour Code, but also in special legislation (in particular that applicable to teachers and temporary employees), not always, when it comes to details, fully meet the requirement to minimise any and all interferences by the legislator that disturb the normal course of holiday rest. Objectionable are, e.g. the practicalities of the rules within holiday entitlement which were posited to ensure full achievement of the objectives of holiday leave, but also, in certain cases, the terms and conditions of acquiring the right to holiday leave.

Also, worthy of note is the absence of an adequate legislative response to growing fatigue caused by the length of service of long-term employees, or the increasingly doubtful rules of eligibility for the right to rest - also including holiday entitlement. It is rather difficult to find convincing arguments that would weigh in favour of restricting this right exclusively to individuals enjoying the employee status, especially that over the last dozen or so years the legal basis for performing gainful work has changed dramatically. Employees are still the prevalent group of working people, but there is a high percentage of individuals working otherwise than on employment contracts, in particular on civil law contracts, in terms of which the conditions of working do not essentially vary from employment contracts.

The perception of the title holiday leave as an instrument of exercising the right to rest obviously required some systemisation of the normative material and output of the doctrine and judicature in respect of the right to rest. Therefore, the first part of the book attempts not only to clarify the very notion of rest, its meaning and nature, but makes references to the basic legal measures which in the past were and now are to serve the purpose of rest (daily and weekly rest, days off work, rest breaks at work, holiday leaves). Such measures ensue not only from the fundamental principle of an employee's right to rest enshrined in Polish laws and regulations, but also in international and European acts, whose regulations are more broadly discussed in the book. 


\section{Od Redakcji}

Doktor Monika Nowak ukończyła w 2000 r. studia na Wydziale Prawa i Administracji Uniwersytetu Łódzkiego, a następnie podjęła studia doktoranckie. W 2004 r. na podstawie przedłożonej rozprawy doktorskiej Prawo do godziwego wynagrodzenia za pracę uzyskała stopień naukowy doktora nauk prawnych i została zatrudniona na stanowisku adiunkta w Katedrze Prawa Pracy na Wydziale Prawa i Administracji Uniwersytetu Łódzkiego. Prowadzi wykłady, ćwiczenia i seminaria z zakresu prawa pracy, jest też wieloletnim wykładowcą na studiach podyplomowych oraz opiekunem wydziałowego Biura Karier. Jest autorką wielu publikacji poświęconych przede wszystkim różnym kwestiom indywidualnego prawa pracy, w tym m.in. monografii przedstawiającej w sposób kompleksowy problematykę wynagrodzenia za pracę (Wynagrodzenie za pracę, Wolters Kluwer, Warszawa 2014), a także ekspertyz dla Komisji Europejskiej dotyczących zgodności polskiego prawa pracy z prawem Unii Europejskiej w zakresie regulacji obowiązku informacyjnego pracodawcy oraz ochrony roszczeń pracowniczych w razie niewypłacalności pracodawcy. 
